

MEMOIR S

AND

MEMORA NDA. 



\title{
MEMOIRS AND MEMORANDA,
}

\author{
CHIEFLY BOTANICAI.
}

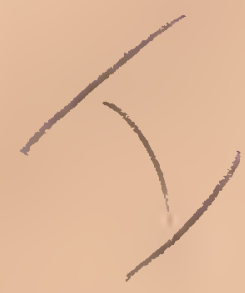

DAVID PRAIN.

Reprints from Periodicals, 1887-1893.

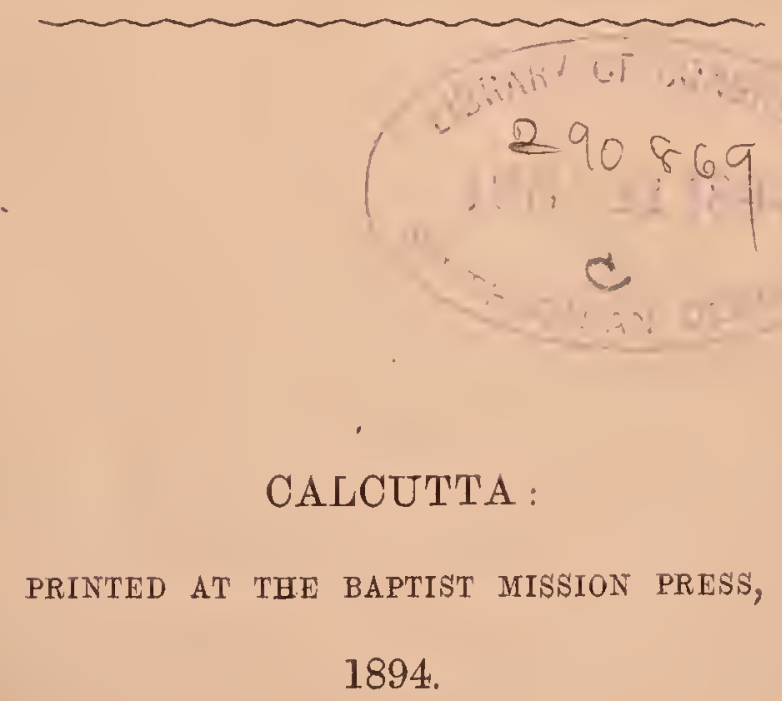


$x^{k} 3$
$P_{7}$ 


\section{CONTENTS.}

[The references are to the numbers at the outer bottom corners of the pages.]

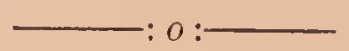

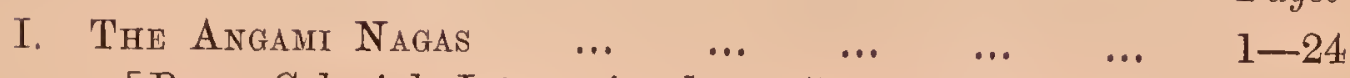

[Revue Coloniale Internationale, $\mathrm{v}, 472-494$; (1887revised 1890).]

II. The non-indigenous specres of the Andaman Flora

[Journal of the Asiatic Society of Bengal, lix, pt. 2, $235-261 ;(1890)$.

III. A list of Diamond Island plants $\quad \ldots \quad \ldots 6 \quad \ldots \quad 53-76$

[Journal of the Asiatic Society of Bengal, lix, pt. 2, 272-294; (1890).]

IV. The hot springs of the Namba Forest in the SibSAGAR DISTRICT, UPPER Assam $\quad \ldots \quad \ldots$
Proceedings of the Asiatic Society of Bengal for August, 1887, 201-204; (1887).]

V. ON the PRESENT CONdTTION OF Barren Island

[Proceedings of the Asiatic Society of Bengal for May $1891,84-87$; (1891).]

V1. On an Undescribed Oriental spectes of Nepeta (Plate) 85-87

[Journal of the Asiatic Society of Bengal, 1x, pt. 2, $204-206$; (1891).]

VII. Teratologrcal efFects produced on ACACIA EBURNEA BY ACIDIUM ESCULENTUM (Plate) ... ... ...

[Journal of the Bombay Natural History Society, v, $165-167 ;(1890)$.]

VIII. Note on Lo.kaO, the Chinese Green-Dye, yielded BY VARIOUS SPECTES OF RHAMNUS ... ... ...

[Journal of the Agricultural and Horticultural Society of India, n. s. viii, 278-281; (1888).]

IX. The Vegetation of the Coco Group ... ... ... 93-26.6

[Journal of the Asiatic Society of Bengal, 1x, pt. 2, $283-406 ;(1891)$.

X. On a botanical visit to Little Andaman and the

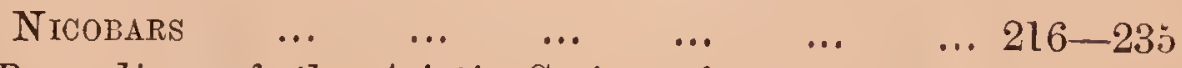

[Proceedings of the Asiatic Society of Bengal for $\mathrm{De}_{e}$ cember, 1891, 156-175, (1891).] 
XI. Remarks on the Fadna of Narcondam and Barren

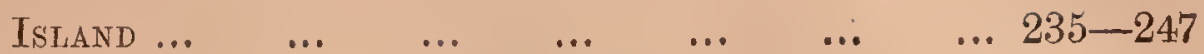

[Proceedings of the Asiatic Society of Bengal for April 1892, 109-121; (1892).]

XII. On the Synonymy of Anthocoma fla vescens Zoli... 247-250 [Annals of Botany, vi, 22, 214-217; (1892).]

XIII. Two species of Pedioularis (two Plates) ... $\quad$... 250 -252 [Journal of the Asiatic Society of Bengal, lxii, pt. 2, $7-9 ;(1893)$.

Xiv. On the Flora of Narcondam and Barren Island $\begin{array}{llllllll}\text { (Two Maps) } & \ldots & \ldots & \ldots & \ldots & \ldots & \ldots & 253-300\end{array}$

[Journal of the Asiatic Society of Bengal, 1xii, pt. 2, 39-86; (1893).]

XV. Botany of the Laccadives $\quad \ldots \quad$...

[Journal of the Bombay Natural History Society, vii, 268-295; (1892): vii, 460-486; (1893): viii, $57-87$; (1893).]

XVI. Directions for Drying SPECIMens of plaANts for a $\begin{array}{lllllllll}\text { Herbarium } & \ldots & \ldots & \ldots & \ldots & \ldots & \ldots & 391-400\end{array}$

["Asian" xxviii, No. 401, 194-195; (1892).]

XVII. Note on some methods of preparing botanical $\begin{array}{lllllllll}\text { SPECIMENS } & \ldots & \ldots & \ldots & \ldots & \ldots & \ldots & 401-405\end{array}$ [Journal of the Asiatic Society of Bengal, lxii, pt. 2, 153-157; (1893).] 


\section{NEW SPECIES AND VARIETIES DESCRIBED.}

Capparis sepiaria, Linn. VAR. grandifolia Kurz...

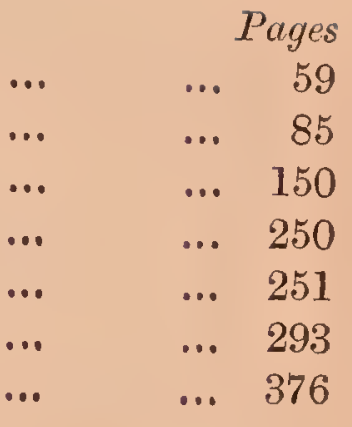




(1)




\title{
THE
}

\section{ANGAMI NAGAS.}

\author{
REPRINTED FRON THE \\ 政ebure Coloniale Enternationale, \\ VoL. v; pt. 6 ; pp. 472.494 : \\ DECEMBER, 1887.
}

(Revised, September I800.) 


\title{
THE ANGAMI NAGAS
}

BY

\author{
D A V I D P R A I N.
}

A mountain range occupying the space between $93^{\circ}$ and $96^{\circ} 30^{\prime} \mathrm{E}$. Lon. and $25^{\circ} 13^{\prime}$ and $27^{\circ} 18^{\prime} \mathrm{N}$. Lat., runs N. E. and S. W. between the Brahmaputra and the Chindwin, and separates Assam from Burma. This, east of the $95^{\circ}$ meridian forms the Patkoi, west of that line, the Bareil mountains.

The eastern portion probably resembles the western, which consists of metamorphic rocks below with tertiary formations above. The older rocks are much contorted clay-shales, schists, and gneiss, on which unconform. ably reposes a vast thickness of soft sand-stones and tertiary clays. The newer formations dip S. E. and with a gradual rise of base from the $93^{\circ}$ meridian, culminate at $94^{\circ} 8^{\prime}$ E. L.on. and $25^{\circ} 34^{\prime} \mathrm{N}$. Lat. in Japvo, "father of waters," 9890 feet high. The mean elevation around is 8500 feet ; to the East the average height is under 6000 feet, some peaks reaching 7500 feet. The clay-shales and schists rise 5000 feet as narrow waterworn ridges crested with villages and tilled along their slopes between the levels of 3000 and 5000 feet. Above and below this zone the country is an unbroken forest.

The climate is agreeable. The cold weather, Oct.-Feb., at first is very pleasant. After November mists rise from the valley of Assam, and between ro and I I a. m., the temperature daily falls about $8^{\circ} \mathrm{C}$. in consequence. By night the mists dissolve and hoarfrost forms. Rainstorms occur in January; the temperature then may be $4^{\circ} \mathrm{C}$. or less at 5000 feet, with sometimes snow at 6000 feet. The hot weather, Mar.June, is not severe. In March and April daily gales blow from the S. W. ; these cease at night. The rains begin in June. After the first outburst they are moderate, only 74 inches falling annually. The nights are usually 
clear, the sky at sunrise cloudless, and the Bhutan snows, I 75 miles west, distinctly visible. After sunrise cumulus forms on the hill-tops, extending westward peak by peak till by noon all are clouded and rain begins. It may however rain constantly for several days; and, especially after thunderstorms, several days may pass without rain. In September the rains cease, and then false sunsets, with the afterglows in the eastern sky and rays of coloured light converging to the East, are frequent phenomena.

The tribes of this region are members of the Tibeto-Burman family, They speak languages belonging sometimes to separate groups of this family, and which, even when of the same group, are so distinct, that natives of villages but twenty miles apart can only communicate through an interpreter. The dialects in different villages where the same language is spoken may vary so widely as to render intercourse difficult $\left.{ }^{1}\right)$. The name Naga [naked (Assamese)] is applied to all; those of the Patkoi range being the Abor [remote (Assamese)] Nágas : the latter name Abor, or Borabor-very remote, is given also to another group of tribes in the hills which connect the Patkoi with the Himalaya. The Nagas have no endemic collective race-name. The independent tribes of the Patkoi and Eastern Bareil are little known, the Western Bareil is peopled by several tribes, the Angami, Regma, Sema, Lhota, Arung,--under British rule ; the Kachha-partly British, partly subject to the protected kingdom of Manipur; the Tangkal,-under Manipur.

The most important and warlike tribe is the Angami, which furnishes 40,000 of the total 95,000 at which the British Naga population is estimated $\left.^{2}\right)$. It has no general tradition of origin. Villages have mostly sprung from older ones; where a conmunity forgets this the parent one may refresh its memory. Thus Konoma village says that its neighbour Mozamá was originally one of its clans expelled for unruliness, owing its name to the fact, from themuze, murder. Those villages near the higher hills are largest, owing their power to position, and their wealth to the plunder of weaker neighbours. They are perhaps the oldest, for in some of them special traditions linger. It is believed in Kohima, that long

1) Stewart: Jour. Asiat. Soc. Bengal, vol. xxiv, p. 658 et seq. (I855) gives an Angami vocabulary. Dalton: Descriptive Ethnology of Bengal, p. 7I et seq. (1872) copies this. McCabe : Grammar and vocab. of the Angami Naga Lang. (I887) has given it again from original observation. Hence the writer only gives the few Naga words needed to render the text clear.

2) Hunter : Imperial Gazetteer of India, vol. x, p. 147, 2nd edit. I886, says 35,000. 
ago the Angami, seeking a home, had consulted omens often but in vain. Finding at length a favourable site, they called it Kohi, "turning", from their wanderings-hence their name ${ }^{1}$ ). This village, now the seat of the British government, is one of the largest. It consists of seven clans and contains 900 houses. The Angami estimate a village by its houses, though a house may contain several families. A house averages four to five individuals; altogether Kohima contains about 4000 Nagas. Few villages are so large, 300 houses making a large village; many contain but 30 to 40 houses, and on the lower spurs near the plains often no more than ten. They have little history. Perhaps they once paid tribute to Manipur. A carved monolith near Kohima is still termed "the Manipur stone." It bears the symbols of the sun, and the sacred bull, with an inscription round these. On a flat slab at its base is the carved imprint of two human feet. On the Basama, a spur high above the sites of villages, some ruined walls are said by the Asamese to be the remains of a Burmese occupation fort. Their appearance does not bear this out; the Angami explanation ton, is the common-place one that a clan of Mozama, at feud with the rest of the village, temporarily retired to this spot.

Whatever was their attitude to former rulers of Assam, the British found them raiding annually on the plains. They first came in contact with Europeans in $183^{2}$ ); between then and $185_{1}$ ten expeditions had to be sent against them. Government was desirous of establishing political control over the tribes, not of subduing them, but as raiding still took place,-twenty raids occurring between $185 \mathrm{r}$ and $\mathrm{I} 866$ - a station was established within the hills in $\left.1867^{3}\right)$. This was intended as a point whence raiding could be checked, and as a base for survey operations. No more raids touk place towards Assam, but on several occasions survey parties were attacked and, oftener than once, more or less completely cut off. This and renewed raiding into Cachar, to the S. W., led in 1878 to another expedition and the establishment of the British station in the midst of the strongest villages. Next year, however, the British magistrate was killed, and a final expedition-the twelfth-was sent against the Anganis ${ }^{4}$ ). After some hard fighting this ended, in 1880 , in the subjection and

1) The termination - ma in proper names means man, inhabitant.

2) Butler: Travels \& Adventures in Assam, (London 1855) p. I02. This is the first work in which the Angami Nagas are described from personal observation.

3) Hunter: Imp. Gazetteer of India, loc. cit.

4) Hunter: Imp. Gazetteer of India, loc. cit. 
disarming of the whole tribe, which has since been directly under British rule.

The race is bronze-coloured, with coarse black hair, hazel eyes, prominent cheek-bones, and rather flat noses, especially the women; men have often quite straight noses. The eyes are not always oblique, nor is the hair always straight; the chin is narrow but rather prominent. Beards are uncommon, consisting when present of straggling hairs along the cheeks and under the chin. The average height of men is $1.5^{8}$ metre; of women I.45 metre. The limbs are lithe and muscular; the genitals are undersized; the mammae globular and, even in old women, but slightly pendulous. During menstruation, which begins early, the ordinary avocations are pursued and sexual intercourse is permitted. Micturition is performed by both sexes standing. They are strong and active, running with agility up as well as down hills. Eyesight and hearing are keen; the voice is clear and musical. They do not bear weights on the shoulder, but carry heavy burdens on their backs, supporting the load by a band across the forehead. A man's load is 6r Ibs. avoirdupois, a woman's $50 \mathrm{lbs}$. This they carry 20 miles a day for many days. But when choosing their own loads, many men take 90 tbs. some even iro fbs. and will carry this 35 miles in one day. Girls of twelve will carry 30 to $40 \mathrm{Hbs}$. a whole day, and after a march of twenty miles, lay down their loads and at once set off home. When climbing hills the feet are turned in, the large toe being pressed into the ground to prevent slipping. When marching with loads, they emit a ho ho; a clear flute like note which appears to relieve their distress; if a considerable party be at work this is done in unison, producing a far-reaching sound which has a pleasing effect. They have considerable capacity for music with a good idea of time. Among themselves many musical calls and hollas are in use, and bugle calls are readily and correctly imitated by whistling.

Their chief occupations are cultivation and the keeping of cattle. But they are expert hunters also, and, where the streams are large, take quantities of fish. They are likewise good traders. Formerly the larger villages made plunder a regular occupation. Now they find it more profitable to work for government. The young practise leaping and kindred sports in special places near their village, but much of their spare time is spent in feasting.

The Angami dress is a blue cotton kilt I metre long, wound on from left to right so that the free end is at the right side. Girls adopt this about eight, boys about fourteen; the former 
wear it plain though sometimes it has red borders-the depth of the kilt being .5 metre; the latter wear a narrower kilt, one third of a metre deep, ornamented by three horizontal rows of cowries, except on the part in front which is overlapped; where it overlies the trochanters also, cowries are omitted. This plain underpart is pulled close to the right thigh by means of a string attaclied to the lower corner and fixed to the upper border behind. There is worn besides, a white cloth of cotton or nettle-fibre with narrow red and blue borders, or with black stripes. This is 1.75 metre long, I metre wide. It is thrown loosely over the shoulder, or if the wearer be actively employed is bound firmly on. Men sometimes discard it when at work, but women always wear it tightly bound over the mammae. Above this is worn another cloth, the same in size, but coloured ; usually it is blue with particoloured borders and fringes, distinctive of different groups of villages. Many men wear leggings of finely plaited cane, so padded with cotton as to make the shin bulge equally with the calf: these are never removed. Bands of narrow canes dyed black are worn between the knee and the calf. When a youth comes of age he puts one or two conch shells on his neck and dons armlets of brass or ivory or, if he cannot get these, of plaited cane. These ornaments are meant to ward off blows. After slaying an enemy he wears round his neck strings of cowries, or of cornelian beads, interspersed with locks of hair. When many foes have fallen by his hand, he wears on his breast an oblong frame of neatly plaited cane ornamented with rows of cowries and locks of his victims' hair. The great ambition is to possess these; women treat undecorated suitors with scorn: once gained they are always worn. The desire to gain these insignia led formerly to much bloodshed. Brass ornaments, - huge rings or coils of wire-are worn in the ears, and when their favorite flowers, Orchids and Alpinias, are not in bloom, tufts of coloured cotton are placed beside the rings. Warriors often replace the rings by wild-boar tusks, ornamented with elytra of beetles and locks of dyed hair. The women are less ornamented than the men; still, they wear ear-rings and armlets of brass, and cornelian necklaces, placing bright flowers and tufts of dyed cotton in their ears, like the men. The hair of children is closely cropped; one tuft is left on a boy's head, nothing on a girl's. The boy's hair may grow when he reaches puberty, the girl's when she is no longer a virgin. Women bind the hair loosely behind; men wear it long and loose, or bound in a queue; or cut in various patterns by way of decoration. 
The style of hair is sometimes, but not always, distinctive of different villages; a good deal of individuality is displayed in the matter.

Angami villages occupy the crests of ridges usually at an elevation of about 5000 feet. They are strongly fortified by stone walls, and ditches are cut if need be to check attacks along the ridge. Stone outworks and monoliths to screen defenders guard all the approaches, which consist of paths led directly up the spurs and present great natural difficulties. The easiest ascent to the fortress of Konoma, for instance, is that from the valley to the west, and it consists of an unbroken staircase with gra steps. Close to the villages the paths are converted into covered ways by hedges of prickly spurge ${ }^{1}$ ); the walls themselves are screened by a tangled jungle, the basis of which is a violent stinging nettle ${ }^{2}$ ) and a prickly $\mathrm{palm}^{3}$ ). The passages through the walls are along ditches $2^{\prime}$ metres in depth, guarded by great doors, each a single plank, ornamented with rude reliefs of the heads of buffaloes and men, the latter rendered more realistic from having two rows of teeth taken from slain enemies. Sentries are always on guard here by night; if the village be at feud, or if epidemics are raging in the hills, by day also. In time of war the paths for miles are studded with pitfalls and bristle with "pangies,"-_small bamboo stakes, with ends sharpened and hardened by fire, stuck in the grass beside the narrow path and sloped to receive on the point the foot of an advancing enemy, on whom they inflict disabling and often dangerous wounds. These village sites are always strong against direct attacks, but often capable of being turned, and usually commanded by some neighbouring height. Most communities contain several clans, inhabiting distinct parts of the village separated by deep ditches, along which sentries are placed during civil fends, or when epidemics prevail in the village. The houses are not, as with many Tibeto-Burman tribes, raised on platforms. The walls are huge wooden planks, the ridge-pole and rafters, small trees; the thatch, grass and hamboo. For security against the April gales the eaves almost reach the ground. All the parts are bound together with canes. Sometimes the houses are placed in two irregular rows, the street between being the common receptacle of the village filth; usually they are placed anyhow; one end abutting on the hill while the entrance is by the other. Houses

1) Euphorbia antiquorum.

2) Girardinia heterophylla.

3) Plectocomia assamica. 
are often 12 metres long by 6 wide, the ridge-pole being 2 metres from the ground in front but much less behind. A fenced courtyard 6 metres square is situated in front of each house. Houses are divided into two rooms, an inner and an outer. The inner, which is the common sleeping apartment and in which the weapons are kept, is furnished with solid wooden bedsteads, shaped in section like a Greek $\pi$ the whole hewn from a single tree. These often exceed 1.5 metre in width, and stand over half a metre from the floor, occupying lengthways a side of the room. The outer is the sitting and store room. In the midst is the fire where cooking is done, and round which wooden benches are placed; grain baskets are ranged along one side, a heer-tub stands in a corner opposite. Dogs, pigs, and fowls have free access from the courtyard where the cattle are penned at night and into which all refuse is thrown. The house is only approached through this yard which is so dirty that stepping stones are necessary in order to cross it dry-shod. The houses of the chief men of a village are distinguished from the rest by the beams of the rafter over the entrance not meeting under the eaves like a Greek $\Lambda$, but extending beyond like a Greek $X$; the free arms projecting above the thatch are rudely carved to resemble buffalo-horns.

The weapons used are the "dhao" or handbill, with spear and shields. A bamboo-tube or "chunga" full of "pangies" is also carried. The "dhao," which is likewise the main industrial implement, is heavy, square at the end, and sharpened, like a chisel, with one bevel. It has a short wooden handle, and is worn, without a sheath, in a wooden frog at the back. The other weapons are of two kinds, plain and decorated; - the one for use, the other for show. When on an expedition a couple of spears, two metres long, are carried. The heads are 0.25 metre long, of thin iron with sharpened edges and unbarbed. The shafts are plain and shod with pointed spikes to balance the weapon. A similar spear, but only one metre long and with a smaller head and spike, is used by women and old men in climbing hills. The shield is an oblong framework of split canes, strengthened behind by a board. It is $I_{\text {.I }} 5$ metre high by 0.5 metre wide. The "chunga" for "pangies" is simply a joint of a large bamboo. One spear is thrown, the other retained for use, with the "dhao," at close quarters. Spear-wounds seem to heal easily as compared with those caused by the sharp pointed "pangies" which are carried in order to stud the path and retard the enemy during the retirement of an attacking party. At festivals each warrior carries a spear with a head 
0.5 metre long, like a broad two edged sword and with five or six barbs on each side. To balance this the shaft is shod with a heavy iron spike about as long. The shaft itself is about a metre in length, and adorned, sometimes with plaited cane, but oftener with alternate bands of red and black hair. The holiday shield is as the fighting one, but covered in front with tiger or bear skin; when these cannot be had, a row of human masks; made of black hair, are inwoven down the centre. The top is adorned at the corners with wooden horns and there is a spike in the middle, all three decked with locks of hair. Along one side are hung as many bunches of hornbill's feathers as the bearer has slain of his enemies. At. the same time the warrior wears in his hair a hornbill's feather for eacly foe he has killed. The "pangi-chunga" is also ornamented with locks of hair, and instead of being a mere bamboo-tube, is often a curved piece of wood worn behind like a tail. Great eagerness is shewn to possess guns, and the Angami having obtained a considerable supply by way.of Manipur gave much trouble to the attacking forces during the later expeditions against them. Now only a limited number are allowed to carry muskets, which are used with some skill in hunting. In cultivating a hoe, a short rake, and a rude sickle are used. The hoe which is much like that used in the plains has a heavy iron head, fixed, owing to the steepness of their fields, at an unusually acute angle to the short wooden handle. Poorer villagers use a light hoe of thin iron with bent ends attached to canes, these being bound together form a shaft. The rake is a piece of bamboo, one end of which is divided to a joint into several slips; these, turned down at right angles to the shaft, kept in position by canes and trimmed to one length form the teeth. The sickle is not in common use; it is a thin piece of iron with a short wooden handle. During the rains men wear broadbrimmed peaked hats and waterproof coats. Women carry food and implements to and from the fields in baskets, and instead of hats wear triangular rainshields, which rest at once on the head and the basket, protecting both from the wet. The baskets, like other burdens, are supported from the forehead by bands of plaited grass, as broad as the palm of the hand, attached at their extremities to grass ropes which are tied beneath the burden. The hats, rain shields, and baskets consist of a double frame-work of cane with dry plantain leaves between. The waterproofs are nets of woven sedge; each blade has one end free; the free ends are all to the side that is worn outwards and form an impervious thatch. For jungle work, besides the "dhao", a hatchet is used. 
This has a shaft 0.75 metre long, perforated in the thicker end by square hole into which an iron head is set; according to the plane in which the edge of this is placed the instrument becomes an adze or an axe. The baskets for storing grain are like those already described, but are often as much as two metres deep, and are frequently plastered over with mud. They are annually renewed, as old baskets spoil the grain.

Each village is a commune: if an Angami be asked who was his overlord before the British came he plants his spear in front of the questioner and points to that. Still certain headmen are selected for their wisdom in council, their skill in debate, their courage in the field; these guide the village deliberations, speak for it to outsiders, lead it in war; at the same time whoever has amassed means enough to feast the whole village at one time, becomes a headnan, and may adorn his house, as a selected headman does, with horns above the entrance. The position is honourable, but carries no more than a personal authority. Though sons may succeed their fathers, or indeed may share the position, for it is not confined to any age, it is in no way hereditary, nor is it necessarily held for life. De. cisions are made by the whole village in council, often in opposition to the opinion of the headmen. These meetings are held on stone platforms in open parts of the village. Every clan has one of these for the old men, another for the young, and the two sets do not mix, at least in the preliminary discussions. The platforms have huge fires in the centre during the cold weather; the elders have their platform on the highest part of the ridge. The decision of the elders is rarely questioned in land disputes or petty disagreements; in questions of policy, however, the headstrong views of warriors thirsting for distinction often prevail over wiser counsels. But it is a point of honour with dissentients to acquiesce, and share the fortunes while disapproving the policy of their village. A leader who has used every argument against an undertaking, may be implicitly trusted to conduct it, and this confidence he will not betray. Still no obstacle is put in the way of any one retiring to another village if he refuses to commit himself to the action of his own. This want of government leads to few disturbances; offences against the conmunity are restrained by fines paid in feasts to the village or clan at the delinquent's expense, while those against individual honor are checked by the dread of revenge. Insult or adultery can only be expiated by the offender's blood, and this at once establishes a vendetta. Villages in this way get involved in endless feuds, which, beginning in enmity between 
families, embroil clan with clan in the same or in separate villages, in the last case at length plunging the two villages into hostilities. During a civil feud the women of the rival parties may communicate freely while the men are taking every opportunity of attacking or surprising their opponents. But in feuds between villages the most dastardly deeds are done; the murder of a woman in a field, of a boy herding cattle, of a girl bathing at a spring, counts as much to the warrior's credit as the conquest of a worthy foe. During such feuds regular expeditions are organized. The warriors assemble in arms, and with food for several days, consult the omens, and set off. Where resistance is expected a careful and stealthy approach is made, and a surprise attack, if possible, delivered just before day break, when the enemy are most likely to be off their guard. If the village attacked be weak, as is usual when mere plunder is the object, it is entered by day. Though weak villages were formerly exposed to attacks. from every more powerful neighbour, yet it was only in the last extremity that the site was abandoned for a safer. Sometimes a number of warriors may enter a village as friends and fall on its inhabitants, when overcome after the feast with which they have entertained their guests. In any case they rush through the village, firing the houses and spearing the people as they escape from the flames. Little blood is shed really; every one who plunges his spear into a body while life remains may count the victim's head to his score, so that the pursuit of an enemy in the jungle is less attractive than the plunder of his village. Usually only those who fall in the first rush are killed, their heads, hands, and feet are carried off as trophies; unwounded prisoners who do not resist are taken away with the rest of the plunder as slaves; if they resist their heads are at once taken. On the return of the expedition the heads are on view during five days, after which they are buried and a feast is held. The ransom of heads and captives is a point of honour among the Angamis ${ }^{1}$ ). The Nagas of the Eastern Bareil on the other hand store the heads of victims in a village dead-house set apart for the purpose. Among them heads can only be recovered by a successful counter attack ${ }^{2}$ ). Another custom to which the Angami are less prone than their eastern neighbours is that of waylaying an inoffensive traveller for the

1) Butler: loc. cit. p. 156. All this is now, fortunately, to be spoken of in: the past tense.

2) Peal : in "Papers relating to Hill.Tracts bet. Assam \& Burmah (1873) p. 325. 
sake of placing his head and hands and feet in their fields to ensure a more abundant harvest ${ }^{3}$ ). The fate of slaves is not hard. They are made to work, but not harder than the women of the village in which they are captives. Two forms of mimic warfare are practised. There is the war-dance in which warriors, in full festival panopiy, review, with realistic war-cries, every circumstance of defence and attack. This has the effect of inflaming undecorated youths to sally forth and win the "cordons" and "garters" of warriors. The stonethrowing and fisticuff festivals held at certain seasons are on the other hand excellent outlets for their pent up martial ardour. During these, rival parties assemble outside the village and attack each other fiercely with fists and teeth. Sometimes stones may be thrown, but all weapons are debarred, and the severest blows bestowed on an opponent are rarely taken into account and never lead to subsequent feuds ${ }^{1}$ ). The warcry used is a shrill hîh, huh ; not to be confounded with the ho, ho already described, from which it differs in being articulate. Both sexes join in slow figure-dances-commemorative of love-episodes. Onlookers sing bars before and clap hands after each figure. Women dance by themselves a lively quickstep.

Hunting is a universal occupation. The forests contain deer and wild pig; on the higher hills are found bears and telu, - a ruminant akin to the "serao" 2 ) but peculiar to the Bareil range. These are usually pursued by hunting parties, though those who have muskets sometimes go out alone or in pairs. They have a tall fierce breed of dogs with short erect ears and usually of a black and white colour. Men are often severely injured and sometimes killed outright by the bears. Tigers and leopards from the lower valleys at certain seasons carry off cattle or even kill men. Then a blood-feud is declared ; armed warriors beat the jungle systematically till the animal is discovered and surrounded. The ring of spears converges: though more than one may succumb when the tiger tries to force the circle no one flinches and the animal rarely escapes. All try to spear it, fot its head counts only less than a man's ; hence good skins cannot he had. The birds taken are pheasant, partridge and woodcock, also the hornbill for the sake of its feathers. A large rat is also eagerly sought.

1) Butler: loc. cit. p. 157 .

2) Stewart : Jour. Asiat Soc. of Bengal loc. cit.

3) Capricomis bubalina: a rare ruminant of the N. W. Himalaya. For an account of its habits see Adams: Wanderings of a naturalist in India p. 220. The Bareil serao is rather larger and is red,.. Its habits are identical with those of its western congener. 
Game is oftener trapped than hunted however. The commonest trap consists of two parallel fences which vary in height, strength and distance apart with the animal to be caught. Two longitudinal weighted beams rest on cross supports between the fences near the top. The supports are retained by strings of bark looped over a peg that projects into the path below. Traps for birds or rodents are baited with grain, those for Felidae with fowls or flesh, and set in places likely to be visited. For deer they are placed where tracks pass along narrow ridges or ledges of rock, the jungle being obstructed for a considerable distance before the trap is reached to ensure the animal taking only the path that passes through it. The least touch deranges the mechanisnl, and the victim is crushed by the falling beams. Pitfalls, two metres deep and one metre across, neatly covered with decaying branches and grass, are common. The earth removed to make these is carried some distance to obviate suspicion on the part of the game. They may be simple pits, or be studded with "pangies" often so closely set that the animal's feet must be transfixed and it too severely disabled to escape in the event of its struggling out. Nearer the plains, the pits are made so large that buffaloes and even elephants are captured. To snare birds gins of hair are used; those for woodcock are set along the streams where they feed, those for pheasants in a circle round a "decoy" placed in an open part of the jungle. Rats are simply dug out. An innocent looking creeper lying on the path may, if disturbed, relax a huge bamboo which catapults a couple of spears across the path. Should a man upset the mechanism one spear passes in front and one behind him; a deer, touching it with either pair of feet, no matter in what direction it is going, must be transfixed by one spear. It is said that fish are poisoned and the juice of a prickly spurge is indicated as the substance used ${ }^{1}$ ). But the practice seems to be uncommon. Generally the fish are trapped. A strean is forced by a series of weirs into a succession of "races"; where these debouch into the lower pool, long bamboo cages are made to project the direction of the "race." The fish frightened by waders from the pool above into the race are forced by its current into the cage where they remain while the water escapes through its bars. When sufficiently filled the water is turned aside and the cage removed.

1) Euphorbia antiquorum was shewn to the writer as the plant yielding their fish poison. They did not use it on any occasion in his presence. 
They cultivate partly by irrigation, partly by "jhum." For the first the hill-side is terraced for hundreds of feet; the height and breadth of terrace vary with the slope; the necessary water-channels are skilfully engineered, often along the face of steep cliffs and across narrow ravines. In the valleys near the central range immense detrital deposits occur; the angularity of the component blocks and their proximity to their source seem to mark these as denudative; at the same time the size of the boulders, and especially the facies of the whole, almost leave it an open question whether they are not glacial1). Where these exist the stones are used to revet the terraces and miles of hill side may be seen so retained through rooo feet of elevation, each wall averaging a metre in height while few terraces are as much as two metres wide. The skill and labour implied it is hard to estimate justly. But revetment is no necessary feature ; in valleys where there is no deposit the retaining walls are only earth. The "jhums" are mainly grass lands formerly cultivated. Virgin forest is not extensively cleared for new cultivation because the whole zone which they care to till has already been absorbed. In no case does the Angami commit the wanton destruction done by so many similar tribes. $\mathrm{He}$ is restrained mainly by his fixity of abode and by the soil which he does till being fairly good. The part to be cropped is cleared in spring by the "dhao"-when the jungle is dry it is fired. Not being virgin forest there are no tall trees in their "jhums", but certain kinds, - notably an alder ${ }^{2}$ ) -are left as pollards to yield firewood. The irrigated land is tilled from year to year ; "jhums" on the contrary are usually only cropped for two seasons, then allowed to rest for several years. Cultivation is a public duty. At intervals of aboul seven years the village decides to let a whole section lie fallow for a season. This obviates the necessity of repairing the irrigation system which supplies a set of fields for the sake of a few. Any one however may choose to leave his fields untilled for one year and cannot be compelled to grow his crops during the next, but after that, if illness or idleness prevent him from overtaking the work, his village insists on the fields being let. Should the owner be contumacious the village council sells the fields for what they will bring and hands him the price.

It is usual in cases of illness for the owner to ask his friends

1) See Godwin-Austen : Jour. Asiat. Soc. Bengal, vol. XLIV, p. 52 (1875), p. 209, and Oldham : Memoirs of Geol. Survey of India, vol, XIX (1883), art. 4, for a full account of the opposing theories.

2) Ainus nepalensis. 
to plant his crops for him; when the work is over he entertains them with a feast. The fields close to the village are naturally the richest; their owners can grow more rice than they require, and therefore usually let a portion. At times they let the whole and take exclusively to trading. The rents are paid mainly in rice. During the rains an Angami family usually lives in a temporary hut beside its fields which are often miles from village. The principal rice crop is grown on the inrigated ground; on the "jhum" an inferior early rice, maize, and Job's tears ${ }^{1}$ ) are the chief crops. Among these are scattered plants of a labiate ${ }^{2}$ ) grown for the sake of its oily leaves and seeds. Cotton is only grown on the lower ranges near the plains. Colocasia, chillies, cucumbers, gourds and of late years potatoes, are grown near the hut, while the soybean ${ }^{3}$ ) is cultivated close by. The boys spend their time scaring birds : scarecrows too stud the fields. Of these there are many kinds, but the most artistic is a framework of cane over which is drawn a Naga cloth with leggings hung at a proper distance below, and some black cloth at the top for a scalp. There is no mask, but the ear tufts are present and, catching the eye from afar, make the simulacrum hard to distinguish from a man. The pigs and cattle accompany their owners to the fields, but are kept out of the crops by fences of felled trees and "pangis". The pigs are black, very dirty feeders - as are fowls, which resemble jungle-fowl and lay a small but well-flavoured egg. When the pigs are taken to and from the fields they are not driven; their legs are tied together and their snouts bound with canes, after which they are deported in the field-baskets. Similariy fowls are brought for sale woven each into a wide-meshed cane frame inside which it cannot move. The heads alone emerge through the wicker; when the dealer stops to trade he empties his basketful of fowls on the path where they roll about like so many balls, and scatters a handful of rice for them to pick till the bargain is concluded. Ducks are not kept. Very few possess buffaloes; the cattle usually kept belong to a small duncoloured sleek haired breed with flesh of good flavour, but yielding no milk. Milk is considered by the Angami to be excrementitious. The udders of this breed are small and after the calves are weaned speedily resume their original size. The animals are timid with

1) Coix lachryma.

2) Perilla ocimoides.

3) Glycine hirsuta. 
strangers but docile with their herds, each one responding to a name. They are driven in the morning to feed on the grass lands, and the boys who tend them, assemble their charge at dusk by a sort of vocal ranz de vache. During the rains they are sheltered at night in leaf-thatched huts near the fields, for if exposed to the wet constantly they become affected by a severe mange. At other seasons they are taken at night to the village. The grain is lusked and winnowed in the fields, and then carried home for storage in the large grain baskets. When the last of the crop is housed the family with its live-stock returns to the village. Quantities of firewood are now collected, mainly from the pollard alders; but some is brought from the higher forests, while close to each village there is a considerable jungle reserve in the cultivation zone, to be drawn upon in cases of emergency.

Thatching-grass is obtained from the old "jhums." Building materials come from the virgin forests where huge trees are felled by "dhaos" with the assistance of fire; each tree yields but a single adze-trimmed plank. These great planks are dragged to the village by large companies; small trees are employed as rollers in difficult places, but leverage is not made use of. When climbing trees sometimes footholds are notched, sometimes. pegs of bambno are driven into the stem. Wild honey is got from the jungle by smoking the bees out of their nests; many fruits, such as figs, mulberries, citrons, apples; several potherbs, especially a Polygonum and Houttuynia. The unopened buds of a Baukinia are much used, and several kinds of mushrooms are collected both for their own use and for sale. The villagers on the lower spurs grow oranges, limes, and sweet limes.

Intercourse between different villages is not free. Much of the country is a dense and difficult jungle, infested with leeches and similar pests, and the paths are little more than animal tracks utilized. There are the usual risks from wild animals and snakes, of which there are some poisonous kinds, with the additional dangers of hunting traps and pitfalls. Added to this is the tendency to waylay a stranger for the sake of his head. Village paths lead over spurs, rarely along. them, and never round the head of a stream. But the Angami knows the value of a level road and shews this by abandoning the old tracks for the roads made by government. He shews too by his watercourses that he could make a good road himself. But he prefers a steep ascent, he argues that an easy path makes his home too accessible. He can bridge 
streams too by trees or canes supported on the cantilever principle. In spite of this isolation however the Angami are keen traders. Among themselves they traffic in cotton, rice, fowls, cloth; to the plains they take cotton and nettle cloth, ivory, wax; these they exchange for salt, shells, brass, and iron, and, if they can obtain them, gunpowder and muskets. The difficulties of communication are partly overcome by a curious hospitial system. The Angami of one village finds in every other at least one house in which he will obtain shelter and food, and be safe from any sudden murderous impulse. Between his village and this house there exists a kind of "guest-friendship." And as natives of A are 'guest friends' to one house in B, so are natives of B 'guest-friends' to one or more houses in A. Other houses in both villages have similar and reciprocal relations with $\mathrm{C}$, or $\mathrm{D}$, or $\mathrm{E},-$ with all the villages around. No feud, however bitter, admits of the complete violation of this relationship. In their dealings they do not chaffer; a price, usually fair, is named as what they will take or give, and the bargain is concluded or abandoned at once. They use no measures or weights of their own, but are adopting the Indian ones along with Indian currency. They count beyond roo and have a word for 1000. They have no name for gold or copper, but use an expression for silver, whose purchasing powers they realize. Their old currency was of shells and brass, though iron was their great desire and its possession the chief index of wealth. In some of the neighbouring tribes to the east it forms still, in the shape of thin slips, singly or in bundles, a medium of exchange.

The home-life of the Angami is quiet and peaceable. The women do all the household work, carry water-often a very laborious occupation-and weave. The men sit about on the stones or on wooden platforms beside their houses, nursing the children or doing nothing, gossiping with neighbours and drinking. The national beverage is termed $d z \hat{u}$, (literally, water); it is made from pounded Coix, is whitish and, as offered to strangers, of a thin consistence and with a sub-acid taste. It is refreshing and very slightly intoxicant. This kind is carried about in bottle gourds. A thicker variety, a food rather than a beverage, is eaten with the aid of a stick out of a buffalo-horn by the well-to-do; out of a bamboo "chunga" by their poorer neighbours. Besides this, rice pounded by a stone on a wooden platter, sodden, and mixed with stewed or roasted flesh is the staple food. Pig, cows, fowls, deer yield the flesh, but hardly any thing comes amiss. Dogs, cats, rats, squirrels, owls, lizards, frogs, fish, land-crabs are all eaten, nor does the Angami palate relish 
them less if decomposition has set in. And yet there are some curious restrictions. Only dogs with erect ears - tafinh-may be eaten, lop eared dogs - venafith - are not touched. Cats may be eaten, but a penalty is involved in their purchase. Tiger may not be eaten by the general com munity, but a family on whom one may have inflicted loss must partake of its flesh as part of their revenge.

Household utensils are mainly tubes of bamboo in which the flesh is stewed or sodden. It may also be subjected to a rude roasting. The most recherché dish is a dog, kept for several days without food, then permitted to gorge itself on a full meal of rice. When sufficiently "stuffed" it is killed, cooked, and eaten entire. When fire is required it is obtained by the friction of a pointed piece of bamboo in a hole in another piece. The heat produced sets fire to some scrapings of bamboo placed on the edge of the hole. Water is heated either by dropping hot stones into it, or by placing the vessel, a bamboo tube, directly in the fire. Cotton brought from the lower hills is spun into yarn by a single stick, and woven into cloth on a moveable loom, which when used is fixed by one end to a stake, by the other to the worker's waist. Yarns are dyed by "rhum", the product of a Strobilanthes, from blue to rusty black; by a madder, from brick red to brown, or yellow by a turmeric. The blue colour seems the principal one used by those tribes which communicate exclusively with Assam - the Regmas, the Lhotas and the Semas. The Tangkal and other tribes which only come in contact with Manipur wear cloths that are mainly red or brown. The Angami who are more centrally situated, have blue as their chief colour but have borders of yellow and red and fringes of yellow, red, and even green. They are acquainted with tobacco but do not grow it. The prepared leaf is eagerly eaten ; a cheroot, if lit for them, is awkwardly smoked, and soon goes out; what remains is devoured. In the nearly related Regma tribe, smoking is habitual on the part of the women, the juices being collected in a bamboo cup fixed underneath the bowl of the pipe. When full this cup is removed and carried by the men, who do not smoke but who exchange sips from it on meeting neighbours. ${ }^{1}$ ).

Religion hardly exists. The sun, moon, and stars which move

1) This custom prevails among the Kukis, a tribe settled in North Cachar. It also exists among the Lushais, who now occupy the country, from which these Kukis were displaced. For an account of the custom among the Lushais see Woodthorpe: The Lushai Expedition, 1871-72, (Lond. 1873), p. 77. 
across the sky come from durhoma; to this the moon returns every month. The notion of a future existence occasionally appears to exist. It does not however seem to be indigenous. The more intelligent Angami if questioned gives a decidedly agnostic reply on this point, usually there is not much trace of the conception. There are spirits-medooi-beneficent and the reverse which take a concern in mundane affairs. Some attention is bestowed on these fron utilitarian motives. Good spirits, naturally favourable, need no homage : the others are propitiated to ward off prospective evils; misfortunes which have happened and are beyond remedy provoke however an attitude of defiance-revenge is so axiomatic to the Angami that a feud is declared even against the unseen. Observances of all kinds, compulsory or voluntary, seasonal or incidental have one general name, genna. This implies a period of rest, during which no food prepared by women can be eaten, and is followed by a feast which is great in proportion to the length of the fast. This is imposed on the individual who violates communal customs : at the same time a person may of his own accord undertake a genna of abstinence or silence. A general great genna of three days marks the first full moon of the year, which is a lunar one. Great gennas are held when the rice crop is to be planted or reaped; lesser ones mark the sowing and gathering of the other crops. The parents of a new born child, the family of a man being married, the clan in which a person dies, huld genna : if the deceased be a headman the whole village is involved. A genna precedes an expedition; another marks its termination. Stone throwing and fisticuff gennas have been already alluded to : others are held if iliness or accident befall people or cattle. Lastly it is genna to do certain things, that is, genna would be imposed on the delinquent as a penalty. Gennas are distinguished by no special rites, yet they vary in importance, duration, and extent. The people involved kill fowls, pigs, or cattle, offer the refuse parts to perverse demons, give the less select pieces to outsiders, and use the choice portions themselves. The usual hospitality cannot be shown; during general genna strangers may not enter the village; in special genna outsiders are excluded from the houses involved.

No secret rites exist to explain this; the Angami say that were strangers admitted during genna they would have an unfair advantage over men gorged with food and overcome by liquor. But a curious code of fictions is observed which enables them to evade these restrictions to some extent. Officers and sepoys in the 
discharge of their duties cannot be excluded--they are said to be more than mortal and therefore do not count. A friend returned from a journey, or a trader guest cannot be entertained at a house in genna-a show of resistance made to his taking what he requires is sufficient to obviate any violation. It is genna to eat a lop eared dog;-if its ears be first cut-short, it may be eaten so soon as they are healed. The buying or selling of a cat involves genna-if the animal is spoken of as a fowl throughout the transaction, no penalty is incurred. When however a genna is really violated it begins de novo. The Angami are for all this naturally a truthful race : simple truth is highly regarded. It is rare for a statement to be made on oath, rarer still for it to be false. Indeed when such a statement is made, it is Angami "good manners" to pretend to believe it even when palpably untrue. Oaths are taken in a striking manner; a fowl is pulled asunder by the parties engaged to betoken what it is wished may happen to them if they fail of truth; or a weapon is placed between the teeth to shew that a violent death is invoked if the engagement be not fulfilled. On such occasions stones of witness are sometimes set up. These are monoliths like those set up for defence along the approaches to a village. Similar monoliths are placed at the head of a warrior's tomb. They are merely large blocks from the detrital deposit in the valleys, dragged up with great labour by companies of men to the positions they occupy. They are primarily defensive, for while villages with few inhabitants, or whose valleys contain no deposit, have brought stones considerable distances to set up on their paths, they are content with rudely carved wooden posts as monumental pillars for tombs. They salute each other verbally only. Those who have travelled to the plains greet Europeans with a rude salaam; well known faces elicit an Aposatha "my father sahib", and the delight is great if in return they are addressed "my friend." The salaan, such as it is, must not be confounded with the habit, especially common in women, of raising that hand nearer the stranger and peeping at him under the arched palm as he passes. This is done to prevent the consequences of 'evil-eye', which all Europeans are considered to possess. They are childishly inquisitive; every new 'Sahib' is closely examined to see if he too be really white all over; his belongings are keenly commented on. Gifts afford great pleasure, a common formula of thanks being "the Sahib has made me his son". Their curiosity and love of presents combined lead to petty pilfering. They are not however 
prone to robbery. Their trust in Europeans where they can see, though unable to coniprehend, is great; but a lively incredulity is expressed towards any statement that is beyond their comprehension and is not immediately demonstrable. Omens are sought before every undertaking; the flights of birds is occasionally consulted, but usually the augury is from the fall of the pieces of a reed placed with one end on the path to be taken and sliced longitudinally with a dhao. If both pieces fall to one side the path is open and the omen favourable; otherwise, it is barred and the undertaking must fail. If an expedition meets a deer en route it is at once abandoned; the cry of the barking deer at night similarly puts a stop to a surprise attack.

No special preparation is made for the lying-in of women, who go about their work till close on confinement, which occasionally takes place in the fields. The labour is not generally severe; yet, owing perhaps to the hard work they perform, Angami women are by no means prolific. The parents are in genna for a day; after that fowls are killed and the family feasts. Children are kindly treated and are nursed by both parents; indeed the fathers often stay at home to nurse, while the wives are sent afield. The Angami say, that this custom has arisen from the precautions necessary during civil feuds. When they get older the boys help in the fields, or tend the cattle, the girls do field and household work. A pleasing trait among them is the presence of little corners, with five or six rice plants in each, among the irrigated lands, - "children's fields". Among the young almost unrestricted sexual intercourse prevails. Girls consider short hair, the symbol of virginity, a disgrace, and are anxions to become entitled to wear it long; men are desirous before marriage to bave proof that their wives will not be barren. In consequence of this, female children are offered to strangers for small sums; such females are more highly valued than their neighbours on returning to their homes. To check this promiscuous intercourse there are however in some villages two common sleeping houses, consisting of a single room as much as 30 metres long, in one of which the girls, in the other the boys of the village spend the night ${ }^{1}$ ). This arrangement is the customary one among the Arung and other neighbouring tribes. Sometimes an Angami village has one such house for the boys, the girls sleeping in the houses of their parents.

1) See Peal : Jour. Asiat. Soc. Bengal, vol. lii, pt. 2 (1883), p. 16, 17, as to the existence of this custom among the eastern Naga tribes ; much variety seems to prevail in different tribes. The text clescribes the state of matters among the Angami only. 
More often no such provision is made for keeping the sexes apart. This youthful licentiousness never ends in marriage, and the children of this period, who for some reason are not numerous, are the property of the father. Chastity begins with marriage; conjugal infidelity, though not altogether unknown, is exceedingly rare. Marriages are exogamic: though clans sometimes intermarry, wives are preferred from a neighbouring village in which a similar pattern of upper cloth is worn. The choice lies mainly with the woman who judges by "thews and sinews" and by decorations. The younger men complain bitterly that the British, by stopping their raids and so preventing them from gaining marks of distinction, have made it impossible for them to get wives. The accepted bridegroom gives, according to his means, a present to the bride's parents. Having previously collected materials for a house, his friends build it while he observes a genna; at the close all partake of a feast of fowls and pigs at his expense. Widows and women who have been divorced do not return to their own village, but live in houses by themselves and may marry again. During sickness the family holds a genna : a fowl is killed; the head and feet are offered to the medovi; the legs and neck are given to friends; the rest is eaten at home. When the medovi are satisfied the illness passes off. If the patient dies the clan is involved in genna for a day in the case of a woman, and two days in the case of a man. If a headman dies the whole village is implicated and the genna lasts three days. A feast of fowls, pigs or cattle, according to the position of the deceased, is then given by the relatives to the clan or the village, after which the body is buried. At the obsequies of a warrior the men wear all their decorations, and when the grave is closed warcries are raised and spears brandished, and the cowardly spirits who have killed their friend are challenged to show themselves and fight. Over graves they erect oblong stone tombs, those in memory of warriors are often a metre in height. Upon the tombs are placed the apparel, ornaments, and implements of the deceased-the man's handbill and hoe, the woman's loom and spindle. At the head of a nian's grave are placed his spear and shield - the witnesses of his prowess; at the head of a woman's are stuck the skulls of pigs and cattle-the tokens of her hospitality. While the other things are ultimately removed, the skulls and weapons remain till they decay, it being genna to remove them. A warrior's tomb is carefully preserved by his immediate generation. It is marked by pillars of stone or wood, protected by a railing, and adorned at intervals with flowers. More 
striking stiil is their treatment of the tombs of foes who have fallen near their village, on which as much care is sometimes bestowed as on those of their own warriors.

The prevalent diseases depend on want of cleanliness, on local conditions, and on epidemics. Like most hill-tribes they are infested with parasites. The eczemas and ringworms which result they treat by bathing in hot springs, which they often travel many miles to visit. Fever and dysentery are not uncommon; mainly in the cold weather, and owing to chills. At this season they say they cannot sleep at night but sit huddled round their fires till sunrise. When the stones outside their houses are warmed by the sun, they sleep on these till the mists shut out his rays. If caught in the jungle by the winter rainstorms they sometimes succumb to exposure; those who have goitre appear to die more readily. Goitre is comparatively infrequent in those villages whose watersupply filters primarily through the tertiary formations, but is more common in villages where the water used drains entirely from metamorphic rocks. Epidemics of chicken-pox and measles sometimes prevail, but are counted trifling. Should however small-pox or cholera break out in a village the news rapidly spreads and no one from the infected village is permitted to enter another. The clans not yet affected compel those in which cases have occurred to leave the village at once. The families so ariven out spread themselves abroad among their fields. When a certain time has elapsed and no new case has appeared the clan may return. If the disease appears in a new clan that also disperses, and in bad epidemics the whole village goes to the fields. The neighouring villages maintain a quarantine against the infected community, sometimes as long as a year and a half, and enforce it as rigorously in the case of an epidemic among cattle as when men are affected. Beyond genna the Angami know of no remedy nor will they submit to any. They are particularly averse to vaccination, although some of the neighbourıng tribes submit to it readily. When an epidemic is thoroughly established and several deaths have occurred the men of the village go in a body to the jungle and liberate there a living fowl. The disease it is hoped will be committed to the bird and so conveyed away from the community. A severe form of ulcer known to the natives of the plains as "Naga sore" frequently occurs. When a case appears in a village others are certain to result; slight injuries, such as abrasions or pricks of skin in the jungle, developing into similar open angry rodent sores. As they have no treatment the patient 
usually dies ultimately of exhaustion. Villages have been known to be decimated by this scourge. Venereal ailments are common; the moral code of their early years tends largely to their propagation. They admit a long acquaintance with gonorrhœa but insist that syphilis is an accompaniment of the British government. Since however they are of the same opinion as regards cholera, which is known to have prevailed among them long before the advent of the British, they may be mistaken in this respect also. Specific eruptions and other secondary manifestations are, it must be admitted however, more common in the villages which come most in contact with sepoys, and the ravages they commit are such as would be expected in a race newly inoculated with the virus.

The Angami Nagas have already been described by the following authors; - BUTLER; (son of the officer whose work is referred to in foot-notes) Jour. As. Soc. Beng. 1875. part. I; WoodrHORPE; Jour. Anth. Inst. Gt. Brit. \&o Ir. vol. XI. They have also been incidentally referred to in the latter periodical by PEAL: - vol. III; Godwin Austen; - vol. IV; and WatT; - vol. XVI.

These publications were not accessible at the time the noles which constitute the paper were being arranged. 
From the Journal, Asiatic Society of Bengal, Vol. LIX, Part II, No. 3, 1890.

Natural History Notes from H. M.'s Indian Marine Survey Steamer "Investigator," Commander R. F. Hoskyn, R. N., Commanding-No. 16. The non-indigenous species of the Andaman Flora.-By D. Prain.

[Received 28th Febrnary 1890; Read 2nd April 1890.]

The non-indigenous element in a flora-the weeds of cultivation and the cultivated plants-species introduced, involuntarily or intentionally, by man-is not often dealt with apart, since weeds are rarely in themselves interesting, and because a local treatment is hardly satisfactory where cultivated forms are concerned. But the intrusion of this element is a subject of peculiar interest, particularly when it is possible to review it historically, and as opportunities for doing this are rare, it is well to make use of all that occur.

The Indian convict settlement of Port Blair in the Andaman islands affords such an opportunity. This settlement was commenced 
in its present form in 1858 , but it occupies the site of a settlement that existed for a few years in the end of the 18th century, so that some common weeds may possibly have been already introduced and established, when the present colony was founded. This prevents us from going back without question to the year 1858 as a starting-point in our enquiry; but, while we are unable to do this, we have nevertheless a quite satisfactory date of commencement in the year 1866, for in that year the late $\mathrm{Mr}$. S. Kurz waid a botanical visit to the Andamans the results of which are enbodied in a Report on the Vegetation of the

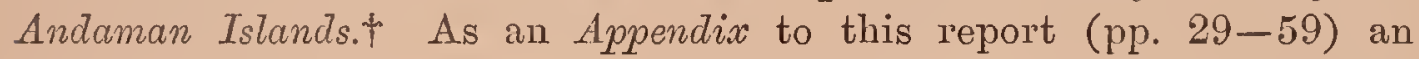
Enumeration of the Plants on the Andaman Islands is given; in this enumcration and in a tabular Recapitulation (pp. 22, 23) Mr. Kurz has distinguished the non-indigenous element and dealt separately with its items. The treatment cannot be better explained than it is by $\mathrm{Mr}_{\mathrm{r}}$. Kurz himself in the following passage taken from his Report (p. 24) :-

"A considerable number of plants on the Andamans are only in"troduced, though some of these species in the surrounding countries "are without any hesitation enumerated in their floras as indigenons. "I noted not less than 76 of these introduced species, while in Singa"pore the numbers are only 31. This great difference, however, is "scarcely a real one, as we can be certain that most plants at the latter "place are introduced only when they are known to be nou-Indian "forms.

"The introduced herbaceous plants on the Andamans are 74 in "number" thus being in proportion to the woody plants as 37: 1. Of "these, seven only are American; which are, therefore, surpassed in "number by nine times the introduced species from the old Continent. "As regards dissemination, the American species supersede the old "Asiatic forms (except grasses), however, in number of individuals.

"An enquiry into the causes of the different modes of immigration " of the non-indigenous plants on the Andamans would show that the "whole number has been introduced by the agency of man, direct and "indirect-a fact which also proves how little chance there is for exotic "plants to cross the sea. I am inclined also to believe that introduction "by means of winds, birds, \&c., is applicable only to continents and "adjacent islands, but not to isolated groups of islands. The Andamans "will become an instructive spot for inquiries into the change of a flora

* Wilhelm Sulpiz Kurz, native of Angsburg, Curator of the Herbarium of the Royal Botanic Garden, Calcutta, from 1863 till his death in 1878.

$\uparrow$ Calcutta; Office of Superintendent of Government Printing, Ed, 2, 1870 : [the first issue, a purely official document of which the edition quoted is a reprint, was circulated by the Government of India in 1867.] 
"by introductions. As I directed my full attention to herbaceous "plants, I hope that I have noted nearly all the plants growing at my "visit in the cleared lands."

During a brief risit to the Andamans, in November 1889, the writer made as complete a collection as the time at his disposal would permit of the naturalised species in the settlement at Port Blair, in order to ascertain the number and nature of the species introduced between 1866 and 1889. And Dr. King, who paid a short visit to the settlement in April 1890, very kindly collected such weeds as were flowering then, but had not been secn in the previous November. The results of the visits are given below, the plants collected first by Dr. King being indicated by a $(K)$; the following method has been adopted in presenting them:-

1. Cultivated species and weeds-enumerated together by Mr. Kurz-are here dealt with separately.

2. Species (of both kinds) present in $\mathbf{1 8 6 6}$ are taken from the Enumeration by $\mathrm{Mr}_{\mathrm{r}}$. Kurz referred to above; for convenience of reference the synonymy of the Report has been made to conform with the nomenclature in the Flora of British India.*

3. Additional species (of both kinds) are those first met with by the writer in 1889, or by Dr. King in 1890.

It ought to be noted that the list of cultivated spccies for 1866, as the remarks of Mr. Kurz shew, is not exhaustive. This is equally true of the corresponding list for 1890 . It has been felt that an exhaustive list of exotic specics could serve no useful purpose; it is sufficient if attention be directed to such plants, introduced since 1866, as may be reasonably supposed to be capable of becoming in the course of time spontaneous or subspontaneous, and to such plants as possess a direct economic interest. The remarks attributed to Mr. Kurz are in every case taken verbatim from his report; where necessary the condition of the species in 1889-90 is commented on; when no secoud remark occurs the condition of the species is to be understood as having remained apparently unchanged during the period between 1866 and 1890.

* This it has boen possible to do with cortainty since the original specimens on which Mr. Kurz' Report is based are preserved in the Calcntta Horb riam and have in every case been re-examined by the writer. 
A. Species under cultifation, obfiously planted or intentionally INTRODUCED.

I. Species under cultivation or obviously planted in 1866.

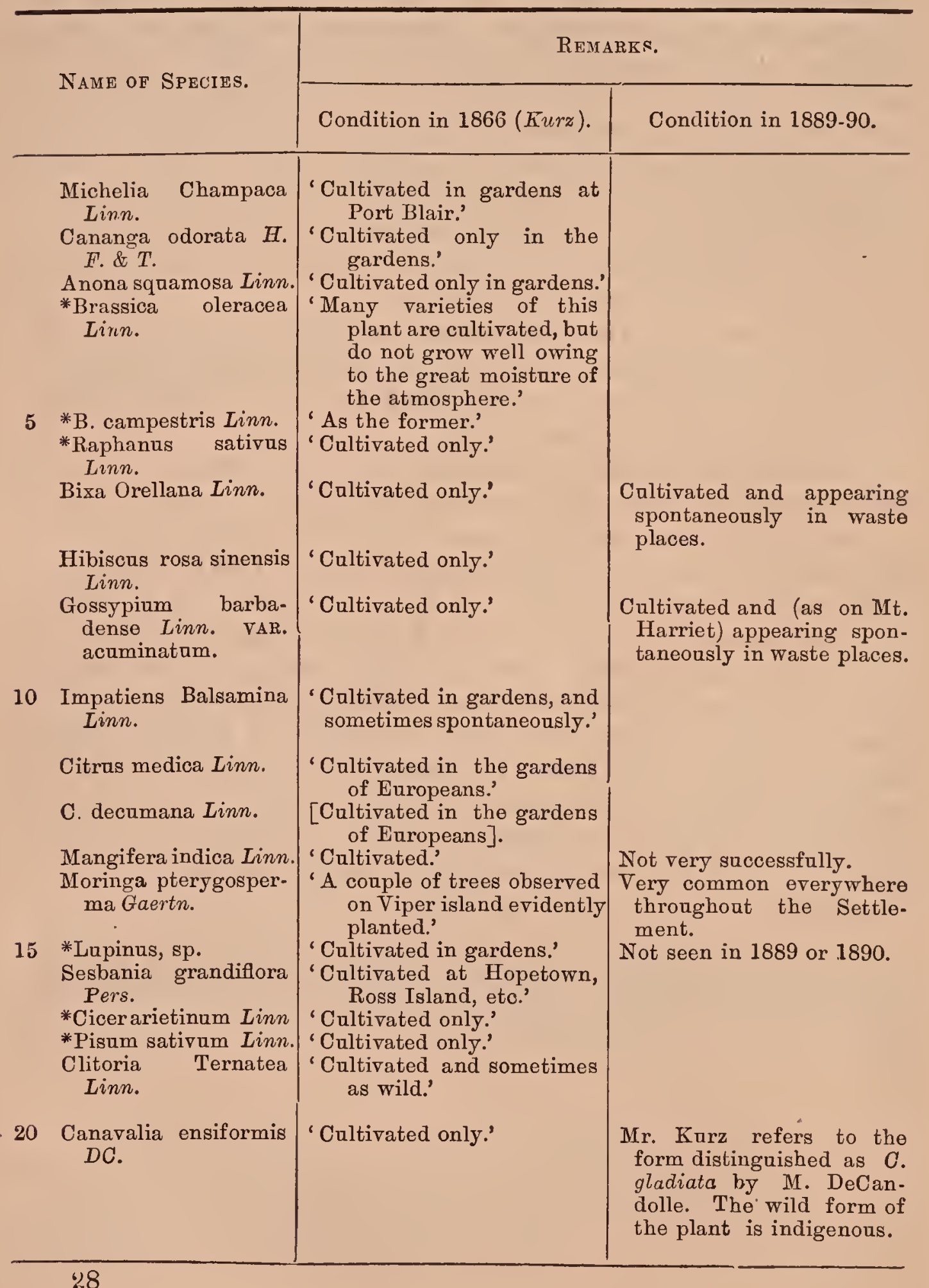




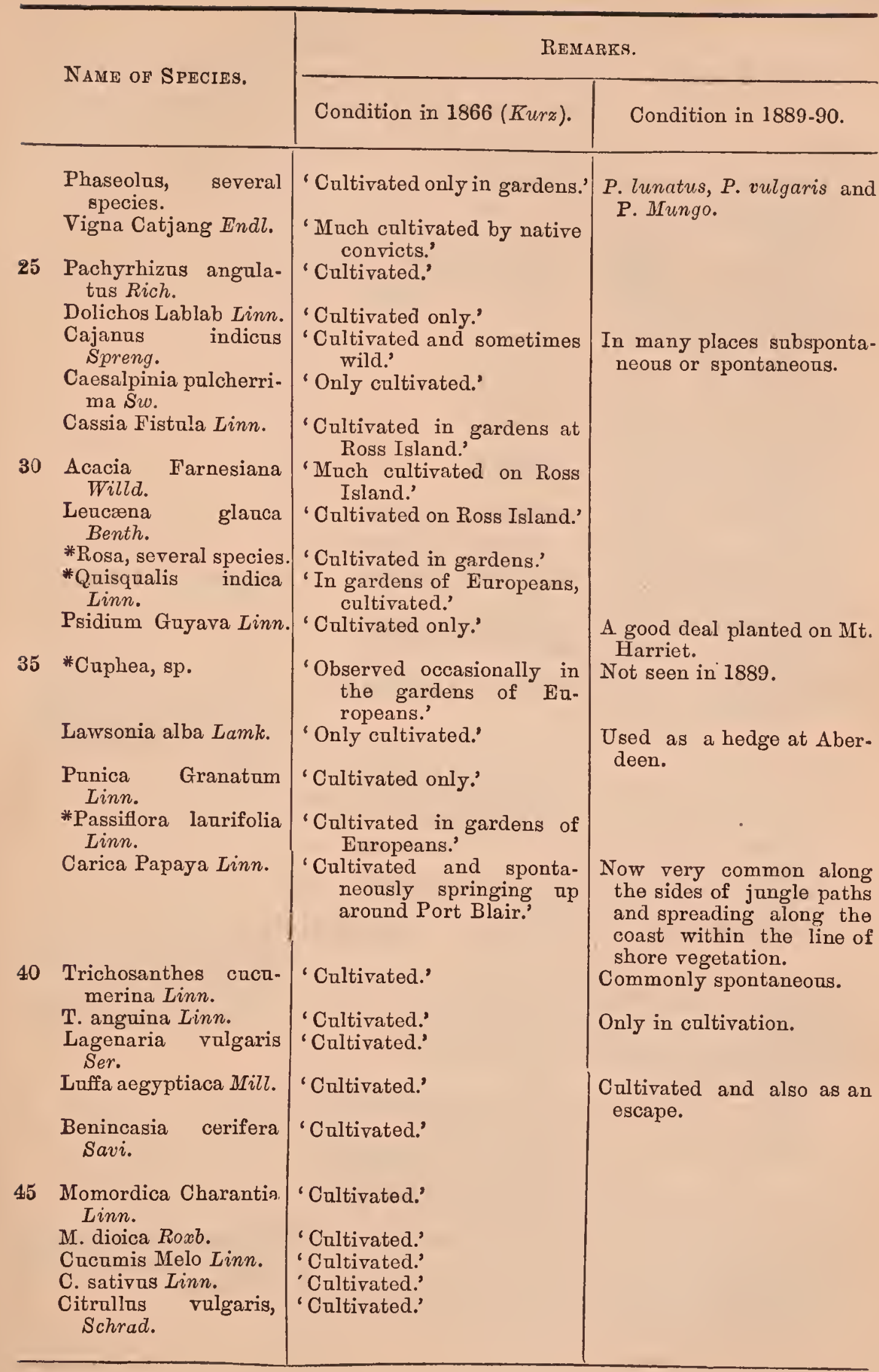




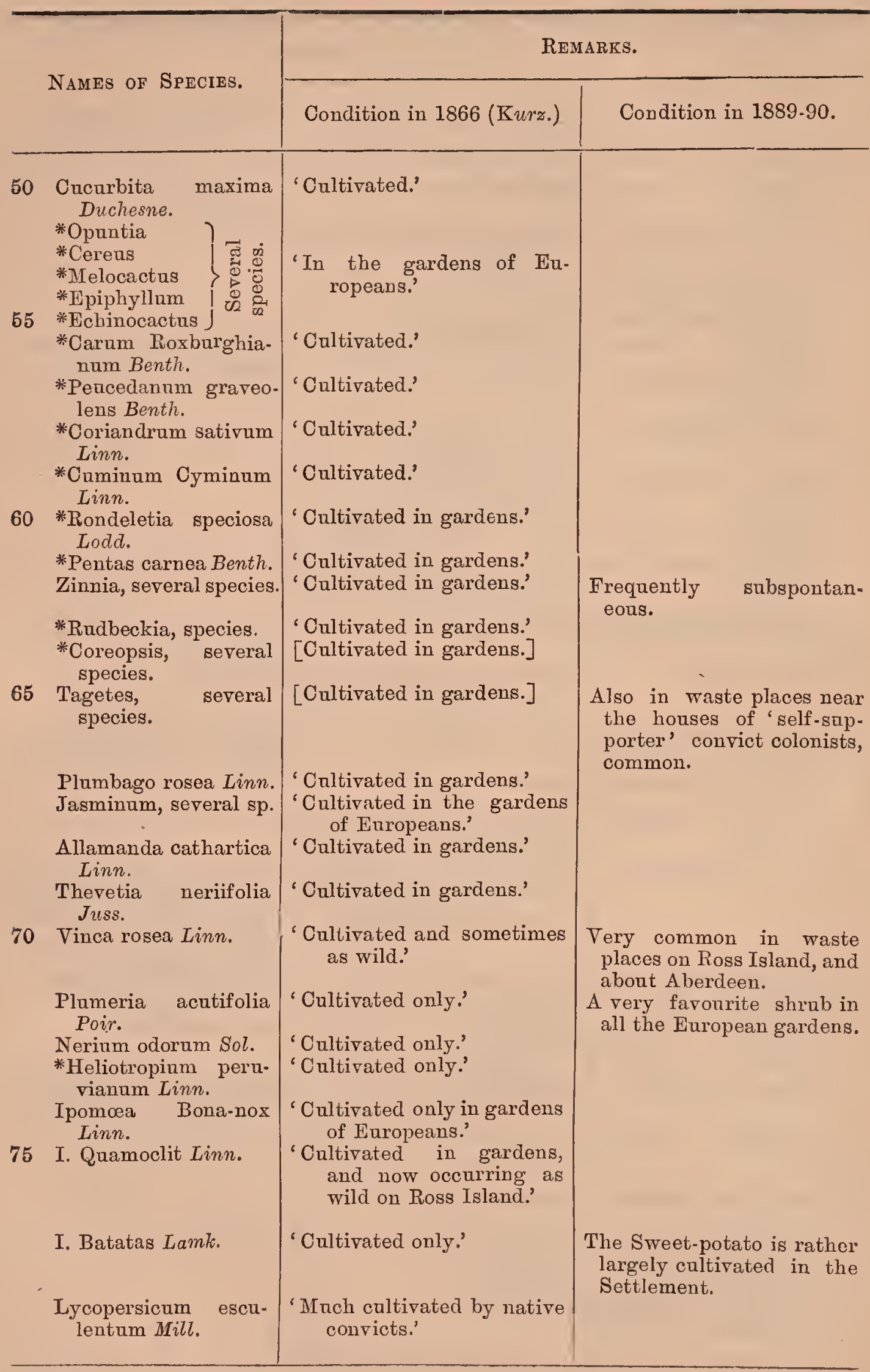




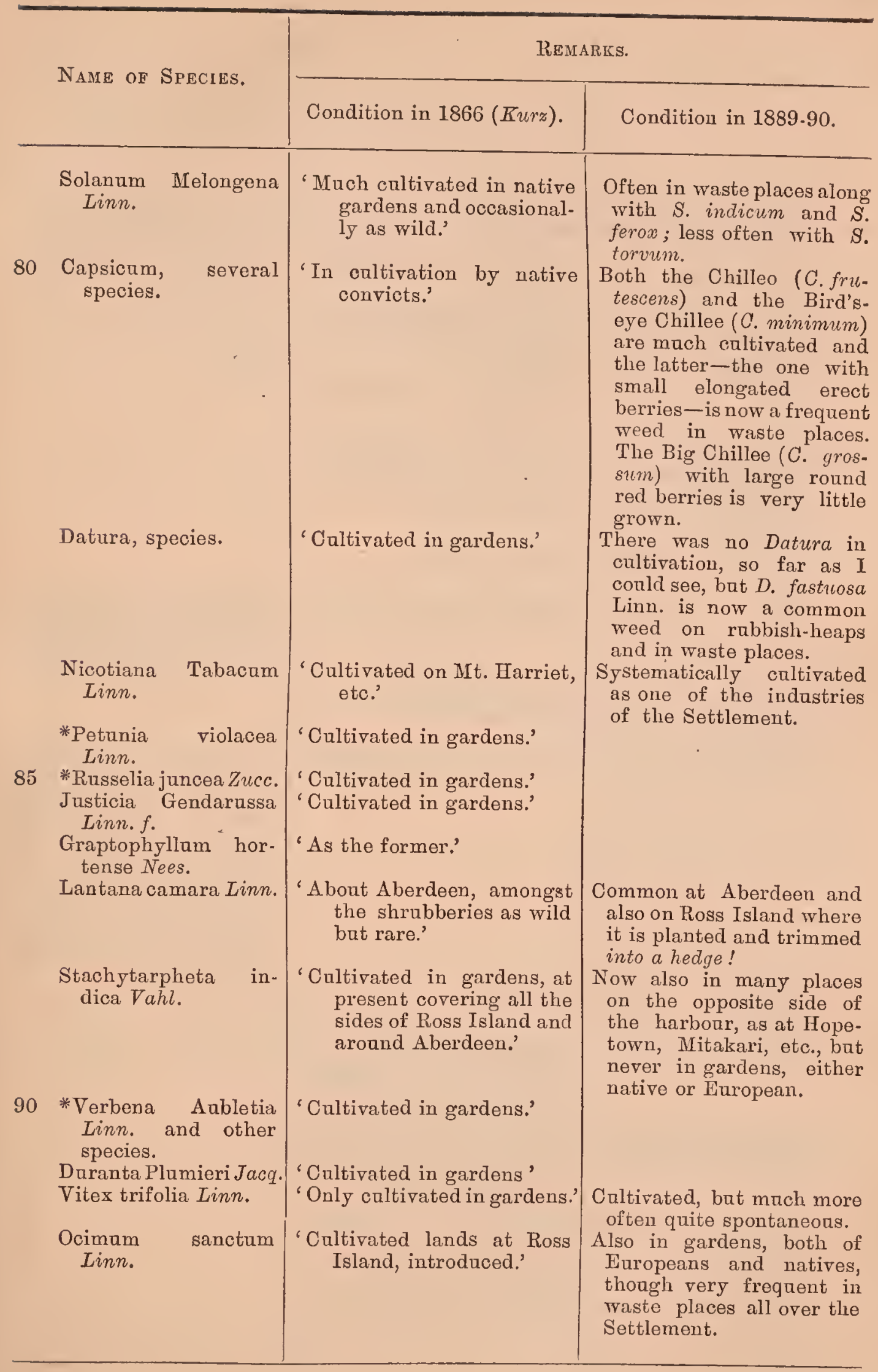




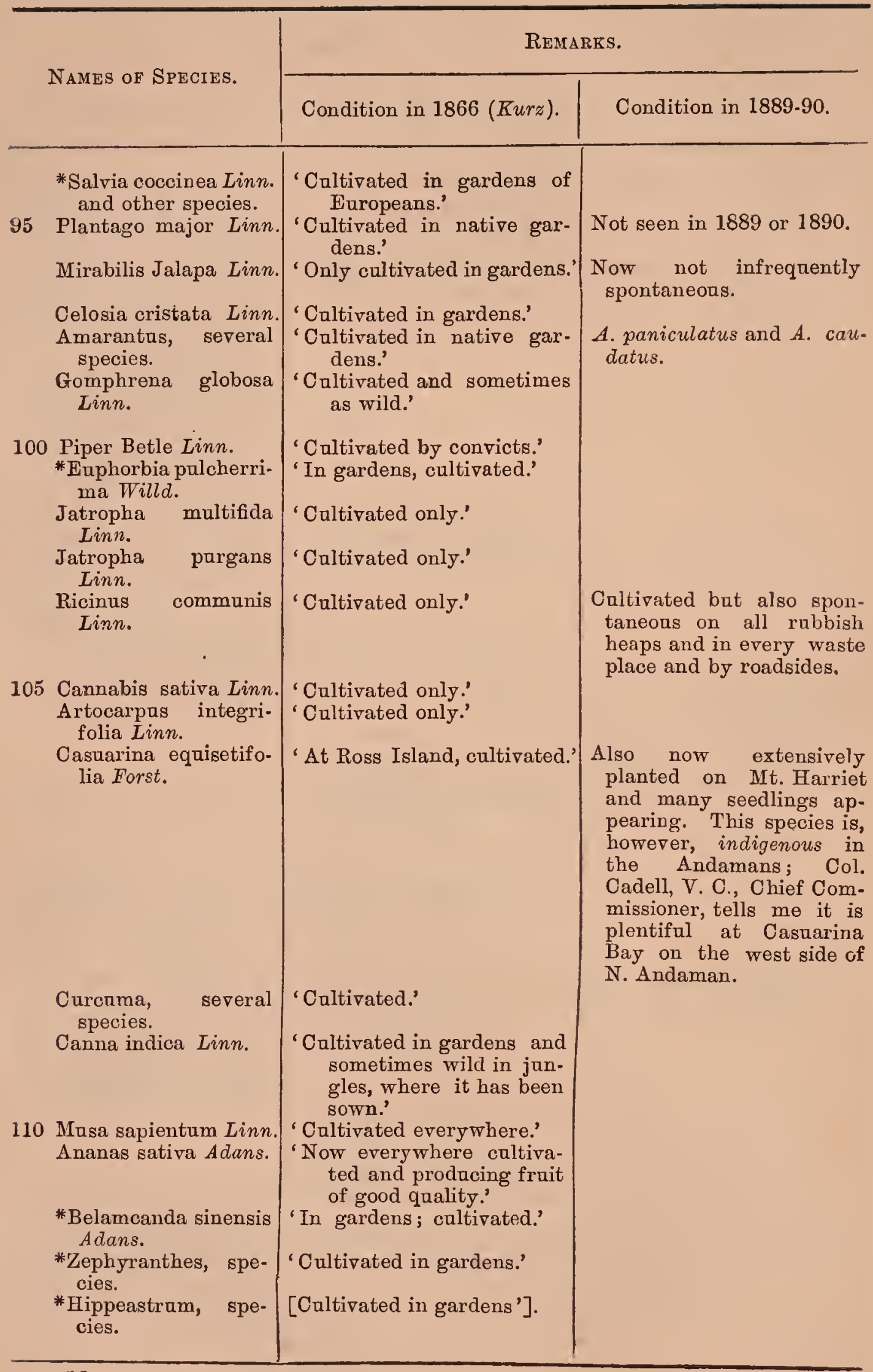




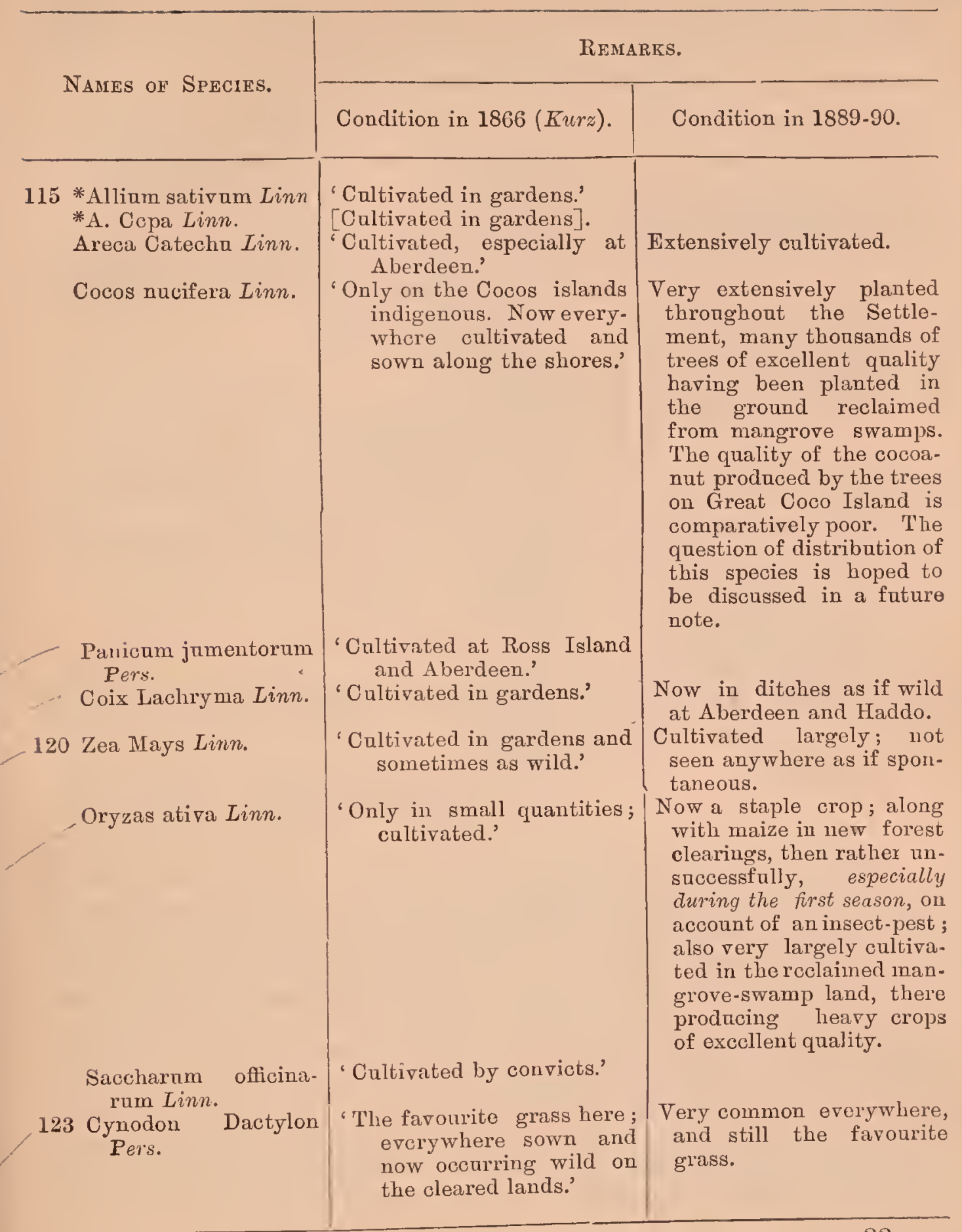


II. Species cultivated or planted, or obviously introduced, seen in 1889 and 1890 not present in 1866.

Names of Species.

Anona reticulata Linn.

125 Garcinia Mangostana Linn. Camellia theifera Griff.

Hibiscus esculentus Linn.

H. Subdariffa Linn.

Durio Zibethinns $D C$.

130 Swietcnia Mahogani Linn.

S. macrophylla King.

* Nepheliam Litchi Camb.

Phaseolus trilobus Ait.

Bauhinia acuminata, Linn.

135 Poinciana regin $B o j$.

Brownea, several varietics.

Amherstia nobilis Wall.

Tamarindus indica Linn.

Saraca indica Linn.

140 Pithecolobium dulce Benth.

P. Saman Benth.
REMARKS.

Cultivated.

Coltivated and doing well.

Systematically cultivated as one of the indus. trics of the Settlement; the tea produced is of excellent quality.

Coltivated in gardens.

Cultivated by conricts.

Cultivated.

Planted.

Planted and thriving well, does much better than the true mahogany.

Caltivated bat with poor results.

Cultivated by convicts, but also very common in waste places as a weed.

Cultivated, but also appearing spontaneously. (K.)

Planted.

Planted.

Planted and thrives very well.

Planted.

Planted.

Planted as a shade-tree and also trinmed as a hedge; many seedlings appearing sponta. neously.

Planted very generally; does well on roadsides and on ground too indiscriminately clearedwhich few native species will.*

* Pithecolobium Saman, the Rain-tree, a native of the West Indies, Central America, Veneznela and Guiana, though yielding a timber useless except as firewood is nevertheless a valuable tree. It is a fast-growing and easily-raised species and, if planted along with morc valuable kinds, forms an effective nurse for these during the carlier years of their growth. It also yields a valuable crop of sweet pulpy pods greedily eaten by cattle. It is said, moreover, to improve the quality of land encrusted with reh inflorescence. The following girth measurements of 13 trees in the Botanic Garden, Calcutta, will give some idea of the rate at which the specics grows. 'T'he measurements in every case are taken at 60 inches from the surface of the soil - the trees measured were not selected (except No. 13 which was added as being the largest in the whole line) but were contiguous trees in the road known as the College avenue. The trees all date from 1876; the measurements were made in January 1890.

$\begin{array}{cc}\text { No. } & 1 . \\ , & 2 . \\ " & 3 . \\ " & 4 . \\ " & 5 . \\ " & 6 . \\ , & 7 .\end{array}$

in.
$5 \frac{1}{2}$
4
4
7
5
6
$10 \frac{1}{8}$

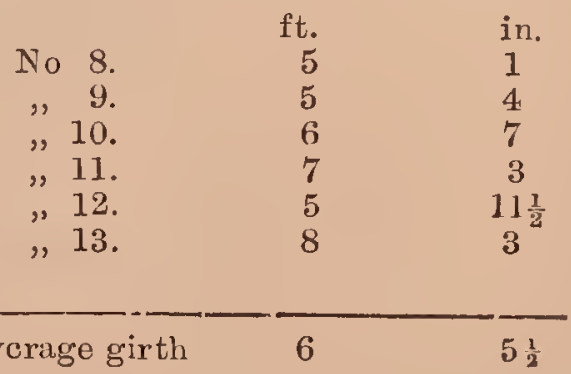


Names of Species.

\section{Remarks.}

Melalenca Lencadendron Linn,

Engenia Jambos Linn.

* Dancrs Carota Linn.

145 Ixora coccinea Linn.

* Coffea arabica Linn.

Carissa Carandas Linn.

Ipomœa coccinea Linn.

Solanum tuberosnm Linn.

150 Physalis peruviana Linn.

Torenia, sp.

Thunbergia alata $B o j$.

T. erecta T. And.

Dredalacanthus salaccensis T. And.

155 Tectona grandis Linn. $f$.

Bongainvillea glabra Choisy.

Deeringia celosioides $B r$.

Cinnamomum zeylanicum, Breyn.

Enphorbia antiquorum Linn.

160 Ficns bengalensis Linn.

F. Rumphii Blume.

F. religiosa Linn.

Ravenala madagascariensis Adans.

Agave vivipara Linn.

165 Dioscorea sativa Linn.

Colocasia antiquorum Schott.

Bambasa Brandisii Munro.

Dendrocalamus strictus Nees.

169 Cephalostachyum pergracile Nunro.

\section{Planted.}

Cultivated.

Cultivated.

Very common in gardens of Europeans.

Cnltivated.

Critivated, not very successfully.

In gardens, brt also a frequent escape.

The notato does very poorly.

Cultivated.

Cultivated, but also often appearing spontaneously.

Cultivated, bnt also appearing as an escape, e. g., at Namuna ghat. (K.)

Planted as a hedge on Mt. Harriet.

Frequent in gardens.

The teak-plantations under the care of the Forest Department are doing exceedingly well.** In gardens of Europeans.

In gardens, but also appearing subspontaneously.

Cultivated and doing very well. (K).

Grown as a hedge-plant.

Planted.

Largely planted on roadsides at Aberdeen nnder the impression that it was the Pípal (F. religiosa).

A few trees only.

Planted.

Very common in gardens of Europeans.

Cultivated.

Caltivated but also appearing spontaneously in marshy spots around Aberdeen.

( These Bamboos have beén planter somewhat $\int$. extensively throughont the Settlement.

These intentionally introduced species belong to three distinct classes :-

1. Such as probably never could become naturalized-truly exotic species, such as temperate vegetables and garden flowers and plants

The name Rain-tree is derived from a phenomenon of condensation or exudation (both explanations have been offered) said to be exhibited by the tree in America; in India nothing of the sort occurs.

* It should be noted also that the Forest Departinent is actively engaged in propagating Padouk, a ver.y valnable indigenons timber tree (Pterocarpus indicus Will.) and that the Andamanese Pyenmah, another good timber tree (Lagerstrcemia hypoleuca Kurz) is extersively planted. 
that affect a drier climate than that of the Andamans; such species have been distinguished by an (*) :-

2. Such as might be expected to hold their own in the struggle for existence should the Settlement happen to be abandoned-a class the precise limits of which cannot be laid down with certainty; this is the class not marked (*) and at the same time not noted as occurring spontaneously; it is moreover from this that the next class is recruited;

3. Such as are naturalized in the Andamans now-the species for which there was evidence either in 1866 or 1890 that spontaneous appearance has actually commenced.

The two former classes do not require further consideration; taken in detail we find that of the last class 14 species were naturalized prior to 1866 . These were :-

Impatiens Balsamina.

Clitoria Ternatea.

Cajanus indicus.

Carica Papaya.

Vinca rosea.

Ipomcea Quamoclit.

Solanum Melongena.
Lantana camara.

Stachytarpheta indica.

Ocimum sanctum.

Gomphrena globosa.

Canna indica.

Cocos nucifera.

Cynodon Dactylon.

Before 1889 14 other species, that had been introduced prior to 1866 but had not at that date become naturalised, had begun to appear spontaneously. These were:-

Bixa Orellana.

Gossypium barbadense.

Moringa pterygosperma.

Trichosanthes cucumerina.

Luffa cegyptiaca.

Zinnia elegans.

Tagetes, sp.

Capsicum minimum.

Datura fastuosa.

Vitex trifolia.

Mirabilis Jalapa.

Ricinus communis.

Casuaria equisetifolia.

Coix Lachryma.

At the same time 9 other species not present in the Andamans at all in 1866 were nevertheless appearing spontaneously in 1890. These were :-

Phaseolus trilobus.

Bauhinia acuminata.

Pithecolobium dulce.

P. Saman.

Ipomcea coccinea.

Torenia, sp.

Thunbergia alata.

Deeringia celosiodes.

\section{Colocasia antiquorum.}

So that in 1890 there were in the Andamans no fewer than 37 species occurring spontaneonsly that had originally been intentionally introduced, as against 14 species of this kind in 1866 .

It is necessary to note further that one species, Zea Mays, which 36 
Mr. Kurz found occurring spontaneously in 1866, was only seen cultivated in 1889 and 1890.

\section{B. WEEDS OR UNINTENTIONALLT INTRODUCED SPECIES.}

III. Species unintentionally introduced prior to 1866.

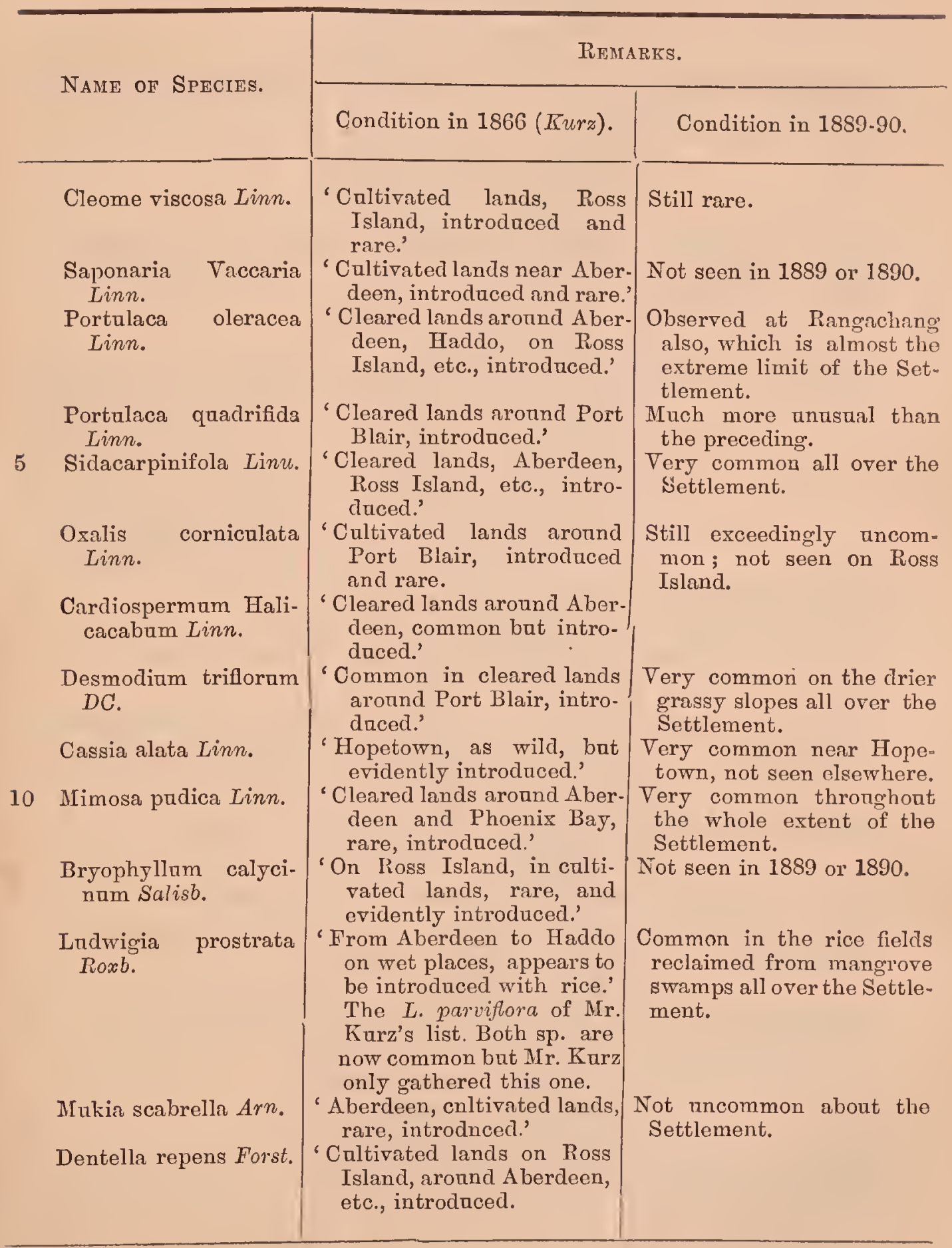




\begin{tabular}{|c|c|c|c|}
\hline & \multirow{2}{*}{ Name of Species. } & \multicolumn{2}{|c|}{ REMARKS. } \\
\hline & & Condition in 1866 (Киэғ.) & Condition in $1889-90$. \\
\hline \multirow[t]{3}{*}{15} & $\begin{array}{l}\text { Oldenlandia corym- } \\
\text { bosa Linn. } \\
\text { Vernonia cinerea Less. }\end{array}$ & $\begin{array}{l}\text { 'Cultivated lands around } \\
\text { Port Blair, introduced.' } \\
\text { 'Common all over the } \\
\text { cleared lands but only } \\
\text { introdnced.' }\end{array}$ & A very common species, \\
\hline & $\begin{array}{l}\text { Elephantopus scaber } \\
\text { Linn. } \\
\text { Ageratum conyzoides } \\
\text { Linn. }\end{array}$ & $\begin{array}{l}\text { 'Ross island in cultivated } \\
\text { lands, rare, introdnced.' } \\
\text { 'Common on cleared } \\
\text { ground, rapidly penetra- } \\
\text { ting into the jungles } \\
\text { whenever a little cleared, } \\
\text { introduced.' }\end{array}$ & Not seen in 1889 or 1890 . \\
\hline & $\begin{array}{l}\text { Blnmea amplcctens } \\
\text { DC. }\end{array}$ & $\begin{array}{l}\text { 'Phonix Bay, cleared lands, } \\
\text { introduced.' }\end{array}$ & $\begin{array}{l}\text { Common everywhere, but } \\
\text { possibly indigenous. }\end{array}$ \\
\hline \multirow[t]{5}{*}{20} & Eclipta alba Hassk. & $\begin{array}{l}\text { 'Common on cultivated or } \\
\text { cleared lands around Port } \\
\text { Blair, introduced.' }\end{array}$ & \\
\hline & $\begin{array}{l}\text { Synedrella nodiflora } \\
\text { Gaertn. }\end{array}$ & $\begin{array}{c}\text { 'Common on cleared lands } \\
\text { around Hopetown and } \\
\text { Aberdeen, introduced.' } \\
\text { (Blainvillea latifolia Kurz, } \\
\text { non DC ); 'cultivated } \\
\text { lands, Ross Island, rare, } \\
\text { introduced'; (Spilanthes } \\
\text { oleracea Kurz, non Linn.). }\end{array}$ & $\begin{array}{l}\text { Extremely common every- } \\
\text { where and in two striking- } \\
\text { lydistinctconditions; one, } \\
\text { the gentinc plant, and an- } \\
\text { other, larger in habit and } \\
\text { ranker of growth bat } \\
\text { smoother in all its parts, } \\
\text { strikingly like Blainvillea } \\
\text { latifolia at first sight. }\end{array}$ \\
\hline & $\begin{array}{l}\text { Centipeda orbicularis } \\
\text { Lour. }\end{array}$ & $\begin{array}{l}\text { 'Cultivated lands on Ross } \\
\text { Island, aronnd Aberdeen, } \\
\text { etc., introduced.' }\end{array}$ & \\
\hline & $\begin{array}{l}\text { Ileliotropium indicum } \\
\text { Linn. }\end{array}$ & $\begin{array}{l}\text { 'Cultivated lands around } \\
\text { Aberdeen, rare and intro- } \\
\text { duced.' }\end{array}$ & Not very common. \\
\hline & $\begin{array}{l}\text { Cynoglosstum micran- } \\
\text { thuin Desf. }\end{array}$ & $\begin{array}{l}\text { 'Between Aberdeen and } \\
\text { Phonix Bay, I snspect } \\
\text { introduced only, as I saw } \\
\text { it nowhere else.' }\end{array}$ & $\begin{array}{l}\text { Not seen in November, } 1889 \\
\text { found in April, } 1890 .\end{array}$ \\
\hline \multirow[t]{5}{*}{25} & Solanum nigrum Linn. & $\begin{array}{l}\text { 'Cultivated lands around } \\
\text { Aberdeen, rare, intro- } \\
\text { troduced.' }\end{array}$ & Very common. \\
\hline & Solanum torvum $S w$. & 'Around Aberdeen, etc. ; & Very cominon. \\
\hline & $\begin{array}{l}\text { Solanum xanthocar- } \\
\text { pum Schrad. }\end{array}$ & $\begin{array}{l}\text { 'Cleared lands around } \\
\text { Phœenix Bay and Aber- } \\
\text { deen; introduced.' }\end{array}$ & Not at all common. \\
\hline & $\begin{array}{l}\text { Angelonia salicariae- } \\
\text { folia } H . B . \& K\end{array}$ & $\begin{array}{l}\text { 'Common in cultivated lands } \\
\text { on Ross Island; intro- } \\
\text { duced.' }\end{array}$ & Not common. \\
\hline & Mazus rugosus Lour. & 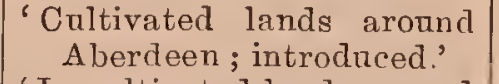 & \\
\hline 30 & $\begin{array}{l}\text { Vandellia crustacea } \\
\text { Benth. } \\
\text { Bonnaya vcronica- } \\
\text { folia Benth. }\end{array}$ & $\begin{array}{l}\text { 'In cultivated lands around } \\
\text { Port Blair ; introdnced.' } \\
\text { ' Cultivated lands around } \\
\text { Aberdeen ; introduced.' }\end{array}$ & \\
\hline
\end{tabular}




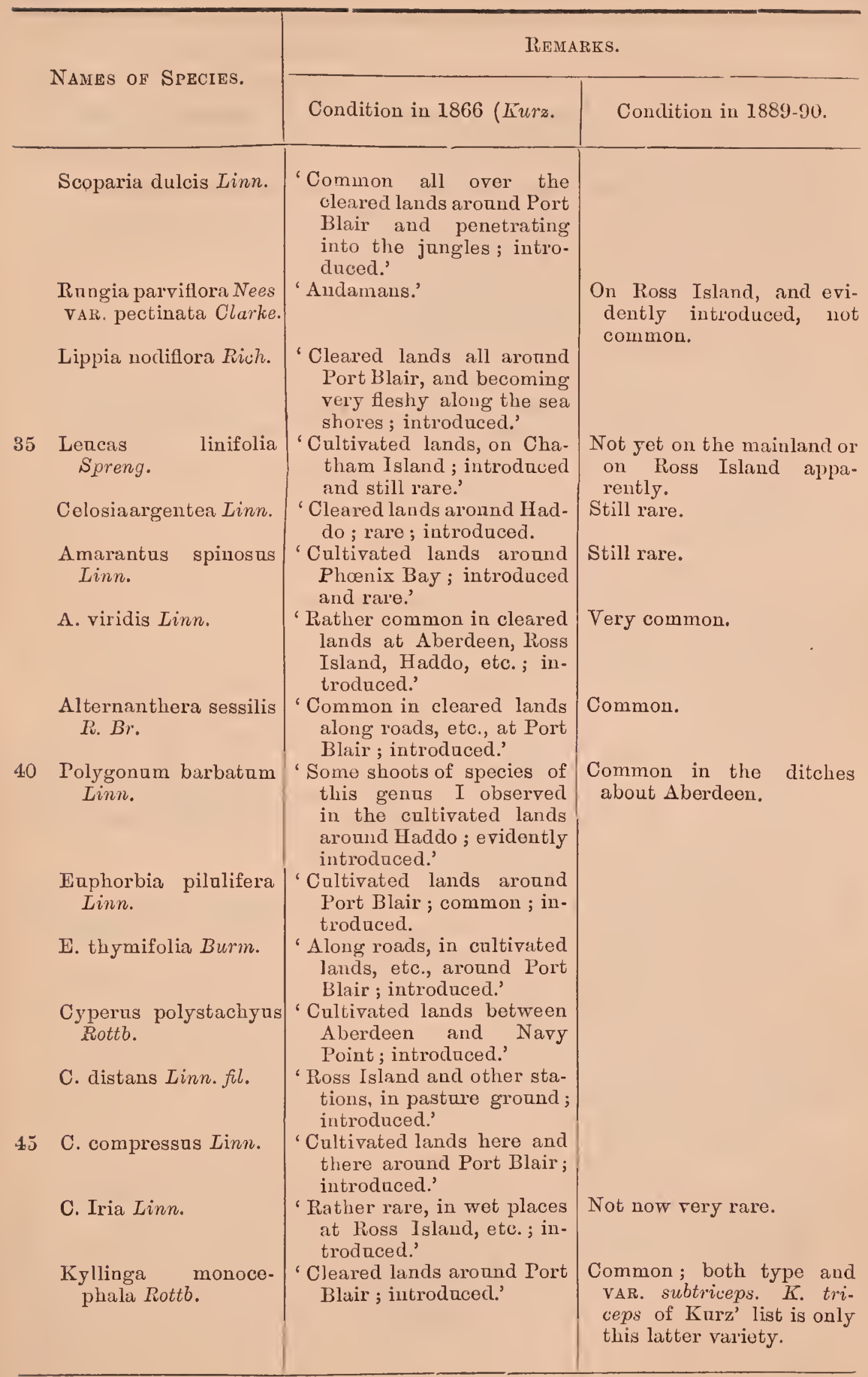




\section{REMARKS.}

\section{Names of Species.}

\begin{tabular}{l|l|l}
\hline NAMES OF SPECIES. & Condition in 1866 (Kurz.) & Condition in 1889-90. \\
\hline
\end{tabular}

Fimbristylis diphylla Vahl.
'Common all over' the cleared lands around Port Blair ; introdnced.' The $F$. miliacea of Kurz' list is only another state of this species and is not $F$. miliacea of Vahl.

Paspalum filiculmum Nees.

P. scrobiculatum Linn.

Eriochloa Nees.

Panicum Linn.

P. ciliare Retz.

P. sangainale Linn.

55 Andropogon pseudoischæmam Nees.

A. contortum Linn.

Chrysopogon acicalatum Trin.

Sporobolus diander Trin.

Eleusine indica Gaertn.

60 E. aegrptiaca Pers.

61

Leptochloa filiformis R. $\mathrm{Br}$.
' On Ross Island; introduced.'

'Cultivated lands around Port Blair ; introduced.

'On Ross Island; introduced.' etc., in caltivated lands; introduced.'

'Common in cultivated lands around Port Blair; introdaced.'

'Cultivated lands around Pcrt Blair ; introduced.'

'Cultivated lands and gardens at Ross Island; introduced.'

' Only in garden land on Ross Island ; introduced.'

'Common on Chatham Island ; introduced.'

'Common on Chatham Island ; introduced.'

'Cultivated lands everywhere around Port Blair; introduced.'

'Cultivated lands on Ross Island ; introduced.'

'Along the path from Phœnix Bay to Aberdeen; scarce; introduced.'
'South Point, Aberdeen,
Perhaps indigenous.

Common.

Also about Aberdeen.

Common everywhere.

Common throughout the Settlement.

Very common throughout the Settlement.

Common every where around Port Blair.

IV. Species unintentionally introduced between 1866 and 1890.

NAME of SPECIES.

Sida rhombifolia Linn.

Melochia corchorifolia Linn.

Triumfetta rhomboidea Jacq.

65 Crotalaria retusa Linn.

\section{REMARKS.}

Everywhere throughout the Settlement and quite as common as $S$. carpinifolia is.

Occasional.

On Ross Island, and also at Aberdeen, not yet very comnion.

Not infrequent about Aberdeen, not seen in cultivation. 
Smithia sensitiva Linn.

Desmodium polycarpon $D C$.

D. auricomum Grah.

Alysicarpus vaginalis $D C$.

70 Cassia occidontalis Linn. C. Tora Linn.

Ammannia baccifera Linn. Jussiæa suffraticosa Lamk.

Ludwigia parviflora Roxb.

75 Hydrocotyle asiatica Linn.

Oldenlandia diffusa $R o x b$.

O. crystallina Linn.

O. paniculata Linn.; forma ' minima' = Hedyotis minima Burm.

Adenostemma viscosum Forst.

80 Blumea glomerata $D C$.

Wedelia calendulacea Less.

Cosmos sulphureus Cav.

Tridax procumbens Linn.

Crepis japonica Benth.

85 Sonchus arvensis Linn.

Launea nndicanlis Less.

Ipomœa aquatica Forsk.

Solanum ferox Linn.

S. indicum Linn.

90 Physalis minima Linn.

Striga lutea Lour.

Sosamum indicum $D C$.
Common on dry grassy slopes at Aberdeen.

Common at North Bay and on the cleared hill. sides above. Not met with by Mr. Kurz, bat, perhaps, it may be indigenous for it also occurs on Great Coco Island and Barren Island.

Common along with Smithia and with Desmodium triflorum. It is rather an interesting addition to the Flora; for though a mere weed this plant has hitherto only been collected in Tenasserim, Martaban and Arracan.

Common on grassy slopes (K.)

Common (K.).

Very common everywhere.

In wet places, not uncommon.

In wet places, along with the two Ludwigias and mnch more plentiful than either.

Common in ricefields, but not quite so frequent as $L$. prostrata.

Common on stone walls and roadsides all over Ross Island, but not yet present on the mainland or on the other islands.

Aberdeen etc., not very common.

The commonest Oldenlandia on Ross Island. The commonest both at Aberdeen and on Mt. Harriet is O. corymbosa.

Common on Ross Island and obtained both by the writer in 1889 and by Dr. King in 1890.

Only met with in one place on a rubbish heap Ross Island.

Common on Ross Island, etc., (K.).

Ross Island only (K.)

Very common on hill sides and waste places. This the writer was assured had never been grown as a garden plant. It forms large patches where it occurs, the individual plants being 6 to 10 feet in height.

Common on Ross, not jet common on the mainland.

Introduced at Aberdeen (K.).

Common in gravel pits on Mt. Harriet.

Both on Ross and at Aberdeen (K.).

Jn ponds at Aberdeen; the modo of introdnction of this species is open to question. It may have been introdnced by birds, but it may equally well have becn introduced as a weed.

Very common all over the settlement on drier hill sides along with $S$. torvum.

Quite as common as the preceding. [S. nigrum and $S$. xanthocarpum, though introduced bofore 1866 , arc by no means so frequent.]

Not at all common.

Common on dry hill sides at Aberdeen, parasitic on introduced grasses.

Frequent (K.). 


\section{$\frac{\text { Names of Species. }}{\text { Phaylopsis parviflora Wiild. }}$}

Hygrophila quadrivalvis Nees.

95 Lippia geminata H. B. $K$.

Hyptis brevipes Poit.

Børhaavia repens Linn.

Aerua lanata Juss.

Achyranthes aspera Linn.

100 Phyllanthus urinaria Linn.

Monochoria vaginalis Prest.

Paspalum distichum Linn.

P. pedicellatum ITees.

Panicum erncæeorme Sibth.

105 P. excurrens Trin.

P. longipes $W . \& A$.

P. myosuroides $R . B r$.

Imperata cylindrica Kunth.

Rottbollia exaltata Linn.

\section{ReMaRKS.}

Rare, on Ross only (K.).

Common in wet places along with Jussioe a and Ludroigia.

At Namuna ghat $(\mathrm{K})$, rare.

Common (K.).

Not common and not met with by Mr. Kurz; it may, however, be indigenons; it certainly seems to be so on Great Coco Island.

Not very common.

Very common in every part of the settlement and penetrating into the jungles.

Common on Ross and on Mt. Harriet; not so plentiful at Aberdeen.

In ponds at Aberdeen ; perhaps introduced by means of wading-birds.*

Common on Ross and at Hopetown.

Common on Ross, not seen elsewhere.

Aberdeen, common.

By edge of pond at Aberdeen.

On Mt. Harriet.

Very common.

Common everywhere.

Common in marshy ground about Aberdeen and Haddo.

* There is another species that has, however, been exclnded from this list, because neither Dr. King in 1890 nor the writer in 1889 met with it, to which the same remark applies. This species is Barcluya longifolia. The Andamans is first given as a locality for this species in King: Materials for a Flora of the Malayan Peninsula, p. 34. The Andamans specimens were obtained by one of Dr. King's garden collectors in 1884 in a ditch among rice-fields near Haddo. It may be said with something like certainty that the species was not there in 1858; at all events there was no rice-field and no ditch then. And it is almost as certain that it was not present in 1866, for Mr. Kurz, as his Report shews, gave particular attention to aquatic vegetation, jet he did not meet with it. Probably the ditch where Dr. King's collector found Barclaya, like the pond where the writer found MIonochoria and Ceratopteris, did not exist at all in 1886. Another circumstance that tends to con. firm the idea of the introduction being recent is that it does not appear to be present in any of the ditches or ponds examined by the writer in 1889 , and Dr. King, to whom this fact was particnlarly mentioned, and who looked for Barclaya with especial care in 1890, was equally unsuccessful in his search. It may, therefore, be safely presumed to be still quite local. For the appearancc of Barclaya, as for that of Monochoria, bird-agency at once suggests itself; introduction by indirect human agency is not, however, precluded in cither case. Allowing the mode of introduction to be a point altogether doubtful, there still remains an interesting fact-this species (like Desmodium auricomum) is one hitherto only known from the opposite shores of the Andaman Sea. And this fact weakens the evidence from other sources as to introduction; for it is the Burmese, and particnlarly the PeguTenasserim element, that seems to predominate in the indigenous Andaman flora. 


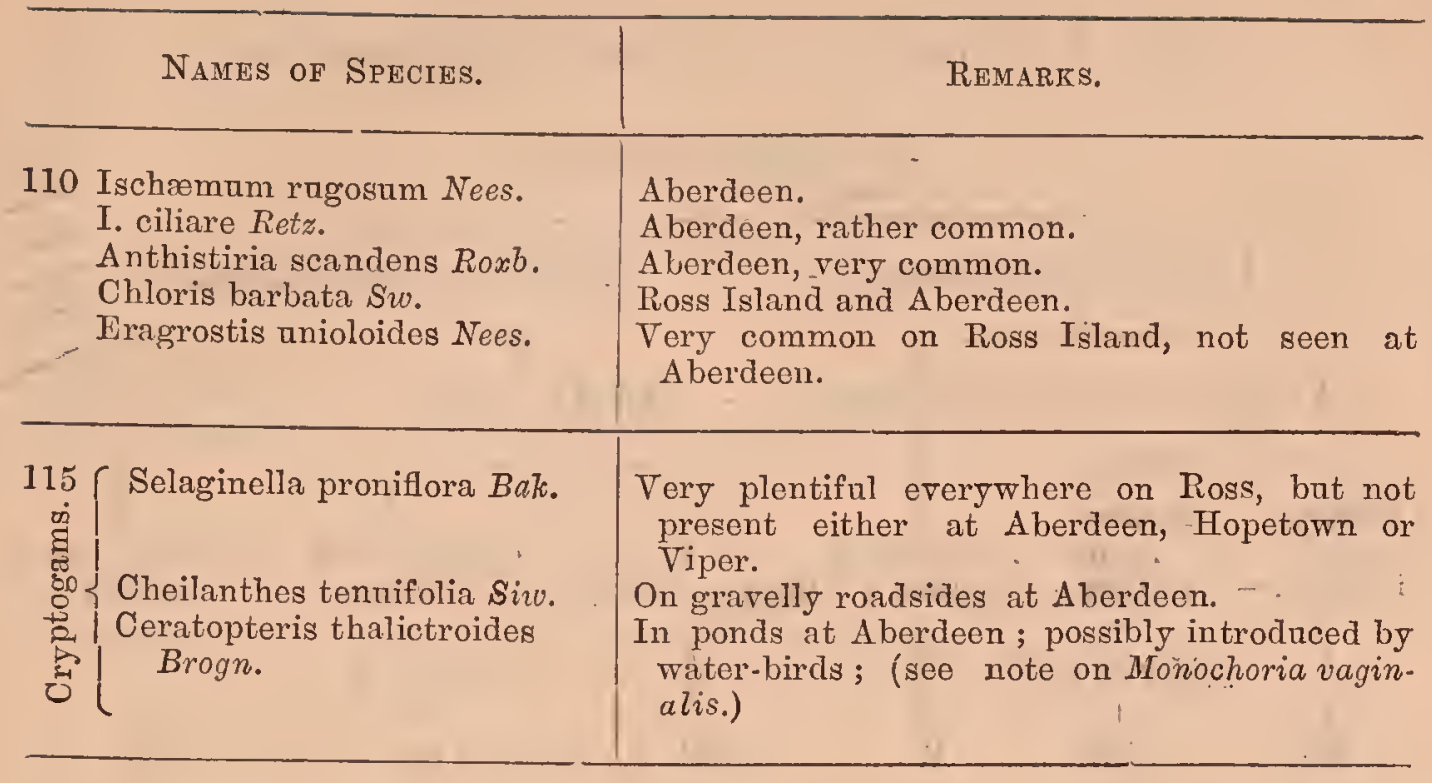

Comparing the state of affairs in 1866 with that prevailing in 1890 we find that at the former date there were present in the Andamans 61 weeds of cultivation of which 58 were again met with, either in November 1889 or $^{\circ}$ in April 1890. But too great weight should not be placed on the absence of any plant, since it is quite possible that in visits of such short duration as those of the writer and Dr. King species that are not very common might easily be overlnoked.

In November 1889 and in April 1890, on the other hand, we find that not only were 58 , or $95 \%$, of the weeds of 1866 , present, but that 56 others had found their way into the settlement during the interval between 1866 and 1890.

Briefly reviewed the results indicated by these four lists are :-

1. That in 186615 intentionally introduced plants and 61 weeds of cultivation had apparently or actually become : so established in the Andamans that, though not indigenous plants, they had become an integral portion of the Andamans flora.

2. That by 189014 more of the plants intentionally introduced prior to, but only seen under cultivation in, 1866 had become similarly naturalised; that along with these 9 species, intentionally introduced during the interval between 1866 and 1890 , had begun to appear spontaneously; also, that during the same interval 56 more weeds had been introduced.

3. That, on the other hand, a species appearing spontaneously in 1866 was only seen cultivated in 1890 , and that three of the 1866 weeds were not met with in 1889 or 1890 .

The subjoined table exhibits the intrusion of the non-indigenous element at present existing in the flora of the Andamans. 
TABLE I. Intrusion of non-indigenous Andamans plants.

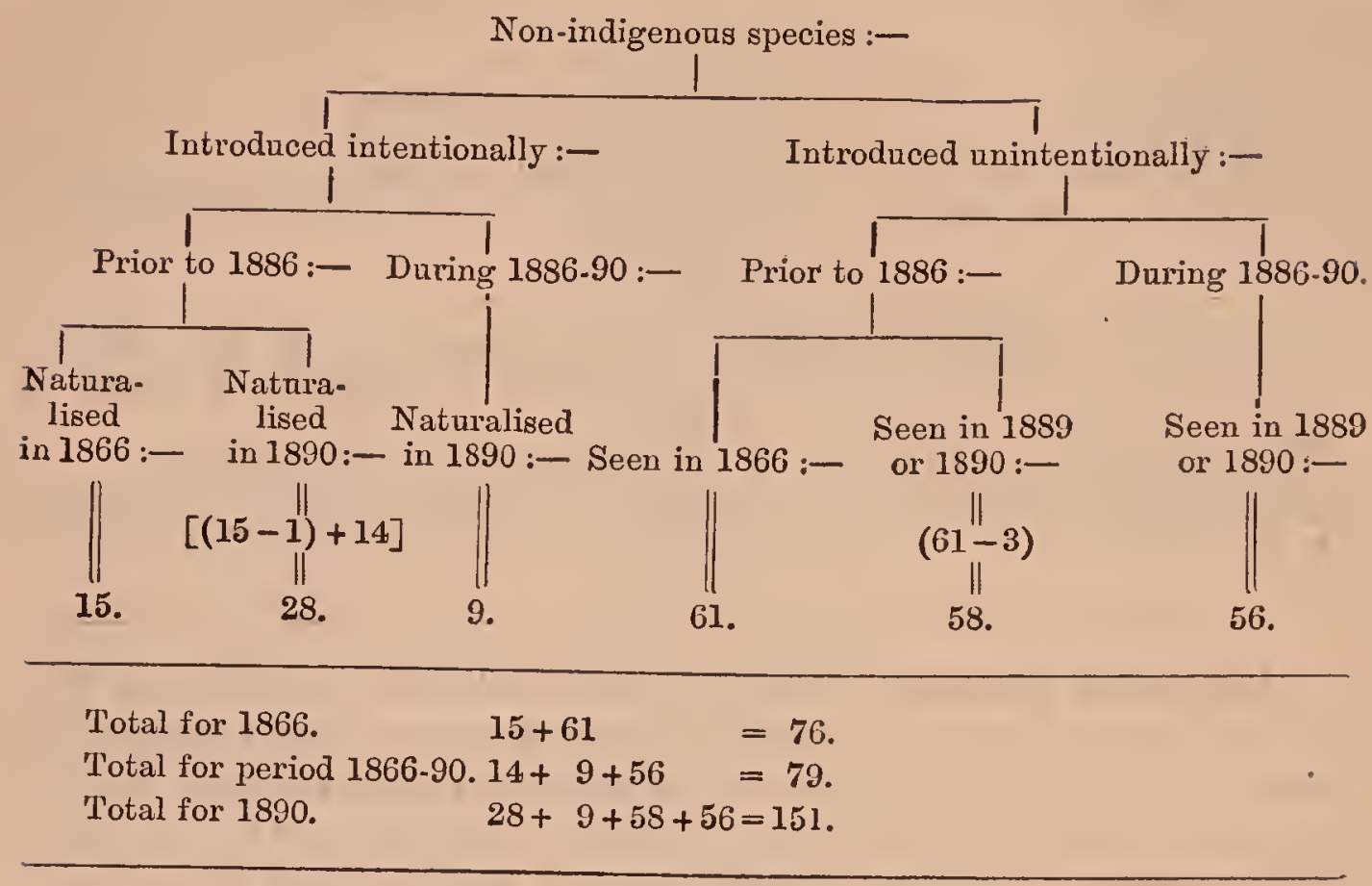

During his stay in the Andamans in $1866 \mathrm{Mr}$. Kurz observed 520 indigenous species. But he has pointed out (Report, p. 19) that this "is only an approximation to the actual number existing on the is"lands." Since 1866 the number of indigenous species has been raised to about 600 . Mr. Kurz has recorded the number of species found growing on 100 square yards in a suitable locality in the interior on the eastern side of the island and not far from Aberdeen. He shews (Report, p. 21) that an estimate based on this record and extended to the rest of the islands of the Andaman group gives scarcely more than 600 or 700 species for the whole. At the same time, he thinks that an estimate of the same kind deduced from the conditions that prevail on the western side of the island would give quite other results, and, taking everything into consideration, he concludes that "the number of really "indigenous phænogamic plants may range between 1500 and 1800 "species." In all probability the second estimate is too high and perhaps a number nearer 1000 will be ultimately found to express the actual total of indigenous phanerogams. But the question need not be discussed here, and if in the meantime absolute records of the appearance of non-indigenous species be supplied, the precise proportion of introduced to indigenous species at various periods in the history of the islands can easily be ascertained when their flora shall have been completely investigated.

44 
But a relative proportion is only less useful than an absolute one would be, and if we take 1000 as a convenient approximation to the actual total we may compare the state of affairs in 1866 with that in 1890. In this case we must confine ourselves to introduced phanerogams only, and exclude the three cryptogams that have been introduced during the interval between 1866 and 1890. The following are the results :-

1866. Proportion of introduced to indigenous species $=\frac{76}{1000}$ or, $1: 13$.

$$
\text { Percentage of introduced species } \quad=\frac{76}{1076} \text { or, } 7.06 \% \text {. }
$$

1890. Proportion of introduced to indigenous species $=\frac{146}{1000}$ or, $1: 7$.

" Percentagc of introduced species

$$
=\frac{146}{1146} \text { or, } 12 \cdot 74 \% \text {. }
$$

The greater number of these introduced plarts are herbaceous; but the proportion of woody species is slowly increasing, as the following figures shew :-

1866. Proportion of woody to herbaceous species $=\frac{2}{74}$ or, $1: 37$.

" Percentage of woody species

$$
=\frac{2}{76} \text { or, } 2 \cdot 63 \% \text {. }
$$

1890. Proportion of woody to herbaceous species $=\frac{7}{139}$ or, $1: 20$.

" Perccntage of woody species

$$
=\frac{7}{146} \text { or, } 4.79 \% \text { 。 }
$$

Human agency is responsible for the introduction of the whole of this non-indigenous element in the Flora of the Andamans. That it is directly responsible for the introduction of such species as have been intentionally introduced that have subsequently become spontaneous is self-evident; that it is equally directly responsible for the unintentionally introduced weeds is hardly less plain. They are with very few exceptions the commonest of Indian road-side and rice-field weeds whose seeds would readily be found mixed with imported grain or attached to the belongings of convict immigrants or of the police sepoys of the Settlement. This mode of introduction explains not only the occurrence of the weeds of dry ground but of the majority of the marsh species, such as Hygrophila, Jussicea, Ludwigia, as well. And species of the only class for which this explanation is not altogether satisfactory-water-plants like Monochoria, Ceratopteris, or Ipomcea aquatica-nevertheless owe their introduction indirectly to human agency, 
since but for the existence of the Settlement the ditches and pools in which they occur would not exist. The agency of winds, so often supposed to be highly effective, suggests itself for very few of the species, the most probable being the Selaginella and the Cheilanthes,almost the only posssible one among phanerogams being the Calotropis. But if these be wind-introduced species then as regards all three the questions at once arise;--why were they not to be found in 1866 ? and, why are they only to be found within the limits of the Settlement now? And as regards Selaginella a closer enquiry makes the agency of wind highly improbable, for it is as yet only to be found on Ross Island, although there, as it happens, it is exceedingly common. Now Ross Island is the part of the Settlement that is in immediate intercourse with Burma and India, and unless it has been imported as a weed one can hardly explain its absence from the rest of the Settlement where the conditions are quite as favourable for its existence as they:are on Ross. As regards Calotropis too there is a striking fact to record. It happens to be the chief food-plant of a particular species of butterfly-Danais genutia-which is dispersed throughout India and Burma. This butterfly was long supposed to be absent from the Andamans, but within the past few years it has bcen sparingly reported thence.* It thus seems as if till the establishment of its food-plant in the Settlement this butterfly was not known from the Andamans. To what agency the introduction of Danais genutia itself is due it is foreign to the purpose of this paper to enquire, but it is a suggestive fact that once the food-plant had become established the butterfly appeared. And the absence of the butterfly while there was no evidence of the presence of the plant seems presumptive evidence that the plant was not present till very recently, and that, therefore, human agency is not merely indirectly responsible for its introduction, by providing conditions suitable for the survival of wind-conveyed seeds, but is dirently responsible, from the unintentional conveyance of its seeds along with grain or in some other way. For it is long since these suitable conditions have come into existence, and wind-agency, if a factor at all, is in these latitudes a fairly constant one.

Human agency being so completely responsible, one might hope that the channels of introduction of particular species, which must coincide with the routes of traffic between the Settlement and the adjacent mainland, could be easily ascertained. But this is far from being the case. These traffic routes are :-

* This information was offered by Mr. L. de Nicóville in the course of a brief conversation that followed the reading of this paper at the meeting of the Asiatic Society of Bengal in April 1890. 
1. Calcutta to Port Blair; implying introduction from Northern India and especially the Gangetic plain. Burma.

2. Port Blair to Rangoon; implying introduction from Lower

3. Port Blair to Madras; implying introduction from Southern India.

4. Moulmein to Port Blair; implying introduction from Tenasserim-a route used by native craft.

5. Port Blair to the Nicobar Islands ; implying introduction from these-the Nicobars are a dependency of the Settlement at Port Blair.

The distribution of the majority of these introduced species is so wide that (with the exception of 4 species whose introduction has almost certainly been confined to the Rangoon or the Moulmein route and other 4 almost certainly restricted to the Madras or the Calcutta route) any one of them may have equally well reached the Settlement by any or all of these routes. This is best shewn by a tabular view of the species thus introduced.

TABLE II. Distributional features of the Non-indigenous element in the Flora of the Andamans.

\begin{tabular}{|c|c|c|c|}
\hline \multicolumn{3}{|c|}{ 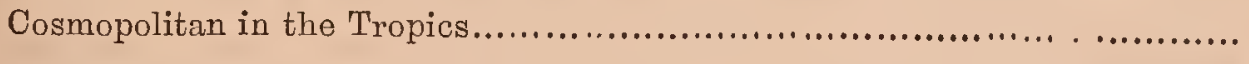 } & 62 \\
\hline \multicolumn{3}{|c|}{ 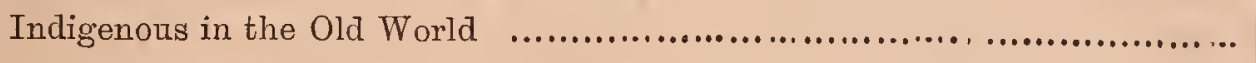 } & 65 \\
\hline 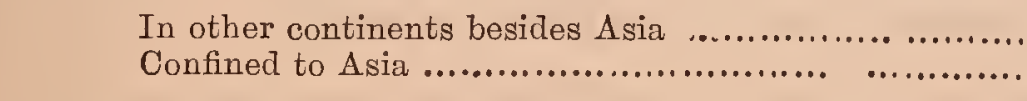 & (n... & $\begin{array}{l}36 \\
29\end{array}$ & \\
\hline 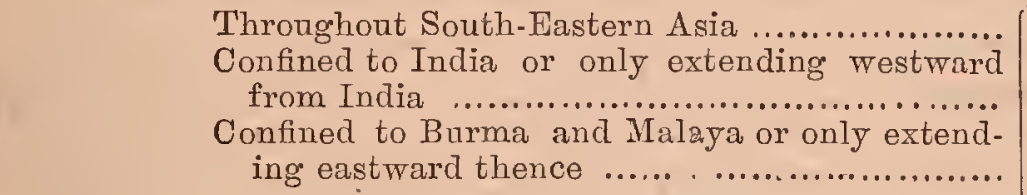 & $\begin{array}{l}21 \\
4 \\
4\end{array}$ & & \\
\hline Indigenous in the New World, but now cosmopolitam or nea & & & 19 \\
\hline
\end{tabular}

It may therefore be concluded that there is a practical indifference displayed as regards route; here, as everywhere else, when man is engaged in cultivation he involuntarily introduces weeds, and here as elsewhere a certain proportion of the species introduced by him for economic or for aesthetic reasons escape and become spontaneous.

It has been already said that the present Settlement occupies the site of an carlier one. This earlier settlement was founded under the 
name of Port Cornwallis by Lieut. Blair* in 1789, in obedience to orders issued in September of that year. In November 1792 orders were issued for the removal of the Settlement to another and more spacious harbour in North Andaman; to this new settlement the original name Port Cornwallis was again applied. It is nowhere distinctly stated, though, considering the transfer of name from the old settlement to the new, it is highly probable, that old Port Cornwallis was entirely abandoned in 1792. We know, however, that in 1796 orders were issucd for the removal of the whole establishment to Penang. The doubtful point, so far as our present enquiry is concerned, is the length of time prior to the establishment of the present Settlement that its site was exposed to influences favourable for the active introduction of non-indigenous species. But we know that altogether these influences only existed for six seasons and could only have been active during three seasons; probably they only existed at all during these three seasons. The present Settlement was commenced in March 1858; Mr. Kurz visited it during AprilJuly 1866 ; to the eight seasons (1858-66) that had passed between the foundation of the Settlement and the date of that visit we must therefore add three more seasons (1789-92) in order to make up the whole period during which the non-indigenous species recorded by Mr. Kurz were being introduced. Even if the original site was not wholly abandoned in 1792 the subsequent seasons (1792-96) may be neglected without producing any appreciable error. Assuming, therefore, that a period of eleven seasons has been responsible for the naturalisation and introduction of the species in the two lists for 1866 we are able to calculate the rates of these processes and to compare them with the rates between 1866 and 1890. These are shewn in the following table:-

TABLE III.-Rate of Introduction of Non-indigenous Species.

\begin{tabular}{|c|c|c|c|c|}
\hline \multirow[t]{2}{*}{$\begin{array}{l}\text { Non-indigenons species na- } \\
\text { turalised. }\end{array}$} & \multicolumn{2}{|c|}{$\begin{array}{c}\text { DuRing Period I. } \\
\text { Prior to } 1866(1789-92+ \\
1858-66)=11 \text { seasons. } \\
\end{array}$} & \multicolumn{2}{|c|}{$\begin{array}{c}\text { DURing Period II. } \\
\text { Bet. } 1866 \& 1 \text { \& } 90,(1.866-90) \\
=24 \text { seasons. }\end{array}$} \\
\hline & $\begin{array}{l}\text { No. } \\
\text { of species. }\end{array}$ & $\begin{array}{c}\text { Rate } \\
\text { per annum. }\end{array}$ & $\begin{array}{c}\text { No. } \\
\text { of species. }\end{array}$ & $\begin{array}{c}\text { Rate } \\
\text { per annum. }\end{array}$ \\
\hline $\begin{array}{l}\text { Cultivated plants introduced } \\
\text { during Period I ... } \\
\text { Cultivated plants introduced } \\
\text { during Period II } \\
\text { Weeds of cultivation }\end{array}$ & $\dddot{61}$ & $\dddot{5} \cdot{ }_{54}$ & $\begin{array}{r}9 \\
56\end{array}$ & $\begin{array}{l}0.58 \\
0 \cdot 37 \\
2 \cdot 33\end{array}$ \\
\hline Totals $\ldots$ & 76 & $6 \cdot 90$ & 79 & $3 \cdot 28$ \\
\hline
\end{tabular}

* The name of the 1789 Settlement having been transferred to the one founded in 1792 , the present Settlement, which occupies the site of the 1789 one and which dates from March 1858, has been named PoRT BLAIR in honour of the original founder. The name Port Cornwallis is still used to designate the site of the Settlement in North Audaman that existed from 1792 to 1796. 
The rate per annum for the second period requires a slight correction by the deduction from it of the rate per annum of disappearance of naturalised species. We have seen that one introduced plant occurring spontaneously in 1866 was only under cultivation in 1889 and 1890 and that three of the 1866 weeds were not met with in 1889 or 1890 . These 4 species, therefore, give a disappearance rate of $\frac{4}{24}=\frac{1}{6}$, or 0.16 species per annum, and the corrected rate for Period II is thus $3.28-0.16$, or 3.12 species per annum.

When we find on comparing the two periods that the rate of introduction in the second is only $3 \cdot 12$ species, as compared with 6.90 in the first, we naturally endeavour to find some explanation of the discrepancy. But, unfortunately, no very satisfactory explanation offers itself. So far as cultivated species are concerned, we are not in a position to compare the 15 naturalised species of 1866 with the 23 similar species of 1890, but only with those 9 species that had been both introduced and naturalised subsequent to 1866 . The proportions indicated by these two classes being 1·36:0.37 evidences a rate of naturalisation per annum $3 \frac{1}{2}$ times as great for the earlier as for the later period. But when the circumstances of the case are considered we are not surprised that the difference should be so great; we are, rather, astonished at its being so small. Owing to the abandonment of the 1789 Settlement the species that had been introduced while it existed were left to their fate, and it would be no more than reasonable to expect that when the new Settlement was founded in 1858, and when $\mathrm{Mr}_{\mathrm{r}}$. Kurz visited it in 1866, the majority of the common tropical cultivated species had already become fairly naturalised. So far, however, was this from being the case that we find there were in 1866 only 15 such species naturalised, and we are compelled to conclude either, that the original settlement was very ill provided for, or that the species which on a priori grounds we might consider likely to hold their own in the struggle for existence in an abandoned settlement are really far from being able to do so. Now not only is there no ground for supposing that the Settlement was illprovided for, but there is ample proof, from the evidence that exists of a direct and extensive reciprocal correspondence between its founders and the first Superintendent of the recently established Hon'ble Company's Botanic Garden at Calcutta, that the number of species introduced at Port Cornwallis was, for a Settlement so young, unusually high. We are com. pelled, therefore, to accept the other explanation and to conclude that cultivated species are not as a rule able to exist when they have to struggle on equal terms with a native jungle. Without mentioning other instances, we may refer to the lists of Cucurbrtacece and Leguminosce present in 1866 as cultivated plants only, yet in 1890 beginning to occur 
spontaneously and appearing likely as time goes on to increase perceptibly the numbers of the non-indigenous flora. The greater number of these must have certainly been introduced in the $1789-92$ period, and many of them are such as at first sight suggest for themselves the possibility of survival.

Perhaps, however, it ought not to surprise us greatly that species which readily appear spontaneously elsewhere and which are appearing spontaneously in the Andamans now, should, if they were previously introduced, have perished betwern 1792 and 1858. Most of them are plants that, when they do escape from cultivation and appear spontaneously, affect such situations as waste places, rubbish heaps, road-sides, hedgerows and margins of clearings, - situations that have at least this in common, that they afford their denizens abundance of air and light. Many of them too are herbaceous, or at most fruticose, and the native jungle as it reinvades the abandoned clearings overshadows them and either chokes them completely, or by merely preventing them from flowering, makes their fate only a matter of time. Even trees that seem quite naturalised in clearings must soon succumb to the weight of creepers that rapidly overload them in a forest.

If, however, the survival of even a small proportion of the cultivated species abandoned in 1792 will suffice to explain the higher rate of naturalisation during Period I, deducible from the figures in TABLE III (Carica Papaya and Cocos nucifera are excellent examples of such survival), there is no similar explanation possible for the higher rate of weedintroduction during the same period. A considerable number must have been already introduced by 1792 , and, though many doubtless yielded to the influences adverse for naturalised cultivated species, weeds are often proverbially tenacious of life and a good few, as the notes against them show, in place of aroiding the jungle are actually penetrating into it. Taken altogether we find that the rate of introduction during the first period was $2 \frac{1}{3}$ times as high as it has been during the second, and the most probable explanation of this higher early rate of weed introduction appears to be that in the dirty grain of an Indian bazaar seeds of most of the commoner Indian weeds are certain to be present. This being the case so many weeds become introduced with the very earliest sowings of any grain that the subsequent rate of introduction of species can be but small. And it is highly probable that for the same reason the rate of weedintroduction becomes year by year diminished. L'nfortunately it has not occurred to any one to make observations on these weeds during the interval 1858-66 or 1866-90. And without repeated observations after short intervals of time, especially towards the commencement of a settlement, it is impossible to test the adequacy of this explanation. 
But it is not improbable that by the close of another period equal in length to the second the annual fall in the rate of introduction and, indeed, the annual rate of introduction itself will have become very small.

There is not likely to be the same falling off in the rate of naturalisation of intentionally introduced species. For, as the Settlement extends, localities suitable for the spontaneous appearance of already introduced species become year by year more numerous and at the same time the number of species capable of naturalisation becomes increased.

We find on briefly reviewing the results of our enquiry :-

1. That the total number both of naturalised and of unintentionally introduced species constantly increases.

2. That the rate of naturalisation of intentionally introduced species has hitherto been lower than the rate of introduction of unintentionally introduced species.

3. That in both cases the rate has been lower for the second period (1866-90) than for the first (prior to 1866).

4. That this lower rate for the second period is more apparent than real, and is probably due as regards naturalised species to the survival of some cultivated species left to their fate when the early Settlement (1789-92) was abandoned, and as regards weeds to the fact that the greater number of common Indian weeds are necessarily introduced with the earliest sowings of grain.

5. That in both cases the rate has now probably become nearly uniform, but that while for naturalised species it is steady or even uniformly increasing, for weeds it is probably uniformly decreasing.

The first three conclusions are borne out by the facts contained in the lists of species : the fourth is an expression of opinion, which it is unfortunately now impossible either to endorse or to refute as regards the Andamans ; it is, however, a question worthy of attention during the initial stages of any subsequent similar settlement: the last it will be easy for some fature student of the subject to finally dispose of.

In concluding, the writer wishes to express his great obligations to Col. Cadell, v. c., Chief Commissioner of the Andamans, but for whose kind assistance it would have been impossible to collect so many species during his short stay at Port Blair; also to Dr. G. King, F. R. s., C. I. E., for his kindness in supplementing the collection of 1889 with many specimens collected in April 1890. 

From the Journal, Asiatic Society of Bengal, Vol. LIX, Part II, No. 4, 1890.

Natural History Notes from H. M.'s I. M. Survey Steamer "Investigator," Commander R. F. Hoskrn, R. N., CommandingNo. 17. A List of Diamond Island Plants.-By D. Prain.

[Received and reid-7th May 1890.]

\section{$\S$ INTRODdCTORY.}

Diamond Island is a small lozeng'e-shaped islet off the Arracan coast. It is situated at the mouth of the Bassein River, in Long. 94 ${ }^{\circ}$ $18^{\prime}$ E. and Lat. $15^{\circ} 51^{\prime}$ N., about 5 miles from Pagoda Point, 8 from Cape Negrais, and 9 or 10 from the lighthouse on Alguada reef. Its length is somewhat under a mile and a half, and it is about three quarters of a mile wide. The N. E. and S. W. corners which terminate its longer axis rise rather abruptly from the sea. Except, however, at the extreme eastern end its shore all round is rather bluff and rises rapidly to what is rather a central small plateau than a ridge, the general level of this central portion being about sixty feet above the sea. There are three small breaks, however, in the sea-face; a little water-channel, dry in November, opens to the north; another, with a very little water in November, opens to the south; a third, somewhat larger and quite near to the last, has at one time found its way to the sea through the small patch of flat land on the east, but a bund having been thrown across its course, about 100 yards from the sea, its channel has been converted into a tank about 150 yards long and 40 wide. 
The island is said never to have been occupied by the Burmese, and has evidently been originally densely wooded.

The greater part of it is indeed densely wooded still, but a corner has been completely cleared between the watercourse that has been converted into a tank and the watercourse that passes south. On the cleared high ground between these two streams stands a telegraph offico with a house for the telegraph-master attached; a little way off are servants' quarters. The clearing has been extended across this latter stream for a short distance, so as to provide a site for a shelter-hut for Bassein pilots while they await vessels bound for that port. Between the tank-bund and the sea, but nearer to the tank and close to its overflow, stand two Burmese huts occupied by collectors of turtles' eggs; between these huts and the beach is situated a small European graveyard. At the outlet of the other streamlet and opposite the safest landing place is a boat shed; from this point eastward for about 400 yards-along the sea-view of the telegraph-office, in fact-the jungle has been cleared away down to the beach. Everywhere else the jungle along the sea-face of the island remains intact. A plantain garden and a paddock of considerable size have been cleared on the central plateau behind the telegraph-office; elsewhere the jungle remains untouched; altogether between two-thirds and three-fourths of the surface of the island has not been interfered with. The beach itself consists of deep solt sand in which the streamlets disappear before they reach the sea; at low tide, however, long reefs, extending south and west of the island proper for half a mile or more, are laid bare. On the east side, where the telegraph cable lands, no reefs appear; at the north-west corner they do, but only extend seaward for 50 or 60 yards. The reefs consist of the same sandstone that forms the Arracan Yomah and that appears again first in the Andaman and afterwards in the Nicobar group of islands; they are altogether without coral.

The reefs and pools between them are remarkably destitute of marine vegetation, Padina pavonia and Caulerpa clavifera being the principal species, and both being in very small quantity. Not only are there very few growing Algae, but very few are washed ashore; these consist chiefly of a small green Sargassa. The absence of the submarine meadows of marine Hydrocharide, so characteristic of the otherwise similar pools among the coral-encrusted reefs of the Great Coco, is very striking. There is no mangrove belt on any. part of the shore, unless it be considered as represented by some small patches of Avicennia officinalis on the reefs abont 30 paces from the beach; the individual plants send their roots along the seams between the layers of sandstone for considerable distances, and these gire off rootlets that rise vertically 
through the sand and mud, exposing to the water of the sea at high tide, to the air and the sun at low tide, from 6 inches to a foot of a structure as thick as the little finger and of the consistence of solah pith. The jungle along the south and east sides of the island commences at the edge of the sandy beach, the roots of the trees bcing washed by the waves at very high tides; the trees that grow at this line are Thespesia popuinea, Pongamia glabra, Enythrina indica, Terminalia Catappa, Stephegyne diversifotia, and Ficus Rumphii. East of the cleared part in front of the telegrapl office and round as far as the graveyard, are a number of large Tamarind trees; it is not improbable that these have been planted. One specimen of Terminalia Catappa growing close beside the boat house differcd from all the others in being in flower. There is no doubt that this particular tree is T. Catappa, and there is hardly a doubt that it is an introduced tree. But that the others (and it is a plentiful species in Diamond Island) which were all, like those on the coast near Port Blair in the Andamans, and like those seen a weck later on Table Island and the Great Coco, in almost ripe fruit in November and December, are quitc wild and indigenous in the island scarcely admits of a donbt.* Underneath these trees along the sonth side occur Hibiscus titiaceus, not plentifully, however, and, especially towards the south-we it angle of the island, Desmodium umbellatum. On the west side of the islaud, which is the most weather-beaten side, the trees are not so tall, and they are fewer in number, thongh all these species except Pongamia appear. But close to the beach we find there is a dense hedge-like mass of Desmodium umbellatum, Tabernaemontana crispa, Premna integrifolia and Clerodendron inerme, with here and there some bushes of Vitex Negundo. All these species occur on the north side of the island also, and at the extreme north-east corner there is a considerable patcli of Guettarda speciosa. All round the island Canaralia ensiformis is plenti$\mathrm{ful}$; it is associated on the western sea-face with Pueraria phaseoloides, Ipomoea grandiflora and Ipomoea digitata; the last named species is common also in the interior. On the south side a form of Capparis sepiaria, the most plentiful of the interior climbers, comes to the very onter limit of the jungle all along; it is here and there accompanied by Colubrina asiatica. There are sereral patches of Ipomoea bitoba on the beach, but the species is not so common as it usually is in such situations; and Ipomoea denticulata, which has not been generally believed to occur so far north, is many times more plentiful. Near the mouths of all threc streamlets, and also at the almost bare south-western corner of the island, there are considerable patches of Cyperus pennatus. The cleared space near the telegraph-office is mainly covered by a short turf

* As regards Great Coco Island a dombt on the point is impossible 
in which Eleusine indica is the only grass that appears in tufts; behind the boat house is a tangled patch of Colubrina asiatica and Caesalpinia Bonducella; on the road leading from the boat house to the telegraph office is a quantity of Ipomoea denticulata, at the back of the office a Jarge patch of Adenostemma viscosum, between the office and the servants' quarters a large patch of Ocimum basilicum, lower down and near the tank two or three extensive patches of Cassia alata. Vernonia cinerea is very common all over the older clearing, but Ageratum conyzoides, usmally such a common weed, is quite rare as yet. Urena lobata is common towards the edge of the elearing nearest the jungle, but is less common than Melochia corchorifolia is; the latter is also the commonest weed in the newer elearing in the centre of the Island. Scoparia dulcis is plentiful in botl the old elearing and the new, but the common Sidas are conspienous by their absence. The wet soil near the edge of the tank is covered with broad patehes of Euphorbia thymifolia; associated with it is Vandellia crustacea whieh is, however, less plentiful: nearer the tank still, or even growing in the shallow water at the eastern end, are Sphenoclea zeylanica, Hydrolea zeylanica, Limnophila conferta, Scirpus articulatus and Ceratopteris thatictroides, all very profuse. In the tank itself grows Nymphaea Lotus, but not very commonly; the red form is not present*; Nymphaea stellata too is absent; Nelumbium speciosum, however, is there. Perhaps the most interesting water plant present is Limnanthemum parvifolium, only known previously from the transgangetie peninsula through a gathering in Chittagong by Hooker and Thomson and one in Tavoy by Wallieh. The present gathering thus eomes in midway between these two and perhaps indieates that the speeies only requires to be looked for in order to be found elsewhere in lower Burma. Besides the Tamarinds already referred to, there are near the houses of the Burmans some trees of Moringa pterygosperma that have evidently been introdueed; in the same situation there are also a few Coco-nut trees and some Plantains. In the eentral clearing the telegraph master shewed nie what he imagined to be Mangosteen trees belonging to him; the trees are, however, not trees of Garcinia mangostana but of Garcinia cornea. He had, beside these, some trees of Citrus medica and $O$. Aurantium not doing very well; there were elose by also some trees of each of the speeies Myristica glauca, Artocarpus Chaplasha and Antiaris toxicaria, all either planted or preserved when the elearing was made; the present telegraph-master, who has been there many years, sars they have been there sinee before his time. In his plantain garden, where he lias some of the finest fruit-giving varieties and all

* In Great Coco Island it is only the red variety of $N$. Lotus that occurs in its small lake. 
bearing well, there are the ordinary tropical vegetables; the only one that is noticeable from our present point of view is the bird's-eye chillie (Capsicum minimum) which here, as in the Andamans and in Great Coco Island, has spread itself everywhere about the clearing and is even penetrating into the adjacent jungle. In front of the telegraph-office there are two rows of very weather-beaten Coco-nut trees of which only 14 are now left; probably if planted or sown along the edge of the beach they would have done much better; there is not at present, it may be remarked, a single Coco-nut tree in this situation anywhere round the island.

The commonest tree throughout the island is Bombax malabaricum, and next to it in point of numbers is A7bizzia procera; towards the western end of the central table-land the latter is the more plentiful species, those trees at the extreme edge being stunted and weather-worn. Among the other trees and shrubs observed were Chailletia gelonioides (very abundant on the south side of the island,) Connarus gibbosus, Ellipanthus sterculiaefolius, Cnestis ramiflora (also very abundant on the southern slope of the island,) Lagerstromia Flos-Reginae (a common tree on the Eastern part of the island,) Ixora rugulosa, Pavetta indica, Psychotria adenophylla, Ehretia laevis, Heterophragma adenophyllum (not uncommon,) Bridelia tomentosa and Flueggia microcarpa (both frequent,) Ficus hispida (not frequent,) Macaranga Tanarius (the only Macaranga present and common on the south side of the island.) A common and very striking undershrub is Leea parallela; in the opener ground on the western weather-beaten side Osbeckia chinensis, Vemonia cinerea and Anisomeles ovata are common herbs; along the water course leading to the north side of the island Adiantum lunulatum occurs, not frequently, however, and it does not appear to be anywhere else on the island; the only other ferns met with were the water-fern Ceratopteris, and a climbing species, Lygodium flexuosum. Quite as striking as the absence of fcrns is the absence of any species of Selaginella; still more striking, pcrhaps, considering the proximity of the island to Burma, is the absence of Bamboos.

fIn the interior the climbers met with were Cyclea peltata (frequent,) Abrus precatorius (exceedingly common,) Mrucuna monosperma, J Lntada scandens, Luffa cogyptiaca (only on the western side and, like the Capparis and like Ipomoea digitata, spreading over the sea-fnce as well as common in the interior jungle.) 'Willughbeia edulis (only met with once,) Ichnocarpus frutescens and Dregea volubilis (both common,) Erycibe paniculata (spreading over adjacent species, but hardly a climber,) Thunbergia laurifolia very common, as are Dioscorea glabra and Smilax macrophylla; a Calamus (C. tigrimus Kurz?) forms a great part of the 
interior jungle; Scindapsus officinalis is very common everywhere in the interior and coast znnes alike and is the principal epiphyte. Not a single orchid was seen anywhere in the island. A few Fungi were found growing on dead wood; the season of the visit was apparently unsuitable for terrestrial species.

The visit of H. M.'s I. M. Survey Steamer "Investigator", in November 1889, to lcave a survey-party is not the first scientific visit that has been paid to this island. Almost exactly one hundred years before it was visited by Captain Kyd and Lient. Colebrooke* who in December 1789 determined its position, both absolntely and in relation to the adjacent headland on the Arracan coast. It is not probable that botanical collection engaged the attention of these officers; but during another visit by a scientific party (April 1866) in H. M's. I. M. S. S. "Prince Artlur" Mr. Kurz, who was on board, landed and collected a few specimens. Mr. Kurz makes a very interesting remark on this visit which is worth repeating here:- "I had only a few minutes stay at "Diamond Island in Pegu, but I was struck, when afterwards coming "to the Andamans, by the similarity, nay rather identity, of the shore "vegetation." $\uparrow$ The present collection is itself the result of only a few hours' work, and is larger than it otherwise could have been, owing to the help given by Dr. Alcock, Surgeon-Naturalist of the "Investigator," who devoted the time during which the state of the tide prevented him from being on the reefs to assisting the writer in obtaining specimens of plants. The 95 species that it includes form it is true only a part of what the island would yield to any one whose stay there could be prolonged; but it is hardly too mucle to assume that they are fairly representative of the flora of this island. And as its geographical position and geological structure both point to it as the first stepping-stone in the series of islands connccting Arracan with Sumatra (through the Andamans and Nicobars) the nature of the flora seems worthy of investigation.

The following is the method of presentation adopted:-

1. A list of the plants collected is given; any interesting featrure as regards a particular species is noted where it seems necessary to do so, and in every case the dissemination of the species is advcrted to.

2. A tabular view of the distribution of the species is presented, 1789 .

* Asiatic Researches, Vol. IV, p. 317 ; the dato of this visit was 14th December

+ Report on the Vegetation of the Andaman Islands, (1870) p. 15. Mr. Kurz nses the word Pega in an extended sense which means all Lower Burma; Diamond Island belongs to Arracan, not to Pegu proper; Mr. Kurz's remark itself will be discnssed further on. 
the distribution within transgangetic India being sub-divided as follows:- $a$. Arracan, Chittagong, Assam; b. Pegu, Tenasserim, Malay Peninsula ; c. Andamans (including Coco Islands,) Nicobars, Sumatra and Java. This is necessary for a proper understanding of the peculiar features of the flora of the island which forms (or at any rate is an excellent representative of) the area wherein these three lines of distribution meet and in which their species intermix.

3. An analysis in terms of the preceding sections is undertaken and the arithmetical values of the various relationships computed.

\section{$\S \S$. List of the Plants collected in Diamond Island.}

MENISPERMACE $\nexists$.

1. Crclea peltata Hook. F. and Thoms. Common.

\section{NYMPH正ACEE.}

2. Nympera Lotus Linn. In the only tank, uncommon; the red form is not present.

3. Nelumbium speciosum Willd. In the tank.

\section{CAPPARIDE $A$.}

4. Capparis sepiaria Linn. var. grandirolia Kurz (MSS. in Herb. Calcutta) ; forma ramis foliisque glabris, foliis floribus et fructu quam in formis varietatum aliarum multo majoribus. Distrib. Table Island and Great Coco Island, (ipse); South Andaman, (Kurz). In Madura Island and in Bali, (Teysmann in Herb. Calcutta). In Timor and in Cochin-China (as Mr. Hemsley informs me) occur forms that connect this very distinct looking form with the typical plants. Branches green ; leaves regularly elliptic, retuse; petioles $0.5-0.7 \mathrm{~cm}$. long; laminæ $6-10$ $\mathrm{cm}$. long by 4-5 cm. broad, quite glabrous both above and below, or with a few scattered hairs, that soon disappear, on young leaves beneath ; flowers $15 \mathrm{~mm}$. in diam.; pedicels $18 \mathrm{~mm}$. long; gynophore $8 \mathrm{~mm}$. long; fruit $12 \mathrm{~mm}$. in diam. (in Java specimens) to $14 \mathrm{~mm}$. (in Diamond Island ones).

In the ordinary Indian plant, which also occurs without any considerable variation in Burma and in Perak, as well as in the S. Indian variety (incanescens) and in the Ceylon variety (retusella), the measurements are; petiole $0.2-0.4 \mathrm{~cm}$., lamina $2-3 \mathrm{~cm}$. long by $1.5-2$ $\mathrm{cm}$. broad; flowers 7-12 mm. in diam., pedicels $16 \mathrm{~mm}$. long ; gynophore $5-6 \mathrm{~mm}$. long; fruit $7-8 \mathrm{~mm}$. in diameter.

Except, however, in the greater size of all its parts-most notable as regards the anthers-which in var. grandifolia more than thrice exceed 
those in any of the other varieties-this plant differs in no essential character from $C$. sepiaria, Wall. ; the ovary as in the type is glabrous, ovoid and pointed, the fruit is spherical and black. It is an extensive climber and in the interior jungle is one of the commonest species; it also extends into and covers the shrubby species of the coast zone.

\section{GUTTIFER丑.}

5. Garcinia cornea Linn. In the telegraph-house garden, cultivated.

\section{MALVACEÆ.}

6. Urena lobata Linn. Clearing behind telegraph-office.

7. Hibiscus tiliaceus Linn. Coast plant, south side of Island.

8. Thespesia populnea Corr. Coast; very frequent all round the Island.

9. Bombax malabaricdm DC. The commonest tree in the Island.

\section{STERCULIACE $\nexists$.}

10. Melochta corchorifolia Linn. Very common in the central clearing.

\section{RUTACEA.}

11. Citrus medica Linn. In the telegraph-house garden and elsewhere; planted.

\section{CHAILLETIACEÆ.}

12. Chatlletia oelonio!des Hook. $f$. Very abundant on the south side of the Island.

\section{RHAMNACE 2 .}

13. Colubrina asiatica Brongn. One large bush beside the boathouse, and here and there throughout the Island.

\section{AMPELIDE $\nexists$.}

14. Leeea parallela Wall. Very common throughout the Island.

\section{MORINGACEA.}

15. Moringa pterygosperma Gaertn. Some trees near the huts of Burmans, between the tank and the sea.

\section{CONNARACE $\nexists$ E.}

16. Connarus gibbosus Wall. In the interior jungle.

17. Chestis ramiflora Griff. Very abundant towards south side of Island.

18. Ellipanthus sterculiefolius Prain. Coast zone, south side. 


\section{LEGUMINOSZE.}

19. Desmodidi umbeliatum DC. Shore species; frequent, especially on the west and north sides of the Island. Island.

20. Abrus precarorius Linn. Very frequent everywhere in the

2l. Erythrina indica lamk. A purely coast species here, as it also is in the Andamans and in Great Coco island. In the Great Coco it is, however, rather uncommon : a striking contrast with the conditions in Diamond Island wliere this tree forms an almost unbroken ring round the coast. jungle.

22. MuCUna monosperia DC. Very common in the interior

23. Pueraria phaseoloides Benth. Common on the western seaface of the Island, climbing over bushes of Tabernomontana crispa and creeping in the grass at the bare south-western corner of the Island,

24. Canatalia enstrormis DC. A climber all round the coast, especially common on west and north sides of the island; not met with) in the interior.

25. Pongamia cilabra Vent. Frequent in the line of trees immediately behind the sandy beach. house.

26. Cessalpinia Bonducella Ham. A thicket behind the boat-

27. Cassta alata Linn. Two or three large thickets between the telegraph-office and the tank.

28. Tamarindus indica Linn. Several large trees behind the beach, between the telegraph-office and the graveyard.

29. Entada scandens Benth. Common all over the island.

30. Albizzia procera Benth. A common tree, especially in the western half of the island; those trees exposed to the S. W. monsoon are gnarled and $d$ warfed and weather-beaten.

\section{COMBRETACE $\nexists$ A.}

31. Terminatia Catappa Linn. Frequent in the beach ring of trees. One tree overhanging the boat-house, and probably an introduced one, was in flower. in November ; the others were all, as they were in South Andaman and in the Great Coco, in fruit.

\section{MELASTOMACEAE.}

32. Osbeckia chinensis Linn.; C. B. Clarke in F. B. I. Frequent in the bare grassy slope at the south-western corner of the Island. The form present in Diamond Island differs from typical $O$. chinensis somewhat in size and form of leaves and calyx; in these specimens, leaves 
$7 \mathrm{~cm} .: 3 \mathrm{~cm}$., ovate, acute, base subcordate; inflated ovary $6 \mathrm{~mm} .: 4$ $\mathrm{mm}$.; tubular neck of calyx $4 \mathrm{~mm}$. long: $3 \mathrm{~mm}$. diam. at junction of inflated and tubular portions and $5 \mathrm{~mm}$. diam. at mouth. The specimens of this gathering precisely accord with specimens collected by Kurz in Arracan; they agree as to calyx with specimens collected by R. Scott in Pegu; as to leaves they resemble specimens collected on Parasnath and in Chutia Nagpur by T. Thomson, by Kurz, and by J. J. Wood.

\section{LYTHRACE $\nexists$.}

33. Lagerstremia Flos-Regre Retz. A common tree in the eastern part of the Island and to the north of the tank.

\section{CUCURBITACE $\not$.}

34. LUfFa EGTPtiaCA Mill. Not infrequent on the western side of the Island.

\section{RUBIACE $\nexists$.}

35. Stephegtane diversifolia Hook. f. Frequent in and immediately behind the coast zone.

36. Guettarda speciosa Linn. Common on the north coast of the Island; this appears to be the first occasion on which the species has been collected so far north as Arracan.

37. IxoRa RUGOsula Wall. Frequent in the interior; previously only known from Pegu and Tenasserim; now, therefore, from Arracan also.

38. Pavetta indica Linn. Common in the interior.

39. Pstchotria adenophylia Wall. Common in the interior.

\section{COMPOSIT 死.}

40. Vernonia cinerea Less. Waste ground about telegraphoffice; also on bare ground at the south-western corner of the Island.

4il. Adenostemma viecosum Forst. var. parviflora Hook. f. Behind the boat-house.

4.2. AGERATUM CONYZOIdes Linn. Only a few plants seen near the side of the tank.

GOODENOVIE $A$.

43. Scærola Kønigir, Vahl. On the west and north shores; common.

\section{CAMPANULACE 的.}

44. Sphenoclea zerianica Gærtn. At the margin of the tank eastern end; profuse. 
APOCYNE $刃$.

45. Willdahbeia eddLis Roxb. In the interior jungle, only once met with.

46. Tabernemontana crispa Roxb. Very abundant on the west and somewhat less frequent on the north shore. A distinct northern extension to the distribution of this species which has been hitherto known from the Andamans and the Nicobars only. Follicles 3-keeled, green, $2.75 \mathrm{~cm}$. long, $1 \mathrm{~cm}$. anteroposterior, $0.75 \mathrm{~cm}$. lateral diams., sessile avicular (beak slender recurved $6 \mathrm{~mm}$. long) semicircular (vèntrally convex, dorsum straight or very slightly concave), when opened flat $2.25 \mathrm{~cm}$. across; endocarp brilliant scarlet.

47. Icinnocarpus frutescens R. Br. Extensive climber; frequent in the interior. Flowers sweet smelling; corolla here pure white, not purple.

\section{ASCLEPIADACE AE.}

48. Dregea volubilis Benth. In the interior jungle; frequent.

\section{GENTIANACE 雨.}

49. Limnanthemum Parvifolidm Griseb. Plentiful near the western end of the tank and the only species present. A species with, so far as is known, a somewhat detached distribution.* It is plentiful in the western Deccan and in Ceylon. This gathering is intermediate as to situation between that of Hooker and Thomson (Chittagong) and that of Wallich (Tavoy) - the only two previous gatherings recorded from the Trans-gangetic Peninsula; perhaps it indicates that it would be oftener found if particularly looked for."

\section{HYDROPHYLLACEA.}

50. Hydrolea zerlanica Vahl. Swampy ground at west end of tank: plentiful.

\section{BORAGINACE 开.}

51. Ehretia Levis Roxb. Common; all the specimens from this locality are absolutely glabrous; there is no indumentum or any trace of sucb, even on young branches, on young leaves, or on the youngest flowerbuds.

* Another species with a similarly detached distribution is L.jaurantiacum Dalz., a common species in the western Deccan and Ceylon (from Bombay southwards), and hitherto supposed to be confined te this area. Excellent specimens have, however, been sent (14th December 1889) by H. T. Peter, Esq., from Narayangunge near Dacca, aud identified by Dr. G. King, F. R. S. 


\section{CONVOLVULACE}

52. Erycibe paniculata Roxb. var. peguensis, Clarke. A small subscandent wide-spreading tree; leaves elliptic cuneately acuminate; at both ends secondary nerves scarcely visible beneath with dense pancles, white flowers and rusty-tomentose shoots. The present locality stands intermediate between those hitherto recorded for the varietyChittagong (Hooker,) and Moulmein (several collectors).

53. Ipoma grandiflora Lamk. Very common, climbing amongst the Coast speciea on the western and northern sides of the Island, and also for a little way amongst the adjacent inland species.

54. I. Digitata Linn. Common with the preceding on the western side of the Island.

55. I. Denticulata Choisy. By the side of the stream between the boat-house and the pilots' house, beside the path from the boat-house to the telegraph-office, along the cleared slope between the telegraphoffice and the sea, and again at the north-east comer of the Island, always plentiful. The distribution of this species, so far as was known in 1883, was (F. B. I. iv, 208) "Matay Peninsula ; from Mergui south"wards. Cerron; near the sea at Galle. Nicobars," its further distribution being "Malaya, Australia, Polynesia, Seychelles." But it is now known to extend further up the Bay. It occurs in the Andamans, is exceedingly plentiful on the Great Coco, was collected by Kurz at Kobah on the shores of S. Burma during his latest journey, is very plentiful here in Diamond Island, and was collected by Kurz at Akyab which is still further north. In the Great Coco a curious feature in this species and the next is their habitat. This species converts raised coral "shingle" beaches into purple meadows; on this shingle not a single plant of $I$. bitoba is to be met with; flat crescentic stretches of level sand at the heads of bays are completely covered with $I$. bitoba and not a plant of $I$. denticulata is to be seen. Whenever a little cleared patch of soil occurs near the sea the two species appear in it plentifully side by side.

56. I. BILOBA Forsk. Sand-beaches on north and west side of island, not plentiful. Also with the preceding species between the boat-house and the telegraph-office.

\section{SOLANACE II.}

57. CaPSiCUM Minimum Roxb. In the telegraph-master's garden, cultivated; but also all over the central clearing, spontaneous.

\section{SCROPULARIACEAE.}

58. Limophila conferta Benth.; Hook. f. In marshy ground along with Hydrolea.

64 
59. Vandertia crostacha Benth. On wet banks of the tank at west side. office.

60. Scoparia dulcis Linn. In cleared space behind telegraph-

\section{BIGNONIACE A.} terior.

61. Heterophragma adenophyllom Seem. Frequent in the in-

\section{ACANTHACE $A$.}

62. Thunbergia ladrifolia Lindley. Common.

VERBENACEA $A$,

63. Premina inifgrifolia R. Br. Iittoral species; common.

64. Vitex Negundo Linn. Leaves mostly 4-pinnate. On the seashore of north side of Island, but only in two places.

65. Clerodendron inerme Gaertn. Very common on the coast here, and also throughout the whole of the Andaman group.

66. Avicennia officinalis Linn. On the sandstone reefs, but only in two or three places, to the south and west sides of the Island.

LABIAT A.

67. Ocrmum Basilicum Linn. Waste ground behind servants' quarters of telegraph-office buildings. This is only Ocimum that has here become spontaneous. In South Andaman the true Tulsi (O. sanctum) is the one that has become naturalised; in the Laccadive group it is the Ram-tulsi (O. gratissimum) that occurs as if wild.

68. Anisoneles ofata R. Br. Here and there in opener parts of the interior and plentiful on the bare part at the south-west corner of the Island; not in the cleared space near the telegraph-office.

\section{MYRISTICACE A.}

69. Myristica aladca Blume. Only one (female) tree seen, near the Garcinia.

\section{EUPHORBIACE $A$.}

70. Euphorbia thymifolia Burm. On wet banks of the tank, plentiful; seeds red.

71. Bridelia tomentosa Blume. Plentiful; absolutely glabrous in every part and in this respect quite like specimens collected by Kurz in Pegu.

72. Flueggta Microcarpa Blume. A small tree; common in the interior. 
73. Macamanga Tanarios Muell.-Arg. Plentiful on the sonth side of the Island. This locality is a very distinct extension northwards for the distribution of this species which has been hitherto known only from South Andaman, Nicobars, Perak and Malacca. Dr. King has very kindly verified this determination for me.

\section{URTICACE $A$.}

74. Artocarpus Craplasha Roxb. Only once seen, near the Garcinia and Myristica.

75. Antiaris toxicaria Lesch. Only once seen; the tree is close beside the preceding and is said by the Burmans (turtle-collectors) to be the only one on the Island; it may have been planted, but it is difficult to suppose by whom.

76. Ficus Rumphir Blume. Litloral; a very large tree, commonest on the south side, but plentiful all round the Island.

77. F. HISPIDA Linn. f. In the interior, not very common.

\section{SCITAMINE王.}

78. Musa sapientum Linn. Planted in the telegraph-master's garden.

\section{DIOSCOREACE $Æ$.}

79. Dioscorea glabra Roxb. Common.

LILIACE $\nexists$.

80. Smilax macrophylda Roxb. With Calamus and Dioscorea forms much of the interior jungle.

PALME瓜.

81. Calames tigrinus Kurz? Very plentiful; not in fruit.

82. Cocos nucifera Linn. Planted only; a double row containing 14 trees in front of the telegraph-office and a few others near the Burmans' huts.

\section{AROIDEA.}

83. Scindapsus officinalis Schott. Epiphyte common in the coast zone and the interior also.

\section{CYPERACEAE.}

84. Cyperus pennatus Lamk. On all barc places round the coast whether grassy or rocky; also in mud beside the tank outlet and on the banks of the water-course beside the boat-house. 
85. SoIrpus articulatus Linn. In the shallow watel at west end of tank.

\section{GRAMINE 玉.}

86. ElEUSINE INDICA Grrtn. Tufts of this grass occur along the path from the shore to the telegraph-office.

\section{FILTCES.}

87. Adiantum hundlatum Burm. Only along the water-course on the north side of the Island.

88. Ceratopteris thalictroides Brongn. Common at the west end of the tank.

89. Lrgodida flexuosum Sw. Common in the interior.

\section{FUNGI.*}

90. Hexagonia similis Berk. On dead wood; interior.

91. Hirneola polytricha Mont. On dead wood: interior.

92. Stereum cyathiforme Fries. On dead wood: interior.

93. Polyporus occidentalis Berk. On dead wood: interior.

\section{ALG丑。}

94. Padina payonia Gaill. On sandstone reefs.

95. Caulerpa clafifera Agardh. On sandstone reefs.

$§ \S$ Distribution of the Species observed in Diamond Island.

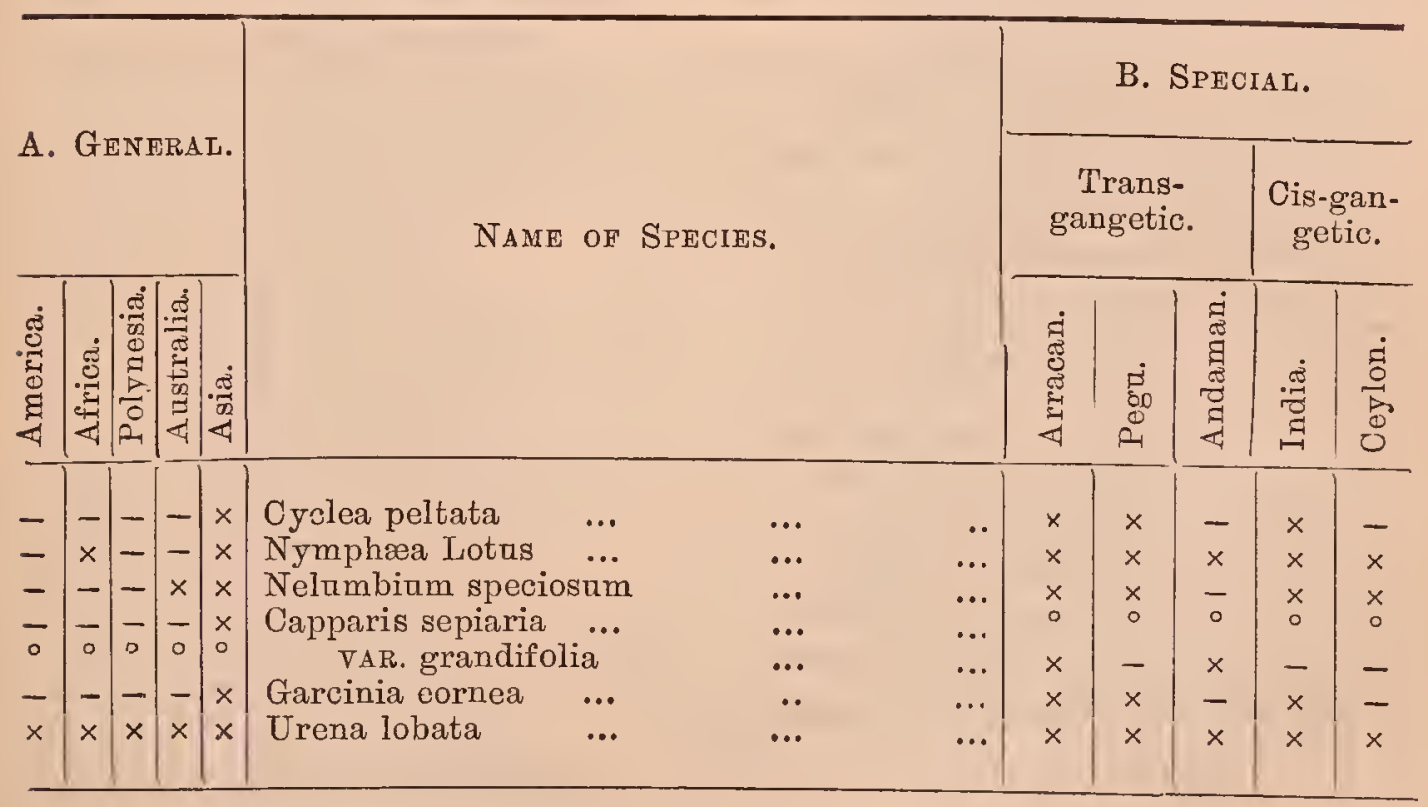

* Mr. Massee, through the good offices of Mr. Hemsley, F. R. S., has very kindly supplied the names of these Fungi. 


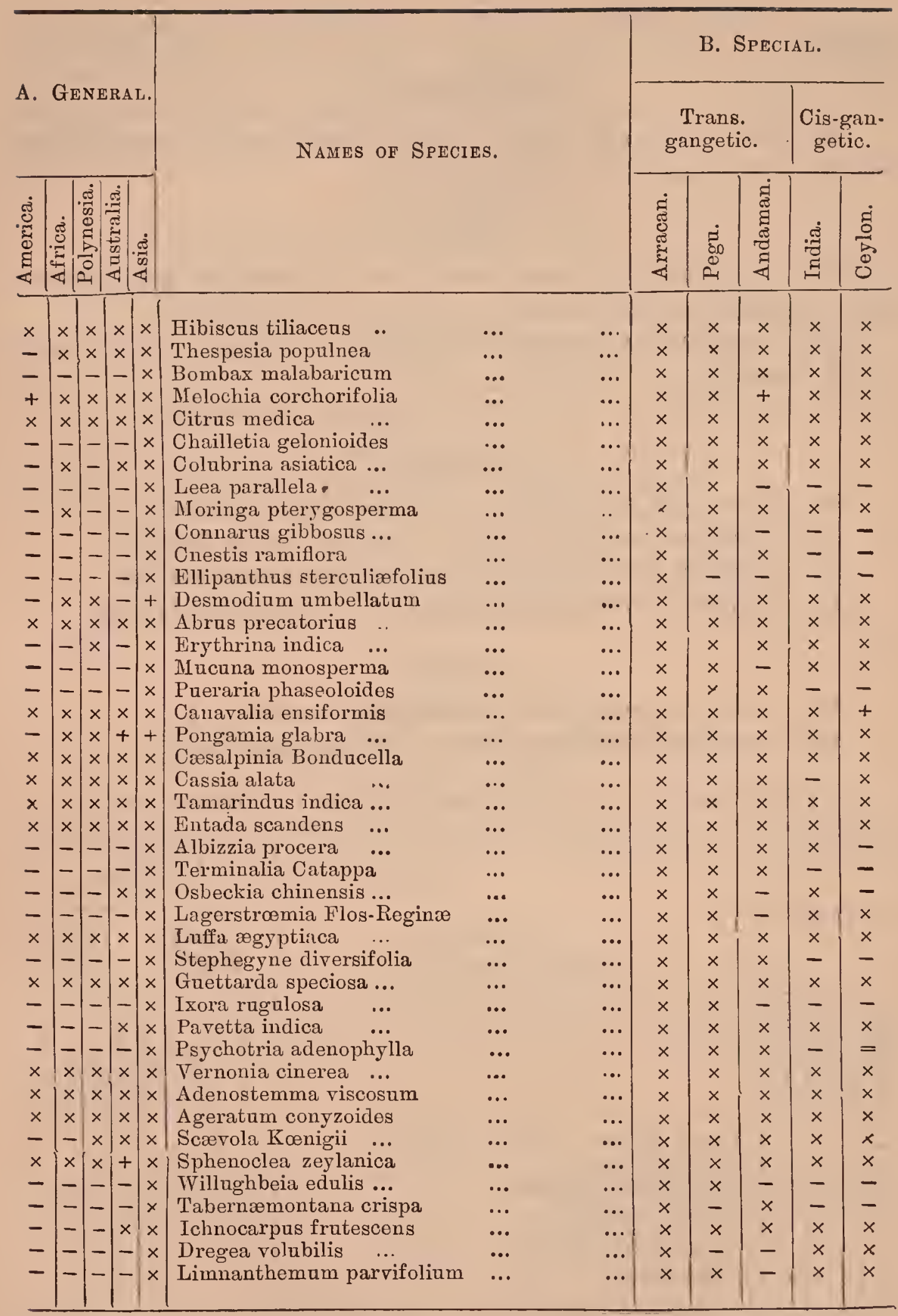




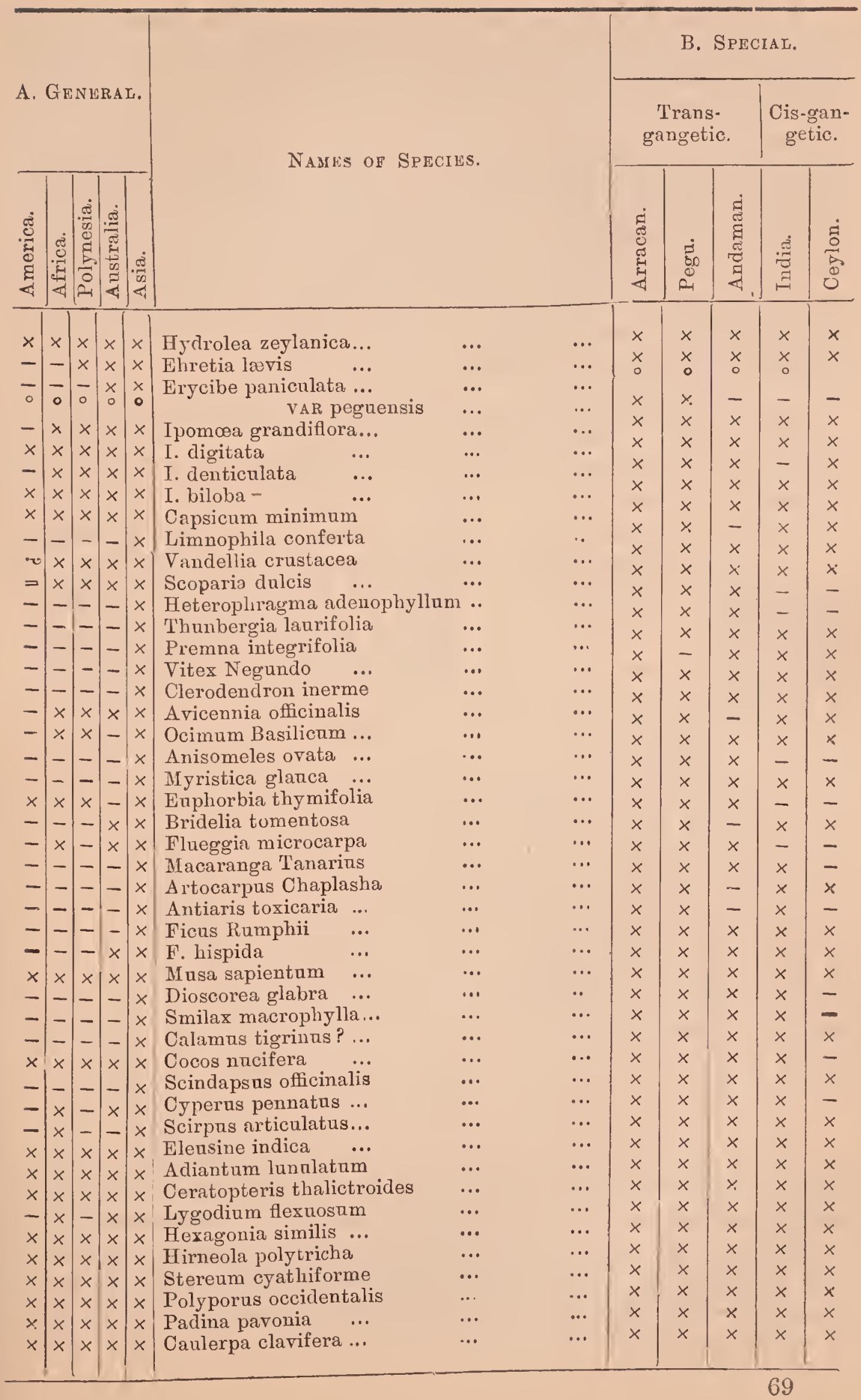


Examining first the general distribution of the Flora we find that, of the 95 species, 36 are species cosmopolitan in the tropics, while, on the other hand, no fewer than 38 are confined to Asia. Of the remaining 21, whose distribution is confined within the old world but extends beyond the limits of Asia, only four occur in Australia, Polynesia and Africa as well as in Asia; tro occur in Asia, Australia and Polynesia; four in Asia, Australia and Africa; and three in Asia, Polynesia and Africa. Six are confined to Asia and Australia, two to Asia and Africa, one to Asia and Polynesia. The following table shews this more clearly, and at the same time indicates the relationships that subsist between the distributional features of the species and, on the one hand, their habitat, on the other, their habit.

\section{Table I. Relationship of General Distribution to Habit and Habitat.}

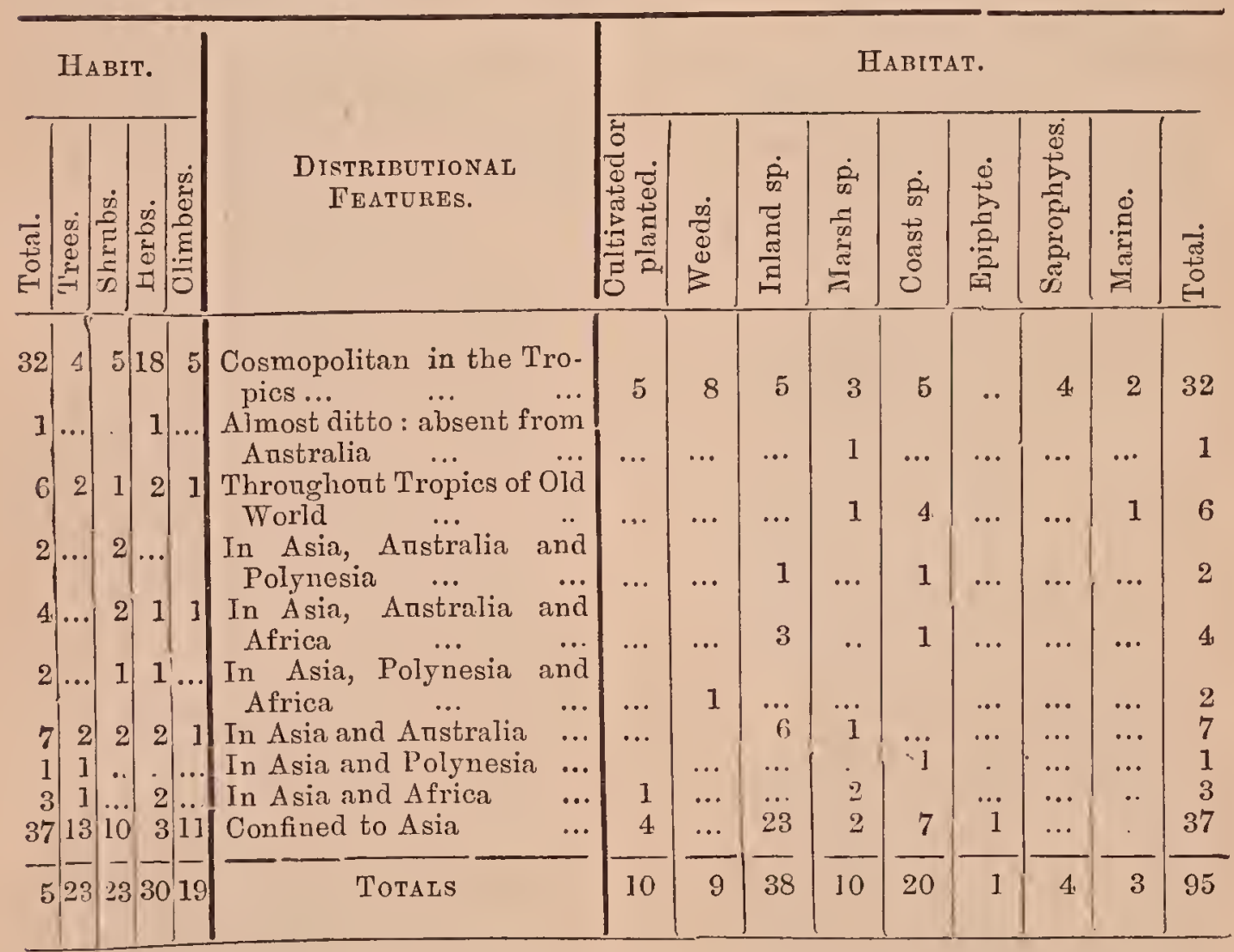

There is no progressive feature in the general distribution of the species; while the highest number of any of the classes is that of species confined to Asia, the next highest is that of species cosmopolitan in the tropics. The cosmopolitan or nearly cosmopolitan species are, however, to a large extent cultivated plants and weeds of waste places or marshes. In the case of the species confined to Asia 70 
the proportion of forest species to the whole is $30: 37$, or 81 per cent. whereas in the case of the cosmopolitan and almost cosmopolitan species the proportion of forest species to the whole is $10: 39$, or $25 \frac{2}{3}$ per cent. only.

To complete the account of the distribution of these species it is necessary to examine their special distribution throughout Southeastern Asia. From this it is possible to compute the relationships of the Diamond Island flora to those of the three adjacent areas ArracanAssam, Pegu-Malaya, Andamans-Nicobars respectively.

We find that 77 species are in distribution both Cis-gangetic (i.e., are present in India, or in Ceylon, or both) and Trans-gangetic (i.e., are present in some or all of the three areas whose influences meet in Diamond island). The remaining 17 species are Trans-gangetic only. So that as regards the composition of the Diamond Island flora the Indo-Chinese influence bears to the Indian a proportion of 95:77 (or very nearly of $9: 7$ ); in other words the Indo-Chinese influence is $\frac{18}{9} \frac{8}{5}$, or just under 19 per cent. stronger than the Indian. The details of this distribution are more compactly given in the subjoined table.

TABLE II. Distribution of the Dirmond Island species in S. E. Asia.

Species both Cis-gangetic and 'Trans-gangetic ; - ........................... 77

Common to all the districts

Absent from a Cis-gan

Absent from Ceylon only $\ldots \ldots \ldots . . . \ldots . \ldots$

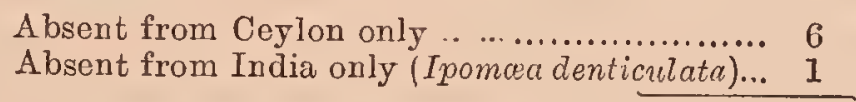

Absent from Trans-gangetic districts $;-\ldots . . . . \ldots \ldots \ldots . . . . . . . .$.

Absent from Andamans-Nicobars only .........

Absent from Pegu-Malaya only (Vitex Ne.

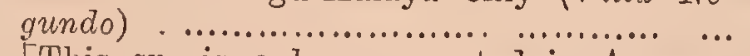
[This sp. is only represented in Arracan by the Diamond I. gathering]:

Absent from both Andaman and Pegu (Dre. gea volubilis)

Absent both from a Cis-gangetic and a Trans-gangetic district;

[These sp. are all absent at once from the Andamans and from Ceylon].

Species Trans-gangetic only :-

Common to the three Trans-gangetic districts :10

Distributed throughout Arracan-Assam district Represented in Arracan by the Diamond $I$. gathering only 
Absent from the Andaman-Nicobar district only;

Distributed throughout Arracan-Assam district

Represented in Arracan by the Diamond $\mathrm{I}$. gathering only

Absent from the Pegu-Malaya district only

2

[These sp. are both represented in Arracan by the Dia-

inond I. gathering only.]

Present only in Diamond Island (Ellipanthus sterculiafolius)

Total

The following remarks on this table may not be out of place. The absence at once from the Andamans and from Ceylon of certain species is at first sight good negative evidence of a statement made by Mr. Kurz (l.c. p. 15) concerning the Andamans;-"A few Ceylon species "indicate some relationship between the Andamans and that island." But it is unwise to believe that a thing does not exist because it has not been seen, and it is, as regards the Andamans at least, no evidence because these species have not yet been met with yet that they do not occur there. The positive evidence from the species that occurs in Ceylon and is very frequent all along the Andamaus group (Iponcea denticulata) but that nevertheless is absent from the western or Indian shore of the Sea of Bengal is also withont value. The curious but coustant feature as regards its habitat already remarled on, may explain its absence from the long line of sand-dunes that stretches from the Coromandel Coast up to Orissa. At the same time, it must not be supposed that Mr. Kurz's remark has been based on facts that are as easily explained as these are.*

In order to provide a basis for the computation of the relative value of the Arracan, Pegu, and Andaman influences in the composition of the Diamond Island flora, it is necessary to tabulate further the facts of distribution so far as these three districts alone are concerned.

* The writer has himself to add an instance quite as striking as any of those that were met with by Mr. Kurz. In November 1889 he collected on Mount Harriet in S. Andaman Strongylodon ruber Vogel, a Polynesian species that has a somewhat peculiar distribution in that it also occurs in Ceylon; to the Ceylou locality has now to be added that of $\mathrm{S}$. Andaman also. 
TaBLe III. Relationship of Transgangetic Distribution to Habit and Habitat.

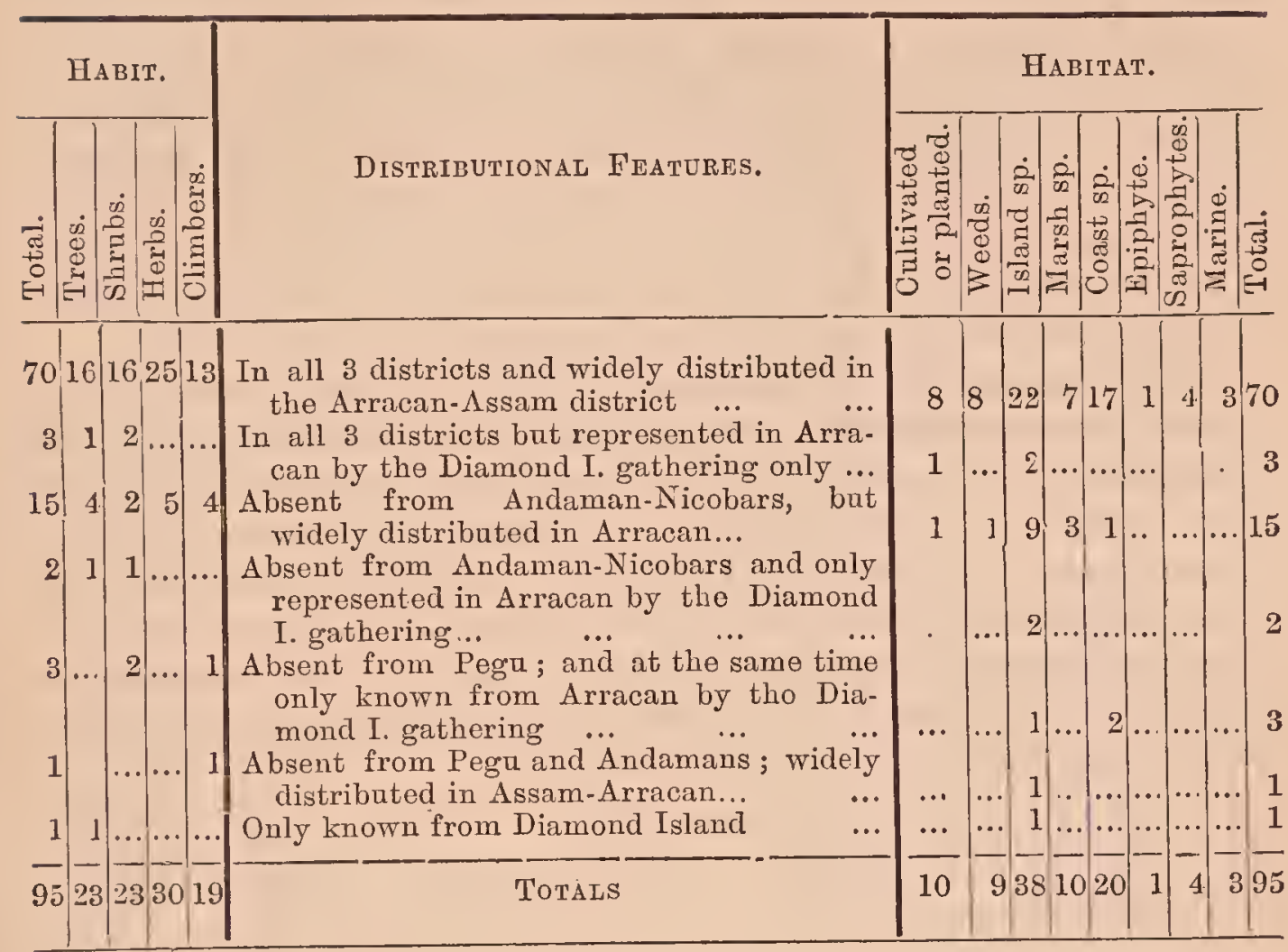

The first line of this table represents that element in the flora of the island wherein the influence of the three adjacent districts may be assumed to act indifferently; the second line that wherein the influence of the Arracan district is to be eliminated and only Pegu-Malayan and Andaman-Nicobar influences (presumably equally) prerail ; the third line that wherein Pegu-Malayan and Arracan-Assam influences prevail, while Andaman-Nicobar influences do not act; the fourth contains the element representative of Pegu-Malayan influences alone; the fifth that representative of purely Andaman-Nicobars influences; the sixth that indicating purely Assam-Arracan influences; the last, like the first, indicates an element wherein the influences of the three areas act indifferently but in the opposite way. As however this element (the endemic) is here only represented by one species, it is not convenient or useful to employ it in computation, and since Diamond Island is geographically inseparable from Arracan this species is treated as indicative of Arracan influence.

Reasoning from particulars the Andaman influence is stronger than either the Pegu or the Arracan influence is, so far as positive evidence goes, for there are here three exclusively Andamanese species as 
compared with only two exclusively Arracan and two exclusively Pegu species. The negative evidence, however, points quite the other way, for there are no fewer than eighteen species* indicating the absence of Andaman influence, as against only fivet indicating the absence of Arracan influence, and five + indicating the absence of Pegu influence. But it has to be kept in mind that the Andaman flora is by no means so well-known as the floras of the other two districts are and this negative evidence may be expected to be decreased, while there is no reason why the positive evidence may not be increased. The figures are in every case too small for special inferences being drawn from them.

The comparative values of the influences of these three adjacent areas are more accurately determinable from general evidence. In applying this it is necessary to use in succession as numerators the figures yielded by each possible distributional arrangement in which adjacent areas are concerned and as denominators in each case the number of adjacent areas involved; by adding together the fractions affecting particular adjacent districts we obtain a number that indicates the proportional influence of each of them in the composition of the flora of the island. The following are the results:-

I. Andaman-Nicobar influence $\frac{70}{3}+\frac{3}{2} \quad+\frac{3}{1}=27 \frac{5}{6}$, or $29 \cdot 29 \%$.

II. Pegu-Malayan influence $\quad \frac{70}{3}+\frac{3}{2}+\frac{15}{2}+\frac{2}{1}=34 \frac{1}{3}$, or $36.14 \%$. III. Assam-Arracan influence $\frac{70}{3}+\quad \frac{1}{2}+\frac{1}{1}+\frac{1}{1}=32 \frac{5}{6}$, or $34.57 \%$.

95. 100.

This method of computation may be extended to each of the subdivisions under the general headings 'habit' and habitat.' For some of these it is not, however, necessary; from others no particular information is to be derived. Under the heading of habitat, however, an analysis of the classes of inland and of coast plants is not without interest, especially when their results, expressed as per-centages, are compared with those afforded by the general total. They are as follows:-

\begin{tabular}{|c|c|c|}
\hline $\begin{array}{l}\text { InLAND } \\
\text { Andamans, } \\
\text { Pegu, } \\
\text { Arracan, }\end{array}$ & $\begin{array}{l}\text { SPECIES :- } \\
=\frac{22}{3}+\frac{2}{2}+\frac{1}{1} \\
=\frac{22}{3}+\frac{2}{2}+\frac{9}{2}+\frac{2}{1} \\
=\frac{22}{3}+\frac{9}{2}+\frac{1}{1}+\frac{1}{1}\end{array}$ & $\begin{array}{l}=9 \frac{1}{3} \text { or, } 24.56 \% \\
=14 \frac{5}{6} \text { or, } 3903 \% \\
=13 \frac{5}{6} \text { or, } 36.41 \%\end{array}$ \\
\hline & & 10000 \\
\hline
\end{tabular}

* Obtained by adding together the totals of lines 3,4 and 7 .

+ Obtained by adding together the totals of lines 2 and 4 .

\# Obtained by adding together the totals of lines 5, 6 and 7 .

74 
COAST SPECIES :-

$$
\begin{aligned}
& \text { Andamans, }=\frac{17}{3}+\frac{2}{1}=\frac{34+12}{6}=\frac{46}{6}=7 \frac{2}{3} \text { or, } 38.34 \% . \\
& \text { Pegu, }=\frac{17}{3}+\frac{1}{2}=\frac{34+3}{6}=\frac{37}{6}=6 \frac{1}{6} \text { or, } 30.83 \% . \\
& \text { Arracan, }=\frac{17}{3}+\frac{1}{2}=\frac{34+3}{6}=\frac{37}{6}=\frac{6}{6} \text { or, } 30.83 \% . \\
&
\end{aligned}
$$

Comparing the results in these three series of figures we find the

\begin{tabular}{|c|c|c|c|c|c|c|c|}
\hline & & & & & \\
\hline & & & & & $\begin{array}{l}\text { Species in flora } \\
\text { generally. }\end{array}$ & $\begin{array}{l}\text { Inland } \\
\text { species. }\end{array}$ & $\begin{array}{l}\text { Coast } \\
\text { species. }\end{array}$ \\
\hline $\begin{array}{r}\text { Andama: } \\
\text { trodnc }\end{array}$ & $\begin{array}{l}\text { fluer } \\
\text { of }\end{array}$ & rest & ible & in. & $29.29^{\circ} \%$ & $24.56 \%$ & $38.34^{\circ} \%$ \\
\hline Pegu & $"$ & $"$ & $"$ & ", & $36.14 \%$ & $39.03 \%$ & $30.83 \%$ \\
\hline Arracan & $"$ & $"$ &, & $"$ & $34.57 \%$ & $36.41 \%$ & $30.83 \%$ \\
\hline
\end{tabular}
general influence differs from the special influence exhibited in the statistics of the inland and the coast element of the flora as follows :-

\section{TABLE IV. Comparison of Results.}

It will at once occur to the reader that a fallacy underlies this calculation so far as the Andaman influence is concerned, when he notes the low figure at which that influence as regards inland species is given. This low figure, however, only affords corroboration of the justness of the system, since it is exactly the inland portion of the Andaman flora that is as yet inadequately known. The Andaman coast species are, however, nearly if not quite as well known as the Burmese or Malayan coast species, and it is interesting to find that for this element the equivalent numerical expression of the Andaman influence is distinctly higher than are the figures for Pegu or Arracan. The only fallacy underlying the evidence from these figures is that which attends all calculations from numbers that are absolutely somewhat small. At all events they show how just was the passing observation made by Mr. Kurz on his visit to Diamond Island in 1866.* The only point on

* Already given in the text (p. 276) and referred to in footnote $\dagger$. 
which emphasis requires to be put in connection with the remark is that this striking "similarity, nay rather identity, of the shore vegetation" is due less, as Mr. Kurz appears to imply, to the general connection that subsists between the Andamans as a whole and BurmaMalaya as a whole than to a special connection that subsists between Diamond Island as the first segment, and the Andamans as the continuation of a special geographical district whereof both are membra disjecta-a connection quite as strikingly exhibited in these features wherein they together differ from Burma and Malaya as in the features wherein they alike agree with those two areas. 
The hot springs of the Namba Forest in the Sibsagar district, Upper Assam. Unpublished Memoranda by the late J. W. Masters, Esq.,* with observations by Surgeon D. Prain, I. M. S., Curator of the Herbarium, Royal Botanical Gardens, Calcutta.

When stationed at Kohima in $\mathrm{x} 886 \mathrm{I}$ often heard both from Europeans and natives of the springs in the Namba forest. On my way. to Calcutta last January I visited one of these. As the only notice of them hitherto published $\dagger$ is meagre and barely correct, further observation seemed called for. I was assured that in place of being of a scalding temperature those who resorted thither bathed in the springs. No European at Kohima knew the exact temperature.

On my way down I received from an officer $\ddagger$ passing up, a better account of the largest spring. The temperature $I$ was told, is that of a comfortable bath, varying little throughout the year; the water in the rains reaching above the knee, at this time, (January), would probably not reach further than half way up the calf.

The spring was reached at noon on January I6th. It is eleven miles from Golaghat on the Golaghat-Dimapur road where this crosses the Namba river, from whose right bank it is six paces distant at a point twenty-five paces above the bridge. Thirty paces below the bridge the Dhunsiri river, a considerable stream, receives the Namba from the left. The Dhunsiri even in the cold weather is muddy, the Namba is a clear stream, with a bed of white sand, containing some rather angular quartz pebbies. The banks of both streams are about I 8 feet high, and are clay with alluvial mud above.

The depression in which the spring lies, is circular, about 20 feet across and 3 feet deep; the edges mud, the bottom white sand with pebbles, as in the bed of the adjacent stream 15 feet lower. This depression is in Long. $93^{\circ} 55^{\prime} \mathrm{E}$. and Lat. $26^{\circ} 24^{\prime} \mathrm{N}$., and is $35^{\circ}$ feet above the sea.§ Gas bubbles up all over its area; a very strong escape in the

* Sub-Assistant to the Commissioner of Assam at Golaghat. (Several botanical papers by Mr. Masters may be found in the Journal of the Agri. Hort. Soc. of India, Vols. III, V and VI, and a paper on the Meteorology of Assam in the Cal. Jour. of Nat. Hist. Vol. IV. The greater part of Mr. Masters' papers have never been published, though they contain matter of much interest.)

† Oldham : Thermal springs of India. Mem. Geol. Survey of India, vol. xix, pt. 2 , p. 5 I.

¥Mr. Lynch, Subordinate Telegraph Department.

$\S$ Assam, 1884. Map issued by office of Surveyor General of India. [Golaghat on the R. bank of the Dhunsiri is marked 349 feet, the country along the banks of the river is fairly level.] 
centre, two well marked minor vents, and small bubbles coming up everywhere, these last not confined to the part under water at the time of my visit. The gas was odourless and did not burn. The water was five inches deep in the centre; my feet sank slowly in the sand, causing more violent ebullition of gas; by the time the sand had reached my knees it was difficult to extract my feet. The water was beautifully clear, with a sharp but not disagreeable taste. The temperature of the spring was $110^{\circ} \mathrm{Fh}$., that of the Namba being $63^{\circ} 6^{\circ} \mathrm{Fh}$. The effects on the skin appeared to be only those of hot water. Still, all classes of natives attribute to it curative properties in cases of skin disease, and take long journeys to bathe there, leaving offerings of money in the pool. These disappear; removed they suppose by the spirit of the spring. I was fortunate enough to find a bronze coin. Its upper surface is much corroded : that which rested on the sand is less affected. To an expert* the effects looked like those which $\mathrm{H}_{2} \mathrm{~S}$ would produce. From a rough calculation I estimated the discharge at over eight gallons per minute. I brought away some of the water for chemical examination.

Before the result of this examination was received a number of manuscripts were discovered in a long unopened drawer in the Library of the Royal Botanical Gardens. Among these was a series of MS. memoranda relating to the hot springs of the Namba forest; these appear so valuable as to deserve publication now

"Memorandat relative to the hot-springs situated in the bed of, and near to, the Nambur river, on the left hank and right bank of the Dhunsiri river in Upper Assam ; obtained from personal observations registered on the spot at the hours and dates stated below.

"No. I. SOROO NOON-POONG, the principal spring, is eleven miles from Golaghat and situated close to the edge of the right bank of the Nambur, exactly where the road leading from Golaghat to Deemapoor crosses it, on the left bank of the Dhunsiri.

Date.

Temperature

I845. Feb. I7, I P. M.

I85T. Jan, I, I2.30 P. M.
Air

Water of Nambur

Ditto spring

Air

Water of spring $72^{\circ}$

$64^{\circ}$ I $12^{\circ}$

$65^{\circ}$ I $10^{\circ}$

* Dr. Warden, the chemical adviser to the Government of Bengal, who also kindly undertook the examination of a sample of the water.

+ The quotation is a transcript of pp. $489-492$ of the MSS. memoranda of the late Mr. Masters, consisting of his notes on the hot-springs in full. 
Date.

I85I. Feb. I6, II A. M.

"Nov. $25,2.30$ P. M.

"Nov. 26, sunrise

1854. Oct. 27 , i I A, M.

19. Oct. 28 , I P. м.

\begin{tabular}{lr}
\multicolumn{2}{c}{ Temperature. } \\
Air, shade & $66^{\circ}$ \\
Ditto, full sun & $98^{\circ}$ \\
Water of spring & $108^{\circ}$ \\
Air & $74^{\circ}$ \\
Water of Nambur & $70^{\circ}$ \\
Ditto spring & I $2^{\circ}$ \\
Air & $61^{\circ}$ \\
Water of Nambur & $67^{\circ}$ \\
Ditto spring & I $2^{\circ}$ \\
Air & $78^{\circ}$ \\
Water of Nambur & $74^{\circ}$ \\
Ditto spring & I $10^{\circ}$ \\
Air, shade & $81^{\circ}$ \\
Ditto, full sun & I $22^{\circ}$ \\
Water of Nambur & $76^{\circ}$ \\
Ditto spring & I $2^{\circ}$
\end{tabular}

"No. 2. Burra Noon-Poong, situated nearly two miles southwest of No. I in the bed of a jan (streamlet) near to the Nambur falls.

Date.

I 845. Feb. I7, 3.30 P. M.

$" \quad$ Feb. I8, sunrise

,

Mar. I 5, I.30 P. M.

I854. Oct. 28, I I A. M.
Temperature.

$\begin{array}{lr}\text { Air } & 80^{\circ} \\ \text { Water of spring } & 96^{\circ} \\ \text { Air } & 59^{\circ} \\ \text { Water of Nambur } & 62^{\circ} \\ \text { Ditto spring } & 100^{\circ} \\ \text { Air, partial shade } & 82^{\circ} \\ \text { Ditto, full sun } & 90^{\circ} \\ \text { Water of Nambur } & 70^{\circ} \\ \text { Ditto spring } & 100^{\circ} \\ \text { Air } & 82^{\circ} \\ \text { Water of jan (streamlet) } & 78^{\circ} \\ \text { Ditto spring } & 100^{\circ}\end{array}$

"No 3. Gilla-Poong, situated on the right bank of the Dhunsiri river distant about a mile north-east, from No. I. A muddy swamp (bheel) spread over some 3,000 square feet of surface and discharging (now) about to gallons per minute; completely above the ordinary floods of the Dhunsiri.

\section{Date.}

I854. Oct. 27,3 P. M.

" Oct. 28, 2 P. M.
Temperature.

Water of spring

Air, perfect shade

Ditto, full sun

Water of Dhunsiri

Ditto spring $110^{\circ}$

$84^{\circ}$ $104^{\circ}$

$80^{\circ}$

I $12^{\circ}$ 
"The springs are not regular in the quantity of water which they discharge. On the $27_{\text {th }}$ of October last, I estimated that the Soroo Noon-poong was discharging about 30 gallons of water per minute. The waters of the Burra Noon-poong being mingled with those of the jan, renders it difficult to form any just estimate of the quantity of water discharged in a given time; this circumstance also accounts for the low temperature of the spring."

The memoranda are dated, Golaghat, November Ist, 1854 .

The chemical examination by Dr. Warden yielded the following information :-

Total solids at $100^{\circ} \mathrm{C}$ parts per 100,000

Chlorine 124 $66 ! !$

The water was too old for estimation of organic matter. Nitrates and sulphates were present: nitrites absent. There was a distinct trace of $\mathrm{H}_{2} \mathrm{~S}$, but whether this was originally present in the water or produced by the action of sulphates in the presence of organic matter the analyst was not in a position to offer an opinion. There was blackening of the solid residue left after evaporation of the water-on ignition-indicating presence of much organic matter.

Printed by Umbica Churn Shome at the New Britannia Press. 78 , Amherst Street, Calcutta 
On the present condition of Barren Island.-By D. Prain.

Barren Island has been so often described that there is little left to say concerning its physical condition. In his exhaustive account of the island (Memoirs of the Geological Survey of India, xxi, part 4) Mr. Mallet has, however, suggested (l. c., p. 30) that future visitors should note "the temperature of the hot spring" at the landing place and "the "thickness of the fresh and undisturbed sulphur-crusts." This the writer, owing to the kindness of Col. T. Cadell, r. C., Chief Commis. sioner of the Andamans, had an opportunity of doing in April 1891. 
The column of steam from the crater which was "visible from the "landing place or even some distance out at sea" to $\mathrm{Mr}$. Mallet ( $l, c$, p. 23) in February 1884 and was "barely visible at 3 miles distance" to Capt. A. Carpenter in 1886 (Records, Geol. Surv., India, xx, 48) was no longer visible from these points in April 1891; on ascending the cone, however, steam was found to issue still at the places indicated in Mr. Mallet's memoir. The most copious discharge was still from the solfatara on the inner aspect of the north side of the crater.

$A$ deposit of sulphur of an average thickness of $2 \frac{1}{2}$ inches had been laid down on this solfatara since 1884. On the other solfataras far less had been deposited; the crusts on the two next largest-that on the inner aspect of the south side of the crater and that outside the crater on the north-east face of the cone-were but $\frac{3}{4}$ in. to 1 inch thick. The new crusts were very similar to the old ones described by $\mathrm{Mr}$. Mallet (l. c., p. 18) except as regards thickness; when pieces were removed, however, they were found to be looser in texture and more friable than the fragments of the old deposit that lay scattered about the crater and in estimating the present value of the solfataras as a sulphur-supply this should perhaps be taken into account. The temperature of the steam at the point of issue was not determined in 1891, but it can hardly be as hot now as in 1884 -it was then $219^{\circ} \mathrm{F}$ - - since there was no crevice in which it was impossible to place one's hand for at least a few seconds.

In taking the temperature of the hot spring Mr. McCausland, Commander of H. M. I. M. Nancowry very kindly assisted me. At high tide there was no trace of percolation of water through the shingle of the small landing-place beach, but when the tide had ebbed water was found to ooze through this shingle at five different points round the head of the bay. Having scooped out pools sufficiently deep for complete immersion of a thermometer at these spots we took temperatures in as nearly as possible the fashion described by Mr. Mallet ( $l$. c., p. 26). In the most northerly small pool (furthest from the recent lava), the thermometer registered $102^{\circ} \mathrm{F}$; in the next pool towards the lava, $103^{\circ} \mathrm{F}$; ; then $104^{\circ} \mathrm{F}$; then $106^{\circ} \mathrm{F}$.; finally in the pool nearest of all to the recent lava $104^{\circ} \mathrm{F}$.; Mr. Mallet found that in 1884 the temperatuxe of the different springs increased with their proximity to the recent lava; the discrepancy of our results as regards the last pool and that next adjacent to it (which, though five yards further from the lava was nevertheless $2^{\circ} \mathrm{F}$. warmer) from the experience of $\mathrm{Mr}$. Mallet led us to repeat the whole observation and to take the temperatures in these two last pools several times; our results werc, however, the samo 
on each occasion. There appears to have been more water in the spring at the time of Mr. Mallet's visit (Feb.) than when our observations were made (A pril) for he found it possible to take temperatures in seven places while we eould only do so in five.

This spring was formerly mueh hotter than it is now, but unfortunately the early observations are not at all definite: 'as hot almost 'as if it had been boiling' (eommander of a vessel, 1832); 'temperature too high to be borne with the hand' (Playfair, 1837); 'natural boiling spring' (Mouat, 1857) ; 'nearly at the boiling point' (Liebig 1858); 'sealding hot' (Parish, 1862). The observations made sinee 1862 being more preeise are here appended :-

\begin{tabular}{|c|c|c|}
\hline Date. & Temperature of Spring. & Authority. \\
\hline April, 1866 & $158^{\circ} \mathrm{F}$. and $163^{\circ} \mathrm{F}$. & $\begin{array}{l}\text { Andaman Committee, } \\
\text { Report in Proc. As. Soc. } \\
\text { Beng. } 1866, \text { p. } 213 \text {. }\end{array}$ \\
\hline March, 1873 & $130^{\circ} \mathrm{F}$. (highest observed) & $\begin{array}{l}\text { Ball, Rec. Geol. Suv'v. } \\
\quad \text { India, vi, p. } 87 .\end{array}$ \\
\hline February, 1884 & $106^{\circ}-116^{\circ} \mathrm{F}$ & $\begin{array}{l}\text { Mallet, Mem. Geol. Surv. } \\
\quad \text { India, xxi, pt. 4, p. } 26 .\end{array}$ \\
\hline A pril, 1886 & $110^{\circ} \mathrm{F}$. (solitary observation) & $\begin{array}{l}\text { Daley, Rec. Geol. Surv. } \\
\quad \text { India, xx, } 48 \text {. }\end{array}$ \\
\hline April, 1891 & $102^{\circ}-106^{\circ} \mathrm{F}$. & Prain. \\
\hline
\end{tabular}

The observations given in this table are not of quite equal value beeanse they have not been taken on a uniform prineiple. The Andaman Committee above referred to (Dr. Gamseks, Lt. Laughton and Mr. Homfray) deseribe the spring aecurately as issuing from underneath the lava aeross the small bay, but though Mr. Ball (l.c.) speaks of them as reeording the temperature "at from $158^{\circ}$ to $163^{\circ}$ " the statement in their report is that at low tide in one place the temperature was found to be $163^{\circ} \mathrm{F}$, and at another $158^{\circ} \mathrm{F}$. We eannot therefore be eertain that these figures give either the maximum or the minimum temperature in 1866 , though it is highly probable even if one of them represents a limit that they do not exhibit the full range of temperature at that time. Mr. Ball's observation is rather more precise; the highest temperature is given as $130^{\circ} \mathrm{F}$. taken close to high-water mark where the spring bubbles up; unfortunately he does not give the range of temperature in 1873. In eonneetion with this it should be noted that Mr. A. O. Hume, speaking of this very observation, says 
(Stray Feathers ii, 104) "the thermometer showed a temperature of "nearly $140^{\circ} \mathrm{F}$." This remark occurs in the narrative portion of a paper on the ornithology of the islands of the Bay of Bengal and is clearly written from memory only; attention is drawn to it now merely in order to prevent any one who may subsequently read the statement from relying upon it as exact. Mr. Mallet's observations are very comprehensive and precise. Only the bare result of Mr. Daley's observation is given and only one temperature is mentioned: it is not stated that it was the highest, and it is possible that the temperature was taken at one spot only.

The rate of cooling of the spring as indicated by the various highest readings of the preceding table is shown in the table subjoined :-

\begin{tabular}{c|c|c|c}
\hline Period. & No. of yearg. & $\Delta$ mt. of cooling. & Rate per annum. \\
\hline 1866.73 & 7 & $33^{\circ} \mathrm{F}$. or $18 \cdot 30^{\circ} \mathrm{C}$. & $4 \cdot 7^{\circ} \mathrm{F}$. or $2 \cdot 6^{\circ} \mathrm{C}$. \\
1873.84 & 11 & $14^{\circ} \mathrm{F}$. or $7 \cdot 70 \mathrm{C}$. & $1 \cdot 2^{\circ} \mathrm{F}$. or $0.6^{\circ} \mathrm{C}$. \\
1884.86 & 2 & $6^{\circ} \mathrm{F}$. or $3 \cdot 3^{\circ} \mathrm{C}$. & $3.0^{\circ} \mathrm{F}$. or $1 \cdot 7^{\circ} \mathrm{C}$. \\
1886.91 & 5 & $4^{\circ} \mathrm{F}$. or $22^{\circ} \mathrm{C}$. & $0.8^{\circ} \mathrm{F}$ or $0.4^{\circ} \mathrm{C}$. \\
\hline
\end{tabular}

The rates per annum shew that the existence of an error in the 1886 observation is not only possible but highly probable; the spot selected for examination can hardly have been that in which the temperature was highest at the time. If it be neglected the rate per annum for the whole $1884-91$ period is $\frac{10}{7}$ or $1.4^{\circ} \mathrm{F} .\left(=0.7^{\circ} \mathrm{C}\right.$.) a rate that, allowing for errors unavoidable in such observations, is practically uniform with that during the 1873-84 period. Between 1866 and 1873 it cooled nearly four times as fast as it has cooled since; if the 1886 observation is correct, six times as fast as it is cooling now. If the rate continues uniform henceforth the spring will, if the 1886 observation be correct, probably cease to deserve the appellation " hot" by 1925 , if the 1886 observation was not taken where the'water was hottest at the time, the spring will probably be cool by 1910 . 
From the Journal, Asiatic Society of Bengal, Vol. LX, Part II, No. 2, 1891.

On an undescribed Oriental species of Nepeta.-By D. PrAIN.

[Received 2nd March 1891 ; - Read 6th May 1891.]

(With Plate III).

In the Calcutta herbarium there is an example of a very distinct species of Nepeta which appears to be as yet undescribed. As it has been collected beyond the frontiers of India, it could not with propriety be dealt with in the paper on Indian Labiatce recently read before the Society. But as it possesses rather more interest than isolated new species usually do, its position in the arrangement of Oriental species elaborated by the late M. Boissier in his work (Flora Orientalis, iv, 637670) dealing with the area in which it occurs, as well as a description and figure of the specimen, are now presented.

\section{NEPETA LinN.}

Sect. I. Eunepeta. Series I. Perennes. Sub-ser. 2. Nuculø tuberculatæ.

$\S$ Macrostegiz Boiss., Flor. Orient. iv, 638 (1879) ampl.-Verticillastra densiflora vel laxiuscula remota. Bracteæ ovatæ vel oblongæ. Calyx fauce pilosus vel glaber.

1. Calyx ore obliquus.

N. Bellevii.

a. Calyx fauce pilosus.

b. Calyx fauce glaber.

N. glomerulosa, N. juncea.

2. Calyx ore rectus, fauce glaber.

N. Scordotis, N. Sibthorpii, N. leucostegia.

34 $b$. Nepeta Bellevir Prain; robusta, laxe lanata nivea, caulibus elongatis ramosis puberulis obtuse 4-gonis superne subnudis, foliis majusculis sursum decrescentibus oblongo-lanceolatis crenato-dentatis 
subrugosis apice acutis basi truncatis, utrinque parce lanatis, inferioribus breve petiolatis cæteris subsessilibus rauealibus ovato-lanceolatis ; verticillastris multifloris laxiusculis remotis, bracteis membranaceis ovatolanceolatis acuminatis cucullatis calyces æquantibus, calycis longe hirsuti membranacei striati ore intus piloso obliquo, dentibus e basi angustiore subulatis summo tubum subæquante cæteris eo brevioribus, corolla extus puberula tubo calycis fere 2-plo longiore, staminibus exsertis, nuculis oblongis apice obtusis ruguloso-tuberculatis areolâ ferri equini calcaribus sursum dircetis ad instar affixis.

Afghanta adstralr; inter Kandahar et Kelat-i-Ghilzai, Bellew!

Rhizoma de-est, caulis p.q. s. plus quam $40 \mathrm{~cm}$. basi fere $1 \mathrm{~cm}$. crassa, foliis inferioribus $7-9 \mathrm{~cm}$. longis his $3-4 \mathrm{~cm}$. latis petiolis $1 \mathrm{~cm}$. longis, ramealibus $2-2.5 \mathrm{~cm}$. longis his $1-1.5 \mathrm{~cm}$. latis sessilibus, spicâ $12 \mathrm{~cm}$. longâ hac $2.5 \mathrm{~cm}$. latâ verticillastris $(10-12)$ 12-16-floris imis $2 \mathrm{~cm}$. summis vix $1 \mathrm{~cm}$. remotis, bracteis $12 \mathrm{~mm}$. longis $4-7 \mathrm{~mm}$. latis $3-5$ nervis coloratis supra glabris subtus nervis sub lente puberulis margine prope basin parce pilis albis divergentibus ornato prope apicem acuminatum et tandem subulatum sub lente puberulo, calyce tandem subinflato pedicello $1-2 \mathrm{~mm}$. longo tubo $6 \mathrm{~mm}$. longo dentibus summo $6 \mathrm{~mm}$., lateralibus $5 \mathrm{~mm}$., imis $4.5 \mathrm{~mm}$. longis extus æquabiliter pilis albis divergentibus parce hirsuto intus tubi ore et dentium basibus pilis simillimis densissime piloso, corolla tubo $11 \mathrm{~mm}$. longo extus puberulo colore forsan rosea, nuculis $3 \mathrm{~mm}$. longis his $1.5 \mathrm{~mm}$. latis brunneis areolâ albâ calcaribus $1 \mathrm{~mm}$. longis exceptâ manifeste rugulosis.

This very distinct species bears a considerable resemblarce to the European $N$. tuberosa but the whorls are much more lax, the calyx mouth is oblique and no secondary reticulation of the membranous bracts is visible. The nutlets of this species also closely resemble those of $N$. tuberosa and $N$. Sibthorpii, but in these European spccies there is a much smaller areola of the us ual type. Among Oriental species it most resembles $N$. glomerulosa, next to which it is now placed, but it differs greatly in having much larger bracts, much longer spikes and many-flowered lax whorls with longer corollas. The nutlets too are different-the horse-shoe shaped areola of the untlets being perhaps the most remarkable character of this specics; its pilose calyx-mouth also is a character which connects it with $\S$ Psilonepete Benth. to which group this feature has hithcrto been supposed to be confined. Except for this character, however, it is much more obviously related to the other Macrostegle than to any Psiconepera. Perhaps a prefer. able view would be to look on this species as the type of a new subsection intermediate between Psilonepetre and Macrostegire though to be 86 



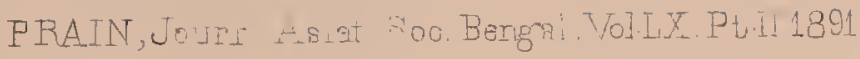

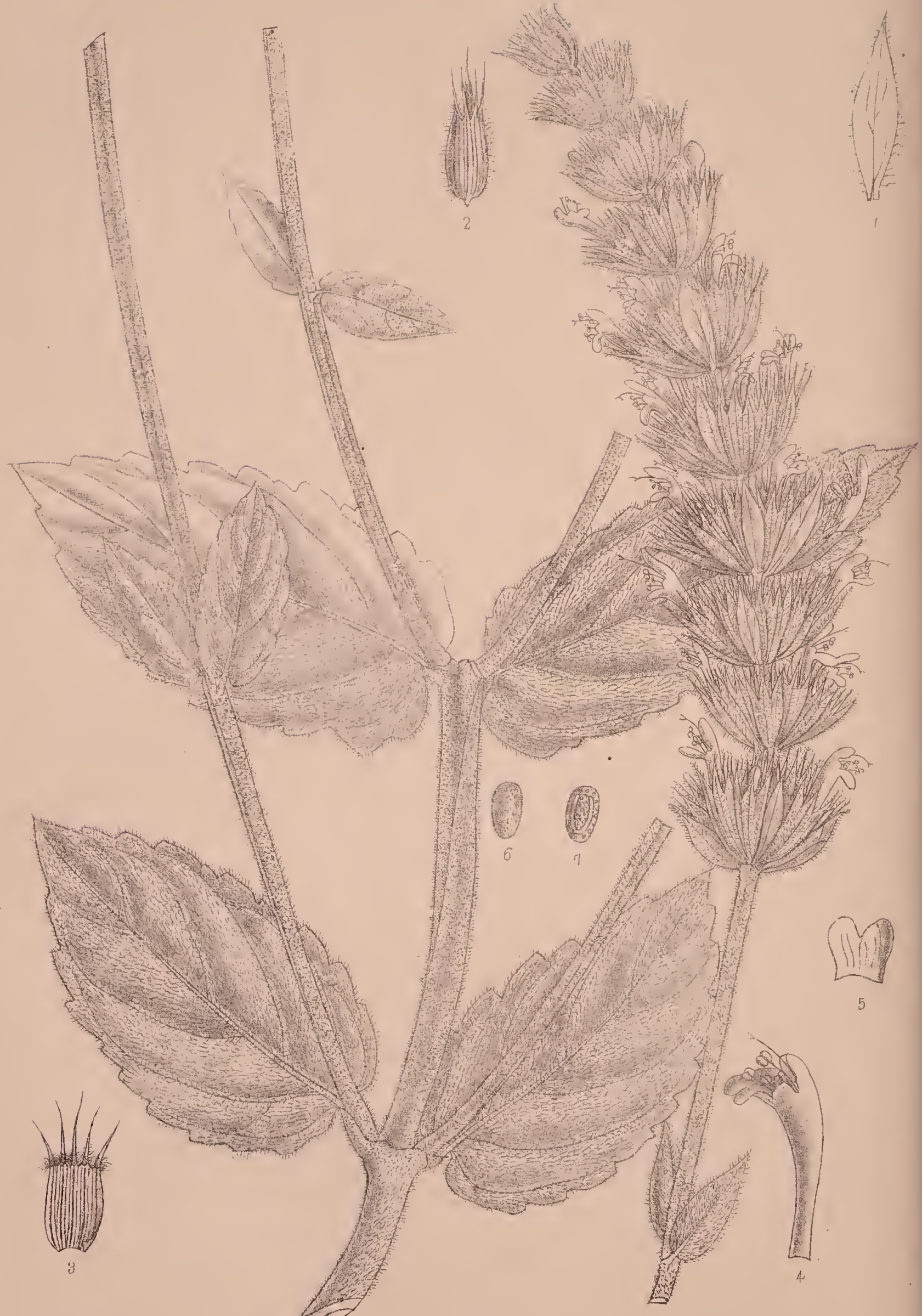


placed in the same subseries as the latter. This subsection would be characterised as follows :-

$\$$ Psilostegie (Sub-sect. nov.).-Verticillastra laxiuscula remota. Bracter ovatæ. Calyx fauce pilusus. (Nuculae tuberculatae).-Inter Psilonepetas Benth. et Macrostegias Boiss. quasi mediantes et proximæ Macrostegis (Boiss., Flor. Orient. iv, 638 et $65 \mathrm{r}$ ) anteponendæ.

\title{
EXPLANATION OF PLATE III.
}

Nepeta Bellevil, Prain.

\author{
Fig. 1. Bract. \\ 2. Calyx. \\ 3. The same, laid open. \\ Fig. 4. Corolla tube. \\ 5. Upper lip of Corolla. \\ 6. Nutlet, external aspect. \\ 7. The same, showing inner face with cha- \\ racteristic horse-shoe shaped areola.
}

[From the Journal, Bombay Natural History Society, Vol. 5, No. 2, 1890.] 165 .

Teratological effects produced on Acacia eburnea Willd. by Ecidium esculentum Barcl.-By D. PraIN.

The fungoid growth produces considerable general hypertrophy and some distortion of the parts involved; it causes at the same time the occurrence of certain abnormalities of structure.

The species affected, Acacia eburnea of Willdenow, is characterised by having its florets arranged in globose heads. These heads are borne on slender stalks that arise from the axils of developed leaves; the stalks are near their middle surrounded by a ring of small bracts. The free ends of the stalks are slightly thickened and it is to this 
slightly thickened sub-globose facetted part of the stalk that the florets are attached. The individual florets do not possess special stalklets. So much of the structure of the normal inflorescence it is necessary to detail in order to make the conditions in the diseased flowers intelligible.

In the diseased flowers a ring of florets makes its appearance in the axils of the bracts near the middle of the stalk, that are normally sterile. The thickened end-parts of the stalk that are normally short and globose become elongated in such a manner as to transform the globular flower-head into a cylindric spike on which the florets instead of being crowded together are arranged at short intervals from each other. At the same time each of the florets developes a short special stalklet, and in place of all the florets opening simultaneously as they do in the normal flower-heads, those florets in the diseased spikes that are nearest to their apices are smaller in size and later of growth than those below them. It ought to be noticed that even in fruit there is no tendency in undiseased plants to elongation of the part of the stalk to which the pods are attached, and no disposition on the part of the pods to ripen more quickly at the outside of the branch than in the centre. At the same time it has to be repeated that it is entirely owing to special elongation of this part of the stalk in diseased flowers that the flower-head becomes changed from a ball into a spike, because the interval that in normal flower-stalks exists between the barren bracts and the flower-heads themselves still continues to exist, destitute of florets, between the circle of florets that appears abnormally in the axils of the bracts and the basal florets of the cylindric spike. This interval, which in undiseased flowers is $5-6 \mathrm{~mm}$. long, measures $10-12 \mathrm{~mm}$. in diseased ones. But the increase in length of this part is merely due to the general hypertrophy produced by the disease, and it is not its size but its existence at all in the diseased flower that is of interest.

Expressed in technical teratological language the conditions in. duced by the disease are:- Increase in the size of the parts affected by general hypertrophy, with some alteration of shape by distortion combined with conversion of florets from sessile to pedicellate by elongation, conversion of a capitate inflorescence into a spike by apostasis, change of a simultaneous and therefore at least sub-definite 


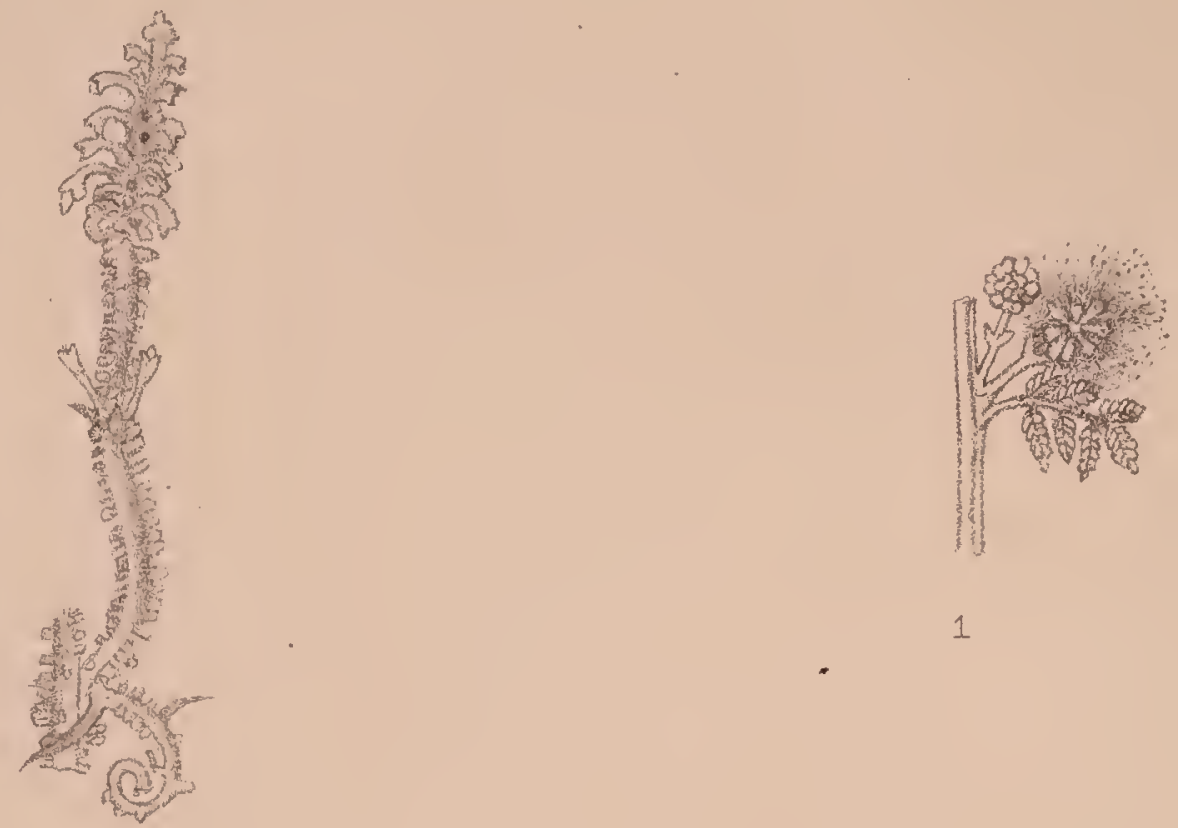

3

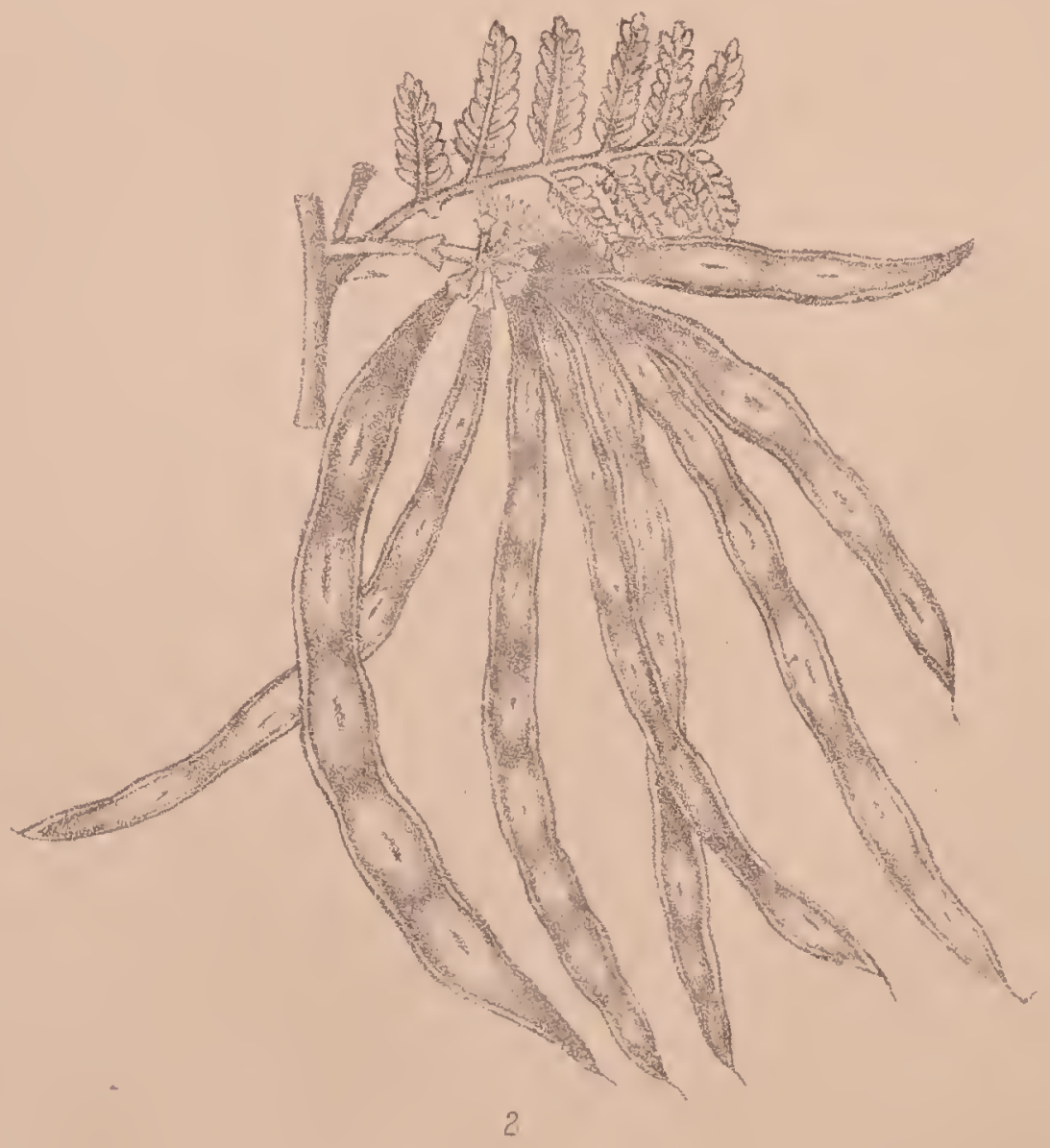

Acacia eburnea. WILLD 
inflorescence into a palpably indefinite one by heterotaxy, and the appearance of a new circle of florets by prolification of flower-buds in the axils of the median peduncular involucre.

Explanation of figures in Plate $B$ :-

I. Flower head with opened florets and head with florets unopened in axil of the same leaf of Acacia ebumea, Willd.

2. Young infruitescence shewing that even in fruit there is no tendency to elongation in that part of the peduncle to which florets and subsequently pods are attached; from the same plant as preceding.

3. Diseased flower (covered with the granular papillæ indicative of the disease) shewing distortion of leaf; general hypertrophy of portion of branchlet, stipular spines and inflorescence; prolification of florets in the axils of the peduncular bracts ; apostasis, and at the same time heterotaxy, in the normally foret-bearing portion of peduncle; with pedicellation of individual florets that are normally sessile.

[Reprinted from the Journal of the Agricultural and Horticultural Society of India. Vol. VIII, Part II, Newe Series, pp. 278-28I.]

Note on Lo-Kao, the Chinese Green-Dye; yzelded by various species of Rhamnus. - By D. PraIN.

The spccies of Rhammus of Eastern Asia are closely allied and therefore not easy to define so that those which-yield a green dye have been variously named by different authors. Two well known plants afford this dye, and to these a third would seem to have to be added.

The first of these is $R$. davuricus, Pall. to which Forbes and Hemsley in Jour. Limn. Soc. xxiii, 128, reduce $R$. utulis, Dene, 
under which name one plant that yields the dye is generally known. Maximowicz in Mem. Acad. Sc. Petersb. 7e ser. x, (reprint p. 8), makes $R$. davuricus itself a variety of $R$. catharticus, Linn., a reduction which Forbes and Hemsley, loc. cit., do not consider advisable.

The second is R. tinctorius, Waldst. \& Kit., .to which Forbes and Hemsley, loc. cit., I29, reduce $R$. chlorophorus, Dcne, under which name the other source of the dye is generally known. To this also these authors reduce $R$. globosus, Bunge, a plant which Lawson in Flor. Brit. Ind., i, 639 unites with R. virgatus, Roxb., reducing both to $R$. davuricus. Probably, however, Roxburgh's plant is a good species, in which case neither of these dye plants is indigenous in India. There appears to be no record of any attempt to ascertain whether indigenous species of Rhammus will yield a green dye. Specimens collected by Fortune and, if not the specimens themselves, very likely identical with those which Thomson says, in the passage quoted in Jour. Agri. \& Hort. Soc. of India, $\mathrm{I}^{\circ}$ ser., ix, 274 (foot note), that he sent to England to be determined are stated by Forbes and Hemsley, (loc. cit., I30) to be typical $R$. chlorophorus.

A third plant is alluded to as "Rhammus sp." in Jour. Linn. Soc., xxiii, I 30 as gathered by Mesny in Szechuen, about Io miles N. of Kweiyong, at 6,500 feet elev. which is "used with other "ingredients to make a green dye for calicoes: its liquor being "blue like indigo. Neither flowers nor fruit seen." It is further stated that this is very different from either of the other dye-yielding species, and that it is apparently an evergreen shrub.

There are only leaf specimens of green-dye plants in the Calcutta herbarium. The ticket on the oldest bears "China green-dye: "A. H. Soc. Gardens, 19-3-56." This should be the plant sent by Fortune, and be thus (teste Forbes and Hemsley) typical $R$. chlorophorus, Dcne, and therefore true $R$. tinctorius, Waldst. \& Kit. The ticket on another is, "Japanese green-dye. Cultivated at Lembong, "Tanka-ban-Prahoe, Java, 5,200 feet, collected by Dr. King, I4-1079." This was known in Java at that time as $R$. chlorophorus. It is however different from Fortune's plant. As it has no flowers or fruit, it cannot be positively determined, but the probability. is that 
it is $R$. utilis, Dcne, and therefore true $R$. daruricus, Pall. It is cxceedingly like specimens of veritable $R$. davuricus here. Dr. King tells me the plant is grown in Java only as a curiosity.

The history of the plant sent from China by Fortune is short. The account of it in Vol. ix. $1^{\circ}$ ser. of the Socicty's Joumal shews that under the special treatment it received in their garden it did fairly well. When the old site was abandoned, the ground reverted to the Botanical Garden, and as the plant appears to have attracted no attention on the part of the public, the special treatment does not seem to have been continued. Left to itself it shewed its exotic nature and within a few seasons all the specimens died. It would be interesting to ascertain if any of the older members of the Society have continued the cultivation of the plant and still preserve it. But its not being generally grown seems to point to practical difficulties, and this is borne out by its speedy extinction when left to itself.

The geographical limits of the species are as follows :-

$R$. davuricus; N. China, Mandshuria, E. Siberia.

$R$. tinctorius; Mid and N. China, Asia Minor, S. E. Europe.

$R$. sp.; Central S. China, but at 6,500 elevation there.

It is therefore doubtful whether períect naturalization of these in the plains of India can be hop $d$ for. Moreover, all the indigenous species are high level plants, the lowest elevation quoted (for one species only, $R$. persicus, Boiss), being 2,000, the usual range being 5,000 to 9,000 . But it is likely that the Chinese species would thrive well at similar levels. It would be interesting to ascertain whether any of the indigenous species, one at least of which has been referred to a dye-yielding species, would not, if suitably treated, yield a similar dye. The property, as has been shewn, is shared by at least three Chinese species.

Mr. Blechynden suggests the recapitulation of the Chinese method of preparing the dye. This is to be found in the Society's Journal, loc. cit., 276, and it is to be noted that in Fortune's account of the process, and also in McMurray's account of the cultivation of the plant which accompanies it, two varneties, a wild and a cultivated, are spoken of, the presence of both being necessary for the production of the dye. These varieties are 
Note on Lo-Kao.

apparently not distinguishable in the herbarium. At all events no mention is made of them by Forbes and Hemsley, loc. cit. Unfortunately there is no note on the Calcutta specimen to indicate which of the two is here preserved,

The process is as follows :-

"Ist.-To take the two kinds, strip the leaves off them, chop "them up into convenient lengths and boil thoroughly.

" "nd.-To leave the residuum undisturbed for three days " and then put it into large earthenware vessels.

" $3 \mathrm{rd}$.- The colouring matter is then taken up by immersion " of cotton cloth prepared with lime.

" 4 th. After five or six immersions the cclour is washed from "the cotton and again boiled.

" 5 th. - Lastly, it is again taken up on cotton yarn and then "sprinkled on thin paper and thoroughly dried." 
From the Journal, Asiatic Society of Bengal, Vol. LX, Part II, No. 4, 1891.

Natural History Notes from H. M.'s I. M. Survey Steamer "Investigator," Commander R. F. Hoskyn, R. N., CommandingNo. 25. The Vegetation of the Coco Group.-By D. Prain.

[Received-Oct. 23rd; read-4th Nov. 1891.]

\section{§ INTRODUCTORY.}

The Cocos are a small group of three islands, Table Island, Great Coco, and Little Coco, Jying about 30-45 miles north of Landfall Island, the most northerly of the Andaman group proper, in Lon. $93^{\circ} 21^{\prime}$ E., Lat. $13^{\circ} 56^{\prime}$ to $14^{\circ} 10^{\prime} \mathrm{N}$., and form one of the links in the islandchain that stretches southwards from Cape Negrais in Arracan to the Nias Islands off the western coast of Sumatra.

The first link in this chain is Diamond Island, Lon. $94^{\circ} 18^{\prime} \mathrm{E}$., Lat. $15^{\circ} 51^{\prime} \mathrm{N}$., 8 miles south of Cape Negrais and 130 miles north-north-east of the Cocos; the next is the island of Preparis, (not yet botanically investigated), larger than Diamond Island but smaller than the Great Coco, 80 miles south-south-west from Diamond Island and 50 miles to the north of the Cocos. The strait between Diamond island and Preparis is somewhat under 100 fathoms, that between Preparis and the Cocos somewhat over that depth. The channel between the Great and the Little Coco is under 50 fathoms, a depth not greatly if at all exceeded in the passage between the Cocos and Landfall. The next link in the chain is the Andaman Group proper, extending from about Lat. $10^{\circ} 40^{\prime}$ to 
$13^{\circ} 45^{\prime} \mathrm{N}$., consisting of scveral large islands that are separated by straits and channels which, with the exception of a passage 30 miles wide and about 100 fathoms deep between Rutland Island and Little Andaman, are all very narrow and usually quite shallow. Further south we find in the same chain the Nicobar Islands; these, separated by wider intervals than the members of the Andaman Group are, extend from $6^{\circ} 45^{\prime}$ to $7^{\circ} 15^{\prime} \mathrm{N}$. Besides being wider, the passages between the individual islands here are much deeper and the main channels between the Andamans and Nicobars on the one hand, and between the Nicobars and Sumatra or the Nias Islands on the other, in place of being under 150 fathoms deep, give soundings of 500, 750, and even 900 fatloms. There is, however, along the line from Little Andaman to the island of Simalu or to Acheen Head an undoubted ridge, for the floor of the Sea of Bengal to the westward is 2,000 fathoms deep, and that of the Andaman Sea to the eastward is in some places at as great a depth. Whether any portion of the now submarine sections of the southern, or Nicobars half of this ridge has ever been subaërial it is diffenlt to say but it seems likely from its present physiographical configuration that the most recent land connection must have been between the northern or Andaman half of the ridge and the adjacent Indo-Chinese district of Arracan.

Table Island, the most northerly member of the Coco group, and lying 45 miles north of Landfall, is about a mile across and is rather longer than broad, with a considerable outlying islet, Slipper Island, at its north-west corner; southward, across a strait about two miles wide, lies the Great Coco some 9 miles long from north to south and about $2 \frac{1}{2}$ across at the widest part with several small islets off both its east and west coasts and with a very considerable outlying islet, Jerry Island, at its southern extremity; finally, some 6 miles south-west of Great Coco, and 30 miles north of Landfall, is the Little Coco about $2 \frac{1}{4}$ miles long from north to south and $\frac{1}{4}$ to $\frac{1}{2}$ a mile wide.

Through the kindness of Capt. Hoskyn, R.N., the writer, in company with Dr. Aleock of H. M. I. M. "Investigator," has been able to visit the group on two occasions. On Nov. 30th and Dec. 1st, 1889, Table Island was examined. On Dec. 2nd, 1889, a naturalist's party, which the writer was privileged to join, landed on Great Coco and remained encamped on a small cleared hill in its north-eastern peninsula until Dec. 8th. From Nov. 14th till Nov. 23rd, 1890, a similar party, of which the writer again was a member, was encamped on a sandy spit covered with coco-nut trees at the south end of the island; while between Nov. 25th and Nov. 30th, 1890, the Little Coco was examined.

On Table Island is situated the well known lighthouse of this name and the western slopes of the main island as well as most of Slip94 
per Island, which at low-tide is not separated from the main island, are cleared on account of some cattle of which the lighthonse-keeper has charge. Throughout the rest of the island, however, except for a few pathways that have been cut on account of the cattle, the jungle is very dense and uniform. Around a bay at the south side of this island as well as on the north coast is a fringe of coco-nut trees. The height of Slipper Island is 110 feet; the highest point of Table Island proper is 150 feet. On the occasion of the visit referred to, the eastern half of the island, where the jungle is as yet intact, was traversed from south to north; the northern and western coasts were examined; the island was traversed from west to east along one of the cattle paths; the clearing was also examined for introduced weeds and escapes from cultivation.

On Great Coco Island there is a small clearing on a peninsula that forms the north-eastern extremity of the island, the site of an abandoned settlement which, some years ago, it was attempted to effect and where the writer was encamped during his first visit. Except at this point and on two or three of the more exposed cliffs and slopes on the western seaface of the island, which are only grass-clad, there is a uniform jungle from end to end of the island and from base to summit of the numerous more or less parallel steep ridges that compose it. The shore is fringed with coco-nut trees in quite a thin belt where the ridges that compose the island come close to the shore, and this fringe is broken here and there where these ridges end in abrupt headlands; the belt widens however at the heads of the various bays and in two places in particular, -on the eastern side of the island along the bay that cxtends southward from the north-eastern peninsula already mentioned, as well as across the isthmus joining this peninsula to the main island and thence along the northern end of the island to the mouth of the principal creek-again, on the western side of the island for half a mile or more northwards from the southern end-this belt of coco-nut trees is 100 yards or more in width. Where the beach meets the coco-nut bclt there is an invariable sea-fence of Panclanus with other ordinary Indian Ocean littoral plants; this fence is generally less dense where the bcach is composed of sand than when it consists of coral shingle. Except on the very crests of the ridges, and sometimes even there, and on the more exposed wostern headlands, the forest is composed of very tall trees with below these a dense undergrowth; this nudergrowth is particularly donse, owing to the number of creepers, on the crest of ridges destitute of tall trees, and on the slopes of the western sea-face that are not grassy. It is also very dense immediately behind the coco-nut belt especially if, as frequently happens, this belt passes insensibly into the mudflats that characterise the outskirts of a mangrove swamp. On the sides of ridges however, as 
opposed to their erests, the under-jungle is not so dense, largely owing to the mass of creepers being carried up to the tall trees above, while on the neck of land that connects the main island with the peninsula at the north-east corner, and on the narrow, more level tongue that forms the south end of the main island and stretches towards Jerry Island, the jungle is rather opener and more penetrable than elsewhere. The height of the outlying north-eastern peninsula which probably at one time has been a separate islet, at least at high-tide, is 80 feet; the highest ridge of the main island has an elevation of 300 feet; the other ridges mostly reach from 150-200 feet. Jerry Island, the chief outlying islet off Great Coco, consists at the southern end of a low ridge 60 feet high with a vegetation quite like that of the ridges on the main island; the northern half, however, consists of a level spit stretching towards the main island; this spit is composed of coral-shingle, and though covered with coco-nut and other trees there is only a sparse undergrowth within its Pandanus belt. Between Jerry and the main island extend wide sandstone reefs on which the waves and currents have thrown up a small eyot of sand, coral-shingle, dead shells, and drift timber on which stranded fruits and seeds are germinating. The other outlying islets call for no remark; all of them look like detached continuations of particular: ridges and most of them have the regetation characteristic of these. During the first visit daily excursions were made into the island towards the northern and eastern parts; the jungle was found to be so dense on the ridges and the level ground so difficult owing to the ramifications of a considerable creek, which, with its concomitant mangrove swamps, finds an outlet into the northern bay, that it was only on one occasion that the western coast was reached. It was impossible to do anything like justice to the interior; still, the northern and northeastern peninsulas, the northern half of the east coast, the north coast and about two miles of the west coast at the north end were fairly thoroughly examined. During the second visit, profiting by the experience of the former season, fewer attempts were made to force a passage in a straight line through all obstacles, and the cdges of ridges-juga ipsissima-were in particular carefully avoided. The compass was discarded, no particular objective in the shape of a hill visible from the sea-shore was permitted to occupy the attention exclusively; the easiest rather than the shortest road was chosen as the route to be followed. In this way the island was crossed in four or five different places, all, however, towards the southern end; the west coast was explored for about four miles and the east const examined northwards as far as the point reached when working in the opposite direction in the previous year. The outlying islet, Jerry, was also examined fairly thoroughly and its coasts skirted. 
Little Coco consists of several ridges the highest having an elevation of 200 feet. The ridge jungle is much as in the other islands, but the level land is more largely composed of a basis of coral-shingle than is the case in the other two islands and the undergrowth is not quite so dense as in the level land on Great Coco. The coco-nut fringe is quite as uniform as in the Great Coco, but there is only one point, - - at the head of a shallow bay in the middle of the west coast,- -where the belt is as much as thirty yards wide. During his visit to this island the writer was able to cut his way from west to east across the highest ridge; to cross in another part along more level and frequently swampy ground; to work through a lagoon that occupies the south-western part of the island, and to skirt the whole coast on two different occasions.

The islands have all the physical features of the Andaman islands of the main chain as opposed to those of the Archipelago lying to the north-east of Port Blair; the rocks indeed recall at once those of Ross Island and of the shores of Port Blair in South Andaman. They are also equally like those forming Diamond Island, off the Arracan coast at the mouth of the Bassein river and, as in these localities, are best seen at points where the inland ridges end in abrupt headlands or are coutinued as long reefs exposed wholly, or in part, at low-tide.* Such reefs not infrequently rise into outlying islets. These islets are some distance from the main island, and are bare and rocky, or jungle-clad, according to size and exposure, those off the west coast being all very bare. The bays between the headlands are mostly wide and shallow, and are filled up, except opposite the mouths of creeks, with an accnmulation of coral debris that becomes at times banked up, causeway-like, between the shore and an outlying island; these causervays are in some instances becoming stocked with the mangrove-vegetation of the neighbouring creeks.

The floor of these shallow bays is remarkably flat and uniform and is, at the sea-edge of the bay where the reef ends, generally rather shallower than it is within, so that at low-tide each bay consists of a long shallow pool, one to two feet deep, separated from the sea itself by a long low bank of exposed coral. The bottom of such a pool is usually covered by a close meadow of Cymodocea ciliata, but though this species is so common there seems to be no other marine pbanerogam present. Algce, too, are remarkably inconspicuous, being of small size and very

* For further notices of the physiography of the islands the reader is referred to Alcock; Nat. Mist. Reports in Hoskyn, Administration Reports of the Murine Survey of India 1889-90, pp. 14, 15; 1890-91, pp. 11, 12; where also notices of the fanna, particularly marine, will be found. In Hume; The Islands of the Bay of Bengal in Stray Feathers, vol. ii, pp. 111-119, an account of these islands will also be found; there the ornithology of the group is exhaustively discussed. 
scarce; the only exceptions are Turbinaria ornata, which is fairly frequent both on the coral reefs and on the sandstone ledges; Padina pavonia, more common on the exposed sandstone reefs but less frequent on the coral than Turbinaric ; and Sargassum ilicifolium, which is the only really common seaweed and which occurs in great meadows at the outer margins of the fringing reefs and sandstonc ledges that are exposed at low-tide, as well as in the deeper water beyond.

Reefs such as those described are extremely common in all the islands of the Andaman and Nicobars groups that the writer has visited, and the marine vegetation is remarkably uniform in appearance as well as in specific constituents. On Car Nicobar, for example, as well as on Rutland Island, at the extreme south end of the Andaman main group, localities which the writer has visited on different occasions, it is hardly possible to detect a species not represented on the reefs of the Cocos. On similar reefs in South Andaman, howerer, a second species of Oymodocea, quite as profuse where it exists, bnt more local in its occurrence, has been gathered, and on a similar reef in Little Andaman large meadows of Halophila ovalis were found associated with those of Cymodocea. The beach between such a reef and the Pandanus sea-fence consists, so far as the writer's observations extend, almost exclusively of coral sand mixed with small shells or fine fragments of large shells. The heavy surf in such a bay as this breaks at the outer margin of the reef, and even at high-tide in rough weather the swell is so weakened there that the waves which break on the beach are not so heavy as to have any great erosive power. Indeed their effect appears to be on the whole accretive, for the sand that accumulates at the head of the bay becomes bound by Ipomoea biloba, Sesuvium, Euphorbia Atoto, etc., the Pandanus fence encroaches on the beds of Ipomnea; the coco-nut zone widens seawards, and behind it the first line of beach-forcst, containing Terminalia, Hernandia, Erythrina, Pongamia, Stephegyne, Thespesia, and the second line of the same forest, characterised by Mimusops, Gyrocarpus, Pisonia, Ardisia, Cycas assert themselves in an area previously covered by the tides. In certain situations, too, the true mangroves stalk forward into the tolerably quiet waters of these bays, while in a different but equally effective manner, by sending up suckers from among its curious pith-like roots, Avicennia establishes itself upon the reef. The guyed and stilted habit of the former makes their position very secure; the latter, from the enormous area covered by its roots, must also be difficult to overthrow. The process of land-making behind a fringing reef, either as a sandy flat covered with coco-nut trees, or as a mangrove swamp spreading seawards, is well cxemplified in the two bays lying respectively to the south and to the north of the position of the first season's 98 
camp ; the effects are so like what must result if land were' slowly rising that it is only after careful examination of all the conditions that one's mind becomes disabused of this specious impression. There is no direct evidence that the land is rising and, as will be evident on considering what has been said above, there is no necessity for supposing that it is. But though this is a very common type of bay, it is not the only type. On Great Coco, in some cases, and on Little Coco very generally a different stage may be observed. The shallow pools described as existing between the surf-built embankment at the margin of the fringing-reef and the beach, have in them many living corals that raise great rings which rise to almost the surface of the water in the pool at low-tide and, like huge lichens, grow peripherally till they meet and coalesce. The surf, too, breaks off pieces of greater or smaller size which are lodged in the pool behind, and by-and-bye become more or less cemented together. In this way the whole of a pool becomes in time completely filled up with growing coral and cemented blocks, and there are many reefs, especially on Little Coco, that are completcly uncovered at low-tide, while small patches of similar recf are here and there seen that ordinarily the high-tides do not cover. The uniformity that the surfaces of some of these exposed reefs display is very striking. They are almost as even as a paved floor and are as bare and destitute of marine vegctation as they are of living coral. The edge of such a reef, in place of being a fairly continuous embankment higher than the floor of the bay behind, is now broken into hundreds of jagged gulleys through which the wave-wash from the almost level platform tears its way back to the deep water beyond the fringing-reef. The main interest of this stage of the reef is less, however, from she present point of view, its actual physical condition than its effect on the vegetation of the shore.

Behind a coral bay like one of those first described, and which charactcrises a less advanced stage of the history of the fringing-reef, has gone on a long and steady growth of land, wihl some shingle in it doubtless, cspecially as one approaches the nearest ridge, but chiefly composed of coral sand with a thin coating of humus derived from the vegetation it has supported. The main force of the surf has for long been spent on the outer embankment, and the force of the waves that at high-water passed over its top has been so much diminished ere these reached the beach that there they did not act destructively. Now all this is altered. At low-tide the force of the surf is still all expended on the edge of the reef, but as soon as the water has risen so high that the edge of the reef is covered, this force instead of being dissipated in the deeper water of a pool is accentuated as the breakers roll landward across a reef on which the water shallows slightly as the shore is approached; by the 
time the surf ceases to break on the cdge of the reef practically its whole force rolls in over this even and slightly shallowing reef till it falls on the shore in huge erosive breakers that eat a way the soil, so that Pandanus fence, coco-nut zone, and beach-forest all in turn disappear, and the waves at high tide grind on the prostrate stems of huge Mimusops, Ficus Rumphii, and Dipterocarpus trees, and undermine the roots of their old companions that are still standing but that the next storm will lay beside those on the beach. But this active denudation no more indicates a sinking of the land than do the heightened reefs that cause the action indicate that the land has risen, and as direct indications either of rising or of sinking are altogether absent we must conclude that the islands are at present practically stationary. But it is interesting to find, as one does here, in adjacent bays, such diverse indications of the same condition.

There are bays of a third type in the group, few in number, however, and of small size, in which the water is deep quite up to the beach; the sweep of the waves in these is extremely large, even when the sea outside is quiet, owing to the strong currents that prevail round the islands. They have all, as might be expected, rocky sides; the beaches on which the waves break are of sand, not shingle, and owing apparently to this excessive sweep of the waves the Pandanus fence and coco-nut zone at the head of such a bay is a good number of yards away from the beach; a considerable sand-bank covered with Ipomoea biloba, Vigna lutea and other sand-binding species, intervening between the limits of ordinary tides and the woody vegetation.

The nature of the beaches behind the numerous long, comparatively flat sandstone ledges, exposed at low-water and therefore not coralcovered, has yet to be noted. Such beaches are always of coral-shingle mixed with large shells, the pieces of coral being rounded or oblong and sometimes of considerable size. The most remarkable example of such a beach in this group is that at the south end and south-east corner of Little Coco where the sandstone reef is particularly extensive and whero the south-west monsoon must break with singular force. This beach consists of an abrupt shingle wall, in many places 6 or 7 feet high, and yet not much wider at the base than twice its own height. Though very steep towards the sea-face it slopes more gradually at the back; behind it at this point there stretches a low flat tract of muddy land not much higher than the reef itself, covered by a dense jungle of Hibiscus tiliaceus, Vitex Negundo, Leea, and similar shrubs, but with few trees, the whole loaded with tangled masses of Cassytha. The Pandanus fence is here particularly dense, and along with it are coco-nut trees growing on the shingle; from the appearance and size of these it seems clear that, slight 100 
as the defence seems, this shingle beach completely prevents erosion though at the same time accretion is probably very slow. In the case of the highest and most advanced coral reefs usually the same shingle beach occurs; from which fact we might conclude that as the initial stage of any fringing-reef must have been that of a simple submerged sandstone ledge of greater or less extent, we see here the original shingle beach, thrown up where this ledge originally became subaërial, to which the waves have eaten back over the present raised reef until all the sandy soil formed during the earlier "embankment and pool" stage has, with the vegetation it supported, been swept into the sea. This shingle having been reached the erosive action has been checked, and the surer, if slower process of shingle accumulation has been initiated or, at all events, renewed. From this account of these bays it will be seen that the fringing-reef exhibits in some parts a phase more advanced than it exhibits in others. But it does not therefore follow that these more advanced "platform" portions are older than the earlier "embankment and pool" portions. They cannot, in one sense, be so old, for we must suppose that all these reefs commenced contemporaneously, and the "embankment and pool" reefs are still growing, whereas the "platform" reefs have now no living coral. The different stages therefore merely indicate that the sandstone reefs running out from the headlands in which the various ridges end are in different parts of the islands situated at different depths, and the condition of the reefs indicates that the sandstone ledges are shallower, and that deep water is further from the shore towards the south than towards the north end of the islands. At quite the southern extremity of Little Coco bare sandstone reefs, too shallow for the growth of a coral fringing-reef, stretch away southeastward in much the same way as the well-known Alguada reefs extend southward off Cape Negrais. On the east coast of Little Coco are high coral reefs exposed at low-tide, fringed by a coral-shingle beach, while towards the north end of the island are similar high reefs fringed by a shore of sandy soil which, with the beach-forest growing on it, is being washed away by the sea. On the west coast, where the reefs are high, and, though still in the "pool" stage appear from their jagged edges to be approaching the "platform " stage, a line of low sand-dunes, perhaps the highest development of the epoch of sand-accretion, have been thrown up; these at present protect the shore and have actually closed up, at the south-west corner, the mouth of a mangrove-creek.

Similarly, in Great Coco, near the southern extremity and between the main island and Jerry there is a large bare sandstone reef which exhibits very well the arrangement and dip of the strata; further up the east coast denudation is going on, still further north the site of a beach- 
forest is being composed by accretion, while at the north end a mangrove forest is invading the sea. The west coast of Great Coco is more or less rocky and abrupt, for nearly the whole extent of the island.

No denudation is taking place in Table Island, the shores of which rise rather abruptly from the beach in most of its circumference, though there is a bay at the north side looking towards Slipper Island that is fringed with Pemphis acidula and has a small flat space immediately within its Pandanus fence.

When the beach between the reef and the Pandanus sea-fence consists of coral sand it is usual to find outside the jungle proper a belt of Ipomoea biloba, at times covered with parasitic Cassytha; where it is composed of shingle Ipomøa biloba may also occur, though it is more nsual to find its place taken by Ipomoea denticulata. Along with these Ipomoeas occur Euphorbia Atoto and, less frequently, Sesuvium Portulacastrum. Usually just within these occurs the common sea-face junglefence of Pandanus, Sophora tomentosa, Ccesalpinia Bonducella, Tournefortia argentea, Desmodium umbellatum, Premna integrifolia, Clerodendron inerme, Colubrina asiatica, Canavalia obtusifolia, Vigna lutea, Guettarda speciosa, Allophylus Cobbe, etc., and then, particularly if the beach is a shingle one, as trees in the same zone, Ixora brunnescens, Terminalia Catappa, very common, Stephegyne diversifolia, Thespesia populnea, Hernandia peltata, Erythrina indica, Pongamia glabra, Ficus Rumphii, Barringtonia speciosa, Gyrocarpus Jacquinii, etc., with a thin line of Cocos nucifera growing up slantingly beneath these and stretching their crowns seawards as if in search of light. Where the beach is sandy the sea-face jungle makes a less dense hedge, and within it lies a flat space of sandy soil with a grove of Cocos nucifera, stretching back from 10 to 100 yards to where, usually on lower and muddy ground tunnelled by Carclisoma and other land. crabs, commences a dense jungle that shades off almost insensibly into the regetation of a true mangrove-swamp. The sand beneath the coco-nut trees in these groves is covered in Great Coco by a close sward of Thuarea sarmentosa, with here and there patches of Ipomoea biloba, clumps of Tacca pinnatifida, or large examples of Crinum asiaticum and Cycas Rumphii, and with patches of Eranthemum here and there beneath these. The more rocky portions of the coast have in the sea-face jungle-fence described above some other species that do not seen to care for sand or shingle, such as Hibiscus tiliaceus, Taberncemontana crispa, Desmodium polycarpon and Desmodium triquetrum, Briedelia, Derris uliginosa, Pluchea indica, etc. Within the coco-nut zone on the flat land we meet with more Gyrocarpus Jacquinii, with the Andamanese Bullet-wood (Mimusops littoralis), various species of Dipterocarpus, Miliusa sp., common, and some species of Meliacex; the climbing undergrowth in this tract 102 
is very characteristic, more so than the trees, consisting of Cosalpinia Nuga, Capparis sepiaria, and, very largely, of Pisonia aculeata. In the more muddy soil which occurs on the outskirts of the mangroveswamps other shrubs and creepers occur; such as Leea sambucina with stilted roots like the mangroves, Cynometra ramiflora, Hibiscus tiliaceus, Flagellaria indicá, Mucuna gigantea, remarkably common, Sarcostigna edule, Plecospernum andamanicum, Antitaxis calocarpa, Salacia prinoides, which extends also into the swamp proper, Acrostichum scandens, etc. Not infrequent in such situations, when there is no high forest over. lead is Vitex Negundo which is particularly common on Little Coco. In this muddy tract the tall trees remain much the same as in the drier area just behind the beach. Further inward the vegetation is that characteristic of a true mangrove swamp, Bruguiera, Ceriops, Rhizophora, Aegiceras, Avicennia. The Avicennia, strangely, does not appear to be common in many of the creeks, though there is onc creek, on the east side and near the south end of Great Coco, in which it is the prevailing tree; except indeed for a few Bruguiera gymnorhiza trees along the open channel of the creek, the whole swamp consists of Avicennia officinalis with thousands of its curious roots protruding through the mud and water as described already in a former paper (J.A.S. B. rol. lix, p. 272); considering the situation and loose structure of these roots, which are of the consistencc of solah-pith, there seems every possibility that they are concerned in the process of transpiration; the large area covered by the roots of each tree must also afford great stability to a spccies which affects, as this one does, the situation of the mangroves without having their stilted roots. In this particular swamp each tree was loaded with the climbing form of Salacin prinoides and, as the lattcr happened to be in flower at the time of the visit, the foetid nature of the atmosphere experienced may be imagined.

Between the headlands, in most cases, a choked-up creek is to be found; generally this extends but a short way into the jungle, though sometimes it winds about on the level ground for a considerable distance as a mangrove-swamp. In two places the creeks on Great Coco are apparently open at all times to the tide; the chief creek is that which debouches at the north end of the island. There are no open creeks in the other two islands, though at the south-west corner of Little Coco what has been a creek of considerable extent is now converted into a large lagoon by a broad bank of sand having been blown and beaten up by the south -west monsoon into a firm embankment across its former outlet.

On the ridges the trees are much the sarne, as to species, as on the lower ground, cxcept that the Milius'a which is common below is scarce 
there, and the Gyrocarpus is rather uncommon. The Mimusops too, is not so abundant on the drier ground. The Pandanus, however, especially on the western side of the islands, ascends to the tops of the ridges and along with the Capparis sepiaria occurs Capparis oxyphylla (C. tenera, var.), the other common creepers being Lygodium flexuosum, Abrus precatorius, Mezoneuron enneaphyllum, Mucuna pruriens, Thunbergia laurifolia, Dioscorea (two species), Calamus (two species) exceedingly abundant and making an almost impassable cane-brake especially on the crests of the ridges; Pcederia foetida is another common creeper, as also is Modecca cordifolia. The jungle with which these are associated contains, besides the shrubs met with on the lower ground, thickets of Cyclostemon assamicus and other Euphorbiaceous shrubs, Alsodeia bengalensis, Glyptopetalum calocarpum, Grewia (two species), Diplospora singularis, Ficus (several species), etc. On one hill, in Great Coco, there is a limited patch of bamboo-jungle, the species being a Dendrocalamus, probably a variety of $D$. Strictus. This species also occurs on Table Island, where flowering specimens were obtained, and at first there seemed to be room for doubt as to whether it might not have been introduced on the lightiouse-island, though certainly it only occurs there in the untouched jungle and no examples exist in the clearing. The presence of the same species, however, in quantity, in the interior of Great Coco, on a hill which it is liardly extravagant to suppose had not been before ascended by any one, may be held to dispose finally of the doubt. Among the features of the jungle on exposed seaslopes that are not grass-clad must be noted the presence in quantity, besides the other creepers found on the ridges, of Ipomcea palmata, Ipomoea grandiflora and Convolvulus parviflorus, the latter a particularly characteristic species on the west coast. The herbaceous undergrowth consists of Oplismenus compositus, Cyperus elegans, and a few other sedges and grasses in local patches or as stray examples; in places also occur patches of Alocasia fornicata, Calanthesp. (apparently C. veratrifolia), Draccena spicata, Desmodium laxiflorum; in one place nearly in the centre of the island, some plants of Urena lobatr (this species does not occur in the clearings of either island and cannot here be looked upon a weed introduced by human agency); in the drier parts considerable quantities of Acrostichum appendiculatum; along the sides of dry torrents a good deal of Adiantum lunulatum; and in one or two damp, flat spots Ceratopteris thatictroides.

On Table Island the west side has been artificially cleared and it is impossible to say that it ever has been jungle-covered, but several of the headlands on the west side of the Great Coco, as has already been mentioned, have naturally bare grassy slopes. There are none of these, 104 
however, on the Little Coco. The principal grass on these slopes, and throughout the two clearings as well, is the very uninviting Andropogon contortus, mixed with a small amount of Ischomum ciliare; besides these there is some Cyperus polystachyus, and in the clearings of both islands Eleusine indica in tufts, with here and there a little Panicum colonum. In Table Island, though not in Great Coco, Eleusine cegyptiaca and Panicum Helopus have also become established. In this connection it should be mentioned that Thuarea sarmentosa, which is the common sward. grass under the coco-nut trees of Great Coco, is very rare in Little Coco; the only spot where the coco-nut zone is there of any width has Ischcemum muticum growing throughout it in abundance; in Great Coco Ischcemum muticum is rare.

On the low ground the epiphytes in the taller trees are two species of Hoya, Scindapsus officinalis, Dendrobium secundum (the only common light-loving orchid, which is particularly common on trees of Heritiera littoralis, etc., about the mouths of creeks), Davallia solida, Polypodium (Niphobolus) adnascens, and Polypodium quercifolium. There is a great absence of epiphytes from the trees growing in the interior, the ferns mentioned are in particular confined to the trees nearest the sea. In the muddy ground behind mangrove-swamps there are on the stems of Cynometra and other trees, great numbers of an orchid that proves, on having been flowered in the Calcutta garden, to be a Dorites with violet flowers; apparently, however, it is only a variety of $D$. Wightii.

Perhaps a better idea of the regetation of the islands may be obtained if extracts from the writer's notes, enumerating the species met with in particular localities, be given. Of these only a few are selected, illustrative, as far as possible, of different kinds of soil and of diverse situations. From these it will be seen that any altempt to divide the forest into distinct zones and regions is attended with difficulty, since the various forests-Mangrove, Beach, Mud-Alat, and Dry-ridge jungles-merge into each other on every hand.

In crossing the island on the drier level ground near the south cul of the island one finds after the belt of coco-nuts, which is there about 100 yards wide on the western side, a jungle at first not very dense of Canarium commune; Aglaia andamanica; Miliusa sp. ; Gyrocarpus Jacquinii, very common; Mimusops littoralis, the most common tree, with often great masses of Hoya, and near the sea with Polypodium quercifolinm as epiphytes-all the Mimisops here is uniformly dying back in the topmost branches; Bombax sp., looking much more like B. malabaricum as to leaves than like the Andaman species identified by Kurz with $B$. insigne; Dracontomelum sylvestre; Spondias mangifera; Semecarpus heterophylla; Albizzia procera.; Dipterocarpus sp.; Sterculia alata ; Erio- 
dendron anfractuosum, etc. Under the Cocos nucifera on the sandy soil a sward of Thuarea sarmentosa with patches of Ipomoea biloba and with a quantity of Eranthemum succifolium; further inland there is a dense undergrowth of Glycosmis pentaphylla; Ardisia humilis; Ficus brevicuspis and Ficus Domonum; Alsodeia bengalensis; Glyptopetalum calocarpum; Cyclostemon assamicus; etc.-covered with a mass of Pisonia aculeata; Ccesalpinia Nuga ; Capparis sepiaria; Mucuna gigantea, less common here than on muddy soil ; Calamus sp., not very common ; Sarcostigma edule; Antitaxis calocarpa; Derris scandens; Thunbergia laurifolia; Dioscorea, two sp.; Vitis pedata, very common; Acacia rubricaulis, often. Of subherbaceous plants may be mentioned Draccena spicata, it is, however, less common on level ground than on the ridges. Further on were met with Cynometra ramiflora, with occasionally Dorites Wightii epipliytal, but less commonly so than where the soil is moist and muddy; considerable quantities of Leea sambucina; Sterculia villosa, as a small tree; Stephegyne diversifolia, though rarely; Artocarpus Gomeziana; Terminalia bialata; some Siphonodon celastrineus; Oroxylum indicum ; and, as the opposite side of the island is approached, Crotonsublyratus; Hernandia peltata; Sterculia rubiginosa; Terminalia Catappa; Erythrina indica; and the Pandanus seafence. Just before reaching this coast-zone a single example of a stemless palm (Livistona sp. ?) was met with; another example of this was obtained on the hill where the 1889 encampment was made at the north-east corner of the island. In cutting a path across the island at another point a level sandy tract was reached on which for several hundred yards grew nothing except young Gyrocarpus Jacquinii.

Crossing at a point where a ridge had to be passed it was found that much of the flat land behind the coco-nut zone was taken up with a jungle of Gyrocarpus Jacquinii, Macaranga Tanarius and Mallotus andamanicus to the exclusion of other species; but even as far as the base of the ridge many fruits of Cocos nucifera that had been floated inland during the rainy season, when the whole of this level tract is evidently water-covered, are germinating freely and some coco-nut trees that have reached the light have begun to bear. On the ridge itself a dense jungle prevails, much matted, especially along the crest, with creepers; the chief of these is Thunbergia laurifolia, the others being Dioscorea sp.; Capparis sepiaria and Capparis tenera; Derris uliginosa; Anodendron paniculatum; Abrus precatorius and A. pulchellus; Calamus; Pcediria fretida; Modecca; Trichosanthes palmata; Porana spectabilis; a little further along this ridge the west side and the flat land at its base was found to be a dense thicket of Caryota sobolifera; the herbaceous undergrowth was remarkably sparse and consisted of a few plants of Zingiber sp.; some patches of Alocasia, and a few patches of Oplis. 106 
menus. The eastern side of this ridge had no flat land between it and the sea and was rather more open, the tall trees and creepers were much as on the west side, with the addition of Argyreia tiliofolia and $A$. Hookeri; large masses of Erycibe paniculata, which is here always a heavy climber and not shrubby; and among the nndergrowth with the addition of Claoxylon sp.; Corypha sp.; and near the shore Blachia andamanica; Pluchea indica; Cnesmone javanica. On bare isolated rocks lying well out on the reefs, and never covered completely by the tide, the species found are always Fimbristylis sp.; Cyperus pennatus; and Borhaavia repens. The same species also occur on bare rocky patches of the coast all round the island but especially on the west coast. Other species associated with these in such situations are Desmodium polycarpon; D. triquetrum; Blumea virens; Vernonia divergens; V. cinerea; Pluchea indica, etc.

The isthmus uniting the outlying peninsula at the north-east corner with the main island has, mixed with the coco-nut trees occurring there, a sparse forest of Mimusops and Dipterocarpus, with an undergrowth towards the north coast almost exclnsively of Macaranga Tanarius, towards the south almost entirely of Dodoncea viscosa, though here and there on hummocks of soil as opposed to sand, are other trees, like Oroxylum indicum; Heterophragma adenophyllum, etc. Among the herbaceous species here the most noteworthy is Anisomeles ovata, the only Labiate on the islands, which is, however, at this particular spot, very plentiful. On the coast of the north-east peninsula Physalis minima is a common species, it occurs, however, in similar situations here and there on both the Great and the Little Coco; on the slope above Strobilanthes phyllostachyus is gregarious and plentiful, as it likewise is at the north end of Little Coco in a similar situation.

As an example of the regetation of level ground, where the soil is shingle instead of sand, the north end of Jerry island may be described. Here on the beach is a dense thicket of Pemphis acidula; behind this, a few examples of Pandanus odoratissimus; many Sccevola Konigii; some Tournefortia argentea and Sophora tomentosa bushes; many coco-nut trees; much Coesalpinia Bonducella. Behind this sea-fence the shingle is covered with a mass of Ipomcea biloba, a striking contrast to what occurs at the north-east corner of the island where the shingle has I. denticulata only. The trees on this shingle are Terminalia Catappa, Cocos nucifera, Ardisia humilis, Ixora brunnescens, Guettarda speciosa, Macaranga Tanarius, Mimusops littoralis, Gyrocarpus Jacquinii, Hernandia peltata. Besides the Ipomoea the only herbaceous vegetation consisted of a few fruiting Amorphophalli; the tubers of these brought to Calcutta have since sent np bulbiferous leaves that shew the species to be nearly 
related to, but probably quite distinguishable from, $A$. bulbifer and $A$. tuberculiger, the two species hitherto known which exhibit this character. The east side of this island has outside the Pandanus fence, which is there about three times as broad and thick as on the west, a belt of Thespesia populnea and Guettarda speciosa, with patches of Pemphis acidula and Clerodendron inerme, and some trees of Cordia subcordata and Champereia Griffithiana as well as a few thickets of Vitex Negundo and Desmodium umbellatum.

The sandy isolated spit on the reef between Great Coco and Jelry Island is not covered even by spring-tides-it is about 70 feet long from north to south by some 30 feet across, and at the time of the writer's visit there could be counted on it (mostly near the east side, and towards the south end) about a dozen germinating coco-nuts; three seedling Hibiscus tiliaceus, a seedling Thespesia, some seedlings of Gyrocarpus, four seedling Mucuna, two seedling Erythrina, six seedling Carapa moluccensis, one seedling Barringtonia speciosa, one seedling Entada scandens, some young Ipomcea biloba, and one young Cynometra, with two or three other species not recognised.

In general features Little Coco so greatly resembles the other islands that it is unnecessary to deal with it in detail. The chief feature is perhaps the great abundance of Corypha elata and Siphonodon celastrineus; still both species were met with, though sparingly, on the Great Coco.

Before concluding, however, this general account of the vegetation of the islands the two fresh water accumulations deserve to be more particularly noted. That on the Great Coco consists of a small lake in the narrow neck of land that joins the ontlying north-eastern peninsula to the rest of the island. This lakelet is about 300 yards long and hardly 100 yards wide, with its longer diameter across the isthmus. Its depth is a little over $3 \mathrm{feet}$; it is uniformly deep from side to side and from end to end, with a hard, even bottom. At either end it is only separated from the sea by some 80 to 100 yards of shingle bank, and it seems difficult to understand why the water it contains does not ooze out, and how it is that it is unaffected by the adjacent salt water, since the bottom of the lake is lower than the point reached by the waves that beat up on the single beach, if not actually lower than the level of the highest tides. The bottom seems to be no more than the floor of what has formerly been a shallow bay on the fringing-reef, and the shingle banks which separate it at either end from the sea seem to be nothing more than the ultimate embankments that would result when the causeways connecting outlying islets with the main island are so enlarged by accretion as to cease to be covered by the tides. This postulates that the present out- 
lying north-eastern peninsula had originally been detached from the main island and, being an islet of considerable width, that a causeway, ultimately becoming an embankment, has been thrown up by wave-action from each of the two adjacent bays. Soil washed down from the adjacent slopes during the rainy season has in the form of fine silt closed up the porous shingle banks at either end till these can now retain the fresh water within them and prevent the percolation of sea-water from without. To the east side of this lake there is a small flat meadow covered with Kyllinga and Fimbistylis along with some Cyperus polystachyus but very little grass. Whether this meadow was originally a naturally bare patch or is only part of the clearing made in connection with the abandoned settlement on the adjacent hill it is difficult to say. If, however, it was artificially cleared, it is unlike the rest of the clearing in this, that no woody jungle is reappearing in it now. At the time of our visit a number of snipe frequented the meadow. Close to the edge of the lake is a continuous belt of Hygrophila quadrivalvis; within this, and extending into the water, is a belt of Polygonum all round the margin of the lake; inside the Polygonum float large matted patches of Panicum Myurus. Here and there are patches Limnanthemum indicum; there is also a considerable quantity of Nymphoea rubra. The ordinary white Nymphraa Lotus, so common in similar spots in the Andamans, is not present, a circumstance which inclines one to think that this red waterlily may have possibly been introduced during the attempt to settle in the island. The water is quite potable and apparently wholesome; neither Chara nor Zanichellia is present, perhaps the water is rather deep for these.

Very different in many respects is the lagoon on Little Coco which is simply a mangrove creek that has been banked off from the sea by a small sand-dune having been thrown up across its mouth. It is not more than $1 \frac{1}{2}-2$ feet deep anywhere, with also a level but at the same time a softer botlom than the Great Coco lake, and this bottom is covered uniformly throughout by a meadow of Chara mixed with Zanichellia. Here the water, though perhaps potable on an emergency, and though used by native craft that call in for it, is slightly brackish, and the lake is fringed throughout by Bruguiera, Lumnitzera, Ceriops, Avicennia. etc., while clumps of similar mangrove trees occur throughout it. Its area is considerably greater than that of the Great Coco lake, for it is about a quarter of a mile long and a furlong across at the widest part; it was haunted at the time of our visit by teal. Here, curiously enough, Panicum Myurus does not occur, its place being taken by Paspalum scrobiculatum which floats in great patches at its south-western corner. There is no Limnanthemum and the Nymphoea 
present is, as in the Andamans in such situations, the common N. Lotus and not, as in the Great Coco, the red-flowered variety. On the banks and extending into the water are considerable beds of Scirpus subulatus which does not occur in the other lake. Here on the other hand there is neither Polygonum nor Hygrophila present.

Beyond the coco-nuts the vegetable products of the island can hardly be very highly assessed. Mimusops littoralis (Andamanese Bullet-wood) is common and so is Lagerstrcemia hypolenca (Andamanese Pyen-ma); Ptercarpus indicus (Padouk) is rare however; and even of second- or third-rate timber trees such as Diospyros Kurzii (Zebrawood); Dipterocarpus sp. (Wood-oil trees); Heritiera (Sundri); there is no great quantity; the only bamboo found (Dendrocalamus strictus VAR ?) is not very valuable and is not abundant; while the only abundant natural grass (Andropogon contortus) is so uninviting that the cattle on the island prefer eating Pandanus leaves to grazing it.

In the subjoined list of the species obtained during the two visits (which must not, however, be considered complete, though it may safely be assumed to be representative of the vegetation of the islands), it will be seen that a number of species are undetermined. As a matter of fact they are probably mostly species hitherto undescribed, but owing to the shortness of time at the writer's disposal, and owing to both the visits being at the same season of the year, it was impossible to obtain complete material of these, and it has therefore been impossible to prepare for them specific descriptions. In some cases roots or seeds of these have been brought to Calcutta and are now in cultivation there, so that their identification will, it is hoped, only be a matter of time.

In presenting this list the writer wishes to acknowledge much kind assistance received by him in its preparation; as regards Phanerogams, from his friends Mr. W. B. Hemsley, F. R. s., who has kindly compared a number of the more critical specimens at Kew ; Mr. J. F. Duthie, F. L. s., who kindly assisted him in naming the grasses, and Mr. J.S. Gamble, F. L. S., who examined the solitary bamboo; and as regards Cryptogams, from Dr. G. King, F. R. S., who kindly assisted him in determining the Ferns; Mr. G. Massee, F. L. s, who, through the good offices of Mr. Hemsley, kindly named the Fungi and supplied the description of a new species of Xylaria; and Mr. G. R. Milne Murray, F. L. s., who, through the intervention of $\mathrm{Dr}$. King, most kindly examined the Algoe.

The list is followed by an analysis indicating its systematic, its physical, and its phytogeographic nature.

110 


\section{§ §. List of Plants collected in the Great Coco, Lititle Coco and Tabie IsLand.}

\section{PHANEROGAM正.}

\section{Thalamiflorer.}

ANONACE $\Phi$.

\section{Miliosa sp.}

Great Coco; Little Coco; very common in both islands.

The specimens obtained are in fruit only; the leaves are glabrous but otherwise are much like those of $M$. Roxburghiana; the fruits are very like those of $M$. macrocarpa.

\section{MENISPERMACE $A$.}

2. Crclea peltata $H$. f. and T.

Great Coco; common.

Burma, Nicobars. Not previously recorded from the Andaman group.

3. Antitaxis calocarpa Kurz.

Great Coco; common.

Andamans, Nicobars.

NYMPHЖACE $Æ$.

4. NrMpHea Lotus Linn.

Great Coco; plentiful in the small lake at the north-east corner of the island-only the red flowered form (N.rubra Roxb.). Little Coco; sparingly in the lake at the south-west corner of the island-only the white form ( $N$. Lotus Linn.).

This species is not included in any Andamans list and Kurz (Report on the Vegetation of the Andamans, p. 15) comments on the absence of NrmpHeACE瓜. As a matter of fact this species does occurs in the Andamans; as does Barclaya longifolia. Nymphoea Lotus is very plentiful everywhere about the settlement at Port Blair, and in one arm of a creek that had been shut off from the tide by a bank of earth only three months before, the writer in December 1890 found hundreds of seedling plants already springing up. The lake in which it occurs on Little Coco is only a mangrove creek naturally closed from the sea by a sand-bank and the water is still slightly brackish; the vegetation around consists of Bruguiera, Lumnitzera, Ceriops, Avicennia, and other mangrove swamp species. 


\section{CAPPARIDE $\AA$.}

5. Capparis sepiaria Linn. var. grandifolia Kurz Mss. ex Prain, Jour. As. Soc., Beng., lix, Pt. 2, p. 275.

Table Island; Great Coco; Little Coco. Very common everywhere in the group, both on ridges and flat land.

Diamond Island (Arracan); Andamans; Java; Bali; Madura.

6. Capparis tenera Dalz. var. Latifolia H. f. and T. (C. oxyphylla Wall.)

Table Island; Great Coco; Little Coco. Very common everywhere in the group, but only on ridges.

Tenasserim; Andamans (Middle Island and South Island).

\section{VIOLACEA.}

7. Alsodeia bengalensis Wall.

Table Island; Great Coco; Little Coco. One of the commonest undershrubs in the group.

Silhet, rare; Martaban, frequent; Andamans, very common everywhere; Nicobars, very rarc.

\section{GUT'TIFER A.}

8. GaRCinia? sp.

Great Coco.

An altogether doubtful plant represented by one leaf specimeu among the plants collected by Mr. Kurz in 1866; nothing resembling it was met with in 1889 or 1890 . Mr. Kurz did not himself collect in Great Coco. A deputation that visited the island while he was at Port Blair brought him a few specimens; there may even bc some confusion as to the locality - the deputation visited Narcondam and elsewhere as well as the Cocos.

9. Calophyludm inophyllum Limin.

Little Coco. In beach-forests on shingle behind the sea-face vegetation, not common.

Shores of India, Andamans, Nicobars, Burma, Malaya, Polynesia, Australia, and E. African islands.

\section{DIPTEROCARPEAE.}

10. Dipterocarpus pilosus Roxb.?

Great Coco; eastern coast, inland from Ford Bay, common. Only leaf specimens obtained and it is not impossible that they may belong to D. Ariffithii, Miq.

112 
11. Dipterocarpus alatus Roxb.

Great Coco; common. Little Coco; infrequent.

Chittagong, Burma, Tenasserim, Andamans.

\section{MALVACE 无.}

12. Sida ACUTA Burm.

Table Island ; cleared hillsides near lighthouse.

A cosmopolitan tropical weed.

13. Urena lobata Linn.

Great Cocn; in one spot only, in interior of island.

A ccsmopolitan tropical weed, introduction in this case may be attributed to bird agency. It hardly seemed to be indigenous as there were where it was gathered only a few plants. Yet human agency appears impossible : the species is not present at the north-east of Great Coco where ouce a small clearing was made, nor on Table Island where there is now a large clearing. It does not seem to be present in the Little Coco.

Cosmopolitan in the tropics.

14. Hibiscus Sabdariffa Linn.

Great Coco only; as if spontaneous in the small clearing; one of the few remains of a garden that existed during the short time an attempt was made to settle in the island; the few plants seemed unhealthy.

Cultivated in the tropics.

15. Hibiscos Abelmoschus Linn.

Table Island only; common throughout the clearing, escaped from cultivation.

Cosmopolitan in the tropics.

16. Hibiscus tiliaueus Linn.

Table Island ; Great Coco ; Little Coco ; common, especially on the western coast, also plentiful at times in muddy flats behind mangrove swamps. A stunted almost glabrous form occurs on coral-shingle on Jerry Island.

Littoral species, cosmopolitan in the tropics.

17. Thespesia popolnea Corr.

Very common on all the islands.

Littoral species on all tropical coasts in eastern hemisphere, intro. duced into West Indies.

18. Bombax INSIGNe Wall.? vars.—??

There are two forms of Bombax present in the islands:-

1. A tree with armed trunk and branches; leaflets about 6, entire, narrowly lanceolate $5-8$ inches long, $1-1 \frac{1}{2}$ inches wide, gradually tapering to botlı cnds almost scssile, stamens numerous. This is com- 
mon in all the islands, and if the writer is correct in considering the character of armed or unarmed trunk a trivial one, is the common Bombax in S. Andaman. The leaves suit exactly, and though in S. Andaman the trunk of old tall trees is smooth, young saplings are armed, as are the ultimate branchlets even of old trees. The leaves are unlike any of the Indian or Burmese gatherings either of Bombax malabaricum or of Bombax insigne.

2. A tree with unarmed trunk and branches, leaflets about 6, entire, obovate, acuminate $9-11$ inches long, $2 \frac{1}{2}-3$ inches wide, gradually tapering into petiolules $\frac{1}{2}-\frac{3}{4}$ inches long, stamens numerous. This was obtained only in Little Coco, it occurs in South Andaman also, for there are specimens at Calcutta, obtained by Mr. Kurz at Port Monat on the west coast. It does not at all resemble as to leaves of the other form nor does it resemble the leaves of Wallich's type specimen of $B$. insigne. But its leaves precisely resemble those of Wall. Cat. 1840/4 (from Taong Doung, Burma), which was issued as $B$. malabaricum vAr. albiflorum, Wall. The number of stamens makes it impossible to refer the Andaman plant at least to $B$. malabaricum.

In South Andaman both forms have the leaves glaucous beneath; in the Cocos neither form has; so that this character perhaps cannot be beld as valid. Mr. Kurz did not consider the two Andamans forms separable from each other, and in one place he referred them to $B$. malabaricum, but afterwards, on account of the staminal character, united them to B. insigne. He has, however, left a manuscript name "B. heterophyllum," which proves both that he had noted the existence of the two kinds of foliage and that he could not separate the plants exhibiting them from each other.

It should be noted that the convicts and others at Port Blair distinguish two kinds of "Semul" or " Cotton-tree." The distinction does not, however, apply to the two forms referred to above, but to these two taken together and to the following species.

Both islands.

South Andaman. Burma?

19. Eriodendron ankractuosem D C.

Both islands, common.

India, Burnia, Malaya, Africa, and America.

STERCULIACEAE.

20. Strerculia tillosa Roxb. Great Coco; Little Coco.

India.

114 
21. Sterculia rubianosa Vent, var. glabrescens King. Great Coco.

A variety restricted to the Andamans and Nicobars.

22. Sterculia parvifiora Roxb.

Little Coco; only leaf specimens which, however, agree with some from Penang.

23. Steroulia alata Roxb.

Both islands, frequent.

India, Burma, Malaya.

24. Sterculia colorata Roxb.

Great Coco.

India, Burma, Malay Archipelago.

25. Sterculita campandiata Wall.

Little Coco.

Burma, Andamans, Java.

26. Heritiera littoralis Dryand.

Great Coco ; Little Coco ; common in the creeks.

Littoral species on tropical coasts of eastern hemisphere.

27. Buettneria andamanensis Kurz.

Little Coco ; common.

Andamans, Tenasserim.

TILIACE $A$.

28. Berrya Ammonilita Roxb.

Little Coco, frequent.

India, Ceylon, Burma, Andamans.

29. Grewia limVigata Vahl.

In all the islands, common.

India, Burma, Malaya, Australia, Africa.

30. Grewia calophylla Kurz.

Little Coco, common.

Andamans.

31. Grewia Microcos Linn.

Great $\mathrm{Coco}$, infrequent.

India, Burma, China, Malaya.

DISCIFLORE.

RUTACE $A$.

32. Glycosmis pentaphylla Corr.

In all the Islands; both the arboreous ard the shrubby form extremely common.

Throughout India, Indo-China, and Malaya. 


\section{BURSERACE $\Phi$.}

33. Garuga pinnata Roxb.

Great Coco ; common.

India, Burma, Malaja.

34. Canarium euphyllom Kurz.

Great Coco ; very common.

Andamans.

\section{MELIACE}

35. Aglaia andamanica Hiern.

Great Coco, Little Coco ; common. Flowers sweet-smelling.

Andamans.

36. Amoora Rohituka W. \& A.

Great Coco ; common.

India, Burma, Malaya.

37. Carapa moldccensis Lamk.

Great Coco; rather uncommon. The form with obtuse leaves $(C$. obovata $\mathrm{Bl}$.) only occasional in the creeks, but very fiequent germinating along the beaches of all the islands. The form with ovate cordate acuminate leaves in two or three places on rocky parts of the eastern coast. Little Coco; in one place only (form $=C$. ob ovata B1.)

38. Chickrassia tabdlaris A. Juss. ?

Great Coco; common. In leaf only, but evidently identical with the tree identified with this species by Mr. Kurz in Reg. Veg. Andam., p. 33.

\section{OLACINE $\nexists$.}

39. Cansjera Rheedil Gmel.

Great Coco; a common climber.

India, Burma, Malaya, N. Australia, S. China.

40. Phlebocalimina Lobbiana Mast.

Little Coco.

Tenasserim and Martaban.

41. Sarcostigma Wallichil Baill. (S. edule Kurz.)

Great Coco; rather common.

Andamans. Mr. Kurz has in the Calcutta herbarium suggested the reduction of his own species to $\mathrm{S}$ Wallichii Baill., a plant from the Salween valley, nor is there any character by which the two can be distinguished.

\section{CELASTRINE正。}

42. Gliyptopetaldm calocarpdi Prain, Jour. As. Soc. Beng., lx, 2, 209 -Euonymus calocarpus Kurz. 
Common in all the islands, also reported from Narcondam (leaf specimens only, and the locality perhaps a mistake-the writer could not find the shrub in Narcondam). Very nearly rclated to G. zeylanicum Thwaites, from Ceylon and S. India, but easily distinguished by its shorter racemes, smaller flowers and hardly foveolate petals. The fruits and seeds are exactly as in G. zeylanicum. In this the lcaves are always entice.

43. SalaCia prinoides DC.

Great Coco; in creeks, an extensive climbing slurub, associated with Avicennia officinatis.

India, Burma, Malaya, Philippines.

44. Siphonodon cetastrinedes Griff.

Grent Coco, occasional; Little Coco, very common. A considerable tree.

Pegu, Penang., Java.

\section{RHAMNEA}

45. Ventilago calyculata Tulasue.

Great Coco.

India, Burma, Malaya.

46. Zizyphos CEnoplia Mill.

Great Coco, not at all common.

India, Burma, Malaya, N. Australia.

47. Coldbrina asiatica Brogn.

Little Coco ; const at north end of island.

India, Ceylon; Burma, Malaya; N. Australia ; S. W. Africa.

\section{AMPELID Æ.}

48. Vitis pentagona Roxb.

Table Island and Great Coco; common.

Chittagong, Arracan, Andamans.

49. Vitis carnosa Wall.

Common on all the islands.

India, Burma, Malaya.

50. Vitis Pedata Wall.

Great Coco, and Little Coco; very common.

India, Burma, Malaya.

51. LeEa sambucina Willd.

Interior of all the islands, common.

India, Burma, Malaya.

52. Leea hirta Roxb.

Great Coco.

India, Burma, Malaya. 


\section{SAPINDACE $\nexists$.}

53. Erioglossum eddue Blume.

Both islands, on ridges, common.

India, Burma, Malaya, North Australia.

54. Allophylus Cobbe Blume.

Great and Little Coco; not uncommon along the western sea-face.

India, Burma, Malaya.

55. Sapindus Danura Voigt.

Great Coco.

Assam, Burma.

56. Pometia tomentosa Kurz.

Great Coco, common.

Indo-China, Andamans, Nicobars, Malaya, Ceylon.

57. Dodonera viscosa Linn.

Great Coco; a small tree very common at the north-east corner of the island.

Cosmopolitan in the tropics.

\section{ANACARDIACEA}

58. Odina Wodier Roxb.

Great Coco.

India, Ceylon; Burma, Tenasserim.

59. Parisnia iNsignis Hook. $\mathrm{f}$.

Great Coco ; in leaf only.

Tenasserim, Andamans.

60. Semecarpus subpanduriformis Wall.

Great Coco only, but there rather frequent near the eastern coast.

Chittagong; Gamble. Arracan, in the Kolodyne valley, Kurz; on

Boronga Island, Kurz. Originally this was known only from specimens grown in the Calcutta garden (introduced from Chittagong) distributed by Dr. Wallich (Cat. n. 987).

61. Semecarpus heterophyluds Blume.

Great Coco, interior, rather frequent; Little Coco, interior, extremely common.

Pegu, Tenasserim; Andamans, Nicobars; Sumatra, Java.

62. Spondias Mangifera Willd.

Great Coco and Little Coco, very common in the interior of both islands; the fruits are yellow and extremely sour, but much eaten by the wild pigs (Sus andamanensis) which abound.

Tropical Asia; Mr. Kurz found this in S. Andaman also.

63. Dracontomelum mangiferum Blume.

Great and Little Coco, frequent: in leaf only.

118 
Andamans, Nicobars; Malay Peninsula and Archipelago; Philippines and Fiji Islands.

\section{MORINGE $\mathbb{A}$.}

64. Moringa pterygosperma Gaertn.

Great Coco; a few trees liave been planted at the north-east corner of the island by the people of the attempted settlement; a large number of seedlings have already appeared though the introduction has been so recent.

India; indig. in North-West Himalaya, elsewhere cultivated in tropical countries.

\section{Calyciflore.}

CONNARACE.AE.

65. Connarus aibbosus Wall.

Great Coco.

Teuasserim, Malaya; Andamans.

\section{LEGUMINOSA.}

66. Crotalaria sericea Retz.

Table Island; very common throughout the clearing; apparently introduced, as it was not found in Great Coco or Little Coco. This species does not seem to occur in the Andaman group proper; at Port Blair in S. Andaman Crotalaria retusa is the species that has been introduced and occupies similar localities.

India, Burma, Malaya.

67. Desmodidu umbeliatum DC.

In all the islands, very common on the coast. islands.

India, Burma, Andamans, Malaya, Philippines, Polynesia, Mascaren 68. Desmodidu triquetrum DC.

Table Island and Great Coco ; very common on bare rocky slopes on west coast, occasional on higher ground in the interior; Little Coco, occasional in the interior.

India, Burma, Malaya, Andamans; Philippines; S. China.

69. Deamiodium LaxiflorUa DC. interior.

In all the islands, rather frequent on the higher ground in the

India, Burma; Andamans, Nicobars; Malaya.

70. Desmodidm polycarpum DC.

Table Island and Great Ccco; very abundant on all the rocky slopes 
on the western coasts. This species has been referred to (Jour. As. Soc., Beng., lix, pt. 2, p. 251) as perhaps introduced iuto the Audamans, becauso Mr. Kurz did not meet with it in 1866 when he explored a part of the yroup. But from what the writer has been able to note since, he is convinced that the species is indigenous in the Andaman group.

East Africa; Tropical Asia; Malaya, Philippines; China, Japan; Polynesia.

71. Deshodium triflorum DC.

Table Island, in the lighthouse clearing on grassy slopes. There is a white- and a red-flowered variety and both are equally common.

Cosmopolitan in the tropics.

72. Alisicarpus vaginalis DC.

Great Coco, in the small clearing at the north-east corner of the island, probably introduced.

Tropical weed indigenous in eastern hemisphere; introduced in America.

73. Phaseolus sp.

Great Coco. Appearing as seedlings in the droppings of the halfwild cattle on a bare grassy hill-side in the sonth-west of the island, much frequented by these, were seen during the second visit to the island numerous examples of what appears to be a species of this genus. Each leaflet has in the centre a reniform white mark which ought to be distinctive, yet the writer cannot recall a variety which exhibits this. The origin of the seeds could not be traced, no Phaseolus was observed in the abandoned clearing in 1889 , and unfortunately it was impossible to reexamine that locality in 1890.

74. ABRUS PRECATORIUS Linn.

Great Coco, common; Jittle Coco, very common.

Cosmopolitan in the tropics.

75. ABROS YULCHELLUS Wall.

In all the islands, very common.

Africa, India, Burma, Malaya, Andamans.

76. ERythrina indica Lamk.

In all the islands, in coast zone; not nearly so common as it is on Diamond Island at the mouth of the Bassein river.

India, Burma, Malaya; Andamans, Nicobars.

77. Mucdna gigantea DC,

Great and Little Coco; one of the commonest climbers on flat land in the interior behind the mangrove swamps.

India, Andamans; Malaya; Philippines; Polynesia.

78. Mucuna pruriens DC.

Table Island, very common, interior jungle on ridges.

Cosmopolitan in the tropics.

120 
79. Pueraria Gandollei Graham.

Little Coco, common.

Pegu, Tenasserim.

80. Pulraria phaseoloides Benth.

Great Coco, common on the western coast.

India, Burma, S. China, Malaya.

81. Canavalia obtustrolia DC. (Dolichos lineatus Thumbg.)

In all the islands, one of the commonest climbers along the sea-face here as on the Burmese, the Andamans, Nicobars and Malay coasts.

Cosmopolitan on tropical shores.

82. Vigna lutea A. Gray.

Little Coco, very common on coasts both east and west; Great Coco, rather rare.

Martaban, Malaya; Andamans, Nicobars.

Cosmopolitan in tropics, but absent from India.

83. Pterocarpus indicus Willd.

Great Coco, infrequent.

India, Burma, Andamans, Malaya; Plilippines; S. China.

84. Derris scandens Benth.

Great and Little Coco; very common.

India, Burma, Andamans, Malaya; S. China, N. Australia.

85. Derris sindata Benth.

Great Coco, extremely common on the eastern coast.

Pegu, Tenasserim, Malay Peninsula; Andamans, Malay islands; Ceylon.

86. Derris uliginosa Benth.

Both islands, common, on rocky parts of the coast.

India, Burma, Malaya, Africa, Australia, Polynesia.

87. Pongamia glabra Vent.

In all the islands, a common tree in the coast zone and especially along the sides of mangrove creeks; never seeu climbing.

India, Burma, Andamans, Malaya; Polynesia; N. Australia; Seychelles.

88. Sophora tomentosa Linn.

Great and Little Coco, west coast, but infrequent.

Cosmopolitan on tropical sea-shores.

89. Mezonedron enneaphyluUm W. \& A.

Great Coco, common on summits of interior ridges.

Cachar, Chittagong ; Pegu, Tenasserim, Ceylon, Malay Archipelago.

90. Casalfinia Bonddoella Flem.

In all the islands, very common in the sea-face jungle along the beaches.

Cosmopolitan in the tropics. 
91. Casalpinia Nuga Ait.

In all the islands; very common in the jungle on flat land behind beaches and mangrove-swamps.

India, Ceylon; Burma; Malaya; Philippines; N. Australia; S. China; Polynesia.

92. Tamarindus indica Linn.

Great Coco ; a single large tree on west side of mouth of creek opening into Pollok Bay. This tree grows in a place where it could hardly havo been planted; if planted where it grows it can hardly bo imagined for what object the position was selected and the tree is obviously much older than the last attempt at settlement in the island. This bay is at certain seasons an anchorage for Burmese junks calling to obtain coco-nuts and the introduction of the tree is probably due to a tamar. ind fruit having been cast overbroad from one of thess junks and thrown up by the tide where the tree now grows.

Throughout the tropics, cultivated; perhaps indigenous in Africa.

93. Cynometra ramiflora Linn.

In all the islands; very common in flat, muddy lands behind mangrove swamps.

India, Ceylon; Burma, Andamans, Nicobars, Malaya; Philipines; N. Australia.

94. Entada scandens Benth.

In all the islands, frequent; its seeds occur in all the shore-drifts and it was one of the species found germinating on a sandy spit (an incipient island) between Jerry Island and the south end of Great Coco.

Cosmopolitan in the tropics.

95. Adenanthera patonina Benth.

Table Island and Great Coco, common.

India, Ceylon; Burma, Andamans, Malaya; Philippines; S. China.

96. Achola concinna DC.

Great Coco, rather common.

India, Ceylon; Burma, Malaya; S. China.

97. Acacia pennata Willd.

In all the islands, very common.

Africa; India, Ceylon; Burma, Andamans, Malaya.

98. Albizzia Lebber Benth.

Great Coco.

Africa; India, Ceylon; Burma, Tenasserim, Malaya: Andamans; China ; N. Australia.

99. Albizzia procera Benth.

In all the islands exceedingly common on the interior ridges; stunted and weatherbeaten where it approaches the west coast. 

Andaman).

India, Burma, Malaya, Philippines, (not yet recorded from south

\section{RHIZOPHORE A.}

100. Rhizophora mucronata Lamk.

Great and Little Coco, frequent in mangrove swamps.

Tropical shores of Africa, Asia, and N. Australia.

101. Rhizophora conjugata Linn.

Great Coco, common.

Tropical shores of Asia, and Africa.

102. Ceriops Candolleana Arn.

Great Coco, common.

Tropical shores of Eastern Hemisphere.

103. Ceriops Roxburghiana Arn.

Great Coco, not common.

Tropical shores of Eastern Hemisphere.

104. Bruguiera gymorhiza Lamk.

In all the islands, common. This is the chief constituent of the mangrove jungle in the group; it germinates very freely also along the sandy beaclies though there it doubtless does not persist; it also germinates along the ridges of coral that are formed between the mainland and small outlying islets like Lascelles Island, Rat Island, Button, and others, and as the roots spread they help to collect the "drift" of the tides and shew how it is possible for the island to increase in size without postulating a general upheaval for the group. On bare rocky promontories on the west coast where long rocky ledges and reefs of loose boulders run many yards out to sea, number's of seedlings also appear and though these spots are exposed to the full force of the south-west monsoon many of these resist the waves for at lcast several seasons; the only other constituent of the mangrove jungle that does this is Avicennia, many specimens of which thongh dwarf and weatlerbeaten are evidently of considerable age. Pemphis, which also greatly affects such positions is not partial to mangrove swamps proper at all and was never seen along the creeks. In the small lake on Little Coco the water of which was potable though not good almost all the constituents of a mangrove swamp were growing freely.

Tropical shores of Eastern Hemisphere and Polynesia.

COMBRETACE 庈。

105. Terminalia Catappa Linn.

In all the islands; one of the commonest trees on the shore and 
not infrequent in the interior on flat lands, but not met with ascending the ridges. There is apparently no such species as $T$. procera.

Andamans, Malaya; planted elsewhere in the tropics.

106. Terminalia bialata Kurz.

Great Coco, frequent.

Burma, Tenasserim, Andamans.

107. Lumntzera racemosa Willd.

Little Coco, very common among mangroves in the lagoon.

Tropical shores of Eastern Hemisphero and Polynesia.

108. Iluigera Conyzadenia Meissn.

Great Coco, a rather common climber.

Tenasserim, Andamans.

109. Grrocarpus JacQuini Roxb.

In all the islands, probably the commonest species in the group.

Tropical sea-shores of the old world and Polynesia.

MYETACEAE.

110. Barringtonia speciosa Forst.

In all the islands, very common.

Ceylon; Andamans, Nicobars; Malaya; Australia; Polynesia: on sea-shores.

111. Barringtonia racemosa Blume.

In all the islands, very common.

India, Ceylon; Burma, Malaya; Andamans, Nicobars; Polynesia: on sea-shores.

\section{MELASTOMACE 2 .}

\section{Meyecylon edule Roxb.}

Great Coco; east coast, on rocky promontory at south end of Ford Bay-only one tree seen.

Andamans, Malaya, Philippines. Mr. Kurz has a specimen from Great Coco also, only in leaf, and has it from S. Andaman in flower.

\section{LYTHRACE $\nexists$.}

113. Pemphis acidola For'st.

In all the islands; very common, especially on the west coast on rocky or shingly promontories.

Tropical shores of Eastern Hemisphere.

114. Lagerstromia hypoledca Kurz.

Great $\mathrm{Coco}$, common in the interior.

Andamans.

124 
115. Lagerstremia sp.

Little Coco; one tree only seen.

A tall straight tree, about 100 feet, leaves sessile, oblong-lanceolate 8 in. long, $2 \frac{1}{4}-2 \frac{3}{4}$ in. wide, thinly coriaceous, fruit $\frac{1}{2}$ in., calys woody, lobes spreading.

The leaves of this are unlike those of any Indian species; the fruit is very like that of $L$. calyculata Kurz, from Martaban, but the leaves ar'e very different, being larger, much thinner, and perfectly glabrous. This, when flowers are found, will almost certainly prove a distinct species.

\section{PASSIFLOREAE.}

116. Modecca cordifolia Blume (fide Masters).

Great Coco, common.

Andamans; the specimens are exactly like the common Andaman coast Modecca and the flowers appear not to differ from those of M. cardiophylla Mast.

117. Carica Papata Linn.

Great Coco, introduced but perfectly naturalised and already extending in an unbroken line among the coco-nuts on the east coast, from the north-east corner to within 3 miles of the south end of the island; one or two isolated specimens occur at the south-east corner evidently originating from fruits washed up by the sea. Half a mile from the south end on the west coast is another spot, well into the interior, where some trees occur-the result apparently of independent introduction as they occur near the remains of some huts used by coco-nut gatherers who visit the island at intervals.

Cultivated in warm countries; originally American.

\section{CUCURBITACE $A$.}

118. Trichosanthes palmata Roxb.

Little Coco; near north end of island.

India, Ceylon; Burma, Andamans; Malaya; N. Australia; China, Japan.

\section{FICOIDE $刃$.}

119. Sesuridm Portulacastrum Linn.

In all the islands; common on sandy beaches on the east coast. All tropical and sub-tropical sea-shores. 


\section{COROLLIFLORE.}

\section{RUBIACE $A$.}

120. Stephegre diversifolia Hook. $f$.

In all the islands, extremely common.

Chittagong, Burma, Tenesserim ; Philippines.

121. MUSS ANDA CALYCINA Wall. (M. macrophyllce forma distinctior).

In all the islands very common. The calyx-teeth in these examples are $\frac{3}{4}$ in. long and $\frac{1}{4}$ in. broad.

Pegu, Tenasserim, Andamans.

122. Webera Kurzi Hook. f.

Little Coco; common in interior.

Andamans.

123. RANDIA LONGIFLORA Lamk.

Little Coco, common.

Assam, Chittagong, Burma, Tenasserim, Malaya; Andamans, Nicobars.

124. Diplospora singelaris Korth.

In all the islands, extremely common.

Assam, Burma, Tenasserim; Malaya. Not yet reported from other parts of the Andaman group.

125. Guettarda spectosa Linn.

Great Coco, east coast; frequent.

Cosmopolitan on tropical sea-shores.

126. Ixora grandifolia Zoll. \& Mor., var. Kurzeana Teys. \& Binnend. In all the islands, common in the interior jungle ; a small straggling shrub.

Nicobars. This is exactly like the type of Teysmann and Binnendyk's I. Kurzeana.

127. Ixora brunnescens Kurz.

In all the islands; very common along the beaches. A fine tree, often 60-80 feet; extremely unlike the preceding.

Andamans, Nicobars.

128. Ixora cuneifolia Roxb.

Little Coco; infrequent.

Assam, Burma, Tenasserim.

129. Pavetta indica Linn.

In all the islands, very common.

India ; Burma, Andamans ; Malaya; S. China ; N. Australia.

130. Morinda citrifolia Linn., var. bracteata Roxb.

In all the islands, exceedingly common along the coast.

Laccadives; Andamans; Nicobars; Sunderbuns; Arracan.

126 
131. Parchotria adenophyla Wight.

Very common in all the islands.

Assam, Pegu, Tenasserim; Andamans.

132. Paderta fétid. Linn.

Very common in all the islands.

India, Burma, Malaya.

\section{COMPOSITA.}

133. Vernonia cinerea Less.

Table Island, common in the clearing near the lighthouse; Great Coco, frequent in the small clearing at the north-east corner but also plentiful on bare rocks on the western sea-face of the island. Though probably an introduced plant in the two first situations, its appearance on the west coast, where it is extremely plentiful, indicates that it has also reached the island independently of human agency.

Tropical Asia, Africa and America.

134. Vernonia ditergens Benth.

Great Coco; plentiful on rocky promontory at north end of island.

India, Burma, Tenasserim.

135. Adenostemia riscosum Forst.

Great $\mathrm{Coco}$, on the western coast and at the north end of the island.

Cosmopolitan in the tropics.

136. Ageratum Conyzordes Linn.

Table Island, common in the clearing near the lighthouse.

Cosmopolitan in the tropics; originally American.

137. Blumea tirens DC.

Great Coco, profuse on rocks on western sea-face; in one sheltered cove the stems were over 8 feet high.

India, Burma, Tenasserim (Mergui, Griffith).

138. Plucjea indica Less.

Great Coco, common on the coast.

India, Burma, Malaya, China; sea-shores.

139. Wedelia scandens C. B. Clarke.

In all the islands, common in the sea-fcnce jungle, a rather brittle woody climber with stems $30-50$ feet long.

Tropical sea-shores of India, Burma, Malaya, Andamans and Nicobars.

\section{GOODENOVIE $Æ$.}

140. Scerora Kønigir Vahl.

In all the islands, very common in the coast zone.

India, Burma, Malaya, Australia, Polynesia ; on sea-coasts. 


\section{MYRSINEA.}

141. Ardisia humils Vahl.

In all the islands, common in the beach forest.

India, China, Malaya.

142. Aggiceras majos Gaertn.

Great Coco; fruits seen in the sel-drifts on the coast; doubtless the species occurs frequently in the mangrove swamps, though no individual tree was met with.

Cosmopolitan on tropical sea-coasts.

\section{SAPO'TACEAL.}

143. Mindsops Littoralis Kurz.

In all the islands; next to Gyrocarpus Jarquini, this (the Andaman Bullet-wood) is the commonest tree in the group.

In Jerry Island, off the south end of Great Coco, and for about two miles along the coast at the south end of Great Coco, nearly every tree that has attained a height of 80 feet presents from the sea the appearance of being dead. Closer inspection, however, shews that in many (perhaps most) cases only the whole of the main branches are dead, while about their bases or along the main trunk numerous close bunches of snall branches have appeared, the leaves of which keep the trees still alive. The same thing is apparent at the south-west corner of Little Coco but is less striking because less extensive.

Andamans, Nicobars.

\section{EBENACEA.}

144. Diosprros Kurzil Hiern.

Little Coco; Great Coco, rare.

Andamans, Nicobars.

\section{APOCYNEAD.}

145. Rauwolfia serpentina Benth.

Great Coco, common.

India, Burma, Tenasserim, Java; not previously reported from the Andamans.

146. Cerbera Odolilam, Gaertn.

Great Coco, rare; in mangrove swamps.

India, Malaya, Andamans ; China; Australia, Polynesia.

147. Ochrosia borbonica Gmel.

Little Coco, common; in beach forests.

Andamans, Malaya, Seychelles, Mascarene Islands.

128 
148. Tabernemontana crispa Roxb.

In all the islands, very common along the west coast.

Audamans Nicobars, Diamond Island (off Arracan coast).

149. Strrophanthus Wallichir A. DC.

Great Coco; a large climber, in leaf only.

India, Assam, Chittagong.

150. Anodendron paniculatum $A$. DC.

In all the islands.

India, Burma, Malaya, Philippines.

151. Chonemorpha macrophilla G. Don.

Little Coco, common.

India, Andamans, Malaya.

\section{ASCLEPIADE $A$.}

152. Sarcolobus grobosus Wall.

Great Coco and Little Coco; common in mangrove swamps.

Sunderbuns, Tenasserim, Malay Peninsula; Nicobars.

153. Hoya Parasitica Wall.

Great Coco.

Assam, Khasia, Chittagong, Tenasserim, Malaya; Andamans.

154. Hoya diversifolia Blume.

In all the islands; extremely common.

Burma, Malaya.

155. Dischidia nuamularia R. Br.

Little Coco; not common.

Cachar, Chittagong, Tenasserim, Malaya, Andamans; Australia.

\section{GENTIANACEAE.}

156. Limnanthendm indicon Thwaites.

Great Coco; abundant in the small lake at the north-east corner of the island; not in the lake on Little Coco and not previously reported from the Andamans. The lake is adjacent to the small clearing and the species may possibly be an introduced one in this locality.

Afghanistan; India, Burma, Malaya; Australia, Fiji; Mascarene islands.

\section{BORAGINEAE.}

157. CORdia SUBCORDATa Lamk.

Great Coco, a rather common tree in the beach-forests on the east coast.

Andamans, Malaya; Australia; Sandwich Islands. 
158. Tournefortia argentea Linn. $f$.

Great Coco, very rare; Little Coco, extremely common on the western coast and in the beach-forests, where it often reaches a height of 35-40 feet with a trunk of sometimes a foot diameter.

Ceylon; Malaya, Andamans, Nicobars; Australia; Mauritius.

\section{CONVOLVULACE $A$.}

159. Erycibe paniculata Roxb.

Great Coco, very common in interior.

India, Burma, Tenasserim; Malaya; Andamans, Nicobars; Australia.

160. Argyreia tiliefolia Wight.

Great Coco; common on the coasts.

India; Andamans, Malaya; Philippines; near the sea.

161. Argyreia Hookeri Clarke.

In all the islands, common.

Sikkim, Bhutan, Assam, Martaban.

162. Argyreia lanceolata Choisy.

Great Coco : exactly $=$ Wall. Cat. 1395.

Tenasserim, Andamans.

163. Lettsomia peguensis Clarke.

Little Coco.

Pegu, Tenasserim, Andamans.

164. Ipoma Grandiflora Lamk.

In all the islands, very abundant on the coasts.

East Africa; India, Burma, Malaya, Andamans; Australia, Polynesia; introduced in America.

165. Ipon æa Coccinea Linn.

Table Island, rampant in the jungle near the lighthouse clearing; escape from the light-keeper's garden.

Native of America; cult., and a frequent escape, in tropical Asia.

166. Ipoma Batatas Lamk.

Table Island, cultivated in the lighthouse garden.

Native of America; cult., in the tropics generally.

167. Iтомжа digitata Linn.

Great Coco, on the west coast, occasional.

Cosmopolitan in the tropics.

168. Ipomata denticulata Choisy.

Great Coco, very plentiful at north end of island, but almost altogether restricted to the coral-shingle; at south end of island and on Little Coco, exceedingly uncommon. 

Polynesia.

Seychelles; Ceylon; Malaya, Andamans and Nicobars; Australia, 169. Iromea Turpethum R. Br.

Both islands, not uncommon.

India, Burma; Malaya; Australia, Polynesia; Mauritius, Seychelles. 170. Іромжа вILOBA Forsk.

In all the islands, very common; affects principally the sandy beaches; in Jerry Island, however, grows on the shingle and occurs under rather dense jungle, from side to side of that island, at its north end.

Cosmopolitan on tropical sea-shores.

171. Contoltulus parviflorus Vahl. sea-face.

In all the islands; very common in the jungle along the western

Africa ; India, Burma, Malaya, Andamans; Australia.

172. Porana spectabilis Kurz.

Great Coco.

Tenasserim, Andamans.

\section{SOLANACEA.}

\section{Solandm Melongena Linn.}

Table Island, cultivated in the light-house garden ; Great Coco, plentiful and quite naturalised all over the clearing at the north-oasi corner of the island; remains of the garden.

Cult. in all warm countries.

174. Physalis minima Linn.

Great Coco; abundant on rocky parts of the coast just above limits reached by spray during storms, on east, north and west coasts; Little Coco, on rocks in similar situations at north end of island.

Cosmopolitan in the tropics.

175. Capsicum minimum Roxb.

Table Island, in clearing, occasional, escape from the light-keeper's garden; Great Coco, throughout the clearing very abundant; unlike Solanum Melongena this is not confined to the clearing but is extending into the jungle much as Carica Papaya is.

India and Malaya; cultivated and frequent as an escape.

\section{SCROPHULARINE 洢.}

176. Scoparia dolcis Linn.

Table Island and Great Coco; abundant in the clearings on both islands; introduced.

An American weed, now cosmopolitan in the tropics. 


\section{BIGNONIACE $A$.}

177. Oroxilum indicum Vent.

Little Coco, very plentiful at north-east corner of the island; Great Coco, rare.

India, Ceylon; Indo-Clina, Andamans; Malaya.

178. Heterophragita adenophyllum Seem.

In all the islands, very common.

Assam and Eastern Bengal, Burma, Tenasserim; Andamans.

\section{ACANTHACE $\nexists$.}

179. Thunbergia laurifolia Iindl.

In all the islands, very common.

Arracan, Tenasserim, Malaya; Andamans.

180. HYGROPHILA QUADRIVALVIS T. And.

Great Coco, abundant in the wet ground at the margin of the small lake and forming a continuous ring outside the belt of Polygonum growing at the water's edge.

India; Andamans, Burma, Malaya.

181. Strobilanthes Phylos'rachyds Kurz.

Great and Little Coco, a gregarious species common on most of the rocky promontories on the east coast of both islands.

Pegu, Tenasserim.

182. ERanthemdM albUm Nees.

Great Coco; common in the beach-forests.

Chittagong, Burma; Malaya; Andamans, Nicobars.

183. Eranthemum cinnabarindm Wall, var. succisifolia Clarke (E. SUCCIFOLIOM Kurz.).

Great and Little Coco; common in the beach-forest.

Nicobars.

These two species are recorded because in the large suite of specimens collected, some examples agree exactly with Andamans specimens named $E$. album by Dr. T. Anderson, and others agree exactly with the original specimens of Mr. Kurz's E. succifolium. But I do not think that there are really two species present. The plants are referred by Anderson to $E$. album, but are considered by Clarke a white-flowered fern of $E$. cinnabarinum, and are held by Kurz to be two distinct species. The original specimens of Kurz's Eranthemum album, T. And.? (314 of Nicobars list) I cannot, however, distinguish from those of $E$. succifolium (313 of that list).

184. Rungia Parviflora Nees, var. pectinata Clarke.

Table Island; in the light-house clearing.

India, Burma, Andamans; a weed, introduced. 
185. Peristrophe actminata Nees.

Great Coco, very common on the east coast.

Tenasserim, Malaya ; Andamans.

\section{VERBENACEA.}

186. LitPPIA NODIFLORA Rich.

Little Coco, in swampy ground at west side of island, plentiful.

Cosmopolitan in the tropics.

187. Prema integrifolita Linn.

In all the islands, very common on the coast.

India, Ceylon; Burma, Malaya; Andamans, Nicobars ; on sea coasts.

188. Premina sp.

Great Coco; a climber common on the western soa-face, also obtained on Rutland Island.

In fruit only; almost certainly P. obtusifolia.

South Andaman, Malayan Archipelago, Australia.

189. Vitex NegUndo Linn.

Great Coco; east coast, very rare; Little Coco; in salt marshes, extremely common.

Afghanistan, Tropical Asia, Philippines.

190. Vitex pubescens Vahl.

Table Island; common on north coast.

India, Burma, Malaya.

191. Vitex WimberLeyi Kurz.

Little Coco, not common.

Andamans.

192. Clerodendron INerMe Gaertn.

In all the islands, extremely common on the coasts.

India, Burma, Tenasserim, Andamans and Nicobars.

193. Avicennia officinalis Linn.

Common in one mangrove swamp near south end of Great Coco; elsewhere rare.

Indian, Malayan, and Polynesian sea-coasts.

\section{LABIAT 死。}

194. Anisomeles ofata R. Br.

Great Coco; abundant in beach-forest at north end of island. This does not occur in the small clearing, but is very abundant in the jungle near it. It may have been introduced by man but is more probably indigenous ; it occupies much the same situations and is even more plentiful in Diamond Island. Not previously reported from the Andamans.

India, Burma, Malaya, China, Philippines. 


\section{INCOMPLET}

\section{NYCTAGINE Æ.}

195. BoerhaAtia repens Linn.

In all the islands, common on every rocky promontory and on all the isolated rocks on the reefs not covered by the tides.

Cosmopolitan in the tropics.

196. Pisonia aculeata Linn.

In all the islands, one of the commonest climbers in the beach-forests.

Cosmopolitan in the tropics.

197. Pisonia excelsa Blume.

In all the islands, common in the beach-forests.

Andamans, Malaya.

\section{AMARANTACE A2.}

198. Celosia cristata Linn.

Table Island, an escape in the light-house clearing.

Cosmopolitan in the tropics.

199. ACHYRANTHES ASPERA Linn. var. TYPICA.

Table Island and Great Coco, common in the clearings, introduced.

Cosmopolitan in the tropics.

var. PORPHYRISTACHYA Hook. f.

Little Coco, very abundant in the beach-forests; stems 10-15 feet long, climbing over the sea-face jungle. A plant in habit remarkably unlike the preceding.

South-Eastern Asia.

200. Gomphrena gLobosa, Linn.

Table Island, an escape, but very plentiful and extending into the jungle.

Cosmopolitan in the tropics ; probably originally American.

\section{POLYGONACE珢.}

\section{Poliggondi barbatum Linn.}

Great Coco ; this plant fringes the small lake at the north-east corner of the island, growing partly in and partly out of the water, just within it is a floating belt of Panicum Myurus, while outside is a ring of Hygrophila quadrivalvis. None occurs in the lake on Little Coco.

Africa; India, Ceylon; Burma, Malaya.

\section{ARISTOLOCHIACE A.}

202. Bragantia tomentosa Blume.

Little Coco; abundant on the interior ridges.

Tenasserim, Andamans; Java. 
203. Aristolochia tagala Cham. \& Schlecht.

Both islands, frequent.

India, Burma, Malaya; Nicobars.

\section{PIPERACEA.}

204. Piper canindm Blume.

Great Coco.

Tenasserin, South Andaman, Malaya.

\section{MYRISTICE 冉。}

205. Mrristica Irya Gaertn.

Great Coco; frequent in interior towards eastern side.

Ceylon, Andamans, Tenasserim, Malaya.

206. Myristica gladea Blume.

Great Coco.

Burma, Andamans, Malaya.

\section{LAURINEÆ.}

207. Dehaasia Kurzi King.

Little Coco,

Tenasserim, Andamans.

208. Hernandia peltata Meissn.

In all the islands, on the eastern coasts.

East Africa, Madagascar; Laccadives, Ceylon; Andamans, Nico. bars; Mergui, Malaya, Archipelago ; North Australia; Polynesia.

209. Casstitha filiformis Linn.

Great Coco, occasional; Little Coco, extremely plentiful on all the coasts.

Cosmopolitan in the tropics.

\section{LORANTHACEA}

210. Loranthus longiflorus Desrouss.

Great and Little Coco.

India, Ceylon; Burma, Malaya; Andamans.

\section{SANTALACEAE.}

211. Champereia Griffithiana Planch.

Both islands; common on the coasts.

Tenasserim, Malaya; Andamans, Nicobars. 
212. EUPHORBia AтоTo Forst.

\section{EUPHORBIACEA.}

In all the islands, very common on the sandy beaches.

India, Ceylon; Andamans, Nicobars; Malaya; Australia; China; Polynesia.

213. EUphorbia PILULIFERA Linn.

Table Island; in light-house clearing, still rare.

Cosmopolitan tropical and subtropical weed.

214. Bridelia KurziI Hook. $f$.

In all the islands, common on the western sea-face.

Nicobars.

215. Bridelia tomentosa Blume.

Great Coco, common.

India; Burma; Andamans, Malaya; China; Philippines; North Australia.

216. Phyldanthus coldmaris, Muell.-Arg.

Table Island, common.

Pegu, Tenasserim.

217. Fluggia microcarpa Blume. Great Coco.

Africa; India, Ceylon; Assam, Burma, Malaya; Australia ; China.

218. Cyclostemon assamicus Hook. $f$.

In all the islands, a very common tree, gregarious where it occurs.

Sikkim, Assam.

219. Aporosa villosula Kurz.

Great Coco.

Pegu, Tenasserim, Andamans.

220. Crotor sublirates Kurz.

In all the islands, common in the beach-forests.

Andamans and (perhaps) Tenasserim.

221. Blachia andamanica Hook. $f$. forests.

Great Coco, coasts, very common; Little Coco, frequent in beacl--

Andamans.

222. Claoxylon longifolitom Muell.-Arg.

Great Coco.

Malaya.

223. Maliotus acdminatus Muell.-Arg. ( $=$ M. Helferianus Kurz.).

Great Coco, common.

Tenasserim; Andamans; Malaya.

224. Mallotus andamanicus Hook. $f$.

Great and Little Coco; common, aud, where it occurs, gregarious.

Andamans.

136 
225. Macaranga Tanarios Muell.-Arg.

Great Coco and Little Coco; common in the beach-forests.

Arracan (Diamond Island); Andamans; Malaya.

226. Chesmone javanica Blume.

Great Coco; plentiful on rocky promontories at north end of island. Bengal, Assam, Burma, Malaya.

\section{URTICACE 梀.}

227. Phyllochlamys spinosa Bureau.

\section{Little Coco, common.}

India, Ceylon; Burma, Malaya; Andamans.

228. Plecospermum andamanicum King.

Little Coco.

Tenasserim, Andamans.

229. Ficus Benjamina Linn.

Great Coco; not in fruit, therefore the particular variety cannot be determined.

India, Assam, Burma, Andamans, Malaya.

230. Ficus Rumprit Vahl.

Little Coco, on the east coast; this species is here very rare. In Diamond Island, Arracan, this is one of the commonest trees on the coast.

India, Burma, Malaya, Andamans.

231. Ficus retUá Linn. var. nitida Thunbg. (sp). F. comosa Curtis, Bot. Mag., t. 3305 [1834].

In all the islands, very common. The fruits of this species, as Mr. Kendall, I. M., pointed out to me, is one of the favourite foods of a large pigeon, Carphopaga bicolor, which visits the group in enormous numbers during the cold weather.

India; Burma; Andamans, Malaya; China; Australia; New Caledonia.

232. Ficds BRevicuspis Miq.

In all the islands, common. The fruits are borne both on young branches in leaf axils, and on old wood in bunches.

Andamans, Malaya.

233. Ficdés callosa Willd.

Great Coco.

India, Burma, Malaya.

234. FIICUS HISPIDA Linn. $f$.

Great Coco, common.

India, Ceylon; Burma, Malaya. var. D\&MONOM Koønig (sp.). 
Little Coco.

Distribution of type.

235. Ficus Grisea Wall. Cat. 4544.

Great Coco. Fruits of this a favourite food of the Green Parrots.

Burma. (Salween valley).

236. Antiaris toxicaria Leschen.

Great Coco.

India, Ceylon; Burma, Tenasserim, Malaya.

237. Artocarpds Gomeziana Wall.

Great Coco and Little Coco, very common.

Tenasserim, Malaya, Andamans.

\section{Grmnosperme.}

\section{CYCADACEAE.}

238. CrCas Romphir Miq.

In all the islands, very common in beach-forests, sometimes attains a height of 50 feet, and a girth of over 5 feet. Guinea.

Tenasserim, Andamaus, Nicobars; Malaya; North Australia, New

\section{Monocotyledones.}

\section{ORCHIDACEA.}

239. Dendrobium SeCUndum Wall.

In all the islands, common. The only very common orchid on forest trees; specimen brought and flowered at Calcutta.

Martaban, Tenasserim; Penang, Sumatra, Java, Cochin China.

240. Calanthe veratrifolia R. Br.

Great Coco, not uncommon on the interior ridges. The same species was also found, a few days later, on Rutland Island at the opposite end of the Andaman group.

India, Andamans, Malaya.

241. Dorites Wighti Benth. var.—?

Great Coco, frequent on trees in the low, flat swampy land near the coast; specimens were brought and flowered at Calcutta. The foliage as well as the shape and markings of the flowers quite agree with those of the typical plant, but in the Coco Island specimens the flowers are distinctly larger and the ground colour is violet instead of yellow.

242. Aerides multiflorum Roxb.

Great Coco, occasional near the sea.

India, Burma, Andamans, Malaya.

138 
243. Pholidota imbricata Lindl.

Great Coco, occasional.

India, Burma, Malaya.

\section{SCITAMINE $\nexists$ A.}

244. Costus speciosus Linn.

Great Coco, frequent.

India, Himalaya, Indo-China, China, Malaya.

245. Zingiber sp.

Great Coco, common. Near Z. corollinum Hance; probably a new species (Baker in sched.). In fruit only on the occasion of these visits; the rhizomes brought to Calcutta have not yet flowered.

246. Musa sapientum Linn.

The Plantain is cultivated in the light-house garden; it has already disappeared, probably owing to the presence of cattle, from the site of the garden on Great Coco.

\section{AMARYLLIDACE $\nexists$ 世.}

247. Crindu astaticom Linn.

In all the islands, very common in the coast zone.

Andamans, Nicobars, Malaya.

\section{TACCACE $A$.}

248. TaCCa pinnatifida Forst.

In all the islands, common in the coast zone. Some of these were huge specimens and the tubers brought to Calcutta produced leaves and flowers in no way inferior to those in their native habitat. The following measurements are from an average specimen-the tallest grown had a peduncle 116 inches high.

Leaf-stalk 40 inches, lamina 3 -fid, each lobe $36 \mathrm{in.} \mathrm{long,} \mathrm{the} \mathrm{lateral}$ lobes 2-fid from the 8th inch; the central lobe and each segment of the lateral lobes 36 in. across ; peduncle 80 inches; leafy bracts 3 in. long, $2 \mathrm{in.} \mathrm{across;} \mathrm{filiform} \mathrm{bracts} 16 \mathrm{in}$. long, their basal sixth green, the remainder pale purple; perianth segments $\frac{3}{8}$ in. long, $\frac{1}{8}$ in. across, pale green with purplish edges.

India, Burma, Malaya, Andamans,

DIOSCOREACE $A$.

249. Droscorea glabra Roxb.

In all the islands, common.

India, Burma, Malaya, Andamans. 
250. Dioscorea pentaphylla Linn.

In all the islands, common.

India, Ceylon, Burma.

\section{LILIACE $A$.}

251. Smilax macrophylla Roxb.

In all the islands, common.

Eastern Himalaya, Assam, Arracan, Pegu.

252. Asparagus racemosus Roxb.

Great Coco; in low-lying lands behind the mangrove-swamps at north end of island.

India, Burma, Audamans, Java.

253. Draceina angustifolia Roxb.

Both islands; small tree in coast zone.

India, Burma, Andamans, Malaya; N. Australia.

254. Dractena spicata Roxb.

In all the islands, frequent on interior ridges.

India, Burma, Malaya, Andamans, Nicobars.

255. Gloriosa superba Linn.

Great Coco ; east coast, frequent.

Tropical Asia and Africa.

\section{COMMELYNE $A$.}

256. Pollia zorzogonensis Endl.

Great Coco, rather common.

India, Burma, Andamans, Narcondam, Malaya.

257. Commelina obliqua Hassk.

Great Coco. Seeds smooth, but only two in number in both specimens collected.

India, Burma, Malaya; not before reported from the Andamans. 258. Aneilema ofatum Wall.

Great Coco, Little Coco ; common.

Pegu, Tenasserim, Andamans.

\section{FLAGELLARIE Æ.}

259. Flagellaria indica Linn.

In all the islands, very common in beach-forests. tius.

India, Indo-China, Andamans, Nicobars, Malaya; Australia; Mauri- 


\section{PALMEAE.}

260. Caryota sobolifera Wall.

In all the islands, very common in beach-forests.

Indo-China, Andamans, Malaya.

261. Corypha elata Roxb., Flor. Ind. 2, 176 ; Griff., Ind. Palm. 112, t. 220 D.-C. Gebanga Kurz, Jour. As. Soc. Beng. 43, pt. 2, 206, nec Blume.-O. macropoda Kurz, 1. c. 205, t. 15.

Great Coco, rare; Little Coco, very common.

This palm, which is very common in Little Coco and particularly so near the lake at the south-west corner of the island has leaf stalks up to 25 feet long and leaves up to 20 feet across and is clearly identical with Kurz's O. macropoda. But Kurz's plant does not appear to be specifically distinct from $C$. elata. Kurz has himself in his subsequent writings noted that his first impression that this is a stemless palm was erroneous, admitting that it has a stem at least 8-12 feet high. Moreover in Little Coco at least one example had reached a height of 60 feet and was not yet in flower in 1890, while in 1889 and 1890 Dr. King and myself obtained both flowering and fruiting specimens of Kurz's Andamanese Corypha near Port Blair; these prove the species to be Corypha elata. Kurz is, I believe, in error in identifying Roxburgh's C. elata with Blume's C. Gebanga, the two trees-as grown in Hort. Calcutta-are very different in appearance; the leaves of $O$. Gebanga are much paler in colour and Blume's figure of the inflorescence of $C$. Gebanga (Rumphia 2, tt. 97, 98 and 105) shows an open panicle that will not at all suit $O$. elata, which has a very dense inflorescence like a gigantic head of parsley. In any case Roxburgh's name (1832) has four years' priority and Kurz's reduction is, therefore, on that ground alone, untenable. The writer is of opinion, and Dr. King agrees, that the examples of O. elata in Hort. Calcutta may have been originally introduced from the Andamans and that the species is only there indigenous. At all events it has not hitherto been found wild in any part of India or Burma.

262. Livistona sp.

Great Coco; occasional on inland ridges. This palm, the 3 or 4 examples of which met with were stemless or had stems under two feet high, seems to be nearly related to L. Jenkinsiana Griff., Palm. Brit. Ind. 128, t. 226 A. B. and to L. speciosa Kurz, Jour. As. Soc. Beng., $43,2,204$, t. 13, 14, the differences between which species Mr. Kurz himself admits are not great. The Coco species may not of course be a dwarf one, but if it is not it seems remarkable that no tall examples were met with. The leaves are remarkably like those of $L$. speciosa and $\mathrm{Mr}$. 
Kurz's description would suit them very well except that the transverse veins are, in the Great Coco plant, even more prominent than in $L$. speciosa; the ligula however is very different.

Mr. Kurz does not describe the ligula in L. speciosa; it is, however, shewn (perfectly accurately) in t. 13, f. 5. as cordate and entire-just as it is in L. Jenkinsiana. In the species under review the ligula is larger, ovate orbicular, and armed at the margin with small but hard, flat black blunt spines, a character exhibited by no flabellate-leaved palm of which specimens are preserved in Calcutta Herbarium.

263. Calamus andamanicus Kurz.

In all the islands, common.

Andamans.

264. Calamus tigrinus Kurz.

In all the islands, common.

Andamans, Tenasserim.

265. Cocos NoCifera Linn.

In all the islauds, extremely abundant. Probably not truly indigenous, though perhaps not intentionally introduced. It has long been known that this palm occurred on these islands; the name "Cocos Islands," applied to the group, is of older date than 1652, and it has often been the subject of remark that while this is so and while every island in the Nicobars, even uninhabited ones like Batti Malv, has Coco-nut trees, the species is altogether absent from the intervening Andaman islands. Kurz, in Forest Flora Brit. Burma, says the Coconut occurs on north-east Andaman also, but the writer is unable to ascertain on what authority, and the statement is contradicted by the officers of the settlement at Port Blair who alone know the coasts of the group intimately. There are here and there individual trees on the Andaman coasts now; Dr. Alcock tells me there is one on South Sentinel; the writer saw one on Rutland Island; Captain Simpson, Assistant Port Officer, Madras, tells me he recollects being in a small bay in one of the islands of the Eastern Andaman Archipelago where there are some trees. But all these are quite recent introductions and are mainly due to the humanitarian efforts of the officers of the Andamans who plant them when they visit various places along the coasts; the instance quoted by Captain Simpson is, however, attributed to a wreck. No explanation based on the set of currents in these seas is sufficient to explain the peculiar distribution of the Palm, and the writer is inclined to believe that the presence of the species in the Coco Islands is due to the wreck of some Coco-laden craft on their coasts.

Once established the species spreads with great rapidity. On Barren Island one tree was known in 1881 ; in 1891 thirteen were counted, of $\mathrm{I} 42$ 
which seven were bearing. In Narcondam there were in 1891 Coco.nut trees, many of them bearing, in 3 separate bays on the N. W., N., and $\mathrm{N}$. E. aspects of the island respectively. These may have been brought from the Coco group by a strong North-East to South-West current that sets down on this island from the neighbourhood of that group, but I am inclined to think they owe their presence to an act of unrecorded piety on the part of some humane individual who has visited the island, for in the Nortl Bay where the trees are most niumerous there is, just behind the coco-nut zone, a large patch of Plantains which clearly must have been introduced intentionally.

It should not be forgotten that at some remote period a colony may have been started in the Coco group and then abandoned. It is known that in recent times two such attempts have been made and that both have failed owing to the unhealthiness of the place. It may be that the Coco-nut was intentionally introduced on some similar occasion of which no record has been left. In any case, to speak of the coco-nut as "wild" here, as Mr. Kurz does (Jour. As. Soc. Beng., xliii, Pt. 2, p. 200) is apt to convey the erroneous impression that the species is here truly indigenous.

The coco-nut cannot be said to be known in a truly wild state, though it occurs on many uninhabited islands, and its original home is by no means certain.

The quality of these coco-nuts is little inferior to that of those cultivated at Port Blair and though distinctly inferior to those cultivated in the Nicobars they are much the same as those on Batti Malv where there are no inhabitants.

America, Polynesia, Malaya, India.

\section{PANDANE 2 .}

266. Pandanus odoratissimus Linn. $f$.

In all the islands, common on the coasts.

India, Indo-China, Malaya, Andamans, Nicobars.

AROIDE A.

267. Amorphophallus sp. (aff. A. bulbifer).

Great Coco, common; Little Coco, occasional. Only leaves and very advanced fruit obtained; tubers brought to Calcutta have as yet only produced leaves, but these leaves are bulbiferous and indicate this as a species nearly related to, but apparently distinct from, both $A$. bulbifer and $A$. tuberculiger.

268. Alocasia fornicata Schott.

Great Coco, common.

India, Indo-China, Malaya, Andamans. 
269. Scindapsus offucinalis Schott.

In all the islands, common.

India, Indo-China, Malaya, Andamans.

270. Pormos scandens Linn.

In all the Islands, common.

India, Indo-China, Malaya, Andamans.

\section{NAIADACE $A$.}

271. Cymodocea cilita Ehrb.?

On the reefs of all the islands; extremely common and forming vast submarine meadows. This species is exceedingly common in the Andamans and has been met with in equal abundance at Rangachang near. Port Blair (there associated with another species of apparently the same genus), at Rutland Island, at Little Andaman (there in company with Halophila ovalis), and at Car Nicobar. No flowering or fruiting specimens have yet been reported at Calcutta. This is the plant supposed by Kurz (Jour. As. Soc. Beng., xlv, Pt. 2, p. 154) to be a small form of Enhalus aceroides.

27.2. Zanichellia palustris Linn.

Little Coco, in the small lake along with Chara fcetida.

Cosmopolitan in salt-marshes.

CYPERACEA.

273. Cyperds polystachyos Rottb.

Great Çco; west coast, rather common on the bare grassy slopes. Cosmopolitan.

274. Cyperos elegans Linn.

Great Coco; frequent in wet patches in the dense interior jungle.

India, Indo-China, Malaya, Andamans; America.

275. Cyperus dilctu: Vahl.

Great Coco ; occasional.

India, Indo-China, Malaya, Andamans.

276. Cxperus pennatus Lamk.

In all the islands, very common on the coast in rocky places.

Sea-shores of the Indian Ocean.

277. Kyllinga brevifolia Roxb.

Great Coco, clearing at north-east corner; Table Island, clearing near light-house ; common.

India, Indo-Shina, Malaya, Andamans.

278. Fimbristrulis diphylla Vahl. coasts.

Table Island and Great Coco, in the clearings; also on the rocky

India, Burma, Malaya, Andamans; Australia, Africa, America. 
279. Fimbristylis ferruginea Vahl.

Great Coco and Little Coco, on coral-shingle.

India, Burma, Malaya.

280. Fimbristylis quinqueangularis Kunth.

Great Coco and Table Island, in marshy ground.

India, Indo-China, Malaya.

281. Fimbristylis militace Vahl.

Great Coco, flat marshy ground near the small lake.

India, Indo-China, Malaya.

282. Scirpus subulatus Vahl.

Little Coco, in the lake at tke south-west corner of the island, abundant.

Bengal (Salt lakes); Beluchistan, Panjab; Africa, (Egypt).

\section{GRAMINEA}

283. Paspalum scrobiculatum Retz.

Little Coco, abundant in the lake.

India, Indo-China, Malaya.

284. Panicum cilitare Retz.

Great Coco, near south end of island.

India, Indo-China.

285. Panicum colonum Linn.

Table Island, light-house clearing; Great Coco in the clearing, also at south end of island in Coco-nut zone.

Cosmopolitan in the tropics.

286. Panicum Hecopes Trin.

Table Island, in the clearing.

India, Indo.China.

287. Panicum jafanicum Poir.

Great Coco, common.

India, Indo-China, Malaya.

288. Panicum Mrurus Lamk.

Great Coco; in matted manses flonting in the small lake at northeast corner of island.

India, Indo-China, Malaya.

289. Panicum montanum Roxb.

Great Coco, with the next species, in deep jungle.

India, Indo-China, Malaya, Andamans.

290. Oplismenus compositus Roem. \& Schult.

Great Coco, in dense jungle, occasional.

Cosmopolitan or nearly so. 
291. Thuarea sarmentosa Pers.

Great Coco, common as a turf under Coco-nut trees.

Shores of Indian Ocean.

292. ISCh

Great Coco, common on grassy slopes and under Coco-nut trees.

India, Indo-China, Malaya.

293. Isch жMUM мUпICUM Linn.

Great Coco, occasional only; Little Coco, extremely abundant.

India, Indo-China, Malaya.

294. Andropogon contortus Linn.

Table Island and Great Coco; the common grass both in the clearings and on the naturally bare headlands of the western coast.

Cosmopolitan in the tropics.

295. Eleusine indica Gaertn.

Table Island, frequent; Great Coco, rare.

Cosmopolitan in the tropics.

296. Eleusine egrptiaca Roxb.

Table Island; in the light-house clearing, scarce.

Cosmopolitan, or nearly so, in the tropics.

297. Dendrocalamus strictus Nees, var.-?

Great Coco, on one hill, abundant; Table Island, plentiful. Flowering examples were obtained on Table Island which have been kindly examined by Mr. J. S. Gamble. There seems no doubt as to the species, the specimens do not however quite agree with typical examples. There is little doubt that this Bamboo is here indigenous and, from an account received from Mr. Godwin-Austen (formerly of Port Blair), appears to occur on Saddle Peak in North Andaman also. It does not occur in South Andaman.

India, Burmah.

\section{CRYPTOGAMA.}

VASCULiRES.

FILTCES.

298. Davallia solida Sw. tall trees.

Great Coco, east coast, very common on Mimusops littoralis and other

Andamans, Malaya, Polynesia, Australia.

299. Adiantum lunulatum Burm.

Great Coco, on interior ridges frequent; Table Island, common.

Cosmopolitan in the tropics. 


\section{Ceratopteris thalictroides Brogn.}

Great Coco, in wet places in the interior with Cyperus elegans.

Cosmopolitan in the tropics.

When discussing the weeds of the Andaman Flora (Jour. As. Soc. Beng.) the writer imagined this fern to have been introduced into these islands by human agency, at least indirectly. But the Coco locality proves sufficiently to his mind that its presence is altogether independent of man's presence, and he has since then collected it in similar situations in South Andaman. It is probably not at all common however, and hence it had escaped the notice of Mr. Kurz when he collected in the Andamans.

301. Polypodium irtordes Lamk.

In all the islands, frequent.

India, Indo-China, Andamans, Malaya; Australia, Polynesia; Africa 302. Poltpodium adnascens $\mathrm{Sw}$.

Great Coco, on trees in mangrove swamps; Little Coco, on trees in lagoon at south-west end of island. Africa.

India, Indo-China; Andamans, Nicobars; Malaya; Polynesia; 303. Polypodidm QUercifolrum Linn.

In all the islands, very plentiful in the same situations as Davallia solida.

India, Indo-China; Andamans, Nicobars; Malaya; North Australia. 304. Vittaria elongata Sw.

Great Coco, not very common. Africa.

India, Indo-China; Andamans, Malaya; Australia, Polynesia; 305. Acrostrchum scandens J. Sm.

Great Coco, very common in the low-lying lands behind the coast zone.

India, Indo-China; Andamans, Malaya; Australia, Polynesia.

306. Acrostichum appendiculatum Willd, var. Setosa.

Great Coco, the only common ground fern on the interior ridges.

India, Indo-China; Andamans, Malaya.

307. Lygodidy Flexdosdy Sw.; Bedd. ridges.

In all the islands, common in the dense drarfed jungle on the

India, Burma; Andamans, Malaya; Australia; Africa.

\section{CHARACEA®.}

308. Chara fæetida A. Braun.

Little Coco; abundant in the lagoon.

India, Indo-China. 


\section{MUSCI.}

309. Calymperes Dozpanem Mitt.

Great Coco, on damp rocks in a sheltered bay on west coast, also on Mimusops trunks in coast zone; Little Coco, on trunks of Mimusops littoralis.

Samoa; Java, Philippines ; Ceylon; Admiralty Islands. 310. Bryum coronatum Schwaegr.

Great Coco, on charred stumps of Mimusops littoralis at south end of island.

Tropics of both hemispheres.

\section{HEPATIC $A$.}

31l. LejeUnia sp.

In all the islands, on trees, common.

312. HEPATICA sp. (genus indeterminable).

Great $\mathrm{Coco}$, on trees in mangrove swamps.

\section{Celuluhares.}

\section{LICHENES}

313. Collema nigrescens Achar.

Little Coco, soft puipy masses on stems of Cycas Rumphii Cosmopolitan.

314. Physcia sp. (near Ph. obscura Fr.)

Little Coco, on stems of Cycas Rumphii

315. Physcia sp.

Great $\mathrm{Coco}$, on rocks, west coast.

316. Lepraria sp. (specimens imperfect).

Great Coco.

\section{FUNGI.}

317. Lentinus leucochrods Fries.

Great $\mathrm{Coco}$, on dead wood, common.

* Asia.

318. Lenzites deplanata Fries.

Great Coco, on dead wood, common.

* Asia.

319. Lenzites subferrdginea Berk.

Great Coco

* Asia.

148 
320. Polyporos folfos Fries.

Great Coco.

* Asia.

321. Polypords xanthopus Fries.

Great Coco, on dead stems.

Cosmopolitan in the tropics.

322. Polyporus sanguineus Fries.

Great Coco; on dead stems of Cocos nucifera.

Cosmopolitan in the tropics.

323. Polyporus grammatocephalus Berk.

Great Coco, on dead wood.

India, Indo-China, Malaya, Australia, America.

324. Polyporus australis Fries.

Great Coco.

Cosmopolitan in the tropics.

325. Hexagona yergamenea Berk. \& Broome.

Great Coco,

Ceylon (Berkeley and Broome, Jour. Linn. Soc. xiv, 57).

326. Hexagona sRriceo-hirsutos Kl.

Great Coco; on dead wood.

North America (Klotzsch, Linnoea viii, 483).

327. Hexagona tenurs Hook.

Great Coco, on dead wood.

Nicobars (Fenzl, Novara Bot. ii, 138); Mauritius (Klotzsch, Linnoea viii, 482).

328. Dedelea flabellud Berk.

Great Coco, on dead wood.

* Asia.

329. Dederlea sanguinea Kl.

Great Coco, on dead wood.

India (Klotsch, Linnoea viii, 481).

330. Dederlea quercina Fries.

Great Coco, on dead wood.

Cosmopolitan.

331. Ded elea concentrica Fries.

Great Coco, on dead wood.

Cosmopolitan in the tropics.

332. Thelephora incrustans Pers.

Great Coco, on Pongamia glabra; Little Coco, on Cycas Rumphii.

Cosmopolitan.

333. Botista lilacina Berk.

Great Coco, on grassy slopes.

Cosmopolitan in the tropics. 
334. Hirneola polytricha Mont.

Great Coco, on dead wood.

Tropics of both hemispheres and Polynesia.

335. Xylaria clatarioides G. Massée, sp. nov.

Xylaria (Xylocoryne) stromatibus sæpius solitariis rarius in cæspitibus $2-5$ connatis cylindraceis, $2-4 \mathrm{~cm}$. altis, $\frac{1}{3}-\frac{1}{2}$ diam.; extus atris papilloso-scabris, intus candidis stipite elongato, coriaceo-suberoso nigro-velutino demum nudo; peritheciis clavulæ omnino immersis; ascis cylindricis, pedicellatis, octosporis; sporidiis oblique monostichis, ellipticis, nigricantibus $10-11 \times \mu$. (Prain n. 45). In lignis putridis.

Great Coco, common on dead stems of Mimusops littoralis.

336. Daldinia vernicosa Cos. \& de Not.

Great Coco, on dead wood.

India, America.

\section{Rhytisma sp.}

In all the islands, on leaves of Ficus lrevicuspis.

Andamans, (the same species apparently is equally common at Port Blair).

338.

Besides the above there occurs on both islands a Fungus which appears to be very widely dispersed thronghout the Andamans and Nicobars, but has so far been only found as a white mycelium that appears as a narrow band on the bark of slender branches, runs upwards along these and divides into still narrower bands on the branchlets; these branch and anastomose and send still narrower bands (threads) upwards along the petioles of the leaves and finally spread as a thin network on the under surface of the lamina. The writer has found the same blight (known to the officers at Port Blair as "thread-blight") on the following species: Alsodeia bengalensis, Ochna squarrosa, Bombax insigne, Camellia theifera, Hibiscus rosa-sinensis, Gardenia sp., Pongamia glabra, Diplospora singularis, Blachia andamanica, Ficus nitida; it is also reported to occur on a species of Phalcenopsis. Its effect is in every case the same, the leaves affected become yellow and sickly, and as regards Ochna among indigenous species and the Tea-plant among cultivated species, when affected they become brown and die. The blight spreads with great rapidity and for a time threatened the existence of the Tea-industry at Port Blair. Drs. Cunningham and Barclay have both examined specimens but as there is no sign of any advance beyond the mycelial stage the position of the Fungus is at present indeterminable. 
339.

A second fungus of some interest is an Uredine that was found in considerable quantity on Clerodendron inerme. This the writer has met with, always producing the same characteristic effects on this Clerodendron, in South Andaman, Little Andaman, and Car Nicobar, as well as on Great Coco. The specimens were examined by the late Dr. Barclay, but were found insufficient for determination.

340.

A third fungus of note causes a "dry-rot" in the fallen trunks of Mimusops littoralis on the beach. The effect produced simulates in a wonderful manner charring by fire; it appears to be confined, so far as the drift timber and wreckage on these islands is concerned, to Mimusops and Quercus - the planks of a wooden vessel, apparently of oak, that had been wrecked on Little Coco, being attacked like the Bullet-wood trees; Teak, Sundri and other logs were not affected.

\section{ALG丑.}

\section{Sargassumi tlicifolidm J. Agardh.}

In all the islands; in great beds at the outer margins of the fringing reefs and in the deeper water beyond; the only really common sea-weed.

Almost Cosmopolitan in the tropics; not from Australia (Hemsl., Report on Bot. of Admiralty Islands, p. 271).

342. Turbinaria ornata J. Agardl.

In all the islands; rather common both on coral and on sandstone reefs.

\section{* Indian Ocean.}

343. Padina patonia Gaill.

In all the islands; on both coral and sandstone.

Cosmopolitan in tropical seas.

344. Dicryota pichoтoma Lamour.

Great Coco; on coral reefs. tropics.

Common in both north and south temperate seas, rarer in the

345. Lithothamnion polimorphum Aresch.

Great Coco; on coral reefs.

Atlantic, Mediterranean, South Africa; Chonos Archipelago.

346. Acanthophora Thieril Lamour.

Little Coco; pools on coral reefs.

Cosmopolitan in tropical seas.

347. Jania tenelia Kuetz.

Great Coco; on reefs, on Lithothamnion polymorphuin.

* Indian Ocean. 
34.8. Gracilaria crassa Harv.

In both islands; in pools on coral sand.

* Indian Ocean.

349. Gelidium conneum J. Agardh.

Great Coco; on coral reefs; also growing on Halimeda Opuntia.

Almost Cosmopolitan.

[A specimen of a Gelidium washed up by the tide on Little Coco, was too much withered and bleached to be identified; another was collected there on the reefs, but in too early a stage of development to be named.]

350. Caulerpa clatifera J. Agardh.

Both islands; on reefs.

Cosmopolitan in tropical seas.

351. Caulerpa plomaris J. Agardh.

Little Coco; in pools on coral recfs.

* Indian Ocean.

352. Valonia fastigiata Harv.

Great Coco ; on coral reefs.

Indian Ocean and Pacific.

353. Valonia confervoides Harv.

Great Coco; in pools on coral sand.

* Indian Ocean.

[A species of Valonia was collected on Little Coco also, but in too early a stage of development to be named].

354. Halimeda Opuntia Lamour.

In both islands; both on sandstone and on coral reefs, rather common.

Cosmopolitan in tropical seas.

355. Siphonocladus? Filfformis De Toni.

Washed ashore on the coast of Little Coco after stormy weather that prevailed for three days during our visit.

356. VAUCHERIA $\mathrm{sp}$.

Little Coco; on sandstone reefs. None of the specimens obtained were in fruit.

Andamans and Nicobars, the same species apparently was found by the writer to be plentiful in South Andaman and in Car Nicobar.

357. Calothrix Pulvinata J. Agardh.

Little Coco; in pools above high water mark.

Cosmopolitan.

358.

A Nostocaceous Alga in habit, very like the preceding, was obtained 152 
in the shallower tidal pools on Great Coco, but the specimens were too much withered to be detcrminable.

LWhere an asterisk precedes the distribution of any Fungus or Alga it has been impossible to ascertain whether the species in question extends beyond the area indicated].

\section{§ § Nature, Distribution, and probable Origin of the Flora.}

In this list 358 distinct species are recorded, distributed among 268 genera and 95 natural ordcrs; 297 species are Phanerogams and 61 are Cryptogams, giving a proportion of nearly five flowering plants to one flowerless species, the exact proportions and percentages being :-

Phanerogams : Cryptogams : : 4.85: 1.

Phanerogams $=83 \% ;$ Cryptogams $=17 \%$.

In the two groups Filices and Algce the list represents the Cryptogamic flora with probably the same degree of adequacy that it does the Phanerogamic. In the other Cryptogamic groups it is to be feared the representation is not so complete. Still the scarcity of Mosses and Lichens is a very striking feature of the flora, so is the paucity of Ferns; with all three groups it is not merely a case of few species being present, there are, except perhaps in the case of Acrostichum scandens, which is common, remarkably few individuals of these species.

Among the 297 Phanerogams, 238 are Dicots; only one of these (Cycas Rumphii) is a Gymnosperm, the othcr 59 bcing MIonocots. The Dicots are distributed amongst 59 natural orders and 178 genera, the Monocots amongst 14 natural orders and 45 genera. The proportions and percentages here are :-

Dicots: Monocots : : $4: 1$.

Dicotyledons $=80 \% ;$ Monocotyledons $=20 \%$.

Altogether 66 per cent. of the flora consists of Dicotyledons, whilst among these the Polypetalce exceed in number the rest of the groups combined, a somewhat unusual circumstance, since, as regards species at least, the Indian Gamopetalce usually exceed the Polypetalce; Polypetalce here constitute, as it happens, one-third, or $33 \%$ of the whole flora.

There are only 15 Vascular Cryptogans in the list as against $46 \mathrm{Cel}$ lular Cryptogams; these are together distributed amongst 45 genera and 22 natural orders; The proportions and percentages are :-

Vascular: Cellular: : $1: 3$.

Vascular Cryptogams $=25 \%$; Cellular Cryptogams $=75 \%$.

The subjoined table gives a synoptic view of the systematic disposition of the Coco Island Flora. 
TABle I. Systematic synopsis of Coco Island orders, genera and species.

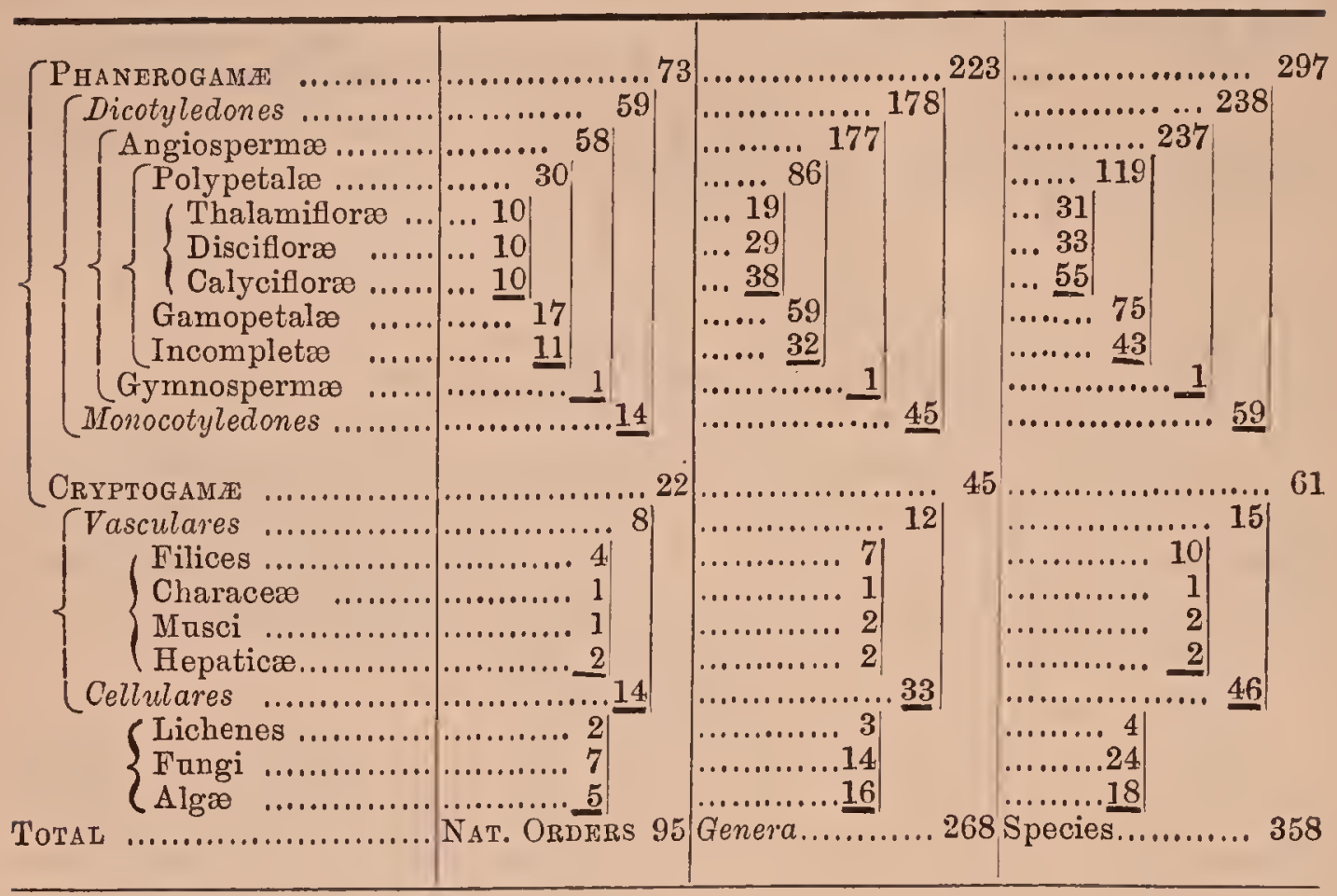

Of the 73 natural orders of Phanerogams 24 are represented by single species and 14 more by two species each. The most extensively represented natural order is Leguminosce, with 34 species ; followed after a long interval by Euphorbiacece and Graminece, each $15 \mathrm{sp}$; Convolvulacee, $14 \mathrm{sp.;}$ Rubiacea, 13 sp.,; Urticacece, 11 sp.; Cyperacee, $10 \mathrm{sp.}$ Filices, amongst Cryptogams, are also represented by 10 species. None of the other orders have more than 8 species.

As to genera: 29 of these natural orders of Phanergams are represented by one genus; 13 by 2 genera: 11 by 3 genera; 6 by 4 genera; 5 by 5 genera; 4 by 6 genera; one natural order each where there are 7 genera (Apocynece); 8 genera (Graminece); 11 genera (Rubiacece) 12 genera (Euphorbiacece); and 22 genera (Leguminosce): Leguminosce thus leads both as regards genera and species. The subjoined table exhibits the relationship of the orders according to the wealth of their representation.

TABLE II. Natural orders of Coco Island Phanerogams arranged according to their richness in species.

\begin{tabular}{|c|c|c|}
\hline $\begin{array}{c}\text { Number } \\
\text { of } \\
\text { species. }\end{array}$ & $\begin{array}{c}\text { Number } \\
\text { of } \\
\text { orders. }\end{array}$ & NAMES OF ORDERS. \\
\hline $\begin{array}{l}34 \\
15 \\
154\end{array}$ & $\begin{array}{l}1 \\
2\end{array}$ & $\begin{array}{l}\text { Leguminosce. } \\
\text { Euphorbiacece, Graminece. }\end{array}$ \\
\hline
\end{tabular}




\begin{tabular}{|c|c|c|}
\hline $\begin{array}{l}\text { Number } \\
\text { of } \\
\text { species. }\end{array}$ & $\begin{array}{l}\text { Number } \\
\text { of } \\
\text { orders. }\end{array}$ & Naues of ORDERs. \\
\hline 14 & 1 & Convolvulacece. \\
\hline 13 & 1 & Rubiacece. \\
\hline 11 & 1 & Urticacece. \\
\hline 10 & 1 & Oyperacece. [Filices are also represented by 10 species.] \\
\hline 8 & 3 & Malvacece, Sterculiacece, Verbenacece. \\
\hline 7 & 3 & Compositoe, Apocynece, Acanthacece. \\
\hline 6 & 2 & Anacardiacea, Palmece. \\
\hline 5 & 6 & $\begin{array}{l}\text { Ampelidere, Sapindacece, Rhizophorece, Combretacece, } \\
\text { Orchidacece, Litiacece. }\end{array}$ \\
\hline 4 & 4 & Tiliacee, Meliacece, Asclepiadacece, Aroidece. \\
\hline 3 & 10 & $\begin{array}{l}\text { Olacinece, Celastrinece, Rhamnece, Iythracece, Solan- } \\
\text { acece, Nyctagineo, Amarantaceo, Laurinew, Scita- } \\
\text { minece, Commelynacece. }\end{array}$ \\
\hline 2 & 14 & $\begin{array}{l}\text { Menispermacece, Capparidece, Guttiferce, Dipterocarp- } \\
\text { ece, Burseracee, MIyrtacece, Passifloracece, Myrsinece, } \\
\text { Boraginece, Bignoniacece, Aristolochiacece, Myristicece, } \\
\text { Dioscoreacece, Naiadece. }\end{array}$ \\
\hline 1 & 24 & $\begin{array}{l}\text { Anonacece, Nymphoeacece, Violacece, Rutacece, } \\
\text { Moringece, Connaracece, Melastomacece, Cucurbitacee, } \\
\text { Ficoidece, Goodenoviece, Sapotacece, Ebenacee, } \\
\text { Gentianacece, Scrophularinece, Tabiatce, Polygonacece, } \\
\text { Piperacece, Loranthacece, Santalacece, Cycadacee, } \\
\text { Amaryllidacece, Taccacece. Flagellariece, Pandanacece. }\end{array}$ \\
\hline
\end{tabular}

If the species are classified according to their habit we find that 78 are climbers, 74 are trees that may exceed 30 feet in height, 20 are small trees that do not exceed 30 feet, 48 are shrubs and 138 are herbaceous, (treating as herbaceous species like Carica, Sccevola, Musa, Crinum, etc., and all Cryptogams except the two climbing ferns, Lygodium and Acrostichum scandens, which are here included among the other climbers). But though as regards number of species herbaceous forms are so largely represented they are as a matter of fact extremely inconspicuous, two-fifths of them being cryptogams and one-third of these being marine. Nor, if we except the herbaceous climbers, which are here dealt with along with the woody ones, and the species that occur on the few bare grassy slopes, are herbaceous phanerogams more numerous than herbaceous cryptogams. The most numerously represented herbs are Andropogon contortus, Desmodium polycarpon, Desmodium triquetum, Vernonia cinerea, Blumea virens, the various species of Fimbristylis, Cyperus pennatus and polustachyus, Boerhaavia repens, Ischcemum muticum, Thuarea sarmentosa. Herbaceous species that frequent deep 
jungle only, such as Desmodium laxiflorum, Urena lobata, Cyperus elegans, Oplismenus compositus, Panicum montanum, Alocasia fornicata, Costus speciosus, Zingiber sp., Amorphophallus sp., Acrostichum appendiculatum, Ceratopteris thalictroides, etc., are not only very rarely met with, but are represented by extremely few individuals where they do occur.

Woody shrubs and small trees taken together do not, as regards species, quite equal in number the large trees. In point of number of individuals, however, this is not the case, for it is not unusual to find these, woody shrubs and the smaller trees truly gregarious, particularly on the ridges; the chief examples are Glycosmis pentaphylla, Alsodeia bengalensis, Glyptopetalum calocarpum, Cyclostemon assamicus, Macaranga Tanarius, Miliusa sp., Cynometra ramiflora, Leea sambucina, Dendrocalamus strictus; a far larger area is covered by small trees and woody undershrubs heavily loaded with creepers than is covered by tall forest. In the mangrove-swamps most species may be spoken of as gregarious, but even here there is no great number of trees over 40 feet high; and the only gregarious tall trees are Mimusops littoralis and Gyrocarpus Jacquinii, both denizens of the beach-forest behind the Coco-nut zone, and Cocos nucifera itself. Among the arboreous species in these islands have to be included Cycas Rumphii, which is very commonly 30-35 feet high and of which one specimen measured in Great Coco had a clear stem from ground to crown of 42 feet; also Tournefortia argentea which in Little Coco (and elsewhere in the Andaman group) is a tree $25-40$

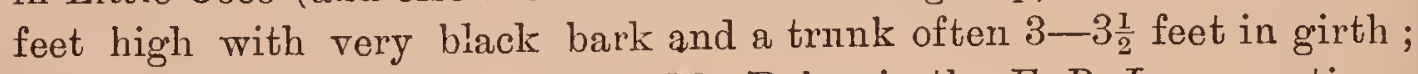
Pongamia glabra too, recorded by Mr. Baker in the F. B. I. as sometimes a climber, is here, as it also is in Bengal, always a tree from 20-60 feet in height. Salacia prinoides on the other hand is here always a heavy extensive climber.

Erect woody species therefore, including both trees and shrubs in this category, form almost exactly two-sevenths of the flora as regards number of species. As regards individuals, however, it will be no overestimation to say that these constitute six-sevenths of the vegetation, not merely in bulk but in actual number of individuals.

Climbing species, as compared with those having an erect or prostrate halit, show a much higher proportion of woody to herbaceous species. This is owing to the fact that of the 78 climbers only two are cryptogams, while in the other group 59 cryptogams are included. To give therefore an accurate conception of the conditions that prevail, the Cellular cryptogams ought to be excluded. Of the 312 Phanerogams and Vascular cryptogams 234 are of erect habit and 78 are climbing, giving a proportion of :-

Erect sp. : climbing sp. : : $4: 1$.

156 
Among these erect vascular plants the proportion of woody to herbaceous is therefore:-

Woody sp.: Herbaceous sp. : : $3: 2$.

Of the climbers 35 are woody and 43 are berbaceous so that here the proportion is :-

Woody sp.: Herbaceous sp. : : $2: 2 \frac{1}{2}$.

Instead therefore of being lower amongst climbers than erect species, the proportion of herbaceous species to woody ones, when attention is confined to vascular plants only, is actually higher. And in number of individuals too there is a much more eren balance among climbing species, since herbaceous climbing species, as well as woody ones, can easily raise themselves to the light and air for want of which no great quantity of herbaceous undergrowth can exist; indeed the herbaceous climbing species possess many advantages over their woody rivals, for they are not as a rule so heavy and as, moreover, they sometimes (e.g., Modecca, Trichosanthes, Dioscorea, Gloriosa) die down annually, they do not destroy the species on which they are supported so soon as do heary perennial creepers like Calamus, Thunbergia, Anodendron, Chonemorpha, Derris, etc., which in a few season: drag down the trees on which they climb.

Some of the woody climbers, such as Anodendron and Thunbergia, climb to great heights, and are not surpassed in this respect even by the Modecca. The majority of the woody climbers, however, like Sarcostigma, Salacia, Pisonia aculeata, Plecospermum, the species of Acacia and of Capparis, are not to be found on tall trees at all, but load henvily the woody undergrowth of small trees and shrubs that forms the bulk of the forest. Nor is it unusual to find the forest, where composed of tall trees, exhibiting both classes of creepers; the characteristic lofty creepers on the tall trees overhead, the heavy woody creepers on the shrubby undergrowth below.

Of the climbing species 20 , or $25 \%$, are armed. As a rule the armed species may be said to belong to the class of undergrowth climbers; with the exception of the two species of Calamus, the lofty climbers are unarmed.

The habit of the Coco Island species is shewn in the subjoined table. 
TABLE III. Habit of Coco Island species.

Vascular species (Phanerogams and Vascular Cryptogams) .... 312

Species with erect habit .................234

Woody species $\ldots . \ldots \ldots$......

Trees

Exceeding 30 feet..... 74

Under 30 feet $\ldots \ldots \ldots 20$

Shrubs.................. 48

Herbaceous species (Herbs and Herbaceous shrubs)

Climbing species.

Woody climbers

Armed...

Unarmed.

Herbaceous climbers

Armed

Unarmed

.....

Non-vascular species (Lower Cryptogams)

Total Coco Island species

As regards habitat it will be gathered from what has been said above that a very large proportion of the flora is of arborescent foresttype. Next in point of numbers to the inland forest species, though only half as numerous, are the litoral species; following these at about an equal interval are parasitic or saprophytic species-a class here almost entirely composed of Fungi; after these in succcssion epiphytes; marine species, (mainly Algce); weeds of cultivation; cultivated species; marsh or water plants; and species of open grassy slopes.

The subjoined table gives the numbers of each class of species; the meadow species, here separated from the forest species, are, owing to the smallness of their numbers, in all subsequent tables included with the forest species.

Table IV. Habitat of Coco Tsland species.

Civilized species

Cultivated plants

Weeds of cultivation

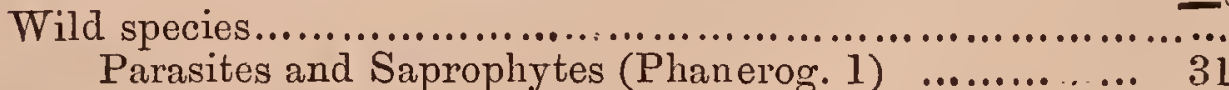

Epiphytes ............................................... 19

Marine plants (Phanerog. 1) $\quad$.......................... 19

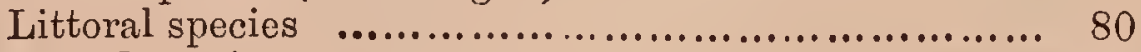

Inland species ......................................... 176

Forest species

Jungle

162

Grassy species

Marsh and water species 
The subjoined table exhibits the relationship that subsists between the systematic disposition of the species and their habit and habitat.

TABLE $\nabla$. Relationship between systematic arrangement, habit and habitat.

\begin{tabular}{|c|c|c|c|c|c|c|c|c|c|c|c|c|c|c|c|c|c|}
\hline \multicolumn{5}{|c|}{ HABIT. } & \multirow{2}{*}{\multicolumn{4}{|c|}{ Systematic Arrangement. }} & \multicolumn{9}{|c|}{ HABITAT. } \\
\hline 氶 & \begin{tabular}{c}
$\dot{1}$ \\
2 \\
$\Xi$ \\
0 \\
$\dot{g}$ \\
\hdashline \\
0
\end{tabular} & 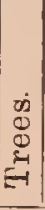 & 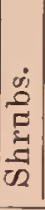 & $\begin{array}{l}\dot{0} \\
0 \\
010 \\
01\end{array}$ & & & & & 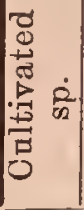 & $\mid \begin{array}{c}\dot{y} \\
\dot{\partial} \\
0 \\
0 \\
3\end{array}$ & $\left|\begin{array}{c}0 \\
02 \\
+0 \\
0 \\
0 \\
0 \\
0 \\
E_{1}\end{array}\right|$ & 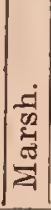 & 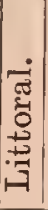 & 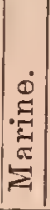 & 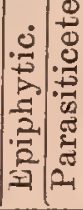 & . & \\
\hline 1 & $\ldots$ & 1 & $\ldots$ & $\ldots$ & Anonacer & $\ldots$ & $\ldots$ & ... & $\cdots$ & $\ldots$ & 1 & ... & ... & $\ldots$ & $\ldots$ & & 1 \\
\hline 2 & 2 & ... & $\ldots$ & $\ldots$ & Menispermacea & & $\ldots$ & ... & $\ldots$ & $\ldots$ & 2 & $\ldots$ & ... & $\ldots$ & $\ldots$. & .. & 2 \\
\hline 1 & .. & .. & ... & 1 & Nymphæaceæ & & ... & ... & $\ldots$ & $\ldots$ & $\ldots$ & 1 & ... & $\ldots$ & $\ldots$... & . & 1 \\
\hline 2 & 2 & $\ldots$ & $\ldots$ & $\ldots$ & Capparideœ & ... & .. & ... & ... & $\ldots$ & 2 & $\ldots$ & ... & $\ldots$ & $\ldots$. & .. & 2 \\
\hline 1 & .. & 1 & $\ldots$ & $\ldots$ & Violacer & $\ldots$ & ... & $\ldots$ & $\cdots$ & $\ldots$ & 1 & ... & ... & ... & $\ldots$ &.. & 1 \\
\hline 2 & ... & 2 & $\ldots$ & $\ldots$ & Guttiferre & ... & $\ldots$ & ... & $\ldots$ & $\ldots$ & 1. & $\cdots$ & 1 & $\ldots$ & $\ldots$ & .. & 2 \\
\hline 2 & & 2 & $\ldots$ & $\ldots$ & Dipterocarpea & & $\ldots$ & ... & $\cdots$ & $\ldots$ & 2 & $\ldots$ & ... & ... & $\ldots$ & .. & 2 \\
\hline 8 & .. & 3 & 2 & 3 & Malvacer & $\ldots$ & $\ldots$ & ... & 2 & 2 & 2 & $\cdots$ & 2 & ... & $\ldots$. & ... & 8 \\
\hline 8 & 1 & 7 & .. & $\ldots$ & Sterculiaces & ... & $\ldots$ & ... & ... & $\ldots$ & 6 & $\cdots$ & 2 & & $\ldots$. & $\ldots$ & 8 \\
\hline 4 & .. & 1 & 3 & $\ldots$ & Tiliace» & ... & $\ldots$ & ... & $\ldots$ & $\ldots$ & 4 & $\cdots$ & $\cdots$ & & .1. & ... & 4 \\
\hline 1 & .. & ... & 1 & ... & Rutaceæ & $\ldots$ & $\ldots$ & ... & $\cdots$ & ... & 1 & $\cdots$ & ... & . & $\ldots$ & $\cdots$ & 1 \\
\hline 2 & .. & 2 & $\ldots$ & $\ldots$ & Burseraceæ & $\cdots$ & $\cdots$ & $\ldots$ & $\ldots$ & $\cdots$ & 2 & $\cdots$ & $\ldots$ & $\ldots$ & $\cdots$ & ... & 2 \\
\hline 4 & .. & 4 & $\ldots$ & $\ldots$ & Meliaceæ & $\ldots$ & $\cdots$ & $\ldots$ & $\ldots$ & $\ldots$ & 3 & $\ldots$ & 1 &. & $\ldots$ & ... & 4 \\
\hline 3 & 2 & 1 & ... & $\ldots$ & Olacineæ & ... & $\ldots$ & ... & $\ldots$ & $\ldots$ & 3 & ... & ... & $\ldots$ & $\ldots$ & ... & 3 \\
\hline 3 & 1 & 1 & 1 & $\ldots$ & Celastrineæ & $\ldots$ & ... & ... & $\cdots$ & $\cdots$ & 2 & ... & 1 & $\ldots$ & $\ldots$ & ... & 3 \\
\hline 3 & 3 & .. & $\ldots$ & $\ldots$ & Rhamnea & $\ldots$ & ... & ... & ... & $\ldots$ & 2 & ... & 1 & $\ldots$ &.. & $\ldots$ & 3 \\
\hline 5 & 3 & ... & 2 & ... & Ampelideæ & $\ldots$ & $\ldots$ & $\ldots$ & $\ldots$ & ... & 4 & ... & $1)$ & ... & $\ldots$ & ... & 5 \\
\hline 5 & .. & 4 & 1 & ... & Sapindaceæ & ... & $\ldots$ & $\ldots$ & $\ldots$ & ... & 5 & ... & ... & $\cdots$ & $\ldots$ & ... & 5 \\
\hline 6 & ... & 6 & ... & $\ldots$ & Anacardiacer & $\ldots$ & $\ldots$ & $\ldots$ & ... & ... & 5 & $\cdots$ & 1 & $\ldots$ & $\ldots$ & ... & 6 \\
\hline 1 & ... & 1 & $\cdots$ & $\ldots$ & Moringere & $\ldots$ & $\ldots$ & ... & 1 & $\ldots$ & $\ldots$ & $\ldots$ &.. & ... & ... & $\ldots$ & 1 \\
\hline 1 & ... & 1 & $\ldots$ & $\ldots$ & Connarace: & $\ldots$ & ... & & $\cdots$ & ... & 1 & $\cdots$ & ... & ... & ... & .. & 1 \\
\hline 34 & 18 & 6 & 7 & 3 & Leguminosæ & ... & $\ldots$ & ... & 3 & 2 & 19 & $\cdots$ & 10 & ... & ... & ... & 34 \\
\hline 5 & ... & 5 & $\cdots$ & $\ldots$ & Rhizophoreæ & $\ldots$ & $\ldots$ & $\ldots$ & ... & ... & $\ldots$ & $\cdots$ & 5 & .. & ... & ... & 5 \\
\hline 5 & 1 & 3 & 1 & ... & Combretacea & $\ldots$ & ... & $\cdots$ & $\ldots$ & ... & 2 & $\ldots$ & 3 & ... & ... . & ... & 5 \\
\hline 2 & ... & 2 & ... & $\ldots$ & Myrtaceæ & ... & ... & ... & $\ldots$ & ... & $\ldots$ & $\cdots$ & 2 & ... &.. & ... & 2 \\
\hline 1 & $\ldots$ & $\ldots$ & 1 & $\ldots$ & Melastomacer. & $9 \ldots$ & ... & ... & ... & $\ldots$ & 1 & $\ldots$ & $\ldots$ & ... & ... & ... & 1 \\
\hline 3 & ... & 2 & 1 & $\ldots$ & Lythracem & ... & ... & ... & $\ldots$ & $\cdots$ & 2 & $\cdots$ & 1 & $\ldots$ & ... & $\ldots$ & 3 \\
\hline 2 & 1 & $\ldots$ & $\ldots$ & 1 & Passifloreæ & $\ldots$ & ... & ... & 1 & .. & 1 & ... & ... & $\ldots$ & $\cdots$ & $\ldots$ & 2 \\
\hline 1 & 1 & ... & $\ldots$ & $\ldots$ & Cucurbitaceæ . & $\ldots$ & $\ldots$ & ... & $\ldots$ & ... & 1 & ... & ... & $\ldots$ & $\ldots$. & $\ldots$ & 1 \\
\hline 1 & ... & $\ldots$ & $\ldots$ & 1 & Ficoideø & $\ldots$ & $\ldots$ & ... & $\ldots$ & $\ldots$ & $\ldots$ & ... & 1 & $\ldots$ & $\ldots$. & $\ldots$ & 1 \\
\hline 13 & 2 & 6 & 5 & $\ldots$ & Rubiaceæ & ... & & ... & $\ldots$ & $\ldots$ & 9 & ... & 4. & $\ldots$ & $\ldots$. & ... 1 & 13 \\
\hline 7 & 1 & $\ldots$ & 1 & 5 & Compositæo & $\ldots$ & ... & ... & $\ldots$ & 3 & 2 & $\ldots$ & 2 & ... & $\ldots$. & $\ldots$ & 7 \\
\hline 1 & $\cdots$ & $\ldots$ & ... & 1 & Goodenovieæ . & $\ldots$ & ... & $\cdots$ & $\ldots$ & $\cdots$ & $\ldots$ & ... & 1 & ... & $\cdots$ & ... & 1 \\
\hline 2 & ... & 2 & $\cdots$ & $\ldots$ & Myrsineæ & ... & $\ldots$ & $\cdots$ & $\ldots$ & $\cdots$ & $\ldots$ & ... & 1 & $\cdot$ & ... & ... & 1 \\
\hline 1 & ... & 1 & ... & $\ldots$ & Sapotacem & ... & $\ldots$ & ... & $\ldots$ & $\cdots$ & $\ldots$ & ... & 1 & ... & ... & ... & 1. \\
\hline 1 & $\ldots$ & 1 & ... & $\ldots$ & Ebonaceæ & ... & $\cdots$ & ... & ... & ... & 1 & $\cdots$ & $\cdots$ & ... & .... & $\ldots$ & 1 \\
\hline 7 & 2 & 2 & 2 & 1 & Apocynea & ... & $\ldots$ & ... & ... & $\ldots$ & 4. & ... & 3 . & ... & $\ldots:$ & .. & 7 \\
\hline 4. & 4. & $\cdots$ & .. & $\ldots$ & Asclepiadace & & $\cdots$ & $\cdots$ & ... & $\cdots$ & $\ldots$. & $\cdots$ & 1 & ... & 3 . & .. & 4 \\
\hline 1 & & $\ldots$ & ... & 1 & Gentianaceæ & ... & $\ldots$ & ... & $\cdots$ & $\cdots$ & ... & 1 & $\cdots$ & $\cdots$ & $\ldots 1$. & .. & 1 \\
\hline 2 & $\ldots$ & 2 & ... & $\ldots$ & Boraginea & ... & ... & ... & $\cdots$ & $\ldots$ & $\ldots$. & ... & $\div$ & ... & ... & .. & 2 \\
\hline 14 & 14 & $\cdots$ & $\cdots$ & $\ldots$ & Convolvulaces & & & & 2 & ... & 31. & ... & 9 & $\cdots$ & ... & & 14 \\
\hline 3 & $\ldots$ & & 1 & 2 & Solanaceæ & ... & & ... & 2 & $\cdots$ & $\ldots$. & ... & 1 . & ... & ... & & 3 \\
\hline 1 . & & ... & ... & 1 & Serophularinea & & & $\ldots$ & ... & 1 & $\ldots$. & $\cdots$ & ... & $\cdots$ & $\ldots$. & .. & 1 \\
\hline 2 & ... & 2 & $\cdots$ & $\ldots$ & Bignoniacero & ... & ... & ... & ... & ... & 2 . & $\cdots$ & ... & ... & ... & & 2 \\
\hline 7 & 1 & & & 6 & Acanthaceæ & ... & $\ldots$ & ... & $\ldots$ & 1) & 3 & 1 & 2 . & & ... & & 7 \\
\hline
\end{tabular}




\begin{tabular}{|c|c|c|c|c|c|c|c|c|c|c|c|c|c|c|c|c|}
\hline \multicolumn{5}{|c|}{ НАВіт. } & \multirow{2}{*}{\multicolumn{4}{|c|}{ SYSTEMATIC ARRANGEMENT. }} & \multicolumn{8}{|c|}{ HABITAT. } \\
\hline $\begin{array}{l}\text { तुं } \\
\text { हैं } \\
\text { - }\end{array}$ & 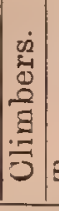 & 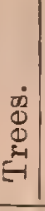 & 官 & $\mid \begin{array}{l}\dot{0} \\
\frac{0}{0} \\
0 \\
0 \\
\ddot{n}\end{array}$ & & & & & 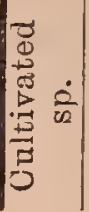 & \begin{tabular}{|}
$\mid$ \\
$\dot{z}$ \\
$\dot{z}$ \\
$\dot{D}$ \\
$\dot{D}$ \\
3
\end{tabular} & 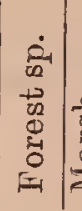 & 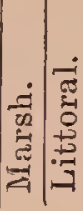 & 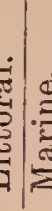 & 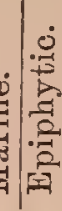 & 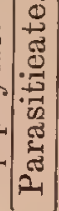 & 蹗 \\
\hline 8 & 2 & 3 & 2 & 1 & Verbenaceæ & $\cdots$ & ... & ... & $\ldots$ & $\cdots$ & 2 & 1 & & & $\ldots$ & \\
\hline 1 . & & & & 1 & Labiatæo & ... & ... & ... & ... &.. & $\ldots$ & $1 \ldots$ &.. &.. & $\ldots$ & 1 \\
\hline 3 & 1 & 1 & $\ldots$ & 1 & Nyctagineæ & $\ldots$ & ... & ... & ... & ... & $\ldots$. & ... 3 & $3 .$. & $\ldots$ & $\ldots$ & 3 \\
\hline 3 & & ... & $\ldots$ & 3 & A marantaceæ & $\ldots$ & $\cdots$ & ... & 2 & 1 & ... & $\ldots \ldots$ &... & $\ldots$ & ... & 3 \\
\hline 1 & $\ldots$ & & $\ldots$ & 1 & Polygonaceæ & & $\cdots$ & ... & $\cdots$ & $\cdots$ & $\ldots$ & $1 \ldots$ &.$\cdot$. & $\cdots$ & $\cdots$ & 1 \\
\hline 2 & 1 & $\ldots$ & $\ldots$ & 1 & A ristolochiace & & ... & $\cdots$ & $\cdots$ & $\cdots$ & $2 .$. & .... & .. & $\cdots$ & $\cdots$ & 2 \\
\hline 1 & 1 & .. & $\ldots$ & .. & Piperaceœ & ... & $\ldots$ & $\ldots$ & $\ldots$ & $\ldots$ & 1. & ... $\ldots$ &... & $\ldots$ & $\ldots$ & 1 \\
\hline 2 & $\ldots$ & 2 & & $\ldots$ & Myristicer & $\ldots$ & $\ldots$ & $\ldots$ & .. & $\ldots$ & 2. & $\ldots \mid .$. &. & $\cdots$ & $\ldots$ & 2 \\
\hline 3 & 1 & 2 & ... & $\ldots$ & Lanrineæ & ... & $\cdots$ & $\cdots$ & ... & ... & 1.. & $\ldots$ & $1 .$. & $\ldots$ & 1 & 3 \\
\hline 1 & & .. & ... & 1 & Loranthacex & $\ldots$ & $\ldots$ & $\ldots$ & $\ldots$ & $\ldots$ & $\ldots .$. & ... &.. &. & 1 & 1 \\
\hline 1 & & 1 & & $\ldots$ & Santalacex & $\ldots$ & & $\ldots$ & $\ldots$ & $\ldots$ & \begin{tabular}{l|l}
$\ldots$ &..
\end{tabular} & $\ldots$ & 1 1.. & $\cdots$ & $\ldots$ & 1 \\
\hline 15 &.. & ... & 13 & 2 & Euphorbiaceæ & & $\cdots$ & $\ldots$ & $\ldots$ & 1 & $13 .$. & $\ldots$ & $1 .$. & $\ldots$ & $\ldots$ & 15 \\
\hline 11 & 1 & 10 & $\ldots$ & $\ldots$ & Urticace & $\ldots$ & $\ldots$ & $\ldots$ & $\ldots$ & $\ldots$ & $11 .$. & $\ldots$ &... & $\ldots$ & ... & 11 \\
\hline 1 & & & ... & $\ldots$ & Cycadacer & ... & ... & $\ldots$ & $\ldots$ & $\ldots$ & \begin{tabular}{c|c}
$\ldots .$. &. \\
\end{tabular} & $\ldots$ & $1 \mid .$. & $\cdots$ & $\ldots$ & 1 \\
\hline 5 & & .. & $\ldots$ & 5 & Orchidaceæ & $\cdots$ & $\cdots$ & $\cdots$ & $\cdots$ & ... & $1 .$. & $\ldots$ &... & & $\ldots$ & 5 \\
\hline 3 & & ... & ... & 3 & Scitamineæ & $\ldots$ & $\cdots$ & $\cdots$ & 1 & $\ldots$ & $2 .$. & .. & & .. & .. & 3 \\
\hline 1 & $\ldots$ & ... & $\ldots$ & 1 & Amaryllidacex & & $\ldots$ & .. & $\ldots$ & ... & \begin{tabular}{l|l}
$\ldots .$. &
\end{tabular} & .. & 1 ... & & $\ldots$ & 1 \\
\hline 1 &.$\bullet$ & $\ldots$ & ... & 1 & Taccace» & $\cdots$ & $\cdots$ & $\cdots$ & .. & ... & $\ldots \cdot \cdot \cdot$ & .. & $1 \ldots$ & ... & .. & 1 \\
\hline 2 & 2 & $\ldots$ & ... & $\ldots$ & Dioscoreaceæ & & .. & $\ldots$ & $\ldots$ & ... & 2 & .. & ... & ... & $\ldots$ & 2 \\
\hline 5 & 3 & $\ldots$ & 1 & 1 & Liliaceæ & ... & $\ldots$ & $\cdots$ & $\cdots$ & $\ldots$ & 4... & .. & $1 .$. & & & 5 \\
\hline 3 & & $\ldots$ & ... & 3 & Commelynaces & & ... & $\cdots$ & $\cdots$ & ... & 3. & .. & & $\cdots$ & $\ldots$ & 3 \\
\hline 1 & 1 & ... & ... & $\ldots$ & Flagellarieæ & $\ldots$ & .. & $\cdots$ & $\ldots$ & ... & \begin{tabular}{c|c}
$\ldots$. &.. \\
\end{tabular} & 1 & $1 .$. & $\cdots$ & $\ldots$ & 1 \\
\hline 6 & 2 & 3 & 1 & . & Palmex & ... & .. & $\cdots$ & & ... & 4... & .. & $1 .$. & $\cdot \cdots$ & $\ldots$ & 6 \\
\hline 1 & ... & ... & 1 & $\ldots$ & Pandanaceæ & ... & ... & $\cdots$ & $\cdots$ & $\cdots$ & .. $\mid .$. & .. & $1 .$. & $\cdots$ & .. & 1 \\
\hline 4. & 2 & $\cdots$ & ... & 2 & Aroideæ & $\ldots$ & & $\ldots$ & $\ldots$ & ... & $2 \mid$. & & & - 2 & $\ldots$ & 4 \\
\hline 2 & & $\ldots$ & ... & 2 & Naiadaceæ & $\cdots$ & ... & $\cdots$ &. & ... & ... & 1 & & $\cdots$ & & 2 \\
\hline 10 & & ... & $\ldots$ & 10 & Oyperaces & $\ldots$ & ... & $\ldots$ & & 2 & 3 & 4. & $1 .$. & $\ldots$ & .. & 10 \\
\hline 15 & $\ldots$. & ... & 1 & 14 & Gramine» & $\ldots$ & $\ldots$ & $\ldots$ & $\ldots$ & 5 & 6 & 2 & $2 .$. & $\ldots$ & $\ldots$ & 15 \\
\hline 10 & 2. & & $\ldots$ & 8 & Filices & ... & $\ldots$ & $\ldots$ & $\ldots$ & ... & 1 & 1 & $\cdots$ & 8 & $\ldots$ & 10 \\
\hline ] & & & & 1 & Characex & $\ldots$ & $\cdots$ & $\ldots$ & $\ldots$ & $\cdots$ & $\ldots$ & 1 &... & $\ldots$ & $\ldots$ & 1 \\
\hline 2 & & & & 2 & Masci & $\ldots$ & & $\ldots$ & $\ldots$ & ... & $\ldots$ & $\ldots$... &.. & 2 & & 2 \\
\hline 2 & & & & 2 & Hepaticæ & ... & ... & $\ldots$ & $\ldots$ & $\cdots$ & $\ldots$ & $\ldots$ &.$\cdot$. & 2 &.. & 2 \\
\hline 4 & & & & 4 & Lichenes & ... & $\ldots$ & $\cdots$ & $\ldots$ & ... & $\ldots$ & ... & & & 4 & 4 \\
\hline 24 & & & & 24 & Fungi & $\ldots$ & $\ldots$ & $\ldots$ & $\ldots$ & ... & 1 & & & & 23 & 24 \\
\hline & & & & 18 & Algæ & $\cdots$ & $\ldots$ & $\cdots$ & $\cdots$ & ... & $\cdots$ & & 18 & ... & ... & 18 \\
\hline 358 & 78 & 44 & & 138 & & & Totals & $\ldots$ & 15 & 18 & 1621 & 1480 & 15 & 21 & 29 & 358 \\
\hline
\end{tabular}

In considering the distribution of the species in this list it has to be borne in mind that the islands in which they have been collected form an integral portion of the phytogeopraphic province of South-Eastern Asia-an area comprising the Indian Peninsula and Ceylon, the lower slopes of the Himalaya-particularly its eastern and central portion, South China, Indo-China and Malaya. To this area too apparently ought to be added, at least as regards many littoral species and many 160 
species with succulent fruits, Northern Anstralia. While, therefore, in the table of distribution the occurrence of the species in the large divisions of the globe are given on the left hand side, on the right hand the distribution within South-Eastern Asia itself is given. Further, since the geographical position of these islands indicates that they are an integral portion of the Andaman chain, and as the Andamans altogether form as it were part of the debatable land between Indo-China and Malaya, the occurrence of the species there is also noted. In all cases where the occurrence of a species in the Andamans is, at least so far as we yet know, only due to its presence in the Coco Islands, the species in question is indicated by [ ] brackets. The other debatable territory, so far as Malaya and Indo-China are concerned, is Tenasserim, and in all cases where the occurrence of a Coco Island species in Indo-China depends entirely on its occurrence in Tenasserim it is marked by the same [] brackets in the Indo-Chinese column. Similarly when, as is frequently the case, a species is only African in the sense of occurring in the Mascarene Islands, the same [] brackets are used in the African column.

\section{TABle VI. Distribution of the species observed in the Coco Group.}

\begin{tabular}{|c|c|c|c|c|c|c|c|c|c|c|c|c|c|}
\hline \multicolumn{7}{|c|}{ Distribution in S. E. Asia. } & \multirow{3}{*}{\multicolumn{2}{|c|}{ Names of Species. }} & \multicolumn{5}{|c|}{$\begin{array}{c}\text { General Distri- } \\
\text { BUtion. }\end{array}$} \\
\hline \multicolumn{3}{|c|}{$\begin{array}{l}\text { Westn. } \\
\text { Section. }\end{array}$} & \multicolumn{4}{|c|}{ Eastn. Section. } & & & & & & & \\
\hline $\begin{array}{l}\frac{\dot{0}}{0} \\
\frac{0}{0} \\
0\end{array}$ & & 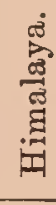 & 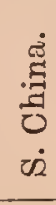 & 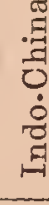 & 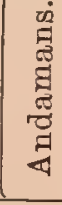 & 胥 & & & 总 & 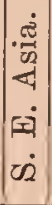 & 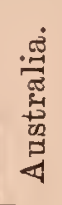 & 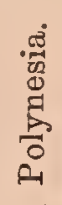 & 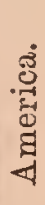 \\
\hline - & - & - & - & - & $x$ & - & Milinsa sp. & $\ldots$ & - & $x$ & - & - & - \\
\hline$x$ & $x$ & - & - & $x$ & $x$ & $x$ & Cyclea peltata $\quad \ldots$ & $\cdots$ & - & $\hat{x}$ & - & - & - \\
\hline - & - & - & - & - & $x$ & - & Antitaxis calocarpa & $\ldots$ & - & $x$ & - & - & - \\
\hline$x$ & $x$ & $x$ & - & $x$ & $x$ & $x$ & Nymphæa Lotus ... & $\ldots$ & $x$ & $x$ & - & - & - \\
\hline- & - & - & - & $x$ & $x$ & $x$ & $\begin{array}{c}\text { Capparis sepiaria } r a{ }^{\circ} \\
\text { grandifolia }\end{array}$ & & & $x$ & - & - & - \\
\hline - & - & - & - & $x$ & $x$ & - & Capparis tenera var. latifolia & $\ldots$ & - & $x$ & - & - & - \\
\hline- & - & - & - & $x$ & $x$ & - & Alsodeia bengalensis & $\ldots$ & - & $x$ & - & - & - \\
\hline- & - & - & - & - & {$[x$} & - & Garcinia sp. . $\quad \ldots$ & ... & - & $x$ & - & - & - \\
\hline$x$ & $x$ & - & $x$ & $x$ & $x$ & $x$ & Calophyllum inophyllum & $\cdots$ & $x$ & $x$ & $x$ & $x$ & - \\
\hline - & - & - & - & $x$ & $x$ & $x$ & Dipterocarpus pilosus & $\ldots$ & - & $x$ & - & - & - \\
\hline- & - & - & - & $x$ & $x$ & $x$ & Dipterocarpas alatus & ... & - & $x$ & - & - & - \\
\hline$x$ & $x$ & $x$ & $x$ & $x$ & $x$ & $x$ & Sida acuta $\quad \ldots$ & $\cdots$ & $x$ & $x$ & $x$ & $x$ & $x$ \\
\hline$x$ & $x$ & $x$ & $x$ & $x$ & $x$ & $x$ & Urena lobata ... & $\cdots$ & $x$ & $x$ & $x$ & $x$ & $x$ \\
\hline$x$ & $x$ & $x$ & $x$ & $x$ & $x$ & $x$ & Hibiscus Sabdariffa & $\cdots$ & $x$ & $x$ & $x$ & $x$ & $x$ \\
\hline$x$ & $x$ & $x$ & $x$ & $x$ & $x$ & $x$ & Hibiscus Abelmoschas & .. & $x$ & $x$ & $x$ & $x$ & $x$ \\
\hline$x$ & $x$ & - & $x$ & $x$ & $x$ & $x$ & Hibiscus tilliacens & $\cdots$ & $x$ & $x$ & $x$ & $x$ & $x$ \\
\hline$x$ & $x$ & - & - & $x$ & $x$ & $x$ & Thespesia populnea & $\ldots$ & $x$ & $x$ & $x$ & $x$ & - \\
\hline- & $x$ & - & - & $x$ & $x$ & - & Bombax insigne ... & 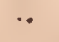 & - & $x$ & - & - & - \\
\hline
\end{tabular}




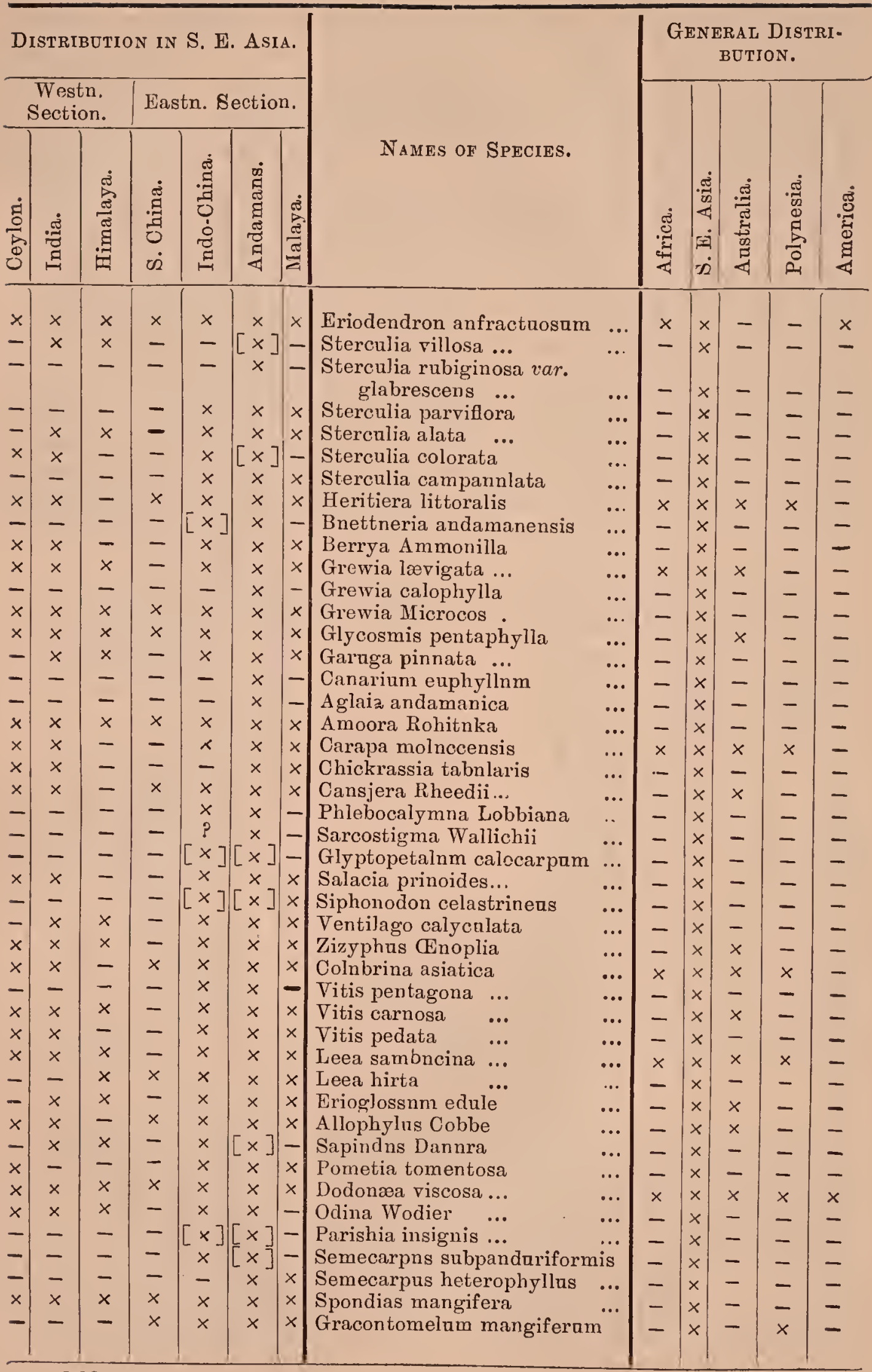




\begin{tabular}{|c|c|c|c|c|c|c|c|c|c|c|c|c|c|}
\hline \multicolumn{7}{|c|}{ Distribution in S. E. Asia. } & \multirow{3}{*}{ Names of Species. } & & \multicolumn{5}{|c|}{$\begin{array}{c}\text { GeNeraL DigTRI- } \\
\text { BUTION. }\end{array}$} \\
\hline \multicolumn{3}{|c|}{$\begin{array}{l}\text { Westn. } \\
\text { Section. }\end{array}$} & \multicolumn{4}{|c|}{ Easta. Section. } & & & & & & & \\
\hline 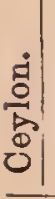 & 苞 & 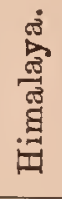 & 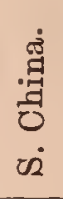 & 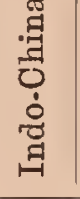 & 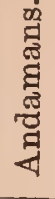 & 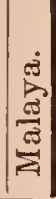 & & & 苞 & 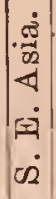 & 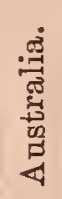 & 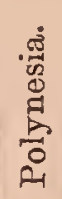 & 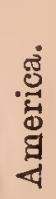 \\
\hline$x$ & $x$ & $x$ & $x$ & $x$ & $x$ & $x$ & Moringa pterygosperma & $\ldots$ & $x$ & $x$ & & & \\
\hline- & - & - & - & - & $x$ & $x$ & Conuarus gibbosus & $\ldots$ & - & $x$ & - & - & 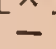 \\
\hline- & $x$ & $x$ & - & $x$ & $x$ & - & Crotalaria sericea & $\ldots$ & - & $x$ & - & - & \\
\hline$x$ & $x$ & - & $x$ & $x$ & $x$ & $x$ & Desmodium umbellatam & ... & $x$ & $x$ & $x$ & $x$ & \\
\hline$\times$ & $x$ & $x$ & $x$ & $x$ & $x$ & $x$ & Desmodiam triquetrum & ... & $x$ & $x$ & - & - & - \\
\hline- & - & - & $x$ & $x$ & $x$ & $x$ & Desmodium laxiflorum & ... & - & $x$ & - & - & - \\
\hline$x$ & $x$ & $x$ & $x$ & $x$ & $x$ & $x$ & Desmodium polycarpum & ... & $x$ & $x$ & $x$ & $x$ & - \\
\hline$x$ & $x$ & $x$ & $x$ & $x$ & $x$ & $x$ & Desmodium trifioram & $\ldots$ & $x$ & $x$ & $x$ & $x$ & $x$ \\
\hline$x$ & $x$ & $x$ & $x$ & $x$ & $x$ & $x$ & Alysicarpas vaginalis & $\ldots$ & $x$ & $x$ & $x$ & $x$ & $x$ \\
\hline ? & ? & ? & ? & ? & $x$ & ? & Phaseolus sp. ... & $\ldots$ & - & $x$ & - & - & - \\
\hline$x$ & $x$ & $x$ & $x$ & $x$ & $x$ & $x$ & Abras precatorins & $\ldots$ & $x$ & $x$ & $x$ & $x$ & $x$ \\
\hline$x$ & $x$ & $x$ & - & $x$ & $x$ & $x$ & Abras palchellas & $\ldots$ & - & $x$ & - & - & - \\
\hline$x$ & $x$ & $x$ & $x$ & $x$ & $x$ & $x$ & Erythrina iudica . & $\ldots$ & $x$ & $x$ & $x$ & $x$ & - \\
\hline- & $x$ & - & - & - & $x$ & $x$ & Mucuna gigantea & $\ldots$ & $=x$ & $x$ & $x$ & $x$ & - \\
\hline$x$ & $x$ & $x$ & $x$ & $x$ & $x$ & $x$ & Mucuna prurieus & ... & $x$ & $x$ & $x$ & $x$ & \\
\hline- & - & - & - & $\times]$ & $x$ & $x$ & Pneraria Candollei & & - & $x$ & - & - & - \\
\hline - & - & $x$ & $x$ & $x$ & $x$ & $x$ & Pueraria phaseoloides & $\ldots$ & - & $x$ & - & - & - \\
\hline$x$ & $x$ & - & $x$ & 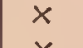 & $x$ & $x$ & Canavalia obtasifolia & ... & $x$ & $x$ & $x$ & $x$ & $x$ \\
\hline - & - & - & $x$ & $x$ & $x$ & $x$ & Vigua lutea $\ldots . .$. & $\ldots$ & $x$ & $x$ & $x$ & $x$ & $x$ \\
\hline- & $x$ & - & $x$ & $x$ & $x$ & $x$ & Pterocarpus indicus & $\ldots$ & - & $x$ & - & - & - \\
\hline$x$ & $x$ & $x$ & $x$ & $x$ & $x$ & $x$ & Derris scandens ... & ... & - & $x$ & $x$ & - & - \\
\hline$x$ & - & - & - & $x$ & $x$ & $x$ & Derris sinuata $\quad .$. & $\ldots$ & - & $x$ & - & - & - \\
\hline$x$ & $x$ & $x$ & $x$ & $x$ & $x$ & $x$ & Derris uliginosa ... & ... & $x$ & $x$ & $x$ & $x$ & - \\
\hline$x$ & $x$ & - & $x$ & $x$ & $x$ & $x$ & Pongamia glabra & $\ldots$ & $x$ & $x$ & $x$ & $x$ & - \\
\hline$x$ & $x$ & - & $x$ & $x$ & $x$ & $x$ & Sophora tomeatosa & $\ldots$ & $x$ & $x$ & $x$ & $x$ & $x$ \\
\hline$x$ & - & - & - & {$[x]$} & $x$ & $x$ & Mezonearon enneaphyllum & $\ldots$ & - & $x$ & - & - & - \\
\hline$x$ & $x$ & $x$ & $x$ & $x$ & $x$ & $x$ & Crsalpinia Bonducella & $\ldots$ & $x$ & $x$ & $x$ & $x$ & $x$ \\
\hline$x$ & $x$ & - & $x$ & $x$ & $x$ & $x$ & Cæsalpinia Nuga & $\ldots$ & - & $x$ & $x$ & $x$ & - \\
\hline$x$ & $x$ & $x$ & $x$ & $x$ & $x$ & $x$ & Tamarindns indica & $\ldots$ & $x$ & $x$ & $x$ & $x$ & $x$ \\
\hline$x$ & $x$ & - & - & {$[x]$} & $x$ & $x$ & Cynometra ramiflora & $\ldots$ & - & $x$ & $x$ & - & - \\
\hline$x$ & $x$ & $x$ & $x$ & $x$ & $x$ & $x$ & Eutada scandens & $\ldots$ & $x$ & $x$ & $x$ & $x$ & $x$ \\
\hline$x$ & $x$ & $x$ & $x$ & $x$ & $x$ & $x$ & Adenauthera pavoniua & $\ldots$ & - & $x$ & - & - & - \\
\hline$x$ & $x$ & $x$ & $x$ & $x$ & $x$ & $x$ & Acacia concinna & $\ldots$ & - & $x$ & - & - & - \\
\hline$x$ & $x$ & $x$ & - & $x$ & $x$ & $x$ & Acacia peunata ... & $\ldots$ & $x$ & $x$ & - & - & - \\
\hline$x$ & $x$ & $x$ & $x$ & $x$ & $x$ & $x$ & Albizzia Lebbek ... & & $x$ & $x$ & $x$ & - & - \\
\hline - & $x$ & $x$ & - & $x$ & $x$ & $x$ & Albizzia procera ... & $\ldots$ & - & $x$ & - & - & - \\
\hline$x$ & $x$ & - & - & $x$ & $x$ & $x$ & Rhizophora mucrouata & $\ldots$ & $x$ & $x$ & $x$ & $x$ & - \\
\hline$x$ & $x$ & - & - & $x$ & $x$ & $x$ & ajugata & $\ldots$ & - & $x$ & - & - & - \\
\hline$x$ & $x$ & - & - & $x$ & $x$ & $x$ & Ceriops Candolleana & $\ldots$ & - & $x$ & $x$ & - & - \\
\hline - & - & - & - & $x$ & $x$ & $x$ & Ceriops Roxbarghiana & $\ldots$ & - & $x$ & - & - & - \\
\hline$x$ & $x$ & - & $x$ & $x$ & $x$ & $x$ & morhiza & 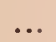 & {$[x-$} & $x$ & $x$ & $x$ & - \\
\hline - & - & - & - & - & $x$ & $x$ & Terminalia Catappa & $\ldots$ & 5 & $x$ & - & - & - \\
\hline - & - & - & - & {$[x]$} & $x$ & - & Terminalia bialata & $\ldots$ & - & $x$ & - & - & - \\
\hline$x$ & $x$ & - & - & $x^{-}$ & $x$ & $x$ & Lumnitzera racemosa & $\ldots$ & $x$ & $x$ & $x$ & $x$ & - \\
\hline - & - & - & - & {$[x]$} & $x$ & - & Illigera Couyzadenia & .. & - & $x$ & - & - & - \\
\hline- & $x$ & - & - & - & $x$ & $x$ & Gyrocarpus Jacquinii & $\ldots$ & $x$ & $x$ & $x$ & $x$ & $x$ \\
\hline$x$ & & - & - & - & $x$ & $x$ & Barringtouia speciosa & $\ldots$ & {$[x]$} & $x$ & $x$ & $x$ & - \\
\hline
\end{tabular}




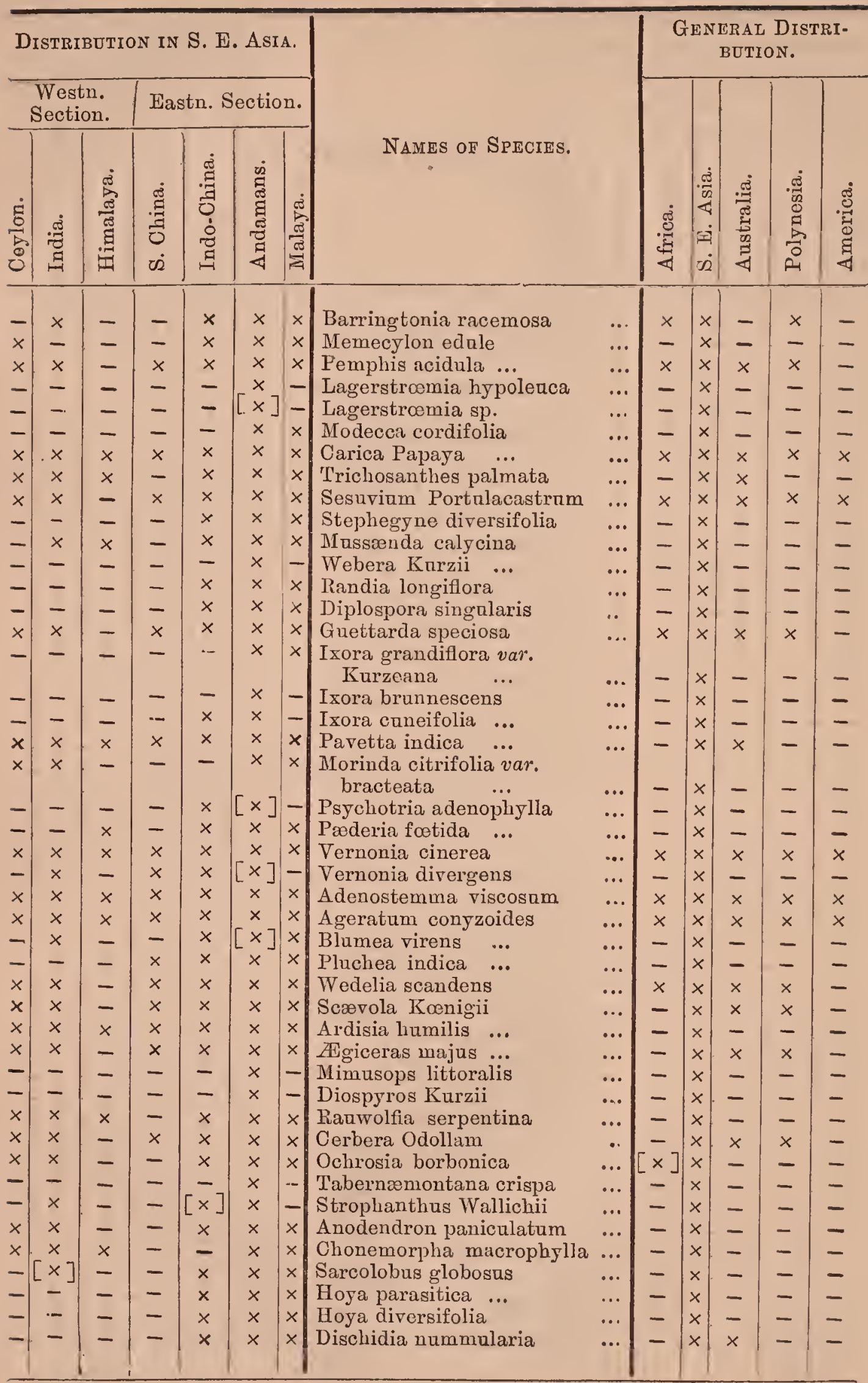




\begin{tabular}{|c|c|c|c|c|c|c|c|c|c|c|c|c|c|}
\hline \multicolumn{7}{|c|}{ Distribution in S. E. Asia. } & \multirow{3}{*}{\multicolumn{2}{|c|}{ - }} & \multicolumn{5}{|c|}{$\begin{array}{c}\text { GENERAL DISTRI- } \\
\text { BUTION. }\end{array}$} \\
\hline \multicolumn{3}{|c|}{$\begin{array}{l}\text { Westn. } \\
\text { Sectn. }\end{array}$} & \multicolumn{4}{|c|}{ Eastn. Sectn. } & & & & & & & \\
\hline 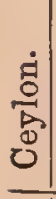 & 劲 & 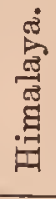 & 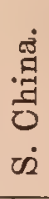 & 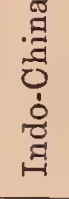 & 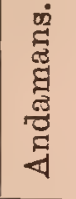 & $\mid$ & & & 氙 & 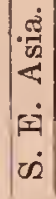 & 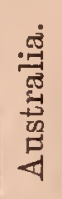 & 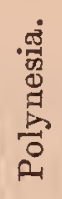 & 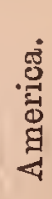 \\
\hline$x$ & $x$ & $x$ & - & $x$ & $x$ & $x$ & Limnanthemnm indicnm & ... & $x$ & $x$ & $x$ & $x$ & - \\
\hline$x$ & $x$ & - & - & $x$ & $x$ & $x$ & Cordia sulucordata & ... & $x$ & $x$ & $x$ & $x$ & - \\
\hline$x$ & $x$ & - & $x$ & $x$ & $x$ & $x$ & Tournefor tia argentea & $\ldots$ & $x$ & $x$ & $x$ & $x$ & - \\
\hline$x$ & $x$ & $x$ & - & $x$ & $x$ & $x$ & Erycibe paniculata & $\cdots$ & - & $x$ & $x$ & - & - \\
\hline$x$ & $x$ & - & - & $x$ & $x$ & $x$ & Argyreia tiliæfolia & $\ldots$ & - & $x$ & $x$ & - & - \\
\hline 一 & - & $x$ & - & $x$ & $x$ & - & A rgyreia Hookeri & $\ldots$ & - & $x$ & - & - & - \\
\hline - & - & - & - & $x$ & $x$ & - & Argyreia lanceolata & $\ldots$ & - & $x$ & - & - & - \\
\hline - & - & - & - & $x$ & $x$ & - & Lettsomia pegnensis & $\ldots$ & - & $x$ & - & - & - \\
\hline$x$ & $x$ & - & - & $x$ & $x$ & $x$ & Ipomæa grandiflora & $\ldots$ & $x$ & $x$ & - & $x$ & - \\
\hline$x$ & $x$ & $x$ & $x$ & $x$ & $x$ & $x$ & Ipomæa coccinea ... & $\ldots$ & $x$ & $x$ & $x$ & $x$ & $x$ \\
\hline$x$ & $x$ & $x$ & $x$ & $x$ & $x$ & $x$ & Ipomæa Batatas ... & $\ldots$ & $x$ & $x$ & $x$ & $x$ & $x$ \\
\hline$x$ & $x$ & - & $x$ & $x$ & $x$ & $x$ & Ipomæa digitata ... & $\ldots$ & $x$ & $x$ & $x$ & $x$ & $x$ \\
\hline$x$ & - & - & - & $x$ & $x$ & $x$ & Ipomæa denticulata & $\ldots$ & $x$ & $x$ & $x$ & $x$ & - \\
\hline$x$ & $x$ & $x$ & $x$ & $x$ & $x$ & $x$ & Ipomæa Tnrpetham & $\ldots$ & $x$ & $x$ & $x$ & $x$ & - \\
\hline$x$ & $x$ & - & $x$ & $x$ & $x$ & $x$ & Ipomæa biloba $\quad .$. & $\ldots$ & $x$ & $x$ & $x$ & $x$ & $x$ \\
\hline$x$ & $x$ & - & $x$ & $x$ & $x$ & $x$ & Convolvulus parviflorus & $\ldots$ & - & $x$ & $x$ & - & - \\
\hline - & - & - & - & {$[x]$} & $x$ & - & Porana spectabilis & $\ldots$ & - & $x$ & $x$ & - & - \\
\hline$x$ & $x$ & $x$ & $x$ & $x$ & $x$ & $x$ & Solanum Melongena & $\ldots$ & $x$ & $x$ & - & $x$ & $x$ \\
\hline$x$ & $x$ & $x$ & $x$ & $x$ & $x$ & $x$ & Physalis minima ... & $\ldots$ & $x$ & $x$ & $x$ & $x$ & $x$ \\
\hline$x$ & $x$ & $x$ & $x$ & $x$ & $x$ & $x$ & Capsicum minimum & $\ldots$ & - & $x$ & $x$ & - & - \\
\hline$x$ & $x$ & $x$ & $x$ & $x$ & $x$ & $x$ & Scoparia dalcis $\quad .$. & $\ldots$ & $x$ & $x$ & - & $x$ & $x$ \\
\hline$x$ & $x$ & $x$ & - & $x$ & $x$ & $x$ & Oroxylum indicum & $\ldots$ & - & $x$ & $x$ & - & - \\
\hline - & - & - & - & $x$ & $x$ & - & $\begin{array}{l}\text { Heterophragma adenophyl- } \\
\text { lnm }\end{array}$ & & - & $x$ & - & - & - \\
\hline - & - & - & - & $x$ & $x$ & $x$ & Thunbergia laurifolia & $\ldots$ & - & $x$ & - & _ & - \\
\hline$x$ & $x$ & $x$ & - & $x$ & $x$ & $x$ & Hygrophila quadrivalvis & $\ldots$ & - & $x$ & - & - & - \\
\hline - & - & - & - & $x$ & {$[x]$} & - & Strobilanthes phyllostachyns & & - & $x$ & - & - & - \\
\hline$x$ & - & - & - & $x=$ & $x$ & $x$ & Eranthemum album & $\ldots$ & - & $x$ & - & - & - \\
\hline - & - & - & - & - & $x$ & ? & Eranthemum succifolium & $\ldots$ & - & $x$ & - & - & - \\
\hline$x$ & $x$ & $x$ & $x$ & $x$ & $x$ & $x$ & $\begin{array}{l}\text { Rungia parviflora var. pec- } \\
\text { tinata }\end{array}$ & & - & $x$ & - & - & - \\
\hline- & - & - & - & - & $x$ & $x$ & Peristrophe acuminata & $\ldots$ & - & $x$ & $x$ & - & - \\
\hline$x$ & $x$ & $x$ & $x$ & $x$ & $x$ & $x$ & Lippia nodiflora $\ldots$ & $\ldots$ & $x$ & $x$ & $x$ & $x$ & $x$ \\
\hline$x$ & $x$ & - & $x$ & $x$ & $x$ & $x$ & Premna integrifolia & $\ldots$ & - & $x$ & ? & ? & - \\
\hline - & - & - & - & - & $x$ & - & Premna sp. (? P. obtusifolia) & & - & $x$ & $?$ & - & - \\
\hline$x$ & $x$ & $x$ & $x$ & $x$ & $x$ & $x$ & Vitex Negando & $\ldots$ & $x$ & $x$ & - & - & - \\
\hline$x$ & $x$ & - & - & $x$ & $x$ & $x$ & Vitex pubescens ... & $\ldots$ & - & $x$ & - & - & - \\
\hline - & - & - & - & - & $x$ & $?$ & $\begin{array}{c}\text { Vitex Wimberleyi (? V. Sum } \\
\operatorname{tran} \alpha)\end{array}$ & & - & $x$ & - & - & \\
\hline$x$ & $x$ & - & $x$ & $x$ & $x$ & $x$ & Clerodendron inerme & .. & - & $x$ & $x$ & $x$ & - \\
\hline$x$ & $x$ & - & $x$ & $x$ & $x$ & $x$ & Avicennia officinalis & $\ldots$ & $x$ & $x$ & $x$ & - & $x$ \\
\hline$x$ & $x$ & $\dot{x}$ & $x$ & $x$ & {$[x$} & $x$ & Anisomeles ovata & $\cdots$ & - & $x$ & - & - & - \\
\hline$x$ & $x$ & $x$ & $x$ & $x$ & $x$ & $x$ & Boerhaavia repens & ... & $x$ & $x$ & $x$ & $x$ & - \\
\hline$x$ & $x$ & - & $x$ & $x$ & $x$ & $x$ & Pisonia aculeata ... & $\ldots$ & $x$ & $x$ & $x$ & - & $x$ \\
\hline - & - & - & - & - & $x$ & $x$ & Pisonia excelsa $\quad . .$. & $\ldots$ & - & $x$ & - & - & - \\
\hline$x$ & $x$ & $x$ & $x$ & $x$ & $x$ & $x$ & Celosia cristata ... & $\ldots$ & $x$ & $x$ & - & - & $x$ \\
\hline$x$ & $x$ & $x$ & $x$ & $x$ & $x$ & $x$ & Achyranthes aspera & ... & $x$ & $x$ & $x$ & $x$ & $x$ \\
\hline
\end{tabular}




\begin{tabular}{|c|c|c|c|c|c|c|c|c|c|c|c|c|c|}
\hline \multicolumn{7}{|c|}{ Distribution in S. E. Asia. } & \multirow{3}{*}{\multicolumn{2}{|c|}{ Names of Spectes. }} & \multicolumn{5}{|c|}{$\begin{array}{l}\text { GENERAL DISTRI- } \\
\text { BUTION. }\end{array}$} \\
\hline \multicolumn{3}{|c|}{$\begin{array}{l}\text { Westn. } \\
\text { Sectn. }\end{array}$} & \multicolumn{4}{|c|}{ Eastn. Sectn. } & & & \multirow[b]{2}{*}{ 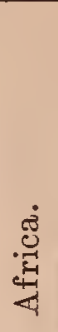 } & \multirow[b]{2}{*}{$\begin{array}{l}. \frac{\pi}{0} \\
\frac{\pi}{4} \\
\dot{\theta} \\
\dot{0}\end{array}$} & \multirow[b]{2}{*}{ 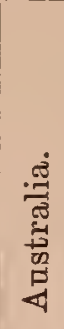 } & \multirow[b]{2}{*}{ 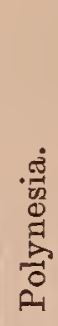 } & \multirow[b]{2}{*}{ 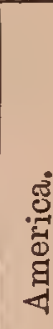 } \\
\hline$\frac{\stackrel{d}{0}}{\stackrel{0}{0}}$ & 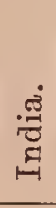 & 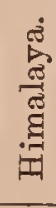 & 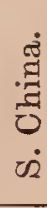 & 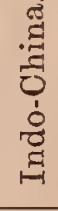 & 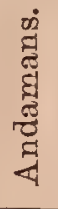 & $\frac{\sqrt{6}}{\frac{3}{3}}$ & & & & & & & \\
\hline$x$ & $x$ & - & - & $x$ & $x$ & $x$ & $\begin{array}{l}\text { Achyranthes aspera var. por } \\
\text { phyristachya ... }\end{array}$ & & - & $x$ & - & - & - \\
\hline$x$ & $x$ & $x$ & $x$ & $x$ & $x$ & $x$ & Gomphrena globosa & & $x$ & $x$ & $x$ & $x$ & $x$ \\
\hline$x$ & $x$ & $x$ & $x$ & $x$ & $x$ & $x$ & Polygonnm barbatum & ... & $x$ & $x$ & $x$ & - & - \\
\hline - & - & - & - & $x$ & $x$ & $x$ & Bragantia tomentosa & ... & - & $x$ & 一 & - & - \\
\hline$x$ & $x$ & $x$ & $x$ & $x$ & $x$ & $x$ & A ristolochia tagala & ... & - & $x$ & - & - & 一 \\
\hline- & - & - & - & {$[x$} & $x$ & $x$ & Piper caninum ... & $\ldots$ & - & $x$ & - & - & - \\
\hline$x$ & - & - & - & {$[x$} & $x$ & $x$ & MIgristica Irya $\quad \ldots$ & $\ldots$ & - & $x$ & - & - & 一 \\
\hline - & 一 & - & - & - & $x$ & $x$ & Myristica glauca ... & $\ldots$ & - & $x$ & - & - & - \\
\hline- & - & - & - & - & $x$ & - & Dehaasia Kurzii ... & $\cdots$ & - & - & - & - & - \\
\hline$x$ & $x$ & - & $x$ & $x$ & $x$ & $x$ & Hernandia peltata & $\ldots$ & {$[x]$} & $x$ & $x$ & $x$ & - \\
\hline$x$ & $x$ & $x$ & $x$ & $x$ & $x$ & $x$ & Cassytha filiformis & $\ldots$ & $x$ & $x$ & $x$ & $x$ & $x$ \\
\hline$x$ & $x$ & $x$ & - & $x$ & $x$ & $x$ & Loranthus longiflorus & ... & 一 & $x$ & 一 & - & - \\
\hline 一 & - & - & - & {$[x$} & $x$ & $x$ & Champereia Griffithiana & $\ldots$ & 一 & $x$ & - & 一 & - \\
\hline$x$ & $x$ & - & $x$ & $x$ & $x$ & $x$ & Euphorbia A toto ... & $\ldots$ & - & $x$ & $x$ & $x$ & 一 \\
\hline$x$ & $x$ & $x$ & $x$ & $x$ & $x$ & $x$ & Euphorbia pilulifera & & $x$ & $x$ & $x$ & $x$ & $x$ \\
\hline - & - & - & - & - & $x$ & - & Bridelia Knrzii ... & ... & - & $x$ & - & - & 一 \\
\hline$x$ & $x$ & $x$ & $x$ & $x$ & $c^{x}$ & $x$ & Bridelia tomentosa & & - & $x$ & $x$ & - & - \\
\hline 一 & - & - & - & {$[x]$} & {$[x$} & - & Phyllanthus columnaris & & - & $x$ & - & - & 一 \\
\hline$x$ & $x$ & $x$ & $x$ & $x$ & $x$ & $x$ & Flueggia microcarpa & ... & $x$ & $x$ & $x$ & $x$ & 一 \\
\hline- & - & $x$ & 一 & $x$ & {$[x]$} & - & Cyclostemon assamicus & $\ldots$ & - & $x$ & - & - & - \\
\hline- & - & - & - & $x$ & $x$ & - & Aporosa villosula & $\cdots$ & - & $x$ & - & - & - \\
\hline - & - & - & - & {$[x$} & $x$ & - & Croton sublyratas & $\ldots$ & - & $x$ & - & - & - \\
\hline- & - & - & - & - & $x$ & - & Blachia andamanica & $\ldots$ & 一 & $x$ & - & - & - \\
\hline - & - & - & - & - & $x$ & $x$ & Claoxylon longifolium & $\ldots$ & - & $x$ & - & - & - \\
\hline- & - & - & - & {$[x$} & $x$ & $x$ & Mallotus acuminatus & $\ldots$ & - & $x$ & - & - & - \\
\hline- & - & - & - & - & $x$ & - & Mallotus andamanicus & $\ldots$ & - & $x$ & - & - & - \\
\hline- & - & - & - & - & $x$ & $x$ & Macaranga Tanarius & & - & $x$ & - & - & - \\
\hline - & - & - & - & $x$ & $x$ & $x$ & Onesmone javanica & ... & - & $x$ & - & - & - \\
\hline$x$ & $x$ & - & 一 & $x$ & $x$ & $x$ & Phyllochlamys spinosa & $\ldots$ & - & $x$ & - & - & - \\
\hline- & - & - & - & {$[x$} & $x$ & - & Plecospermum andamanicum & & - & $x$ & - & - & - \\
\hline- & $x$ & $x$ & - & $x$ & $x$ & $x$ & Ficus Benjamina ... & ... & - & $x$ & $x$ & - & - \\
\hline- & $x$ & $x$ & - & $x$ & $x$ & $x$ & Ficas Rumphii & ... & - & $x$ & - & - & - \\
\hline$x$ & $x$ & $x$ & $x$ & $x$ & $x$ & $x$ & Ficus retusa var. nitida & ... & - & $x$ & $x$ & - & - \\
\hline- & - & - & 一 & - & $x$ & $x$ & Ficus brevicuspis ... & ... & - & $x$ & - & - & - \\
\hline$x$ & $x$ & 一 & - & $x$ & $x$ & $x$ & Ficus callosa $\quad \ldots$ & $\ldots$ & - & $x$ & - & - & - \\
\hline$x$ & $x$ & $x$ & $x$ & $x$ & $x$ & $x$ & Ficas hispida & ... & - & $x$ & $x$ & - & - \\
\hline- & 一 & - & - & {$[x$} & {$[x]$} & - & Ficus grisea ... & ... & - & $x$ & - & - & - \\
\hline$x$ & $x$ & - & - & $x$ & $x$ & $x$ & Antiaris toxicaria & ... & - & $x$ & - & - & - \\
\hline- & - & - & - & - & $x$ & $x$ & Artocarpus Gomeziana & & - & $x$ & - & - & - \\
\hline- & 一 & - & - & {$[x]$} & $x$ & $x$ & Cycas Rumphii & ... & - & $x$ & $x$ & - & - \\
\hline- & - & - & 一 & $x$ & $x$ & $x$ & Dendrobium secundam & & - & $x$ & - & - & - \\
\hline$x$ & $x$ & 一 & 一 & - & $x$ & $x$ & Calanthe veratrifolia & & - & $x$ & $x$ & - & - \\
\hline$x$ & $x$ & $x$ & - & $x$ & {$[x$} & - & Dorites Wightii ... & ... & - & $x$ & - & - & 一 \\
\hline - & $x$ & $x$ & - & {$[x$} & {$[x$} & - & Arides multiflorum & ... & - & $x$ & - & - & - \\
\hline$x$ & $x$ & $x$ & - & $x$ & $x$ & $x$ & Pholidota imbricata & $\cdots$ & - & $x$ & - & - & - \\
\hline$x$ & $x$ & $x$ & $x$ & $x$ & $x$ & $x$ & Costus speciosus ... & $\ldots$ & - & $x$ & - & - & - \\
\hline
\end{tabular}




\begin{tabular}{|c|c|c|c|c|c|c|c|c|c|c|c|c|c|}
\hline \multicolumn{7}{|c|}{ Distribution in S. E. Asia. } & \multirow{3}{*}{\multicolumn{2}{|c|}{ Names of Species. }} & \multicolumn{5}{|c|}{$\begin{array}{c}\text { General Distri- } \\
\text { Bution. }\end{array}$} \\
\hline \multicolumn{3}{|c|}{$\begin{array}{l}\text { Westn. } \\
\text { Sectn. }\end{array}$} & \multicolumn{4}{|c|}{ Eastn. Sectn. } & & & \multirow[b]{2}{*}{ 总 } & \multirow[b]{2}{*}{ 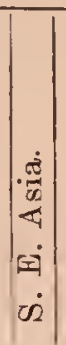 } & \multirow[b]{2}{*}{ 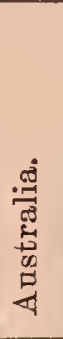 } & \multirow[b]{2}{*}{ 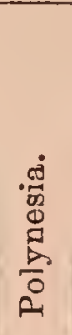 } & \multirow[b]{2}{*}{ 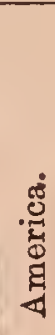 } \\
\hline $\begin{array}{c}\frac{\dot{8}}{5} \\
\frac{5}{0} \\
0\end{array}$ & 芯 & 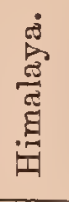 & 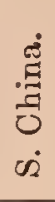 & 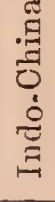 & 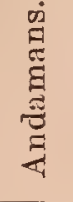 & 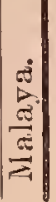 & & & & & & & \\
\hline- & - & - & - & - & {$[x]$} & - & Zingiber sp. $\quad \ldots$ & $\ldots$ & - & $x$ & - & - & - \\
\hline$x$ & $x$ & $x$ & $x$ & $x$ & $x$ & $x$ & M[asa sapientum ... & ... & $x$ & $x$ & $x$ & $x$ & $x$ \\
\hline$x$ & $x$ & - & - & $x$ & $x$ & $x$ & Crinam asiaticam & ... & - & $x$ & $x$ & $x$ & - \\
\hline$x$ & $x$ & - & - & $x$ & $x$ & $x$ & Tacca pimnatifida ... & $\ldots$ & $x$ & $x$ & $x$ & $x$ & - \\
\hline$x$ & $x$ & $x$ & - & $x$ & $x$ & $x$ & Dioscorea glabra ... & ... & - & $x$ & - & - & - \\
\hline$x$ & $x$ & $x$ & - & $x$ & $x$ & $x$ & Dioscorea pentaphylla & ... & - & $x$ & - & - & - \\
\hline- & $x$ & - & - & $x$ & $x$ & - & Smilax macrophylla & ... & - & $x$ & - & - & - \\
\hline$x$ & $x$ & 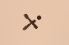 & - & $x$ & $x$ & $x$ & Asparagus racemosns & $\ldots$ & - & $x$ & - & - & - \\
\hline-1 & - & - & - & $x$ & $x$ & $x$ & Dracæena angustifolia & $\ldots$ & - & $x$ & $x$ & - & - \\
\hline$x$ & $x$ & $x$ & $x$ & $x$ & $x$ & $x$ & Dracæena spicata ... & ... & - & $x$ & - & - & - \\
\hline$x$ & $x$ & $x$ & $x$ & $x$ & $x$ & $x$ & Gloriosa superba ... & ... & - & $x$ & - & - & - \\
\hline-1 & - & - & - & $x$ & $x$ & $x$ & Pollit zorzogonensis & $\ldots$ & - & $x$ & - & - & - \\
\hline$x$ & $x$ & $x$ & $x$ & $x$ & $x$ & $x$ & Commelina obliqua & ... & - & $x$ & - & - & - \\
\hline- & - & - & - & $x$ & $x$ & $x$ & Aneilema ovatum & ... & - & $x$ & - & - & - \\
\hline$x$ & $x$ & - & - & $x$ & $x$ & $x$ & Flagellaria indica & $\ldots$ & $x$ & $x$ & $x$ & - & - \\
\hline- & - & - & - & $x$ & $x$ & $x$ & Caryota sobolifera & ... & - & $x$ & - & - & - \\
\hline- & - & - & - & - & $x$ & - & Corypha elata ... & ... & - & $x$ & - & - & - \\
\hline- & - & - & - & - & $x]$ & & Livistona sp. ... & ... & - & $x$ & - & - & - \\
\hline- & - & - & - & $x$ & $x$ & - & Calamus tigrinus ... & $\ldots$ & - & $x$ & - & - & - \\
\hline- & - & - & - & - & $x$ & - & Calamus andamanicus & ... & - & $x$ & - & - & - \\
\hline$x$ & $x$ & - & - & $x$ & $x$ & $x$ & Cocos nucifera $\quad \ldots$ & $\ldots$ & $x$ & $x$ & $x$ & $x$ & $x$ \\
\hline$x$ & $x$ & - & - & $x$ & $x$ & $x$ & Pandanus odoratissimus & ... & {$[x]$} & $x$ & $x$ & - & - \\
\hline- & - & - & - & - & {$[x]$} & - & Amorphophallus sp. & $\ldots$ & - & $x$ & - & - & - \\
\hline$x$ & $x$ & $x$ & $x$ & $x$ & $x$ & $x$ & Alocasia fornicata & ... & - & $x$ & - & - & - \\
\hline$x$ & $x$ & $x$ & $x$ & $x$ & $x$ & $x$ & Scindapsus officinalis & $\ldots$ & - & $x$ & - & - & - \\
\hline$x$ & $x$ & $x$ & $x$ & $x$ & $x$ & $x$ & Pothos scandens ... & ... & - & $x$ & - & - & - \\
\hline$x$ & $x$ & - & - & $x$ & $x$ & $x$ & Cymodocen ciliata & $\ldots$ & $x$ & $x$ & $x$ & - & - \\
\hline$x$ & $x$ & $x$ & $x$ & $x$ & $x$ & $x$ & Zanichellia palnstris & $\ldots$ & $x$ & $x$ & $x$ & $x$ & $x$ \\
\hline$\times$ & $x$ & $x$ & $x$ & $x$ & $x$ & $x$ & Cyperas polystachyas & $\ldots$ & $x$ & $x$ & $x$ & $x$ & $x$ \\
\hline$x$ & $x$ & $x$ & $x$ & $x$ & $x$ & $x$ & Cyperus elegans ... & $\ldots$ & - & $x$ & - & - & - \\
\hline$x$ & $x$ & $x$ & $x$ & $x$ & $x$ & $x$ & Cyperas dilatas ... & $\ldots$ & - & $x$ & - & - & - \\
\hline$x$ & $x$ & - & $x$ & $x$ & $x$ & $x$ & Cyperus pennatus & ... & {$[x]$} & $x$ & $x$ & $x$ & - \\
\hline$x$ & $x$ & $x$ & $x$ & $x$ & $x$ & $x$ & Kyllinga brevifolia & $\ldots$ & $x$ & $x$ & $x$ & $x$ & $x$ \\
\hline$x$ & $x$ & $x$ & $x$ & $x$ & $x$ & $x$ & Fimbristylis diphylla & $\ldots$ & $x$ & $x$ & $x$ & $x$ & $x$ \\
\hline$x$ & $x$ & - & $x$ & $x$ & $x$ & $x$ & Fimbristylis ferraginea & $\ldots$ & $x$ & ; & $x$ & $x$ & $x$ \\
\hline$x$ & $x$ & $x$ & $x$ & $x$ & $x$ & $x$ & Fimbristylis quinqueangular & & $x$ & $x$ & $x$ & - & - \\
\hline$x$ & $x$ & $x$ & $x$ & $x$ & $x$ & $x$ & Fimbristylis miliacea & $\ldots$ & $x$ & $x$ & $x$ & - & $x$ \\
\hline$x$ & $x$ & $x$ & $x$ & $x$ & {$[x]$} & - & Scirpas subulatus & $\ldots$ & $x$ & $x$ & - & - & - \\
\hline$x$ & $x$ & $x$ & $x$ & $x$ & $x^{2}$ & $|x|$ & Paspalum scrobicalatum & ... & $x$ & $x$ & $x$ & - & - \\
\hline$x$ & $x$ & $x$ & $x$ & $x$ & $x$ & $x$ & Panicum ciliare ... & $\ldots$ & $x$ & $x$ & $x$ & $x$ & - \\
\hline$x$ & $x$ & $x$ & $x$ & $x$ & $x$ & $x$ & Panicum colonnm & $\ldots$ & $x$ & $x$ & $x$ & $x$ & $x$ \\
\hline$x$ & $x$ & $x$ & $x$ & $x$ & $x$ & $x$ & Panicam Helopus & $\ldots$ & $x$ & $x$ & $x$ & - & - \\
\hline- & - & - & - & - & $x$ & $x$ & Panicum javanicum & $\ldots$ & - & $x$ & - & - & - \\
\hline$x$ & $x$ & $x$ & $x$ & $x$ & $x$ & $x$ & Panicum Myaras ... & $\ldots$ & $x$ & $x$ & $x$ & $x$ & $x$ \\
\hline$x$ & $x$ & $x$ & $x$ & $x$ & $x$ & $x$ & Panicam montanum & ... & - & $x$ & - & - & - \\
\hline$x$ & $x$ & $x$ & $x$ & $x$ & $x$ & $x$ & Oplismenns compositus & $\ldots$ & $x$ & $x$ & $x$ & $x$ & $x$ \\
\hline$x$ & $x$ & - & - & - & $x$ & $\times$ & 'Thuarea sarmentosa & ... & {$[x]$} & $x$ & $x$ & $x$ & - \\
\hline
\end{tabular}




\begin{tabular}{|c|c|c|c|c|c|c|c|c|c|c|c|c|c|}
\hline \multicolumn{7}{|c|}{ DISTRIBUTION IN S. E. AsIa. } & \multirow{3}{*}{\multicolumn{2}{|c|}{ Names of Spficies. }} & \multicolumn{5}{|c|}{$\begin{array}{c}\text { General Distri- } \\
\text { BUTION. }\end{array}$} \\
\hline \multicolumn{3}{|c|}{$\begin{array}{l}\text { Westn. } \\
\text { Sectn. }\end{array}$} & \multicolumn{4}{|c|}{ Eastn. Sectn. } & & & \multirow[b]{2}{*}{ 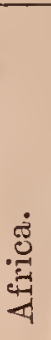 } & \multirow[b]{2}{*}{ 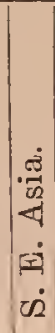 } & \multirow[b]{2}{*}{ 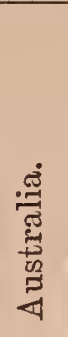 } & \multirow[b]{2}{*}{ 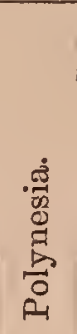 } & \multirow[b]{2}{*}{ 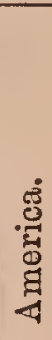 } \\
\hline 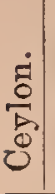 & 胥 & 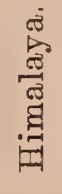 & 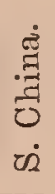 & 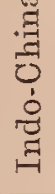 & 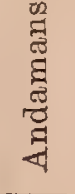 & 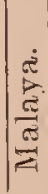 & & & & & & & \\
\hline$x$ & $x$ & $x$ & $x$ & $x$ & $x$ & $x$ & Ischæmam ciliare & $\ldots$ & - & $x$ & $x$ & - & - \\
\hline- & - & - & - & $x$ & $\times$ & $x$ & Ischæmum muticum & $\ldots$ & - & $x$ & $x$ & $x$ & - \\
\hline$x$ & $x$ & $x$ & $x$ & $x$ & $x$ & $x$ & Andropogon contortus & $\ldots$ & $x$ & $x$ & $x$ & $x$ & $x$ \\
\hline$x$ & $x$ & $x$ & $x$ & $x$ & $x$ & $x$ & Elensine indica ... & $\ldots$ & $x$ & $x$ & $x$ & $x$ & $x$ \\
\hline$x$ & $x$ & $x$ & $x$ & $x$ & $x^{x}$ & $x$ & Eleusine ægyptiaca & $\ldots$ & $x$ & $x$ & $x$ & $x$ & $x$ \\
\hline- & $x$ & $x$ & $x$ & $x$ & {$[\times]$} & - & Dendrocalamus strictus & $\ldots$ & - & $x$ & - & - & - \\
\hline- & - & - & - & - & $x$ & $x$ & Davallia solicla ... & $\ldots$ & - & $x$ & $x$ & $x$ & - \\
\hline$x$ & $x$ & $x$ & $x$ & $x$ & $x$ & $x$ & Adiantum lunulatum & $\ldots$ & $x$ & $x$ & $x$ & $x$ & $x$ \\
\hline$x$ & $x$ & $x$ & $x$ & $x$ & $x$ & $x$ & Ceratopteris thalictroides & $\ldots$ & $x$ & $x$ & - & $x$ & $x$ \\
\hline$x$ & $x$ & $x$ & $x$ & $x$ & $x$ & $x$ & Polypodium irioides & $\ldots$ & $x$ & $x$ & $x$ & $x$ & - \\
\hline$x$ & $x$ & $x$ & $x$ & $x$ & $x$ & $x$ & Polypodium adnascens & $\ldots$ & $x$ & $x$ & $x$ & $x$ & - \\
\hline$x$ & $x$ & $x$ & $x$ & $x$ & $x$ & $x$ & Polypodium qucreifolinm & $\ldots$ & - & $x$ & $x$ & $x$ & - \\
\hline$x$ & $x$ & $x$ & $x$ & $x$ & $x$ & $x$ & Vittaria elongata ... & $\ldots$ & $x$ & $x$ & $x$ & $x$ & - \\
\hline$x$ & $x$ & $x$ & $x$ & $x$ & $x$ & $x$ & Acrostichum scandens & ... & - & $x$ & $x$ & $x$ & - \\
\hline$x$ & $x$ & $x$ & $x$ & $x$ & $x^{\prime}$ & $x$ & Acrostichnm appendicalatur & & - & $x$ & - & - & - \\
\hline$x$ & $x$ & $x$ & $x$ & $x$ & $x$ & $x$ & Lygodium flexuosum & $\ldots$ & $x$ & $x$ & $x$ & - & - \\
\hline$x$ & $x$ & $x$ & $x$ & $x$ & $x$ & $x$ & Cliara fotida $\quad \ldots$ & ... & - & $x$ & - & - & - \\
\hline$x$ & - & - & - & - & $x$ & $x$ & Calymperes Dozyanum & $\ldots$ & - & $x$ & - & $x$ & - \\
\hline$x$ & $x$ & $x$ & $x$ & $x$ & $\dot{x}$ & $x$ & Bryum coronatum & $\ldots$ & $x$ & $x$ & $x$ & $x$ & $x$ \\
\hline-1 & - & - & - & - & $x$ & - & Lejennia sp. $\quad .$. & $\ldots$ & - & $x$ & - & - & - \\
\hline$x$ & $x$ & $x$ & $x$ & $x$ & $x$ & $x$ & Collema nigrescens & $\ldots$ & $x$ & $x$ & $x$ & $x$ & $x$ \\
\hline$x$ & $x$ & $x$ & $x$ & $x$ & $x$ & $x$ & Physcia obscura? & ... & $x$ & $x$ & $x$ & $x$ & $x$ \\
\hline- & - & - & - & - & $x$ & - & Pliyscia sp. $\quad$... & ... & - & $x$ & - & - & - \\
\hline - & - & - & - & - & $x$ & - & Lepraria sp. & $\ldots$ & - & $x$ & - & - & - \\
\hline- & - & - & - & - & $\times$ & $x$ & Lentinus leucochrous & $\cdots$ & - & $x$ & - & - & - \\
\hline$x$ & $x$ & $x$ & - & $x$ & $x$ & $x$ & I.enzites deplanata & ... & - & $x$ & - & - & - \\
\hline$x$ & $x$ & - & - & $x$ & $x$ & $x$ & Lcnzites subferruginea & $\cdots$ & - & $x$ & - & - & - \\
\hline- & - & - & - & - & $x$ & $x$ & Polyporus fulvas ... & $\ldots$ & - & $x$ & - & - & - \\
\hline$x$ & $x$ & $x$ & $x$ & $x$ & $x$ & $x$ & Polyporus xanthopus & $\ldots$ & $x$ & $x$ & $x$ & $x$ & $x$ \\
\hline$x$ & $x$ & $x$ & $x$ & $x$ & $x$ & $x$ & Polyporns sanguinens & & $x$ & $x$ & $x$ & $x$ & $x$ \\
\hline$x$ & $x$ & $x$ & - & $x$ & $x$ & $x$ & Poly porus grammatocephalo & & - & $x$ & $x$ & - & $x$ \\
\hline$x$ & $x$ & $x$ & $x$ & $x$ & $x$ & $x$ & Polyporus australis & $\ldots$ & $x$ & $x$ & $x$ & $x$ & $x$ \\
\hline$x$ & - & - & - & - & $x$ & * & Hexagona pergamenea & $\ldots$ & - & $x$ & - & - & - \\
\hline- & - & - & - & - & {$[x]$.} & - & fiexagona sericeo-hirsuta & $\ldots$ & - & $x$ & - & - & $x$ \\
\hline- & - & - & - & - & $x$ & - & Hexagona tenuis ... & $\ldots$ & $x$ & $x$ & - & - & $\underline{-}$ \\
\hline- & $x$ & - & - & - & $x$ & - & Dedælea flabellum & $\ldots$ & - & $x$ & - & - & - \\
\hline- & $x$ & - & - & - & $x$ & 一 & Dedælea sanguinea & $\cdots$ & - & $x$ & - & - & - \\
\hline$x$ & $x$ & $x$ & - & $x$ & $x$ & $x$ & Dedælea quercina & $\ldots$ & $x$ & $x \mid$ & $x$ & $x$ & $x$ \\
\hline$x$ & $x$ & $x$ & - & $x$ & $x$ & $x$ & Dedælea concentrica & $\ldots$ & $x$ & $x$ & $x$ & $x$ & $x$ \\
\hline$x$ & $x$ & $x$ & $x$ & $x$ & $x$ & $x$ & Thelephora incrustans & $\ldots$ & $x$ & $x$ & $x$ & $x$ & $x$ \\
\hline$x$ & $x$ & $x$ & $x$ & $x$ & $x$ & $x$ & Bovista lilacina ... & $\ldots$ & $x$ & $x$ & $x$ & $x$ & $x$ \\
\hline$x$ & $x$ & - & - & $x$ & $x$ & $x$ & Hirneola polytricha & $\ldots$ & $x$ & $x$ & - & $x$ & $x$ \\
\hline- & - & - & - & - & $x$ & - & Xylaria clavarioides & $\ldots$ & - & $x$ & - & - & 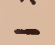 \\
\hline - & $x$ & - & - & - & $=x$ & - & Daldinia vernicosa & $\ldots$ & - & $\hat{x}$ & - & - & $x$ \\
\hline - & - & - & - & - & $x$ & - & Rhytisma sp. $\quad \ldots$ & $\ldots$ & - & $x$ & - & - & - \\
\hline$x$ & $x$ & - & - & $x$ & $x$ & $x$ & Sargassum ilicifolium & $\ldots$ & $x$ & $x$ & - & $x$ & $x$ \\
\hline - & - & - & - & - & $x$ & $x$ & Turbinaria ornata & ... & - & $x$ & - & - & - \\
\hline
\end{tabular}




\begin{tabular}{|c|c|c|c|c|c|c|c|c|c|c|c|c|c|}
\hline \multicolumn{7}{|c|}{ Distrieution in S. E. Asta. } & \multirow{3}{*}{\multicolumn{2}{|c|}{ Names of Species. }} & \multicolumn{5}{|c|}{$\begin{array}{c}\text { Generat Distri- } \\
\text { Bution. }\end{array}$} \\
\hline \multicolumn{3}{|c|}{$\begin{array}{l}\text { Westn. } \\
\text { Sectn. }\end{array}$} & \multicolumn{4}{|c|}{ Eastn. Sectn. } & & & & & & & \\
\hline 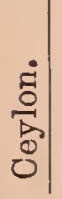 & 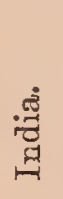 & 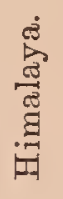 & 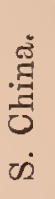 & 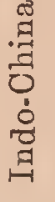 & 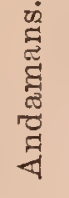 & 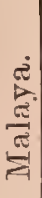 & & & 胥 & 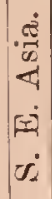 & 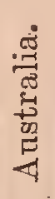 & 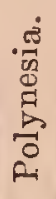 & 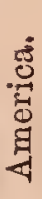 \\
\hline$x$ & $x$ & - & - & $x$ & $x$ & $x$ & Padina paronia ... & . & $x$ & $x$ & $x$ & $x$ & $x$ \\
\hline- & - & - & - & - & $x$ & $x$ & Dictyota dichotoma & $\ldots$ & $x$ & $x$ & $x$ & $x$ & $x$ \\
\hline$x$ & $x$ & - & $x$ & $x$ & $x$ & $x$ & Lithotliarnnion polymorph & & $x$ & $x$ & $x$ & - & - \\
\hline$x$ & $x$ & - & - & $x$ & $x$ & $x$ & Acanthophora Thierii & $\ldots$ & $x$ & $x$ & $x$ & $x$ & $x$ \\
\hline- & - & - & - & - & $x$ & $x$ & Jania tenella $\quad \ldots$ & $\cdots$ & - & $x$ & - & - & - \\
\hline- & - & - & - & - & $x$ & $x$ & Gracilaria crassa ... & $\ldots$ & - & $x$ & - & - & - \\
\hline$x$ & - & - & - & - & $x$ & $x$ & Gelidinm corneum & ... & $x$ & $\hat{x}$ & $x$ & $x$ & $x$ \\
\hline$x$ & $x$ & - & - & $x$ & $x$ & $x$ & Canlerpa clavifera & $\ldots$ & $x$ & $x$ & $x$ & $x$ & $x$ \\
\hline- & - & - & - & - & $x$ & $x$ & Canlerpa plumaris & $\ldots$ & _ & $x$ & - & - & - \\
\hline$x$ & $x$ & - & - & $x$ & $x$ & $x$ & Valonia fastigiata & ... & $x$ & $x$ & $x$ & $x$ & $x$ \\
\hline$x$ & $x$ & - & - & $x$ & $x$ & $x$ & Valonia confervoides & $\ldots$ & $x$ & $x$ & $x$ & - & - \\
\hline$x$ & $x$ & - & - & $x$ & $x$ & $x$ & Halimeda Opnntia & $\ldots$ & $\hat{x}$ & $\hat{x}$ & $x$ & $x$ & $x$ \\
\hline - & - & - & - & - & $x$ & $x$ & Siphonocladus? filiformis & ... & $x$ & $x$ & $x$ & - & - \\
\hline - & - & & - & - & {$[x]$} & - & Vaucheria sp. & ... & - & $x$ & - & - & - \\
\hline$x$ & $x$ & - & - & - & $x$ & $x$ & Calothrix pulvinata & $\ldots$ & $x$ & $\hat{x}$ & $x$ & $x$ & $x$ \\
\hline
\end{tabular}

Reviewing the generaI distribution of the flora as given in TABLE $\nabla I$, we find that of the 358 species, 70 are cosmopolitan in the tropics, 10 more are nearly so, 49 are more or less widely spread throughout the. tropics of the old world, 41 extend from South-eastern Asia to Australasia, while 188 species are confined to South-eastern Asia. The subjoined synoptic table indicates these distributional features more exactly and gives at the same time the relationship of this distribution both to the habit and to the habitat of the species. 
TABLE VII. Relationship of General Distribution to Habit and Mabitat.

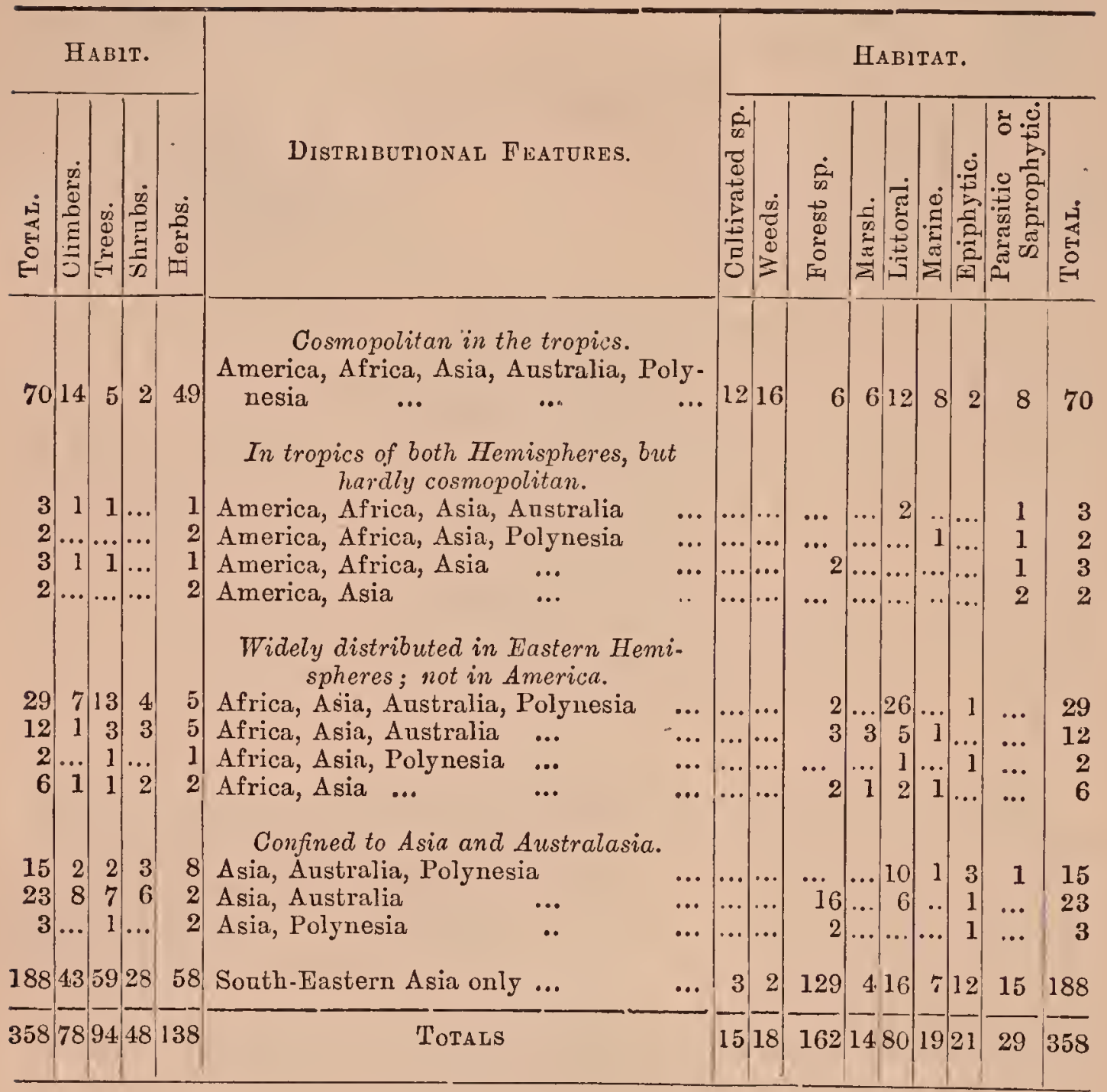

In discussing the phytogeographic distribution of these spccies within the province of South-Eastern Asia it is necessary to distinguish between the districts forming the Western section, viz.:- - the lower Himalayan slopes with the plains at their foot, Peninsular India, and Ceylon - from the Eastern section, which comprises Southern China, IndoChina, Malaya, including the Philippines, New Guinea, and the coasts of Northern or Tropical Australia. Of the 358 species in the Coco Islands, which therefore necessarily all occur in the Eastern section, 252 species, or 70 per cent., are found in the Western section as well. Of the whole number 153 species, or 43 per cent., extend to Australia, whereas only 140, or 39 per cent., are known to occur in South China.

The following tables indicate the distribution of the species so far as these three portions of S. E. Asia are conccrned. 
TABLE VIII. Distribution in S. E. Asia of the species extending from the Coco-group to Cis-gangetic India.

In all three Cis-gangetic districts (Himaluya, India, Ceylon) :-.........

In China, Indo-China, Malaya, Australia ................. 72

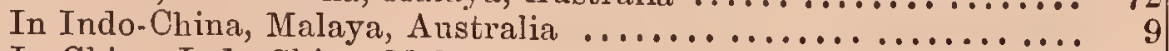

In China, Indo-China, Malaya ........................ 26

In Indo-China, Malaya ............................. 24

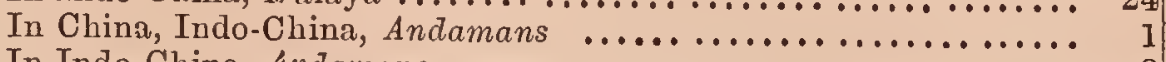

In Indo-China, Andamans...........................

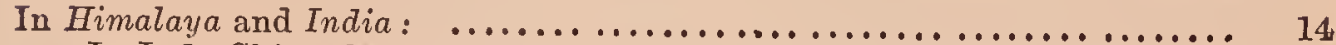

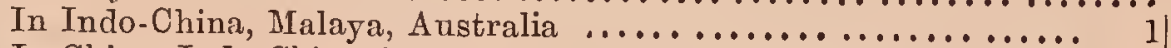

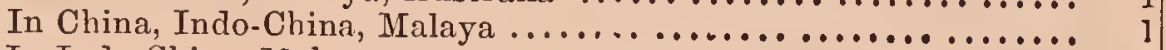

In Indo-China, Malaya .......................... 7

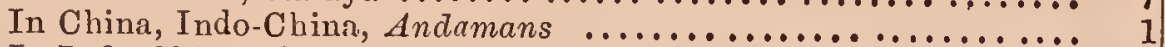

In Indo-China, Andumans .............................

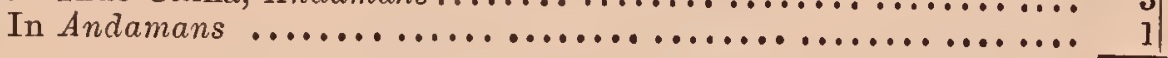

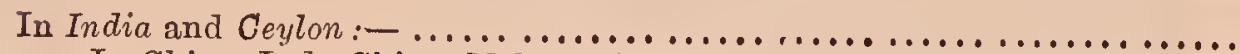

In China, Indo-China, Malaya, Australia ................... 33

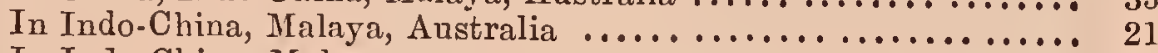

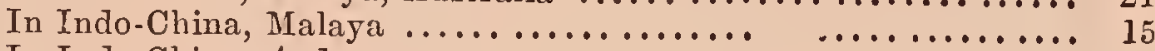

In Indo-China, Andamans ............................ 1

In Andamans, Malaya, Australia .................... 3

In Andamans, Malaya ............................ 3

In Himalaya $:-\ldots \ldots \ldots \ldots \ldots \ldots \ldots \ldots \ldots \ldots \ldots \ldots \ldots \ldots \ldots \ldots \ldots$

In China, Indo-China, Malaya $\ldots \ldots \ldots \ldots \ldots \ldots \ldots \ldots \ldots \ldots \ldots \ldots \ldots \ldots \ldots$

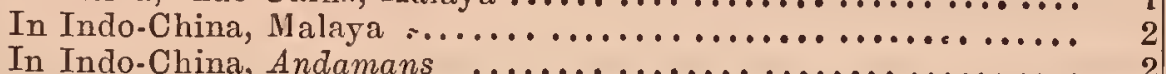

In Indo-China, Andamans $\ldots \ldots \ldots \ldots \ldots \ldots \ldots \ldots \ldots \ldots . \ldots \ldots, 2$

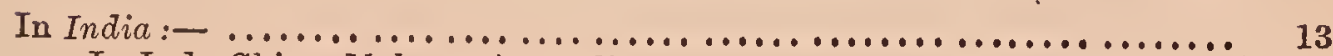

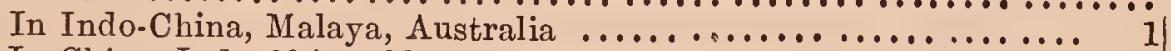

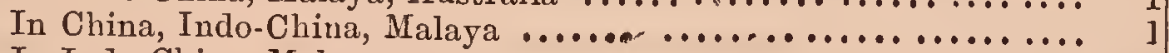

In Indo-China, Malaya .................................

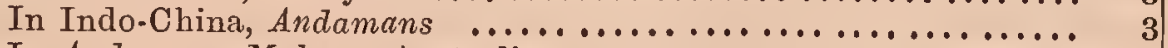

In Andamans, Malaya, Australia.................... 2

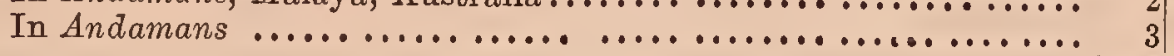

In Ceylon $:-\ldots . \ldots \ldots \ldots \ldots \ldots \ldots \ldots \ldots \ldots \ldots \ldots \ldots \ldots \ldots \ldots \ldots$

In Indo-China, Malaya, Anstralia $\ldots \ldots \ldots \ldots \ldots \ldots \ldots \ldots \ldots \ldots \ldots \ldots \ldots \ldots \ldots \ldots$

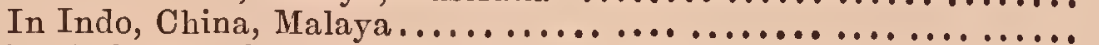

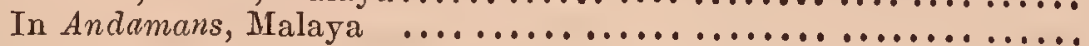

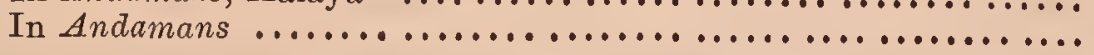

Total number of species extending from the Coco Group to Cis-gangetic India

\section{TABLE IX. Distribution in S. E. Asia of the species extending from the Coco Group to China.}

Extending as far as Australia :- $\ldots \ldots \ldots \ldots \ldots \ldots \ldots \ldots \ldots \ldots \ldots$

In Indo-China, Malaya, Australia; Himalaya, India, Ceylon.......

In Indo-China, Malaya, Anstralia ; India, Ceylon............ 33

In Indo-China, Malaya, A ustralia ..................... 1

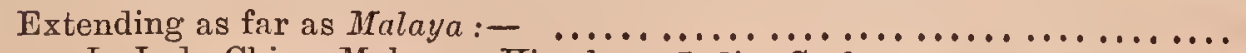

In Indo-China, Malaya; Himalaya, India, Ceylon .................

In Indo-China, Malaya; Himalaya, India ...................

In Indo-China, Malaya ; Himalaya ......................

In Indo-China, Malaya 
Extending as far as the Andamans only :- ................... s

In Indo-China, Andamans; Himalaya, India, Ceylon ........... 1

In Indo-China, Andamans; Himalaya, India ............. 1

In Indo-China, Andamans; India .................. 1

Total number of species extending from the Coco Group to China ... 140

TABLE X. Distribution in S. E. Asia of the species extending from the Coco Group to Australia.

Extending as far as China $:-\ldots \ldots \ldots \ldots \ldots \ldots \ldots \ldots \ldots$

To Malaya, Indo-China, China; Himalaya, India, Ceylon ....... 72

To Malaya, Indo-China, China; India, Ceylon.............. 33

To Malaya, Indo-China, China $\ldots \ldots \ldots \ldots \ldots \ldots \ldots \ldots \ldots . . \ldots \ldots$

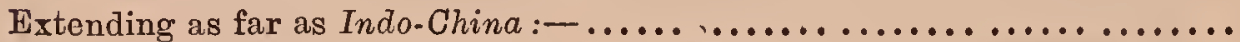

To Malaya, Indo-China; Himalaya, India, Ceylon ............. g

To Malaya, Indo-China; Himalaya, India .............. 1

To Malaya, Indo-China; India, Ceylon .................. 21

To Malaya, Indo-China; India...........................

To Malaya, Indo-China; Ceylon ..................... 2

To Malaya, Indo-China $\ldots . . \ldots \ldots \ldots \ldots \ldots \ldots \ldots \ldots \ldots$. 4

Extending as far as the Coco Group (Andamans) only:-..............

To Malaya, Andamans; Ceylon, India .......................

To Malaya, Andamans; Ceylon .................... 1

To Malaya, Andamans; India ..................... 2

To Malaya, Andamans $\ldots \ldots \ldots \ldots \ldots \ldots \ldots \ldots \ldots \ldots \ldots$

Total number of species extending from the Coco Group to Australia ... 153

The analysis of these species thus shows that the figures do not indicate any special connection either with China, with India, or with Australia; many of the species in these tables are cosmopolitan or nearly so, and thus possess no special phytogeographical interest. 'The number of species that extend from India, Ceylon or the Himalaya to the Andamans and no further, is only 23 , or $6 \frac{1}{2}$ per cent. of the whole flora; this figure, therefore, more nearly represents what may be considered the peculiarly Indian element in the Flora of the Andamans. T'lere are only three species that extend from South China to the Andamans and no further southwards, and as all three are found in India and may as readily be extensions from India to China as from China to India we may assert that there is no distinctive Chinese feature in the flora at all. Only 9 species extend upwards from Australia as far as the Andamans, but not as far as Indo-China; but all these are characteristic Malayan species and may just as well be considered extensions from Malaya to Australia as from Australia through Malaya to the Coco Islands. The occurrence of as many as 10 of the species in Ceylon and not in India would seem at first to indicate that there is some foundation for a remark by $\mathrm{Mr}$. $\mathrm{Kurz}$, already alluded to in connection with the vegetation of Diamond Island (J.A.S. B. lix, pt. 2, p. 290), concerning the presence of a Ceylon 
element in the Andamans flora. But a consideration of that section of TABLE VIII in which they are detailed shows that they afford little corroboration of this hypothesis for there is only one species (Dedoelea flabellum) restricted to the Andamans and Ceylon, and as this is a Cryptogam, too great a reliance ought not to be placed on the fact; Indian Cryptogams, other than ferns, have not as yet been assiduously collected and the occurrence here of this Ceylon species perhaps indicates rather a wide dispersion for it than any peculiar affinity of the flora of the group with that of Ceylon.

The general conclusion to which we are led by the evidence these tables afford is, that the flora of the Coco Group is almost purely Trans. gangetic, and that while this is the case there is no appreciable Chinese or Australian element present. We have still to ascertain whether it is an Indo-Chinese or a Malayan element that prevails in the flora, and to what extent any independent element exists.

From their geographical position we have to look upon the Coco Islands as part of the Andaman Group : in one sense therefore all the Coco Island species are Andamanese. But there are as many as 30 of the species in the list,* or about 8 per cent. of the flora, whose presence in the Andamans is due only to their having been found in the Coco Group. At the same time, lowever, it must be remembered that 19 species, or over 5 per cent. of the flora, are peculiar to the Andamans as a whole, not occurring either in Indo-China or in Malaya, while 24 more are only known as Indo-Chinese from their presence in Tenasserim. $f$ Of these 24 Andamans-Tenasserim species, 22 , or 6 per cent. of the flora, are confined to these two districts, only two of them extending even as far as the Malay Peninsuln. The bearing of this peculiar distribution in the Andamans and in Tenasserim, but neither north ward to Indo-China nor southward to Malaya, the writer has already had occasion to note ; $\ddagger$ it will be referred to agnin below in connection with the probable origin of the Coco Island flora. Another circumstance that must be borne in mind is that as yet very little is known of the flora of North Andaman, and it is not improbable that some of the 30 Non-Andaman Coco species will yet be found to occnr in that island.

* Indicated in the list of distribation by [] brackets in the Andamans column.

+ Indicated by [] brackets in the Indo-Chinese colnmn.

¥ Ann. Roy. Bot. Garden, vol. iii, p. 238.

$\S$ As an example of this possibility may be instanced Dendrocalamus Strictus which does not occur in South Andaman. Mr. Godwin-Austen, formerly of Port Blair, one of the very few officers who have ascended Saddle Peak, the highest point of North Andaman, has informed the writer that at one point in the ascent a Bamboo is net with quite different from the Bamboos near Port Blair; not very 
Of the 358 species, 232 , making 65 per cent. of the whole, occur at once in Indo-China, Malaya and the Andamans; 40 occur in Malaya and the Andamans, 8 of these extending to Tenasserim but not occurring in Burma or Siam (Indo-China proper) ; 22 occur in Indo-China but not in Malaya, 12 of them being present in the Andamans also; 40 occur in the Andamans without appearing either in Indo-China or in Malaya, though 8 of these appear in Tenasserim, which connects Indo-China with the Malay Peninsula, just as the Andamans connect Indo-China with the Malay Archipelago ; 8 occur only in the Coco Islands and Tenasserim, and 13 are apparently confined to the Coco group. This last number is probably too high; some of these species, as well as some of those others for which the Coco locality is as yet the only record from the Andamans, may occur in North Andaman.

The following table gives the distribution of the species in these three districts as well as in the sub-district of Tenasserim :-

\section{Table XII. Distribution of Coco Island species in the Indo-Chinese and Malayan districts.}

A.

Species extending from Coco Group to :-

Indo-China, Tenasserim, Andamans, Malaja, ... $\quad$.. 232

Indo-China, Tenasserim, ——.., Malaya, ... $\quad \ldots . r 2$

-

——, Tenasserim, - _..., Malaya, ... $\quad \ldots .1$

$\longrightarrow$ - Andamans, Malaya, $\ldots . \quad \ldots \quad 32$

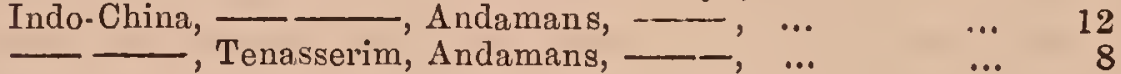

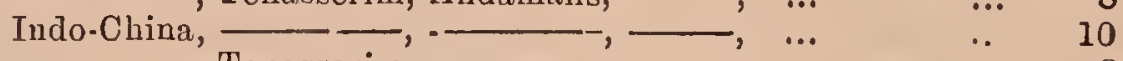

$\longrightarrow$, Tenasserim, $\longrightarrow$-.., —, $\ldots, \quad \ldots \quad 8$

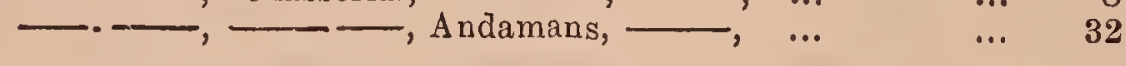

Total species extending from Coco Group ... 345

\begin{tabular}{rrrrr} 
Coco Group &.. & $\ldots$ & $\ldots$ & 345 \\
& & $\ldots$ & 13 \\
\hline
\end{tabular}

Total Coco Island species $\quad \ldots \quad 358$

B.

Species occurring in :-

Indo-China

Tenasserim

Andamans

Malaya

No. of species.

percentage of flora.

Species confined to Coco Group

\begin{tabular}{c|c|c} 
& No. of species. & percentage of flora. \\
\hline$\ldots$ & 256 & 71 \\
$\ldots$ & 259 & 72 \\
$\ldots$ & 324 & 90 \\
$\ldots$. & 275 & 76 \\
& 13 & $3 \frac{1}{2}$ \\
\hline
\end{tabular}

This table therefore leads to the conclusion that phytogeographically

tall, but extremely hard and tongh, and forming dense thickets very difficult to pass through-a general description agreeing very well with that of Dendrocalamus strictus as it occurs in Great Coco. 
as well as physiographically the Coco Group forms an integral part of the Andamans. Further, it shows that of the possibly predominating elements in their flora, the Indo-Chinese element, as a whole, is slightly weaker even in that part of the Andamans nearest to Burma than is an element indicating a Tenasserim influence and an element indicating a Malayan influence. This seems strange when we recollect that not only do the Cocos form that part of the Andamans nearest to Burma but that there is a shallow ridge, at times raised into islands, along the lin Cocos and the nearest point on the Burmese mainland, whereas Tenasserim is at the opposite side of a deep sea, while Malaya is separated from the opposite extremity of the Andaman group by a much greater distance and by much deeper straits than Burma is from the area under discussion.

In order, if possible, to account for this peculiarity of distribution, it becomes necessary to discuss the probable origin of the flora of the group.

The first step in such an inquiry is to ascertain the species in a flora that may possibly have beeu introduced and that do not therefore necessarily postulatefor an isolated locality sucl as the Cocos any former connection with neighbouring land. It is, of course, evident that if a previous land connection be shewn to be necessary to explain the presence of any species in the islands this same land connection would sufficiently explain the presence of most of the species that occur there without requiring the suggestion of any extraneous means of introduction. But until all the possibilities of introduction by means of physical agencies now at work under existing physiographical conditions are completely exhausted, we are, not at liberty to assume the existence of dissimilar physiographical conditions or a different application of the present physical agencies.

There is, however, always great difficulty in deciding absolutely what species are indigenous and what species are introduced in any locality, and here no species will be considered "indigenous" for which it is possible to suggest in the remotest fashion any means of introduction. At the risk therefore of including among introduced species many that are probably quite entitled to be termed indigenous, the possibilities are discussed under the headings of the various active introducing agencies. As this involves a use of the terms "indigenous" and "introduced" somewhat different from the sense in which they are generally accepted, it seems better that the possibly introduced species be spoken of as "migrant"; and the certainly indigenous residuary species termed " remanent," many of the "migrant" species being doubtless perfectly "indigenous" in the generally received sense.

Even within the group of "migrant" species difficulties often arise owing to certain species being assisted in one way from island to island 
over intervening seas and in another way along continuous land. As an example may be mentioned Gyrocarpus Jacquinii, whose progress from island to island is clearly a sea-assisted process, yet whose dispersal inland when it is once established is greatly aided by wind because of its curious dipteroid fruit. It might even be suggested that the wings of this fruit may be sufficient to account for its transmission across intervening seas ; but no one who has carefully observed the fall of its fruits is likely to consider this possible. Another very pertinent instance is Terminalice Catappa, a species distributed by ocean currents over all the coasts of the Andaman Sea, but which nevertheless occurs far inland as well as on the beaches. The explanation of its inland dispersal is extremely simple, for rats and frugivorous bats are extremely fond of the fleshy part of its fruits while they leave uninjured the stone and kernel. Both these animals are apt when disturbed wlile eating to carry off in their mouths the fruit they may be devouring, ultimately dropping it some distance from the place where the parent tree grew. But though bats occur in far off lonely islands like Batti Malv and Barren Island, and though their presence there indicates the possibility that animals of the kind may, like fruit-eating birds, carry undigested seeds from one island to another, it is clear, since they do not swallow the stones of 'lerminalia Catappu that they are not to be held respossible for the passage of that species across intervening seas. The further spread of these species within new localities by agencies quite distinct from that necessary to account for their initial appearance is, it will be admitted, amply demonstrated.* Other. examples are Pisonia aculeata and excelsa which are perhaps introduced by the sea along these coasts. If they are, however, it is quite certain that their presence inland may be amply accounted for owing to their sticky fruits having become attached to birds or animals that have come in contact with them. $\dagger$

* Residents in India are familiar with the treatment of "country-almonds" by the large "flying-foxes;" fruits carried off by them, and with a portion bitten out of the fleshy side, may be constantly found dropped at considerable distances from the trees on which the almonds grew In Barren Island there is no doubt that the frugivorous bats which exist there are partly responsible for the same thing, and the writer had an opportanity of witnessing the rats, which abound on that island, engaged in the same act, these creatures having come down to the shore for the fruits that are common there and when disturbed scampering off up gullies with fruits in their mouths.

† A striking instance of the possibility of their becoming attached to the bodies of passing animals was witnessed by the writer on a path between Rangachang and Ali Mlusjid in South Andaman in April 1891. Though some miles from the sea a considerable number of Pisonia excelsa trees occurred at the place, and the patl was strewn with their fruits. A tree-snake was seen which had become entangled in a fallen panicle of these so that all escape was impossible, its every movement in. 
And in addition to these instances it may be remarked that the whole group of species which may possibly have been introduced in the crops of grain-eating birds can be only considered as indirectly birdintroduced, since some accident must have happened to account for the death of the introducing bird in order to explain the germination of the seed and final introduction of the plant.

The "migrant" species, meaning thereby all that have certainly been introduced and all for which introduction is conceivable, may be divided into "civilized" species introduced by man, and "sylvestrian" or wild species. The wild species may be divided into "coast" species, further subdivided into "marine" and "littoral" species, the whole of the coast species being sea-introduced; and into "inland" species. These lattcr, which may of course also occur on the shore, but for the introduction of which the sea lias not been responsible, may best be classed as "wind-introduced" and as "bird-introduced" species Species introduced by birds may have been introduced eithcr attached. to the bodies of these or carried in their crops. These different groups will be discussed in detail; last of all the "remanent" species will bc considered.

The "civilized" species comprise cultivated plants and weeds of cultivation or of wastc places; the former corresponding practically to domestic animals like the cow or horse, and to domestic insects like the bee or silk-worm, the latter to the vermin that associatc themselves with, or accompany man and his domestic creaturcs. This group therefore contains the species that may, directly as economic or æsthetic plants, or indirectly as weeds, have been introduced by man. The list subjoined includes the whole of the species present in the islands that are known to be sometimes thus introduced; those that are likely to be here indigenous, or to have been introduced by other than human agency, are enclosed within brackets and will be found again in ove or, at times, more than one of the subsequent lists.

List of Civilized species found in the Cocs Group.

* Nympliæa rubra.

This variety has perbaps been introduced intentionally into Great Coco, where it occurs in the small lake. It has to be recollected that it is a favourite flower with the Burmese and is sold for votive purposes in the Pagodas

volving it more hopelessly in the tangled sticky mass. After the snake died its body was carefully examined and it was found that it had suffered no previous physical injury which could account for its inability to escape. 
Sida carpinifolia.

[Urena lobata.

* Hibiscus Sabdariffa

5. Hibiscus Abelmoschus.

* Moringa pterygosperma.

* Crotalaria sericea.

* Desmodium triflorum.

* Alysicarpus vaginalis.

10. * Phaseolus sp. about Rangoon; also that the settlement was attempted by a Rangoon gentleman whose servants were, at least partly, Burmese. But typical white Nymphæa Lotus occurs in Little Coco, clearly independently of human agency.

Table Island (the older clearing) only.

As a rule this species would, without hesitation, be dealt with as a weed; in Great Coco, however, it does not occur iu the clearing and it was not found on Table Island at all. If introduced here, we may safely say that human agency is not responsible for its appearance; more probably it has been introduced by the agency of birds].

Great Coco ; in the old garden and evidently struggling against extinction.

Table Island only; but common in many parts of the clearing.

Great Coco; a few trees evidently planted; these are very healthy, and seedlings are already springing up under the adjacent Coco-nut trees.

Table Island only; but very abundant; the species may have been unintentionally introduced, but more probably has been brought by the servants at the light-house, who are Burmans and with whom the flower is a favourite.

Table Island only; common however on all the grassy slopes.

Great Coco; not seen on Table Island, though it probably occurs there.

Seedlings in cow-dung on one grassy slope at south-west corner of island. These were seen in 1890; no species was seen in 1889 likely to have given origin to these and there is no indigenous species to which it seems likely they could belong. Unfortunately 
* Tamarindus indica.

* Carica Papaya.

[Vcrnonia cinerea.

[Adenostemma viscosum.

15. * Ageratum conyzoides.

* Ipomæa coccinea.

* Ipomæa Batatas. neither clearing could be revisited in 1890 to enable the writer to make further investigation.

Great Coco; only one tree and that, though almost certainly introduced by man probably unintentionally so.

Great Coco; perfectly naturalised and very profuse in the Coco-nut zone, especiallyin the north end of the island.

Both islands ; extremely abundant in the clearings, but also plentiful on grassy slopes and bare rocky headlands of the western coast of Great Coco; it also occurs on Rutland Island, at the opposite extremity of the Anda man group, where introduction by man is hardly conceivable: here probably it owes its presence to the agency of wind.]

Great Coco; common on bare rocky pro. montories on west side and at north end of island. If introduced here it has been introduced independently of human agency; it is probably a seaintroduced species, but perhaps its fruits may have come attached to the feathers of birds.]

Table Island; common in the clearing ; not present in Great Coco.

Table Island; a garden escape, but very plentiful on the edges of jungle-paths far from the lighthouse garden.

Table Island; cultivated only: has not survived on Great Coco, probably owing to the presence of wild pigs. These the writer did not see on Great Coco but their traces were abundant on Table Island and the pigs themselves were obtained on Little Coco. Moreover, Mr. Hume (Stray Feathers, ii, p. 111) actually met with them on Great Coco. During our visits 5 or 6 abandoned pariah dogs were seen 
* Solanum Melongena.

Capsicum minimum.

20. * Scoparia dulcis.

* Rungia pectinata.

[Anisomeles ovata.

[Boerhaaria repens. on the island; but, though these must necessarily have rendered the pigs shy, it can hardly be supposed that they have exterminated them.

Table Island; cultivated. Great Coco ; in the old garden and also plentiful all over the clearing; apparently quite naturalised.

Table Island; cultivated, and as an escape. Great Coco; very plentiful and spreading far into the jungle.

Both islands; common in the clearings. Table Island; only in the clearing; not plentiful and as it is not met with in Great Coco is probably here, as it often is, an introduced weed. But it need not always be so since the species is abundant on bare rocky promontories at the south end of Rutland Island where introduction by human agency is not to be thought of.

Great Coco ; this species is not present on Table Island apparently, and on Great Coco it was only found on the isthmus connecting the north-eastern peninsula-where the clearing is-with the main island. But the species does not occur in the clearing, and it is remarkably abundant where it occur's. Moreover it is exceedingly abundant in Diamond Island, off the Arracan Coast, which is another section of the same island chain; the writer is therefore inclined to believe that the species does not owe its introduction to human agency but that it may be classed among the remanent species.]

In all three islands, common on rocky promontories and bare isolated rocks though a frequent weed of cultivation this owes its presence here, not to kuman influence, but to the agency of 
* Celosia cristata.

25.* Achyranthes aspera.

* Gomphrena globosa.

*Euphorbia pilulifera.

* Musa sapientum.

* Cocos nucifera.

30. * Kyllinga brevifolia.

* Fimbristylis diphylla. the sca or to that of littoral birds, such as the Bitterns and Terns that frequent the reefs and rocks, its sticky fruits probably attaching themselves to the fect of these.]

Table Island, a common escape.

Both islands, common in the clearings and undoubtedly introduced by man. But on Little Coco, the very distinct VAR. porphyristachya is abundant as a climber in the Pandanus sea-fence and is probably, like the same variety in the Nicobars, Laccadives, etc., a plant introduced by the sea.

Table Island, an abundant escape.

Table Island, a weed in the clearing, still rare.

There is a Plantain-garden attached to the lighthouse on Table Island. No Plantains are left on Great Coco, doubtless owing to the cattle. These animals eat not only coco-nut leares but also the leaves of Pandanus odoratissimus, so that one is surprised to find that they lave left anything in the garden atall. Except for the cattle (and perhaps the pigs, which might grout up the stocks) there is no reason why the Plantain should not thrive if left to itself. In Narcondam there is a grore of Plantains, introduced (by Col. Tytler ?), in excellent health.

Common in all three islands but deserving neither to be deemed indigenous nor to be considered a species introduced by the sea. The question whether its presence is due to somc old attempt at settlement or to the shipwreck of some coco-nut laden craft is discussed more fully below.

Both islands, only in the clearings. Both islands, only in the clearings. 
* Panicum ciliare.

Panicum colonnm.

* Panicum Helopus. 35. * Eleusine indica.

* Eleusine xgyptiaca.

Great Coco; near south end of island beside some shelter liuts used by coco-nut collectors.

Both islands, in the clearings and also at south end of Great Coco near the shelter huts.

Table Island, in the clearing.

Table Island, clearing, common ; Great Coco, rare in the clearing, also a few tufts among droppings of cattle on a bare hill at south-west corner of the island.

Table Island; lighthouse clearing, still rare. [All the Cyperaceo and Graminex may have been introduced by birds.]

Of the above, nineteen are species which are, or may be, cultivated for economic or æsthetic reasons-the economic plants being Hibiscus Sabdariffa (the Rozelle), Hibiscus Abelmoschus (the Musk-mallow), Moringa pterygosperma (the Horse-Radish tree), Phaseolus sp., Tamarindus indica (the Tamarind), Carica Papaya (the Papaw), Ipomoea Batatas (the Sweet- Potato), Solanum Melongena (the Bringal), Capsicum minimum (the Bird's-Eye Chillee), Musa sapientum (the Plantain), Cocos nucifera (the Coco-nut),/Panicum ciliare, colonum and Helopus (three wild fodder-millets). Ten of these have undoubtedly been intentionally introdnced-one (the Tamarind) certainly has not, and the three fodder grasses may have come as weeds, or equally probably, may have been introdnced by grain-eating birds. The æsthetic plants are Nymphoca rubra, Crotalaria sericea, Ipomcea coccinea, Celosia cristata, and Gomphrena globosa. Crotalaria sericea may have been involnntarily introduced, the others almost certainly have been brought intentionally. The other seventeen are, or may be, weeds, but thcre is evcry probability that five of them, Urena lobata, Vernonia cinerea, Adenostemma visocosum, Anisomeles ovata, and Boerhaavia repens do not owe their presence here to human agency.

Of the introduced economic species three are evidently unfitted to survive under the conditions to which, when abandoned, they are exposed. The Rozelle succnmbs to climatic influences, the Sweet-Potato and the Plantain are destroyed by animals. On the other hand the propagation of two of these species-the Papaya and the Eird's-Eye Chillee-is remarkable both for its extent and rapidity, and for the fact that the flavour and pnngency of the fruit of these species remains undiminished. 
The Coco-nut tree deserves to be specially noticed. It is not known where Cocos nucifera is "indigenous" and the suggestion that it is "really wild" on the Coco Islands and along the north-western coast of North Andaman, made by the late Mr. Kurz, (Forest Flora of British Burma ii, 540), though true enough so far as the Coco Islands are concerned, is denied, as regards North Andaman, by those officers at Portt Blair who have had opportunities of investigating the shores of the group. Mr. Kurz did not himself visit either the Coco group or North Andaman, and unfortunately he does not give any authority for the latter part of his statement. But, granting its correctness, the fact remains that about Port Blair the tree only occur's as a recent introduction and it is not met with elsewherc cither in South on Middle Andaman, except as a few young trees that have, on Rutland Island, the Sentinels, etc., been deliberately planted. More recently, the writer has been told of a bay in one of the islands of the "Archipelago," near Port Blair, which is lined with Coco-nut trees, the result of the wreck of a particular craft that was lost on her way from the Nicobars to a Burmese port; this statement the writer has not yet been able personally to verify. In Narcondam therc are Coco-nut trees in no fewer than three places, and as there is absolutely nothing to disturb them there, they are spreading rapidly. In Barren Island also there is one bay where a considerable number of Coco-nut trees grow and where also the species is rapidly spreading. But in both these islands the introduction has been deliberate and quite recent; this in Narcondam is particularly evident from the fact that the oldest trees occur along with a grove of Plantains, though it is equally apparent that the spread of the species to one, and probably to both, of the two other bays where it occurs, has been unassisted by man and is due to fallen nuts having been drifted round from the first planted trees. It is, however, very remarkable that Cocos nucifera should be so abundant in the Coco group and be absent from, or very rare in, the Andamans proper, including Little Andaman, and that the species should again occur' in such abundance in the Nicobars. 'The direction of the ocean currents has been suggested as possibly explaining the fact, but with very unsatisfactory results, because, whatever be the theoretical direction assumed for these currents in order to explain the distribution of Cocos nucifera, it must fail to coincide with the direction postulated to explaiu the distribution of Casuarina equisetifolia, a tree which is extremely common in the Nicobars and is so plentiful in Little Andaman, where there are no Coco-nuts, that the English equivalent for the Andamanese name of the island is "Casuarina-sand," the name taking its origin from the great prevalence of this species on all its beaches. But though there are no Coco-nut trees in the Andaman group 
proper, there is one place where Casuarina equisetifolia occurs. This is a small bay, Casuarina Bay, on the west coast of North Andaman, on the beach of which the species is plentiful. In the Coco group, where there are Coco-nut trees, there is no Casuarina equisetifolia though it occurs again in Arracan and Chittagong where there are no Coco-nuts. As a matter of fact there is a steady current northward along the west coast of the Andamans for a considerable period of the year and it is difficult to understand why both Cocos and Casuarina do not occur plentifully along the whole west coast of the Andaman chain. The writer's examination of the ocean-drifts of the Coco group during his two visits did not throw much light on the subject. Wreckage iu considerable quantity is to be found along the whole of the coasts, in most cases, however, belonging to wrecks that have occurred on the spot; the disposition of the fragments therefore only throws light on the "set" of local currents. Among the exceptions to this were a dressed teak-log on the east side of Great Coco, a padouk-log on the east side of Jerry Island, a quantity of Burnese sea-fishing-gear on the eyot between Great Coco and Jerry, fragments of two different Audamanese canoes on the east coast of Great Coco, a clump with roots of a very large Bamboo (not improbably Bambusa gigantea) on the west side of Great Coco, part of a third Andamanese canoe on the east side of the Little Coco, and a fruit, with part of stalk, of Nipa fruticans at the south end of Little Coco. Except the Andamanese canoes the whole of these objects indicated a "set" of ocean-current from Burma, for though Nipa fruticans which, strangely, appears to be absent from the Cocos, is both a Burmese and an Andamans species, this particular fruit had its stalk cut cleanly off by some sharp implement, and if it came from the Andamans it must therefore have floated from the neighbourhood of the settlement at Port Blair, a sufficiently improbable circumstance, as the examination of a map of the Andaman sea will show. Now if the set of the currents is such as to bring "drift" from Burma, and if these currents have brought the Coco-nut tree originally to the islands, we must explain how it happens that the islands of the "Archipelago" near port Blair, on the shores of which an undoubtedly Burmese "drift", in the shape of teaklogs, etc., is very plentiful, do not have Coco-nut trees on all their coasts. It has been suggested that the ocean-currents have thrown up Coco-nuts on the shores of the Andamans as well as on those of the Cocos, but that owing to the presence of the aboriginal inhabitants, always on the outlook for what they may pick up on the shore, the establishment of the species in the larger group has been impossible because any nut thrown up is found by them and immediately eaten or destroyed. This suggestion the writcr owes to Mr. M. V. Portman of 
Port Blair ; it remains nevertheless difficult to understand why not a single Coco-nut should have escaped the notice of the Andamanesewho after all are not a numerous race-while, as it happens, we have Mr. Kurz's positive statement that in certain parts of Nortl Andaman the species does occur.

It seems to the writer that for this particular group of islands, although the spread of the Coco-nuts within the group is undoubtedly due to the agency of the sca, the ocean-current theory does not explain the presence of the species, and that the original introduction has niore probably been due to human interference. The question remains whether this was voluntary or involuntary. It may have been the result of an attempt at settlement in the island. 'I'lie most recent attempt, which dates from 1878, is not the only one on record. An earlier attempt, as unsuccessful as the last, was made in 1849. But it does not follow, though these are the only attempts known, that they are the only ones which have been made. Both were made entirely on account of the Coco-nut being present in the islands, as perhaps other attempts before them may have been, for it appears that the name Coco Islands, implying the establishment thcre of Coco nucifera and the knowledge of that fact by navigators, dates from some of the very earliest European visits to Eastern seas. But it is not impossible that a yet earlier attempt to settle here may have been made and that the introduction of the Coconut may have been one of its results. It is easy to understand that thesc islands should have been chosen in preference to the more invitinglooking Andaman group owing to the character for ferocity which, for somc curions reason, was attributed to the inhabitants of the Andamans by early navigators, and it is as easy to understand that the adverse natural conditions which prevail, and which have caused the failnre of all rccent attcmpts at settlement, must soon have led to the abandonment of the earliest attempt. The writer feels inclined to think that this may be the true explanation of the presencc of Coco nucifera in the Cocos Islands. Bnt it may quite as readily have been due to involuntary introduction by ship-wreck; for whilc disinclined to accept the suggestion that there are no Coco-nut trees in the Andamans becausc the Andamanese have eaten all the stranded Coco-nuts, when it is applied to nuts thrown up by ocean-currents, the writer thinks this cxplanation may well enough account for the presence of Coco-nut trees in the Cocos while they are absent from the main islands, if intruduction by rcason of shipwreck is postulated. In the Cocos there are no inhabitants, while in the main islands there are; and though it is scarcely reasonable to suppose that the Andamanese would detect every nut that is cast up on the bcach, therc is little doubt that they would soon become aware of the 
wreck of a Coco-nut craft and, becoming aware of it, there is as little doubt that they would soon consume every Coco-nut the vessel contained.

Now that the Coco-nut tree is established in the islands, it germinates profusely. Even towards the centre of the island on flat or muddy tracts one meets with groves, containing from a score to several hundreds of trees, that have originated from nuts which have been floated inland by unusually high tides aud left stranded far from the coast. The stems of these inland examples are abnormally tall, shooting up till the leafy head rises above the surrounding jungle; as far as can be seen, they do not flower till this happens. Once they have flowered and fruited the fallen nuts multiply the species fifty-fold. The nut appears to have but few enemies, and though a good many may be seen with a hole drilled through the husk and with the kernel scooped out, (apparently both crabs and rats are able to effect this,) the number thus destroyed forms quite an inappreciable proportion of the whole. The tree does not, however, invade the ridges, the soil is doubtless, as it is in South Andaman, too poor to suit it; while in trees growing along the bays on the west side of Great Coco the contents of the nut are distinctly less and their quality is appreciably poorer than in trees at the head of the bays on the opposile side; these in turn produce nuts that do not bear comparison with the magnificent ex. amples grown in the Nicobars.

In the subjoined table the distribution of the "civilized" species is given; in those cases where the species is believed to be truly indigenous in a particular area the distribution mark indicating the area in question is enclosed within ( ) brackets. From this table we learn that 28 of these species, or 80 per cent. of the whole, are cosmopolitan in the tropics, and that, with the exception of one weed and two cultivated species, which do not occur in the Orient, they are sub-tropical as well as tropical species. The original home of about one-half of the species is known with some degree of certainty and it is interesting to note that 7 , or 20 per cent. of the class, are originally natives of the New World, introduced in consequence of human intercourse into, and now established in, the Eastern Hernisphere as well. Ten of them are known to be natives of South-Eastern Asia; only six of these have spread beyond that area. 
TABLE XII. Distribution of "Civilized" species present in the Coco Group.

\begin{tabular}{|c|c|c|c|c|c|c|c|c|c|c|}
\hline 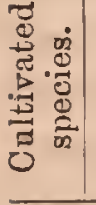 & 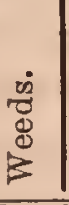 & SPeCies. & & & 胥 & 菢 & 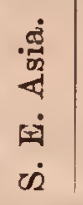 & 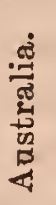 & 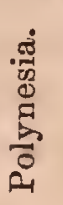 & 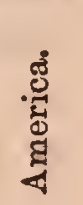 \\
\hline 1 & - & Nymphra rubra $\quad .$. & ... & ... & $x$ & $x$ & $x$ & - & - & - \\
\hline- & 1 & Sida carpinifolia $\quad .$. & ... & ... & $x$ & $x$ & $x$ & $x$ & $x$ & $x$ \\
\hline- & 1 & [Urena lobata] ... & $\ldots$ & $\ldots$ & $x$ & - & $x$ & $x$ & $x$ & $x$ \\
\hline 1 & - & Hibiscus Sabdariffa & ... & $\ldots$ & $x$ & $x$ & $(x)$ & $x$ & $x$ & $x$ \\
\hline 1 & - & Hibiscus Abelmoschas & ... & $\ldots$ & $x$ & $\times$ & $(x)$ & $x$ & $x$ & $x$ \\
\hline I & - & Moringa pterygosperma & ... & $\ldots$ & $x$ & $x$ & $(x)$ & $x$ & $x$ & x. \\
\hline 1 & - & Crotalaria sericea $\quad .$. & ... & $\ldots$ & - & - & $(x)$ & - & - & - \\
\hline - & 1 & Desmodiam triflorum & $\cdots$ & $\ldots$ & $x$ & $x$ & $\times$ & $x$ & $x$ & $x$ \\
\hline - & 1 & Alysicarpas vaginalis & ... & $\ldots$ & $x$ & $x$ & $(x)$ & $x$ & $x$ & $x$ \\
\hline 1 & - & Phaseolus sp. $\quad \ldots$ & ... & $\ldots$ & $?$ & $?$ & $\times$ & $?$ & $?$ & ? \\
\hline 1 & - & Tamarindus indica ... & ... & $\ldots$ & $(x)$ & $x$ & $x$ & $x$ & $x$ & $x$ \\
\hline 1 & - & Carica Papaya $\quad$... & ... & ... & $x$ & $x$ & $x$ & $x$ & $x$ & $(x)$ \\
\hline - & 1 & Vernonia cinerea $\quad .$. & ... & $\ldots$ & $x$ & $x$ & $x$ & $x$ & $x$ & $x$ \\
\hline - & 1 & Adenostemma viscosum & ... & $\ldots$ & $x$ & $x$ & $x$ & $x$ & $x$ & $x$ \\
\hline - & 1 & Ageratum conyzoides & ... & .. & $x$ & $x$ & $x$ & $x$ & $x$ & $(x)$ \\
\hline 1 & - & Ipo mœa coccinea $\quad .$. & ... & $\ldots$ & $x$ & $x$ & $x$ & $x$ & $x$ & $(x)$ \\
\hline 1 & - & Ipomœa Batatas ... & ... & $\ldots$ & $x$ & $x$ & $x$ & $x$ & $x$ & $(x)$ \\
\hline 1 & - & Solanum Melongena & ... & $\cdots$ & $x$ & $x$ & $(x)$ & $x$ & $x$ & $x$ \\
\hline 1 & - & Capsicum minimam & ... & $\ldots$ & - & - & $(x)$ & - & - & - \\
\hline - & 1 & Scoparia dnlcis & ... & $\ldots$ & $x$ & $x$ & $\times$ & $x$ & $x$ & $(x)$ \\
\hline - & 1 & Rangia pectinata & $\ldots$ & $\ldots$ & - & - & $(x)$ & - & - & - \\
\hline - & 1 & [Anisomeles ovata] & $\ldots$ & $\ldots$ & - & - & $(x)$ & _- & - & - \\
\hline - & 1 & [Boerhaavia repens] & ... & $\ldots$ & $x$ & $x$ & $x$ & $x$ & $x$ & - \\
\hline 1 & - & Celosia cristata & ... & $\cdots$ & $x$ & $x$ & $x$ & - & - & $x$ \\
\hline - & 1 & Achyranthes aspera & ... & $\ldots$ & $x$ & $x$ & $x$ & $x$ & $x$ & $x$ \\
\hline 1 & - & Gomphrena globosa & $\ldots$ & $\ldots$ & $x$ & $x$ & $x$ & $x$ & $x$ & $(x)$ \\
\hline - & 1 & Eaphorbia pilalifera & ... & ... & $x$ & $x$ & $x$ & $x$ & $x$ & $x$ \\
\hline 1 & - & Musa sapientum $\quad \ldots$ & $\ldots$ & $\ldots$ & $x$ & - & $(x)$ & $x$ & $x$ & $x$ \\
\hline 1 & - & Cocos nucifera $\quad \ldots$ & $\ldots$ & $\ldots$ & $x$ & - & $x$ & $x$ & $\bar{x}$ & $(x)$ \\
\hline - & 1 & Kyllinga brevifolia ... & $\ldots$ & $\ldots$ & $x$ & $x$ & $x$ & $x$ & $x$ & $x$ \\
\hline - & 1 & Fimbristylis diphylla & ... & $\ldots$ & $x$ & $x$ & $x$ & $x$ & $x$ & $x$ \\
\hline 1 & - & [Panicam colonum]... & $\ldots$ & $\ldots$ & $x$ & $x$ & $x$ & $x$ & $x$ & $x$ \\
\hline - & 1 & Panicam ciliare $\quad .$. & $\ldots$ & $\ldots$ & $x$ & $x$ & $x$ & $x$ & $x$ & $x$ \\
\hline 1 & - & [Panicum Helopns] & ... & $\ldots$ & $x$ & $x$ & $x$ & $x$ & - & - \\
\hline - & 1 & Elensine indica $\quad \ldots$ & $\ldots$ & $\ldots$ & $x$ & $x$ & $x$ & $x$ & $x$ & $x$ \\
\hline - & 1 & Eleusine ægyptiaca & ... & ... & $x$ & $x$ & $x$ & $x$ & $x$ & $x$ \\
\hline
\end{tabular}

The only Cryptogam that belongs to this class is the incompletely known Fungus the mycelium of which has proved so destructive to the tea-crop at Port Blair. From what has been said in the account of this species it will be seen that the species, whatever it may be, is certainly indigenous in, or at any rate has not been introduced by human agency into, the Andaman group.

We have now to consider the "sylvestrian", or truly wild, "migrant" species. These may be conveniently subdivided into "coast" and "inland" species-the former a group the members of which may, and here in most instances probably do, owe their presence 
to introduction by means of ocean-currents. But just as we have seen that some of the weeds may be claimed as indigenous, or at all events as introduced by other than human agency, so here we find that these classes pass insensibly in to each other and that species which may be introduced by the sea, such as Entada scandens, Gloriosa superba, Boerhaavia repens, Cocos nucifera, etc., may quite as reasonably owe their presence to a previous land-connection, to wind, to birds, or to involuntary or voluntary human agency. The more doubtful instances, however, will be found discussed in detail below. This group of species, howerer, as a whole, is characterised by a general distribution which is directly affected by the physiographical features of, and the currents that prevail in, the surrounding seas, and is only indirectly, if at all, influenced by the configuration of the adjacent land.

The "coast" species have to be further subdivided in "marine" and "littoral" species, and the former group, as comprising the plants for which the influence of ocean-currents is most evident, will be considered first. Only one Phanerogam belongs to this class; this species, Cymodocea ciliata, is however almost the most plentiful, the only other common species being Sargassum ilicifolium; all the others are very inconspicuous, being few in number, small in size, and scantily represented.

The following table gives at once a list of, and indicates the marine distribution for, these species; for six of them, as the general list shews, this is, as regards the Algce, only approximate.

TABLE XIII. Distribution of the "Marine" species present in the Coco Group.

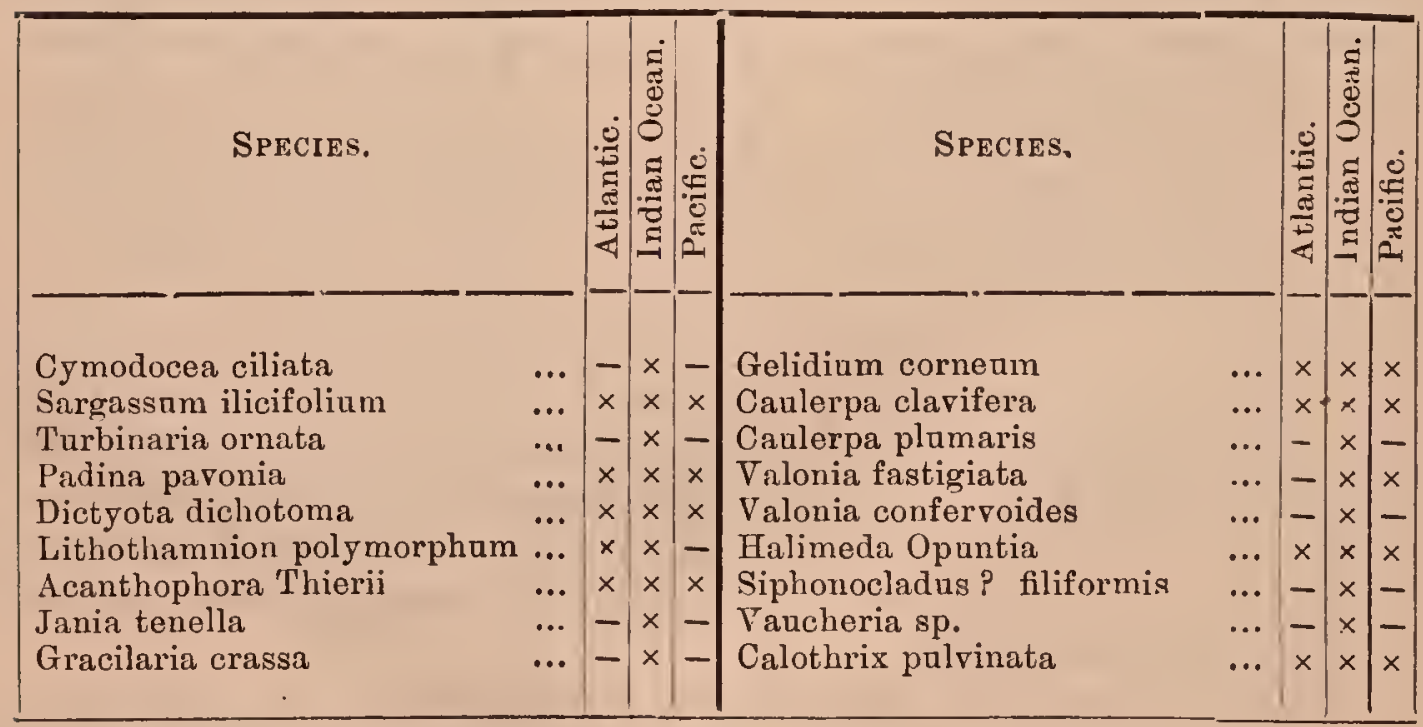

Nearly one-half of the species are cosmopolitan in tropical seas; probably some of the six of which the distribution is not accurately ascertained are also cosmopolitan. One species appears to extend 
only to the Pacific from the Indian Ocenn, another only to the Atlantic from the Indian Ocean. The Cymodocea, though present in Afriea, appears not to be recorded from the Mascarene Islands, and Sargassum ilicifolium though occurring in Malayan waters, has not yet been found on the coasts of Northern Australia. One speeies, Dictyota dichotoma, is rather more frequent in sub-tropieal than in tropieal seas and is eosmopolitan in both the northeru and the sonthern hemispheres.

The next group of species to be eonsidered-the "littoral "-ineludes many plants for which the evidence of introduetion by the sea is almost as palpable as in the case of the "marine" speeies themselves. They germinate on the beaches, and grow only near the sea, preferably in muddy creeks or on the sand or shingle; their fruits and seeds are found in every "drift" and the species themselves oceur on every Indian or Malayan eoast. Sueh are the true mangroves and the speeies like Avicennia, Aigiceras, Carapa, that are eonstantly assoeiated with the mangrove-vegetation; the sand-binding species like Ipomoea biloba, Euphorbia Atoto, Sesuvium Portulacastrum, Vigna lutea, Thuarea sar. mentosa; the tropieal sea-fenee of Pandanus adoratissimus, Desmodium umbellatum, Sophora tomentosa, Tournefortia argentea, Clerodendron inerme, Vitex Negundo, with its coneomitant climbing vegetation, Cana. valia obtusifolia, Ipomoea digitatu, Argyreia tilicefolia; the outer beachforest of Terminalia Catappa, Hernandia peltata, Evythrina indica, Stephegyne diversifolia; the inner beaeh forest of Cycas, Mimusops and Pisonia; and even the speeies of the mud-flats within, like Leea sambucina, Hibiscus tiliaceus, Cynometra ramiflora, Flagellaria indica and many more. The seeds of all these have been observed by the writer in the "drifts" of these islands and many of them hare been noted, either in the Andamans and Nieobars, or in Nareondam, germinating on the beaeh. There are others, however, that are more doubtful, and, though the whole of the speeies for whieh this mode of introduetion is coneeivable are given below, the speeies for whieh any donbt is possible are enclosed in braekets and the more equivocal of these are discussed at the end of the list.*

* Since this paper was written and while these pages have been passing through the press two papers have appeared that deal with this section of the flora of the Malayan conntries mach more fully than the scope of the present paper permits. To these papers, viz:-Schimper: Die Indo-Malayische Strandflora (Jena: Gastar Fischer, 1891) and Karsten: Ueber die Mangrove-Vegetation in Malayischen Archipel; Bibliotheca Botanica, Heft 22 (Cassel : Theodor Fischer, 1891) neither of which had appeared when the writer's remarks were written and which he greatly regrets having been nnable to refer to in the text, the writer would refer those who are interested in the subject of mangrove and coast plants and the influence of ocean-currents and their distribntion. 
TABLE XIV. Distribution of "littoral" species present in the Coco Group.

\begin{tabular}{|c|c|c|c|c|c|c|c|c|c|c|c|c|}
\hline \multirow{2}{*}{\multicolumn{2}{|c|}{ SPECIES. }} & & \multicolumn{2}{|c|}{ Atlantic. } & \multicolumn{4}{|c|}{$\begin{array}{l}\text { Indian } \\
\text { Ocean. }\end{array}$} & \multicolumn{2}{|c|}{$\begin{array}{l}\text { Malay } \\
\text { seas. }\end{array}$} & \multicolumn{2}{|c|}{ Pacific. } \\
\hline & & & 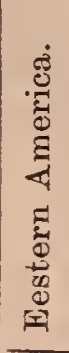 & 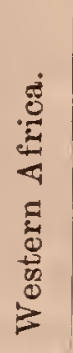 & 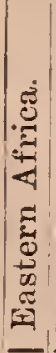 & 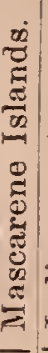 & 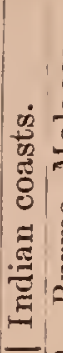 & 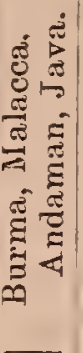 & 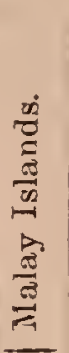 & 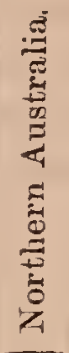 & 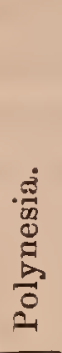 & 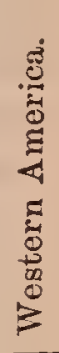 \\
\hline Calophyllum inophyllum & ... & & - & - & - & $x$ & $x$ & $x$ & $x$ & $x$ & $x$ & - \\
\hline Hibiscns tiliaveus & $\ldots$ & $\ldots$ & $x$ & $x$ & $x$ & $x$ & $x_{1}$ & $x$ & $x$ & $x$ & $x$ & $x$ \\
\hline 'Thespesia populnea & $\ldots$ & ... & - & $x$ & $x$ & $x$ & $x$ & $x$ & $x$ & $x$ & $x$ & - \\
\hline [Sterculia rubiginosa, $v a$ & $a r]$. & ... & - & - & - & - & - & $x$ & - & - & - & - \\
\hline 5. Heritiera littoralis & $\ldots$ & $\ldots$ & - & - & $x$ & $x$ & $x$ & $x$ & $x$ & $x$ & $x$ & - \\
\hline Carapa molnccensis & $\ldots$ & $\ldots$ & - & - & $x$ & $x$ & $x$ & $x$ & $x$ & $x$ & $x$ & - \\
\hline Colubrina asiatica & .. & ... & - & $x$ & $x$ & $x$ & $x$ & $x$ & $x$ & $x$ & $x$ & - \\
\hline Leea sambncina & ... & $\ldots$ & - & $x$ & $x$ & $x$ & $x$ & $x$ & $x$ & $x$ & $x$ & - \\
\hline [Leea hirta] ... & ... & .. & - & - & - & - & $x$ & - & - & - & - & - \\
\hline 10. [Dodonæa viscosa & $\ldots$ & $\ldots$ & $x$ & $x$ & $x$ & $x$ & $x$ & $x$ & $x$ & $x$ & $x$ & $x$ \\
\hline [Dracontonelum mangif & feruin] & ... & - & - & - & - & - & $x$ & $x$ & - & $x$ & - \\
\hline Desmodiam umbellatam & & $\cdots$ & - & - & $x$ & $x$ & $x$ & $x$ & $x$ & $x$ & $x$ & - \\
\hline [Desmodium triquetrum & & $\ldots$ & - & - & - & - & - & $x$ & $x$ & - & - & - \\
\hline [Desmodinm polycarpun & & ... & - & - & $x$ & $x$ & $x$ & $x$ & $x$ & $x$ & $x$ & - \\
\hline 15. Erythrina indica & $\cdots$ & $\ldots$ & - & - & - & $x$ & $x$ & $x$ & $x$ & $x$ & $x$ & - \\
\hline Mucuna gigartea & $\ldots$ & $\ldots$ & - & - & - & $x$ & $x$ & $x$ & $x$ & $x$ & $x$ & - \\
\hline Canavalia obtusifolia & ... & $\ldots$ & $x$ & $x$ & $x$ & $x$ & $x$ & $x$ & $x$ & $x$ & $x$ & $x$ \\
\hline Vigna lutea ... & ... & $\ldots$ & $x$ & $x$ & $x$ & $x$ & $x$ & $x$ & $x$ & $x$ & $x$ & $x$ \\
\hline Derris sinnata & $\cdots$ & $\cdots$ & - & - & - & - & $x$ & $x$ & $x$ & - & - & - \\
\hline 20. Derris nliginosa & ... & $\ldots$ & - & - & $x$ & $x$ & $x$ & $x$ & $x$ & $x$ & $x$ & - \\
\hline Pongamia glabra & ... & $\ldots$ & - & - & - & $x$ & $x$ & $x$ & $x$ & $x$ & $x$ & - \\
\hline Cæsalpinia Bondncella & $\cdots$ & $\ldots$ & $x$ & $x$ & $x$ & $x$ & $x$ & $x$ & $x$ & $x$ & $x$ & $x$ \\
\hline Cæsalpinia Nuga & ... & $\ldots$ & - & - & -1 & - & $x$ & $x$ & $x$ & $x$ & $x$ & - \\
\hline Sophora tomentosa & $\ldots$ & $\ldots$ & $x$ & $x$ & $x$ & $x$ & $x$ & $x$ & $x$ & $x$ & $x$ & - \\
\hline 25. Cynometra ramiflora & $\ldots$ & $\cdots$ & - & - & - & - & $x$ & $x$ & $x$ & $x$ & - & - \\
\hline Entada scandens & ... & $\ldots$ & $x$ & $x$ & $x$ & $\times$ & $x$ & $x$ & $x$ & $x$ & $x$ & - \\
\hline Rhizophora mncronata & $\ldots$ & $\ldots$ & - & - & $x$ & $x$ & $x$ & $x$ & $x$ & $x$ & $x$ & - \\
\hline Khizophora conjugata & $\cdots$ & $\ldots$ & - & - & - & - & $x$ & $x$ & $x$ & - & - & - \\
\hline Ceriops Candolleana & ... & $\ldots$ & - & - & -1 & - & - & $x$ & $x$ & $x$ & - & - \\
\hline 30. Ceriops Roxbnrghiana & $\cdots$ & ... & - & - & - & - & $x$ & $x$ & $x$ & - & - & - \\
\hline Bruguiera gymnorhiza & $\ldots$ & $\ldots$ & - & - & $?$ & $x$ & $x$ & $x$ & $x$ & $x$ & $x$ & - \\
\hline 'Terninalia Catappa & $\ldots$ & $\ldots$ & - & - & - & - & - & $x$ & $x$ & - & - & - \\
\hline Lumnitzera racemosa & $\ldots$ & $\cdots$ & - & - & $\times$ & $x$ & $x$ & $x$ & $x$ & $x$ & $x$ & - \\
\hline Gyrocarpus Jacquinii & $\ldots$ & $\ldots$ & $x$ & $x$ & - & - & $x$ & $x$ & $x$ & $x$ & $x$ & $x$ \\
\hline 35. Barringtonia speciosa & $\ldots$ & .. & - & - & - & $x$ & $x$ & $x$ & $x$ & $x$ & $x$ & - \\
\hline Barringtonia racemosa & $\cdots$ & $\cdots$ & - & - & $x$ & $x$ & $x$ & $x$ & $x$ & - & $x$ & - \\
\hline Pemplis acidula & & $\cdots$ & - & - & $x$ & $x$ & $x$ & $x$ & $x$ & $x$ & $x$ & - \\
\hline $\begin{array}{l}\text { Sesuviuun Portulacastru } \\
\text { Stephegrne diversifolia }\end{array}$ & & $\cdots$ & $x$ & $x$ & $x$ & $x$ & $x$ & $x$ & $x$ & $x$ & $x$ & $x$ \\
\hline $\begin{array}{l}\text { Stephegyne diversifolia } \\
\text { 40. Guettarda speciosa }\end{array}$ & $\cdots$ & $\cdots$ & - & - & - & - & - & $x$ & $x$ & - & - & - \\
\hline $\begin{array}{l}\text { 40. Guettarda speciosa } \\
\text { Ixora brunnescens }\end{array}$ & $\cdots$ & $\cdots$ & - & - & $x$ & $x$ & $x$ & $x$ & $x$ & $x$ & $x$ & - \\
\hline $\begin{array}{l}\text { 1xora brnnnescens } \\
\text { Morinda bracteata }\end{array}$ & $\begin{array}{l}\cdots \\
\ldots\end{array}$ & $\cdots$ & - & - & - & - & - & $x$ & - & - & - & - \\
\hline Adenostemma viscosnm & $\ldots$ & ... & $\bar{x}$ & $\bar{x}$ & $\bar{v}$ & - & $x$ & $x$ & $x$ & - & - & - \\
\hline Pluchea indica & $\ldots$ & & $\underline{-}$ & - & $x$ & $x$ & $x$ & $x$ & $x$ & $x$ & $x$ & $x$ \\
\hline 45. Wedelia scandens & .. & & $=$ & $=$ & - & - & - & $x$ & $x$ & - & - & - \\
\hline Scærola Kœnigii & $\ldots$ & & - & - & $\begin{array}{l}x \\
-1\end{array}$ & $\begin{array}{l}x \\
-\end{array}$ & $\begin{array}{c}x \\
x\end{array}$ & $\begin{array}{l}x \\
x\end{array}$ & $x$ & $x$ & $x$ & - \\
\hline
\end{tabular}




\begin{tabular}{|c|c|c|c|c|c|c|c|c|c|c|c|c|}
\hline \multirow[b]{2}{*}{ SPECIES. } & & & \multicolumn{2}{|c|}{ Atlantic. } & \multicolumn{4}{|c|}{ Indian Ocean. } & \multicolumn{2}{|c|}{$\begin{array}{l}\text { Malay } \\
\text { seas. }\end{array}$} & \multicolumn{2}{|c|}{ Pacific. } \\
\hline & & & 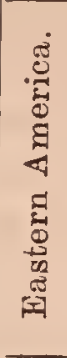 & 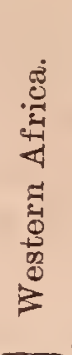 & 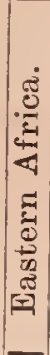 & 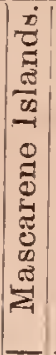 & 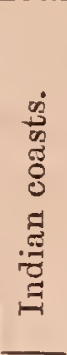 & 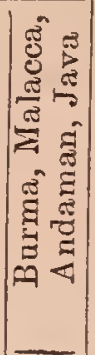 & 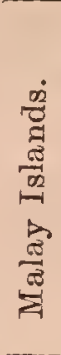 & 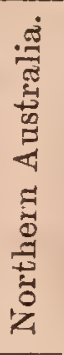 & 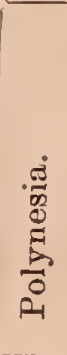 & 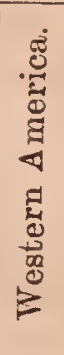 \\
\hline [Ardisia humilis] & $\ldots$ & & - & - & - & - & $x$ & $x$ & $x$ & - & - & - \\
\hline Aegiceras majus & ... & $\ldots$ & - & - & - & - & $x$ & $x$ & $x$ & $x$ & $x$ & - \\
\hline Mimusops littoralis & $\ldots$ & ... & - & - & - & - & - & $x$ & - & 一 & - & - \\
\hline 50. Cerbera Odollam & ... & $\ldots$ & - & - & - & - & $x$ & $x$ & $x$ & $x$ & $x$ & - \\
\hline Ochrosia borbonica & ... & $\ldots$ & - & - & - & $x$ & $x$ & $x$ & $x$ & - & - & - \\
\hline Tabernæmontana cris] & & .. & - & - & - & - & - & $x$ & - & - & - & - \\
\hline Sarcolobas giobosus & $\ldots$ & $\ldots$ & - & - & - & 一 & $x$ & $x$ & $x$ & - & - & - \\
\hline Cordia subcordata & $\ldots$ & $\ldots$ & - & - & $x$ & $x$ & {$[x]$} & $x$ & $x$ & $x$ & $x$ & - \\
\hline 55. Tournefortia argentea & $\ldots$ & $\ldots$ & - & - & $x$ & $x$ & $x$ & $x$ & $x$ & $x$ & $x$ & - \\
\hline Argyreia tiliæfolia & $\ldots$ & $\ldots$ & - & - & - & - & $x$ & $x$ & $x$ & - & - & - \\
\hline Ipomaa grandiflora & $\ldots$ & $\ldots$ & - & - & $x$ & $x$ & $x$ & $x$ & $x$ & $x$ & $x$ & - \\
\hline Ipomæa digitata & $\ldots$ & $\ldots$ & $x$ & $x$ & $x$ & $x$ & $x$ & $x$ & $x$ & $x$ & $x$ & $x$ \\
\hline Ipomæa denticulata & $\ldots$ & $\ldots$ & - & - & - & $x$ & $x$ & $x$ & $x$ & $x$ & $x$ & - \\
\hline 60. Ipomæa biloba & ... & $\ldots$ & $x$ & $x$ & $x$ & $x$ & {$[x]$} & $x$ & $x$ & $x$ & $x$ & $x$ \\
\hline Convolvalus parvifloru & & $\ldots$ & - & - & - & - & $x$ & $x$ & $x$ & $x$ & - & - \\
\hline Physalis minima & $\ldots$ & $\ldots$ & $x$ & $x$ & $x$ & $x$ & $\times$ & $x$ & $x$ & $x$ & $x$ & $x$ \\
\hline [Oroxylum indicam] & $\cdots$ & $\ldots$ & - & - & - & - & $x$ & $x$ & $x$ & - & - & - \\
\hline Eranthemum succifolic & $\mathrm{am}$ & $\ldots$ & - & - & - & - & - & $x$ & $?$ & - & - & - \\
\hline 65. [Peristrophe acuminat & ta] & ... & - & - & - & - & - & $x$ & $x$ & - & - & - \\
\hline [Lippia nodiflora] & $\ldots$ & $\ldots$ & $x$ & $x$ & $x$ & $x$ & $x$ & $x$ & $x$ & $x$ & $x$ & $x$ \\
\hline Premna integrifolia & $\ldots$ & $\ldots$ & - & - & - & - & $x$ & $x$ & $x$ & $x$ & $?$ & - \\
\hline Premna sp. & $\ldots$ & ... & - & - & - & - & - & $x$ & ? & ? & - & - \\
\hline Vitex Negundo & ... & $\cdots$ & - & - & $x$ & $x$ & $x$ & $x$ & $x$ & - & - & - \\
\hline 70. [Vitex pubescens] & $\ldots$ & $\ldots$ & - & - & - & - & $x$ & $x$ & $x$ & - & - & - \\
\hline [Vitex Wimberleyi] & ... & $\ldots$ & - & - & - & - & - & $x$ & - & - & - & - \\
\hline Clerodendron illelme & $\cdots$ & $\cdots$ & - & - & - & - & $x$ & $x$ & $x$ & $\times$ & $x$ & - \\
\hline Avicennia officinalis & $\ldots$ & $\ldots$ & $x$ & $x$ & $x$ & $x$ & $x$ & $x$ & $x$ & $x$ & - & $x$ \\
\hline Boerhaavia repens & $\cdots$ & $\ldots$ & - & $x$ & $x$ & $x$ & $x$ & $x$ & $x$ & $x$ & $x$ & - \\
\hline 75. Pisonia aculeata & ... & ... & $x$ & $x$ & $x$ & $x$ & $x$ & $x$ & $x$ & $x$ & - & - \\
\hline [Pisonia excelsa] & $\ldots$ & $\ldots$ & - & - & - & - & - & $x$ & $x$ & - & - & - \\
\hline Achyranthes porphyri & istachya & $\ldots$ & - & - & - & - & $x$ & $x$ & $x$ & - & - & - \\
\hline Hernandia peltata & ... & $\ldots$ & - & - & - & $x$ & $x$ & $x$ & $x$ & $x$ & $x$ & - \\
\hline Cassytha filiformis & $\ldots$ & $\ldots$ & $\times$ & $x$ & $x$ & $x$ & $x$ & $x$ & $x$ & $x$ & $x$ & $x$ \\
\hline 80. Enphorbia Atoto & ... & ... & - & - & - & - & $x$ & $x$ & $x$ & $x$ & $x$ & - \\
\hline Macaranga Tanarius & ... & $\ldots$ & - & - & - & - & 一 & $x$ & $x$ & - & - & - \\
\hline Cycas Rumphii & ... & $\ldots$ & - & - & - & - & $x$ & $x$ & $x$ & $x$ & - & - \\
\hline Crinum asiaticum & $\ldots$ & ... & - & - & - & - & $x$ & $x$ & $x$ & $x$ & $x$ & - \\
\hline Tacca pinnatifida & $\ldots$ & $\ldots$ & - & $x$ & $x$ & $x$ & $x$ & $x$ & $x$ & $x$ & $x$ & - \\
\hline 85. Dracæena angustifolia & $\ldots$ & $\ldots$ & - & - & - & - & - & $x$ & $x$ & $x$ & - & - \\
\hline [Gloriosa superba] & $\ldots$ & ... & - & - & - & - & $x$ & $x$ & $x$ & - & - & - \\
\hline Flagellaria indica & $\ldots$ & ... & - & - & $x$ & $x$ & $x$ & $x$ & $x$ & $x$ & - & - \\
\hline Caryota sobolifera & ... & ... & - & - & - & - & - & $x$ & $x$ & - & - & - \\
\hline [Cocos nucifera] & $\ldots$ & .. & $x$ & $x$ & $x$ & $x$ & $x$ & $x$ & $x$ & $x$ & $x$ & $x$ \\
\hline 90. Pandanus odoratissim & & $\ldots$ & - & - & - & $x$ & $x$ & $x$ & $x$ & $x$ & - & - \\
\hline Cyperus pennatus & $\ldots$ & ... & - & - & - & $x$ & $x$ & $x$ & $x$ & $x$ & $x$ & - \\
\hline Fimbristylis ferragine & & $\cdots$ & $x$ & $x$ & $x$ & $x$ & $x$ & $x$ & $x$ & $x$ & $x$ & $x$ \\
\hline Thuarea sarmentosa & $\ldots$ & .. & - & - & - & $x$ & $x$ & $x$ & $x$ & $x$ & $x$ & - \\
\hline Ischæmam muticum & $\ldots$ & ... & - & - & - & - & - & $x$ & $x$ & $\times$ & $x$ & - \\
\hline
\end{tabular}


This list includes 94 species for which sea-introduction is conceivable, and for the presence of most of the species it contains this mode of introduction is almost certainly responsible. The list might even be made more extensive than it is, for if Sterculia rubiginosa, which is a purely "littoral" species here as it is elsewhere throughout the Andaman and Nicobar groups-to which area the variety found in the Coco Islands is strictly confined,- - be sea-introduced, there is no reason why some of the other species of Sterculia should not be added. As a matter of fact the writer has collected specimens of species of Sterculia in Narcondam and in Batti $\mathrm{Malv}$, the first island a locality where certainly, the second one where probably, every species present has been somehow or other introduced. But no Sterculia seeds were recognised in the "drifts" and therefore the whole of the species have been left out except this purely 'littoral" one, while even it has been omitted from consideration in the analysis of the table which follows. Again, Leea hirta might well be sea-introduced if Leea sambucina is; their fruits are very similar and Leea fruits are common in the "drifts." All the fruits found, however, were precisely the same and seemed to be undoubtedly those of Leea sambucina, which is a very common species in the mud flats that skirt the mangroveswamps, where it occurs as a considerable shrub or small tree with stilted roots that imitate the style and appearance of those of the mangroves. Both species, however, may have been introduced by fruitcating birds; only one therefore, owing to its habitat, is taken as an example of this mode of introduction, the other bcing relegated to the list of species that are bird-introduced. Another species to which the same remarks apply is Ardisia humilis, which is a purely beach-forest species and, as such, is equally common here, on Narcondan, in the Andamans, and in the Nicobars; perhaps it is, on the whole, more likely to have been introduced owing to birds having eaten its purple-berried fruit. Allophylus Cobbe, which is almost certainly bird-introduced, may be quoted in support of this, for though it also occurs in the interior it is a common tree in the Pandanus fence and in the beach-forcst. Dracontomelum manyiferum might be a sea-introduced species, for $\mathrm{Mr}$. Hemsley records a Dracontomelum? fruit from the New Guinea "drift", with cmpty seedcells however (Challenger Reports; Botany, vol. i, part 3, p. 290). And if Dracontomelum be included so night Spondias and Canarium, for though birds and bats eat the pulpy fruits of these species they cannot swallow the stone and, as in the case of Terminalia Catappa, can hardly do more than assist in dispersing them locally. Desmodium triquetrum and Desmodium polycarpum are both very common on the rocky parts of the coast just above the spray-line and their fruits therefore are extremely common in the "drifts." But it is not at all clear that they must therefore 
be put down in the list of sea-introduced species; they are well-known as weeds of cultivation elsewhere, being diffused because of the readiness with which the indehiscent segments of their fruits attach themselves to the clothes of man and to the fur of his domestic animals. Here they are undoubtedly not weeds introduced by man, but it may well be that they have been introduced by birds, owing to fragments of their pods having attached themselves to their feathers. Another species to which the same remarks apply is Adenostemma viscosum, though this is more probably sea-introduced than the other; still another is Boerhaavia repens; perbaps all four are distributed at one time by the sea, at another by birds. Lippia nodiflor a may also be a bird-introduced species ; its seeds may have been brought in the pellets of mud that become attached to the feet, and to the feathers at the base of the bill of wading-and swimming-birds. Achyranthes porphyristachya which, from its situation in these islands, cannot be a weed introduced by man, and which is a common sea-shore species in the Nicobars and in the Laccadives also, may perhaps be bird-introduced like the Desmodia. If, as is suggested, now one agency, now another is responsible for the dispersal of these species, it is easy to understand why those species should all be "littoral" in these islands and yet occur as inland species in other localities. Mucuna gigantea will be readily admitted as an unequivocal example of this mode of distribution, as will Derris sinuata, for both occur in the beach-forest more commonly than they do on the ridges; so too, will the other Leguminosce of the list except perhaps Entada scandens. And yet Entada scandens must be sometimes an introduced species, for it is one of the plants that occur on Narcondam, an island for which it seems impossible to postulate any previous land-connection; the writer moreover had the good fortune to find one of its enormous seeds germinating along with those of Mucuna, etc., on the sandy islet between Great Coco and Jerry.

Physalis minima is a specics that at first suggests bird-introduction rather than sea-introduction, and its wide inland dispersal undoubtedly is largely owing to its fruits being eaten and to the subsequent voiding of its hard discoid seeds. But here it is only found close to the sea just above the spray-line and its fuits were found in the "drifts" here and there, the light bladder-like calyx amply accounting for their flotation; the pulp of the fruit probably protects the seeds, if such protection be necessary, from the action of the salt water. Among the Convolvulacece, for which this means of dispersal is not at all uncommon, the only species now included that calls for remark is Convolvulus parviflorus. It is, however, one of the commonest of the sea-face creepers along the west coast of Great Coco, and is equally common on Narcondam, Barren 
Island, Rutland Island and Batti Malv, and is included in the list without any feeling of doubt in the mind of the writer. On the other hand, indeed, it is with some diffidence that another species, Ipomiea Turpethum, is omitted. All three species of Vitex given are "littoral," but while there seems no doubt that Vitex Negundo is sea-introduced, it is on the whole more probable that the others are introductions by fruit-eating birds. Macaranga Tanarius is also a species that from it:s habitat the writer has no hesitation in considering a sea-introduced species; another that he would have wished to include is Blachia andamanica which occurs on the coast with Desmodium umbellatum, Pluchea indica and other unequivoca!ly littoral species. Moreover there are several of these shrubby and arborcous Euphorbiacece on Narcondam; their presence there indicates that some mode of introduction for species of this order must be possible. In the absence, however, of direct experiment with their seeds the others have been left to swell, probably unduly, the list of "remanent" species. Tacca pinnatifida, which is an inland as well as a coast species, may be bird-introduced, for its seeds are embedded in a sweet pulp. But though a species of ant is very fond of this fruit and scoops out all the ripe pulp, leaving the seeds bare but uninjured in an otherwise empty bag, no bird, so far as the writer could see, appears to eat them. The twu Pisonias, one a climber, the other a tree, are both "littoral" and so may well be sea-introduced, but as both have peculiar fruits with glutinous lines along their sides they may equally well be bird-introduced species. The sticky lines along the angles of the fruits of Pisonia excelsa in particular have all the tenacity of bird-lime. As this species occurs some way inland as well as along the coast there is little doubt that, even if sea-introduced, its further dispersal is assisted by ground-feeding birds or small mammals. The fruits of two species of Dipterocarpus were seen in the "drifts," but the writer has no hesitation, from what is known regarding the delicacy of the seeds in this order and the rapidity with which their power of germinating is lost, in excluding both from the list. From what has already been said regarding "civilized" species it will be seen that though Cocos nucifera is undoubtedly capable of being introduced by the sea, it is probably not to this agency that its presence in these islands is due. Caryota sobolifera, however, which is throughout the whole Andaman group a very common species, both on flat and on rising ground, and which is as common on Narcondam as in the Cocos, is probably a sea-introduced species.

Peristrophe acuminata is another species that affects only the localities in which Desmodium polycarpum and its companions are found and ought probably to be included among the littoral species; in the absence 194 
of further evidence, however, it is treated as only doubtfully seaintrodnced. Another doubtful species is Dodoncea viscosa, a cosmopolitan species. Still another, equally doubtful, is Gloriosa superba which is exceedingly common in the coast zone on both the Coco Islands, and which the writer has collected, in the coast zone also and only there, in South Andaman, in Rutland Island, in Batti Malv, in Car Nicobar, in Narcondam, and in Barren Island, and which Dr. Alcock has collected, near the sea, in the Laccadives. On the whole therefore we might feel justified in considering it a sea-introduced species. But it is very abundant also throughout the whole of India; it extends from the Nilghiris and Central India to Rajputana, the Panjab, and the Gangetic plain, as well as to the Himalaya from Kamaon to Bhutan, and is common in Bengal, Assam and Burma. It cannot very easily be bird-introduced and one must therefore incline to the opinion that the agency responsible here is that of winds, a view which is favoured by the nature of its seeds. But even then it is not easy to suppose that winds could carry these as far as some of the islands mentioned and still that its distribution should be limited to South-Easteru Asia. Oroxylum indicum might possibly be sea-introduced, but on the whole has more probably been brought by wind. It need not be indigenous for it occurs in abundance in Narcondam. Though its fruits occur in the "drifts" they are always split open and it is unlikely that the seeds could remain attached to the fruit-segments during their transit from any of the neighbouring coasts.

Few of the cryptogams can be considered "littoral " and the statements that have been made of the possibility of $F$ ungi, etc., being brought to ocean-islands attached to logs of wood or trunks of trees are not as a rule made by those who have seen and carefully examined ocean-drifts. Even Polyporus sanguinale, which apparently has a prediliction for dead or dying trunks of Cocos nucifera, being commoner there than in any other situation, was not found growing on any of the trunks that lie on the beaches exposed to the sun after having been soaked in salt water. The logs that are cast up on the beach and the roots that protrude from the sand at those points where denudation is going on, are scrubbed bare by the coral-sand and bleached white by the sun; they harbour no Fungi and seem preserved from decay by the treatment to which they have been subjected. There is, however, a striking exception in a "dry-rot" which attacks Iimusops littoratis trunks and some other timbers. In the case of the Bullet-wood it was seen both on Great and Little Coco; the same appearance was presented by the remains of a wooden vessel in Little Coco. The appearance and consistence of this "dry-rot" so closely resemble the results of charring that it was difficult to realize that the wood in question had not been subjected to 
fire. The effects of actual charring were, however, observed in the hollow trunk of a large Mimusops near the shelter huts at the south end of Great Coco ; closer comparison shows that the product of the Fungus has a facies of its own unlike that of true charcoal. This difference is difficult to express in words, but is very recognisable when the two things are placed side by side. The phenomenon was not noticed in the case of Erythrina, Heritiera, Stephegyne, or other dead trees on the beach.

Excluding from consideration all the doubtful species enclosed in brackets we find that there are 80 unequivocally sea-introduced plants, or more than one-fourth of the phanerogamic species and over 22 per cent. of the entire flora. On consulting the distribution it is seen how greatly the coast flora is one characteristic of the Indian Ocean and of Malayan Seas, particularly the latter, since 76 species, or 97 per cent, occur on the shores of the Malay Islands, whereas only 66, or 83 per cent., occur on the Indian coasts of the Sea of Bengal. Moreover one of these, Sarcolobus globosus, might almost be omitted, its only Indian locality being the Sunderbuns, at the head of the Bay of Bengal. Another, Ipomcea denticulata, though extending up the eastern side of the Bay to the coast of Arracan, is, on the western side, confined to Ceylon. This indication of a tendency to extension eastward is borne out by the features of the further distribution of these species, for 60 species, or 76 per cent., extend south-eustward to the shores of northern Australia, while only 47, or 59 per cent., extend south-west to the Mascarene Islands; and 51 species, or 64 per cent., occur in one or other of the Polynesian groups, while only 36 , or 46 per cent., reach continental East Africa. But, while this is the case, it is interesting to note that 21 species, or 24 per cent., occur on the AfricanAtlantic coast, and 15 species, or 19 per cent., cross the Atlantic to the Eastern coasts of America, whereas only 13 species, or 16 per cent., extend across the Pacific from Polynesia to the Western American coasts. These features of the littoral flora are given more compactly in the subjoined table.

Table XV. Extension of "littoral" species present in the Coco Group.

\begin{tabular}{|c|c|c|c|c|c|c|c|c|c|}
\hline \multicolumn{5}{|c|}{$\begin{array}{l}\text { Species } \\
\text { extending westward to }\end{array}$} & \multirow{2}{*}{$\begin{array}{c}\text { Species } \\
\text { present in the }\end{array}$} & \multicolumn{4}{|c|}{$\begin{array}{l}\text { Species } \\
\text { extending eastward to }\end{array}$} \\
\hline 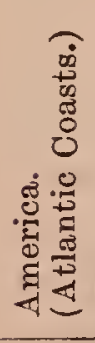 & 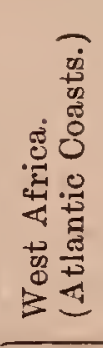 & 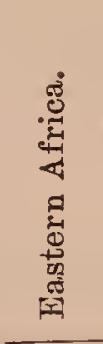 & 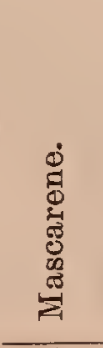 & 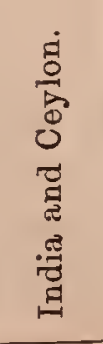 & & 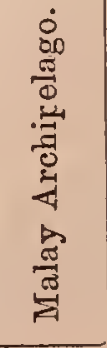 & 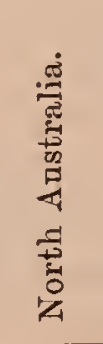 & $\begin{array}{l}\text { 要 } \\
0 \\
0 \\
0 \\
0 \\
0 \\
0\end{array}$ & 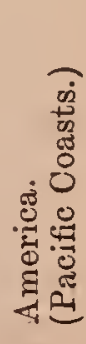 \\
\hline 15 & 21 & 36 & 47 & 66 & 80 & 76 & 60 & 51 & 13 \\
\hline $19 \%$ & $24 \%$ & $46 \%$ & $59 \%$ & $83 \%$ & $100 \%$ & $97 \%$ & $76 \%$ & $64 \%$ & $16 \%$ \\
\hline
\end{tabular}


An analysis of the table of distribution from the opposite point of view is given below ; from it we learn that 11 spccies, or 14 per cent., are cosmopolitan on tropical sea-shores; that four more are nearly cosmopolitan, being present in both hemispheres; that only four, so far as is known, are limited to the coasts of these islands, the Andamans and the Nicobars; and that, excepting these four, every one of the species is found on the Malayan Coasts. So far then as the "littoral" species are concerned we must conclude that the flora of the Coco Group is decidedly Malajan.

Table XVI. Analysis of distribution of "Littoral" species.

Present on both Pacific and Atlantic coasts :- ....................

Cosmopolitan on tropical sea-shores : $\ldots \ldots \ldots \ldots \ldots \ldots \ldots \ldots \ldots \ldots$ 11

Almost ditto, (present in both hemispheres):- $\ldots \ldots \ldots \ldots \ldots . .4$

Absent from Pacific American coasts only :- ........ 2

Absent from Pacific Polynesian coasts only ........... 1

Absent from Eastern African and Mascarene coasts only 1

Absent from New World entirely :- .......................... 4

Present on Atlantic and Indian Ocean (not on Pacific) coasts .......... 1

Present on Pacific and Indian Ocean (not on Atlantic) coasts .......... 33

Extending from Africa to Polynesia :- .................. 15

On all intervening shores $:-\ldots \ldots \ldots \ldots \ldots \ldots \ldots \ldots, 14$

Absent only from Northern Anstralia ............. 1

Extending from Mascarene islands to Polynesia :- .......... 9

Extending from India to Polynesia .................... 8

Extending from Coco Islands to Polynesia $\ldots \ldots \ldots \ldots \ldots \ldots \ldots \ldots$

Confined to Indian Ocean and MIalayan Seas $\ldots \ldots \ldots \ldots \ldots \ldots \ldots \ldots . . . .27$

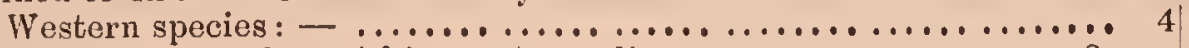

Extending from Africa to Anstralia : $\ldots \ldots \ldots \ldots \ldots{ }_{2}$

In both Africa and Mascarenes ........... I

In Mascarenes, not in Africa............. 1

Extending from Africn to Malaya only ..............

In Continental Africa, not in Mascarenes .....
In Mascarenes, not in Africa.............

Wastern species :-............................ 6

Extending from Australia to India $\ldots \ldots \ldots \ldots \ldots \ldots \ldots \ldots$
Extending from Australia to the Coco Groap $\ldots \ldots \ldots \ldots$

Central species $:-\ldots \ldots \ldots \ldots \ldots \ldots \ldots \ldots \ldots \ldots \ldots \ldots$

Extending from India to Malaya .............. 8

Extending from Coco Gronp to Malaya ............ 5

Fixtending from $\mathrm{C}$ oco Group to Nicobars only $\ldots . . . . . .4$

Total number of "Littoral" speciss. ................... $\overline{80}$

In discussing the inland "immigrant" species the first agency to be considered is that of winds. This influence must here be stronger 
than in many places, for though the south-west monsoon, which blows for half the year, sweeps only over a wide expanse of sea before it reaches the islands, there is a very distinct and tolerably powerful north-east monsoon which, during a considerable part of the remaining half-year, blows from the direction of the adjacent Burmese coast.

It is, however, easy to overrate the effect of this agency and however well adapted certain friuts, such as those of the two Dipterocarpi, Terminalia bialata, Pterocarpus indicus, Sterculia companulata, Porana spectabilis, Illigera conyzadenia, Ventilago calyculata, or seeds, such as those of Sterculia alata, Gloriosa superba, Aristolochia tagala, may at first sight appear to be for transmission by wind, it seems very doubtful on further consideration if any of those mentioned could possibly be carried so far as from the ncarest mainland to these islands. In most of these cases the wings of the fruits or seeds can only, as in that of Gyrocarpus, assist in local dispersal. Regard must be paid, too, to the usual situation of the species, and in the case of Orchids, for example, the seeds of which are light, and well adapted for carriage in this way, it is doubtful if Calanthe veratrifolia, which is always found in densely shady places, could have been brought in this way. Similarly among the inland Cryptogams, for all of which except Chara this means of dispersal is doubtless possible, it seems more probable that Acrostichum appendiculatum, which affects the same localities as Calanthe, and Ceratopteris thalictroides, which undoubtedly is sometimes, if not always, bird. introduced, ought to be excluded from this list.

'The table below gives the whole of the possibly "wind-introduced" species present in the group.

TABLE XVII. Distribution of Wind-introduced "inland" species present in the Coco Group.

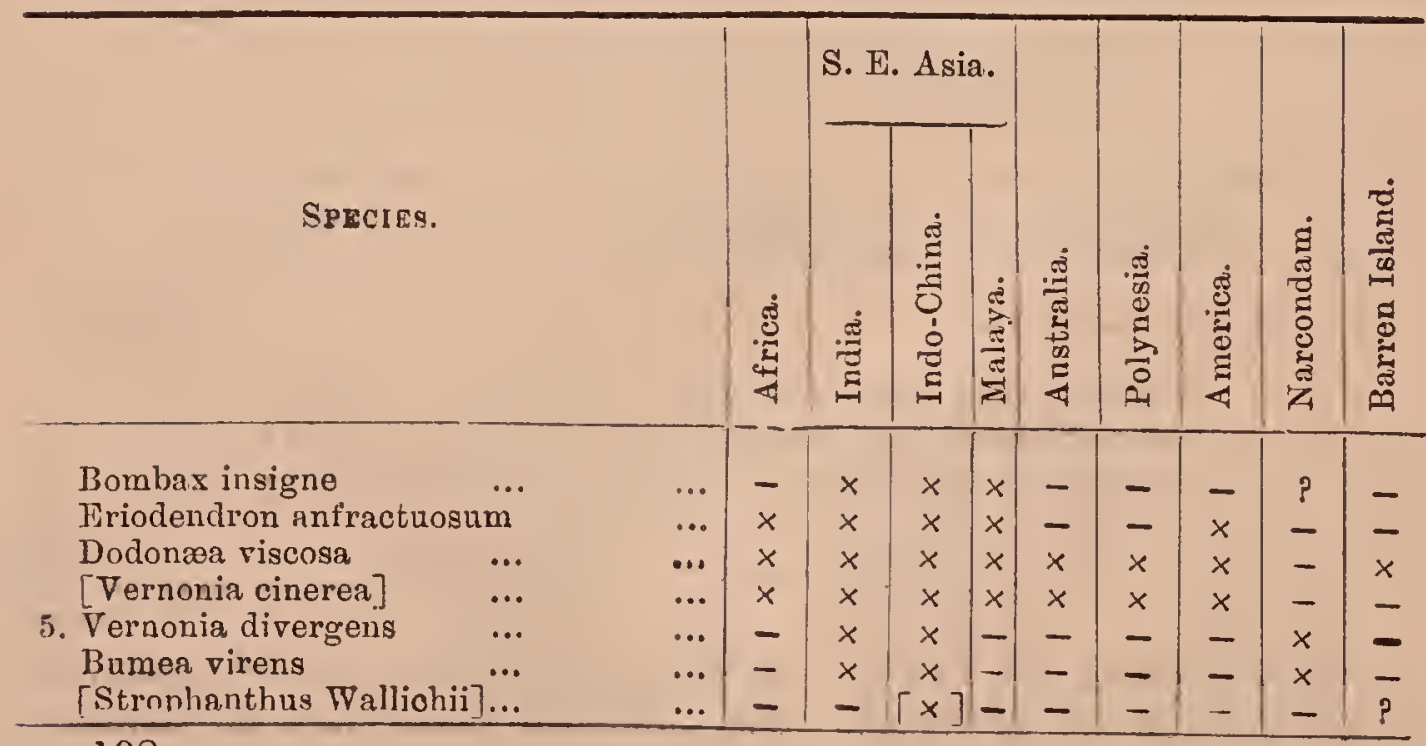

198 


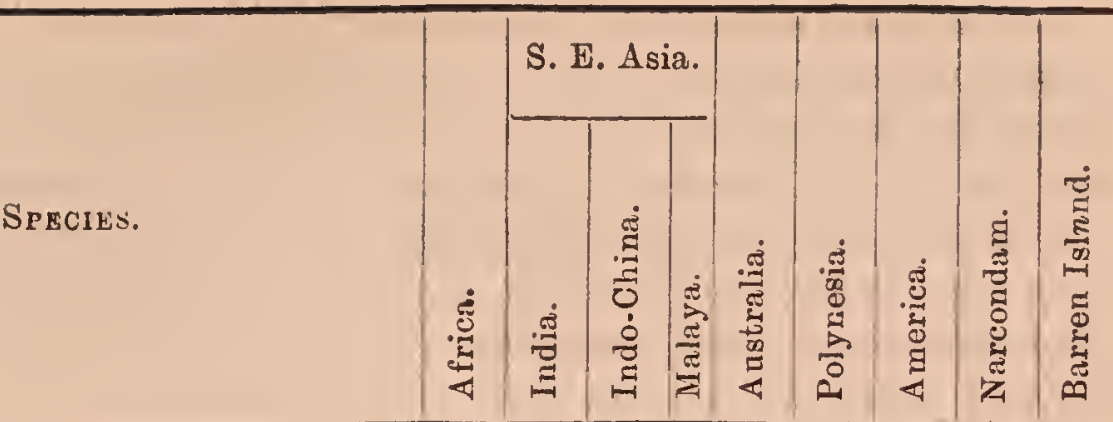

Anodendron paniculatum

Chonemorpha macrophylla

10. Hova parasitica

Hoya diversifolia

Dischidia nummularia ...

Oroxylnm indicum ...

Heterophragma adenophyllum

15. Aristolochia tagala

Dendrobium secundum ...

[Calanthe veratrifolia] ...

Dorites Wightii

Aërides maltiflorum

20. Pholidota imbricata

Dioscorea glabra

Dioscorea pentaphylla

Gloriosa superba $\quad \ldots$

[Ischremmm ciliare]

25. [Andropogon contortus] ...

Davallia solida

Adiantum lunulatum $\quad \ldots$

Polypodiam irioides $\quad$...

Poly podium adnascens ...

30. Poly podium quercifolium...

Vittaria elongata

Acrostichum scandens ...

[Acrostichum appendiculatum]

Lygodium flexuosum ...

35. Calymperes Dozyanum ...

Bryam coronatum

Collema nigrescens

Physcia obscura

Lentinns lencochrons $\quad \cdots$

40. Lenzitcs deplanata

Lenzites subferruginea $\quad .$. .

Polyporas fulvas $\quad$...

Polyporus xanthopus

Polyporus sanguineas

45. Polyporus grammatoceptalus

Polyporns australis

Hexagona pergamenea ...

Hexagona sericeo-hirsuta

Hexagona tenuis

50. Dedrelea flabellum

Dedælea sanguinea

Dedælea quercina

Dedælea concentrica

Thelephora incrustans

55. Bovista lilacina

Hirneola polytricha $\quad .$.

Daldinia vernicosa

Rhytisma sp. ...

\begin{tabular}{c|c|c|c|c|c|c|c|c|c}
$\ldots$ & - & $x$ & $x$ & $x$ & - & - & - & $x$ & - \\
$\ldots$ & - & $x$ & {$[x$} & $x$ & - & - & - & $x$ & - \\
$\ldots$ & - & - & $x$ & $x$ & - & - & - & $x$ & $x$ \\
$\ldots$ & - & - & $x$ & $x$ & - & - & - & $x$ & $x$ \\
\end{tabular}

$\begin{array}{llllllllll}\ldots . . & - & x & \times & x & - & - & - & x & x\end{array}$

... - - $-x$ - - - - - $x$ -

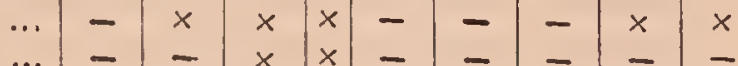

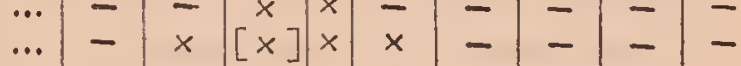

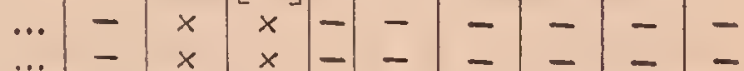

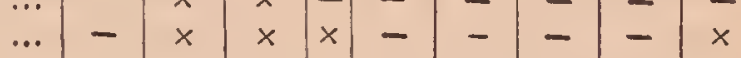

$\begin{array}{llllllllll}. . . & - & x & x & x & - & - & - & x & x\end{array}$

$\begin{array}{llllllllll}\cdots & = & x & x & x & - & - & - & x & x \\ x & x & x & - & - & - & x & x\end{array}$

$\begin{array}{llllllllll}\ldots & - & x & x & x & - & - & - & x & x \\ \ldots & - & x & x & x & x & - & - & - & x\end{array}$

$\begin{array}{lllllllllll}\ldots & x & x & x & x & x & x & x & - & x\end{array}$

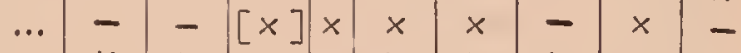

$\ldots x \times x \times x$

... $x \times$

$\ldots \times x$

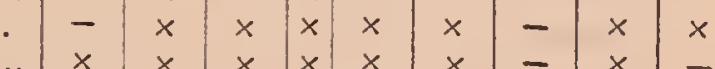

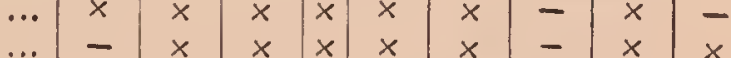

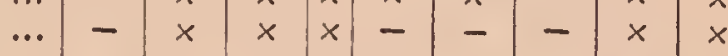

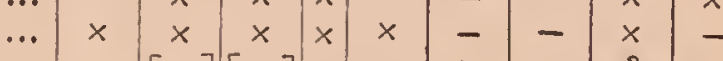

... - $[x][x] \times-1 \times-$

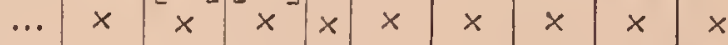

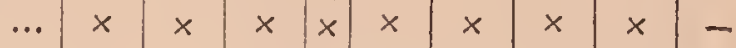

... $\times$

... $x\left[\begin{array}{c}x \\ x\end{array}\right] x$

... -

$-x \times x=$

$\cdots-$

... $x$

$\cdots \times x \quad x \quad x$

… $-1 \times x \quad x \quad x \quad x$

$\ldots \times \times \times \times$

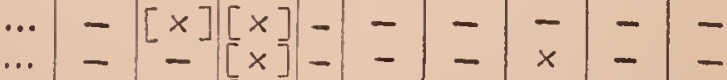

... $\times-[x]----$

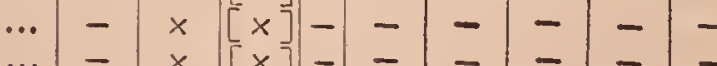

$\begin{array}{cccccccccc}\ldots & - & x & {[x]} & - & - & - & - & - & - \\ \ldots & x & x & x & x & x & x & x & ? & -\end{array}$

$\ldots \times x \times x$

... $\times x \times x$

$\times \times x$

... $x$

... $x$

... - 
It will be seen that the majority of the species in this table are actually present in one or other of the two volcanic islands of the Andaman Sea, Narcondam and Barren Island, and even in these cases where they are not present allied species are. There is a Bombax in Narcondam and though its specific identity or otherwise with the Andamans one cannot be here discussed, it is evident that any Bombax may be wind-introduced. And whatever agency explains the presence of Bombax will, pari passu, explain that of Eriodendron.

Not a single orchid was found on Narcondam though on Barren Island two were found-a species of Dendrobium on trees on the outer cone, and Pholidota imbricata, which occurs at the top of the inner cone within the crater-cup where the ground is kept moist by the condensation of escaping steam. Then the Hoyas are both present in great abundance on the exposed rocks and tall trees of both islands. The most doubtful species undoubtly are Aristolochia tagala, Gloriosa superba, and, especially, the two species of Dioscorea. Yet these must all be immigrant. The writer has collected Aristolochia tagala on Batti Malv, a small outlying uninhabited fragment of the Nicobar Group, on Barren Island, and on Narcondam. And even if it be claimed that on Batti Malv the species may be a remanent one on the other two islands it, like every other species, must be immigrant. The case of Gloriosa superbu has already been discussed when dealing with the species introduced by the sca. The Dioscoreas are still more difficult to explain, but it hardly seems as if they could be bird-introduced, and it is almost as difficult to think that they have been introduced by the sea. They are never littoral, being even in these islands strictly confined to the higher dry ridges. Yet they are certainly not necessarily remanent, for the writer has collected not these only but a third species, Dioscorea bulbifera, or at all events a bulbiferous one, which is present along with these two in great quantity in Narcondam and especially in Barren Island. In both thesc islands the species must all be immigrant and fron the physiographical history of Barren Island should there be, biologically speaking, extremely recently so. Though no Strophanthus occurs in Barren Island, an Aganosma is common therc. The distribution of the Cryptogams of this class calls for little remark, the pcculiarities displayed in this respect by the F'ungi being probably altogether owing to this class being imperfectly known in most floras. The presence, for instance, of two species here that are recorded only from North Amcrica probably implies that they are both in reality cosmopolitan or nearly so.

To the 58 species enumerated above should be added six imperfectly represented Cryptogams, giving a total of 64 species; the following table cuntains an analysis of their distribution. 
TAFLE XVIII. Analysis of the distribution of Wind-introduced species. Species present in both hemispheres:-........................ 21

Cosmopolitan in the tropics (Phanerog. $3 ;$ Cryptog. 12) .............. 15

Almost Cosmopolitan (Phanerog. $1 ;$ Cryptog. 5) $\ldots . \ldots \ldots \ldots \ldots, 6$

In Africa, Asia, Polynesia, America (Cryptog.)......... 2

In Africa, Asia, America (Phanerog.) ..................... 1

In Asia, Anstralia, America (Cryptog.) ....................... 1

In Asia, America (Cryptog.) ................................

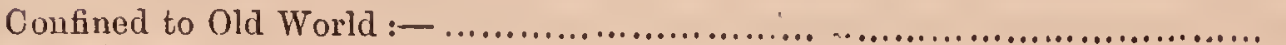

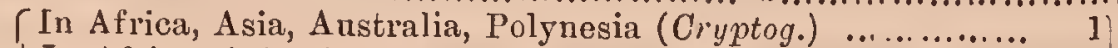

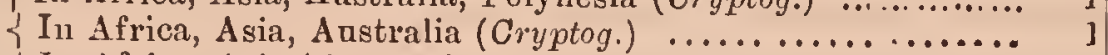

(In Africa, Asia (Cryptog.) .......................... ]

In Asia, Australia, Polynesia (Cryptog.) $\ldots \ldots \ldots \ldots \ldots \ldots . . . \ldots$

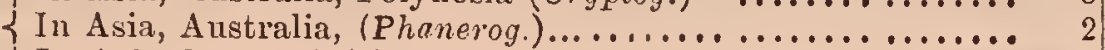

(In Asia, Polynesia(Cryptog.) ..................... 1

Confined to Asia, (Phanerog. 18; Cryptog. 16) $\ldots \ldots \ldots \ldots . . . . .34$

'T'otaL of possibly wind-introduced species :- $\ldots \ldots \ldots \ldots \ldots \ldots, 64$

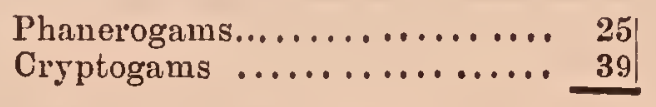

We thus see that 32 per cent. of the species are cosmopolitan, but that at the same time as many as 53 per cent. are confined to SouthHastern Asia, figures which tend to shew that the agency of wind appears to be less active than we might expect. So far as the more local distribution is concerned we find that 40 species, or 62 per cent., may have reached the islands either from Indo-China or from Malaya ; 10 species, or 15 per cent., appear to be local species; 3 species appear to have reached the islands from Malaya and one must have come either from Malaya or Ceylon, these four are, however, all Cryptogams and may possibly yet be found in Indo-China. Even if it be assumed that these do not occur in Burma, it.leaves the south-west monsoon responsible for the introdnction of only $6 \frac{1}{2}$ per cent. of this group of species. The remaining 10 species, or about 16 per cent. of the class, have more probably been introduced by the north-east monsoon, a circumstance that might be expected, seeing that this monsoon blows from the direction of the nearest land. And as this is the case it will follow that the probability is strong that most of the species which may, so far as their present distribution indicates, have come either from Indo-China or Malaya have in reality come from the north-east. The only species of the kind for which this is doubtful is Chonemorpha macrophylla, which, though abundant in India and in the Himalaya, and equally so in Malaya and in the Andamans, has not yet been recorded from any part of Indo-China to the east of Khasia and Sylhet.

The last group of introduced species-those carried by birds-has now to be considered. In discussing this it its necessary to distinguish 
between species the seeds or fruits of which may arrivo attached to the bodies of birds, and species of which the fruits and seeds have been eaten. The species carried externally will be first considered and may further be conveniently subdivided into two sub-groups, viz., species that have probably been introduced only by swimming- or wading-birds, and species introduced by birds of any kind. The species of the first kind give a sub-group distinguished by an aquatic or paludine habitat, and characterised by small inconspicuous fruits or seeds that readily become attached, along with pellets of mud, to the feet, the leg-feathers, or the feathers at the base of the bill, of birds frequenting pools and marshes. The following table exhibits the whole of this kind present in the Coco Group.

TABLE XIX. Distribution of the species probably introduced by swinming or wading birds.

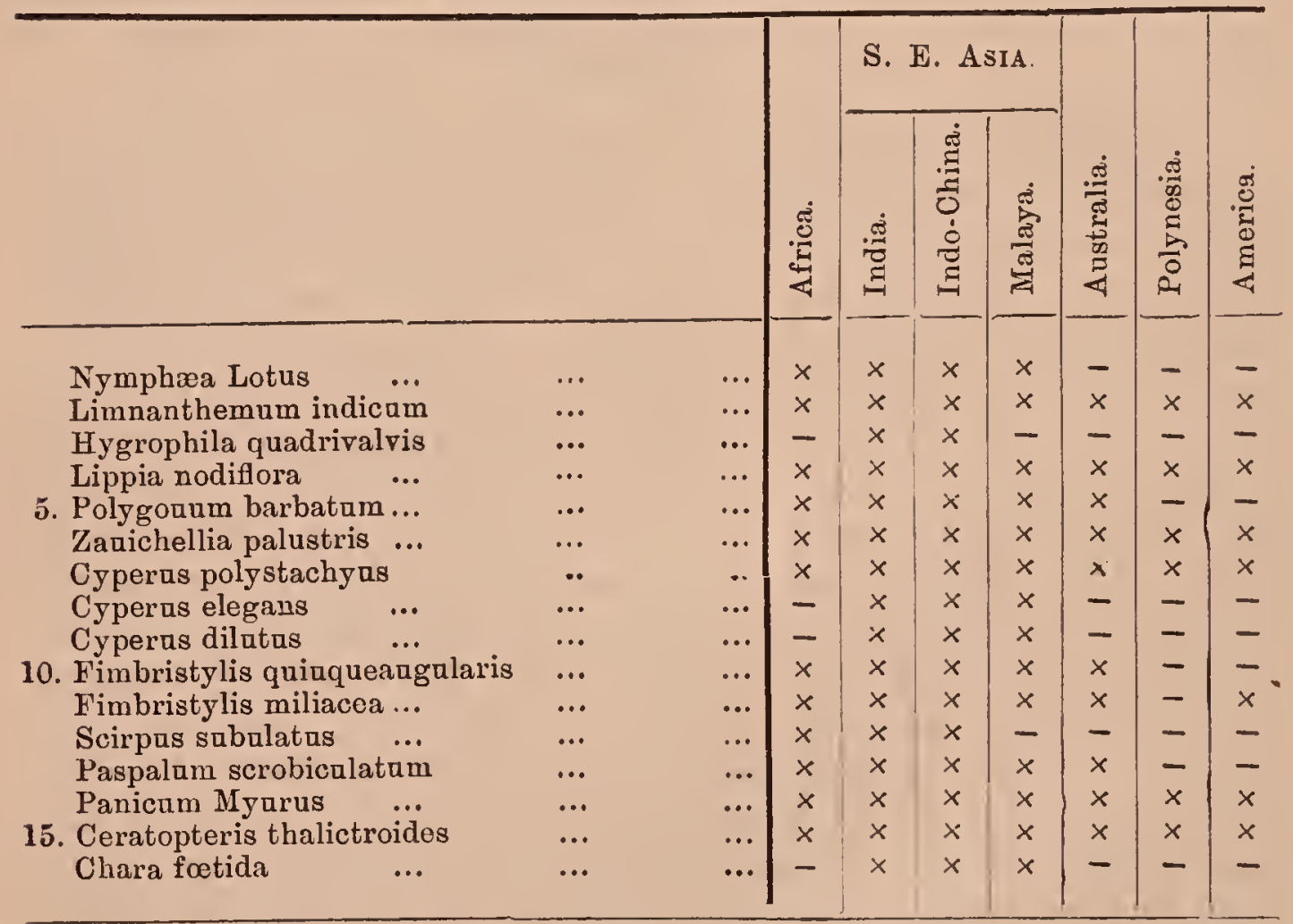

The next table gives the analysis of this distribution; the most striking feature the two tables reveal is the extent to which species of this kind are cosmopolitan. Among the non-cosmopolitan species the indications are altogether in favour of introduction from the northward and westward, for while only 10 of the species occur in Australia, and only the 6, which are all cosmopolitan, occur in Polynesia, 12 occur in Africa and 7 in America. Of the more local distribution we learn that none need necessarily have been introduced from Malaya since the 14 that occur 
there all occur in India and Indo. China also, while two that occur in India and Indo. China but do not occur in Malaya must have been intro. duced from the north. This being the case the probability is that the others have mainly been introduced from the same direction, a circumstance quite in accordance with expectation, since it is from the nor th that the stream of migration of marsh-and water-birds annually flows. During our visits to the islands snipe were found in the meadow near the lake on Great Coco, while teal and other water-birds frequented the lake itself and abounded in the lagoon on Little Coco.

TABLE XX. Analysis of distribution of Marsh and Aquatic species.

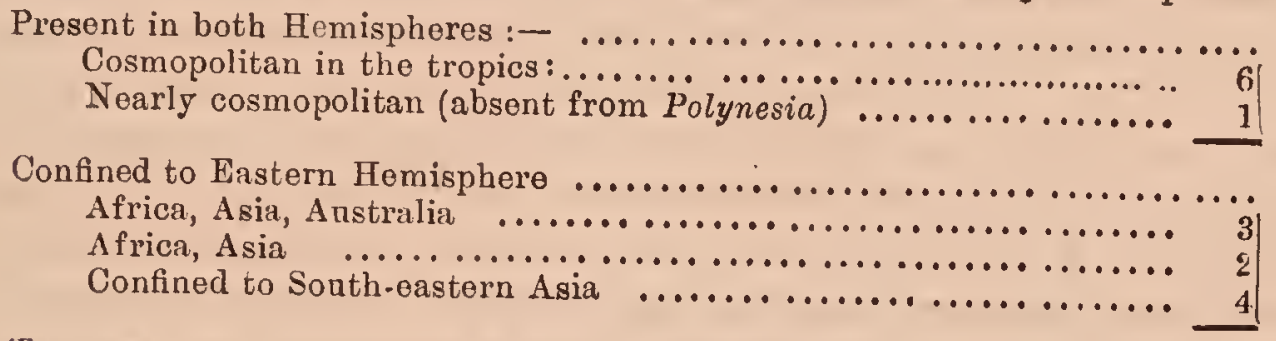

'Гота species probably introduced by water-birds

The second kind of species that may be introduced by becoming attached externally to birds is somewhat more difficult to deal with. Urena lobata, which is here clearly not a weed, may have been introduced in this way: its fruits sticking, burr-like, to the feathers of some bird; Buettneria antamanensis, might also have been thus introduced, though this is not so probable as in the other case. Three of the DesmodiaDesmodium triquetrum, D. laxiflorum and $D$. polycarpon-may very well o we their introduction to this mode of dispersal. Boerhaavia repens, as has already been said, is probably sea-introduced, though there is no reason why it may not partly owe its dispersal to bird-agency. Its habitat on these islands is always the rocky headlands or isolated rocks along the coast on which sea-birds sit to devour the Grapsus crabs they capture on the wave-washed ledges below, and nothing is more likely than that the fruits may become at times attached to their feet and be carried at lcast from point to point along the coast. The Pisonias may both very well have been introduced in this fashion, though it is less likely as regards $P$. aculeata than as regards $P$. excelsa. From what has been already said of this tree in discussing it among the "littoral" species, it will be evident that its fruits are of such a nature as to admit of their being carried for great distances attached to a bird's feet or body, if only the bird should happen to come in contact with them, and the objection that scraping-birds, which might do so, are not of ten migratory, while frugivorous birds, which are migratory, would not come in contact with the fruits because they are not likely to alight on a Pisonia, is not a valid one. 
Though many such birds, as for instance Carpophaga bicolor, appear always to feed on trees and therefore would probably very rarely come in contact with Pisonia fruits, many others, as for instance Calcenas nicobarica, appear to feed as much or more on the ground, on fallen ripe fruits, as on the trees that bear the fruits they eat.* And in such a case there is no doubt that they might very easily come in contact with Pisonia fruits. Though essentially a beach-forest tree, the writer has collected specimens of Pisonia excelsa (and the tree was plentiful where he did so) three or four miles iuland and 250-300 feet above sea-level; some mode of dispersal other than, or at any rate supplementing, oceandispersal, must therefore, as has already been pointed out, be postulated as regards this species. Of the grasses placed in this list Andropogon contortus already mentioned as pussibly wind-introduced, much more probably owes its presence to this mode of introduction Oplismenus compositus is also sufficiently well endowed to render this mode of introduction likely. The only Cryptogam likely to have been thus introduced is Acrostichum appendiculatum, the spores of which might easily get brushed off by the feathers of a bird walking through a patch of it. This would also apply to the seeds of Calanthe.

The following table gives the names and distribution of the species likely to be thus introduced or likely to have their local dispersion assiat. ed by this means.

TABLE XXI. Distribution of species probably introduced attached to the feet or feather's of land.birds.

\begin{tabular}{|c|c|c|c|c|c|c|c|c|c|}
\hline \multirow[b]{2}{*}{ SPECIES. } & & & \multirow{2}{*}{ 胥 } & \multicolumn{3}{|c|}{ S. E. AsIA. } & \multirow{2}{*}{ 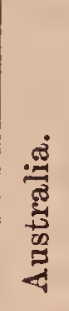 } & \multirow{2}{*}{ 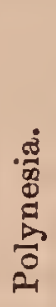 } & \multirow{2}{*}{$\frac{.}{.0}$} \\
\hline & & & & & . & & & & \\
\hline Urena lobata $\quad \ldots$ & $\cdots$ & $\ldots$ & $x$ & $x$ & $x$ & $x$ & $x$ & $x$ & $x$ \\
\hline [Buettneria andamanensis] & $\ldots$ & $\ldots$ & - & - & {$[x]$} & - & - & - & - \\
\hline Desmodinm triquetrum & $\ldots$ & $\ldots$ & $x$ & $x$ & $x$ & $x$ & - & - & - \\
\hline Desmodium laxiflornm & ... & $\ldots$ & - & - & $x$ & $x$ & - & - & - \\
\hline 5. Desmodium polycarpum & $\ldots$ & .. & $x$ & $x$ & $x$ & $x$ & $x$ & $x$ & - \\
\hline [Loranthus longifloras] & ... & ... & - & $x$ & $x$ & $x$ & - & - & - \\
\hline [Boerhaavia repens] ... & ... & ... & $x$ & $x$ & $x$ & $x$ & $x$ & $x$ & - \\
\hline [Pisonia aculeata] $\quad$... & ... & $\cdots$ & $x$ & $x$ & $x$ & $x$ & $x$ & - & $x$ \\
\hline Pisonia excelsa $\quad$... & & .. & - & - & {$[x]$} & $x$ & - & - & - \\
\hline 10. Calanthe veratrifolia... & $\ldots$ & $\ldots$ & - & $x$ & {$[x]$} & $x$ & $x$ & - & - \\
\hline Oplismenus compositus & $\ldots$ & ... & $x$ & $x$ & $x$ & $x$ & $x$ & $x$ & - \\
\hline Andropogon contortus & $\ldots$ & ... & $x$ & $x$ & $x$ & $x$ & $x$ & $x$ & $x$ \\
\hline Acrosticham appendiculatum & $\ldots$ & $\ldots$ & - & $x$ & $x$ & $x$ & - & - & - \\
\hline
\end{tabular}

* This at least was the writer's experience in Batti Malv, the small uninhabitec. almost inaccessible island of the Nicobar Group already referred to, where Calonas nicobarica breeds, and on which thousands of individuals of this species congregate. 
The list is so short that an analysis of it is unnecessary; it is sufficient to note that the possibility of introduction from Malaya or from Indo-China is, so far as its evidence goes, evenly balanced.

While the two lists probably include all the species usually introduced by being attached externally to birds they do not exhaust all the possibilities of the case. For, if the mud of a marsh may fix the seeds or fruits of paludine species to the feet or head of wading-birds, other substances may fix the seeds of forest species to the bodies of forest-birds. There is almost no limit to the number of species that might be suggested as introduced in this way, provided their seeds be sufficiently small; this very circumstance, combined with the necessarily liypothetical nature of the subject, makes it impossible to attempt the suggestion of this mode of dispersal in connection with any particular species.*

The next kind of "bird-introduced" species to be considered-those introduced in consequence of having been eaten-may also be conveniently divided into two sub-groups; one consisting of species where dissemination by birds is an every-day process, the other consisting of species that can only be occasionally disseminated in this fashion since the process implies the destruction of the bird itself.

The first sub-group corresponds fairly closely with those species

* The following facts will shew that, though necessarily hypothetical, the snbject is not far-fetched but is, on the contrary, highly deserving of attention. When in Narcondam the writer was particularly anxions to obtain the seeds of a species of Bombax present there, for sowing at Calcutta; for some days the search was hopeless becanse the capsules as they ripen are broken open and the seeds are eaten by a species of Horn-bill that is common in the island, while any seeds that escape the birds and fall to the gronnd are devoured by the rats that swarm in the place. At length nnder one tree, where there happened to be on the under-growth one or two large spider's webs, four seeds were found sticking in these webs; these were the only seeds he was fortunate enough to obtain; they were brought to Calcutta, germinated there, and the four young trees are now alive in the Botanic Garden. This will shew that seeds easily may, and at times do, stick in spider's webs.

In spring 1890 a Barbet was fonnd lying on the ground in the Botanic Garden unable to fly; on being picked up and examined it was found that its left wing and left leg were fixed together by means of a spider's web; on freeing these it was found that the toes of its left foot were fnrther bound ap in a ball and the flight-feathers were firmly tied together. When finally completely freed from its entanglement the bird flew away, frightened, but physically uninjured. This will shew that birds do sometimes come in contact with spider's webs and that these are capable not merely of fixing objects to a bird's feathers but of fixing these feathers so that the bird itself cannot move them.

All that is therefore required in order to establish the truth of the hypothesis is direct observation of a bird having come in contact with a spider's web which happened to have seeds lodged in it at the time, and of its carrying away seeds and web together. 
that have pulpy fruits with a hard stone or with hard indigestible seeds. It cannot, how ever, be held to include all these, for though birds do eat the pulpy part of the fruits of Canarium, Spondias and Drucontomelum, the stones of these are too large to be swallowed; probably therefore some other mode of dispersal must be held accountable for the presence in these islands of species of those genera. For Dracontomelum introduction by the sea has been suggested, though doubtfully; the others are left, with some reluctance, among the "remanent" species. There are other species for which this agency is only doubtful, such as Mitiusa, the fruits of which do not look very inviting-some polyalthias are, however, so dispersed, e.g., P. longifolia by frugivorous bats; Physalis minima might well enough have been introduced in this way, but is, all things considered, more probably sea-introduced; some of the Convolvulacere may also have been thus introduced. Moreover it must not be forgotten that indirect introduction in this way is not impossible. As has been pointed out, some of the fruit-eating pigeons are groundfeeding creatures, and if a sticky pulpy fruit should fall into a patch of Oplismenus, Panicum, Aneilema, or other small-fruited or -seeded herbaceous ground-species, the seeds or fruits of these may become attached to the fruits in question and, if then swallowed unnoticed by a fruit-eating bird, be voided uninjured along with the stone or seeds of the fruit itself and subsequently germinate. The subjoined table gives a list of all the species probably directly introduced; the indirect method, as being too hypothetical for discussion here, is not mentioned in connection with any particular species.

As in the case of species introduced by wind the occurrence of species of this kind in the islands of Narcondam and Barren Island is given; these being islands for which it is necessary at the outset to exclude from consideration any hypothetical " remanent" element.*

* This part of the list is not so complete as it might be, since owing to the pressure of other duties the writer has not yet been able to complete the examination of the species collected by him in those islands in April 1891. This much may be said, that all the species quoted as occurring there do occur. But many of the others though not present are represented by nearly allied species and by species of this kind. There is for example at least one Grewia in Narcondam, there are several Rubiacece and there is an Amorphophallus. In Narcondam too there is a species of Strychnos, while a species of Eugenia is common in Barren Island. These two isolated localities therefore present two genera, with species that have fruits of the kind now discnssed, of which no representatives were met with in the Coco Gronp. Similarly Batti Malv, equally isolated, and quite uninhabited, has an Alangium and a Datura; it may therefore be repeated that this list by no means overstates the possibilities of the agency in such a locality as this, 
TABLE XXII. Species probably introduced by fruit-eating birds.

SPECIES.

[Miliusa sp.]...

Capparis sepiaria

Capparis tenera

Grewia lævigata

5. Grewia Microcos

Glycosmis pentaphylla

Garuga pinnata

Aglaia andamanica

Cansjera Rheedii

10. Sarcostigma edule

Salacia prinoides

Zizyphus Enoplia

Vitis pentagona

Vitis carnosa

15. Vitis pedata ...

Leea hirta

Erioglossum edale

Allophylas Cobbe

Sapindus Danura

20. Pometia tomentosa

Odina Wodier

Semecarpns sabpanduriformis

Semecarpas heterophylla

Memexylon edule

25. Modecca cordifolia

richosanthes palmata ...

Mussæuda calycina

Pavetta indica

Psychotria adenophylla $\cdot$.

30. Pæderia fotida

Ardisia humilis

Rauwolfia serpentina

Erycibe paniculata $\quad \cdots$

[Physalis minima]

Myristica Irya

35. Myristica glanca

Dehaasia Karzii

Bridelia tomentosa

Bridelia Kurzii

Flneggea miclocarpa

40. Phyllochlamys spinosa

Plecospermum andamanicum

Ficas Benjamina

Ficas Ramphii

Ficus retusa ...

$\ldots$
$\ldots$
$\ldots$
$\ldots$
$\ldots$
$\ldots$
$\ldots$
$\ldots$
$\ldots$
$\ldots$
$\ldots$
$\ldots$
$\ldots$
$\ldots$
$\ldots$
$\ldots$
$\ldots$
$\ldots$
armis

...

$\cdots$

...

$\cdots$

$\cdots$

$\ldots$

...

...

$\ldots$

...

...

...

üm

$\cdots$

$\cdots$

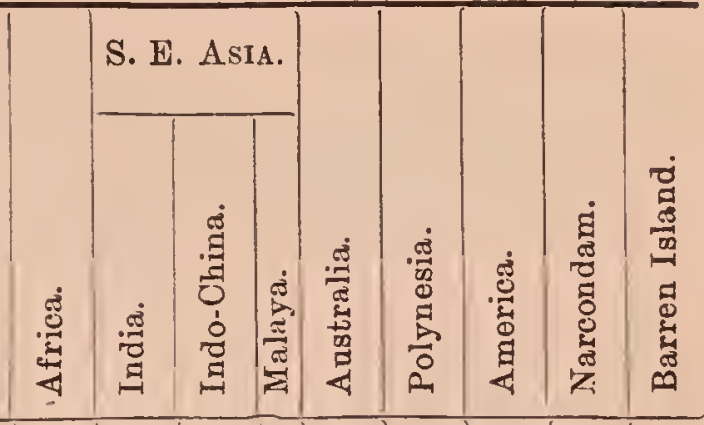




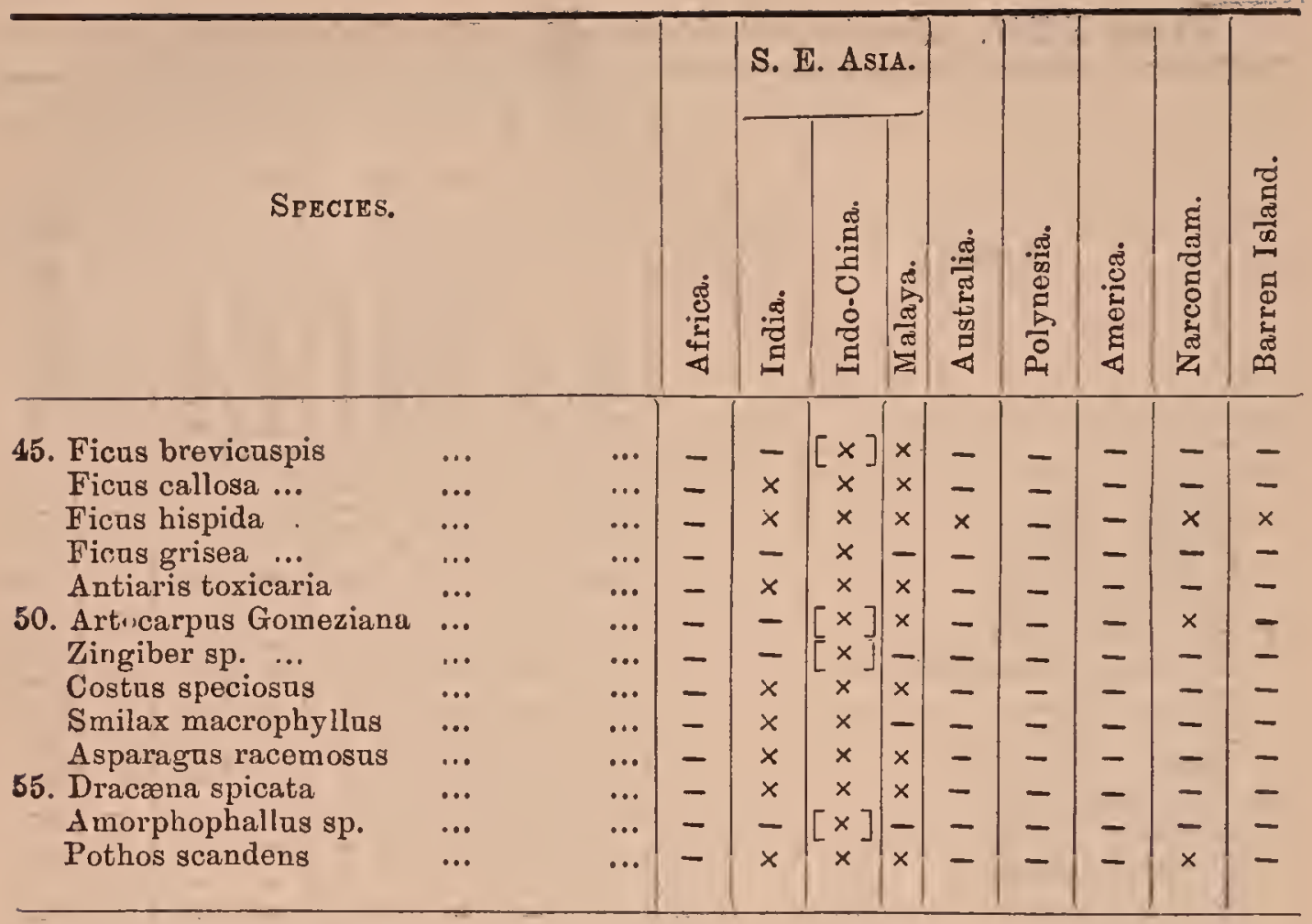

The most remarkable feature of the list is that it gives us for the first time a well-defined group of species none of which extend to America or even to Polynesia, and only two of which extend to Africa, though no fewer than 15, or 27 per cent., extend to Australia. The remaining 40 are confined to South-Eastern Asia. As regards theil. mole local distribution there, 17 , or 31 per cent., are confined to lands lying to the east of the Sea of Bengal, while 3 more occur in Ceylon but not in India, a circumstance which perhaps indicates that birds which feed on these species pass from Malaya to Ceylon but do not visit India. If this be the case the agency of frugivorous birds may partly explain the existence of a Ceylon element in the flora of the Andamans generally, a circumstance that has, as already said, been made the subject of remark by the late Mr. Kurz, (Report on the Vegetation of the Andaman Islands, p. 15); this point will be more fully discussed below.

As many as 36 species, or 64 per cent., occur both in Indo-China and in Malaya ; as 15 pass southward to Australia while 14 pass nor.thward to South China, and 5 pass southward to Malaya without going north to Indo-China, while 5 reach the islands from Indo-China without extending to Malaya, we may conclude that; though this element in the flora is distinctly non-Indian, the Indo-Chinese and Malay-Australian influences are, so far as it is concerned, evenly balanced.

Since the active agency in the dispersal of these species is that of 208 
fruit-eating birds, it ought to be possible to show that the known migrations of these creatures sufficiently explain their distribution. For all the species that occur in the Malay Archipelago this is extremely easy to do. The western half of the Malay Archipelago is particularly rich in fruit-eating pigeons and, as this area lies on both sides of the equator; the annual changes of season must cause the fruit-eating species, following the fruits on which they feed as these become mature, to oscillate from side to side of the equator. The samc condition will ensure further migration from Southern Malaya to North Australia and vice versa on the one hand, and from Northern Malaya to the Nicobars and Andamans and vice versa on the other. It is not necessary to suppose that any particular fruit-eating bird must range from one end to the other of the area here considered, though some species, like Calcenas nicobarica, which extends from these islands to New Guinea, nearly or altogether do so; it is sufficient to know that such birds are seasonal visitants in any given locality, as is true of Carpophaga bicolor, Carpophaga insularis, Calcenas nicobarica, and many other species in those very islands; the region depleted of one set of species by the migration of these towards the north is filled with individuals representing another set coming from an area still furthcr south. By the necessary over-lapping of the ranges of migration of different birds a continuous chain of dispersal is kept up and, even if Malayan birds never go further north than these islands, the process is continued by the arrival from and departure to the opposite point of the compass, of Indo-Chinese species; it is therefore not surprising to find that, where the climatic conditions still continue favourable, the same bird-distributed specics of Phanerogams extend from North Australia through all the intervening areas to Southern China. This being so, the appearance of the same species in India and in Malaya, which is the case in 33 species, or 58 per cent., of the group, is simply explained. Certain species of birds, instead of only passing southward from China to Indo-China, pass also southwcstward to the Eastern Himalaya or to the Assam valley, from whence these, or other, species of birds carry the seeds of the plants in question still further south-westward into peninsular India. This may explain also why certain species, like Pcederia fretida, extend from Malaya northwards to Indo-China on the eastern line of migration, but on the western extend only southward to the Eastern Himalaya and not into India; the species of birds that eat their fruits may perhaps not migrate on the more western line of migration further south than the Himalayan slopes. The same reasoning applies to those species, of which there are 3 , or about 5 per cent., that extend to Southern India on the western line of migration but do not go as far as Malaya on the 
eastern line. The species that are common to these islands and to Ceylon are more difficult to explain. If we felt certain that they are species of distinctively Ceylonese type and that they occur, out of Ceylon, only in these islands, we might suppose that Ceylon birds are occasionally driven by storms as far as the Coco Group and consider the dispersal of the seeds of such species as one of the indirect sequels of cyclones of unusual severity. The birds even need not be different, as regards species, from those commonly found in the Andamans; they need only be individuals that have followed the western instead of the eastern line of migration southward, and that under exceptional circumstances have passed directly from one line of migration to the other, carrying in their crops seeds or fruits that are characteristic of the line of migration from which they have been driven. If the species are not of Ceylonese type, their occurrence both in Ceylon and the Cocos may, as has been said already, only indicate that they have been brought directly from Malaya or Australia by soutlern birds that migrate to Ceylon as well as to the Coco Group but do not go as far north as peninsular India.

The remaining sub-group consists of species with seeds or fruits that are eaten by birds of different kinds, not for the sake of any pulpy portion, but on account of the nutritious properties of the whole fruit or seed. We have to realize that the dispersal in this case is not, as in the case of pulpy fruits the seeds of which are afterwards voided, an ordinary circumstance, inasmuch as the seeds are eaten for their own sake and are of necessity digested by the birds that eat them. But though it is not perhaps a common occurrence-the numbers of migrating grain- or seed-eating individuals considered-for newly-arrived birds to be killed, there is no doubt that a certain proportion, tired out by their long flight, must fall victims to raptatorial birds immediately on their arrival, the grains or seeds that their crops may contain falling aside and possibly germinating. Besides this means of introducing such species, and, even if the results be slight, it must nevertheless be in constant operation, there is the further possibility of similar species being introduced during severe cyclones, owing to birds that have been driven to land being captured and devoured, while exhausted by the buffeting of the tempest, by birds or beasts of prey. In this way not only the grain- or seed-eating species that ordinarily visit the islands, but species both of this and of the fruit-eating class that do not usually reach the group, may conceivably arrive and as conceivably bring with them the seeds of plants that birds which are normal visitants have no opportunity of meeting with or may not care to eat. It has to be admitted, however, that species for which this mode of introduction 
is claimed may with some degree of reason be looked upon as distinctly, though indirectly, introduced by wind.*

The species for which this mode of introduction is conceivable are given below. That many of them must be introduced species their presence in Narcondam and Barren Island testifies; it is thereforc, as regards these, somewhat on the principle of exclusion that they are referred to this class, and for some of them, such as Abrus precatorius, it is doubtful if it be not rather the sea that is responsible for their appearance.

TABLE XXIII. Species perhaps introduced by seed-and grain-eating birds.

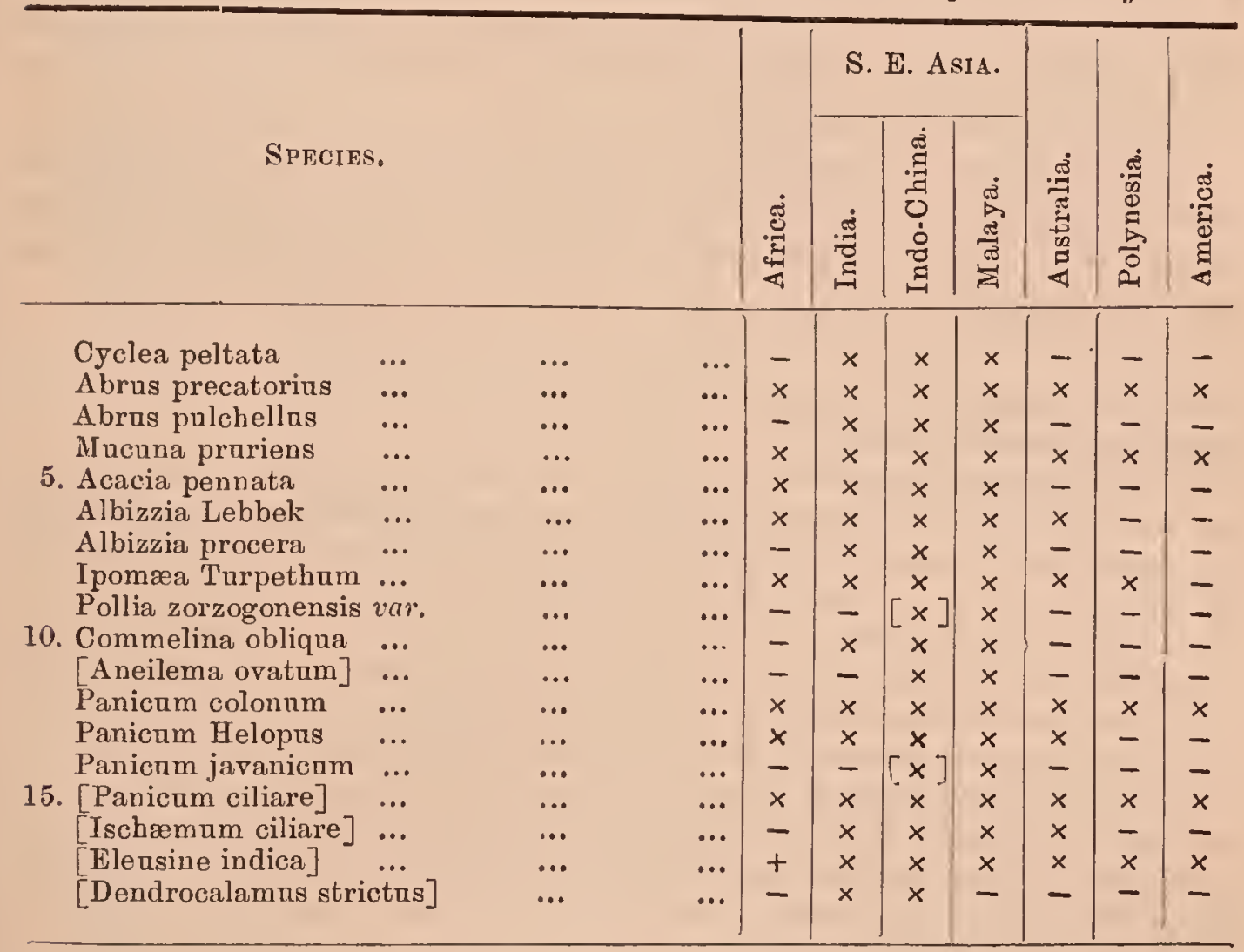

* That there is nothing extravagant in claiming this as a possible means of introduction, the following passage (which refers, as it happens, to one of the islands under discussion), will sufficiently prove:- "Mr. Hawkins told as that when "the storm was over * * * * * * * * * * * * * * "every hollow of the island was tenanted by hundreds of numbed or wounded "sea-birds of all descriptions (such as he had never seen near the island before or "since) so terrified or exhansted that he picked up or took home several of them to "the light-house to show to his wife. Mixed with these were a certain number "of pigeons, parrots, and other land-birds, but the great majority were Petrels, "Terns, Whale-birds and such like sea-fowl with which his experience as a sailor "in southern seas had made him familiar. Most of these birds ultimately recovered and left the island, but many of them hung about it for weeks, and for many days remained so tame that they would not move from the ground or the rocks, 
Of the above, Cyclea peltata, Abrus precatorius, Acacia pennata, Albizzia Lebbek, Albizzia procera, Ipomøa Turpethum, and Pollia zorzogonensis occur in Narcondam. With few exceptions they are widely distributed species; five are cosmopolitan, one extends throughout the Eastern Hemisphere and thence to Australia and Polynesia, two extend from Africa and Asia to Australia, one occurs in Asia and Africa, one in Asia and Australia; only eight species, or less than half of the group, are confined to South.Eastern Asia. Of these latter, three are confined to the countries east of the Bay of Bengal; two of them, Panicum javanicum, and the particular variety of Pollia zorzogonensis that occurs, are moreover distinctively Malayan, as opposed to Indo-Chinese, plants. On the other hand one species, Dendrocalamus strictus, is as distinctively an Indian or Indo-Chinese plant.

We have now in conclusion to consider the "remanent" species, a list of which is given in the subjoined table; in a few cases where in. troduction is remotely possible the agency that may have been responsible is indicated.

"where they happened to alight, to make way for the keeper or his men." (Hume ; stray Feathers, vol. ii, p. 113-4.)

In this passage we have all the evidence that is required to show that not merely the nsnal visitants but even nnnsnal ones may at times be driven to, or seek shelter on, these islands when in an exhausted or injured condition, and to show that this is as likely to happen to grain-, pulse-, and seed-eating species as to fruit-, or fish-, crustacean- or mollnsc-eating ones It is of little moment that the fish-or crastaceaneating species must always be the more nnmerous, if we know that species of the other kind are at any time driven to the islands in this state. All of these exhansted and injured creatures certainly do not recover or escape destrnction. As regards those that simply die, when the insects that abound have eaten all but their bones, the seeds that may have been contained in their crops must fall aside and may germinate and grow. And as regards those that are killed and devoured it would be remarkable if a few of the seeds in their crops did not thus fall aside and obtain an opportnnity of germinating.

Even if no other creature that exists in these islands were capable of, or likely to, catch and eat snch exhausted birds, the presence of a large lizard-Hydrosaurus salvator-which is very common, is sufficient to acconnt for the destrnction of many of them. During our visit to Little Coco one of the officers of the "Investigator" shot two Curpophaga bicolor-right and left-by the side of the lagoon near the south end of the island. Before his attendant could reach the birds, which had fallen among the Pandanus bnshes of the sea-fence, one of these lizards had already eaten all bnt the wings and head of one pigeon and had torn open the breast of the second ere it could be interrupted in its feast. On a previons occasion a Hydrosaurus was killed as it was apparently about to seize a Teal that had just been shot and had been laid duwn on a rock in the same lagoon. On opening ap this creatnre its stomach was found to contain already a large land crab, two fishes, and a quantity of grassy roots (apparently those of Scirpus subulatus). 
TARLE XXIV. Possibly "Remanent" species of the Coco Island flora.

\begin{tabular}{|c|c|c|c|c|c|c|c|c|c|}
\hline \multirow[b]{2}{*}{ SPECIES. } & & \multirow[b]{2}{*}{ 总 } & \multicolumn{3}{|c|}{ S. E. Asia. } & \multirow[b]{2}{*}{ 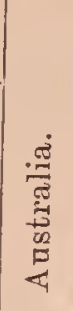 } & \multirow[b]{2}{*}{ 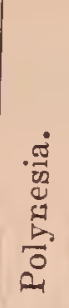 } & \multirow[b]{2}{*}{ 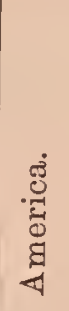 } & \multirow[b]{2}{*}{$\begin{array}{c}\text { Possibly } \\
\text { introduced } \\
\text { by }\end{array}$} \\
\hline & & & : & $\begin{array}{l}\stackrel{\infty}{\Xi} \\
\stackrel{\Xi}{\Xi} \\
\dot{0} \\
\stackrel{\Xi}{\Xi}\end{array}$ & 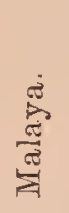 & & & & \\
\hline *Milinsa sp. ... $\quad \ldots$ & $\ldots$ & - & - & {$[x]$} & - & - & - & - & \\
\hline [Cyclea peltata] $\quad \ldots$ & $\ldots$ & - & $x$ & $x$ & $x$ & - & - & - & ? Birds. \\
\hline *Antitaxis calocarpa & $\ldots$ & - & - & {$[x]$} & - & - & - & - & \\
\hline Alsodeia bengalensis & ... & - & - & $x$ & - & - & - & - & \\
\hline 5. Dipterocarpus pilosus & $\cdots$ & - & - & $x$ & $x$ & - & - & - & \\
\hline Dipterocarpus alatus & $\ldots$ & - & - & $x$ & $x$ & - & - & - & \\
\hline Sterculia villosa $\quad \ldots$ & ... & - & $x$ & {$[x]$} & - & - & - & - & \\
\hline * [Sterculia rnbiginosa var.] & ... & - & - & {$[x]$} & - & - & - & - & ? Ocean. \\
\hline Sterculia parviflora ... & $\cdots$ & - & - & $x$ & $x$ & - & - & - & \\
\hline 10. Sterculia alata $\quad \ldots$ & $\ldots$ & - & $x$ & $x$ & $x$ & - & - & - & \\
\hline Sterculia colorata ... & $\ldots$ & - & $x$ & $x$ & - & - & - & - & \\
\hline Sterculia campanulata & $\ldots$ & - & - & $x$ & $x$ & - & - & - & \\
\hline Buettneria andamanensis & $\ldots$ & - & - & {$[\times]$} & - & - & - & - & \\
\hline Berrya A mmonilla ... & . & - & $x$ & $x^{-}$ & $x$ & - & - & - & \\
\hline 15. *Grewia calophylla ... & ... & - & - & {$[x]$} & - & - & - & - & ? Birds. \\
\hline *Canarium euphyllum & ... & - & - & {$[x]$} & - & - & - & - & \\
\hline A moora Rolituka ... & $\ldots$ & - & $x$ & $x^{-}$ & $x$ & - & - & - & ? Birds. \\
\hline Chikrassia tabularis ... & $\ldots$ & - & $x$ & {$[x]$} & $x$ & - & - & - & \\
\hline Phlebocalymna Lobbiana & $\ldots$ & - & - & $x$ & - & - & - & - & \\
\hline 20. Glyptopetalum calocarpum & $\ldots$ & - & - & {$[x]$} & - & - & - & - & \\
\hline Siphonodon celastrineas & $\ldots$ & - & - & {$\left[x^{j}\right]$} & $x$ & - & - & - & \\
\hline Ventilago calyculata... & $\ldots$ & - & $x$ & $x^{-}$ & $x$ & - & - & - & \\
\hline Parishia insignis $\quad$... & $\ldots$ & - & - & {$[x]$} & - & - & - & - & \\
\hline Spondias mangifera ... & ... & - & $x$ & $x$ & $x$ & - & - & - & \\
\hline 25. [Dracontomelum mangiferum] & ... & - & $x$ & $x$ & $x$ & - & $x$ & - & ? Ocean. \\
\hline Connarus gibbosus ... & $\ldots$ & - & - & {$[\times]$} & $x$ & - & - & - & \\
\hline Pueraria Candollei ... & $\ldots$ & - & - & $x^{-}$ & - & - & - & - & \\
\hline Pueraria phaseoloides & ... & - & - & $x$ & $x$ & - & - & - & \\
\hline Pterocarpus indicus ... & $\ldots$ & - & $x$ & $x$ & $x$ & - & - & - & \\
\hline 30. Derris scandens $\quad \ldots$ & ... & - & $x$ & $x$ & $x$ & $x$ & - & - & \\
\hline Mezoneuron enneaphyllum & $\ldots$ & - & {$[x]$} & $x$ & - & - & - & - & \\
\hline Adenanthera paronina & ... & - & $x$ & $x$ & $x$ & - & - & - & \\
\hline Acacia concinna $\quad \ldots$ & ... & - & $x$ & $x$ & $x$ & - & - & - & \\
\hline Terminalia bialata ... & ... & - & - & {$[x]$} & - & - & - & - & \\
\hline 35. *Lagerstrœmia hypoleaca & ... & - & - & {$[x]$} & - & - & - & - & \\
\hline * Lagerstrœmia sp. ... & $\ldots$ & - & - & {$[x]$} & - & - & - & - & \\
\hline Illigera conyzadenia... & $\ldots$ & - & - & {$[x]$} & - & - & - & - & \\
\hline *Webera Kurzii ～... & $\ldots$ & - & - & {$\left[x^{0}\right]$} & - & - & - & - & \\
\hline Randia longiflora $\quad \ldots$ & $\ldots$ & - & - & $x$ & $x$ & - & - & - & \\
\hline 40. Diplospora singularis & ... & - & - & $-x$ & $x$ & - & - & - & \\
\hline Ixora grandifolia $\quad \ldots$ & ... & - & - & {$[x]$} & $x$ & - & - & - & \\
\hline Ixora cuneifolia $\ldots$ & $\cdots$ & - & - & $x$ & - & - & - & - & \\
\hline Strophanthus Wallichii & $\ldots$ & - & $x$ & $x$ & - & - & - & - & ? Wind. \\
\hline Argyreia Hookeri ... & ... & - & - & $x$ & - & - & - & - & \\
\hline 45. Argyreia lanceolata ... & $\cdots$ & 一 & - & {$[x]$} & - & - & - & - & \\
\hline Lettsomia peguensis... & ... & - & - & $x$ & - & - & - & - & \\
\hline Porana spectabilis ... & ... & - & - & {$[x]$} & - & - & - & - & \\
\hline Thunbergia laurifolia & .. & - & - & $x$ & $x$ & - & - & - & \\
\hline
\end{tabular}




\begin{tabular}{|c|c|c|c|c|c|c|c|c|c|}
\hline \multirow[b]{2}{*}{ SPECIES. } & & \multirow[b]{2}{*}{ 胥 } & \multicolumn{3}{|c|}{ S. E. Asia. } & \multirow[b]{2}{*}{ 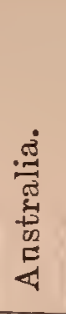 } & \multirow[b]{2}{*}{$\begin{array}{l}\text { 苟 } \\
0 \\
0 \\
0 \\
0 \\
0 \\
0\end{array}$} & \multirow[b]{2}{*}{ 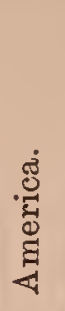 } & \multirow[b]{2}{*}{$\begin{array}{c}\text { Possibly } \\
\text { introduced } \\
\text { by }\end{array}$} \\
\hline & & & & 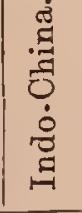 & 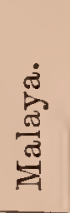 & & & & \\
\hline Strobilanthes phyllostachyus & ... & - & - & $\dot{x}$ & - & - & - & - & \\
\hline 50. Eranthemum album ... & $\ldots$ & - & [x] & $x$ & $x$ & - & - & - & \\
\hline Peristrophe acuminata & $\ldots$ & - & - & {$[x]$} & $x$ & - & - & - & \\
\hline Bragantia tomentosa... & ... & - & - & $x$ & $x$ & - & - & - & \\
\hline Loranthas longifluras & ... & - & $x$ & $x$ & $x$ & - & - & - & ? Birds. \\
\hline Phyllanthas columnaris & $\ldots$ & - & - & $x$ & - & - & - & - & \\
\hline 55. Cyclostemon assamicus & $\ldots$ & - & - & $x$ & - & - & - & - & \\
\hline Aporosa villosula $\quad \ldots$ & $\cdots$ & - & - & $r^{x}$ & - & - & - & - & \\
\hline Croton sublyratus ... & ... & - & - & {$[x$.} & - & - & - & - & \\
\hline *Blachia andamanica & ... & - & - & {$[x$} & - & - & - & - & ? Ocean. \\
\hline Claoxylon longifolium & ... & - & - & {$[x=$} & $x$ & - & - & - & \\
\hline 60. Mallotus acuminatas... & $\ldots$ & - & - & {$[x]$} & $x$ & - & - & - & \\
\hline *Mallotas andamanicas & $\ldots$ & - & - & {$[x]$} & - & - & - & - & \\
\hline Cnesmone javanica $\quad .$. & $\cdots$ & - & - & $x^{x}$ & $x$ & - & - & - & \\
\hline *Livistona sp. $\quad$... & $\cdots$ & - & - & {$[x]$} & - & - & - & - & \\
\hline *Corypha elata $\quad \ldots$ & $\cdots$ & - & - & {$[x]$} & - & - & - & - & \\
\hline 65. *Calamus andamanicus & $\cdots$ & - & - & {$[x]$} & - & - & - & - & \\
\hline *Calamus tigrinus $\quad .$. & $\ldots$ & - & - & $x$ & - & - & - & - & \\
\hline Alocasia fornicata ... & ... & - & $x$ & $x$ & $x$ & - & - & - & ? Birds. \\
\hline Scindapsus officinalis & $\cdots$ & - & $x$ & $x$ & $x$ & - & - & - & ? Birds. \\
\hline Dendrocalamns strictus & $\cdots$ & - & $x$ & $x^{x}$ & - & - & - & - & \\
\hline 70. *Xylaria clavarioides & $\cdots$ & - & - & {$[x]$} & - & - & - & - & \\
\hline
\end{tabular}

To the 67 unequivocal species of this list 3 other apparently local Fungi should perhaps be added; it is, however, extremely probable that when they are better known they will be found to exist elsewhere, in which case they might be added to the list of wind-distributed species; the proportion that results is therefore :-

Migrant $\mathrm{sp}:$ Remanent $\mathrm{sp}:: 4: 1$.

It will be noted that not a single species which seems unquestionably "remanent" extends beyond South-Eastern Asia, and that the species which are here treated as such are only 67 in number, constituting no more than 20 per cent., of the flora. Of these species only 21 , or 32 per cent., occur in India or Ceylon or both, and of these only one (Sterculia villosa) has not hitherto been found elsewhere to the east of the Sea of Bengal. This "remanent" section of the flora may therefore be looked upon as distinctly non-Indian. The point to be ascertained further is whether this element indicates more strongly an Indo-Chinese or a Malayan influence. Thirteen of the species, indicated in the table by an (*) occur only in the Andamans or Nicobars, while seven more occur only in Tenasserim on the opposite shores of the Andaman Sea. But Tenasserim bears to the Malay Peninsula and Indo-China very much the 
relationship that the Andaman-Nicobar chain bears to Indo-China and the Malay Archipelago, and perhaps neither it nor the Andamans ought to be spoken of as physiographically a part either of Indo-China or of Malaya; * these 20 species cannot therefore be cited as indicating either an Indo-Chinese or a Malayan inflnence. The purely Indian Sterculia villosa must obviously be similarly excluded; there are therefore $2 \mathrm{~L}$ species, or 32 per cent. of this group, that afford no evidence eithcr way.

Of the remaining species, one-half, $i . e ., 23$ specics, or 35 per cent. of the wholc, occur both in Indo-China and Malaya; these also give no evidence as regards this question. Of the othcr 23,15 extend from Indo-China to these islands (some of them, like Dendrocalamus strictus, not going further than the Coco Group), without extending to Mnlaya; while only 8 extend from Malaya to thesc islands without occurring in Indo-China. The "remanent" species, therefore, so far as this evidence goes, indicate the predominance of an Indo-Chinese element, a fact that is altogether in accordance with what we should expect from our knowledge of the configuration of the sea-bottom along the line of islands from Cape Negrais in Arracan to the Nias Islands and Sumatra.

Reviewing the results of the preceding paragraphs we conclude that 288 species, or 80 per cent. of the flora, may conceivably have been introduced: 33 species, or 9 per cent., by human agency; 94 species, or 28 per cent., by birds; 60 species, or 17 per cent., by winds and 101 species, or 28 per cent., by the sea. We find moreover that the evidence is in favour of the bird-introduced species having, so far as those brought by wading- and water-birds are concerned, been introduced from the north, and so far as those brought by frugivorous and by seedor grain-eating birds are concerned, having come in almost equal numbers from Malaya or the Andamans to the south, and from Indo-China to the nortli. So far as wind-introduced species are concerned the influence of the north-east monsoon is apparently the more active; so far as the sea-introduced species are concerned the influence of currents from Malayan seas to the south-east has been paramount.

The subjoined table gives a synoptic view of the probable origin of the Coco Island flora.

* The writer has proposed the name "Malay Isthmus" for the conjoint area that inclades Tenasserim, the Andamans and the Nicobars, and believes that it will be found convenient to recoguise this as a distinct phytogeographical subdistrict. See Ann. Roy. Bot. Garden, Calcutta, iii, 238. 


\section{TABLE XXV. Synopsis of origin of Coco Island flora.}

Species possibly introdnced, for the presence of which no former land connection need be nccessary :-.................................

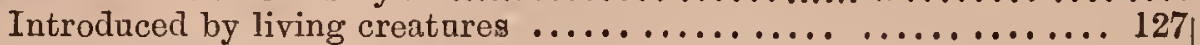

By human agency; (largely cosmopolitan species).

Intentionally; (cultivated plants) .......... is

Unintentionally; (weeds) ................... 18

By birds, (perhaps also to a small extent by bats) ......... 94)

Attached externally to their bodies

Immediately ; (viscous- or prickly-fraited sp.) 9

By mad; (species introduced by water-birds,

mainly from the northward) ........ 16

Carried in crops of birds; (almost in equal propor-

tion from northward and from southward) ..... 69

As a natural sequence of their mode of lifo; (fleshy-fruited species) ................

Accidentally, where bird mnst have been destroyed to admit of germination of seeds ; (by seed- and grain-eating birds): [indirectly due to agency of wind $] \ldots \ldots, 14$

By other natural agencies ......................... 161

By wind directly; (sp. with seeds speciaiised for wind-carriago; also small-spored Cryptogams) ............. 60

By the sea; (mainly Malayan species) $\ldots . . . \ldots \ldots \ldots 101$.

Marine species; (mainly Algc) $\ldots . . . . . \ldots .$. 21

Littoral species; (mangrove-regetation and beach-

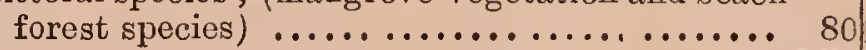

Species probably remanent and indicating former conncetion with adjacent

land, (apparently Indo-China) :-......................... 70

Total of Coco Island species ..................... 358

From the Proceedings, Asiatic Society of Bengal for December, 1891.

On a Botanical visit to Little Andaman and the Nicobars.-By $\mathrm{D}$. Prain.

While awaiting the arrival of the "Investigator" at Port Blair in November 1890, the writer was invited by Col. Cadell, v. C., Chief Commissioner of the Andamans, to visit, in connection with the Botanical Survey of India, the islands of Narcondam and Barren Island, two places 216 
rarely visitcd and not previously botanically explored. Having obtained the permission of Dr. G. King, F. R. S., the writer was enabled to make this visit in the "Nancowry" during March and April 1891. After visiting Narcondam the steamer was required at Port Blair in order to proceed to Little Andaman and Car Nicobar, and Col. Cadell not only permitted the writer to accompany the vessel there, but also, at the suggestion of Mr E. H. Man, kindly directed her to proceed to Batti Malv, a small island without inhabitants and very difficult of access, lying 18 miles south of Car Nicobar. After returning from Batti Malv the steamer took the writer to Barren Island.

The botanical results of the visits to Narcondam and Barren Island, which together formed the central feature of the tour, and the botanical exploration of which was the writer's main purpose, will, it is hoped, soon be made public. The results of the visits to the islands of Little Andaman, Car Nicobar and Batti Malv have been dealt with separately and are now laid before the Society. They have been treated in this fashion, partly because these visits formed an episodc in the tour apart from its main object, but chiefly because the lists are less exhaustive, owing to the short time available for collcction in each place, than the corresponding lists for Barren Island and Narcondam will be.

The details of the visits are as follows:- the "Nancowry" left Port Blair on the morning of Good-Friday, reaching Bomliya Creek, where two natives of Little Andaman, who had been visiting Port Blair, were to be landed, about 2 P. x. As the state of the tidal currents made it inadmissable to leave again till 5-30, the writer had an opportunity of spending three hours collecting at the mouth of the creek and for a mile or two along the north coast of the island to the east of this. The jungle behind the beach forest was too dense and the time available too short to admit of his penetrating any distance into the interior.

The island of Little Andaman, as seen from the sea, presents a somewhat different appearance from Great Andaman. Instead of being diversified by ridges and valleys and isolated hills, it has a long, low uniform rounded outline similar to that of Sentinel Island as seen from the top of Mount Harriet ncar Port Blair, and to that of Car Nicobar. It appears, however, to be uniformly covered with forest and to have none of the barc grass-heaths that characterise Car Nicıbar. The creek at which the writer landed is the principul one on the north coast of the island. It derives its name from an Andamanese word meaning "flies," and certainly these insects abound there in great numbers and are very troublesome. There is nothing in the mangrovc swamp vegetation to distinguish this from similar places in the Andamans and very little in the beach-forest to characterise the island except that Casu. 
arina equisetifolia is here very plentiful immediately belind the beach. This species, the writer was informed at Port Blair, is equally plentifnl in the whole circuit of the coast, so much so that the Andamanese name for the island is Wirra-Mar'n, Anglicé "Casuarina-sand." In Great Andaman this tree, as an indigenous species, is confined to a single bay on the west side of North Island. As in Grcat Andaman there are no Coco-nut trees on the coast. On the reefs the chief distinctive features are the presence of beds of Halophila ovalis and considerable quantities of Halimeda discoidea. The visit took place between half-tide and full-tide and no cxposed rocks were seen in the vicinity at the time.

Leaving about 6 P. M. the "Nancowry" steamed to Car Nicobar to land some men belonging to Kimiós village, who had been in prison at Port Blair. Sáwi Bay was reached on Saturday morning and two men of Moos village, with their canoe, were taken on board to assist in landing on Batti Malv. Owing to the heavy surf running it was found that landing in Kimiós Bay would be very difficult; the vessel therefore, about 2 P. M, anchored off another village 5 miles to the north and the writer was able to land, and walk to Kimiós and hack, along two jungle paths, collecting by the way and getting on board again at dusk. Owing to the short time available attention could only be directed to the sea-fence, the beach-forcst, the under-growth of the Coco-nut zone, and the mere outskirts of the interior jungle. Car Nicobar is so well-known that no particular notice of its appearance is necessary. There is the usual fringing-reef with a sandy beach, behind this the sea-fencc, and within that a zone of beach-forest, of which the arca under Coco-nut trecs forms an integral portion. The indigenous species are very much like those of the Andamans in similar places-the great distinguishing feature being, of course, the wide Coco-nut zone. The Coco-nuts themselves are particularly fine, and though at Port Blair the finest sorts of Nicobarese and Ceylonese Coco-nuts are carefully cultivated they do not equal those of Car Nicobar either in flapour or size. Yet those of Car Nicobar are said to be by no means the best that the Nicobar's can produce. The truc interior forest and the grass heaths the writer had no opportunity of examining.

In the night the "Nancowry" proceeded to Batti Malv, which was reached at dawn on Easter-day, and the writer, going on shore at once, spent the greater part of the day there, collcating. Landing, even with the assistance of the Nicobarese and their conoe, was effected with considcrnble difficulty at the north-west corner of the island, where alone it is said to be possible to go on shore. At this point the shorc is precipitous, sinking into dcep water without any coral fringing-rcef and rising into a jagged wall broken somewhat by gullies and small caverns, nearly 218 
everywhere overhanging; and occasionally with tunnelled projecting points. This wall is here on an average from 10-15 feet above highwater-mark. There was no time to circumnavigate the island, but the coast is said to present similar features in its whole circuit, the cliff being highest at the south-west corner of the island and being there about 50 feet high.

The difficulty of landing is largely due to this feature of overhanging cliff and is much increased by the strength of the tidal currents which, even in calm weather, cause a heavy swell to surge into the caverns and along the cliff-face. On reaching the edge of the cliff we find, at this part of the coast, a rocky platform over which the waves evidently wash in the monsoon. The rock is a limestone, and is, by weathering and wave-action, worn into the most fantastic spikes and pinnacles and ridges,* the sharp edges of which make walking extrcmely difficult. This platform slopes backwards rather rapidly to a height of about 10 feet more when the jungle commences with the ordinary seafence of Pandanus, etc.; the platform itself is almost destitute of vegetation, the only species present in it being tufts of Oldenlandia corymbosa, Boerhaavia repens and Fimbristylis diphylla. Within the sea-fence the surface of the island is even and almost flat from side to side of the island. $†$

The commonest tall tree is Mimusops littoralis, which is not here confined to the coast-zone, but extends from side to side of the island. The jungle is less dense than Andamans and Nicobar forests usually are. There is a wonderful absence of climbing species, especially of the class of armed climbers, and there is a remarkably large number of species with edible fruits, a feature that doubtless owes its existence

* This fantastically-weathered limestone so much resembles the bottom of a coral-pool that the rock has actnally been described as a raised coral-reef. (See Hume: The Islands of the Bay of Bengal, in Stray Feathers, vol, ii, p. 95).

+ The Admiralty maps give the island a "landmark-height" of 130 feet which is doubtless correct, and in some maps it will be seen that a hill is indicated in the centre of the island; this, however, is quite incorrect. The height at the north-east corner is, as has been said in the text, about 30 feet; at the south-west corner the hcight is said to be about 60 feet; assnming that the whole island has an even surface the middle of the island cannot exceed 45 feet. Here, as in all other islands exposed to strong monsoons, the trees immediately on the coast are stuntcd and dwarfed, becoming progressively taller as we pass inland. The principal tree is Mimusops littoralis, and even near the shore this often reaches a height of 60 feet, while trees a few handred yards inland reach 80 feet; this is the common height of the tree and one which it rarely exceeds. The height obtained by angnlar measurement from the sea thus not only does not require us to sappose that there is a hill in the middle, but shows that thcre camnot be anything of the sort and tho newer maps correctly indicate that the island has a flat surface. 
to the fact that the island, being so remote and so inaccessible, is largely frequented by fruit-eating pigeons and is one, (it has been even said, is the only), known locality in which the large Nicobars pigeon (Caloenas nicobarica) breeds. Fruit-eating bats too are abundant in the island and are perhaps partly responsible for the introduction of some of these species. Among the more interesting species of this kind is the Datura, which in most localities is considered, and probably correctly considered, a species introduced by man but which here undoubtedly must be a birdintroduced plant. Not only is it an exceedingly rare thing for the Nicobarese to visit the island, Datura is not a plant with which they are acquainted. The writer, who collected all the possibly introduced species to be found in the neighbourhood of the two villages on Car Nicobar visited by him did not find it present. Moreover it was apparently not found either by $\mathrm{Mr}$. Jelinek during the visit of the frigate "Novara" or by Mr. Kurz during his visit to the Nicobars, and no Solanacece are enumerated in Mr. Kurz's list of Nicobars plants in the Society's Journal, vol. xlv, part 2, p. 115 et seq. Though uninhabited and apparently very rarely visited there are some Coco-nut trees; the nuts are, however, small and their flavour is rather poor. The few trees that occur are just within the Pandanus fence, and there is nothing like a Coco-nut zone. There is no water on the island; still, besides the bats, there occur, of mammalia, both rats and pigs; the traces of the latter were very common and one pig's skull was found in the jungle. The great feature of the island, however, is the enormous multitude of Nicobar pigeons. These swarm everywhere, in the trees and on the ground, and remind one by their numbers of an English "rookery." * No snakes were seen, but the number and variety of the lizards was very remarkable.

One of the most striking features of the island was the freshness and greenness of the foliage, even in March; a circumstance that, considering the nature of the soil, must be altogether explained by the remarkably heavy dews that are deposited in these latitndes. Landing as the writer did, at day-break, he found the leaves quite as beavily laden with water as they could possibly have been after a thundershower, and on the side of the island away from the sun the dervs had not yet become completely dissipated at $10 \mathrm{~A}$. $\mathrm{M}$.

After spending eiglit hours on shore the writer, himself, but not the island, exhausted, had reluctantly to return to the "Nancowry" which at once steamed off to the Andamans, reaching Port Blair on Monday at noon.

* For an interesting account of the appearance of the island see Mr. Hume's paper already roferred to; Stray Feathers, vol. ii, pp. 94-97. 
In the two subjoined lists the plants obtained during this short tour are enumerated. The first list gives, for the sake of convenience, those collected in Little Andaman. Species for which their occurrence here is the first indication of their presence in the Andaman group are distinguished by an asterisk.

The second list gives the plants obtained in Car Nicobar and in Batti Malv. Those for which this is the first record of their occurrence in the Nicobars and which are not given in the Enumeration of the plants of the Nicobar Islands by Mr. Kurz (Journ. As. Soc. Beng., xlv, pt. 2, p. 115-164) are similarly distinguished.

I. List oe plants collected at Bomliya Creek, north end of Little Andaman.

\section{GUTTIFER $A$.}

Calophrleum inophyledm Linn.

\section{MALVACE $\AA$.}

Hibiscus tiliaceus Linn.

Thespesia populnea Linu.

\section{STERCULIACE A.}

Sterculia rebiginosa Vent., var. Glabrescens King. (Sterculia mollis Kurz in Jour. As. Soc. Beng., xlv, pt. 2, 120 not of Wallich.)

\section{MELIACE A.}

5. Carapa obovata Blume.

Having seen both $C$. obovata Bl., and $C$. malaccensis Lamk. in situ and examined them as they grow, it is very difficult for the writer to give his assent to the proposition that treats the two as conspecific. C. moluccensis is common on rocky coasts, while C. obovata is confined to muddy flats, in which it is common, and to mangrove-swamps, of the vegetation of which it forms an integral portion. There is no difficulty with the large suites of specimens that are preserved in the Calcutta Herbarium in distinguishing the one plant from the other, and the residents of Port Blair who know both find it impossible to understand why botanists should wish to believe them to be the same. It may be that their differences, so palpable to the untrained eye, are altogether due to the environment of the two being so different; this, however, if it be a fact, can only be demonstrated by experiment and the onus prolandi 
obviously rests with those who would mite, not with those who can distinguish, the trees; till the point is settled the writer feels compelled to follow Blume in treating them as distinct. In the Andamans Carapa moluccensis flowers in November and December, O. obovata flowers in March and April.

\section{LEGUMINOSA.}

Demadum umbeliatúa DC.

A BRUS PRECATORIUS Linn.

Erythrina indica Lamk.

Canavalia turgida Grah. in Wall. Cat.

This is the common sea-shore Canavalia of the Andaman, Nicobar and Malayan coasts and is uudoubtedly the plant intended by Graham as $C$. turgida Wall. Cat. n. 5534 A, a plant collected by Wallich in Penang. Cat. n. 5534 B, from Siam (Herb. Finlayson), is not represented at Calcutta but most probably is, since Grahani and Wallich thought so, the same plant. C. turgida is certainly not identical with $C$. ensiformis, even if we admit that the Canavalia gladiata, cultivated in the Eastern Hemisphere, is conspecific with the American cultivated plant; nor is it the same as C. virosa W. \& A., with which Mr. Kurz has identified it (Journ. As. Suc. Beng. xlv, pt. 2, p. 127) and which the writer agrees with Mr. Baker in considering the wild form of Cunavalia ensiformis (C.gladiata). The interior of the pod, even more than the different shape, makes the proposal to treat $C$. turgida and $C$. virosa as conspecific quite impossible. Perhaps the confusion of $C$.turgida with O. virosa may have arisen from the fact that Wall. Cat. $5534 \mathrm{C}$, from Ava, is true C.virosa. A reference, however, to the Lithographed Catalogue itself shews that Dr. Wallich only doubtfully refers the Ava plant to Graham's species. Mr. Baker doubtfully refers C. Slocksii Dalz. \& Gibs., Bomb. Fl. 69, to C. turgida; this is, in the writer's opinion, highly improbable because 1., C. turgida seems always strictly confined to sea-shores and to the banks of muddy estuaries and never has been collected inland; and 2, though it extends from the Salt-lakes near Calcutta and from the Sunderbuns at the top of the Bay of Bengal to the Indo-Chinese and Malayan Coasts generally, it has not yet been found anywhere on the coasts of India proper, of Ceylon, or of the Laceadives.

Though a characteristic sea-shore species, $C$. turgida is not conspecific with the O. obtusifolia of the coasts of India proper, which apparently does not occur in the Andamans, the Nicobars, or the Malay Peninsula-on the shores of the Andaman sea-, though it does-occur in Java (as pointed out by Prof. Miquel) to which island C. turgida also extends. 
The writer has not seen fruiting specimens of a Japanese seacoast species identified by Mr. Maximowicz and others with $C$. obtusifolia DC. (O. lineata DC.; Dolichos lineatus Thunbg.) but from two flowering specimens in Herb. Calcutta, it is apparently not specifically identical with the Indian O. obtusifotia figured by Dr. Oleghorn (Madr. Lit. Soc. Journ., n. s., i, t. 4). On the other hand there is no apparent difference in flowers, leaves or habit, between the Japanese Dolichos lineatus and the Indo-Chinese and Malayan Canavalia turgida. If the fruits are also found to agree, and if Dolichos lineatus is the true Canavatia obtusifolia, C. turgida will have to be reduced to C. obtusifolia. If the fruits differ C. turgida undoubtedly deserves the specific rank assigned to it by Graham, Wallich and Miquel. The name "O. obtusifolia," it may be remarked, is as appropriate to the Indian seashore plant, as it is unsuitable to the Japanese littoral $O$. lineata and to the Indo-Chinese and Malayan littoral $O$. turgida.

10. Vigna lutea A. Gray.

Mocona gigantea DC.

Derris scandens Benth.

Derris̀ dliginosa Benth.

Pongamia glabra Vent.

15. Comalpinta Bonducelca Flem.

Cynometra ramiflora Linn.

RHIZOPHORE AE.

Ceriops Candolleana Arn.

Brdquiera grmnorhiza Lamk.

COMBRETACE 我。

Terminalia Catappa Linn.

MYRTACE AE.

20. Barringtonia speciosa Forst.

RUBIACE A.

Hrdnophytum andamanense Becc., Malesia ii, 156, t. 48, fig. 8-13.

WeberA KURZII Hook. f.

GoetTarda SPę̧iosa Linn. f.

IXORA BRUNNESCENS Kurz.

Add to previous descriptions :-Flowers white, sweet smelling, corolla tube $\frac{1}{3} \mathrm{in}$. long, teeth $\frac{1}{6} \mathrm{in}$. long; berries creamy white with purple meridional elongated blotches.

25. Morinda Citrifolia Linn., var. bracteata Hook, f. (M. bracteata Roxb.) 


\section{COMPOSIT 无.}

Wedelia sCandens C. B. Clarke.

MYRSINE A.

Ardisia humilis Vahl. (A. littoralis Andr.)

\section{SAPOTACE A.}

\section{Minusoys littoralis Kuir.}

Common here, as elsewhere in the Andamans and Nicobars, in the beach forest. Three or four lofty trees recently blown down yielded from among their topmost branches, the species $n .30, n .31, n .43, n .44$, $n .45, n .46, n .47, n .53, n .54$, and $n .55$ of this list.

\section{APOCYNEÆ⿸尹口.}

Ochrosja borbonica Gmel.

This species is much more frequent in the Andamans than Cerbera Odollam, and the fruits, especially when the outer skin is removed and only the stringy endocarp is seen, are not distinguishable from those of the latter species.

\section{ASCLEPIADACE $\not$.}

30. Dischidia nommularia $\mathrm{R}$. Br.

* Dischidia Rafflestana Wall.

Not previously recorded from the Andamans. The ants present here in the ascidial leaves were not 'harmless' as Dr. Wallich found those at Singapur to be.

BORAGINEA.

Cordia sUbCORDATA Lamk.

Very common.

Tournefortia argentea Linn.

CONVOLVULACE无.

Iтomga dentrodrata Choisy.

35. I

\section{VERBENACEAE。}

Premna integrifolia Linn.

Clemodendron inerme Gærtn.

\section{LAURINE}

Hernandia peltata Linn.

Very common. 


\section{SANTALACE 2 .}

Champereia Griffithiana Baill.

A very common tree in the coast-zone, $30-50$ feet high.

\section{CASUARINE $\nexists$.}

40. Casuarina equisetifolia Forst.

One of the commonest trees in the coast-zone just within the Pandanus sea-fence. In Great Andaman this species only occurs in one spot, Casuarina Bay, on the west coast of North Andaman.

CYCADACE $\$$.

Cycas Rumphir Miq.

\section{HYDROCHARID 2 .}

* Halophila ovalis R. Br.

Very common; this has not previously been met with on Andaman reefs.

\section{ORCHIDACE स.}

* Dendrobidm secundum Lindl.

This occurs in South Andaman and in the Coco group also.

Dendrobium Tendicadle Hook. $f$.

Also common at Port Blair in South Andaman.

45. Dendrobiom anceps Roxb.

* Dendrobidu terminale Par. \& Reichb. f.

This is also common, along with the preceding, at Port Blair in South Andaman.

Aerides mUltiflorum Roxb.

AMARYLLIDACE $\nexists$.

Crinum asiatioum Linn.

\section{LILIACE $\nexists$.}

Dractina angustifolita Roxb.

FLAGELLARIE

50. Flagellaria indica Linn.

\section{PANDANACE 开.}

Pandanus odoratissimus Linn. $f$.

\section{NAIADACE $\AA$.}

Crmodocea ciliata Ehrenb. 


\section{FILICES.}

Dapallia solida $\mathrm{S} w$.

Poltpodium QUerchfoliom Linn.

55. Polypodium adnascens $\mathbf{S}$.

Acrostichom scandens J. Sm.

ALGA.

Sargassum ilicifoliom Agardh.

Turbinaria ornate Lamk.

Halimeda Opuntia Lamk.

60.* Haltmeda discoidea Dene.

Padina patonia Gaill.

II. List of the plants collected in Car Nicobar and Batti Malt. ANONACE AN.

Popowia partifolia Kurz.

Car Nicobar; Batti Malv.

MENISPERMACE $\nexists$.

Cyclea peltata H. f. \& T.

Batti Malv.

CAPPARIDE 开.

Ginandropsis pentaphylla DC.

Car Nicobar; a weed round the huts of natives at Kimiós.

* Capparis ambigua Kurz.

Batti Malv; a common unarmed climber; previously only known from the Andaman group.

GUTTIFERÆ.

5. Calophtlium inophyllum Linn.

Car Nicobar and Batti Malv.

\section{MALVACE $\AA$.}

StDA ACUTA Burm.

Car Nicobar; a weed near Kimiós village.

Urena lobata Linn.

Car Nicobar; a weed near villages.

Hibiscus tiliaceds Linn.

Car Nicobar and Batti Malv.

Thespesia popdlnea Linn.

Car Nicobar and Batti Malv.

226 


\section{STEROULIACAE.}

10. Sterculia rubiginosa Vent, var. glabrescens King. (S. mollis Kurz, not of Wallich.)

Car Nicobar and Batti Malv.

Melochia velutina Bedd.

Car Nicobar.

\section{RUTACE A.}

Glycosmis pentaphylla Corr.

Car Nicobar.

Triphasia trifoliolata DC.

Car Nicobar.

\section{AMPELIDE $A$.}

\section{Vitis PEdata Vahl.}

Batti Malv.

15. Leea sambucina Willd.

Car Nicobar.

Leea grandifolia Kurz.

Batti Malv, very common.

\section{SAPINDACE 瓜.}

Lepidopetaldu Jachianda Radlk. (Cupania Jackiana Hiern.)

Car Nicobar, flowering specimens; Batti Malv; fruiting specimens. There is now no doubt that this species is correctly referred to Lepidopetalum by Prof. Radlkofer. The flower-buds are oval, pointed; the 4 green, lanceolate calyx-segments alternate with 4 extremely small, white, cordate-acute petals attached to the face of each of which is a single large scale, connate by its margins with the edges of the corresponding petal and forming along with it a small, peltate-infundibuliform pouch ; the stamens are 8 in number with glabrous, slender, short filaments and oblong, pilose anthers; the ovary is 2-celled; the fruit, reddish-brown externally, is bright scarlet within, usually the seed of one of the two cells is abortive; the ripe seeds are black, covered with a mucilaginous substauce and embraced, as to their lower third, in a pink, cup-shaped, thick, fleshy arillus. It is oue of the favourite fruits with Oalcenas nicobarica and the other frugivorous pigeons. Even if, with Bentham and Hooker, (Gen. Plantar. i, 399), generic rank is not accorded to Lepidopetalum, Hiern's location of the species in Cupania (Flor. Brit. Ind. i, 678) is not valid, since, as these authors show, Lepidopetalum is more nearly related to Rutonia, as understood by them, than to Oupania. 
Allophylus Cobbe Blume.

Batti Malv; the specimens agreo exactly wth authentic specimens of A. littoralis Blume.

Erioglossum edule Blume.

Batti Malv.

ANACARDIACE $Æ$.

20. Semecarpus heterophylia Blume.

Batti Malv.

CONNARACEA.

* Connarus sp.

Batti Malv; the specimens are in leaf only, but agree well with specimens of an undescribed Connarus from the Nicobars about to be published by Dr. G. King in the Annals of the Roy. Bot. Garden, Calcutta.

\section{LEGUMINOSAE.}

Desmodium umbellatum DC.

Batti Malv.

Abrus precatorius Linn.

Car Nicobar and Batti Malv.

Erythrina indica Lamk.

Car Nicobar.

25. Canavalia turgida Grah.

Batti Malv.

Derilis scandens Bth.

Batti Malv.

Derris uliginosa Bth.

Batti Malv.

Sophora tomentosa Linn.

Car Nicobar.

Cemsalpinia Bonddeelda Flem. (C. Bondus Kurz, not of Linu.) Batti Malv.

30. Cassia occidentalis Linn.

Car Nicubar, a weed near Kimiós village.

COMBRETACE 我.

Terminalia Catapta Lamk.

Car Nicobar, Batti Malv.

Gyrocarpus Jacquinil Roxb.

Batti Malv.

228 
MYRTACEA.

Barringtonia speolosa Forst.

Batti Malv.

MELASTOMACE $\not$.

Memectlon edule Roxb. var.p-

Batti Malv.

UUCURBITACE 2 .

35. * T'richosanthes palmata Roxb.

Car Nicobar, Batti Malv.

* Mukia scabrella Arn.

Batti Malv.

CORNAOEAE.

Arangium sundanom Miq.

Batti Malv, a very common large climber.

\section{RUBIACE}

* Oldenlandia corymbosa Linn., var.-

Batti Malv, on the bare limestone rocks between the sea and the Pandanus fence. The specimens are exactly like those of Hedyotis alsincefolia R. Br. in Wall. Cat. $n .873$.

WeBERA KuRzII Hook. f.

Car Nicobar.

40. Ophorihiza Mungos Linn.

Car Nicobar.

Guettarda Speciosa Linn.

Batti Malv.

IXORA BRUnNescens Kurz.

Car Nicobar, Batti Malv.

IXORA CDNEIFOLIA Roxb.

Car Nicobar.

IXORA CUNEIFOLIA ROXb., var. MAOROOARPA KuYz.

Batti Malv.

45. MORINDA Citrifolia Linn., var. BRAOTEATA Hook. f. (M bracteata Roxb.)

Car Nicobar, Batti Malv.

Musganda macrophylla Wall.

Car Nicobar.

Pederia fectida Linn.

Batti Malv. 
COMPOSITAE.

Wedelia scandens C.B. Clarke.

Car Nicobar, Batti Malv.

GOODENOVIE $A$.

ScmVoLA Kשnigir Vahl.

Batti Malv.

\section{MYRSINE $A$.}

50. Ardisia humils Vahl. (A. littoralis Andr.)

Car Nicobar, Batti Malv.

\section{SAPOTACEA.}

Mimusops littoralis Kurz,

Car Nicobar, Batti Malv.

\section{EBENACE AS,}

Diosprros Kurzii Hiern.

Batti Malv.

\section{APOOYNE $A$.}

Ochrosia borbonica Gmel.

Car Nicobar.

Tabernamontana orispa Roxb.

Car Nicobar, Batti Malv.

55. Parsonsia spiralis $\mathrm{R}$. Br.

Car Nicobar.

\section{ASCLEPIADACE $A$.}

Dischidia Griffithil Hook. $f . ?$ ( $D$. bengalensis Kurz, not of Colebr.)

Car Nicobar. There are no authentic examples of $D$. Griffithii at Calcutta, with which to compare the plant obtained by the writer in Car Nicobar, and by $\mathrm{Mr}$. Jelinek in Kamorta and Katschall. There are specimens of Novara n. 115 at Calcutta, and an examination of these shows that they are precisely the same as the present Car Nicobar plant and that they have been erroneously referred by Mr. Kurz to D. bengalensis. The Nicobars plant has a hirsute corolla throat, the corollathroat in $D$. bengalensis is glabrous.

\section{LOGANIACE 死,}

Strychos actminata Wall.

Batti Malv. 


\section{BORAGINEZ1.}

Cordia suboordata Lamk.

Batti Malv.

Todrnefortia argentea Linn.

Car Nicobar.

CONVOLVULACE $\nexists$.

60. Ipomea denticulata Choisy.

Car Nicobar, Batti Malv.

Ipomea Cymosa Roem. \& Schult.

Car Nicobar.

IpOMEA BILOBA Forsk.

Car Nicobar, Batti Malv.

Convolvolus partiflords Vahl.

Batti Malv.

\section{SOLANACE无。}

* Solanum Melongena Linn.

Car Nicobar; near huts of natives at Kimiós.

65. * Datura fastuosa Linn.

Batti Malv; interesting as an addition to the Nicobar Flora and as proving from its presence in this island that human agency is not always necessary to account for the dispersal of the species.

\section{ACANTHACEAE.}

Eranthemom cinnabarinum Nees, var. succisifolium Clarke. ( $E$ succifolium Kurz).

Car Nicobar, Batti Malv.

Peristrophe auduinata Nees.

Car Nicobar.

\section{VERBENACE A.}

Premna integrifolia Linn.

Batti Malv.

Clerodendron inerue Gaertn.

Car Nicobar, Batti Malv.

70. Clemodendron panicolatum Ling.

Car Nicobar.

Caliticarpa longifolta Lamk.

Car Nicobar. 


\section{LABIAT $\mathbb{E}$.}

* Ocimum Basilicua Linn.

Car Nicobar"; a weed near Kimiós village.

The dispersal of the species of this genus-the Tulsi plarts-is somewhat curious. In Kamorta, Katschall and Nancowry, where Hindu convicts have been stationed, it is the true or sacred Tulsi (O. sanctum) that has become naturalised. Here, where no Hindus have lived, it is 0 . Basilicum that is grown by the natives, to whom one Tulsi is as good as another. In the Laccadives, where the people are Mussalmans, and to whom the sacred Tulsi does not specially appeal, it is the Ram Tulsi (O. gratissimum) that occurs.

NYCTAGINE $A$.

BoerhaAvia repens Linn.

Batti Malv, on the rocks outside the Pandanus sea-fence.

* Pisonia aculeata Linn.

Batti Malv.

75. * Pisonia alba Spanoghe.

Batti Malv.

* Pisonia excelsa Blumo.

Batti Malv.

\section{AMARANTACEAE.}

* Amarantus spinosus Linn.

Car Nicobar, near Kimiós village.

* Achyranthes aspera Linn.

Car Nicobar, a weed near Kimiós village. Only the sea-shore variety, (A. porphyristachya Wall.), has hitherto been known to occur in the Nicobars; it was obtained by $\mathrm{Mr}$. Jelinek of the "Novara."

ERUa ranata Juss.

Car Nicobar, Batti Malv.

\section{LAURINE $\not$.}

80. Hernandia peltata Linn.

Car Nicobar.

\section{ARISTOLOCHIACE Ж.}

* Aristoloohia tagada Cham. \& Schlecht. Batti Malv.

\section{EUPHORBIACEAT.}

Euphorata Aтотo Linn.

Car Nicobar.

232 
Glochidion oalooarpdia Kurz.

Car Nicobar.

Flueggra microcarpa Blume.

Car Nicobar, Batti Malv.

85. Breynia oblongifolia Muell.-Arg.

Car Nicobar.

Bridelia tomentosa Blume.

Car Nicobar.

Alchornea rogosa Muell.-Arg.

Car Nicobar. The specimens agreo exactly with authentic examples of A. javensis Muell.-Arg.

Claoxylon longifolida Muell.-Arg.

Car Nicobar.

ClaOXYlon MOLLE Endl.

Batti Malv.

90. * Gelonium? sp.

Batti Malv. The specimens are without fruit and perhaps do not belong to this genus. They differ from anything hitherto reported from the Nicobars.

\section{URTICACE A.}

Pipturus velutinus Wedd.

Car Nicobar.

Ficds hispida Linn., var. DæMONUM Koøig.

Car Nicobar, Batti Malv.

Ficus Rumphir Vahl.

Batti Malv.

\section{CYCADACE $\nexists$.}

Cycas Rumphi Miq.

Car Nicobar, Batti Malv.

\section{PALMEA.}

95. Cocos nucifera Linn.

Car Nicobar, Batti Malv.

areca Catechu Linn.

Car Nicobar.

PANDANACEAE.

Pandands odoratissimus Linn. $f$.

Car Nicobar, Batti Malv. 


\section{LILIACEA.}

Dractina angustifolia Roxb.

Car Nicobar, Batti Malv.

AMARAYLLIDACE $\nexists$ A.

Crinum astaticum Linn.

Batti Malv.

FLAGELLARIE $\nexists$.

100. Flagelilaria indica Linn.

Batti Malv.

\section{ORCHIDACEA.}

Sarcanthus? sp.

Batti Malv. The specimen is in fruit only. Eulophia graminea Lindl. (E. decipiens Kurz.)

Car Nicobar.

NAIAD ACE $A$.

Cymodocea ciliata Ehrenb.

Car Nicobar.

\section{CYPERACE $\nexists$.}

Cyperus pennatus Lamk,

Batti Malv.

105. Fimbristylis diphylia Vahl.

Batti Malv, on rocks between the sea and the Pandanus belt.

\section{GRAMINE $\#$.}

Panicum fulites Nees.

Car Nicobar.

Ischдмuм мuтісим Retz.

Car Nicobar, Batti Malv.

ERAGRostis PLUMOSA Linn.

Car Nicobar.

\section{FILICES.}

PoLYPoDIUM QUERCIFOLIUM Linn.

Car Nicobar, Batti Malv.

110. Polypodium adnascens Swartz.

Car Nicobar, Batti Malv.

Poltyodium phymatodes Linn.

234 
Car Nicobar.

LYGODIUM FLEXUOSUM Swartz.

Car Nicobar.

\section{ALGAE.}

Sargassum ilicjfolidu Agardh was the only seaweed seen on Batti Malv. About a dozen seaweeds were obtained on Car Nicobar; they have not yet been determined.

From the Proceedings, Asiatic Society of Bengal for Aprit, 1892.

3. Remarlis on the Fauna of Narcondam and Barren Island.-By D. Prain.

During a botanical visit to these two islands, the results of which are now being elaborated, the writer, though unable and indeed unqualified to devote much attention to their fauna, could not avoid coming in contact to some extent with their animal and inscct life. And perhaps his few rough notes made at the time, if thrown into a connected form, may induce by their perusal some qualified animal biologist to visit and investigate them thoroughly. In Mr. Mallet's exhaustive monograph of the geological structure and physiographical aspects of the islands* their flora and fauna are only casually mentioned; similarly, in the writer's forthcoming notice of their vegetation, there can be but incidental allusions to their topography, geology, or zoology. Yet from what the writer was himself able to observe it is probable that their zoology will prove as interesting as their geology or their botany. It need hardly be said that the notes which follow allude entirely to air-breathing creatures and that no reference will be made to the marine fauna of the localities.

Mammalia:-A rat swarms everywhere on both islands and is the most plentiful mammal present. Examples preserved in the Indian Museum, obtained in Barren Island by Mr. Oldham, show that the

* Memoirs of the Geol. Survey of India, vol, xxi, pp. 251-286. 
species is the Andamanese form of the widely distributed Tree-Rat (Mus rattus VAR. andamanensis.)*

In Narcondam at dusk a frugivorous bat was observed flitting from tree to tree, and in Barren Island the writer came upon an example of Ficus Rumphii, on the outer aspect of the outer cone and about half a mile to the north of the landing place at the hot-spring, which was the home of a colony of these creatures. The writer was able to reach a point on the cliff almost overlooking the tree and where he was not more than twenty-five yards away from the bats. He was able to see that they were of a very dark brown (almost black) colour but, having no fowling-piece, he could not secure a specimen. $\dagger$ It is not improbable that, as in the case of the rats, the bats on the two islands belong to the same species.

Goats have more than once been landed on both islands. On Narcondam there were however none to be seen and when one recollects that for a considerable portion of the year the island is absolutely waterless the fact is not surprising. And those formerly landed on Barren Island must also have perished, for a few years ago, Col. 'Tucker, then in charge of the Andamans, found it necessary to land five more. During our visit we several times saw three goats in company and as we discovered among the lava blocks the skeletons of two others it is not im. possible that we were thus able to account for the whole five. The three seen together were all adults, perhaps therefore they have either not begun to breed or their joung have been unable to survive. A welltrodden foot-path across the lava causeway near the landing-place shows that the goats come daily, at least during the dry season, to drink at the only spring the island possesses, hot-water charged with over 200 grains per gallon of saline matter. $\$$ Each morning during the writer's

* Catal. of Mammalia in the Indian Museum, pt. ii, p. 63.

t Had a specimen been shot it probably could not have been secured, for a direct descent from the writer's position to the foot of the tree was impracticable and to reach the spot where the specimen mast have fallen wonld have entailed:-1, a return to the landing-place ( $t$ wo hours work to begin with) ; 2 , rowing half a mile to the mouth of the galley in which the tree stood; and (granting that the sea-mouth of the proper gulley was hit off and, if it was, that a landing could have been effected-neither event being at all a necessary consequence,) 3, a search for the particular tree involving a climb of over 800 feet throngh a particalarly diffenlt jungle with mach the same prospect of ultimate success that there would be in the proverbial search for " a needle in a haystack." But this shonld only whet the appetite of the truo collector for a visit to the islands; it will however show that the geologist or botanist who visits the place with bat a limited time at his disposal, must confine his attention to his own subject and can do bat dilettante work in any other direction.

I Memoirs of the Geol. Survey of India, vol, xxi, p. 277.

236 
visit we could see when we landed, from the new foot-prints on the wet sand round the spring and from the fresh dung there and along the pathway, that the goats had visited the spot overnight.*

BrRds:-A brief sketch of the Avi-fauna of the islands has already been written by Mr. A. O. Hume. $\nmid$ His visit to each island was however very short; it may not therefore be uninteresting to give a list of the birds seen by him and to mention in addition those seen and recognised by the writer. It is unnecessary to say that even now the list must be very far from complete.

\section{List of the Birds of Narcondam and Barren Island.}

1. Cuncuma leucogaster Gmel. (White-bellied Sea-Eagle.) Stray Feathers ii, 149.

Very plentiful in both islands, but especially in Narcondam, where to watch six or eight of them sweep and wheel and dart at each other, apparently in play, far overhead, was a most fascinating occupation. While ascending the mountain that composes the island we saw what was evidently the nest of this species at about $1,500 \mathrm{ft}$. elev.

Distrib. India, Burma, Andamans, Nicobars, Malaya.

\section{7. \\ 2. Coldocalia Linchi Horsf. (Rock Swiftlet.) Stray Feathers ii,}

A swiftlet is very common on both islands and can be seen as one rows along the coast darting in and out from every cavern hollowed by the sea under the old lava-flows. As no edible birds'-nests are found on either island this is most probably the species that one observes. :

Distrib. Andamans, Nicobars, Malaya.

* The landing of goats on such islands has little to recommend it from the economic point of view while the humanitarian aspect of the act has two sides. It is no doubt praiseworthy to attempt to stock such islands with goats in the hope that their flesh may prove of usc to shipwrecked mariners, but to deliberately condemn the animals to a death by thirst-as is done every time that goats are landed on Narcondam-appears to the writer to be an act which should not be repeated. Nor is it at all certain that the landing of goats on Barren Island may not be-all the physical conditions of the island considered-an act of even more refined cruelty.

† Stray Feathers, vol ii, pp. 103-110. The localitics are again mentioned in connection with the birds themselves in Mr. Hume's detailed list of Andamans birds, $l$. c. pp. 139-324.

I It ought to be observed however that some recent writers, (very notably Guillemard, in the Cruise of the Marchesa, ii, 87), return to the view which Hume, l.c., so strenuously opposes and apparently satisfactorily refates, that Collocalia Linchi is the swift which makes edible ncsts. If Guillcmard be right then the Rock Swiftlet referred to by Mr. Hume and the writer must be a different species. 
3. Halcton atricapiluds Gmel. (Small Kingfisher.) Stray Feathers ii, 168; also p. 104.

This, Mr. Hume says, l. c. p. 104, is most probably the Kingfisher he observed on Barren Island. Oddly enough the writer saw no Kingfisher on Barren Island, but several indiriduals, perhaps of this species, were very actively employed on the coast at the north-east corner of Narcondam.

Distrib. India, Burma, Andæmans, Nicobars.

4. Rhyticeros Narcondami Hume. (The Narcondam Hornbill). Stray Feathers i, 411; ii, 176.

This species, which is confined to Narcondam, is exceedingly plentiful there. It is very fal from shy, for on one occasion when the writer and his attendants were busy cutting down a tree, three or four of these birds, apparently attracted by the noise, came and settled above us, continuing to scream and chatter overhead, while the tree vibrated under our strokes, for some time before making up their minds to fly away.

Distrib. Endemic.

5. Palaeornis affinis Tytler. (Red-cheeked Andaman Paroquet.) Stray Feathers ii, 184.

Common on both islands.

Distrib. Andaman group, including Coco Islands and Preparis.

6. Eudrnamys malayana Cab. (Andaman Koel). Stray Feathers ii, p. 192.

The writer saw this Koel several times during his stay on Narcondam; Mr. Hume did not happen to have an opportunity of noting the species.

Dis'ris. India, Burma, Andamans, Nicobars, Malaya.

7. Arachnechthra andaminica Hume. (Andaman Sun-Bird). Stray Feathers ii, 198.

Observed by Mr. Hume on both islands, not seen by the writer.

Distrib. Andaman group, including Coco Islands and Preparis.

8. Otocoupsa emeria Shaw. (Red-Whiskered Bulbul.) Stray Feathers ii, 225.

Observed by Mr. Hume on Barren island, not seen by the writer.

Distrib. India, Burma, Andamans, Nicobars (introduced).

9. Corvus Levaimlantin Lesson. (The Bow-billed Corby). Stray Feathers ii, 243.

The writer one day noticed five of these large Andaman Crows 238 
on Barren Island. There were none there apparently when Mr. Humo visited the island.

Distrib. Himalaya; India; Burma, Andamans; Malaya. ii, 260 .

10. Carpophaga aenea Linn. (Imperial Pigeon.) Stray Feathers,

Noticed once on Narcondam.

Distrib. Himalaya; India; Indo-China, Andamans ; Malaya.

11. Carpophaga bicolor Scop. (Pied Fruit-Pigeon.) Stray Feathers ii, 260. ward.

Exceedingly plentiful on both islands; a visitant from the south-

Distrib. Malaya; Nicobars; Andamans (a visitant).

12. Caloenas nicobarica Linn. (The Nicobars Frnit-Pigeon.)

Noticed several times on Narcondam, and once (three individuals together) on Barren Island, on the inner aspect of the outer crater to the south of the landing-place; a visitant from the Nicobars.

Distrib. Nicobars; Malaya: Audamans (a visitant).

13. Crrrepidesmus mongolicus Pallas. (Mongolian Shore-Plover.) Stray Feathers ii, 289.

Rather common on both islands.

Distrib. Eastern Asia. ii, 299.

14. Tringordes hypoledads Linn. (Sand-Piper.) Stray Feathers

Very common on both islands.

Distrib. Cosmopolitan.

15. Gallinula phoenicura Penn. (Water-Hen.)

Barren Island. This was not met with by Mr. Hume and it is not a bird that one would expect to see in these islands. Yet each time we landed on Barren Island and each time we returned to the beach from the interior we observed in the vicinity of the small hot-spring at the landing-place what appeared to us to be the same individual of this species. On being disturbed it walked leisurely away and disappeared among the crevices of the adjacent black lava-flow. Mr. Hume notes his having met with the species in suitable localities everywhere from the Great Coco to Acheen ; we must therefore suppose that the individual we saw had by some accident reached the island from one of the neighbouring members of the group and was making the best of the situation.

Distrib. India; Indo-China, Andamans; Nicobars, Malaya. 
16. Demiegretta sacra Gmel. (Blue Reef-Heron.) Stray Feathers ii, 304 .

Common on both islands.

Distrib. India, Burma, Andamans, Nicobars. 309 .

17. Ardeola Grayit Sykes. (Pond-Heron.) Stray Feathers ii,

Barren Island only (Hume); not seen by the writer.

Distrib. India; Andamans (a visitant).

18. Sterndua melanadchen Temm. (Snowy Tern.) Stray Feathers ii, 319 ; also p. 107.

Barren Island (Hume).

Distrib.* Malaya; Nicobars; Andamans.

The common Fowl is said to have been landed on both islands along with the goats, there is now, however, no trace of its existence. Possibly the large lizard-Hydrosaurus salvator-which is common, at least on Narcondam, may be held responsible for its disappearance, nothing being more certain than that a fowl, if nesting on the ground, must sooner or later fall a victim to this voracious creature.

REPTILES:-There is on Narcondam at least one land-snake, for the writer and his companion (Mr. McCausland, commander of the "Nancowry") came upon one cast-off skin in the centre of the island.

Lizards, both iguaniform lizards and skinques, are very common on Narcondam though not at all frequent on Barren Island. The whole of the crested ones were very shy but the skinques were the reverse of timid. $\uparrow$ The large water-lizard, Bydrosaurus salvator, is very common on Narcondam and is so unused to being disturbed that it waits till one comes so close as to be able to touch it before turning aside into the jungle. It was most common near the north bay where there is a small sandy beach frequented by turtles. Doubtless here, as elsewhere, the

* In this list of birds only the distribation within the limits of Sonth-Eastern Asia (India and Ceylon; Indo-China; Malaya and Northern Australia) is given, a more detailed account of the distribation for the few that extend beyond this area being, for our present purpose, unnecessary.

t Having one forenoon crossed the island from the landing-place near the anchorage at the north-east corner to the north bay the writer with his companion (Mr. Kellog, Gunner of the "Nancovry") rested for lanch in the shade of the Coconat grove there; while eating we were amused to watch the skinques prospecting for the crambs that fell aside; after a little-we in the meantime sitting as still as possible-some of the bolder or more confident lizards climbed our iegs in search of more. We observed besides that others of them disputed with the hermit-crabs which swarmed there for a share of the nutty portion of some opened coco-nuts that we had thrown aside after drinking the "milk." 
eggs of the turtle form one of the staple foods of the Hydrosaurus, to the omnivorus propensities of which the writer has already had occasion to allude.* In Barren Island none of these lizards were seen but it is not at all improbable that they are present, for there are two small bays at the south-west corner where there are sandy beaches with a Pandanus fence and some Coco-nut trees behind. Owing to the strong swell and heavy surf the writer was unable to land at either of these places, nor did he succeed in crossing the outer cone at a point whence he could reach them from the interior. It is, however, not at all unlikely that turtles visit these sandy patches and, if so, there is no doubt that, if Hydrosaurus exists on the island, he will be in evidence there.

CRUSTACEAns:-Besides hermit-crabs, which are very plentiful, there are, at least on Barren Island, land-crabs.† And, as might be surmised, Grapsus is plentiful on the rocks along the coast and is a source of interest to the Blue Reef-Heron and some of the other sea-fowl.

Other Air-Breathing Creatures:- - The writer did not see a single beetle on Barren Island, but perhaps the season of his visit (MarchApril) had something to do with their absence. One or two were met with on Narcondam-the specimens obtained including, amongst others, a Golden-Beetle.

Spiders are common on both islands, particularly on Narcondam, where also a scorpion is to be found. It was, however, only seen once, when digging up an Amorphophallus tuber, and was not preserved.+

Ants are very common, the two chief kinds being the common red mango-ant, or a species very like it, both physically and physiologically; and a very small species that makes long powdery tunnels along the outside of, and sometimes also makes its home inside, the stems and branches of various shrubs, e.g., it is common to find it inside living branches of a species of Leea and of two species of Ficus (F. brevicuspis and F. hispida var. daemonum.

Among insects, besides a sand-fly and a mosquito, whose presence goes without saying, there is a very striking form, only noticed however in Barren Island, in the shape of a small hornet which builds sometimes a discoid nest composed of single cells, mouth downwards, in juxtaposition, and sometimes a long narrow nest of single

*.Tourn. As. Soc. Beng. vol. 1x, pt. 2, p. 402, [footnote].

+ Land-crabs were not observed either on Narconłam or on Barren Island, but Mr. Wood Mason has very kindly shown the writer specimens of a land-crab that are preserved in the Indian Museum; these were obtained in Barren Island by Mr. Oldham.

† The writer's native collector promptly treated it as vermin, and ere a protest could be ntterod had crushed it between two stones. 
cells in one or two rows on the under-surface of slender twigs.** Its sting is very sharp at the time; fortunately the irritation passes off almost completely in half-an-hour or so; unfortunately the nests are very numerous on all the drier slopes where there is any jungle.

Butterflies are not numerous in either island. On Narcondam one species (Cynthia erota) is plentiful, and another (Huphina lichinosa) is common; the other species are, at least at the season of the writer's visit, but poorly represented. On Barren Island all the species seen are, at that season, particularly scarce. The writer collected on Narcondam a few of most of the kinds seen, and during his visit to Barren Island he had the pleasure of the company of Mr. R. Wimberley, of the Port Blair Commission, whose ardour as a lepidopterist is well-known to his Indian brethren. As Mr. Wimberley came on purpose to collect the butterflies of Barren Island the writer paid but little attention to them; he had hoped that $\mathrm{Mr}$. Wimberley might prepare a note, which could not fail to be highly interesting, on the species he had collected. Mr. Wimberley has not seen his way to do this; he has, however, most obligingly supplied the writer with a list of the species obtained by him; this list is given below verbatim. As regards the specimens collected on Narcondam the writer has had the privilege of the kind assistance of Mr. deNicéville, who has most obligingly examined the small collection and named the species. $\dagger$

\section{List of Butterflies seen on Barren Island.}

(Prepared by Mr. R. Wimberley, Port Blair.)

1. Hypolimas bolina Linn. o two.

2. Nacaduba colestis DeNicév. Several.

3. Castalius (species, could not tell).

* To the writer's perhaps prejudiced imagination it appeared that it preferred making its nest on Capparis sepinria to building elsewhere. The arrangement is excellent; an outlying sprawling branch hooks itself unobserved to one's leg or one's arm; the next movement sets the whole bush a-shaking and before one is aware his head and face form objects of attack for a whole army of angry wasplets. The nests, from their shape and situation, are particularly difficult to see, and after forming the firmest resolve to be more wary next time, one only knows that he has blundered into another nest when it is necessary to pick the creatures off his face and from ont his hair. So far from trying to obtain specimens our principal object was to keep out of the creature's way.

† While thanking Mr. de Nicéville for his kindness in naming this small collection, the writer wonld take this opportunity of mentioning that Mr. de Nicèville has also kindly pointed out that the butterfly mentioned in Jour. As. Soc. Beng. lix, pt. 2, p. 256, as feeding on Culotropis gigantea, and as a receut introduction into the Andamans is not Danais genutia, as there stated, but Danais chrysippus. 
4. Arhopala centaurus Fabr. $\varsubsetneqq$ one.

5. Hebomoia Roepstorfit Wood-Mason. Several.

6. Ixias andamana Moore. Several.

7. Hophina nama Moore. Two or three.

Unfortunately Mr. Wimberley does not say if it is the Andamans race (coruscans) of Arhopala centaurus, or one of the other local forms, that he obtained.

Besides the species in Mr. Wimberley's list the writer observed two others on Barren Island. One of these was the common "Wandering Snowflake" (Leptosia xiphia) which was seen in a gulley on the east side of the island on the outer aspect of the outer cone; in the same gulley the wings of a bird-eaten example of a very bright Lycaenid were picked up. From this it will be seen that our knowledge of Barren Island butterfles is capable of further extension. The same remark applies with perhaps even greater force to the list of Narcondam butterflies which follows:-

\section{List of Butterflies seen on Narcondam.}

(Of the species marked (!) specimens have been examined and named by $\mathrm{Mr}$. L. de Nicéville.)

1. Cynthia erota Fabr.!

Several of both sexes caught. This is the commonest butterfly on Narcondam, the male being much more usual than the female though both are "abundant." Mr. Wimberley and the Revd. Mr. LathamBrowne have informed me that though not rare, the species is not "abundant" in South Andaman and that there it frequents damp hollows. In Narcondam it is plentiful everywhere from sea-level up to 800 -850 feet elevation.

Distrib. N. E. India; Burma; Andamans.

2. Parthenos gambristus Fabr.!

Distrib. Eastern Bengal; Indo-China; Andamans; Malay Peninsula.

3. LaMPides elpIS Godart.!

One male.

Distrib. Himalaya (Sikkim); India ; Burma; Andamans ; Malaya.

4. Catochrysops Cnejus Fabr.!

One female.

Distrib. India; China; Indo-China; Malaya; Andamans and Nicobars ; Australia ; Polynesia. 


\section{Leptosia xiphia Fabr.}

One specimen caught on high ground near the north end of the island. Not previously found in the Andamans, though a distinct form (var. nicobarica Doherty) occurs in the Nicobars.

Distrib. India; Indo-China; Malaya.

\section{Huphina lichinosa Moore!}

One female; after Cynthia erota the commonest butterfly.

Distrib. India; Indo-China; Malaya; Andamans.

7. Ixias andamana Moore.

Seen during our ascent of the peak at about 1,200 feet elevation; no example was obtained.

Distrib. Andamans.

By reviewing the distribution of the birds and butterflies (of which two groups, so far as these remarks go, anything precise is known) we may perhaps form some idea of the general relationship of the fauna of these two islands to that of the nearest adjacent lands. For it is extremely probable that, though neither group is completely detailed in its list, these lists nevertheless are representative. And it is equally probable that most of the groups of air-breathing creatures will, when thoroughly known, be found to owe their presence here to the agencies that are accountable for the presence of the species enumerated.

The two islands, though spoken of ordinarily as members of the Andaman group, are only to be admitted as such with a very considerable qualification, since in reality they belong to quite a different physiographical system from that to which the Andamans proper are to be referred.

The Andamans themselves are, as in well-known, undoubtedly a continuation of the chain of tertiary sandstone hills known as the Yomah of Arracan, the connecting links being Diamond Island off the south coast of Arracan, Preparis Island and the Coco Group, the same system of peaks reappearing with certain limitations and modifications* in some

* For example, at the southern end of Great Andaman there are to be found, besides the sandstone about Port Blair which is exactly like that of the Coco Group and of Diamond Island, a different kind of sandstone rock in the "Archipelago" to the north-east of Port Blair and a coralline limestone in the "Sentinels" to the south-west; whether the "Archipelago" sandstone recurs in the Nicobars the writer is unable to say, the "Sentinel" limestone undoubtedly does, e.g., in Batti Malv. 
at least of the Nicobar Islands. Beyond the Nicobar group this system is continued southwards, not as is commonly said, (and perhaps generally supposed), into Sumatra, but into the Nias, a chain of islands lying along the west coast of Sumatra.

The two volcanic islands under discussion-as well as a third peak, Flat Rock, which reaches the surface but no more at a point some 50 miles south of Barren Island-are separated from the Andaman chain proper by a strip of sea 90 miles wide and over 1,000 fathoms in depth. In all probability therefore we see in these islands a northward continuation of the chain of volcanoes that stretches upwards from Flores and Sumbawa though the whole length of Java and of Sumatra to Barren Island and Narcondam and perhaps even beyond them to the extinct volcanic peaks of Popals in Upper Bnrma and of Han-Shuen-Shan in Western Yunnan. But even if this be true there is little doubt that both Barren Island and Narcondam conform essentially to the class of "Oceanic" islands and never have possessed any previous land-connection with neighbouring islands either to the south or to the west, or with continental Asia to the North-east. The present physical conditions in Narcondam appear moreover to be very ancient; there is no trace of a crater at the top of its peak* which rises 2,330 feet above the level of the Andaman Sea, and the whole island is clad with a dense jungle much richer in species than the forest on Barren Island is. But thongh the present biological features of Barren Island are of much more modern aspect, is it not necessary to consider that island as really less ancient than Narcondam. The topography of its outer cone, combined with the historical fact of recent activity on the part of the volcano, points to the possibility of some catastrophe similar to that which devastated Krakatau having once happened in Barren Island. And if this has been the case it would follow that the island must have required, even if previously covered with vegetation, to be stocked de novo with vegetable and animal life. Still, granting that the present fauna and flora of Barren Island are of more recent introduction than those of Narcondam, the fact remains that we must look upon every species present, even in the island with the older biological features, as an immigrant one.

Dealing first with the birds since these may include both voluntary and involuntary immigrants, we find that of the eighteen species enumerated, the Sea-Eagle, all the sea- and shore-fowl, the three Fruit-Pigeons and the large Corby, making altogether ten species, or 55 per

* The appearance of the hill indicates however that there never has been a crater. 
cent. of the list, are probably deliberate visitants. And though the SeaEagle has become a permanent resident and breeds on the spot, perhaps most of the others are still seasonal visitants and nothing more. This is certainly the case with the Fruit-Pigeons, two of which, Carpophaga bicolor and Caloenas nicobarica come annually from the Nicobars or from Malaya; the third, Carpophaga cenea, may come from Malaya or from Indo-China. Equally is this the case with Pond-Heron, which is a visitant from India, and it may be the case with the Sand-Plover and the Sand-Piper which are, in all probability, visitants from the north, and with the Snowy-Tern which is probably a visitant from the south. Perhaps the Blue Reef-Heron, though probably at first a deliberate immigrant, is now, like the Sea-Eagle, a permanent resident.

The Rock-Swiftlet and the Small King-fisher may either have come deliberately or may have been driven by stress of weather to the islands. The former is now certainly, the latter is probably, a permanent resident. The Swiftlet, if driven here involuntarily, must have been an immigrant under the influence of the south-west monsoon, the Kingfisher may have reached the island under the influence of either the south-west or the north-east monsoon.

The Water-Hen may also have been driven here involuntarily, but is quite as likely to be a deliberate, though an inadvertent, immigrant. In either case it has probably come from the Andamans, whence also the large Corby has certainly come; the latter has probably, however, not come deliberately but has been driven by stress of weather.

The Paroquet and the Sunbird, the Koel and the Bulbul are probably all involuntary immigrants, the two former under the influence of the south-west, the two latter under the influence of either monsoon.

The most interesting bird of the list is the Narcondam Hornbill, not merely because it is endemic in that island,-pointing to its arrival there being an event of very considerable antiquity since it has had time to develope peculiarities that appear to entitle it to specific rank, and indicating moreover that the event is one which has recurred very infrequently, if at all-but because, there being no Hornbills in the Andaman group proper, whence birds driven by the south-west monsoon must have been derived, we are led to conclude that it owes its presence in the island to the influence of the usually weaker north-east monsoon.

The probabilities of the case are more compactly indicated in the subjoined table. 
Derivation of the Avifauna of Narcondam and Barren Island.

\begin{tabular}{|c|c|c|c|c|c|c|}
\hline \multirow{2}{*}{ SPECIES INTRODUCED } & \multicolumn{2}{|c|}{ Possibl.y } & \multicolumn{2}{|c|}{ Certainly } & \multicolumn{2}{|c|}{ Probably } \\
\hline & Volunt. & $\begin{array}{c}\text { In- } \\
\text { rolunt. }\end{array}$ & Volunt. & $\begin{array}{c}\text { In- } \\
\text { volunt. }\end{array}$ & Volunt. & $\begin{array}{l}\text { In- } \\
\text { volunt. }\end{array}$ \\
\hline From India or Indo-China & 7 & $\cdots \cdots$ & 4 & $\ldots \ldots$ & 5 & $\ldots \ldots$ \\
\hline " Andamans or Malaya & 9 & $\cdots \cdots$ & 5 & $\ldots \ldots$ & 7 & $\ldots \ldots$ \\
\hline By N.-E. Monsoon & $\ldots \ldots$ & 4 & ...... & I & ...... & 2 \\
\hline ,, S.-W. Monsoon & ...... & 7 & ...... & 2 & ...... & 4 \\
\hline Total $\ldots$ & w... & $\cdots \cdots$ & ..... & ...... & 12 & 6 \\
\hline
\end{tabular}

The butterflies must all of necessity be examp'es of involuntary imnigration, and though not of necessity all immigrants under the influence of winds, have probably in most cases been driven thither by one or other of the monsoons.

Leaving out of account those of Barren Island, two of which have not been specifically identified while a third has not had the particular local race determined, and considering only those of Narcondam, we see that one-Leptosia xiphia-has of necessity come from the north-east, and one Ixias andamana-has of necessity come from the south-west; all the others may have arrived under the influence of either monsoon.

Meagre as our knowledge of the Fauna of these islands is, we seem justified in concluding that the predominance of an Andamans element in it is altogether due to the fact that they are nearer the Andaman Group, from the direction of which a strong monsoon blows for the greater part of each year. At the same time it is clear that the opposite monsoon, though blowing with less force and over a wider sea, is not altogether inactive, but on the contrary must be held accountable for the introduction of certain species which, though they have reached these islands from Indo-China, have not yet succeeded in passing beyond them to the Andaman Group proper. The precise extent of either influence it would however be premature, in the present state of our knowledge, to attempt to assess.

From the Annals of Botany, vol. VI, No. 22, July I 892.

On the Synonymy of Anthocoma flavescens Zoll.-By D. PRAIN.

A Labiate genus, Anthocoma, was proposed by Zollinger in 
I 846 to accommodate a plant collected by him in Java. This plant (Anthocoma Alavescens Zoll.) was redescribed in the following year by Hasskarl who, however, at the same time suggested that it might be the same as Zollinger's own Gomphostemma dichotomum; this suggestion was adopted, without seeing a specimen, by $A$. de Candolle in 1848. Miquel in 1856 , though pointing out that the accounts given by Zollinger and Hasskarl are opposed to this specific identification, nevertheless, and again without seeing specimens, has treated the plant as a Gomphostemma: On the other hand Bentham, who also has had to work without a specimen, has never admitted this reduction and, as recently as 1876 , has suggested that, from the descriptions, the plant might perbaps be a Phlomis. The writer has had occasion to point out in another place* that Anthocoma flavescens, as described by Hasskarl, could not be a Phlomis, but owing to the absence of specimens and from the inadequacy of the published descriptions, was then compelled to leave its true position an open question.

Since writing the note referred to the writer has been enabled to examine specimens of this obscure plant kindly sent by Dr. Treub from the Buitenzorg Herbarium to that of Calcutta. These prove that Anthocoma is not entitled to generic rank, but at the same time show that it is neither a Gomphostemma nor a Phlomis.

The plant is in fact Miquel's own Cymaria mollis; as however this Java plant is conspecific with Cymaria acuminata from Timor, the species to which the name Anthocoma flavenscens Zoll. must henceforth be definitely referred as a synonym is Cymaria acuminata Decaisne.

The full synonymy of this species is subjoined and is followed by a few critical remarks supporting the formal reductions. In presenting it the writer wishes to express his own gratitude to Dr. Treub for having afforded an opportunity of finally disposing of a syrionym that has, for the past forty-five years, been a puzzle to students of Labiatæ.

Cymaria acuminata Decaisne in Herb. Timor. Descript. $7 \mathbf{I}$ (1835); De Lessert, Icones Selectæ, iii. 5 I, t. 86 (1837); Benth. in DC. Prodr. xii. 602 (1848); Miq., Flor. Ind. Bat. ii. 992 ( $185^{6}$ ).

Cymaria mollis Miq., Flor. Ind. Bat. ii. 992 (1856).

* Ann. Roy. Bot. Garden, Calcutta, iii. 23I (189I', footnote. 
Anthocoma flavesiens Zoil. in Nat. en Geneesk. Arch. ii. 569 (1846); Hasskarl, Flora, xxx. 596 (1847).

Gomphostemma dichotomum Zoll. et Mor,? Ha skarl, Flora, xxx. 596 (I 847 ).

Gomphostemma dichotomum A. DC. in Prodr. xii. 552 (ad calc.) et xii. 700 ( 1848 ), nec Zoll. et Mor., Syst. Verzeichı.; nec Walp., Rep. vi. ; nes Benth. in Prodr. xii.

Gomphostemma flavescens Miq., Flor. Ind. Bat. ii. 987 (1856).

Phlomis ? sp., Benth. in Gen. Pl. ii. I 216 (1876).

The description by Decaisne and the figure in De Lessert, which Decaisne drew, indicate a plant with glabrous leaves, whereas the Java plant (Cymaria mollis) has leaves hirsute above and below. But the description by De Lessert, which he states is based on fuller material, points out that even the Timor plant may have leaves puberulous on both surfaces. In Java too the character is variable, the examples of Anthocoma flavescens being more hirsute than some of those on which Miquel founded his Cymaria mollis. The character, which is the only tangible one in Miquel's diagnosis of the two plants, is at best a trivial one; the flowers and fruits of the Timor and the Java plants so precisely agree that it is impossible to doubt that they are conspecific.

In the Icones Selectæ the nutlet figured is glabrous; Decaisne's own description, however, as well as those of De Lessert and of Hasskarl, indicate correctly that the nutlets are hirsute at the apex.

In Decaisne's original description, and also in the figure in De Lessert, the true condition of the anthers is expressed; these are not merely (as stated in Gen. Pl. ii, r222) two-celled with cells becoming divaricate, but become ultimately by confluence one-celled. The condition of the anthers in Cymaria elongata is precisely the same*; probably therefore the character should be added to the generic description.

Hasskarl has described the corolla-tube of Anthocoma flavescens as hirsute within; the corolla-tube is however quite devoid of any annulus or hirsute patch within; the filaments are hirsute at the base in this species, as they also are in Cymaria elongata, and this condition may have led to statement which, though inexact, has not produced any serious consequences. The anther-cells, probably from only those of

* Unfortunately the solitary specimen of Cymaria dichotoma at Calcutta is in fruit only, so that no opinion regarding its anthers can be expressed. 
flowers that were too young having been examined, have been unfortunately described by Hasskarl as two-celled with parallel cells; it is doubtless this unhappy misapprehension that has led both De Candolle and Miquel to look upon Anthocoma as a Gomphostemma, and that has obscured so completely and so long the true affinities of Zollinger's plant.

From the Journal, A siatic Society of Bengal, Vol.LXII, Part II, No. I, I 893. 7

Two species of Pedicularis. $-B y$ D. PRAIN.

(With Plates I and II.)

[ Received March 9th-Read April 5th.]

In 1889 (Journ. As. Soc. Beng. lviii, pt, 2, p. 255) the writer had the honour to communicate to the Society descriptions of a number of new Indian species of this genus. Since then a considerable number of new species have been reported from China and Tibet and have been described in various periodicals by Messrs Maximowicz, Hemsley and Franchet, and by the writer. Now, another new Indian species has been reported; of this a description is given below and the present opportunity is taken of describing an allied new. species from Szechuen.

r. Pedicularis diffusa Prain, $s p$. nov. (Pl. I.)

Elata simplex vel e collo diffuse ramosa, radice debili ramosa collo esquamato, caulibus gracilibus simplicibus, foliis radicalibus longe petiolatis mox evanescentibus caulinis 4-natim verticillatis laminis glabrescentibus ovato-oblongis pinnatisectis, segmentis 5-8-jugis oblongis obtusis inciso-serratis; floribus verticillatis verticillis numerosis inter se remotis, bracteis foliaceis oblongo-ovatis petiolatis pinnatifidis et incisu-serratis; calycis breve pedicellati campanulati membranacei inflati totius reticulati antice vix fissi dentibus majusculis inaequilatis anticis et lateralibus ovatis inciso-serratis illis duplo his 4-plo summo deltoideo integro latioribus; corollae roseae tubo sursum ampliato calyce duplo longiore basi infracto, labio 3-lobo lobis oblongoovatis margine sinuatis lateralibus medio dimidio majoribus, galea leviter arcuata tubo subcontinua apice subincurva erostri; staminibus ex adverso summi ovarii insertis filamentis anticis superne hirsutis; ovario oroideo stigmate parum exserto, capsula anguste lanceolata apice acuta calyce duplo longiore, seminibus ovoideis testa nigrescente minute reticulatis. 
In Himalaya ORIentall: Sikkim, Mt. Tankra, i I,500 p. s. m.; G. $A$. Gammie!

Caulibus $40-60 \mathrm{~cm}$. longis, foliis caulinis $2-2.5 \mathrm{~cm}$. longis his $0.75^{-1} \mathrm{~cm}$. latis, segmentis $5 \mathrm{~mm}$. longis $3 \mathrm{~mm}$. latis, petiolis $0^{\circ} 5^{-1} \mathrm{~cm}$. longis; calyce $6 \mathrm{~mm}$. longo hoc $3.5 \mathrm{~mm}$. lato; corollae tubo 10 $\mathrm{mm}$. longo apice $4 \mathrm{~mm}$. latn, galea $5 \mathrm{~mm}$. longa, labio $8 \mathrm{~mm}$. lato; capsula $12 \mathrm{~mm}$. longa $5 \mathrm{~mm}$. lata.

This species is most nearly related to $P$. verticillata Linn, and $P$. refracta Maxim. but besides differing greatly in habit and foliage from both it differs from $P$. verticillata in having a calyx with large teeth and with a tube reticulated throughout while it differs from $P$. refracta in having the anterior and lateral calyx teeth serrate and not entire; from both it differs in having acute, not muticous, anther-cells.

Of Indian species, it in habit much resembles $P$. flexuosa Hook. f., though it is glabrescent while that species is hirsute, but the plan that it imitates most closely is $P$. gracilis Wall. var. macrocarpa Prain, the likeness being so great that though in flower they differ so widely, it is not easy to distinguish fruiting specimens of the two.

2. Pediculakis flaccida Prain, $s p$. nov. (Pl. II.).

Asceridens glabra caulibus gracilibus corymbosim ramosis, foliis ramisque 3-4-natim verticillatis radicalibus mox evanescentibus caulinis breve petiolatis ovatis pinnatifidis segmentis 5-6-jugis obtusis inciso-serratis; floribus in verticillis 4 -floris paucis remotisque dispositis, bracteis foliaceis calycem excedentibus; calycis glaberrimi parvuli campanulati antice parun fissi 5 -dentati segmentis omnibus oblongis integris tubo costato nec reticulato; corollae tubo sursum ampliato calycen 3-plo excedente basi infracto, labio 3 -lobo lobis lateralibus ovatis medio orbiculato basi constricto 3-plo majoribus, galea leviter arcuata tubo subcontinua apice subincurva erostri, staminibus ex adverso medii ovarii insertis omnibus glabris, antheris contiguis muticis; ovario ovoideo stigmate exserto.

In China occidental1; Szechuen occident. prope Tachienlu, Pratt n. 47 I !

Caulibus $20-25 \mathrm{~cm}$. longis foliis caulinis I cm. longis his $0^{\circ} 7 \mathrm{~cm}$. latis segmentis $2 \mathrm{~mm}$. longis I $\mathrm{mm}$. latis, petiolis $0^{\circ} .5 \mathrm{~cm}$. longis; calyce $2.5 \mathrm{~mm}$. longo hoc $2 \mathrm{~mm}$. lato; corollae tubo $8 \mathrm{~mm}$. longo apice $4.5 \mathrm{~mm}$. lato, galea $4 \mathrm{~mm}$. longa, labio $7 \mathrm{~mm}$. lato.

Like the preceding species this is also closely related to $P$. verticillata Linn. but differs considerably in habit, and though it has the calyx tube ribbed and not reticulated, just as $P$. verticillata has, it differs in having the calyx distinctly toothed and extremely small. The stamens also differ in being all glabrous whereas in $P$. verticillata the anterior 
pair are hirsute; the anthers though muticous as in $P$. verticillata are contiguous and not discrete. The fruit is unknown.

As both these species belong to one natural group it may be useful to provide a key, modified, so as to admit of their reception, from the key already published by the writer (Ann. Roy. Bot Garden, Calcutta, iii, 94), in which the relative position of these and of the previously known species is shown.

\section{Verticillatae.}

Galea less than half the length of the lip :-

Bracts flabellate, spike long, dense; calyx small, subglobose, not cleft, teeth small, entire; anterior filaments hairy $\quad \ldots \quad$ P. spicata.

Bracts oblong or linear, spike short; calyx large ovate, teeth large :-

Calyx not cleft, teeth crested except the upper ; filaments not hairy

.. P. lineata.

Calyx cleft, teeth all entire; anterior filaments hairy $\quad \ldots . \quad \ldots \quad$ P. likiangensis.

Galea about equal in length to the lip :-

Calyx-tube not net-veined between the ribs:-

Calyx cleft, hardly toothed; anthers discrete, anterior filaments hairy $\ldots \quad P$. verticillato.

Calyx not cleft, distinctly toothed ; anthers contiguous, filaments not hairy $\quad . . \quad P$. flaccida.

Calyx-tube net-veined between the ribs:-

Calyx hardly cleft, teeth crested except the upper; anterior filaments hairy... $P$. diffusa.

Calyx distinctly cleft, teeth entire :Margin of galea even ; anterior filaments hairy D. Pefracta.

Margin of galea toothed ; filaments not hairy

.. P. szetschuanica.

Explanation of the Plates.

Plate I. Pedicularis diffusa Prain.

I, Flower with bract; 2 , calgx with ovary and style; 3 , half of corolla showing staminal insertion; 4, stamens; 5, capsule; 6 seed: $1,2,3$ and 5 magnified $\frac{2}{1}$; 4 and 6 magnified $\frac{4}{1}$.

Plate II. Pedicularis flaccida Prain.

I, Flower with bract; 2 , calyx with ovary and style; 3 , half of corolla showing staminal insertion : all magnified $\frac{2}{1}$. 
PRAIN, Jour. Asiat. Soc. Bengal, 1893, Vol. LXI, Pt II.

सदि तो

Everist

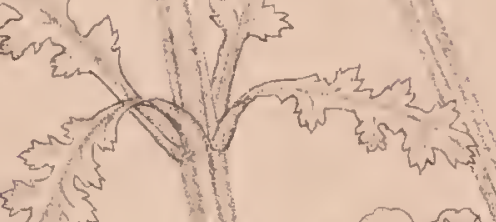

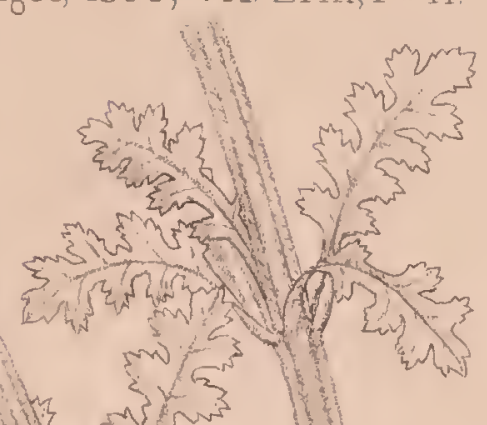

PLATE I

(

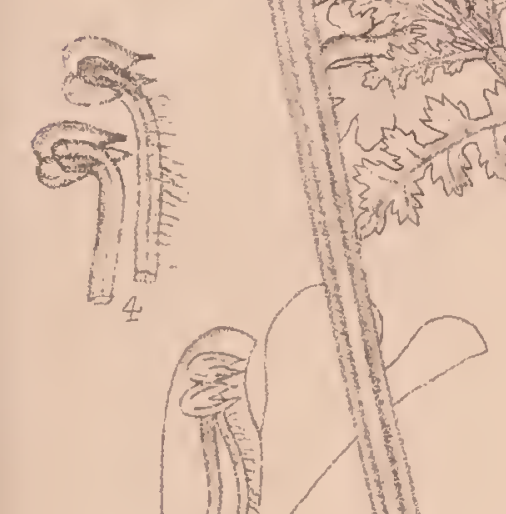

1 .
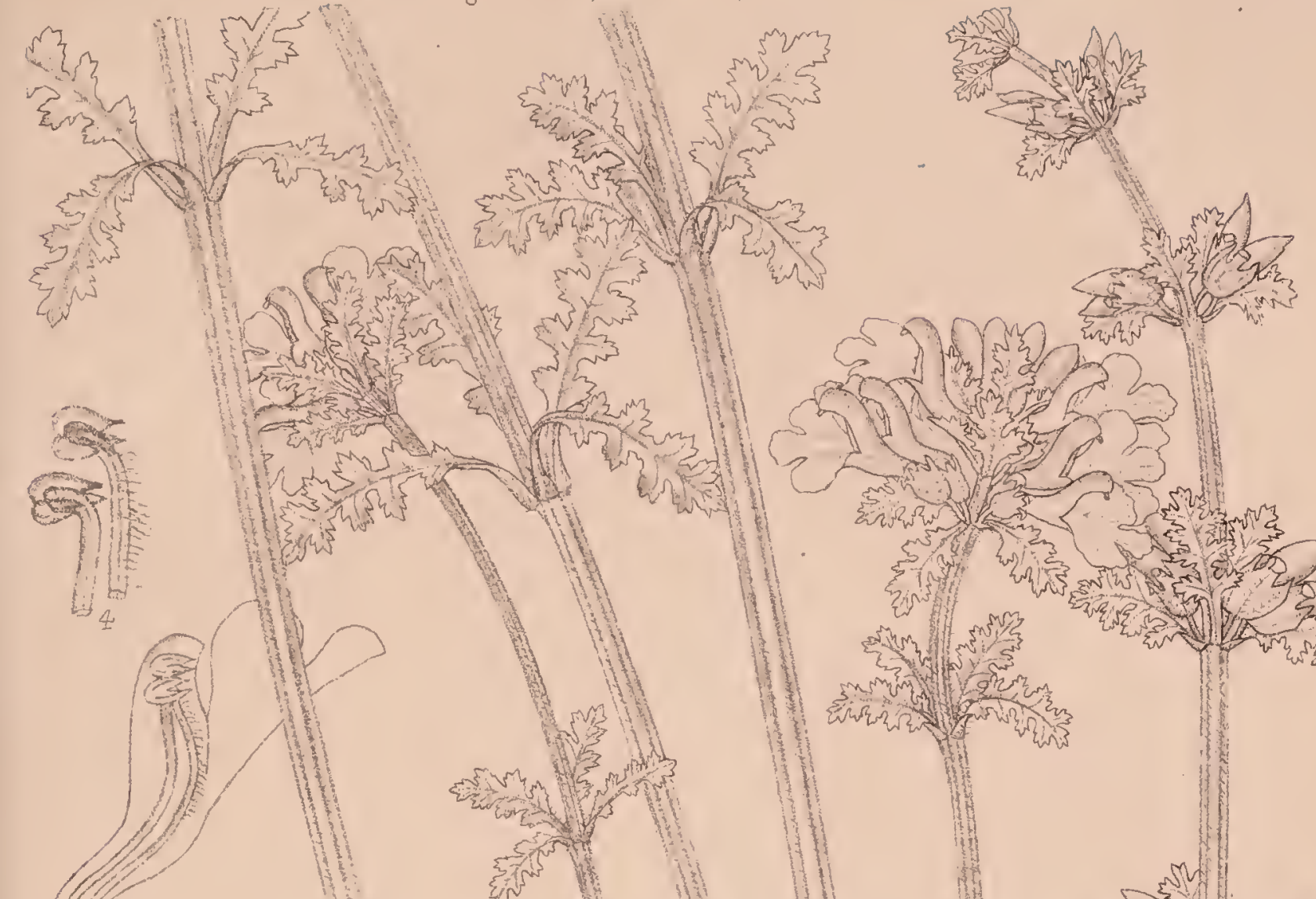

PRAiN, Jour. Asiat. Soc. Bengal, 1893, Vol. LXII, Pt II.

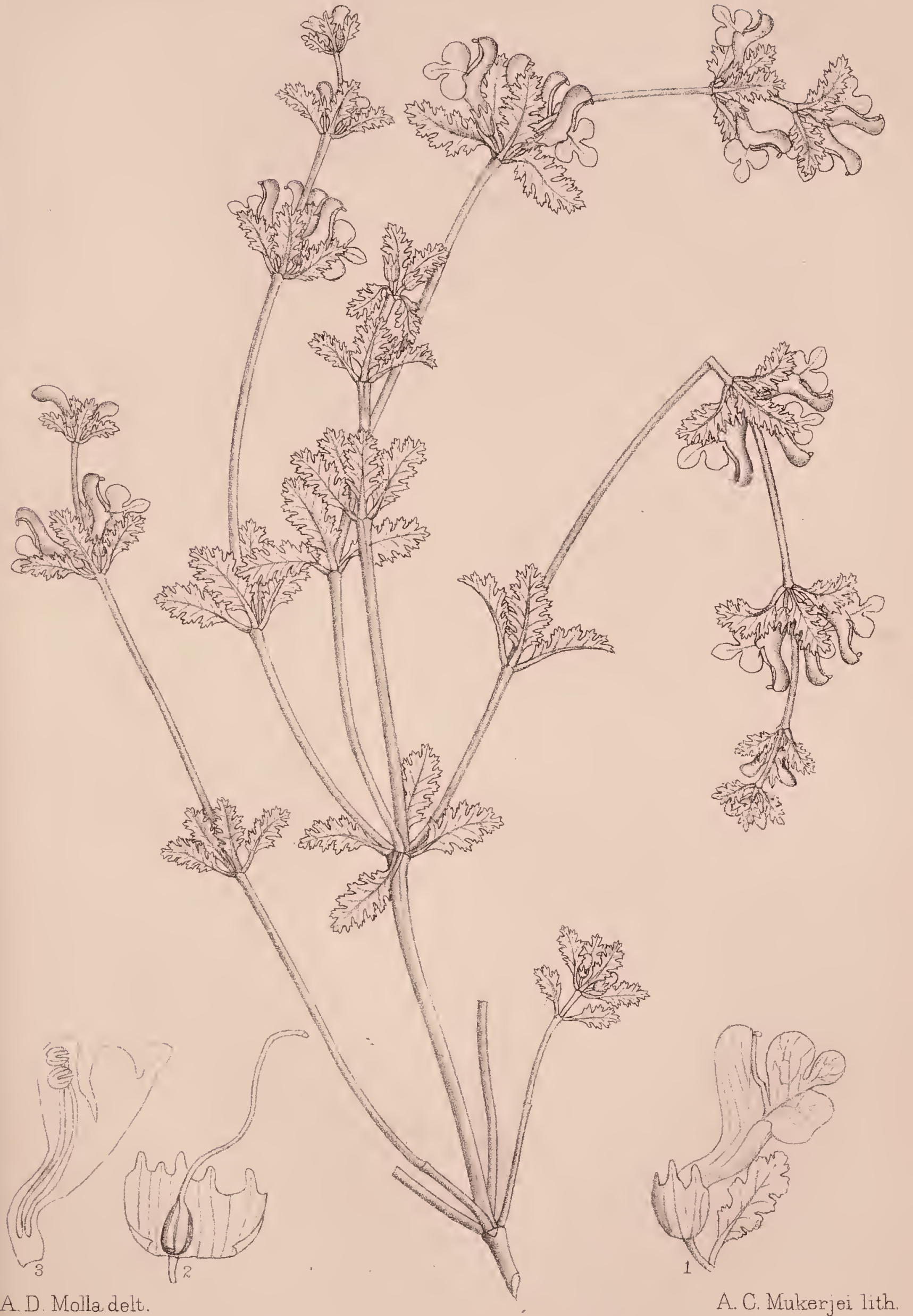

PEDICULARIS FLACCIDA Prain 
. 
From the Joumal, Asiatic Society of Bengal, Vol. LXII, Part II, No. 2, 1893.

On the Flora of Narcondam and Barren Island.-By D. PratN. Plates III and IV.

[Read May 3rd].

§ Introductory SKetch.

The Indian Ocean is broken on the north by the Indian Peninsula into two roughly triangular seas. The eastern, rather the smaller, forms an area known vaguely as the Bay, Gulf, or Sea of Bengal-the first of these names being that most usually employed-bounded on the west by Ceylon and India, on the east by the Malay Isthmus (Tenasserim) and Indo-China, and on the north by the Gangetic Delta. The oceansurface thus defined is, however, further differentiated into three distinct hydrographical areas.

These areas are (a) the BAY OF BENGAL, a bight limited to the west by the Kistna Delta, to the east by Cape Negrais and situated to the north of an arbitrary line-the parallel of Lat. $16^{\circ} \mathrm{N}$.- beyond which it passes into $(b)$ the SEA OF BENGAL, stretching from Coromandel and Ceylon, on the west, to the Andamans and Nicobars on the east. The Sea of Bengal opens southwards into the Indian Ocean proper, from. which it is hydrographically rather definitely limited by the somewhat rapid upward shelving of its floor from the bottom of that ocean to a uniform depth of 2200 fathoms along a line roughly coincident with the parallel of Lat. $6^{\circ} \mathrm{N}$. Thereafter its floor is a plain and practically 
a level one, for it slopes so gradually northwards that, as it passes into the Bay proper, its depth is still 1400 fathoms. No such clear delimitation exists between Sea and Bay; the plain that forms their common floor still slopes gradually upwards towards the north till, in the neighbourhood of Lat. $20^{\circ} \mathrm{N}$, , the edge of the shelf of the Gangetic Delta is reached.

The southern edge of the floor of the Sea of Bengal may, in spite of its depth of over 2000 fathoms, be taken as, in a sense, the margin also of the continent of Asia, for there is more than the rapid increase of slope towards the bottom of the Indian Ocean to characterise it. To the west it coincides with that remarkably abrupt terrestrial elevation which results in the island of Ceylon, off the south-west coast of which island, less than 40 miles from the Basses, the ocean depth of 2300 fathoms is reached. To the east a precisely similar terrestrial elevation, though of smaller size and much less height, is met with. Just as Ceylon lies, a pear-shaped eminence, to the east of Lon. $80^{\circ} \mathrm{E}$., so to the east of Lon. $90^{\circ}$ E. lies the pear-shaped eminence known as Carpenter's Ridge, * a terrestrial mass that rises from a depth of 2300 fathoms in Lat. $5^{\circ} \mathrm{N}$., till in Lat. $6^{\circ} \mathrm{N}$. and Lon. $90^{\circ} 30^{\prime} \mathrm{E}$., it reaches a point which carries only 1380 fathoms. The 'thick end' of the pear in both cases faces the south, and just as the 'stalk,' in the case of Ceylon, tails north-westward into the Indian Peninsula, the 'stalk,' in the case of Carpenter's Ridge, tails north-eastward into Middle Andaman. There are these differences between the two; the connecting ridge between Ceylon and India carries nowhere more than 8 fathoms, that between Carpenter's Ridge and the Andamans carries 1600 fathoms, while the highest point of Carpenter's Ridge is as much beneath as the highest point in Ceylon is above sea-level.

The third area $(c)$ is the land-locked sea $\dagger$, bounded on the west by the Andamans and Nicobars, on the north by the Irrawady Delta, on the east by Tenasserim and Kedah, and prolonged south-eastward into the Straits of Malacca, between Sumatra and the Malay Peninsula. This sea is not, as a rule, distinguished by any general name, though

* Alcock: Annals and Magazine of Natural History, ser. vi., iv., 377.

+ Carpenter: Records of the Geological Survey of India, $x x, 48$, had proved, as conclusively as it is possible in the absence of actual soundings to prove, that this body of water must be separated from the Sea of Bengal by a ridge nowhere deeper than 760 fathomis, the shallowest sounding known between Acheen and the Nicobars, since the temperature at 1200 fathoms east of the ridge is that appropriate to 740 fathoms to the west of it. Since then the indication of 736 fathoms as the depth on the line from the Nicobars to the Andamans is a striking confirmation of the justice of Carpenter's reasoning.

254 
that portion of it close to the Irrawaday Delta is spoken of as the Gulf or Bay of Martaban; it has, however, sometimes been spoken of as the Gulf of Pegu, and more recently bas received the much more appropriate name of the Andaman SeA.*

* Alcock: Annals and Magazine of Natural History, ser. vi., iv., 378. The degree of confusion in nomenclature that prevails is sufficiently exemplified in the various Atlases of recent date. Keith-Johnstone's "Royal Atlas"-an excellent example of an English Atlas-shows, on the same sheet (India, southern sheet) in the general map, the Bay of Bengal and the Sea of Bengal limited as they are in the text, though the Bay is called the "Gulf" of Bengal ! in the small map of the South-Eastern provinces placed on the same sheet this "Gulf" is called, as is more usual, the Bay. No name is given to the Andaman Sea, though the Gulf of Martaban is distinguished. In Stieler's Hand-Atlas-an excellent examplc of a German Atlas-we find (Sheet 67, by Berghans) the phrase "Mecrbusen von Pegu" used as the precise equivalent of Alcock's later-published but perferable name of "Andaman Sea;" the Gulf of Martaban of the English maps is designated, much more correctly than in English maps, "Bai von Martaban." So much confusion of names and their incidence, renders it necessary to insist on some definite system of nomenclature, with a rigid definition of the areas to which the names apply.

It would seem therefore that German geographers are prepared to admit the distinctness of the Andaman Sea as a geographical area, whíle to thodern English geographers the necessity for considering the question has apparently not occurred. If, however, at present they refuse to recognise this as a truly land-locked area deserving of a specific designation, the following passage from a letter dated Calcutta, the 4th March 1795, from Major A. Kyd to Sir John Shore, then GovernorGeneral, will show that even a hundred years ago those who knew the area best realised its true nature. Kyd says :-The Andaman Islands, "comprehending what "are called the Great and Little Andamans, extending from N. Lat. $18^{\circ} 31^{\prime}$ "southward, and lying nearly in a N. and S. direction between $92^{\circ}$ and $93^{\circ} \mathrm{E}$. of "Greenwich, are part of a continued range of islands extending from Cape Negrais "to Acheen Head, including the Preparis, Cocos, Car Nicobar, and the Great and "Little Nicobars, the whole being a chain of islands between which there is reason "to believe that there is a continuation of" soundings, entirely dividing the eastern "part of the Bay of Bengal." Kyd was Superintendent of the second, or Port Cornwallis settlement in the Andamans, instituted in 1792, when the settlement, under Blair at Old Harbour, now Port Blair, begun in 1789, was abandoned.

As an example of the usage which terms the whole sea-area between India and Indo-China the "Bay of Bengal," may be mentioned a paper by Hume (Stray Feathers, vol. ii.) wherein these two islands, along with Preparis, the Cocos, and of course the Andamans and the Nicobars, are termed the Islands in the Bay of Bengal, as opposed to Ceylon, on the one hand, and the Mergui Archipelago, on the other. This is also the usage of the Admiralty Maps of the region, and though it is certainly indefensible on hydrographical grounds, since the area to the east of the Andaman-Nicobar chain fulfils in every particular-far more so than the Sea of Bengal itself-the conditions laid down in the definition of a "Sea," it is preferable to the slip-shod system that distinguishes the Bay of Bengal from the Sea of Bengal, without distinguishing between the Sea of Bengal and the Andaman Sex. 
It is in this last-named area that the islands of Narcondam and Barren Island, which form the subject of the present paper, are situated. These islands the writer was, through the kindness of Col. Cadell, v. C., late Chief Commissioner of the Andamans, enabled to visit in March and April 1891, in order to investigate their Flora. Narcondam was examined for ten days in the end of March ; after an interval occupied in visiting Little Andaman and the Nicobars,* Barren Island was examined from April 5th to April 8th.

The volcanic island of Narcondam is situated in the Andaman Sea in Lat. $13^{\circ} 26^{\prime} \mathrm{N}$. and Ion. $95^{\circ} 15^{\prime}$ E., 80 miles to the east of Port Cornwallis in North Andaman, 74 miles north-north-east of Barren Island, 150 miles to the south of the nearest point on the coast of Pegu, and 250 miles due west of Mergui. The island rises abruptly out of deep water, more especially on its eastern, western and southern sides, to a height of 2330 feet above sea level, and of 8000 feet from the floor of the Andaman sea between it and North Andaman to the west, and between it and Tavoy on the east. $\uparrow$

The soundings on which the conclusion is based are given in the following table:-

TABLE I.f-Soundings in the vicinity of Narcondam.

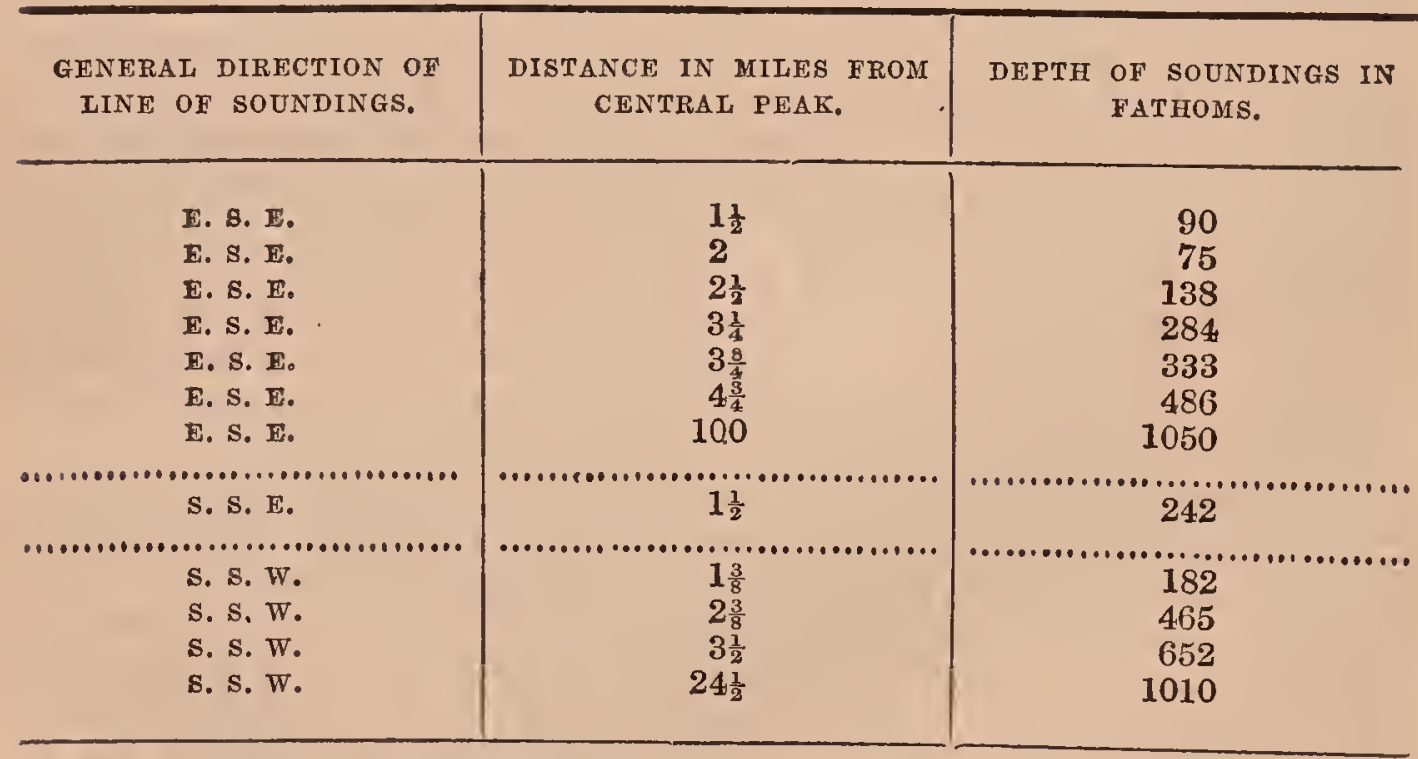

* Proceedings of the Asiatic Society of Bengal for 1891 (December), p. 156.

† Stieler: Hand Atlas, sheet 67 shows depths, which are quite wrong, of 2097 and 2200 fathoms to the E. and S. E. of Narcondam; how these errors have arisen the writer cannot trace. Sheet 58 of the same Atlas gives the true depth.

I This Table, with the corresponding one for Barren Island, is mainly derived from Mallet and Carpenter, Records of the Geological Survey of India, xx, 46, et seq., with additional soundings from a copy of the Sounding-Book of H. M. I. M. Survey Steamer "Investigator," kindly lent by Dr, Alcock.

256 
TABLE I.-Soundings in the vicinity of Narcondam.-(Continued.)

\begin{tabular}{|c|c|c|}
\hline $\begin{array}{l}\text { GENERAT, DIRECTION OF } \\
\text { LINE OF SOUNDINGS. }\end{array}$ & $\begin{array}{l}\text { DISTANCE IN MILES FROM } \\
\text { CENTRAL PEAK. }\end{array}$ & $\begin{array}{l}\text { DEPTI OF SOUNDINGS IN } \\
\text { FATHOMS. }\end{array}$ \\
\hline 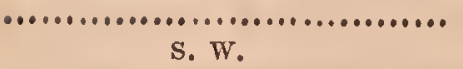 & $\ldots \ldots \ldots \ldots \ldots \ldots \ldots \ldots \ldots \ldots$ & 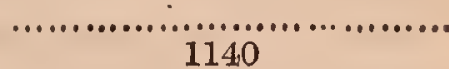 \\
\hline $\begin{array}{l}\text { W. N. W. } \\
\text { W. N. W. } \\
\text { W. N. W. } \\
\text { W. N. W. }\end{array}$ & 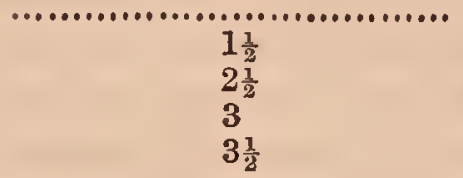 & $\begin{array}{c}162 \\
407 \\
509 \\
585\end{array}$ \\
\hline 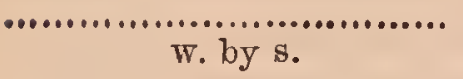 & 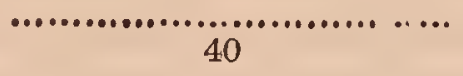 & 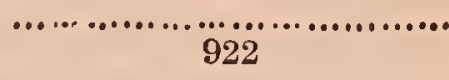 \\
\hline $\begin{array}{l}\text { N. N. E. } \\
\text { N. N. E. } \\
\text { N. N. E. } \\
\text { N. N. E. } \\
\text { N. N. E. } \\
\text { N. N. E. } \\
\text { N. N. E. } \\
\text { N. N. E. }\end{array}$ & $\begin{array}{c}2 \\
2 \frac{1}{2} \\
3 \frac{1}{4} \\
4 \frac{1}{2} \\
9 \frac{1}{2} \\
16 \\
52 \\
70\end{array}$ & $\begin{array}{c}74 \\
104 \\
150 \\
411 \\
362 \\
290 \\
70 \\
50\end{array}$ \\
\hline
\end{tabular}

The island is a fairly-regular oval with the longer diameter in a line running north-north-east to south-south-west; this diameter is two and a half miles long, the other one and a half. The regularity of outline is somewhat broken at the north-east corner by an oblong peninsula about three furlongs long and half a mile across; this spit, which is occupied by a steep-sided twin-peaked hill, quite dwarfed by the central mass, is in no sense detached from the rest of the island but passes through two or three intervening heights into the main peak. This peak, situated slightly to the south and west of the centre of the island, is crowned by three small points of which the most northern is the highest. The two others, situated a quarter of a mile to the south and to the south-east, respectively, are at the seaward ends of two ridges that diverge from the highest peak, and are separated by the beginning of a deep gorge. The northern point, as already mentioned, reaches 2330 feet ; the point to the south is $2150 \mathrm{ft}$., that to the south-east 2200 feet high. The gorge that separates the two latter, after passing southward between them for about a quarter of a mile, turns south-west round the shoulder of the lower one, and thus partially separates the south end of the island, as a narrow ridge 1200 to 1500 feet high, from the rest of the hill. It is, however, only the western end of this ridge that is free, the eastern end is connected, by means of a narrow but lofty ridge, with the south-eastern part of the central peak. Numerous other gorges, none of them however so striking as that just described, furrow the hill on every side. 
The chief interest of this configuration resides in the misapprehen sions as to the structure of the island to which it has given rise. McCelland mistook either the ravines or the ridges between them for streams of lava*; Kurz has described and figured the island as a central volcanic cone, surrounded by an outer ring, not much over half the elevation of the central mass, and very largely broken down. $\dagger$ Seen from Kurz's point of view (N. W., $\frac{1}{2}$ N., at a distance of 20 miles) an oblique view of the mouth of the yawning south-western gorge is obtained, while the main mass hides the connection of its southern wall with the central peak. At the same time the peaks already mentioned as connecting the main hill with the somewhat outlying north-eastern spit, serve to conceal their own connections and complete the illusion. At this distance too the three hummocks at the top of the peak look very much like as many points on the edge of a crater. In a nearer view from the same direction the appearance of a central cone is still wellpreserved, though the regularity of what seems at a distance the remains of an outer ring quite disappears. $\$$ Even close in-shore it is impossible to say whether the three points on the peak are, or are not, indicative of the remains of a crater, the forest that clothes them disguising their true relationship. The appearance from another point of view (W. $\frac{1}{2}$ S., at a distance of 40 miles) agrees well with the description by Horsburgh of "a cone or pyramid with its summit broken off."§

* McClelland: Jour. As. Soc., Beng., vii, 77. It would depend a good deal on the distance from which the island was seen, whether the ravines or the ridges between them be what were taken for ' lava-currents.' Seen from a distance of 6 miles or more, through a glass, the darker shadows caused by the gorges might well enough, as Ball (Records, Geol. Survey of India, vi, 89), and Mallet (Memoirs, Geol. Survey of India, $\mathrm{xx}, 281)$ suppose, be what led McClelland astray; as however the drawing on which McClelland based his opinion was taken from about a mile and a half, or two miles from the eastern shore-the drawing was made by Griffith-there is no doubt that what he took for streams of lava were the ridges between the ravines: on this side of the island these are, towards the top, bare and rugged, and are not unlike streams of lava. After all, however, McClelland had nothing to support his idea that the island was volcanic but its conical shape and its isolation.

+ Kurz : Report on the Vegetation of the Andaman Islands, p. 4. Kurz appears to have had nothing more to go upon in supposing the island to be volcanic than had McClelland; the accident of eonfiguration led him to go further than McCelland, and assume, not only that the island is volcanic, but that it is an island of the same type as Barren Island, in which there is an inner and an outer cone. And with the accounts and the appearance of Barren Island in his recollection-Kurz disposes. cursorily of Barren Island in the sentence immediately preceding the one referred to - the idea is by no means unnatural.

\$ Ball : Records of the Geol. Survey of India, vi, 89.

$\S$ Horsburgh: Indian Directory (ed. v), ii, 56.

258 
Throughout the southern half of the island the coast line has been eaten by the sea into bare cliffs that vary in height from 50 to 800 feet. From the appearance these present to any one circumnavigating the island it would seem that these, even at the mouths of the gorges, and even if landing in spite of the heavy swell that usually surges round the island were feasible, must be altogether inaccessible. Much of the northern half of the island is similarly sea-worn, but the northern cliffs are not in many cases very high. The north-west corner of the island is a sharply triangular ness, with a high cliff for its northern, and a sloping hill-side, ending in lower cliffs, for its western seaface. This western slope overlooks a bight half a mile wide, but of only a furlong's recession. This bight, open to the north-west, is divided into two almost equal bays by a small detached islet, between which and the main island stretches a rocky reef. To the south of this islet and reef is a somewhat indifferent anchorage, and landing from a boat is possible on its small shingle beach, behind which a few coco-nut trees grow. This beach is close to the reef and at the mouth of a rather narrow gorge which leads fairly directly to the main peak.

The cliffs that form the east side of this ness overlook a much finer bight bounded on the east by the oblong spit already described, more than half a mile across, and with a recession almost equalling its width. The head of this bight further recedes into a small inviting-looking bay which, however, begins to shoal* about a hundred yards from the shore, and the strong swell that surges round either cape is broken as it crosses the bay into a heavy surf which renders landing neither pleasant nor safe. $t$ This bay, which may be termed Coco Bay, is bounded by a level stretch of turtle-frequented sand, behind which is the only good example of Pandanus sea-fence on the island; behind the sea-fence is. a fringe of coco-nut trees; beyond the coco-nut zone, and at the mouth of one of the largest gorges in the island, is a small stretch of level land, due, no doubt, like the shallowness of the bay, to the deposition of detritus from the main hill. In this flat patch, immediately behind the coco-nuts and to the west side of the stream-bed, is a grove of plantains.

* Ball : Records of the Geol. Survey of India, vi, 89.

$\uparrow$ Hume : Stray Feathers, ii, 109. The landing mentioned by Ball and described by Hume is the only one on record at this bay. Probably, however, it is not the only one that has been effected. Though the Coco-nuts that line its margin may have been introduced by the sea, this cannot be said of a grove of Plantains that occurs. Landing did not seem possible at the time of the writer's visit, nor was it necessary; the bay, which was visited several times, was reached by cutting a path through the jungle from Anchorage Bay. It is of course possible, though hardly likely, that the individuals who introduced the Plantains also cut such a path. 
To the south-east of the oblong spit, and therefore on the east side of the island, is a third, much wider bight, three-quarters of a mile from cape to cape, but onlv receding a furlong and a half. The northern half of this bay, bounded by the hilly spit, is overlooked by steep hillsides ending in cliffs that, though not lofty, are particularly abrupt. The southern half, limited by the main island-mass, has a beach of rounded boulders; behind this is a straggling sea-fence in which stands a solitary coco-nut tree; a narrow belt of true beach-forest lies beyond. It was with little expectation of being able to land that we put into this bay; we were therefore agreeably surprised to find that-at least at the time of our visit, the end of March-not only could a landing be made without difficulty, but that the bay afforded a more comfortable anchorage than Anchorage Bay itself. The boulder beach slopes rather gradually outwards, and is of a considerable width; probably therefore the surf here is very strong during the north-east monsoon. That the sea-fence is here irregular and thin is no doubt due partly to the surf, and partly to the fact that it has an insecure root-hold among the rounded stones that are piled behind the beach into an embankment which protects the forest beyond. This beach-forest occupies a strip of level land that stretches backwards from 50 to 100 yards to the base of the main hill. Three gorges debouch on this level area and have filled up the interstices of the old beach with the soil on which the trees grow. At the mouth of one of these ravines there is a gap in the beach-forest occupied by a small depression that in March is covered with only a coating of fine sun-cracked mud, but in the rains evidently forms a small lagoon; this appears to be the only spot in the island where water ever lodges.

Though entirely volcanic in structure there is no indication at the summit or elsewhere that the island has recently been active. There is no crater at the top*, and his examination led the writer to think, not that all traces of craterine shape have been obliterated by long erosion, but that there never has been any crater on the peak. The local features, coupled with the nature of the rocks that constitute the island, $\dagger$

* Mallet: Memoirs of the Geol. Survey of India, xxi, 281.

+ Ball: Records of the Geol. Survey of India, vi, 90, only mentions a bed of volcanic agglomerate, (of which several crop out round the coast), at Coco Bay, wherein are embedded trachytic boulders. Mallet-Memoirs of the Geol. Survey of India xxi, 281-283-describes the Narcondam lavas as " compact, or very slightly vesicular "lavas in which crystals of white translucent felspar, and black or dark-brown "hornblende, are disseminated through a ground-mass which is (generally light) "grey in unaltered specimens, but pale red in those that have undergone weathering "and in which the iron has been peroxidised." Farther on, Mallet remarks :- " The "lavas of Narcondam are essentially hornblende andesites, and are of a decidedly "more acid character than those of Barren Island." This character of acidity 260 
appear to indicate that originally Narcondam may have been a volcano, produced, like the volcano that appeared on the Island of Camiguin in July 1871,* by the extrusion of viscid lava without the accompaniment of crater-forming materials. In any case, the depth of the ravines that plougl the flanks of the hill on every side indicates very clearly how remote has been the period of the island's activity. $\uparrow$

The top of the island is frequently bathed in cloud; $\ddagger$ during the ten days spent in the island in 1891, this cloud-cap seemed to envelope, for the greater part of the day, the last 400 feet of the peak. The appearance, however, was slightly deceptive; for it was noticed that the cloud was only condensed on the western aspect of the hill, and that towards evening the peak always became clear. The nature of the vegetation on the peak,- the trees bearded with moss, and their bark covered with Trichomanes-indicates clcarly that this is a usual state of affairs.

Save on the sea-cliffs, which are bare, and on the eastern side of the peak near the top, where the jungle is thin and scrubby, the whole island is clothed with dense forest: this consists mainly of lofty trees, with but few climbers, in the beds of the various watercourses. On the intervening ridges the vegetation consists of a tangled mass of shrubby growth overloaded with creepers. Landing at Anchorage Bay one finds on the shingle some plants of Ipomoea biloba; immediately behind the shingle, and under the shade of about a dozen coco-nut trees, is an attempt at a sea-fence, composed of Sccevola Koenigii, Hibiscus tiliuceus, Morinda bracteata, Guettarda speciosa, Pandanus odoratissimus; some Ipomcea grandiflora, Convolvulus parviflorus, and Wedelia scandens climb over these. Behind these bushes some trees of Barringtonia speciosa, T'erminalia Catappa, Erythrina indica, Sterculia rubiginosa, Thespesia popnlnea, Draccena angustifolia, Ardisia humilis, and Ixora brunnescens represent the beach-forest. There is, howevcr, but scanty room for species of either class, and a few plants of Eranthemum succifolium underneath the trees complete the representation of this sort of vegetation in this situation. To the south of this point are some low cliffs, covered at the top with a tangled mass of Hoya orbiculata, while at their base plants of Pluchea indica, Blumea glomerata, Vernonia divergens, Desmodium polycarpon, Cyperus pennatus, and Thysanolcena acarifera occur; the last-named,-it is, by the way, the only grass that is found on the island-is the most plentiful and seems to be, besides Fimbristylis ferruginea and Boerhaavia

strongly supports the conclusion (to which Mallet also inclines) that there never was a crater in Narcondam, and that the island is of the endogenous volcanic type.

* Moseley: "Notes by a Naturalist on the "Challengor," p. 4.09.

+ Mallet: Memoirs of the Geol. Survey of India, xxi, 284.

* Ball : Records of the Geol. Survey of India, vi 89. 
repens, about the only species that occurs on the rocky sea-cliffs. On the small islet in Anchorage Bay and on the rocks to the north of the reef that connects it with the main island, is a scrubby jungle of Hibiscus tiliaceus, Acacia concinna, Dalbergia monosperma, Premna integrifolia, Glochidion calocarpum, Breynia rhamnoides, Blachia andamanica, and Gelonium bifarium,--the last-named especially plentiful.

In the denser interior jungle on the hill between Anchorage Bay and the gorge that debouches at Coco Bay, one is struck by the familiar Andaman feature of groves of gregarious Euphorbiaceous treelets forming an under-growth in a forest of lofty trees. Of this forest, Ficus nitida and Ficus Rumphii are perhaps the chief constituents; the two commonest gregarious species are Actephila excelsa-undoubtedly the species on the island represented by the greatest number of individuals, and Mallotus andamanicus-also, in many places, very plentiful. The herbaceous species found underneath these treelets are mainly two ferns: Acrostichum appendiculatum, which is not very plentiful, and Asplenium urophyllum, which is. Among other species, found chiefly on a comparatively level tract on the top of the ridge, where the gregarious feature noted during the ascent from the east coast gives place to a mixed forest, the undergrowth includes Alsodeia bengalensis, Cansjera Rheedei, Glycosmis pentaphylla, Capparis sepiaria, Pisonia aculleata, Vitis lanceolaria, Leea sambucina, Memecylon edule, Abrus precatorius, Mucuna gigantea, Bridelia tomentosa, Ficus hispida; Acrostichum appendiculatum is here common, while Asplenium urophyllum is rare. The trees are also more mixed, and include, besides the two species of Ficus already mentioned, a Bombax, Erioglossum edule, Diospyros Kurzii, Oroxylum indicum, Artocarpus Lacoocha, Antiaris toxicaria, Ficus comosa, and Amoora decandra. Besides the two ferns mentioned, a not infrequent herbaceous species is a fine Amorphophallus. Along the ravine that passes northward to debouch at Coco Bay occur the same species; near its mouth, where the ground is flat, the jungle becomes 'scrub'-Morinda, Premna, and such like shrubs, loaded with tangled masses.of Ipomcea vitifolia. This type of jungle takes the place of the absent beach-forest; the sea-fence is however well-developed, and is of the usual Malayan type,-Pandanus, Guettarda, Morinda, Hibiscus tiliaceus, Ccesalpinia Bonducella, Colubrina asiatica, Allophylus Cobbe, Vigna lutea, Canavalia turgida, and such like plants. Round this bay the coco-nut zone is well developed; behind it is the plantain grove already referred to.

East Bay, visited subsequently, may be here most conveniently described. On the beach occur both Ipomoea denticulata and Ipomoea biloba; along with these occur Vigna lutea and Phaseolus adenanthus; the sea-fence is represented by a few examples of Pandanus odoratissimus, 
Hibiscus tiliaceus, Capparis tenera, Colubrina asiatica and Clerodendron inerme. The true beach-forest, here well developed, contains much Pisonia excelsa, with a number of trees of the far less common Pisonia alba; the other trees of the zone are Terminalia Catappa, Calophyllum inophyllum, Thespesia populnea, Gyrocarpus Jacquinii, Ixora brunnescens, Ficus brevicuspis, Ficus callosa, Odina Wodier, and Garuga pinnata; the two lastnamed, though commonest in, are not confined to this zone. The single coco-nut tree mentioned as occurring here has probably grown from a nut drifted round from the other bay; at Coco Bay, however, it is more probable, considering their association with plantains that the trees have been introduced intentionally.* The edges and bed of the dry lagoon already described were covered with Ipomcea Turpethum.

Along the edge of the cliff overlooking the west side of Coco Bay some species, not seen elsewhere, were met with : Entada scandens, Acacia concinna, a Grewia (in leaf only, perhaps $G$ lcevigata), a Tylophora (in fruit only, perhaps T. globifera), Pcederia foctida, and Dioscorea sativa. The steep hill-side overlooking the northern part of Anchorage Bay is covered with a scrub-jungle of Premna, Breynia, and such like shrubs, with a good deal of Capparis sepiaria. All over this hill were seen withered leaves of the Amorphophallus.t The hill-side overlooking the southern portion of Anchorage Bay is covered with the same dense

* These coco-nuts are too old and too numerous to have been introduced of recent years; it seems strange, therefore, that they have never before been mentioned. The recorded visits to Narcondam are:-(1). That of Messrs. Hume and Ball in 1873, when a landing was effected, and no more; (2). that of Messrs. Mallet and Hobday in 1854, when four days were spent in investigating its geology and topography, and an ascent, probably the first, was made of the peak; (3). the present visit, when the peak was again ascended. The account of their landing-place shows that it was at Coco Bay that Ball and Hume landed; at no other bay is there shoal water. Ball mentions some of the plants noticed by him at this place, but neither he nor Hume have recorded the existence of coco-nuts and plantains. Mallet is equally silent, his paper being rigidly confined to the topography and geology of the island. Though these are the only recorded visits, there have been others paid to the island. Hume (Stray Feathers ii, 110) mentions a visit by Col. Tytler. Again, Kurz (Report on the Vegetation of the Andamans, p. 13.) mentions a deputation that visited Barren Island in 1866, in search of pasture-grasses; from specimens in the Calcutta Herbarium, however, we learn that this deputation a few days later visited Narcondam and the Coco Group. In connection with the systematic list, occasion will be taken to refer to the acts of the deputation in question : it is sufficient to say here that to its members is probably due the merit of having introduced, at least the plantains, and perhaps also the coco-nuts. This would make it certain that both species were present at the time of Hume's visit.

+ Corms and seeds of this plant were brought to the Royal Botanic Gardens, Calcutta, where it has sent up leaves and has flowered. 
forest, mainly Ficus, but has for its undergrowth quantities of Caryota mitis, with dense patches of Pollia Aclisia underneath.

The ridges between the gorges are tolerably uniform in the nature of their vegetation; Premna integrifolia extends a good way up, Morinda bracteata is found throughout the island and is as common at the top as it is on the coast; Trema amboinensis, Capparis sepiaria, and Acacia concinna, are common species; not infrequent is Callicarpa arborea, though far less common here than on Barren Island. In the gorges patches of Macaranga Tanarius, Trema amboinensis, Pipturus velutinus, Bohmeria malabarica, as gregarious species, are common, and form, especially in the lower part of the hill, the prevalent undergrowth. The trees are those already enumerated, but as additional species, may be mentioned the following, all obtained in the gorge leading from Anchorage Bay to the summit of the peak:-Amoora Rohituka, Apodytes andamanica, Semecarpus heterophylla, Myristica glauca, Ficus glaberrima-the last mentioned a small tree, at about 2000 feet elevation. The climbers not previously noted were Anamirta Cocculus, frequent; Antitaxis calocarpa, very common; Aristolochia Tagala ; Gouania leptostachya; Trichosanthes palmata; Anodendron paniculatum; Dischidia nummularia; Pothos scandens, and Strychnos acuminata, at about 1200 feet elevation. The herbaceous species not before observed were Blumea myriocephala, only once at about 1600 feet elevation; Asplenium nidus, seen on trees throughout the ascent; Nephrodium terminans, not common below 1000 feet, very frequent above that height; Davallia spelunca, here and there throughout the ascent, Polypodium irioides, at about 1800 feet elevation; Polypodium adnascens, on trees throughout the island, not common; Bryum coronatum.

As the summit is neared, and one passes within the area usually moistened by the cloud-cap, the trees are covered with moss (Neckera rugulosa), and bear on their bark quantities of Trichomanes pyxidiferum. In other respects the jungle on the top does not differ from that lower down, except that, owing to the ridges being of necessity greater in proportion to the gorges than lower down the hill, there is relatively more of scrub jungle than one finds below.

Few Fungi were obtained during the visit: doubtless the season of the year was unfavourable. No Algo were found either on the rocks or washed up on the beaches. The ocean-drifts consisted almost entirely of fruits or seeds of species that occur on the island; the only exception noted was a fruit of Heritiera littoralis found at East Bay.

Barren Island is situated in the Andaman Sea, in Lat. $12^{\circ} 15^{\prime} \mathrm{N}$. and Lon. $93^{\circ} 50^{\prime}$ E., 60 miles to the east of Middle Andaman, 74 miles south-south-west of Narcondam, 80 miles north-north-east of Flat Rock 264 
(a submarine peak that reaches the surface, but no more, in Lat. $11^{\circ} 12^{\prime}$ N. and Lon. $93^{\circ} 36^{\prime}$ E.), and 320 miles due west of Mergui. As shown in the subjoined table, the island, like Narcondam, rises abruptly out of deep water, especially on its eastern, western and northern sides, to a height of 8000 feet or more* above the floor of the Andaman Sea.

TABLE II.-Soundings in the vicinity of Barren Island.

\begin{tabular}{|c|c|c|}
\hline $\begin{array}{l}\text { GENERAL DIRECTION OF } \\
\text { LINE OF SOUNDINGS. }\end{array}$ & $\begin{array}{l}\text { DistanCE IN MILES FROM } \\
\text { CENTRAL CONE. }\end{array}$ & $\begin{array}{l}\text { DEPTH OF SOUNDING IN } \\
\text { FATHOMS. }\end{array}$ \\
\hline $\begin{array}{l}\text { E. S. E. } \\
\text { E. s. E. } \\
\text { E. s. E. } \\
\text { E. S E. }\end{array}$ & $\begin{array}{l}1 \frac{1}{4} \text { ( } \frac{1}{4} \text { mile from shore). } \\
2 \frac{1}{4} \\
3 \frac{1}{4} \\
100\end{array}$ & $\begin{array}{r}118 \\
433 \\
641 \\
1260\end{array}$ \\
\hline $\begin{array}{l}\text { N. N. E. } \\
\text { N. N. E. } \\
\text { N. N. E. }\end{array}$ & $\begin{array}{c}1 \frac{1}{4} \\
2 \frac{1}{4} \\
3 \frac{3}{4}\end{array}$ & $\begin{array}{c}217 \\
545 \\
782\end{array}$ \\
\hline $\begin{array}{c}\text { N. } \\
\text { N. }\end{array}$ & $\begin{array}{l}1 \frac{1}{2} \\
25 \frac{1}{2}\end{array}$ & $\begin{array}{c}325 \\
1,140\end{array}$ \\
\hline $\begin{array}{l}\text { W. N. W. } \\
\text { W. N. W. } \\
\text { W. N. W. } \\
\text { W. N. W. }\end{array}$ & $\begin{array}{l}1 \frac{1}{4} \\
2 \frac{1}{4} \\
4 \frac{1}{2} \\
45\end{array}$ & $\begin{array}{c}180 \\
456 \\
655 \\
1159\end{array}$ \\
\hline $\begin{array}{c}\text { W. } \\
\text { w. }\end{array}$ & 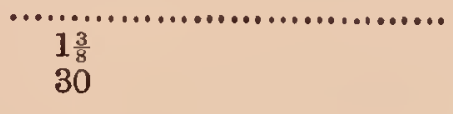 & $\begin{array}{c}169 \\
1130\end{array}$ \\
\hline $\begin{array}{l}\text { s. s. W. } \\
\text { s. s. w. } \\
\text { s. } \text { s. w. }\end{array}$ & $\begin{array}{l}1 \frac{5}{8} \\
3 \frac{1}{4} \\
4 \frac{1}{2}\end{array}$ & $\begin{array}{c}47 \\
238 \\
413\end{array}$ \\
\hline
\end{tabular}

Physiographical accounts of this island have been given by Ball $\uparrow$ and Mallet+ in whose papers a précis of previous information is also contained; a brief description is therefore all that is here necessary.

Nearly circular in outline and about two miles in diameter, the island consists of a linge crater, of which the mouth is a mile wide and the rim is from three-quarters of a mile thick at the base-throughout its southern half, where it is from 920 to 1160 feet high-to barely halfa-mile thick-along the north where its height is from 630 to 790 feet. The rim is further breached to below sea-level on the west side by a part of the original hill having been at one time blown away, the resulting gap being about a-quarter of a mile wide. In the middle of

* Mallet and Carpenter : Records of the Geol. Survey of India, xx, 46, (foot-note).

$\uparrow$ Ball : Records of the Geol. Survey of India, vi, 81 .

$\$$ Mallet: Memoirs of the Geol. Survey of India, 251, et. seq. 
the amphitheatre that results, and therefore about a-quarter of a mile to the north of the centre of the island, a newer perfect volcanic cone rises to a height of 1015 feet. At the top there is an ovoid crater, somewhat straighter along its northern than its southern edge, and somewhat higher on these edges than at either extremity. The edges mentioned are nearly 80 feet above the bottom of the cup which is itself sub-divided into two parts. The western, somewhat irregular, is full of loose lava fragments, and has its floor nearly 40 feet higher than the other, which is an almost perfect circle, about 20 yards wide, with a floor of smooth soft sand. At the west end the rim of the crater is about 4.0 feet lower than along the north and south edges, and is thus very little above the floor of the minor western depression. In the middle of this dip the rim carries a huge lava block, about 20 feet long, $10 \mathrm{ft}$. wide, and nearly 20 feet high.* This block forms a striking object on the cone as seen from the landing-place. At the eastern end of the crater the rim dips even more, and is about 60 feet below the level of the northern and southern edges, or just over 20 feet above the floor; the edge is here narrower than elsewhere. In and about the crater are several solfataras with crevices whence steam escapes.

The cone itself consists of volcanic ashes, fairly firm on the south, east and north sides, but loose and friable on the western face. The slope is very uniform, being about $30^{\circ}$ on every side. The valley between the cones contains, at the base of the inner, two lava streams that have flowed to the sea through the breach in the outer; of these streams the northern overlies the southern. There has also been a third flow to the east, this does not, however, come in contact with either of the others. The sea, it may be remarked, does not enter the breach in the outer cone, the breach, as well as the valley between the cones, being filled to above sea-level by the products of the newer volcano.

The seaward slope of the outer cone is much steeper in the northern than in the southern part of the island, and is furrowed by many nearly meridional ravines, difficult of access where they enter the sea, but more easily traversed further up. The slope of this half of the ancient crater towards the newer volcano is, on the other hand, even and rounded, consisting for the main part of bare, loose black ash, derived from the inner cone. The inner slope of the southern half of the original volcano is, on the other hand, except at its base, steeply precipitous ; the seaward slope of this half, besides being much more gradual than that

* The measurements (Mallet: Memoirs of the Geol. Survey of India, xxi, 267) are:-Length, 22 feet; breadth, 11 feet, height, 13 to 19 feet. The greatest height is at the west end, where it is also narrowest; its most striking aspect is to the spectator on the beach at the landing-place, to whom it looks like a hage tooth.

266 
of the northern half, shows a second subconcentric ridge separated from the true rim by a gorge that debouches on the east side of the island. Gorge and ridge owe their origin, however,-like the ridge and ravine of the same nature, but of more imposing proportions, that occur at the south end of Narcondam-to subaërial denudation, not to volcanic action.

The excentric position of the newer cone, with the lesser relative height, and the steeper seaward slope of the northern half of the original crater, seems to point to subsidence of that half. Perhaps the explosive eruption which effected the breach to the west may have had some connection, direct or indirect, with this subsidence. The volcano represented by the outer cone was doubtless at one time much higher than it is now.

At the landing-place in the breach there is a hot spring on the beach; the temperature of this spring is steadily falling, and at the time of the writer's visit was $106^{\circ} \mathrm{F} . *$ The spring doubtless only represents percolation of rain water through the heated newer materials-the inner cone and lava streams-contained within the circuit of the ancient crater. $\uparrow$

The anchorage in the bay at the breach is of the most uncomfortable description; the safest anchorage is opposite a small bay with a sandy beach, a Pandanus sea-fence and a line of Coco-nut trees, on the south-west side of the island. Landing by boat is, however, usually quite easy on the beach at the hot spring to the north of the point where the lava stream falls into the sea; the surf that rolls into Anchorage Bay must make it impossible, as a rule, to land there.

At Landing Bay the boulders and stones on the beach, bathed by the water of the hot-spring, are covered by a species of Calothrix which occurs in considerable quantities. Another, Alga, also a Calothrix, was obtained from bare rocks in one of the gorges; no marine Algoc were seen. On the beach itself, behind a small bed of drift, are some examples of Ipomcea biloba; the drift contained, in addition to fruits and seeds of species noticed in the island, fruits of Barringtonia speciosa and of Heritiera littoralis. $\$$ Close to the beach and to the lava flow is an example of Pongamia glabra; a little further inland to the north of the lava is a considerable grove of Flueggia microcarpa, with quantities of Mitreola oldenlandioides, in the sandy soil beneath. Beyond this grove is

* Prain : Proceedings As. Soc., Bengal, 1891, p. 84 .

+ Mallet: Memoirs of the Geol. Survey of India, xxi, 274.

I Barringtonia speciosa occurs in Narcondam, and it may possibly also occur at some of the bays on the south-west and south of Barren Island, where the surf made landing impracticable. But Hevitiera littoralis, the fruits of which were collected in Narcondam also, docs not seem to occur in cither island. 
a thicket of Mussuenda macrophylla-the accident of its situation has converted the species into a straggling shrub and imparted to it a very distinct facies. On the lava itself nothing grows, though further inland and to the south of the stream it is in several places partially covered by beds of Aganosma marginata, which, rooted in the adjacent soil, and having no trees on which to climb, prefers sprawling over the bare black lava to spreading along the ground among the grass. This grass, Ischoemum muticum, almost completely occupies the plain between the lava flow and the inner wall of the outer cone, which is thus a great meadow in which, however, there are some patches of scrub jungle, the chief constituents being Dodona viscosa, Flueggia microcarpa, Gelonium bifarium, Phyllanthus reticulatus, Trema amboinensis, Dalbergia tamarindifolia, and stunted examples of Callicarpa arborea.

The inner cone is merely a "cinder-heap," with hardly any vegetation; a few very stunted examples of Trema amboinensis on its southern face, about 650 feet up, and small shrivelled tussocks of Fimbristylis ferruginea scattered unevenly over all the sides except the western, being the only plants present. The interior of the crater has more vegetation than the whole outside of the cone; near the crevices in the inner wall, and especially on the south side where the soil is moistened by the condensation of escaping steam, occur Nephrolepis tuberosa (also obtained elsewhere in the island), Cheilanthes tenuifolia (very small and stunted specimens), Lycopodium cernuum (all over the stones in the western, more shallow depression of the crater), Psilotum triquetrum (also found in Java, on the crater of Gunong Boddas Preanger, by H. O. Forbes), Pholidota imbricata, Vandellia crustacea and Oldenlandia corymbosa; in the sand at the bottom of the deeper eastern craterine depression occur luxuriant patches of Fimbristylis ferruginea.

An attempt was made to land at Anchorage Bay; owing, however, to the heavy surf that rolls in this was found to be impossible. The beach in this bay is sandy; behind it could be seen the usual sea-fence of Pandanus, a species seen nowhere else on the island. Just within the Pandanus fence rise 13 coco-nut trees tall enough to be seen and counted. Judging from the analagous beaches in the Coco Group and Narcondam it may be anticipated that there are many seedlings besides. To verify this surmise an attempt was made later on to cross the outer cone from the amphitheatre and work down to this beach. The attempt did not succeed; the sea was reached at a point too far to the east and the attempt was not considered worth repeating.* Rowing round the island

* Those who have been engaged in similar work will understand how difficult it is under such circumstances to strike the proper ridge or ravine. The results of the journey, which it took a day to accomplish, werc not sufficicntly remuncrative 268 
a landing-place was looked for in bay after bay; to no purpose, however, the heavy south-western swell surged on their beaches in breaker's so huge that any attempt to land was precluded. On the east, north, and north-west sides however, landings were effected; in the first case the crest of the outer rim was attained at a point where further progress was baried by its precipitous nature. By the gorge entercd from the north it was found impossible even to reach the crest; the north-west landing, after some difficult climbing, led to the edge of the outer cone and permitted an easy descent into the amphitheatre.

The inner walls of the outer cone, where too stecp for trees and shrubs, are densely and evenly clothed with Pogonatherum saccharoideum, along with which are associated patches of Desmodium polycarpon, Onychium auratum, Pteris biaurita, Nephrolepis tuberosa (found also within the crater), and Fimbristylis diphylla. On one somewhat damp spot, where there had been recently a small landslip, were found, on the otherwise bare soil, some plants of Pteris longifolia, Oplismenus Burmanni, Physalis minima and Vandellia crustacea (this last was also obtained inside the crater). On the inner northern wall of the outer cone, which is heaped with ashes, there is hardly more vegetation than on the inner cone itself, the only species that grows being the Fimbristylis found on the cone. At the base of the cliff which forms the inner southern wall there is a uniform but not very dense forest the commonest species in which are Terminalia Catappa (certainly the most abundant tree on the island), Eugenia Jambolana and Callicarpa arborea (both very common), Semecarpus heterophylla, Garuga pinnata, Ixora cuneifolia, Ardisia humilis, Oroxylum indicum, Macaranga Tanarius, Trema amboinensis. Quite a feature is the extent to which a wild vine, Vitis repens, prevails in this area; among other creepers noted were Cyclea peltata (not seen in Narcondam), Abrus precatorizu, and two Dioscoreas (only one apparently occurring in Narcondam). Another noteworthy feature of this forest is the presence, though not in grcat quantity, of a species of Dendrobrium. The bare rocks in the gorges over which water in the rains must pour in cascades are here and there covered with dried-up masses of fresh-water Alga, Calothrix tasmanica.

The forest on the outside of the outer cone is much like that just described though the trees are more weather-beaten. The species present inside are all met with outside also, but though Terminalia Catappa is still undoubtedly the most plentiful tree, and there are many

considering the limited time at the writer's disposal, to justify another attempt. The majority of the gorges on the south side of the Island have an eastward. tendeney, and are thus unlike those in the north side which aro more truly radial; this circumstanco led to the solection of a point for descent too fir along the rim. 
examples of Ficus Rumphii and Ficus nitida, with a considerable number of Ficus cuspidifera. The two Dioscoreas are very common climbers; Capparis sepiaria is exceedingly common as a climber, or rather as an undershrub, in the forest; Gloriosa superba was seen in the seaface jungle on the east side of the island; Adiantum lunulatum, another species not seen in Narcondam, is very common on the outside of the outer cone. On bare rocks near the sea Boerhaavia repens is plentiful, and species of the littoral class noted at the points where landings were effected include Hibiscus tiliaceus, Sterculia mbiginosa, Colubrina asiatica, Ixora brunnescens, Pluchea indica, Wedelia scandens, Sccevola Koenigii, Premna integrifolia, Glochidion calocarpum, Gelonium bifarium. Terminalia Catappa, a truly littoral species, spreads here from base to top of the outer cone; the same is true of Morinda bracteata, another plentiful sea-coast species. Cocos and Pandanus have been already mentioned as occurring only at Anchorage Bay.

The question regarding the Coco-nut trees on Barren Island is somewhat simpler than in the case of Narcondam, for they have not been deliberately planted: at the same time it cannot be contended that they afford an unequivocal instance of introduction by the sea. It is not clear that any one has ever landed at Anchorage Bay; ${ }^{*}$ it is certain that for the greater part of the year, to attempt to do so would be very dangerous. At the same time when ships call they usually anchor at this place, and it is not improbable that during some such visit a coco-nut dropping overboard has been washed ashore and germinated in the drift collected by the roots of the sea-fence. Man indirectly, rather than the sea, may therefore be supposed to have been the introducing agent.

Fungi were as scarce on Barren Island as in Narcondam, and the only moss met with was Bryum coronatum.

To complete the account of these islands mention must be made of Flat Rock, situated, as has been already mentioned, in Lat. $11^{\circ} 12^{\prime} \mathrm{N}$., and Lon. $93^{\circ} 86^{\prime} \mathrm{E}$., 80 miles south-south-west of Barren Island, 50

* From the Report of the Andamans' Committee already referred to (Proceedings, As. Soc. Bengal, 1866, p. 215) it would appear that their experience was quite that of the writer. The passage is interesting and is worth quoting verbatizm:- "The only "place where there seemed any chance, was on the south-west, where a small "sandy-beach, with a heary surf running, was discovered, above which four old "cocoanut trees were seen. A boat was sent towards the shore and got bottom at 35 "fathoms, but as we had not much time to spare, the whole of the ground could "not be gone over, ***." The italics are the writer's ; the passage will be referred to again in the systematic list of the plants collected. It is strange that though from the year 1866 onwards these coco-nut trees have been used as the guide-mark to the safest anchorage on the coast of this island, neither Hume, Ball nor Mallet, in their accounts of the island, have noted their presence. 
miles east-south-east of Rutland Island, and the same distance due east of the opening, Duncan Passage, between Rutland Island and Little Andaman. The rock appears above the surface, and no more; but though so much smaller as a subä̈rial peak than Barren Island or Narcondam, as a submarine peak it is evidently larger than either, since its summit appears as a long narrow bank that carries from 15 to 80 fathoms of water; this bank does not extend to the east or the west for more than two miles from the Rock, but towards the south extends at least 10 miles, to the north more than 20 miles. Beyond the edge of this bankthe Invisible Bank of the Admiralty maps-the lead sinks at once into deeper water. The Bank itself has been carefully surveyed but of the absolute depths of the soundings just beyond we know little or nothing, so that though this survey is invaluable to navigators, from a hydrographical point of view it leaves much to be desired. Meagre however as its details are it shows that the soundings are deeper towards the east, south, and west than they are towards the north. The following TABLE indicates the soundings shown in the Admiralty maps:-

TABLE III.-Soundings in the vicinity of Flat Rock.

\begin{tabular}{|c|c|c|}
\hline $\begin{array}{l}\text { GENERAL DIRECTION OF } \\
\text { LINE OF SOUNDINGS. }\end{array}$ & $\begin{array}{l}\text { DISTANCE IN MILES FROM } \\
\text { ROCK. }\end{array}$ & DEPTH IN FATHOMS. \\
\hline $\begin{array}{l}\text { N. N. E. } \\
\text { N. N. E. } \\
\text { N. N. E. }\end{array}$ & $\begin{array}{r}1 \\
10 \\
13\end{array}$ & $\begin{array}{l}14 \\
25 \\
27\end{array}$ \\
\hline 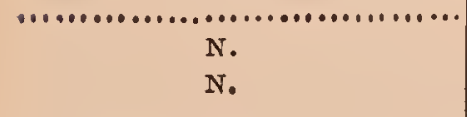 & $\begin{array}{c}5 \\
15\end{array}$ & $\begin{array}{c}\ldots \ldots \ldots \ldots \ldots \ldots \ldots \ldots \ldots \\
38 \\
80\end{array}$ \\
\hline $\begin{array}{l}\text { N. W. } \\
\text { N. W. } \\
\text { N. W. }\end{array}$ & $\begin{array}{c}5 \\
10 \\
15\end{array}$ & $\begin{array}{c}16 \\
59 \\
168\end{array}$ \\
\hline 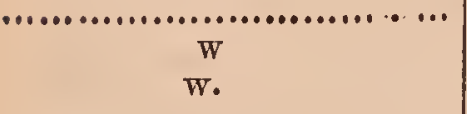 & $\begin{array}{c}10 \\
35\end{array}$ & $\begin{array}{c}90 \text { (no bottom.) } \\
500\end{array}$ \\
\hline $\begin{array}{c} \\
\text { s. w. }\end{array}$ & 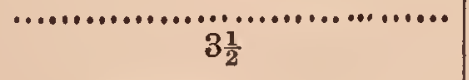 & 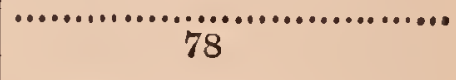 \\
\hline $\begin{array}{l}\text { s. s. w. } \\
\text { s. s. w. }\end{array}$ & $\begin{array}{c}8^{\prime} \\
16\end{array}$ & $\begin{array}{c}35 \\
200 \text { (no bottom.) }\end{array}$ \\
\hline $\begin{array}{l}\text { S. E. } \\
\text { S. E. } \\
\text { S. E. }\end{array}$ & $\begin{array}{c}2 \\
7 \\
12\end{array}$ & $\begin{array}{c}16 \\
48 \\
200 \text { (no bottom.) }\end{array}$ \\
\hline
\end{tabular}

Along the east side of the bank none of the soundings made have touched bottom, but they show that the edge drops into deep water within 5 miles of a line running from south-south-west to north-north-east 
through the rock; along this line the soundings show a rather sharp ridge with relatively shallower soundings for the whole length of the bank; this line, it is hardly necessary to repeat, is that on which both Narcondam and Barren Island also show their shallowest soundings, while the axes of all three islands indicated by this direction form very nearly a continuous straight line.

The nature of the bottom on this bank is only mentioned in the case of one sounding; this depth, 25 fathoms, gives, as might be expected, coral: it would be interesting to ascertain whether the subaerial portion, Flat Rock itself, is part of a raised coral reef, or a remnant of an originally larger island of volcanic structure. Raised coral reefs occur in the Andamans to the west, and in the Nicobars to the south; it may therefore be anticipated that here it will be found that the subaerial portion of the bank is weathered coral; at the same time it would be more satisfactory to have the question settled by a visit to the rock. Reasoning from analogy, however, there is little doubt that the basis of this coral bank is a submarine volcanic peak, and that it forms but one of a series to which the others also belong.

Our knowledge of the bottom-contour of the Andaman Sea is not so satisfactory as is that of the Sea of Bengal. English geographers give no attention to the point; German geographers have mapped the sea somewhat hastily and from rather meagre data. Thus Berghaus indicates by the contour lines in a map of "Heights and Depths" that a deep gap, connecting the Sea of Bengal and the Andaman Sea, exists between Achin Head in Sumatra and the Nicobars. It has how: ever long been known that the ridge in this channel carries only 760 fathoms of water. In a larger map + Berghaus shows deep water as overlying not only the ridge between the Nicobars and Sumatra, but also over that between the Andamans and Nicobars and, what is quite unaccountable, between Preparis and the Coco Group; this last channel has long been known to carry no more than 150 fathoms. As regards that between Little Andaman and the Nicobars, Carpenter had, on grounds of temperature, predicted what Hoskyn has since shown to be true, that the ridge under it could carry at the utmost 740 fathoms; its actual depth is 736 fathoms. In this map also two soundings are shown in the meridian of Lon. $96^{\circ} 10^{\prime} \mathrm{E}$., one of them in Lat. $11^{\circ} .35^{\prime} \mathrm{N}$., for

* Stieler's Hand Atlas, Sheet 8, dated 1878.

+ Stieler's Hand Atlas, Sheet 67, dated 1881 and revised to 1884 ; scale 1 : 12,500,000. Perhaps the contour line in this map means the 100 fathom line; this would explain the shading in the straits mentioned. If so, it is too far from land, and coincides with the 1000 fathom line rather than the 100 fathom one.

272 
which 2300 fathoms are indicated; the other in Lat. $12^{\circ} 30^{\prime} \mathrm{N}$. givés 2097 fathoms. These soundings appear to be devoid of authority; at all events they are quite wrong.*

A more reliable map is, however, to be found in the same work. $t$ This map, designed by Petermann and drawn by Habenicht, is, unfortunately for our purpose, on a smaller scale than Berghaus' map. It shows Carpenter's Ridge jutting southward into the 2000 fathom line immediately to the west of the Andamans; shows comparatively shallow water (between the 100 and the 1000 fathom lines), in the two channels between the Andamans and Sumatra, and indicates a depth of 1137 fathoms in Lon. $96^{\circ} 11^{\prime} \mathrm{E}$. and in Lat. $12^{\circ} 24^{\prime} \mathrm{N}$.- - practically the situation of Berghaus' 2097 fathom mark; this sounding indicated by Petermann has the advantage of being a real one. Going further into detail however, one finds that not even Petermann's map gives any idea of the true state of affairs within this sea $\neq$ For the 1000 fathom line is there shewn as euclosing a long and narrow trough half way between the Andamans and Tenasserim; the three peaks that have just been described are therefore shown as springing from a slope that trends upwards from the bottom of this trough to the Andaman ridge. Instead, however, of indicating a line to the eastward of these peaks the 1000 fathom line passes westward between Narcondam and Barren Island to within 30 miles of the east coast of Middle Andaman, where soundings of 1130 and 1159 fathoms have been obtained; these, it may be remarked, elose inshore though they be, have proved (with the exception of a veritable sounding of 1284 fathoms 50 miles east of little Nicobar, and of a doubtful sounding that gives 1260 fathoms with no bottom in Lon. $95^{\circ} 30^{\prime} \mathrm{E}$, and Lat. $11^{\circ} 45^{\prime} \mathrm{N}$.) the deepest soundings yet obtained in the Andaman Sea, and are more than 100 fathoms deeper than the deepest indicated along the line that connects Barren Island with Narcondam.

There is no doubt that taken collectively these three peaks indicate a northward continuation of the line of volcanic activity known as the "Sunda Range," which stretches up from Sambawa and Flores through Java and Sumatra at least to Barren Island. Von Buch in his work on

* In a previous paper (Journ. As. Soc. Beng. lx. pt. 2, p. 284) the writer was misled by these soundings, which he supposed to have some foundation, into giving the depth of the Andaman Sea as over 2,000 fathoms.

+ Stieler's Hand Atlas, Sheet 58, dated 1884; scale $1: 30,000,000$.

I In criticising these maps the writer would wish it understood that it is from no desire to cavil that he points out their defects; it is only because they are worthy of criticism that reference is made to them. Except the Admiralty maps, which are above reproach, no English map with which the writer is acquainted deserves to be mentioned alongside of those in Stieler's work. 
volcanoes did not carry the chain beyond Barren Island, but Griffith, who in passing Narcondam recognised its volcanic nature, suggested to McClelland that here might be seen a northward extension of the same chain. McClelland not only adopted the suggestion but sought a still further extension to the north, in the mud-volcanoes of Ramri and Cheduba, off the Arracan coast;* and other writers, such as Daubeny, Scrope, Mrs. Somerville and Mallett $\uparrow$ have adopted the same view.

Ramri and Cheduba lie to the west of a tertiary ridge that composes the Yomah of Arracan, which, in the latitude of Ramri, reaches a height of 4,000 feet. This range is continued southward into and beyond the Andaman group. Thus it passes through Diamond Island to the Alguada reef, beyond this, across a channel less than 60 fathoms deep, to Preparis, and again across another of 150 fathoms to the Coco Group, Great Andaman and Little Andaman. It would appear after this to pass to the westward of the Nicobars, though its precise relationship to that group has not yet been made clear; finally it reappears, not in Sumatra, but in a long line of islands-the Nias group - that stretches south-eastward along the western coast of Sumatra.t The line of volcanic activity to which Barren Island and Narcondam presumably belong, lies from Narcondam southwards to the east of this tertiary ridge; if, therefore, Ramri and Cheduba belong to the same line, we have to believe that, after continuing for the whole length of Sumatra and the Andamans parallel to this ridge, the volcanic line at its northern end, where its activity is weaker than elsewhere, crosses the tertiary formations where they have become thicker and stronger. This is in itself a proposition, the truth of which is so hard to accept, that when Blanford§ suggests that the true northern continuation of the Sunda volcanic range is to be found in the extinct Burmese volcano of Popah, and the extinct Yunnan one of Han-shuen-shan, we realise that he must be right, and are surprised that, after all, Mallet is inclined, in a modified sense, to favour the earlier view. $\mid$ The volcanoes of Ramri are of a different type from those of the Sunda Range; they belong to a series of gas vents, all of the same general character, though none of them so active as the Ramri ones. The Sitakund in Chittagong,

* McClelland, Journ. As. Soc. Beng., vii., 77.

+ Mallet does this (Records of the Geol. Survey of India, xi., 203) in a different sense from the earlier writers; they, owing to a want of definiteness in the accounts on which they relied, mistook the "gas" volcanoes of the Arracan Coast for true "steam" volcanoes.

‡ Kurz: Journ. As. Soc. Beng., xlv., pt. 2, 105.

$\S$ Manual of the Geology of India, iii., 725.

|| Mallet: Memoirs of the Geol. Survey of India, xxi., 253. 
and the various hot springs in the valley of Assam, like those in the Namba Forest,* are examples of this series, which forms a continuous line parallel on its western side to the tertiary ridge referred to, just as the true volcanoes, to the line of which Barren Island, Narcondam and Popah belong, are parallel to it on the east. $\dagger$

Whether they belong to that particular group of volcanoes known as the Sunda Range, or not, there is no doubt that Narcondam and Barren Island belong to the general volcanic system extending from the Kuriles, through Japan and the Philippines, to Malaya-a system of which the Sunda Range itself forms but a portion. Like the other members of this system, these peaks are situated, not on, but just within, the margin of the continental elevation forming Eastern and SouthEastern Asia, wherever this rises abruptly from great ocean-depths; the main difference between them and most of the peaks of the system is that, whereas the space between the edge of the continental area and the line of volcanic activity is in other cases sub-aërial, that space is here for the most part sub-marine. This space forms, in the case of Sumatra, the main body of the island-the volcanic line being much nearer the eastern margin-and the rocks of which it is composed include all those that go to form the islands of the Nicobar Group; these rocks appear once more, not in the main chain of the Andamans, but in the small islands to the east of South Andaman (north-east of Port Blair) known as "The Archipelago." $\ddagger$ Neither in, nor opposite, the Nicobars is there any trace of the complementary volcanic ridge; to the east of this "Archipelago," however, it is indicated by Flat Rock and Barren Island.

Not only is the volcanic line of Sumatra absent from the Nicobars, but no trace has yet been found in that group of the sandstones of the Arracan hills, which are prolonged into the main chain of the Andamans and which reappear in the Nias. The result, therefore, is that the Arracan-Sumatra chain, in place of constituting a single ridge consists

* Prain : Proceedings As. Soc. Bengal, 1887, p. 201.

$\uparrow$ The reasons for thinking that the northward prolongation of the Sunda Range has not crossed the Arracan-Andaman ridge are, therefore :-

1. That the volcanoes on the west side of that ridge, which are supposed to continue the Sunda line, are of a different type from the volcanoes of the Sunda Range.

2. That these western volcanoes in Ramri belong to a system of vents of the same type as themselves, characterised by a linear distribution parallel to the western base of the Arracan-Andaman tertiary ridge.

3. That the Sunda Range is continued northward by a series of vents of the same type throughout, the character of linear distribution parallel to the eastern base of the Arracan-Andaman tertiary ridge being maintained unaltered.

‡ Oldham: Rccords of the Geol. Survey of India, xviii., 141. 
of two-a western tertiary ridge most marked in the north and tailing off towards the south, and an eastern volcanic ridge most marked in the south and dwindling into insignificance northwards.

The question whether the line in which Narcondam, Barren Island, and Flat Rock are situated consists of a series of isolated peaks, or if these peaks are only the sub-aërial portions of a continuous ridge, remains to be considered. Such evidence as there is appears to indicate that they are situated on a ridge : it is not, however, at all completc. It has already bcen remarked that the soundings on a line passing north-northeast from Narcondam are relatively shallower than those on any other line. This has been explained by Carpenter as perhaps indicating that the deltaic shelf of the Irrawady extends as far out as Narcondam.* It may be anticipated that this will not be found a sufficient cxplanation of the phenomenon. It will be observed that the soundings gradually deepen for a space of $9 \frac{1}{2}$ miles, till the bottom carries 362 fathoms, and that beyond this point it gradually shallows till the coast of Pegu is reached. If Narcondam were situated on the edge of a delta-shelf, one would expect that the soundings would not show so great a dip within its margin, and would further expect that soundings on lines carried at right angies to the line under discussion would give some indication of a more or less level area. Yet what we do find is that, before four miles to the east or three miles to the west of the island have been reached, greater depths have been obtained than the deepest sounding on the north-north-east line. This appears to indicate that Narcondam is not so much on the edge of a shelf, as at the end of a ridge that runs towards and into the Pegu coast-line. That this ridge is overlaid by the deltaic mud to within ten miles of Narcondam, and that the presence of this mud explains the gentle slope from its deepest point upwards to the Pegu coast is no doubt true; but the steady rise during the last ten miles towards Narcondam, coupled with the more abrupt dips to the east and to the west, indicate the existence of a ridge. The matter is capable of direct demonstration : a few lines of deep-sea soundings coordinate to the line of soundings taken towards the north-north-east, will disclose the true state of matters. It would also be equally easy, by making a line of borings along the continuation of its line, and a few co-ordinate lines across in the mud of the Irrawady delta, to demonstrate whether the supposed ridge passes subterraneously into Burma.

The same comparative shallowness is indicated by the line of soundings to the south-south-west of Barren Island, and to explain the fact Mallct suggests the possibility of eruptions of ash distributed

* Carpenter : Records of the Geol. Survey of India, xxi., 48.

+ Mallet: Records of the Geol. Survey of India, xxi., 47. 
in this particular direction by the action of currents. It would seem easier, however, to explain these soundings by supposing that Barrell Island formed the northern termination of a ridge on which Flat Rock, with Invisible Bank, is situated. Here, too, the matter is easily capable of demonstration: soundings on a line bearing from Barren Island to Flat Rock, with one or two transverse lines of soundings will show whether such a ridge exists.

The hypothesis that in Narcondam we see a contiuuation of the Sunda line of volcanic activity is not invalidated by the depth of the soundings between it and Barren Island. We know that there is a much deeper gap than this between two members of the same chain: in the well-known rift between Bali and Lombok, though the islands mentioned are only 15 miles apart, the narrow strait between is 2,100 fathoms deep.* And as a matter of fact, though the ridge is here deeper, it is by no means absent, for a sounding on the line bearing from Narcondam on Barren Island gives only 1,010 fathoms, while soundings to the west of that line, and between the supposed ridge and the Andamans, give $1,140,1,159$, and 1,130 fathoms. Though our knowledge of the bottom contour of the southern part of the Andaman Sea-the portion to the east of the Nicobars-is very defective, the little that we know bears out the hypothesis of an eastern as well as a western ridge. At a point 50 miles east of Little Nicobar a sounding of 1,284 fathoms is recorded, while 30 miles further east the bottom is only 1,000 fathoms deep. Then north of Pulo Rondo, in Lon. $95^{\circ} 10^{\prime}$ E., the depth is 990 fathoms, while 20 miles further east it is only 930 fathoms. These soundings of 930 and 1,000 fathoms not improbably indicate the ridge on which Flat Rock, Barren Island, and Narcondam are situated. The 990 and 1,284 fathom soundings must indicate the trough between the ridges; for to the west of the latter lies the Nicobar Group, and to the west of the former, in Lon. $94^{\circ} 20^{\prime} \mathrm{E}$., we find a depth of 975 fathoms, doubtless indicative of the western or Indian Ocean slope of the Nicobar-Sumatra ridge, since 25 miles further north, in Lon. $94^{\circ} 26^{\prime} \mathrm{E}$., we have a sounding of 760 fathoms indicating the crest of that ridge. The soundings referred to are shown on the two maps that accompany this paper.

There is, perhaps, some connection between the depth of the rift separating Narcondam from Barren Island, and the fact that from Barren Island itself southwards the volcanoes either still are, or have till recently, been active, while those from Narcondam northwards have long: been extinct. This has a certain bearing on another controverted point. Von Buch, as has becn already stated, recognised the Sunda volcanic line

*Wallace, Island Life, 423 (map). 
as extending to, but not beyond, Barren Island. To Blanford is due the merit of having upset the fanciful hypothesis of the further extension of the line across the Arracan Yomah, and of having suggested its probably true northern continuation. More recently it bas been proposed* by Berghaus and other's to sub-divide the extended Sunda line of Blanford into a Sunda Range proper, ending at the northern limit of Sumatra, and a Pegu Range, containing Barren Island, Narcondam, Popah and Han-shuen-shan. But it is obvious that if any sub-division be necessary, the one proposed by Berghaus is erroneous. A sudden deep gap in the line, with the further character of activity to the south of it, and nonactivity to the north, is a much more natural cleavage than merely a number of miles of intervening sea, the nature of whose bottom is unknown or has been misunderstood. If therefore Berghaus be justified in differentiating a Pegu Range, it is clear that Barren Island must be excluded from it, and that we must return to Von Buch's view, that Barren Island is the most northerly member of the Sunda Range. The Pegu Range of very old and long extinct volcanoes begins then at Narcondam, and extends at least as far as south-western Yunnan.

The biological interest of these islands is not so great as the physiographical, because, whether the ridge here postulated exists or not, there is little doubt that these sub-aërial portions never have been connected with any of the adjacent lands. If Flat Rock has ever been subaërial, and in a fit condition to shelter air-breathing creatures and support vegetation, it is so no longer; how great soever may be the antiquity of the outer cone of Barren Island, it is probable from its configuration, that at one time it has been the scene of a catastrophe like that which in 1883 devastated Krakatau and totally destroyed its animal and regetable life. The only one that, from its topography, has evidently remained for many ages in its present condition is Narcondam. Already the writer has laid before this society some notes on the Fauna of the islands $\uparrow$; it remains now to be seen whether the biological facts indicated by their Flora are in agreement with the deductions that should follow from their physiographical configuration.

All the plants found in the two islands are enumerated in the list that follows; running numbers are added to the locality so as to show at a glance how many species occur in each. In the discussion that succeeds the list the peculiarities of each island are dealt with before thcir common characteristics are considered.

* Stieler: Hand Atlas, sheet 8.

+ Prain : Proceedings Asiat. Soc., Bengal, 1892, p. 109. 


\section{Plants collected in Narcondam and Barren Istand.}

\section{MENISPERMACE $\AA$. I.}

1. Anamirta Cocculus W. \& A. Narcondam (1).

India, Indo-China, Malaya.

2. Crclea peltata H. F. \& T. Barren Island (1). Andamans, Nicobars, Burma,

3. Antitaxis calocarpa Kurz. Nareondam (2), common. Andamans and Nicobar's.

\section{CAPPARIDEA. II.}

4. Capparis sepiaria Linn., var. grandifolia Kurz. Narcondam (3) ; Barren Island (2); common.

Andamans, Burma, Malaya; the variety does not oceur in India.

5. Capparis tenera Dalz., var. latifolia H. f. \& T. Narcondam (4). Andamans, Tenasserim; the variety does not occur in India.

\section{VIOLARIEA. -}

6. Arsodeia bengalensis Wall. Narcondam (5). Assam, Burma, Andamans, Nicobars.

\section{GUTTIFER Æ. - -}

7. Calophyllum inophyludm Linn. Narcondam (6); beach-forest.

Mascarene Isds.; S. E. Asia; Australia ; Polynesia.

\section{v. MALVACE $\AA$. III.}

8. Hrriscus tiliaceds Linn. Narcondam (7); Barren Island (3).

Cosmopolitan on tropical sea-shores.

9. Thespesia populnea Corr. Narcondam (8).

On tropical coasts throughout the Eastern Hemisphere.

10. Bombax insigne Wall., var. Polystemon Prain; var. nov. candice armata, foliolis $7-9$, sessilibus anguste lanceolatis, subtus glaucescentibus, staminibus plurimis (circa 700); capsula 3.5-4 poll. longa: floribus rubris. Narcondam (9); common.

India, Indo-China, Andamans, Malaya; this variety endemic.

There has been some confusion as regards the Asiatic species of Bombax; the writer, therefore, takes this opportunity of giving diagnoses of all of them. His excuse for doing so in this place, is that it was the diffeulty of localising this tree that led to the study of the genus.

\section{Bombaces Asiatice.}

Arbores (ordinis MALVACEARUM) grandes, saltem juniores caudice armatæ foliis digitatis ; calyce coriaceo; stylo simplici ; fructu capsulari, segmentis 5 ; seminibus lana endorcarpii involutis.

Fructus segmentis crassissime coriaccis, seminibus sarcinis 
lans propriis clistincte involntis; cortice diu viridi: tubo staminali 1-seriali, segmentis 5, 1-3-antheris, petalis alternis; floribus minoribus sordide luteo-albis... Bombax pentandrum (Eriorten. dron anfractuosum).

[In India peninsulari et in insulis Andamanensibus, indigena et sylvestris; in India boreali, in Indo-China et prosertim in Malaya late culta et forsan inquilina.]

Fructus segmentis ligneis, lana endocarpii vix in sarcinis distinctis segregata; cortice mox cinerascente; floribus maximis, sæpissime rubris :-

Tubo staminali 5 -seriali, serie interiori segmentis $\mathbf{5}$, 2-antheris, petalis alternis, cum serie altera staminibus simplicibus, 1 -antheris, 10 per paria petalis oppositis fascem centralem stylum amplectentem formantc; ceteris in phalangibus 2 -cruralibus 5 , petalis oppositis dispositis, staminibus phalangium singularum sub-12, omnibus binis 1 -antheris; foliolis longius petiolulatis, laminis acuminato-caudatis subtus viridibus; stylo longibrachiato; capsula velutina ....................................... Bombax malabaricum.

In India peninsulari et boreali, in China australi et IndoChina, in archipelagine Malayana, insulis Philippinensibus et Australia boreali-orientali frequens.]

Tubo staminali multiseriali, staminibus omnibus binis 1-antheris, serie interiori (forsan cum serie altera tantum speciei præcedentis comparanda) staminibus 20 petalis oppositis annulum stylum amplectentem formante; ceteris in phalangibus 2 -cruralibus $\mathbf{5}$, petalis oppositis dispositis, staminibus phalangium singularum numerosis; foliolis breve petiolutatis vel sessilibus, laminis acutis; stylo brevibrachiato; capsula glabra

Bombax insigne.

[In India peninsulari occidentali; in Indo-China et in Malaya.]

Bombax pentandrum and B. malabaricum are wonderfully uniform in the number and arrangement of the elements of their staminal whorl; $B$. insigne, while equally uniform as regards the arrangement, varies considerably as regards the number of stamens in its phalanges. The subjoined key shows the distinguishing features and relative position of the most important of these varieties.

Tubo staminali ovario plus duplo Jongiore

foliolis subsessilibus late lanceolatis, subtus viridibus glabris; floribus albis; (capsula ignota)

Bombar insigne, suB.-SP. anceps (B. anceps Pierre). B. malabarici var. albiflora Wall. [Cat. n. 1840/3 et 1840/4] rel ad hanc sub-speciem, vel ad $B$. insignis genuini ral. albam referenda est. 


\section{[Burma (Shan); Cochin-China.]}

Tnbo staminali ovario vix longiore

Bombax insigne, SUB.-sP genuina.

Staminibus phalangium cruralibus ntrinque circa $20:-$

Staminibus phalangium singularum inter-cruralibus circa 30 , capsula (unius ignota), 10-12-pollicari :-

Foliolis subsessilibus late lanceolatis vel obovato-mucronatis, subtus glancescentibus ; floribus rubris

var. typica (B. insigne Wall ; B. festivum Wall. [Cat. 1841]]).

[Chittagong; Arracan; Pegu.]

Foliolis subsessilibus late lanceolatis, subtus viridibus glabris; floribus albis

var. alba (Ealmalia malabarica

Hort. Bogor., nequaquam Schott).

[Java, culta ; forsan Burma (vide supra B. anceps).]

Foliolis breve petiolulatis anguste lanceolatis, subtus glancescentibus; floribus rubris

var. andamanica.

[Andamans ; ins. Cocos].

Foliolis breve petiolulatis angustc lanceolatis, subtus puberulis; (florum colore ab autore neglecto; capsula ignota)

var. cambodiensis (B. cambodiense Pierre.

\section{[Cambodia.]}

Staminibus phalangium singularum intercruralibus circa 50, capsula 10-12-pollicari, foliolis subsessilibus late lanceolatis, floribus rubris var. Wightii.

[India; in prov. Kanara, Anamallai, Malabar.]

Staminibus phalangium singularum intercruralibus circa 90 ; capsula 3-4-pollicari tantum; foliolis sessilibus anguste lanceolatis, subtus glaucescentibus; floribus rubris var. polystemon.

[Narcondam.]

Staminibus phalangium cruralibus utrinque 10; phalangium singularum intercruralibus circa 30 ; capsula 10-12pollicari; foliolis breve petiolulatis 
lanceolatis subtus viridibus glabris, floribus viridescentibus .................. rar. larutensis

[Perak; prov. Larut: forsan ctiam in archipelagine Malayana apud Priaman].

It will be noted that the writer is unable to perpetuate the generic rank (Eriodendron) assigned by DeCandolle to the Linnean Bombax pentandrum. When the differences in the staminal columns of the three 'species' here recognised are reduced to the simplest possible terms, we observe that in $B$. pentandrum this whorl consists of but one element, the items of which are alternate with the petals; that in $B$. insigne, likewise, there is but one element, the items of which are opposite the petals; that in $B$. malabaricum, on the other hand, both these elements occur. Either, therefore, Bombax malabaricum and Bombax insigne typify two genera as distinct from each other as Eriodendron is from either; or, as is here proposed, all three are congeneric. In another place the writer hopes to show that he is right in thinking, with Schumann, that Pachira does not deserve to be removed generically from Bombax; that he is justified in further reducing Chorisia to Eriodendron, and therefore also to Bombax; and is entitled to believe, with Willdenow, that the characters which separate Adansonia from Bombax are too trivial to be generic.

On the other hand, it will be noted that the material of some of the forms included in $B$. insigne is not yet complete, and it will be readily understood that writers who recognise as distinct the 'genera' referred to in the preceding paragraph, will be still more apt to treat as specifically separable the various forms of $B$. insigne here defined. No work on Indian Botany hitherto published notes $B$. insigne as Indian; the tree, when mentioned, is stated to occur only in Indo-China.

\section{STERCULTACEA. IV.}

11. Sterculia rubigniosa Vent., var. Glabrescens King. Narcondam (10) ; Barren Island (4).

Andamans and Nicobar coasts, general ; the variety only.

- Heritiera litToralis Dryand. Narcondam, fruits on beach, E. Bay; Barren Island, fruits on beach at Landing-place Cove : not found growing in either island.

\section{VIT. TILIACEA. -}

12. Grewia latigata Vahl. Narcondam (11); in leaf only. Africa; India, Burma, Malaya; Australia.

\section{RUTACEAE. -}

13. Glycosmis pentaphylla Corr. Narcondam (12).

India, Indo-China, Malaya.

\section{BURSERACE\#. V.}

14. Gardga pinnata Roxb. Narcondam (13); Barren Island (5); in both islands common.

India, Burma, Malaya.

-. OANARIUM EUPHYLLUM Kurz. Narcondam?

The leares of this species occur in Herb. Calcutta, and are given as from 282 
Narcondam, on tho authority of the Andaman Deputation of 1866 , by whom the specimen was collected; the writer did not see the tree in 1891. As the deputation visited the Coco Group (where the species does occur) as well as Narcondam, and as there are many other errors of locality on the tickets of their collection, the species, though hero mentioned, is not formally included in the list.

X. MELIACEA. -

15. Aroora Rohruka W. \& A. Narcondam (14).

India, Burma, Malaya.

16. Amoora decandra Hiern. Narcondam (15).

Central and Eastern Himalaya; Malaya.

-. Carapa molvocensts Lamk. Narcondam; seeds on beach, E. Bay.

XI. OLACINE $\nexists$ A. -

17. Cansjera Rheeder Gmel. Narcondam (16). India, Burma, Malaya; N. Australia; S. China.

18. Apodytes andamanica Kurz. Narcondam (17). Andamans.

XII. RHAMNE无. VI.

19. Colubrina astatica Brogn. Narcondam (18); Barren Island (6). Africa; India and Ceylon; Burma, Malaya; N. Australia.

20. Gouania leptostachya Brogn. Narcondam (19), very plentiful. India, Burma, Malaya.

XIII. AMPELIDE A. VII.

21. Vitis Repens W. \& A. Barren Island (7), very common. India, Burma, Malaya.

22. Vitis carnosa Wall. Narcondam (20), common.

India, Burma, Malaya.

23. Vitis lanceolaria Roxb. Narcondam (21).

India, Indo-China, Malaya.

24. Leea sambucina Willd. Narcondam (22); Barren Island (8).

India, Burma, Malaya.

\section{SAPINDACEA. VII.}

25. Erioglossum edule Bl. Narcondam (23), common; Barren Island (9). India, Burma, Malaya; N. Australia.

26. Altophylus Cobre Bl. Narcondam (24), at Coco Bay. India, Burma, Malaya.

27. Dodonan viscosa Linn. Barren Island (10), common in the valloy sonth of the lava.

Cosmopolitan in the tropics. 


\section{xv. ANACARDIACEA. IX.}

28. Odina Wodier Roxb. Narcondam (25), very common.

India, Indo-China.

29. Semecarpus heterophylda Bl. Narcondam (26); Barren Island (11). Indo-China, Andamans, Malaya.

\section{xyI. LEGUMINOSA. 'x.}

30. Desmodiun polycarpon DC. Narcondam (27); Barren Island (12). East Africa; S.-E. Asia; Polynesia ; Japan and China.

31. Abrus precatorius Linn. Narcondam (28); Barren Island (13). Cosmopolitan in the tropics.

32. Erythrina indica Lamk. Narcondam (29), coast, Anchorage Bay. India, Burma, Malaya.

33. Mucuna gigantea DC. Narcondam (30), common. India, Indo-China, Malaya; Polynesia.

34. Canavalis turgida Grah. Narcondam (31), Coco and East Bays. India, Indo-China, Malaya.

35. Vigna lutea A. Gray. Narcondam (32), on coast. Cosmopolitan in the tropics.

36. Phaseolus adenanthus G. F. Mey. Narcondam (33), abundant on beach at East Bay.

Cosmopolitan in the tropics.

37. Dalbergia tamarindifolia Roxb. Barren Island (14). India, Indo-China, Malaya.

38. Dalbergia monosperma Dalz. Narcondam (34), coast north of Anchorage Bay.

India, Indo-China, Malaya; Australia; China.

39. Derris scandens Benth. Narcondam (35), East Bay, in sea-fencc. India, Indo-China, Malaya; Australia ; China.

40. Pongamia glabra Vent. Barren Island (15), one trec behind the beach at the landing-place, and close to the lava.

Mascarene Isds; India, Indo-China, Malaya; Australia; Polynesia.

41. Ceesalpinia Bonducelda Flem. Narcondam (36), Coco Bay.

Cosmopolitan in the tropics.

42. Entada scandens Benth. Narcondam (37).

Cosmopolitan in the tropics.

43. Acacia concinna DC. Narcondam (38); Barreu Island (16); common. India, Indo-China ; China.

\section{xvIr. COMBRETACE $A$ XI.}

44. Terminalia Catappa Linn. Narcondam (39); Barren Island (17). Andamans, Malinya.

This is comparatiroly searce in Nareondam, but ou Baren Island it is $\mathrm{m}$. 284 
doubtedly the most numerously represented tree present. Though really a littoral speeies, it is not liere eonfined to the shore, but extends from base to summit of the outer cone on both sides wherever there is soil suitable for it to grow. Its general dispersal in the island has been largely assisted by the rats; they carry off the fruits in order to eat the fleshy outer portion.

45. Grrocarpus JaCQUinit Roxb. Narcondam (40).

Africa; India, Indo-China, Malaya; Polynesia: not in the Mascarene Islands or E. Africa.

\section{x̄II. MYRTACEA. xIт.}

46. Eugenia Jambolana Linn, Barren Island (18), very common. India, Indo-China, Malaya; Australia.

47. Barringtonia speciosa Forst. Narcondam (41). Ceylon; Andamans, Malaya; Australia; Polynesia.

The fruits of this species were picked up on the beaches in Barren Island, bui the tree itself was not found growing.

\section{xix. MELASTOMACEA. -}

48. Memecylon edule Roxb. Narcondam (42).

Ceylon ; Indo-China, Andamans, Malaya; Philippines.

\section{xx. CUCURBITACE Æ. 一 。}

49. Trichosanthes palmata Roxb. Narcondam (43). India, Indo-China, Malaya; Australia; Japan and China.

\section{xxI. RUBIACE无。 xIII.}

50. Oldenlandia corymbosa Linn. Barren Island (19), in the crater. America ; Africa; India, Indo-China, Malaya.

51. Mussenda macrophylda Linn. Barren Island (20), common. Indo-China, Andamans.

This plant, which is common in the valley between the cones, elose to the lava, is one of the speeies reported by the Deputation of 1866 ; flowering speeimens eolleeted then are preserved in the Caleutta Herbarium, but are noted as being from Narcondam, not Barren Island. The species does not appear to occur in Nareondam, for the plant was earefully looked for there. The mistake on these tickets, which requires to be pointed ont, since some of the specimens colleeted in 1866 may have reaehed Herbaria in Europe, is nevcrtheless a fortunate one, as it first ealled the attention of the writer to the faet that, though this Deputation only reported on Barren Island (Proc. As. Soc., Beng., 1866, 215), it visited Nareondam also. The interest of this faet will be shown in diseussing the presence of the Coco-nut.

The species has licre, owing to its situation, dereloped a shrubby habit, but carefnl examination of tho completo material obtained by the writer, leads lim to conclude that it cannot be looked upon as cren varietally distinct. 
52. Guettarda speciosa Linn. Narcondam (44).

Cosmopolitan in the tropics.

53. Ixora BRunnescens Kurz. Narcondam (45), and Barren Island

(21) ; common on the coasts.

Andamans.

54. Ixora cuneifolia Roxb. Barren Island (22), within outer cone. Indo-China.

55. Morinda citrifolia Linn., var. bracteata H. f. (sp. Roxb.) Narcondam (46), very common everywhere, from sea-level to the top of the hill, at 2300 feet elev.; Barren Island (23), common.

India, Indo-China, Andamans.

56. Paderia fetida Linn. Narcondam (47).

India, Burma, Malaya.

xxII. COMPOSIT不. XIV.

57. Vernonia divergens Benth. Narcondam (48), on coast. India, Indo-China.

58. Blumea Glomeratra DC. Narcondam (49), rocks, west coast. India, Indo-China, Malaya; China.

59. Blumea laciniata DC. Narcondam (50), rocks east coast. India, Indo-China, Malaya; China.

60. Blumea myriocephala DC. Narcondam (5l), at 1500-1800 feet. Eastern Himalaya, Indo-China, Andamans.

61. Pluchea indica Less. Narcondam (52), and Barren Island (24), on coasts ; common.

India, Indo-China, Malaya; China.

62. Wedeuia scandens C. B. Clarke. Narcondam (53), common on coasts ; Barren Island (25), coasts.

India, Indo-China, Malaya.

XXIII. GOODENOVIE $A$. $x \nabla$.

63. Scarola Kønigi Vahl. Narcondam (54); Barren Island (26). India, Indo-China, Malaya; Australia; Polynesia.

XXIV. MYRSINE $A$. XVI.

64. Ardisia humilis Vahl. Narcondam (55); Barren Island (27). India, Indo-Clina, Malaya ; China.

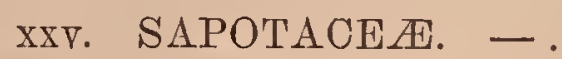

65. Sideroxilon ferrugineum H. \& A. Narcondam (56).

Malaya, Andamans; China.

This is another of the species obtained by the Deputation of 1866 : on this occasion the labels are correct. The form present here has unusually large learesin young trees they are $30 \mathrm{in}$. long by $12 \mathrm{in}$, across.

286 
66. Diosprros Kurzi Hiern. Narcondam (57).

Andamans and Nicobars.

xxvI. APOCYNEAE. XVII.

67. Aganosma marginata G. Don. Barren Island (28), very common in the valley between the cones, to the south of the lava. Indo-China, Malaya.

68. Anodendron paniculatum A. DC. Narcondam (58). India, Indo-China, Malaya.

xXVII. ASCLEPIADACEA. XVIII.

69. Trlophora globifera H. f.? Narcondam (59); in fruit only. Andamans.

70. Hota parasitica Wall. Narcondam (60); Barren Island (29). Indo-China, Malaya.

71. Hoya diversifolia Bl. (H. orbiculata Wall.) Narcondam (61); Barren Island (30). Indo-China, Malaya.

72. Dischidia numidularia $\mathrm{R} . \mathrm{Br}$. Narcondam (62). Indo-China, Malaya; Australia.

xxvIII. EBENACEA. XIX.

73. Mitreola oldenlandioides Wall. Barren Island (31), abundant underneath a thicket of gregarious Flueggia to the north of the lava at Landing-place Cove; not seen elsewhere.

India, Burma, Malaya; N. Australia.

74. Struchnos acuminata Wall. Narcondam (63), once at 1600 feet. Burma, Andamans.

\section{xXIX. CONVOLVULACEA. XX.}

75. Iromea Grandiflora Lamk. Narcondam (64); Barren Island (32). East Africa; India, Indo-China; Malaya, Australia, Polynesia.

76. Ipomea denticulata Choisy. Narcondam (65), at East Bay. Mascarene Islands; Laccadives and Ceylon; Andamans, Indo-China, Malaya; Australia, Polynesia.

77. Ipumea turpethum R. Br. Narcondam (66), in the bed and round the edges of a small dry lagoon in the beach-forest at East Bay.

Mascarene Islands; India, Indo-China, Malaya; Australia, Polynesia.

78. Iромєа вILова Forsk. Narcondam (67); Barren Island (33). Cosmopolitan in the tropics.

79. Ipomea vitifolia Sw. Narcondam (68), Coco Bay, abundant. India, Burma, Malaya.

80. Convolvulus parviflorus Linn. Narcondan (69), Anchorage Bay. Africa; Indo-China, Malaya; Australia. 


\section{一. SOLANACEAE. XXI.}

81. Physalis minima Linn. Barren Island (34), on a small landslip on outer cone, south of Landing-place Bay.

Cosmopolitan in the tropics.

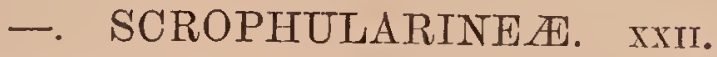

82. Vandelita crustacea Benth. Barren Island (35), on the small landslip, and also inside the crater.

Africa; India, Indo-China, Malaya; Australia, Polynesia; China. xxx. BIGNONIACEA. Xxirr.

83. Oroxyldm indicum Vent. Narcondam (70); Barren Island (36). India, Indo-China, Malaya.

xxxi. ACANTHACE $A$. XXIv.

84. Eranthemum succifolium Kurz. Narcondam (71); Barren Island (37). Andamans, Nicobars.

xxxIr. VERBENACEA $A$. XXV.

85. Calitcarpa arborea Roxb. Narcondam (72); Barren Island (38). India, Burma, Malaya.

86. Prempa integrifolia Linn. Narcondam (73); Barren Island (39). India, Indo-China, Andamans.

87. Cherodendron inerme Gærtn. Narcondam (74), at East Bay. India, Indo-China, Andamans.

xXXIIT. NYCTAGINEA. XXVI.

88. Boerhaatia repens Linn. Narcondam (75); Barren Island (40); common on rocks on the coast. Cosmopolitan in the tropics.

89. Pisonia aculeata Linn. Narcondam (76), not very plentiful. Cosmopolitan in the tropics.

90. Pisonia Alba Span. Narcondam (77), beach-forest, E. Bay. Laccadives, Ceylon; Andamans, Malaya.

91. Pisonia excetisa Bl. Narcondam (78), abundant, E. Bay. Andamans, Malaya.

xXXIV. ARISTOLOCHIACE $\nexists$.

92. Aristolochia tagata Cham. \& Schlecht. Narcondam (79). India, Indo-China, Malaya; China.

xxxv. MYRISTICACEA. - -

93. Mrristica gladca Bl. Narcondam (80).

Indo-China, Andamans, Malaja. 288 
XXxvi. EUPHORBIACEAE. XXVII.

94. Bridelta tomentosa Bl. Narcondam (81).

India, Indo-China, Malaya, Australia, China.

95. Actephila excelsa Muell.-Arg. (A. javensis Miq.) Narcondam (82); gregarious and plentiful, the commonest species in the island.

India, Burma, Malaya.

96. Phyllanthus reticulatos Poir. Barren Island (41), to the south of the lava, near inner base of outer cone.

Africa; India, Burma, Malaya; China.

97. Glochichon calocarpum Kurz. Narcondam (83), and Barren Island (42); common on rocks on the coast.

Andamans and Nicobars.

98. Flueggia microcarpa Bl. Barren Island (43); gregarious and plentiful between the cones to the north of the lava.

Africa; India, Indo-China, Malaya; Australia; China.

99. Breynea Rhannotdes Muell.-Arg. Narcondam (84).

India, Burma, Malaya; China.

100. Crclostemon macropirluus Bl. Narcondam (85).

India, Andamans, Malaya.

101. Crclostemon assamicus Hook. f. Narcondam (86).

Eastern Himalaya, Assam; Andamans.

102. Buachis andamanica Hook. f. Narcondam (87), Anchorage Bay. Andamans.

103. Mallorus andamanicds Hook. f. Narcondam (88), gregarious and common, but less so than Actephila excelsa.

Andamans.

104. Macaranga Tanarius Muell.-Arg. Narcondam (89); Barren Island (44).

Andamans, Malaya.

105. Gelonium bifarium Roxb. Narcondam (90), plentiful on the coast; Barren Island (45).

Andamans, Malaya.

xxxVIr. URTICACEA. xxvII.

106. Trema amboinensis Bl. Narcondam (91), common on rocky coasts and inland also; Barren Island (46), general, some stunted examples occur even on the bare inner cone.

Eastern Himalaya, Indo-China, Andamans, Malaya.

107. Ficus gibbosa Bl., var. cuspidifera King. Barren Island (47). India, Indo-China, Malaya.

108. Ficus glaberrima Bl. Narcondam (92); one of the tallest trees. Himalaya, Indo-China, Malaya. 
109. Ficus Benjamina Linn. Narcondam (93); seeds brought have germinated at Calcutta.

India, Indo-China, Malaya.

110. Ficus RetUsa Linn., var. Nitida King ( $s p$. Thunbg). Narcondam (94), and Barren Island (48) ; very common on both islands.

India, Indo-China, Malaya; Australia; New Caledonia; China.

111. Ficus nervosa Roth. Narcondam (95), at 1,800 feet elevation.

India, Indo-China, Malaya; China.

112. Ficus Rumphir Bl. Narcondam (96), and Barren Island (49); very plentiful.

India, Indo-China, Malaya.

113. Ficus CALlOSA Willd. Narcondam (97), beach-forest at East Bay; a very tall tree.

India, Indo-China, Malaya.

114. Ficus BREvicuspis Miq. Narcondam (98), very common; Barren Island (50); this is one of those species in which many of the branchlets are hollow and afford homes for species of ants.

Andamans, Malaya.

115. FICUS HISPIDA Linn., var. TYPICA. Barren Island (51), in the valley between the cones, at the inner base of the outer cone.

India; Indo-China, Malaya.

var, Dжмолом King (sp. Kœnig.). Narcondam (99), and Barren Island (51); frequent.

India, Indo-China, Malaya.

116. Ficus variegata Bl. Barren Island (52); on the hill at the west end of southern part of outer cone, overlooking Landing-place Bay.

Indo-China, Malaya.

117. Antiaris toxicaria Leschen. Narcondam (100), not common. India, Burma, Malaya.

The leaves of the form present here exactly match those of Malayan specimens named A. rufa by Miquel.

118. Artocarpes Lakoocha Roxb. Narcondam (101). India, Indo-China, Malaya.

119. Bøhaeria malabarica Wedd. Narcondam (102); very plentiful. India, Indo-China, Malaya.

120. Pipturus velutinus Wedd. Narcondam (103), plentiful. Nicobars, Malaya; Polynesia.

\section{一. ORCHIDACE $\nexists . \quad$ XxIx.}

121. Dendrobiom sp. Barren Island (53), rather eommon on trees on inside of outer cone. 
122. Pholidota imbricata Lindl. Barren Island (54), inside crater. India, Burma, Malaya.

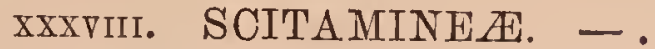

123. Musa sapientum Linn. The Plantain. Narcondam (104), a large grove behind the Coco-nut trees at Coco Bay.

Cosmopolitan in the tropics, cultivated.

No doubt deliberately introduced for the benefit of possibly ship-wrecked mariners, though it is not quite clear who planted it; probably (see under Cocos nucifera) it has been introduced from the Andamans, and perhaps dates from 1866.

XXXIX. DIOSCOREACEAI. XXX.

124. Dioscorea SATIVA Linn. Narcondam (105) Barren Island (55). India, Burma, Malaya; Australia.

125. Dioscorea glabra Roxb. Barren Island (56); common. India, Burma, Malaya.

XL. LILIACE $\nexists$. XXXI.

126. Dracema angustifolia Roxb. Narcondam (106), Anchorage Bay. Indo-China, Malaya, Australia.

127. Gloriosa superba Iinn. Barren Island (57), E. coast near sea. Africa; India; Indo-China, Malaya.

\section{xLI. COMMELINACE A. 一 。}

128. Pollia Aclisia Hassk. Narcondam (107), very abundant on slopes overlooking south end of Anchorage Bay.

Eastern Himalaya, Indo-China, Malaya.

XLII. PALMEA. XXxiI.

129. Caryota mitis Lour. (O. sololifera Wall.) Narcondam (J08). Indo-China, Malaya.

130. Cocos nucifera Linn. Narcondam (109), many at Coco Bay, a few at Anchorage Bay, one, not yet bearing, at E. Bay; Barren Island (58), thirteen trees counted from the offing, behind the Pandanus fence at Anchorage Bay; none seen elsewhere.

India; Malaya; Polynesia; America.

The introduction of this trce into these islands is a question of some interest. The tree at $\mathrm{E}$. Bay, Narcondam, has no doubt been produced from a nut washed round from Coco Bay; in all likelihood the trees at Anchorage Bay have been derived from the same sonrce. The trees at Coco Bay itself may have originated from nuts brought from the Coco Group by a surface-current sweeping from the Sea of Bengal, through the Preparis Channels, from N.-E. to S.-W. across the Andaman Sea; but as they are associated, where they occur, with a grove of IIusa sapientum (which must have been deliberately introduced), it is not unreasonable to suppose that the two species were introduced together. 
Tho question is, when did they first appear? Hume and Ball landed in 1873 at the very spot where they arc now so plentiful, yet no mention is made by either writer of their presence. As Ball speaks of some of the species observed at this Bay, and as Hume describes the Coco-nuts seen by him, shortly after, at the Cocos, it is hard to believe that the trees were there in 1873. Again, Mallet makes no reference to them in 1884; the maps accompanying his account indicate that he and Hobday landed at Anchorage Bay, and he may not therefore have seen the large grove at Coco Bay; but those at the beach where he landed should have been evident to him. Mallet's paper is however confined to the geology and topography of the island, and hardly alludes to its vegetation. But Hume, Ball, and Mallet arc equally silent regarding the Coco-nuts on Barren Island which we know to have been present in 1866, for they wcre seen by the Andaman Deputation-whose report has been already referred to (p. 56)-behind a beach, to which they still seem confined. As these three writers failed to notice Coco-nuts in Barren Island, where we know they existed at the time of these visits, there is no reason why Coco-nuts should not have been present then in Narcondam also. The Andaman Deputation in their Report (Proc. As. Soc., Beng., 1866, 215)., say: "We brouglit from Port Blair with "us a number of Cocoa-nuts, Plantain trees, and Pine-apple cuttings, and these "wc planted on the ground from which the grass had becn cut, in hopes that "they might be of use to some future visitors."* We have seen, in connection with some of the species in this list, that the same deputation visited Narcondam also, though it did not report on that island; nothing therefore is.more probablc than that the deputation did thcre what it had done on Barren Island, and that to its members belongs the credit of having introduced, at least, the Plantains. But the Coco-nut trees are so much more numerous, and so much larger on Narcondam than on Barren Island, that one finds it difficult to think they only date from 1866. It is unfor tunate that the deputation did not find it necessary to report on Narcondam as well as on Barren Island; had they done so, there is little doubt the report would have mentioned any Coco-nuts that were present. However, even if the Coco-nut trees were alrcady there in 1866, the writer is inclined to think that their origin must still be due to introduction by some previous visitor.

The Coco-nuts on Barren Island may be supposed to have originated from nuts swept up by a strong surface-current that flows from the south-west, and that therefore would bring drift from the Nicobars where Coco-nuts are plentiful. But it is more likely that the trecs have been introduced, though involuntarily, by man. For though there is reason to believe that no one has ever landed at this particular bcach, this bay affords the only safe anchorage in the island, and it is thereforc more probable that these trees have sprung from muts that have fallen overboard from

* There was no trace of any of these in the locality indicated during the writer's visit, a circumstance not surprising; because, in the first place, the situation is not over-suitable for such species, and, besides, goats have been since then introduced into the island! It may be mentioned that no one at Port Blair in 1891 knew of the existencc of Coco-nuts in Narcondam, and the writer consequently took a number with him in order to plant them, only to find the act unnecessary. And, bearing in mind the state of affairs in Great Coco (Journ. As. Soc., Beng., Ix, pt. 2, 315), he also took fruits of Carica Papaya for the same purpose. Should, therefore, subsequent visitors find this specics established in the island, they are hereby relieved of tho necessity of inventing an hypothesis to cxplain the circumstance. 
some craft lying off this beach, than that they have been brought by the sea from the Nicobars, or that they have been deliberately introduced by man.

\section{xLIII. PANDANACEA. XXXIII.}

131. Pardanus odoratissimus Linn. f. Narcondam (110), common at Coco Bay and elsewhere; Barren Island (59), at Anchorage Bay. India, Indo-China, Malaya.

\section{AROIDEAE. -}

132. Amorphophaldus (Oandarum) Rex Prain, sp. nov. tubere magno depresso-globoso ; cataphyllis 4, oblongo-lanceolatis; folii petiolo parum asperato vix maculato, lamina trisecta segmentis irregulariter dichotomis iterumque pinnatisectis, pinnulis (imis nonnunquam exceptis) ad costulas decurrentibus, ovato-oblongis, caudato-acuminatis, nervis supra impressis, subtus prominentibus, sinubus angustis ; pedunculo crasso florifero brevi, fructigero elongato; spatha juniore cataphyllis obtecta, matura tubo infundibulari crasso in laminam late campanulatam margine tanden reflexa undulato-plicatam postice acuminatam expanso; spadice spatha subduplo longiore, erecto, stricto, crasso; inflorescentiis tubo spathre subinclusis, fominea sursum parum angustata quam masculam parum obconicam dimidio longiore, appendice crassa conico-pyramidali inflorescentiis dimidio longiore et, saltem prope basin, quam eas triplo latiore. Narcondam (111), very common.

Tubere diam. 9-18-poll.; cataphyllis spiraliter dispositis, imo exteriore 3 poll., altero 9 poll., tertio 12 poll, summo interiore 19 poll. longis, omnibus 2 poll. latis, pallide viridibus maculis olivaceis, demum tamen subconcoloribus luteis; petiolo 2.56-pedali basi ipsa $4: 5$ poll. crasso, sursum spatio brevi ita incrassato ut loco supra solum 4 poll. alto crassitudinis 5-pollicaris, deinde paullatim se coartante et apnd trifurcationem diam. 3.5 poll. tantum, pallide viridi, maculis olivaceis, demrm subconcolore olivaceo; lamina diam. 5.5-ped., supra olivacea subtus prasina, segmentis singulis 36 poll. longis, pinnulis ultimis $8-10$ poll. longis, his $3-3.25$ poll. latis; pedunculo florifero brevi, 2.5 poll. tantum longo, fructigero ad 30 poll. elongato, 1.5-2 poll. crasso, juniore pallide viridi maturo purpurascente; spatha a latere 16 poll., a basi ad apicem versus 19 poll. longa, infra substantiæ carnosæe sursum tenuescente, extus concolore pallide viridi, intus ad basin verruculosam lutea, supra pallide viridi ibi tamen margine excepto cito flavescente; spadice tota 21.5 poll. longa, parte fominea 4.5 poll. longa, basi 2.25 poll. apice 1.75 poll. crassa, (fructigera 7 poll. longa et $3 \cdot 5$ poll. crassa) ex ovariis globosis 0.2 poll. diam. viridibus, 2-(rarissime 3-jlocularibus, sessilibus, subcontiguis, in stylos 0.3 poll. longos, lnteos contractis, stigmatibus plicatim 2-3-lobis, loculis 1-ovulatis, ovnlis semianatropis decurvis, funiculo elongato angulo interiore parnm supra basin affixis, in ala placentali circa basin funiculo exoriente et loculum ferc totum complente innixis eademque amplexis; parte mascula 3 poll. longa, basi 175 poll., apice 2.5 poll. crassa, e floribus $4-5$-antleris spiraliter dispositis, antheris singnlis subsessilibus connectivo sursum parum prodncto, ellipsoileis sursum angustatis apice rimis lunulatis 2-porosis; appendice 14 poll. longa, hac basi 6 poll. crassa, 
post anthesin caduca, spongiosa, rugosa, valleculosa, lutea et brunneo-maculata : bacca 1-2-sperma, 0.75 poll. longa, hao 0.25-0.35 poll. lata, ovata, versus apicem angustata, carnosa, lutea; seminibus pendulis ovatis, triente basilari e funiculo incrassato spongiosis, ceterum embryone corneo semini subconformi cartilagencis.

This speoies resembles the Java form, or a variety, of Amorphophallus campanulatus (A. campanulatus Blume, Rumphia, i, 139. t. 32, 33, as opposed to Arum campanulatum, Roxb, Hort. Beng., 66) in the conic-pyramidal shape of the appendix, but differs in other respects, more particularly in the leaf. It agrees with $A$. virosus Brown (Bot. Mag., 6978) in having the male and female inflorescence of about equal length, but in other respects is very distinct, for $A$. virosus has the dense flowered turbinate male inflorescence, and the short oblong appendix oharacterstic of Roxburgh's Arum campanulatum of which it is probably only a form. The following brief diagnosis $\uparrow$ may assist in indicating how very distinct the present plant is from the forms hitherto known:-

Petiole hardly verrucose; male flowers disposed spirally on an inflorescence not wider than the female: yellow pyramidal appendix (twioe as long as broad, and) onehalf longer than the combined inflorescences: (male and female inflorescences of equal length; spathe green concolorous)

A. rex

Petiole very verrucose; male flowers disposed spirally on an inflorescence much wider than the fcmale : purplishbrown appendix not so long as the combined inflorescences :-

Male and female inflorescences of equal length,spathe green suffused with purple, externally white spotted (oblong appendix not longer than broad)

\section{A. virosus.}

Male inflorescence much shorter than the female, spathe purple ooncolorous

A. campanulatus. Oblong appendix, not longer than broad ........ Arum campanulatum Roxb. (India).

Pyramidal appendix twicc as long as broad Amorphophallus campan. ulatus Bl. (Java).\$

† In connection with this, it may be mentioned that the Amorphophallus from the Coco Group, mentioned (Journ. As. Soc., Beng., lx, 2, 333) as related to A. bulbifer and A. tuberculiger, has since flowered at Calcutta, and has proved, as was then anticipated, to be a very distinct species. As the authors of the other species, have indicatcd by the specific name the tubercle-bearing habit of the species, the writer proposes for this one the name 'Amorphophallus oncophyluts' Prain. The diagnosis between it and the two species for which it might be mistaken, is as follows:-

Stigma sessile, spathe unconstricted, appendix equal in length

to the combined inflorescences :--

Female inflorescence shorter than the male ...............

Female inflorescence as long as the male ...................

A. tuberculiger.

A. bulbifer.

Style distinct, spathe constricted slightly opposite the male infloresccuce, appendix twice as long as the combined in-

florcscences .............................................. A. oncophyllus.

‡ As this paper has been passing through the press, the writer has learned from Sir Joseph Hooker, that he identifies A. rew with Blume's Java A. campanulatus. 294 
133. Pothos scandens Linn. Narcondam (112), on trees; common. India, Indo-China, Malaya.

\section{xLV. CYPERACEA. XxxIV.}

134. Cyperus pennatus Lamk. Narcondam (113); Barren Island (60). Africa, India, Indo-China, Malaya.

135. Fimbristylis diphylua Vahl. Barren Island (61). America ; Africa ; India, Indo-China, Malaya; Australia; China.

136. Fimbristylis ferruginea Vahl. Narcondam (114), rocks on coast; Barren Island (62), tussocks outside inner cone, also inside crater. India, Indo-China, Malaya.

\section{GRAMINEÆA. XXXV.}

137. Oplishenus Burmannt Roem. \& Schult. Barren Island (63). India, Indo-China, Malaya; China, Japan.

138. Thysanolena ACarifera Nees. Narcondam (115) coasts. India, Indo-China; Malaya.

139. Pogonatherum saccharoideum Beauv. Barren Island (64); common. India, Indo-China, Malaya; China.

This species is very abundant on the rocky slopes forming the inner side of the outer cone; it is one of the plants collected by the Deputation of 1866 ; it was also collected in 1846 by Kamphövener, botanist on the Danish Frigate "Galatea," whose visit is commemorated by the name 'Galatea' having been marked on the large block on the crater. Kamphövener's specimens are in the Herbarium at Copenhagen.

140. Irchendm muticum Retz. Barren Island (65); common. India, Indo-China, Malaya; Australia; Western Polynesia.

Usually a coast species, this here extends inland and fills the valley between the cones, covering all the bottom of this except the lava streams.

\section{一. LYCOPODINEÆ. XXXVI.}

141. Lycopodiun Cernudu Linn. Barren Island, (66), interior of crater. Cosmopolitan in the tropics.

142. Psilotum triquetrum Sw. Barren Island (67), interior of crater. Cosmopolitan in the tropics.

\section{xLVII. FILICES. xxxyit.}

143. Davallia solida Sw. Narcondam (116), on trees in beach-forest. Andamans, Malaya, Polynesia; Australia.

144. Davalima speldnce Bak. Narcondam (1L7), common. Africa; India, Indo-China, Malaya; Australia; Polynesia.

145. Adiantuar lunulatun Burm. Barren Island (68), common. Cosmopolitan in the tropics.

146. Trichodanes pyxidiferum Linn. Narcondam, (118), at 2330 feet. Cosmopolitan in the tropics. 
147. Cheilanthes tenorfolia Sw. Barren Island (69), dwarf specimens, plentiful within the crater.

India, Indo-China, Malaya; Australia; Polynesia ; China.

148. Onхснidm auratum Kaulf. Barren Island (70), occasional.

Himalayas, Indo-China, Malaya; China.

149. Pteris longifolia Linn. Barren Island (71), a fer plants.

Cosmopolitan in tropical and sub-tropical countries.

150. Pteris biadrita Linn. Barren Island (72), occasional.

Cosmopolitan in the tropics.

151. Asplenium Nidus Linn. Narcondam (119), on trees, rather common.

Mascarene Islands; India, Indo-China, Malaya; Polynesia.

152. Aspienium falcatum Lamk., var. urophyllua Bak. Narcondam (120), very common on stony hill-sides; Barren Island (73).

Africa; India, Indo-China, Malaya; Australia; Polynesia.

153. Nephrodium terminans J. Sm. Narcondam (121), common. India, Indo-China, Malaya; Australia; Polynesia; China.

154. Nepinolepis tuberosa Presl. Barren Island (74). Cosmopolitan in the tropics.

155. Polyrodiun inioides Lamk. Narcondam (122), at 1800 feet. Africa, India, Indo-China, Malaya; Australia ; Polynesia.

156. Polypodidm adnascens Sw. Narcondam (123); Barren Island (75). Africa, India, Indo-China, Malaya; Polynesia.

157. Poltpodium querctaloium Linn. Narcondam (124); Barren Island (76).

India, Indo-China, Malaya; Australia.

158. Acrostichum appendicdlatum Willd, rar. setosa Bak. Narcon$\operatorname{dam}(125)$, common.

India, Indo-China, Malaya.

159. Acrostichum costatum Wall., var. deltigera. Narcondam (126); exactly $=$ Wallich's Meniscium deltigerum.

E. Himalayas; Indo-China, Malaya.

160. Acrostichum aureja Linn. Narcondam (127); and Barren Island (77); common on rocks on the coast.

Cosmopolitan in the tropics in salt marshes.

161. Acrostichum scandens J. Sm. Barren Island (78), near sea.

India, Indo-China, Malaya; Australia ; Polynesia.

xLVIII. MUSCI. xxxviI.

162. Neckera RUGUlosa Mitt.* Narcondam (128), at 2330 fect. Ceylon.

* Examined, and kindly named for the writer by Dr. Brotherus, Helsing fors. 290 
163. Bryum Coronatum Schwægr. Narcondam (129); Barren Island (79). Cosmopolitan in the tropics.

xLIX. LICHENES. xxxIx.

164. Collema nigrescens Achar. Narcondam (130), rather common ; Barren Island (80), plentiful.

Cosmopolitan.

\section{FUNGI.* xL.}

165. Polyporus australis Fries. Narcondam (131); Barren Island (81). Cosmopolitan in the tropics.

166. Polyporus xanthopus Fries. Narcondam (132).

Cosmopolitan in the tropics.

167. Lenzites platyphyluds Cooke, Grevillea xiii. 1. Narcondam (132). Malay Peninsula.

168. Dedaelea griercina Eries. Narcondam (134); Barren Island (82). Cosmopolitan.

169. Peniophora paptrina Mont. Narcondam (135); Barren Island (83). Cosmopolitan in the tropics.

170. Hirneola polvtricha Mont. Narcondam (136); Barren Island (84). Cosmopolitan in the tropics.

171. Thelephora incrustans Pers. Narcondam (137); Barren Island (85).

Cosmopolitan.

172. Rнytisma, sp. Narcondam (138); Barren Island (86); on leaves of Ficus brevicuspis.

Andamans.

\section{ALG丑. XLI.}

173. Calothrix pulvisata Ag. Barren Island (87); on stones in the hot spring on the beach at Landing-place Cove.

Cosmopolitan.

174. Calothrix tasmanica Kg. Barren Island (88); on rocks in bed of torrent on inside of outer cone to the south of the lava.

Indo-China, Malaya; Australia.

\section{$\S \S \S$ Nature and Origin of the Flora.}

The list includes 174 species, of which 138 occur in Narcondam and 88 in Barren Island; 86, or $62 \frac{1}{3} \%$, of the Narcondam plants are absent from Barren Island, while 36 , or $41 \%$, of the Barren Island species do not occur in Narcondam; only 52 species-making $37 \frac{3}{4} \%$ of

* Examined, and kindly named for the writer by Mr. G. Masseé. 
the Narcondam, $59 \%$ of the Barren Island flora-are common to the two islands. Of the genera, 111 occur in Narcondam and 75 in Barren Island, but only $48,-43 \frac{1}{4} \%$ of the Narcondam ones, $64 \%$ of those in Barren Island-are found in both places. Eleven natural orders present in Narcondam are unrepresented in Barren Island; five present in Barren Island are not found in Nar'condam.

As regards Cryptogams, the two floras seem very similar, each having the same total number; the natural orders, however, indicate greater diversity of character among Barren Island than among Narcondam Cryptogams. There are two Lycopodinece, and two Algce, not represented in Narcondam; on the other hand, in Narcondam, at the top of the hill are a Trichomanes and a Neckera, absent from Barren Island. Of the thirteen ferns on Narcondam and 12 on Barren Island, 5 only are common to the two places; the Narcondam ferns belong to 6 genera, the Barren Island ones represent 8 genera. In Narcondam, one of the features of the vegetation is the presence of large beds of ferns; in Barren Island, ferns are scarce.

All the Cryptogams are herbaceous, and may all have their presence credited to wind-agency; Acrostichum aureum, however, in both islands, and Acrostichum scandens in Barren Island, grow only near the sea; both are denizens of mud-flats in the Sunderbuns, the Andamans and throughout Malaya and possibly therefore are sea-introduced.

Of the 46 natural orders of Phanerogams in Narcondam, 23 are represented by one species, 12 by two species, 3 by three species, and 3 by four species each; the only orders represented by more than four spccies, are Compositce and Convolvulacece, each 6 sp.; Euphorbiacece, 10 sp.; Leguminosce, $12 \mathrm{sp}$. and Utricacec, $13 \mathrm{sp}$. In the 35 natural orders in Barren Island we find that 21 are represented by one species, 8 by two species, and 2 by three species; the only orders represented by more than three species are Leguminosce, Rubiacece and Euphorbiacea, $5 \mathrm{sp}$. each, and Urticacece, $7 \mathrm{sp}$. Urticacece is thus in both islands the leading natural order; this hegemony is due to the facilities that fruits of the ordcr offer for introduction by frugivorous birds.

Of the 115 Narcondam Phanerogams, 33 are trees, 31 are shrubs, 37 are climbing species-woody climbers 16 , herbaceous climbers 21 ; only 5 climbers being armed-and 14 are herbs. Of the 65 Barren Island species, 15 are trees, 17 are shrubs, 16 are climbers-woody 6 , herbaceous 10; only 3 armed-and 17 are herbs. There are roughly speaking twice as many trees, shrubs and climbers in Narcondam as in Barren Island; the number of herbaceous species in the latter island is, however, slightly in excess of the number in the former. Of the herbaceous Phanerogams seven species are common to both islands; all 
are plants that niay have been introduced by the sea. Of inlaud herbaceous specics which may have been introduced by fruit-eating or marsh birds, or by the wind, the islands do not have one in common.

In Narcondam there are four Composite most probably introduced by wind; a grass, Thsyanolcena, may conceivably have been introduced in the same way. The two remaining herbs are the Amorphophallus which, even if in this island it has developed into a distinct form, must have originally been introduced by somc fruit-eating bird, and the Pollia, which most probably has been introduced by the same agency.

In Barren Island, the wind-introduced species are two orchids and one grass, Pogonatherum; Ischcemum muticum has probably been introduced by the sea. The others have been introduced by birds; Physalis and Mitreola probably by fruit-eating birds; Oldenlandia, Vandellia and Oplismenus by birds to whose feet or feathers seeds have clung. Except Pogonatherum, Ischcemum and Mitreola, the Barren Island herbs are scarce.

The paucity of armed climbers in both islands is striking. The proportion of climbers to erect species is considerably higher in Narcondam, where they form one-third of the whole Phanerogamic flora, than in Barren Island, where they form only one-fourth, and partly in consequence of this, the jungle in Barren Island is opener than in Narcondam. Of the thirty-seven climbers in Narcondam, twelve have undoubtedly been introdnced by fruit-eating birds, while one has most probably been introduced by its fruits having stuck to the feathers of some bird; fourteen have been introduced by the sea; six by winds. Of the remaining four species, which are more doubtful, two may be safely assumed to be here sea-introduced species also; one may be put down to the agency of birds, and only one species, the Dioscorea, is quite doubtful; perhaps the sea is on the whole the most likely agency.

Similarly, of the sixtecn climbers on Barren Island, five are clearly species introduced by fruit-eating birds; to these a sixth probably should be added. Four are species certainly sea-introduced; to these another should probably, and two more should perhaps be added; of wind-introduccd species there are threc.

Very few of these species are common to both islands, only nine, or about half the Barren Island and one-fourth of the Narcondam climbers being so; of these four arc again sea-shore species, and the Dioscorea found in both islands may be a fifth of the sea-introduced class. Two, the Hoyas, are wind-introductions; one, Capparis sepiaria, is certainly; another, the Abrus, is probably, a bird-introduced species.

Of the thirty-one Narcondam shrubs, one (MIusa) has been introduced by man; on the other hand not a single shrub owes its prescnce 
to the agency of wind. As many as seventeen are unequivocally birdintroduced specics; and teu are unequivocally sea-introduced species; the rcmaining three, which are all capsular-fruited Euphorbiacece (Actephilu, Macaranga and Mallotus), though not unequivocally sea-introduced, are in all probability species of this class.

Of the seventeen Barren Island shrubs, seven are undoubtedly birdintroduced species; nine are sea-introduced species; one species, Dodoncea. is, though somewhat equivocally, to be looked upon as wind-introduccd.

There is much greater conformity between the floras as regards this class; thirteen of the Barren Island shrubs occur also in Narcondam, only four being peculiar; all but one of the sea-shore, and all but two of the bird-introduced shrubs in Barren Island occur in Narcondam also.

The trees in the two islands have last to be considered. Of the thirty-three in Narcondam twenty-one, or more than three-fifths, have been introduced by birds; two from their fruits having been attached to the feet or feathers, the others, by fruit-eating birds : ten may have becn sea-introduced; for seven this mode of introduction is undoubted, as regards Caryota it is rather equivocal, and the Coco-nut may have been deliberately introduced; two species are wind-introduced.

Of the fifteen Barren Island trees, nine are bird-introduced species; five are sea-introduced; one has been introduced by wind.

Here again great conformity between the floras is observable; of the fifteen Barren Island trees, ten occur in Narcondam: these include all the bird-introduced ones except four, and all but one of the sea-introduced species; one wind-introduced species is common to the two islands.

Among herbaceous species, where the equality of numbers promised most agreement, there is therefore greater diversity between the two floras than among the other's.

Of the 75 species of Phanerogams peculiar to Narcondam, 22 have been introduced by the sea, 42 by birds, and 10 by winds; one species ( $M_{\text {Iusa }}$ ) has been introduced by man. Of the 25 species peculiar to Barren Island, on the other hand 5 have been introduced by the sea, 15 by birds, 5 by winds. Of the 40 Phanerogams common to the two islands ; 24 are sea-introduced, 13 are bird-introduced, 3 wind-introduced. In the common element of the two floras, the sea-introduced species for'm the dominant class, being nearly double the bird-introduced specics and six times as numerous as the wind-introduced ones. In the special elements, on the other hand, the bird-introduced species form in both instances the dominant class; in Narcondam they are nearly twice as numerous as the sea-introduced and four times as numerous as the windintroduced specics; in Barren Island, they are three times as numerous as cither of these kinds. 


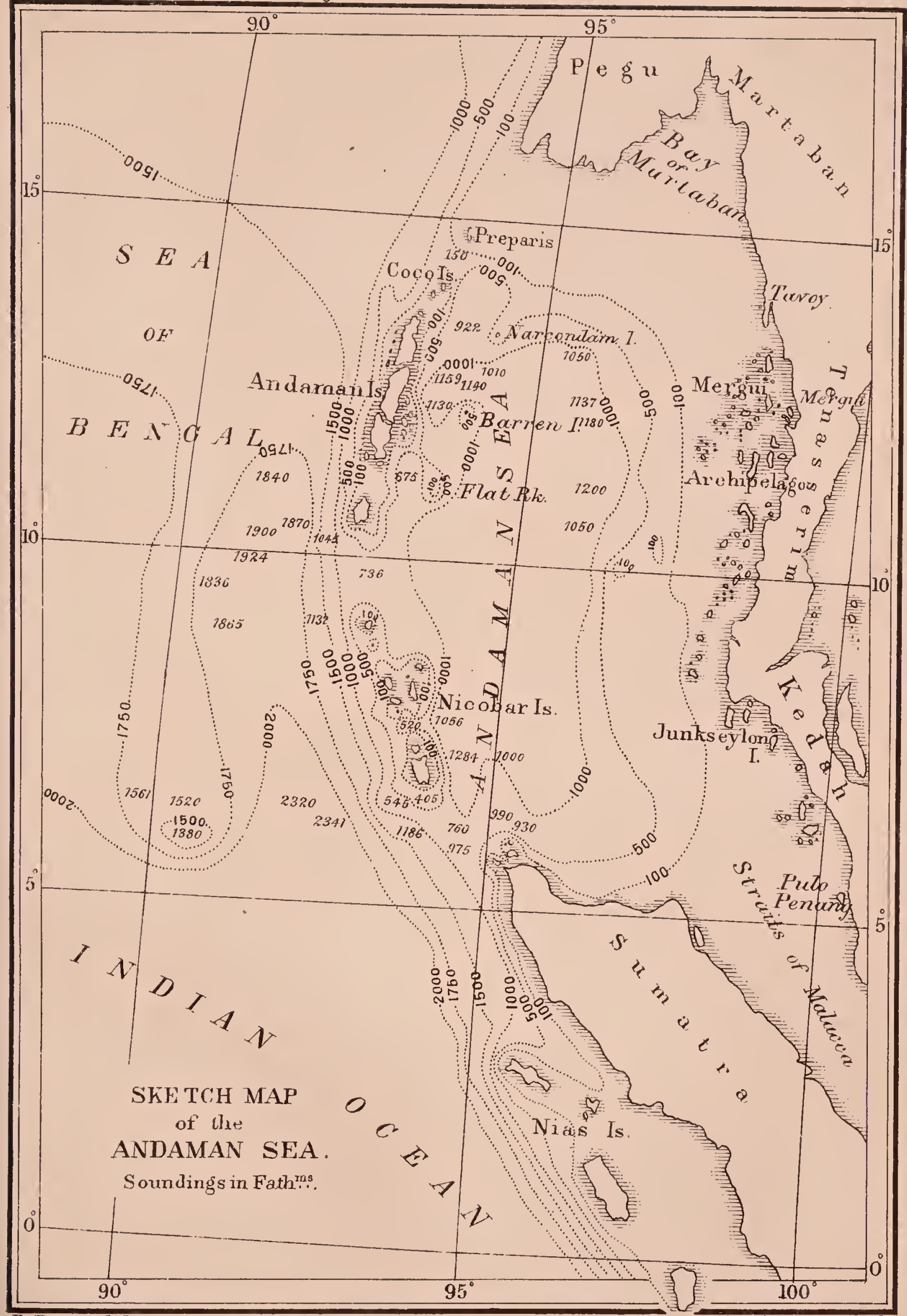





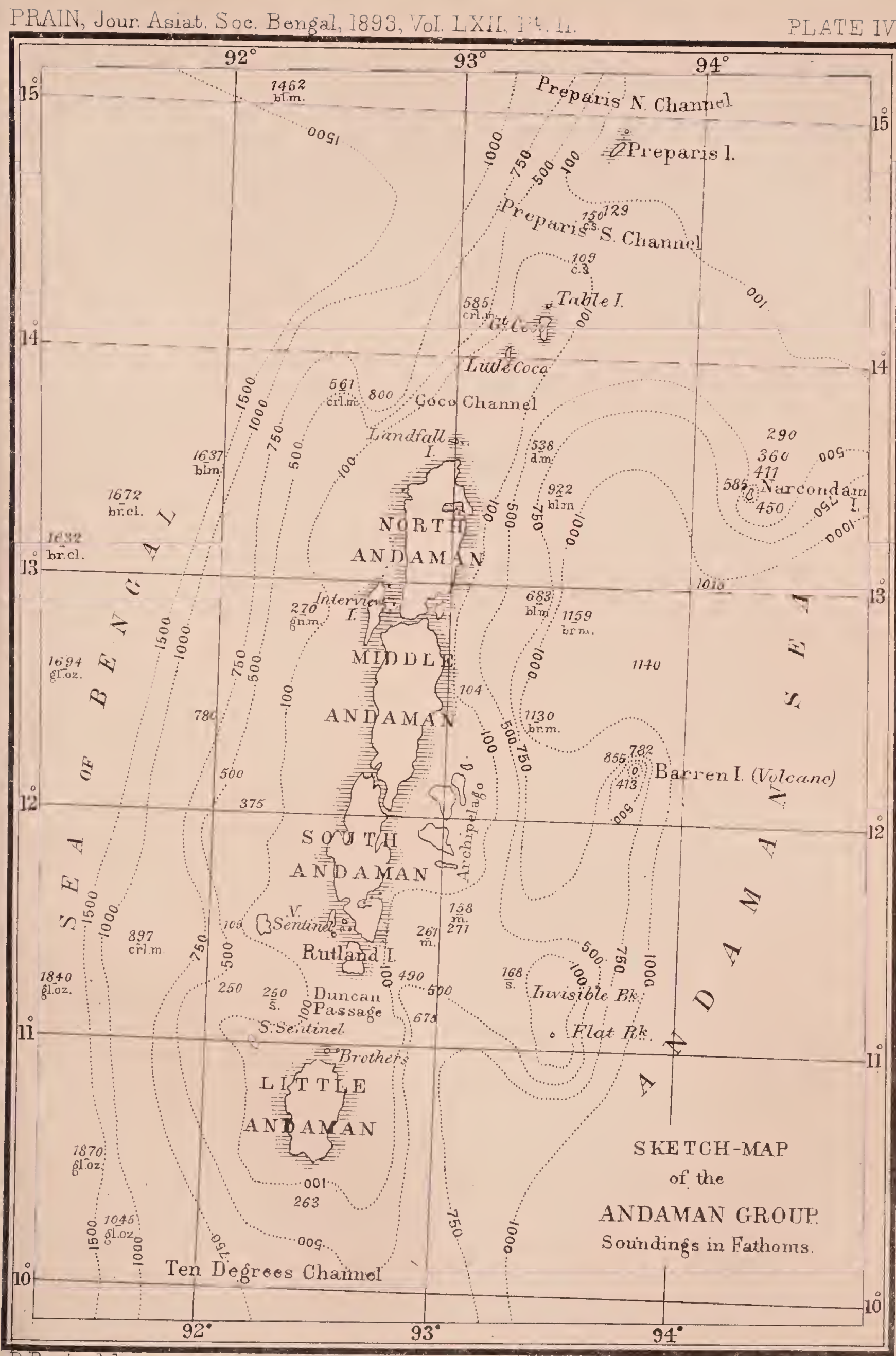





\section{BOT ANY}

OF THE

\section{LACCADIVES.}





\section{CONTENTS.}

I NTRODUCTION.

The Laccadive Archipelago; bibliography; Lt. Wood's account of Anderut ; Lt. Moresty's chart; Sir Wm. Robinson's description of the British Islands; Mr. Hume's account of the Archipelago; visits by the "Investigator"; Cherbanani reef; Cheriapani reef; Bitrapar; Pirmalpar ; Akati ; Chitlac ; Kiltán ; Kadamum ; Améni ; Piti sandbank; Koráti ; Anderut ; Kalpéni ; Minikoi ; lists of the islands

\section{Srstematic List of Plants.}

Source and nature of the list ; authors quoted ; list

\section{Characteristic Features of the Flora.}

Systematic character; habit of the species; origin and distribution of the flora 



\section{BOTANY OF THE LACCADIVES, BEING NATURAL HISTORY NOTES EROM H. M. I. M. SURVEY STEAMER “INVESTTGATOR," CoMmander R. F. HOSKYN, R.N., COMMANDING.}

Series II., No. 5. By D. Prain.

\section{InTRODUCTION.}

The Laccadive Archipelago is situated at the south-eastern angle of the Arabian Sea, between Lat. $10^{\circ}$ and $14^{\circ} \mathrm{N}$. and Lon. $71^{\circ} 40^{\prime}$ and $74^{\circ} \mathrm{E}$., and is composed of 16 or 17 small coral islands, the most easterly of which lies 120 miles to the westward of the Malabar Coast, while the most southerly is about the same distance to the north of the Maldive Archipelago. Between the Laccadivo and the Maldive Archipelagos lies the island of Minikoi in Lat. $8^{\circ} 30^{\prime}$ N., and Lon. $72^{\circ} 40^{\prime} \mathrm{L}$. This island is sometimes spoken of as being one of the Maldives, owing to the fact of its being rather nearer to that Archipelago than to the Laccadives, and because its population is Maldive in language and in manners; usually, however, it is treated, as it will be in this paper, as a Laccadivo Island, because its political allegiance has always, within historical times, been with the latter group. In reality, however, it cannot be precisely looked on as a member of either group, though being one of the atoll-crowned submarine peaks characteristic of the two archipelagos, it is clearly a link in the chain to which both belong. It was at one time supposed that the atolls of this chain were situated on a bank separated from the nearest mainland (the coast of Malabar) by an ocean trough.* This is now found to be incorrect, and the islands form in reality "a chain of peaks rising from a bed of 1,100 "fathoms, or are in themselves 6,600 feet above the bottom, " a height somewhat similar to that of the Western Ghâts in those "latitudes." $\dagger$

* Hume, "Stray Feathers," vol. iv., p. 459.

+ Carpenter, "Auministration Reports of the Marine Survey of India," year $1887-88$, P. 7 ; y oar 1888 89, p. 6 . 
'The chief references to the Laccadive Archipelago are enumerated below :-

W. Hamilton.-Article "Laccadives," in East India Gazetteer [1815] : a very brief notice of the group.

J. Wood.-Extract from Lieut. Wood's Private Journal regarding the Lakeradeevh Archipelago, in Journ. of the Roy. Geogr. Soc., vol. vi. [1836] : contains a full account of Anderut, and gives information concerning the other members of the group obtained from enquiries made by Lieut. Wood when in Anderut. .

W. Robinson.-Description of the Laccadive Islands, in Madras Journ. of Literature and Science, n. s., vol. xiv. [1847]: contains full accounts of the British Islands of the Archipelago, and is preceded by an interesting and valuable historical preface, unfortunately unsigned, drawn up by a member of the Madras Society's Editorial Committee.

A. O. Hume.-The Laccadives and the West Coast, in Stray Feathers, vol. iv., [1876]: an excellent account of the reefs and islands visited by $\mathrm{Mr}$. Hume.

W. W. Hunter.-Article "Laccadives," in Imp. Gazetteer of India, ed. ii., vol. viii. [1886] : a somewhat inexact digest of previous notices based chiefly, however, on that by Mr. (afterwards Sir William) Robinson.

Administration Reports of the Marine Survey of India, 1887-8, 1888-9, 1889-90, 1890-1, 1891-2, Topographical and hydrographical notices by Commander Carpenter, R. N., and Commander Hoskyn, R. N., with biological notices by Surg. Alcock, I.M.S.

J. Shortt.-Monograph of the Cocoanut Palm [1888] : describes (p. 16) the process of coir-manufacture in the Laccadives.

G. Watt.-Article "Cocos nucifera," in Dict. Econ. Prod. of India, vol. ii. [1889]: describes the Laccadive coco-nut and coir trade.

D. Prain. - A list of Laccadive Plants, in Sc. Mem. by Medical Officers of the Army of India, part v. [1890]; W. Roth, in Engler, Bot. Jahrb., vol. xii. [1890]; W. B. Eomsloy, in Nature, vol. xlii. [1890]. 
On studying a chart of the Archipelago we find that the atolls are arranged in three lines, as if there were three chains of peaks; a western rather irregular chain, corresponding roughly to the meridian of Lon. $72^{\circ}$ E., containing from north to south the reefs or islands of Cherbaniani, Cheriapani, Bitrapar, Pirmalpar, Akati, and Suhelipar, with, at tho extreme north, the sunken bank of Koradivh; a central, corresponding roughly to the meridian of Lon. $72^{\circ} 45^{\prime} \mathrm{E}$., containing from north to south tho islands of Chitlac, Kiltán, Kadamum, Améni and Koráti with the Piti sandbank between the two latter, and with, at the extreme north, the sunken Bassas de Pedro bank; and an eastern, corresponding to Lon. $73^{\circ} 40^{\prime} \mathrm{E}$., containing the islands of Anderut and Kalpéni, with, to the north-east of these, the sunken Elikalpéni bank: Minikoi, it will bo seen, corresponds as to position with the central chain of peaks. The parallel of Lat. $11^{\circ} \mathrm{N}$. conveniently separates the Archipelago into two groups; the northern, containing the inhabited islands of Chitlac, Kiltín Kadamum, and Améni with the uninhabited island of Bitra and the open reefs of Pirmalpar, Cheriapani and Cherbaniani, which are attached to the administrative district of South Kanara, and thus orve direct allegiance to British India ; and the southern, containing the inhabited islands of Minikoi, Kalpéni, Anderut, Koráti and Akati, with the three uninhabited islands of Suheli (on the Suhelipar reef), and Bangáro and 'Tangáro ( $a n$ the reef on which Akati is situated), which belong to the Bibi of Cannanore, and thus only indirectly acknowledge British suzerainty.* It will be observed that only one of the atolls of the western chain-that on which Akati stands-has an inhabited island, whereas of the other two the only one without an inhabited island is the Piti sandbank, which, however, is of a somewhat different nature from the other atolls mentioned, being in reality a sunken bank of the same type as Koradivh and Elikalpéni.

* Since, however, the people of Minikoi do thus acknowledge themselves Indian subjects, and since, except for the accident of population, the island has no greater claim to be considered a member of the Maldive than of the Laccadive group, it is better to deal with Minikoi along with the Laccrives, which are patently Indian islands, than along with the Maldives, which acknowledge the suzerainty of Ceylon. 
The earliest topographical account of any of the islands is a description of the Cannanore island of Anderut* by Licut. Wood, who visited it in December, 1834, and who, from enquiries made in this one, drew up a table in which the names of all the islands, with their condition as to popnlation and vegetation, are shown. A chart of the group had, however, already been prepared from a survey by Lieut. Moresby in 1828. $†$ The group was more fully described by Mr. (afterwards Sir William) Robinson, of the Madras Civil Service, who in 1844 and 1845 visited the inhabited islands directly 'under British rule, and made enquiries of the people of Améni, Kadamum, Kiltán, and Chitlac regarding the condition of Bitrapar and of the inhabited islands belonging to the Cannauore Raj. Mr. Robinson's account $\div$ lad prefized to it by the Editoriat Committee of the Madras Literary Sncioty an admirable digest of the history of the islands down to 1845, and this preface, with the paper that follows it, has been made the basis of the official account of the group.§ From the time of Mr. Robinson's visit till 1876

* Extract from Lieut. Wood's private Journal regarding the Lakeradeevh Archipelago; "Journ. of the Roy. Geogr. 'Soc." vol. vi., p. $29-33$ (1836).

+ A redaced reproduction of this chart is given in "Madr. Journ. of Lit. and Sc.," vol. xiv., plate 16 (1847).

\# "Description of the Laccadive Islands," by W. Robinson, Esq., of the Ciril Service; "Madras Journ. of Lit. and Scienco," vol. xiv., pp. 5 -46 (1847).

§ "Imperial Gazetteer of India," ed. ii., vol. viii., pp. 392-396 (1886). Mach of this article is a paraphrase of $\mathrm{Mr}$. Robinson's account, many sentences being taken verbatim, though without acknowledgment, from the Madras Journal. The compiles. accredits to $\mathrm{Mr}$. Robinson one passage in tho paragraph on population; this passage though enclosed within quotation commas, differs rnther more than many of the unacknowledged sentences. The paper by Mr. Robinson being essentially "official," the writer of the Gazetteer may not havo been technically bound to acknowledge the source of his information; this can hardly, howover, apply to tho editorial preface, which is appropriated without remark. In doing so the "Gazettcel" somewhat inexactly speaks of Kalpéni as the " Kaluftee' of Ibn Batuta," although the writer of the paraphrased digest has been careful to say that "no distinct mention of the Laccadives occurs in Ibn Batuta" ("Madras Journ.," xiv. 2), and as carefully indicates that the passage in which Kalnftee is giron as the name of one of the principal inhabited Laccadive Islands occurs in the Tohfat-al-IIujahidin ("Madras Journ., "xiv.3) The identification of Kaluftee with Kalpeni is altogether arbitrary; it is quite as likely that Koráti is intended. 
no account of the islands had been published, though in 1873 they were visited by Dr. Shortt.* Mr. Hume in 1875 paid a visit to the Archipelago, his object being mainly an ornithological survey, but with characteristic energy he made a botanical collection in some of the islands visited by him, and refers to the species that he collected or observed in his account of this visit. $\dagger$ A series of scientific visits have recently been paid to this group by H. M. I. M. Investigator. In October, 1887, Chitlac was visited, but no botanical collecting was done. $\ddagger$ Again in May, 1889, Anderut and Kiltán were visited, and collections of botanical specimens were made by $\mathrm{Dr}$. Alcock, Surgeon-Naturalist to the Marine Survey; $\S$ these collections were described in a preliminary notice of the Flora of the group by the writer.\| In November, 1889, the Investigator visited Kal. péni đ́ad Dr. Alcock again made a collection of the plants. Finally, in November and December, 1891, the vessel re-visited Kiltán, and visited Kadamum and Bitrapar, whence Mr. Hume had already sent specimens, as well as Akati and Minikoi, two islands from which specimens had not previously been obtained.** During these 1891 visits, Dr. Alcock and his assistant, Mr. Fleming, Apothecary on the Investigator, collected most assiduously the plants that were met with, Mr. Fleming at the same time preparing a list of the species under cultivation in the four inhabited islands visited.

All the islands of the group are typical coral-islands, situated on atoll-rings, of which each forms but a small portion, generally on the eastern or leeward aspect of their respective reefs; Anderut, however, is situated on the windward side, the reef being to

* Shortt; MIonograph of the Cocoanut Palm; or, Cocos nucifera, p. 16 (Madras, 1888).

† Hume, "The Laccadives and the West Coast"; "Stray Feathers," vol. iv., pp. 413, 460 (1876).

‡Carpenter, "Administration Report of the Marine Survey of India," year $1 \S 87-88, \mathrm{p} .7$.

$\S$ Alcock in Hoskyn, "Administration Report of the Marine Survey of India," year 1889-90, p. 13.

|| Prain, "A List of Laccadive Plants"; "Scientific Mem. by Medical Officers of the Army of India," pt. จ., pp. 47-70 (1889).

T Hoskyn, "Administration Report of the Marine Survey of India," 1889-90, p. 5.

** Gunn, "Adnainistration Report of the Marine Survey of India," 1891.92, p. 3. 
leeward instead of to windward*, while Akati and its two little satellite islands, Bangáro and Tangáro, are inside a huge lagoon, formed by a separate barrier-reeft Three of the atolls are mere open-reefs. The first of these is the Cherbaniani (called also the Beliapani) reef, situated at the extreme north-west corner of the Archipelago in Lon. $71^{\circ} 55^{\prime}$ E. and Lat. $12^{\circ} 20^{\prime} \mathrm{N}$, minutely described by Mr. Humeł as a long oval atoll, 6 miles in length by $2 \frac{1}{4}$ miles across, the reef consisting of an almost unbroken line about 200 yards in width, just submerged at high-tide and more or less dry at low-water, with two narrow shallow channels through it on the eastern and one on the western side; in three places, at the extreme north, the extreme south, and about the middle of the eastern side are piled-up masses of coral débris forming islets even at high-water. There is no trace of vegetation on any of these tiny islets, the largest of which, that at the northern extremity, is about 200 yards long and about 50 yards across, its highest point not being more than 7 feet above high-water. The lagoon within this reef carries from 3 to $3 \frac{1}{2}$ fathoms at its deepest portion, shallowing to the reef all round.

This reef is apparently not included in Lieut. Wood's list; $\S$ his No. 10 (Tátácum) may indeed refer either to this or to Pirmalla, but cannot include both, and probably indicates the latter. If, however, this should be what is meant by his Tátácum, then the statement that it produces coco-nuts made to him at Anderut, is incorrect. Immediately to the south of Cherbaniani in Lon. $71^{\circ} 50^{\prime}$ E. and Lat. $11^{\circ} 50$ N. lies the Cheriapani reef (Sheréah of Wood's list), called also the Byramgore reef, owing to the wreck there in 1827 of a Bombay vessel of that name. This is shown in the charts as completely submerged at high-water, but from what $\mathrm{Mr}$. Hume was able to ascertain at Améni regarding it, this appears to have several islets like those on the Cherbaniani reef. The statement of the islanders of Anderut to Lieut. Wood, that it produces coco-nuts and

*Wood, "Journ. of the Roy. Geogr. Soc.," vol. vi., p. 30.

+ Hume, "Stray Feathers," vol: iv., p. 439.

\# "Stray Feathers," vol. iv., p. 428, with map.

s "Journ. Roy. Geogr. Soc.," vol. vi., p. 30. 
is visited on that account, is doubtless incorrect; if visited at all it must be for birds' eggs, or for the purpose of fishing in the lagoon.

South-east of the Byramgore reef in Lon. $72^{\circ} 10^{\prime} \mathrm{E}$. and Lat. $11^{\circ} 30^{\prime} \mathrm{N}$. lies Bitrapar, visited by Mr. Hume in 1875. Mr. Rubinson had already given an account of the island.* This reef forms a large very regular oval 7 to 8 miles long and 4 to 5 miles across at the widest part. The island of Bitra, which is the only part of the atoll above high-water mark, occupies the north-east corner, and is about half-a-mile long and a quarter of a mile across, being nowhere more than 9 or 10 feetabove high-water level. The lagoon is shallow at the north end and along the western side, but carries elsewhere 3 to 6 fathoms. The island itself is not, like the islets on Cherbaniani, a mere pile of coral blocks, $\uparrow$ but exhibits the structure characteristic of the larger formed-islands of the group; that is to say, it consists of a soil of coral-sand mixed with a greater or less amount of humus derived from decaying vegetation, this soil overlying a friable calcareous rock with a coarse oolitic structure, one foot to eighteen inches thick, beneath which is found a loose wet sand from whence, if the crust be broken through, and a few spadefuls of it be removed, water percolates and accumulates in the hollow so formed. $\neq$ In Bitra, however, though the overlying soil is said to be excellent and the coco-nut grows luxuriantly, it is impossible for the people to occupy the island permanently because the water which accumulates in the wells made by sinking short shafts through this coral crust, in place of being fresh and drinkable, as in the inhabited islands, is so salt that the fishermen who visit the place, when they run short of water, dig a hole in the sand near the sea and drink the brackish percolations thus obtained in preference

* Mr. Hume speaks inadvertently ("Stray Feathers," iv., p. 435) of Mr. Robinson having visited this island, Mr. Robinson says ("Madras Journ.," xiv., p. 27) that he was unable to visit it himself, though he obtained all the particulars he could ooncerning it. Mr. Hume's own account is, therefore, the first description of the island that has been made from personal observation.

† Hume, "Stray Feathers," vol. iv., p. 431.

\$ Robinson, "Madras Journal of Lit. and Science," vol. ziv., p. 7; Alcock in Hoskyn, "Marine Survey Report," 1889-90, p. 12. 
to the well-water." The island is sacred to a Pir whose tomb, Mr. Robinson was told, has about 200 coco-nut trees planted round it as votive offerings to his name. Mr. Hume speaks of the coco-nut trees but does not mention the tomb. It stands, Dr. Alcock informs the writer, near the north end of the island in the middle of the Coco-nut grove, surrounded also by patches of one of the Tulsi plants. An indication that the island is often visited is the presence in the Investigator collection of specimens of Ricinus communis which is frequent as a weed. Besides the Castor-Oil, the Tulsi, and the Coco-nut, the collections of Mr. Hume and Dr. Alcock contain 16 species, all but three of which are undoubtedly plants of the littoral, sea-introduced class. It is important to note that the Coco-nut does not occur in a fringe round the coast as would probably be the case were that species here introduced by the sea; besides their being confined to the middle of the island we have the express statement of the islanders to Mr. Robinson that the trees were deliberately planted during their fishing and egg-collecting visits. The most interesting species on the island is Pisonia alba, here clearly sea-introduced, which has not been reported from any other member of the group, and has never indeed been found growing undoubtedly wild either in India or in Ceylon.

To the south and a little west of Bitrapar, in Lon. $72^{\circ}$ E. and Lat. $11^{\circ} 10^{\prime} \mathrm{N}$., is situated the third open reef of Pirmalpar which has been visited by $\mathrm{Mr}$. Hume, who describes it $†$ as a huge triangular atoll with only one small bank, at the north-east corner, about 200 yards long and 50 yards across, uncovered at high water but with the greater portion of the reef visible at low tide. The islet-which derives its name of Pirmalla from a tradition of the people that their ancestors, the original settlers in the archipelago, formed part of an expedition which set out from Malayala (the Malabar coast) for Mecca in search of their apostate King Barman Pirmal, but was wrecked in these islands $\ddagger$-is not composed, like those on the Cherbaniani reef, of accumulations of coral débris, but is a bare, smooth,

* Robinson, "Madr. Journ." vol. xiv., p. 27.

† "Stray Feathers," vol. iv., p. 450.

¥ Robinson, "Madr. Journ.," vol. xiv., p. 8. 
wind-swept sand-bank absolutely devoid of any vegetation.* It is therefore clear that, whether the Tátácum of Lieut. Wood's list refers to this reef or to Cherbaniani, the islanders misinformed him when they assured him that it produced coco-nuts. Perhaps, however, the people of Anderut, who probably do not themselves visit this reef, seeing this is a British and not a Cannanore possession, only knew that the island was visited periodically, without being wrare whether the visits were paid in order to obtain coco-nuts or merely for fishing and egg-collecting.

South-east of Pirmalpar between Lon. $72^{\circ} 10^{\prime}$ and $72^{\circ} 20^{\prime} \mathrm{E}$. and between Lat. $10^{\circ} 50^{\prime}$ and $10^{\circ} 57^{\prime} \mathrm{N}$. lies the large atoll of Akati, the most westerly of the inhabited islands and the only inhabited island of the wester'n chain of peaks. This atoll, which encloses a large lagoon inside which vessels of some size find an anchorage, was visited in 1875 by Mr. Hume, who describes the reef as somewhat "shoulder-of-mutton" shaped, the knuckle to the south-west with Akati itself in the middle of the knuckle, and with two small uninhabited islands, Bangæro and Tangáro, towards the edge of the blade at the north-east corner. The barrier reef is high and strongly marked on the north, north-east and more than half the eastern side, where, Mr. Hume thinks, there are some points bare at high water; elsewbere it is much lower, a considerable portion being covered even at low tide, and being pierced by deep shipchannels in several places.t Mr. Hume also mentions a sand bank which is devoid of regetation; this is probably the Akati Féti (No. 17) of Wuod's list. Mr. Hume landed on Bangáro (Bangâram, Wood) which he describes as "a mass of vegetation down to the "water's edge, dense with cocoanuts above and screw pines below," the undergrowth being also very dense; the plants growing with a luxuriance that "contrasted strongly with the generally-stnnted "growth of the same species on Betrapar." The plants that $\mathrm{Mr}$. Hume collected were mainly those he had not already obtained or noted in Bitrapar; the specimens belong to 10 species, all save one of which (S'etaria verticillata) might have been introduced by the

* Humo, "Stray Feathers," vol. iv., p. 351.

+ Hume, "Stray Feathers," vol. iv., 451.

$2 B \dot{L}$ 
sea. The interior of the island was found to be an almost impenetrable thicket, largely composed of Caesalpinia Bonducella bushes.* This account of the zone of coco-nuts points clearly to their having been here introduced by the sea.

Tangáro (Tenâkerry, Wood), the other minor island on the reef, was also visited by Mr. Hume, who describes it as less wooded than Bangáro; he did not collect any specimens. According to Lieut Wood's table this, like the last, is visited on account of its cocoanuts, which is doubtless correct.

On Akati itself Mr. Hume was unable to land, but it was visited in 1891 by Dr. Alcock and Mr. Fleming. The plants collected-which include 32 weeds of cultivation or garden-escapes, and 13 sea-shore species, with only one plant (Tylophora asthmatica) that may be a wind-introduced species-show that there is no true jungle, but that the whole of the island is under cultivation. Mr. Fleming's list of cultivated species includes Calophyllum insphyllum (of which there is but one tree, planted); Thespesia populnea (planted, but also occurring wild); Sesbania grandiflora (planted to support the Peppervine); the Tamarind; the Pomegranate (about half-a-dozen plants bearing good fruit); the Papaya; the Sweet-Potato (only one small plot); the Bird's-eyo Chillie (only in a 'wild' condition); Datura (which occurs pretty frequently, but also only in a 'wild" condition); Mirabilis Jalapa; the Pepper-vine (an object of great care); the Bread-fruit (only one tree, in a garden); Tacca pinnatifida (cultivated only); Colocasia antiquorum (only in a 'wild' condition). Mr. Fleming's list omits the Supari (Areca catechu); from a similar' list for Kiltán, where it does occur, it is also omitted, perhaps therefore the omission here is only an oversight. The island is covered with Coco-nut palms and there are several large fresh-water tanks, paved and terraced and walled with slabs of coral-volite; in these occurs the universal water-weed Chara. $\dagger$

Due south of Akati, in Lon. $72^{\circ} 12^{\prime}$ E. and Lat. $10^{\circ} \mathrm{N}$., lies the Suhelipar reef, which is shown on Lieut. Moresby's Chart as an oral atoll with an opening in the reef at the north-end and with the

* Jume, "Stray Feathers," vo1. iv., 452.

+ Alcock, "Administration Report of Marine Survoy of India," year 1891-2, p. 10. 
uninhabited island of Suheli ('Soilee,' Wood) near the centre of its south-eastern side. According to Lieut. Wood's list, this island is visited on account of its coco-nuts, but no topographical account of the atoll being available, it is impossible to say with certainty whether Suheli is a sand-bank like Pirmalla, an accumulation of coral debris like the islets on Cherbaniani, or a formed-island like Bitrapar.

The most northerly of the formed islands and the northmost member of the central chain is the inhabited island of Chitlac (Lon. $72^{\circ} 45^{\prime} \mathrm{E}$., Lat. $11^{\circ} 45^{\prime} \mathrm{N}$.), visited and described by Mr. Robinson. Mr. Hume was unable to land in 1875,* and Dr. Giles, who landed dnring the Investigator's visit in 1887, confined his attention to the marine fauna.t Mr. Robinson describes the island as two to two and a half miles long and about three-quarters of a mile wide, situated on the eastern side of a large and perfect atoll. The surface is less even than in the other islands, owing to a ridge of sanddrift that runs up the middle, rendering the soil so poor that the growth of coco-nut tree is slow and their outturn poor." "Low mounds of sand occupy a great part of the "centre and best protected parts of the island on which nothing "grows, except scanty crops of a plant called Teerny, on the roots of "which a small ball about the size of a pea grows; after the plant " has withered, these are gathered from among the loose sand and "used by the islander's. Dry cultivation on this island is very in"significant." $\ddagger$ The Teerny is obviously Tacca pinnatifida, which we know from Lient. Wood to be cultivated in Anderut, and from specimeus in the Investigator collections to be grown in Akati and in Minikoi. The tubers, however, are apparently unusually small in Chitlac, for the specimens of those grown in Akati and Minikoi sent to Calcutta are as large as plums. Still even these latter compare very unfavourably with the tubers of Tacca as it occurs wild on the shores of the Andaman Sea; there they are usually larger than a man's fist, and are often as large as the human head.

* Hume, "Stray Feathers," vol. iv. p. 436.

† Carpenter, "Administration Report of Marine Survey of India," year 1887-8, p. 7.

+ Robinson, "Madr. Journ.," vol. xiv., p. 26. 
South-east of Chitlac, in Lon. $73^{\circ}$ E. and Lat. $11^{\circ} 28^{\prime} . N$., lies Kiltán, the smallest inhabited island of the group. It has been visited and described by Mr. Robinson,* by Mr. Hume, $\dagger$ who also has published a map of the island, and by Dr. Alcock: $\neq$ Both Mr. Hume and Dr. Alcock, have made collections, and a third collection has been obtained by Dr. Alcock and Mr. Fleming during the second Investigator visit in 1891. The atoll of Kiltán "is a "long oval reef enclosing the usual lagoon with one entrance at the "north-west corner, surrounded by the usual slelving bank, varying "from one-eighth to half a mile in breadth, beyond the edge of which "the lead drops at once into very deep water, and with the whole " eastern side of the reef converted into an island which is nearly two " miles in length, and may average nearly a quarter of a mile in "wid th." " “The lagoon is large but shallow, and is nearly dry at low "water. The whole island is devoted to the cultivation of the coco" nut, the trees being planted down to the water"s edge on every side; " the substratum of coral-rock is nowhere broken up for grain culti"vation, which therefore hardly exists on the island. The population "being too limited to consume the coco-nut leaves, the ground in "some parts is covered with decaying vegetable matter, most bene"ficial to the trees. In other islands it is necessary to rear plants for "one year with care and then transplant them ; in this, a nut buried "with a knife will grow, requires no attention, and comes into bearing "early." $\|$ Mr. Robinson mentions the Bread-flruit, Areca-nut, and Lime as trees that are planted by the islanders, but says that they do. not thrive; in addition to these $\mathrm{Mr}$. Hume mentions the Papaya, the Horse-radish tree, the Plantain and the Castor-oil plant; beside these, Mr. Fleming also enumerates the Agrati (Sesbaria grandiflora) which is grown as a support for the Pepper-vine, a plant on which the people bestow much attention; the Melon too is reported by $\mathrm{Mr}_{\mathrm{r}}$. Fleming as 'only cultivated,' as perhaps is the Cucumber, of which

* Robinson, "Madr. Journ.," vol, xiv., p. 23.

+Hume, "Stray Feuthers," vol. iv., p. 436, with Map.

$\ddagger$ Alcock, in Hoskyn, "Administration Report of Marine Survey of India," rear $1889-90$, p. 12.

5 Hume, "Stray Feathers," vol. xiv., p. 436.

|| Robinson, "Madras Journal," vol. xiv., p. 24. 
Mr. Fleming has communicated one specimen, found growing 'wild.' Healso found a hummock of Khus-khus grass (Andropogon muricatus), no doubt plitnted, growing near the mosque, and noted the American Aloe, introduced from the mainland, and growing well.

'The indigenous vegetation belongs almost entirely to the class of 'littoral' species, of which Mr. Hume's, Dr. Alcock's and Mr. Fleming's collections contain ten; the only noticeable points concerning this group are that the whole lagoon-face of the island is described by Hume as lined with a hedge of Scaevola Koenigii, and that Thespesia populnea is reported by Fleming as here only an indigenous, never a planted tree.

There is, says Dr. Alcock, no true jungle in the interior, * and the only species that cannot be classed either as 'weeds,' or as 'littoral species' are Vitis carnosa (probably bird-introduced), and Tylophora asthmatica and Leptadenia reticulata (probably both wind-introduced).

As in the case of Akati, the majority of the species present are either weeds or escapes, plant; unintentionally introduced by man; of these, the three collections together contain thirty-one species.

Kadamum lies south-west of Kiltán and due south of Chitlac in Lon. $72^{\circ} 44^{\prime}$ E. and Lat. $11^{\circ} 12^{\prime} \mathrm{N}$. Of this island topographical accounts have been given by Mr. Robinson who visited it in 1844 and 1845, and by $\mathrm{Mr}$. Hume who visited it and made a botanical collection in 1875, while Dr. Alcock and Mr. Fleming made a second and very exhaustive botanical collection in 1891. Kadamum is the largest island of the group and is situated on a long oval atoll like that of Kiltán; the reef here is, however, about $4 \frac{1}{2}$ miles long, and the island itself $3 \frac{1}{2}$ miles long and about three-quarters of a mile across the widest portion. 'The lagoon is also larger and much deeper than that of Kiltán, but with no good passage through the reef. $†$

"The body of the island appears generally lower than that of any " of the other's, and has an excellent natural protection in a ridge of "low sand-drift which runs down the west side." $\ddagger$ The soil is naturally fertile, being damper and firmer than in some of the other

* Alcock, in Hoskyn, "Aảministration Report of Marine Survey of India," year 1889-90, p. 13.

† Hume, "Stray Feathers," vol. vi., pp. 443, 44.4.

\$ Robinson, "Madr. Journ.," vol. xiv., p. 20. 
islands, but the coco-nut cultivation is limited to a strip across the middle, leaving more than three-fourths of the island, divided into two nearly equal parts on either side of this strip, covered with natural jungle, the southern portion of the island being occupied by a thick low scrubby undergrowth in which the Screw-pine is conspicuous, the western part being an open plain covered with grassy woeds and low bushes. The island, "especially in its "northern half, has a deserted and neglected air, and the coco-nuts, "instead of dominating the scene and monopolising attention, are "almost lost sight of in the surrounding jungle".*/There is no area specially prepared for grain-tillage, but the natural soil being better adapted for the purpose than in the other islands, a considerable portion of the dry-grain raised in the group is produced in this island. The people of Améni go there and cultivate during the monsoon, rági (Eleusine Coracana), jowári (Sorghum vulgare), and loba (Vigna Catjang).†) Mr. Hume mentions two species of the cultivated class, viz.: Indigofera tinctoria, which he speaks of as 'wild'; Dr. Alcock also sends specimens of this without any remark, as if he too had found it in a 'wild' state: also Tror'a Bandhuca, which was common at the time of Mr. Hume's visit, but which Dr. Alcock does not appear to have met with. Mr. Fleming's list of cultivated plants includes Sesbania grandiflora, with the Pepper-vine it is grown to support; the Papaya; the Cape Gooseberry (Physalis peruzrana, also reported by $\mathrm{Mr}_{1}$. Hume from the adjacent island of Améni); the Castor-oil plant; the Banyan (of which four examples occur, planted near somo deserted huts); the Plantain (of which four were seen in the neighbourhood of the Banyans). Mr. Fleming does not report Tacca pinnatifida, though probably this, as in the other islands, is the Taro that is cultivatedthe other Taro (Colocasia antiguorum) he reports as present here, as it is in all the other islands, but, as in these, only in a 'wild" condition.

The littoral species reported from Kadamum are 19 in number. These include Thespesia populnea, which, planted in some of the

Alcock, "Administration Report of Marine Survey of India," year 1891-2, p. 9. † Robinson, "Madr. Journ.," vol. xiv., p. 22. 
islands, occurs here as an undonbtedly indigenous, sea-introduced tree, and Guettarda speciosa, occurring in large clumps, not recorded from any other member of the group. Scaevola Koenigii is very abundant all round the coast, as is the Screw-pine, but Ipomoea biloba, very abundant on some of the islands, e.g., in Bitrapar, where it covers the whole beach, and in Akati, where it also extends into the interior of the island, is here confined to the shore, and is not very common even there. Wedelia scandens is one of the most common plants, and is spread all over the interior as well as round the coast; the same is true of Cassytha filiformis, which, in some parts, loads the scrubby undergrowth. Two other sea.coast species that here extend inland from the shore, and form a large part of the shrubby interior jungle, are Morinda bracteata and Premna integrifolia. In strong contrast with Bangáro, where Oaesalpinia Bonducella is so common as to form the basis of the jungle, it is noted in the Investigator collections that only one plant of this species was met with in Kadamum.

Truly inland species that combine with Pandanus, Premna, and Morinda to form the shrubby part of the jungle are Flacourtia sepiaria, Pavetta indica, and Pleurostylic Wightii. All these are noted as "very common throughout the island." The last-named is a particularly interesting addition to the Laccadive Flora; all three are very likely bird-introduced species.

Two creepers, almost certainly wind-introduced, occur both inland and along the shore, these are Leptadenia reticulata and Tylophora asthmatica; "a tall loose-flowering grass (Apluda aristata) fills "all the outskirts of the jungle."*

The weeds and escapes from cultivation that occur number 42; some of these may perhaps be bird-introduced species; probably, however, most of them have been unintentionally introduced by man, and the high total is obviously the result of the fact mentioned by Mr. Robinson, that this is the island where the Améni people grow the greater part of what grain-crops they raise. The most interesting of these weeds is the Mudár (Calotropis gigantea), "very "common in the centre of the island near the huts" (Investigator 
note), and therefore possibly, though not a cultivated species, one originally deliberately introduced because of the excellent quality of the fibre it yields, which is used, by the Mapilla population of the mainland at least, for making fishing-lines. Another interesting weed is a rather insignificant, but very rare sedge (Cyperus hyalinus). The most interesting "escape" is undoubtedly the Indigo plant which forms whole fields, broken only by patches of Ixora coccinec (I. Bandhuca).*

A short distance to the south of Kadamum (Lon. $72^{\circ} 4.3^{\prime}$ E., Lat. $11^{\circ} 8^{\prime}$ N.) lies Améni, the most important of the British Laccadives. This island, about two miles long and three-quarters of a mile across, is low, with a very uneven surface. Situated originally on the eastern side of its atoll, the island has grown westward into the lagoon, till now no lagoon-space isleft, and the island is consequently so ill-protected from the sea that the soaking of coco-nut coir among the sand, practised in all the other islands, is here impossible. The soil in this island is naturally poorer, according to $\mathrm{Mr}$. Robinson, who, as well as Mr. Hume, has visited and described it, than it is in Kiltán or Kadamum, a fact which Mr. Robinson explainst by the consumption in various ways, by its dense population, of the fallen coco-nut leaves, thus depriving the ground to some extent of the advantage of the natural manure that the soil of the other islands receives. The whole island is under cultivation, principally coconut, and there is no underwood. The coco-nut plantation runs down to the sea-side on the east and the north, but along the western, more exposed side, a strip of waste land 200 yards wide is interposed between the plantation and the shore, while at the southwest corner and south end of the island, where the exposure is too great for young trees and the dry sand is deeper than elsewhere many acres are lying waste.

The structure of the island is like that of the other formed islands already described; the soil is of light coral sand, finer than, and quite as dry as, common sea-sand, or, in some parts, of small loose pieces of coral. This soil varies in thickness from two 
to six or eight feet, and has a bare sandy surface, which gets wind: blown unless covered with undergrowth; where the soil is under coco-nut or other cultivation this sand is hidden by the humus, of variable thickness and richness, that has accumulated. Jnderneath this surface soil of sand and humus is the bed of coral-rock already mentioned in the account of Bitrapar. This layer, a foot to two feet thick, appears to be just above water-level and stretches uniformly throughout the island. Underneath this layer lies a bed of wet sand and when the crust is cut through and well or small tanks are dug in the damp subsoil the people obtain a constant supply of water, slightly brackish but still potable, except in the case of Bitra, where, as has been already said, the wells yield water which is quite salt. The water in these tanks and wells rises and falls a little with the tide.

In the middle of Améni, however, unlike any of the islands yet described, the upper soil and the coral-crust have been completely removed from about 50 acres of ground, the surface of the soil thus left being hardly above the level of the sea. This carefully prepared area, termed locally the kat, has a poor, light, sandy soil, but is fertile on account of having the subsoil water within a foot or so of its surface. This kat is reserved praictically for the cultivation of grain and vegetables. "The "coco-nut trees planted in or about its edges are exceedingly "fine;" * the Bread-fruit rees, which are numerous in Améni, grow most luxuriantly here, while considerable numbers of Betel-nut trees occupy the same situation. 'l'he cultivated plants enumerated by Mr. Robinson include, besides the coco-nut, betelnut and bread-fruit, the rági (Eleusine Coracana), jowári (Sorghum vulgare), badag (Setaria verticillata), Sweet-Potato, Yam, Plantain, Castor-oil plant (cultivated for its oil) and Anatto (grown for its dye, several hundredweights of fruit of Bixa Orellana being annually exported to Malabar); the Lime is also mentioned by him as being of excellent quality and the trees as numerous. In addition to these Mr. Hume mentions the Pomegranate, Papaya, and Horse-radish tree as common; he observed also some Banyans, some Tamarind

"Robinson, "Madr. Journ.," vol., xiv, p. 18. 
trees, some Amla (Emblica officinalis), and a number of Poou-trees (Calophyllum inophyllum), planted. He further enumerates among cultivated vegetables Colocasia antiquorum, which in all the other islands appears to be in a 'wild' condition. He notes having obserred all the sea-shore species obtained in Bitrapar except a sedge (Cyperus pachyrhizus), and his specimens include Euphorbia Atoto which has not been found on the coasts of any of the other islands.

Mr. Hume's is the only collection made in Améni; it includes eleven species that may be classed as weeds as, well as the following species that should probably be considered as 'escapes from cultivation' :-Datura fastuosa, Physalis peruviana, Mucuna capitata, Clitoria ternatea,and Barleria Prionitis; all these are garden or hedge plants well known in India, here they all appear to be growing in a 'wild' state.

The Piti sand-bank, situated in Lon. $72^{\circ} 35^{\prime} \mathrm{E}$. and Lat. $10^{\circ} 45^{\prime} \mathrm{N}$., is on the extreme southern edge of a large sunken bank twenty miles long, that extends to this point from the vicinity of Ameni.* The rest of the bank carries from six to twenty fathoms of water, the subaërial patch is about 300 yards long and 200 yards across, standing about 6 or 7 feet above high-water mark, and is quite devoid of vegetation. It evidently occupies the south-eastern corner of a sunken atoll, for, whereas on all other sides bottom is found at 10 or 12 fathoms, on the south-east side one finds 100 fathoms close up to the bank and immediately bejond are deep-sea soundings. Quite like this bank, it may be remarked, is that of Elikalpéni (Lon. $74^{\prime} 5^{\prime}$ E. Lat. $11^{\circ} 15^{\prime}$.N.), a peak about 35 miles north-east of Anderut, which does not, however, become subaërial at all. This peak, the nearest of the Laccadive Group to India, is a small dead-coral bank with a few bunches of live-coral on it, carrying 7 to 8 fathoms and with no sign of shoal water. $\dagger$ Similar also, though of larger size, especially the first named of the three, and giving rather deeper soundings, are the dead-

"Hume, "Stray Feathers," vol. vi., p. 453.

+ Carpenter, "Adninistration Report of the.Marine Survey of India," rear 1888-\$9, p. 6. 
coral banks of Bassas de Pedro (20-30 fathoms)", Sesostris Bank (11-30 fatboms), and Koradivh (23-26 fathoms), lying to the north of the Laccadive Archipelago. It is curious to note that the name of the last mentioned bank appears to be applied by the author of the Tohfat-al-Mujahidin to one of the inhabited islands of the archipelago. $\dagger$

South of the Piti Bank lies Koráti, a large inhabited island in Lon. $72^{\circ} 40^{\prime} \mathrm{E}$. and Lat. $10^{\circ} 35^{\prime} \mathrm{N}$., visited by Mr. Hume。 He speaks of it $\ddagger$ as a fine island of the usual type with a fair lagoon. The soil appears to be better than that of Améni, the cultivation practically identical; the only wild species that Mr. Hume collected was the sea-shore laurel, Hernandia peltata; this he did because he observed it here for the first time. The species is now also roported from Minikoi, whence Dr. Alcock sends specimens, but so far it has not been obtained in any of the true Laccadive Islands except Koráti. A small islet, Koráti Féti, which, according to Lieut. Wood's table has coco-nut trees, occurs on the same reef.

Besides the Elikálpéni Bank, already described, the peaks of the Eastern chain are the atolls of Anderut and Kalpéni.

Anderut, Lon. $73^{\circ} 35^{\prime} \mathrm{E}$. and Lat. $10^{\circ} 45^{\prime} \mathrm{N}$., is a large island occupying the southern face of a very extensive reef of the usual type. According to Lieut. Wood, who visited it in 1834, the island presents a bold front to windward ; that front being, not a reef as is usually the case, but one side of the island itself, while the coralreof on which it is based and the lagoon which the reef encloses project to leeward. He describes it further\$ as "low, well planted " with cocoanut trees, and free from underwood. Its medium height "above the sea is about 9 feet, but towards the centre of the island, "and on its southern side, the surface is lower, and in no part does "it exceed the height of 12 or 15 feet."

"Hume, "Stray Feathers," vol. vi., p. 428.

+ "Madr. Journ. of Lit. and Sc." vol. xiv., p. 3. Kordeeb (Koradivh?) is given as one of the five principal islands which contain "cities;" probably, however, Kiltán is intended by the historian, though the name he gives is apparently that hy which this sunken bank is known.

I Hume, "Stray Feathers," vol. vi., p. 454.

§ Wood,."Journ. Roy. Geogr. Soc.," vol. vi., p. 31. 
"The northern side of the island is low, the centre gently undulat"ing and the south side one continuous sandy plain, with large " Retached masses of coral-rock scattered over it. The little valleys "formed by these clumps, of various figures, are under cultivation " and produce, amongst other things, a plant not unlike our rhubarb, "of a most acrid, pungent taste. It is reared as we do Jerusalem arti"chokes, set in rows, and covered with a manure of decayed vegeta"tion. They have also the Sweot-potato, but of such an inferior "growth that we can scarcely recognise in it the root we meet in "India. A small quantity of rice is grown in the rainy season; not “ more than 15 or 20 days' consumption. 'The rhubarb-looking plant " appears to prefer a damp moist soil, for on the more elevated parts "of the island there was none to be seen."

"Of the soil the most elevated is the richest. In the valleys the " coarse sand which forms the lower stratum is but scantily covered "with a thin coating of vegetable matter; sterile in many places, "and presenting a similar appearance to a field on which a compost "of lime has been partially thrown; but at the higher parts of the "island, where the cocoanut palm has tlourished for ages, a deep "soil is already formed, which every succeeding season must "increase and render more fertile."

"There are many wells on the island, and one small tank, but "good fresh water is to be had all over Anderut by digging to a "moderate depth. Firewood is rather" a scarce article, but where "the cocoaut forms the chief article of food this matters little." "In my ramble over the island I found the Plantain, Orange, "Papaw and Lime-trees, Betel-nut, and two species of Cotton-tree, "besides a fine stately-looking tree, with dark green foliage, not " unlike the broad-leafed Elm; this tree yields fruit, but as it was "not then in season I know not its nature. The Cocoanut, Plantain " and Papaw are the only cultivated fruits; the others ar'e growing in " $\Omega$ wild state, and the Betel-nut excepted, occupy but little atten"tion. Although you meet witl nothing amongst the trees which "you can term brushrood, there are plenty of creepers and coarse "grass."

Dr. Alcock, who has likewise visited Anderut says, "there is no "true jungle, the island being covered with cocosuut palms, with 320 
"a few curiously excavated areas under tillage (rági, sweet-potato " and a species of arrow-root), and wild plants were therefore "scarce."*

It is somewhat remarkable that Lieut. Wood does not mention the existence in 1834 of the excavated areas, the kat, indicated by Dr. Alcock; perhaps they have been formed since the time of Lient. Wood's visit. The "rhubarb-looking plant" of Lient. Wood's account is the Polynesian Taro, Tacca pinnatifida.

Dr. Alcock's collection includes 16 weeds and escapes from cultivation, two of these (Dentella repens and Herpestis Monnieria), being weeds of wet places not recorded from any of the other islands. His 'wild' species that are not weeds include Gitoriosa superba, not reported from any other island; perhaps, however, like Stachytarpheta indica, which he also reports and which also seems confined to Anderut, the Gloriosa may be here only an escape. It is, however, a common littoral species elsewhere, so it may quito well have been introduced by the sea. Thespesia populnea he notes as here planted only; he notes the Bread-fruit, not recorded by Lieut. Wood, and the American Aloe, apparently quite a recent introduction into the Archipelago ; this is present now in Kiltán, however, as well as in Anderut. Lieut. Wood records two species of Gossypium as cultivated; these are not grown in any of the other Laccadive Islands proper; specimens of $G$. barbadese have, however, been sent from Minikoi, and Mr. Fleming enumerates $G$. herbaceum as one of the cultivated species in that island. Lient. Wood also notes that Rice is, or earlier in the present century was, grown to a small extent. He alsu notes having seen the Orange as well as the Lime cultivated. This no one else has reported, though Mr. Fleming reports the Pomelo as well as the Lime from Minikoi.

The "stately-looking tree with dark green foliage not unlike the "broad-leafed elm" is probably the Jack (Artocarpus integrifolia); it has not, however, been met with in any of the other islands.

One of the most noteworthy features of the Anderut flora is that it is in this island only that any ferns appear to occur; Dr. Alcock has sent specimens of two species, Nephrodium molle and

* Alcock, in Hoskyn, "Administration Report of the Marine Survey of-India," yeax 1889.90, p. 13. 
Nephrolepis cordifolia from here, though neither he nor Mr. Hume have seen any ferns elsewhere in the Archipelago.

South of Anderut, in Lon. $73^{\circ} 35^{\prime}$ E. and Lat. $10^{\circ} 5^{\prime} \mathrm{N}$. lies the last true Laccadive atoll of Kalpéni. This island is situated on the eastern side of its reef, on which there is besides, according to Wood's table, a sandbank, Kalpéni Féti, unstocked with vegetation. Kalpéni was visited by Dr. Alcock in November, 1889. He speaks of it * as "a typical coral island, in almost every respect like Anderut and "Kiltán."

His collection includes 19 weeds and escapes from cultivation, the most interesting weeds being Urena sinuata not recorded from any other island, and Ammania baccifera and Polygonum barbatum, two marsh-weeds not reported from any other island; the most interesting escape being Ocimum gratissimun, which, however, he mentions as occurring in Bitrapar, and which he has also collected both in Akati and in Minikoi.

The coast species number 11, including Calophyllum inophyllum, here not planted, and Clerodendron inerme, not reported from any other island, not even from Minikoi. Vitis quadrangularis too, only reported from this island, is common on the sea-face jungle, which is shere much denser than it is in Améni, Anderut, or Kiltán.

The usual cultivated species are reported, and there is a kat in which rági and other grains and vegetables are grown.

The last island to be noticed is Minikoi, the position of which has been already indicated. The atoll is nearly circular and emerges from the sea on the eastern and southern sides to form a long narrow almost semi-circular island about 5 miles long and half a mile broad. The rest of the atoll is a reef that dries in places at low water and with the island encloses a lagoon that in places carries over 6 fathoms. The island stands only a few feet above the sea; its structure is identical with that of the true Laccadive islands. The water in the wells is clear and pleasant to drink; it contains roughly about $40 \mathrm{grs}$. of Chlorine per gallon. $\dagger$

"Alcock, in Hoskyn, "Administration Report of the Marine Survey of India," year $1889-90$, p. 13.

+ Aloock, in "Administration Report of Marine Survey of India," year 1891-2, p. 11. 
The island is covered with coco-nut palms and subordinate jungle and the vegetation exhibits the general characters of that of the true Laccadive islands, but is more luxuriant and is richer both in indigenous and cultivated species than any of these. /Dr. Alcock and Mr. Fleming have made a very extensive collection, including 40 weeds and garden escapes, ten of these (eight weeds and two escapes) not occurring in any of the true Laccadive Islands, with 28 littoral species of which the following eight, Canavalia turgida and Canavalia obtusifolia, Vigna lutea, Terminalia Catappa (which is ubiquitous), Sesuvium Portulacastrum, Ochrosia borbonica, Ipomoea denticulata, and Convolvulus parviflorus are not found in any of the other islands of the group.

The inland 'wild' species include the following not recorded from any other island of the group:-Allophylus Cobbe, Ruellia prostrata, Pancratium zeylanicum, Dioscorea bulbifera, Psilotum triquetrum, Calymperes Dozyanum, Physcia léucomelas and Physcia obscura, Pleurotus cuneatus and Pleurotus tenuissimus, Polyporus igniarius, Trametes Muelleri, Hirneola polytricha and Nostoc verrucosum.

There are, it should be noted, none of the shrubby wild species reported from Kadamum, the whole island, excepting the coast zone, which has, however, a very distinct sea-fence of Pandanus, \&c., being under cultivation.

The cultivated or planted species are numerous, reaching a total of 42, and include the following, not to be met with in any of the other islands:-Anona muricata (one tree); Hibiscus Rosa-sinensis; Murraya Koenigii (carefully cultivated); Citrus decumana (one tree on the island); Mangifera indica (only one tree); Arachis hypogcea; Psidium Guayava; Eugenia Jambos; Eugenia Jambolana ; Lawsonia alba; Luffa aegyptiaca ; Momordica Charantia ; Cucurbita maxima; Capsicum frutescens; Phyllanthus distichus; Ficus nitida.

Calophyllum inophyllum and Terminalia Catappa are planted, though both occur indigenously as well; $\mathbb{E g}$ le Marmelos is perhaps a species originally deliberately planted; Datura fastuosa is scarce bere, Mr. Fleming only noting it once and then finding it cultivated in a garden; Gossypium barbadense is cultivated pretty frequently 
and grows well; Sorghum vulgare grows well, but is very little cultivated. The most striking features in the vegetation of Minikoi, as compared with the other Laccadive Islands, are the presence of thick sheets of the gelatinous Nostoc on the ground at the south-west end of the island, where also the trunks of the trees are encrusted with lichen and covered with moss; the number of Fungi prosent; and the presence of Algae on the reefs of the surf-beaten weatherside of the island. Of these last unfortunately no specimens were collected.

Two tables are appended to this topographical sketch; in the first the various components of the Laccadive Group are shown; this table is a modification of the similar one prepared in 1834 by Lieutenant Wood (Journ. Roy. Geogr. Soc. vi., 30). In the second table, in order to facilitate reference, the spelling adopted by the various authors who have mentioned or described the Archipelago is given; the first column contains the forms adopted by the writer. 


\section{TABLE 1.-List of Laccadive Banks, Reefs and Islands.}

\begin{tabular}{|c|c|c|c|}
\hline \multicolumn{2}{|c|}{$\begin{array}{l}\text { Chain of } \\
\text { Peaks. }\end{array}$} & Name. & Nature. \\
\hline Western & & Koradivh ......... & Sunken bank of dead coral carrying $23-26$ fathoms \\
\hline Ditto & ...... & Sesostris Bank... & Sunken bank of dead coral carrying 11.30 fathoms \\
\hline Ditto & ... & Cherbaniani ...... & $\begin{array}{l}\text { Open reef with three small islets of coral débri } \\
\text { devoid of vegetation. }\end{array}$ \\
\hline Ditto & ... & Cheriapani & $\begin{array}{l}\text { Open reef with (?) several small islets of cora } \\
\text { débris, deroid of vegetation. }\end{array}$ \\
\hline Ditto & ...... & Bitrapar .......... & $\begin{array}{l}\text { Reef with one formed-island (Bitra), clothed with } \\
\text { vegetation and with coco-nut trees in centre, but } \\
\text { withont inhabitants. }\end{array}$ \\
\hline Ditto & & Pirmalpar ..... & $\begin{array}{l}\text { Open reef with one large subaërial sand.ban } \\
\text { (Pirmalla), devoid of vegctation. }\end{array}$ \\
\hline Ditto & ...... & Akati.............. & $\begin{array}{l}\text { Reef with three islands, one inhabited (Akati), and } \\
\text { two clothed with vegetation but not inhabited } \\
\text { (Bangáro and Tangáro), also a sand-bank withou } \\
\text { vegetation ( } \Delta \text { kati Féti). }\end{array}$ \\
\hline Ditto & ...... & Suhelipar .......... & $\begin{array}{l}\text { Reef, probably open, with one island (Suheli), prob } \\
\text { ably clothed with vegetation but not inhabited. }\end{array}$ \\
\hline Contral & & Bassas do Pedro.. & Sunken bank of dead coral carrying 20-30 fathoms. \\
\hline Ditto & ...... & Chitlac ... & Reef with one island (Chitlac), inhabited. \\
\hline Ditto & & Kiltán $\quad \ldots . . . . . . . .$. & Reef with one island (Kiltán), inhabited. \\
\hline Ditto & ..... & Kadamum & Reef with one island (Kadamum), inhabited. \\
\hline Ditto & & Améni ... & Inhabited island (Améni) occupying the whole reef. \\
\hline Ditto & & Piti & $\begin{array}{l}\text { Sunken bank of dead coral carrying } 6-15 \text { fathoms, } \\
\text { with one subaërial sand.bank (Piti), cievoid of } \\
\text { vcgetation. }\end{array}$ \\
\hline Ditto & & Koráti ..... & $\begin{array}{l}\text { Reef with one inhabited island (Koráti) and a } \\
\text { sand-bank devoid of vegetation (Koráti Féti). }\end{array}$ \\
\hline Ditto & & Minikoi .... & $\begin{array}{l}\text { Inhabited island (Minikoi) ; in this island the popn- } \\
\text { lation is Maldive, thongh the island is politically a } \\
\text { Lnccadive one: in position this atoll is inter- } \\
\text { mediate between tho Laccadive and Maldive } \\
\text { Archipelagos. }\end{array}$ \\
\hline Eastern & ...... & Elikalpéni ........ & Sunken bank of dead coral carrying 7-8 fathoms. \\
\hline Ditto & ...... & Anderut $\ldots$ & Recf with ono inhabited island (Anderut). \\
\hline Ditto & ...... & Kalpéni ...... & $\begin{array}{l}\text { Reef with one inbabited island (Kalpéni) and a } \\
\text { small islet (Kalpéni F'éti). }\end{array}$ \\
\hline
\end{tabular}




\begin{tabular}{|c|c|c|c|c|c|c|c|c|c|c|c|c|c|c|c|c|}
\hline 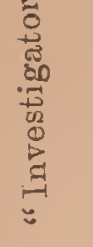 & 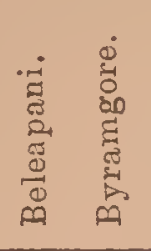 & 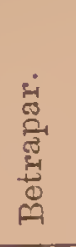 & 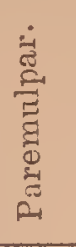 & 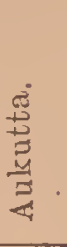 & $\vdots$ & & & 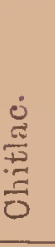 & 焉 & 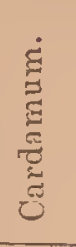 & : & 菑 & & 蒡 & $\frac{\overrightarrow{\tilde{w}}}{\stackrel{\vec{w}}{\tilde{E}}}$ & $\begin{array}{l}\stackrel{0}{\vec{z}} \\
\text { 离 }\end{array}$ \\
\hline $\begin{array}{l}\dot{\overline{0}} \\
\vdots \\
\vdots \\
\vdots\end{array}$ & $\vdots$ & 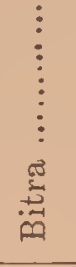 & $\begin{array}{l}\vdots \vdots \\
\vdots\end{array}$ & 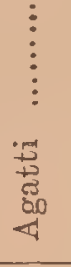 & & & 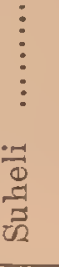 & 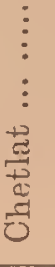 & 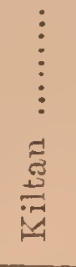 & $\begin{array}{c}\vdots \\
\vdots \\
\vdots \\
\text { g } \\
\frac{5}{0} \\
\vdots \\
\vdots\end{array}$ & है & & 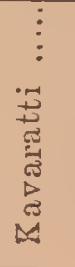 & 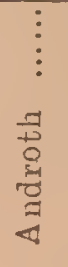 & 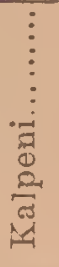 & 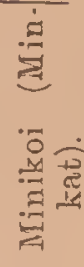 \\
\hline 离 & 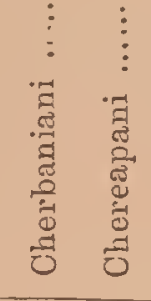 & 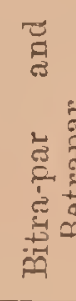 & 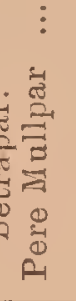 & 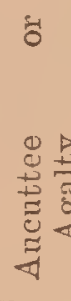 & & 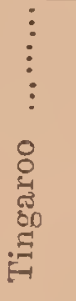 & 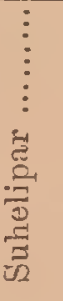 & 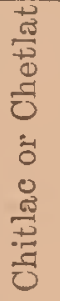 & 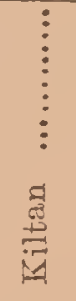 & 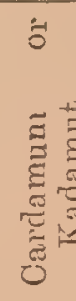 & \begin{tabular}{l}
$\vdots$ \\
$\vdots$ \\
$\vdots$ \\
$\vdots$ \\
$\vdots$ \\
\hdashline
\end{tabular} & 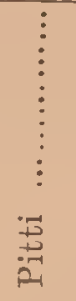 & 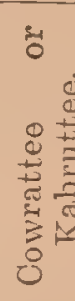 & 5 & 葛 & 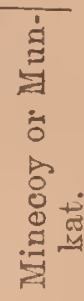 \\
\hline 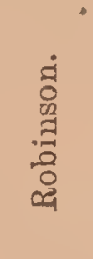 & 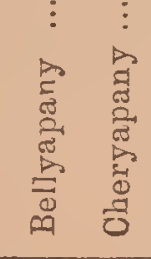 & $\begin{array}{c}\vdots \\
\vdots \\
\vdots \\
0 \\
0 \\
0 \\
0\end{array}$ & 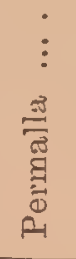 & 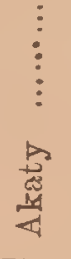 & $\begin{array}{c}\vdots \\
\vdots \\
\vdots\end{array}$ & & 离 & $\begin{array}{c}\vdots \\
\vdots \\
\vdots \\
0 \\
\frac{3}{\overrightarrow{0}} \\
0 \\
0 \\
0\end{array}$ & 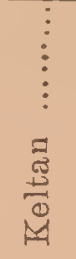 & 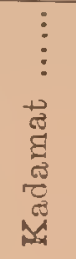 & 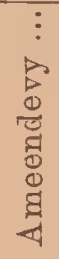 & $\begin{array}{l}\vdots \vdots \\
\vdots \\
\vdots\end{array}$ & 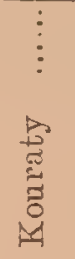 & 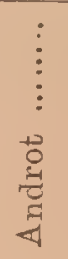 & 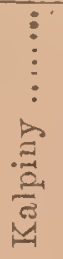 & 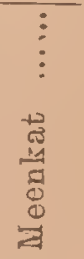 \\
\hline $\begin{array}{l}\overrightarrow{0} \\
\stackrel{0}{2} \\
\ddot{\beta}\end{array}$ & 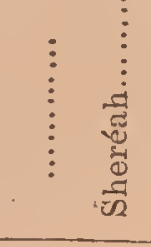 & 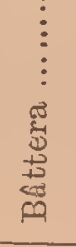 & 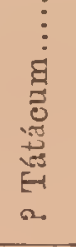 & 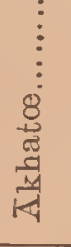 & 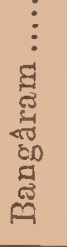 & 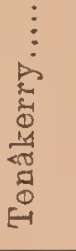 & $\begin{array}{l}: \\
\vdots \\
0 \\
: 0 \\
: 0 \\
0\end{array}$ & 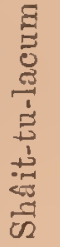 & 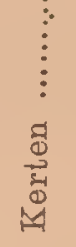 & 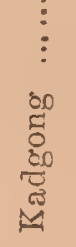 & 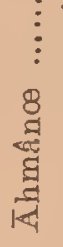 & $\begin{array}{l}\vdots \\
\vdots\end{array}$ & 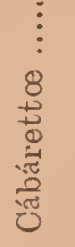 & 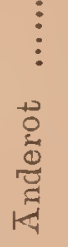 & 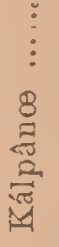 & \\
\hline $\begin{array}{l}\dot{0} \\
0 \\
0 \\
0 \\
0 \\
0 \\
0\end{array}$ & 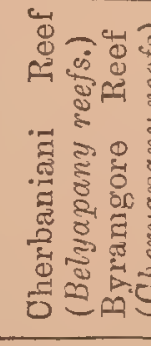 & 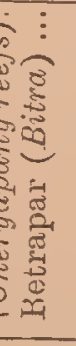 & 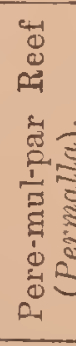 & 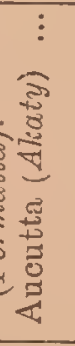 & 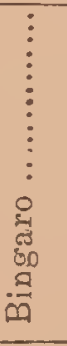 & 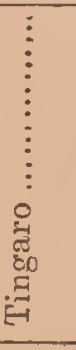 & $\begin{array}{l}\frac{m}{\vec{\Xi}} \\
\frac{\pi}{m} \\
\frac{\pi}{m}\end{array}$ & 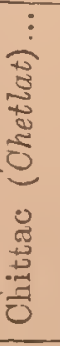 & 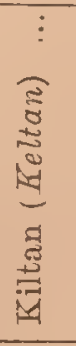 & 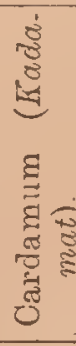 & 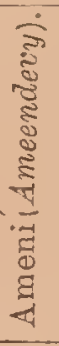 & 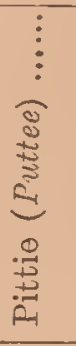 & 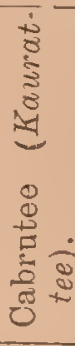 & 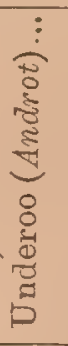 & 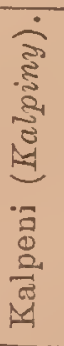 & \\
\hline 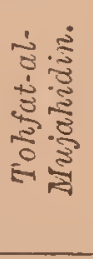 & $\begin{array}{c}\vdots \\
\vdots \\
\vdots \\
\vdots\end{array}$ & & & 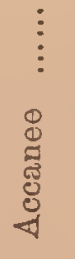 & & & & 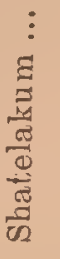 & 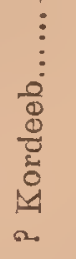 & 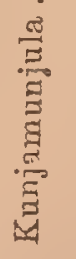 & 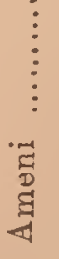 & $\begin{array}{c}\vdots \\
\vdots \\
\vdots \\
\vdots\end{array}$ & 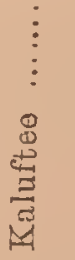 & $\begin{array}{l}\circ \\
\stackrel{0}{0 ँ} \\
\frac{\pi}{4}\end{array}$ & $\vdots$ & 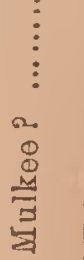 \\
\hline & 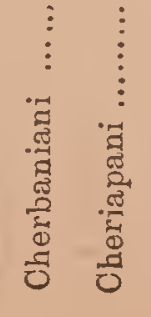 & 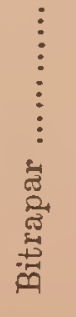 & 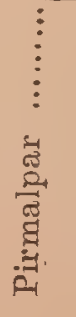 & 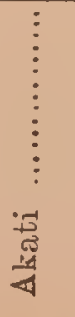 & 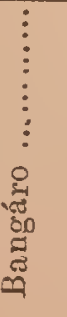 & 。 & 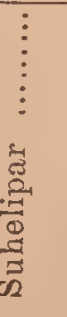 & Uี & 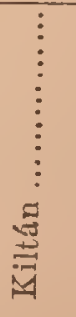 & 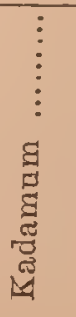 & 京 & 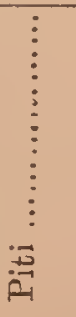 & 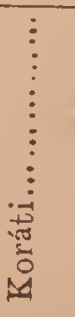 & 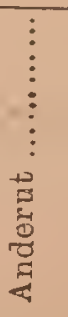 & 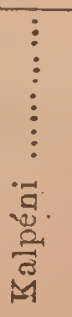 & $\begin{array}{l}\overrightarrow{0} \\
\overrightarrow{0} \\
\vec{*}\end{array}$ \\
\hline
\end{tabular}




\section{Systematic List of Laccadive Puants.}

Subjoined is given an enlarged edition of the Laccadive list already published by the writer.* This new list includes, besides the species recorded in the former one, all those contained in the collections made during the two visits paid by the Investigator subse= quently to its publication and all those mentioned by Lieutenant Wood and Mr. Robinson in their accounts of the Archipelago. As a complete set of the specimens collected by Mr. Hume, Dr. Alcock and Mr. Fleming is preserved in the Calcutta Herbarium, the writer has been in a position to authenticate the whole of their species: these are indicated in the list by an (!). Those names to which no mark of verification is appended belong to the species mentioned by Lientenant $\mathrm{W}^{\mathrm{T}} \mathrm{od}$ and $\mathrm{N}$. Robinson, mentioned but not collected by Mr. Hume, or enumerated in Mr. Fleming's list of cultivated plants, withont specirnens having been sent. In the preparation of the list, the writer has received much assistance from Dr. G. King, F.R.S., ; Mr. W. B. Hemsley, F.R.s., who has kindly verified some dubious species at Kew; Mr. J. F. Dathie, F. Is.S, who kindly named the grasses; Mr. G. Massée, F. S., who equally kindly named the Lichens and Fungi, and Mr. G. R. M. Murray, P.I.S., who kindly named an Ascothamnion ( $A$. intricatum) collected by Dr. Alcock in the lagoon at Kadamum, and who has, from these specimens, been enabled for the first time to state definitely that A scothamnion is. not a vegetable at all, but is the same thing as Zoobotryon pellucidum of Ehrenb., an animal. He wishes to express his great obligation to all these gentlemen, and especially to his friend, Dr. A. Alcock, of the Indian Marine Survey, for the enthusiasm with which he has taken up the subject of the Laccadive Flora and for the thoroughness with which he and his assistant Mr. J. Fleming, Apothecary on board H. M. I. M. Investigator, have made the collections on which this list is mainly based. To Captain Hoskyn, $\dagger$ Commander of the Investigator, who has

\footnotetext{
* "Scientific Memoirs by Medical Officers of the Army of India," Part V.
}

t The sad death of this talented Officer, which has occurred since the last of these collections was made, has rcmoved from the Naval Service one of its most brilliant surveyors. The event is one to be deplored not alone by his own Service, and not only by those outside it who, like the writer, had the privilege of enjoying his personal friendship, but by every zoologist and botanist in the East, because of the interest he took in, and the great practical sympathy he always showed for, every branch of biological research. 
also been most enthusiastic in this matter, the thanks of all who are interested in the subject of island-floras are equally due, for having so kindly afforded his officers these opportunities of landing on, and investigating the botany of, the islands of this group.

In the list itself purely cultivated species are indicated by a distinctive type; species that have become 'escapes,' even though they may at the same time be 'cultivated,' and trees that, though they may be 'planted,' occur also as 'indigenous' species, are not distinguished in this way. The references in the list are mainly to Di:. Roxburgh's Flora Indica and to Sir J. D. Hooker's Flora of British India, and as regards cultivated and economic species also to Dr. Watt's Dictionary of the Economic Products of India.

PIANEROGAMIA.

Thalamifloræ.

ANONACE 2 .

1. Anona muricata Linn., Sp. Pl. 536; Watt, Dict., i., 258. The Sour Sop.

Minikoi; only one tree, Fleming.

Native of Amcrica, cultivated in most tropical countrics, though rarely in India, except in the Madras Presidency, and even there sparingly.

CaPparideet.

2. Cleome viscosa Linn., Sp. Pl. 672 ; Roxb., Fl. Ind., ïi., 128; Hook. f., Flor. Brit. Ind., i., 170.

Améni; Hume! Anderut; Alcocli! Alsati; Fleming! Kiltán Fleming!

A weel of cultivation almost cosmopolitan in the tropics.

\section{Bixinezi.}

3. Bixa Orellana Linn., Sp. Pl. 512 ; Roxb., Fl. Ind., ii., 581; Hook. f., Flor. Brit. Ind., i., 199; Watt, Dict., i., 154. The Anatto; vernac. "Potang."

Améni; cultivated for its dye, "several hundredweights of the fruit are exported yearly to Malabar," Rolinson.

Native of America, generally cultivated throughout the tropics.

4. Flacourtia sepiaria Roxb., Corom. Pl. i., 48, t. 68; Fl. Ind., iii., 835 ; Hook. f., Flor. Brit. Ind., i., 194.

Kadamum; very common, Fleming!

Throughout Bengal, Peninsular India and Ceylon, in dry jungles also in Java. 


\section{Polygalem.}

5. Polygala erioptera DC., Prodr., i., 326 ; Hook. f., Flor. Brit. Ind., i., 203.

Kadamum; Fleming! The narrow-leaved form (P. Vahliana DC.) is alone reported.

India, Burma, Beluchistan, Arabia, Africa.

\section{Portulaceas.}

6. Portulaca oleracea Linn., Sp. Pl. 445 ; Roxb., Fl. Ind., ii., 463; Hook. f., Flor. Brit. Ind., i., 246.

Minikoi; Fleming! Two very distinct forms are communicated: one, the ordinary annual condition; the other, a perennial state with very large tuberous roots exactly like those of $P$. tuberosa, Roxb., from which, however, it is at once distinguished by its opposite flat leaves, and by the denser beard of white hairs on its nodal appendages.

A weed of cultivated ground and waste places, cosmopolitan in the tropics.

\section{GUTtIFera.}

7. Calophyllum inophyllum Linn., Sp. Pl. 513; Roxb., Flor. Ind., ii., 606; Hook. f., H'lor. Brit. Ind., i., 273; Watt, Dict., ii., 29. The Poon-Spar or Alexandrian Laurel.

Améni ; planted, Hume! Kalpéni ; apparentlg indigenous, Alcock! Akati; planted, one tree only, Fleming! Minikoi; planted, but also occurring as an indigenous tree in the coast-zone, Fleming!

Cultivated throughout India. Wild on the sea-coasts of the Mascarene Islands; India, Ceylon, Andamans; Malaya, N. A ustralia and Polynesia.

\section{Malvacea.}

8. Sida humilis Willd., Sp. Pl., iii., 744; Roxb., Flor. Ind. iii., 171; Hook. f., Flor. Brit. Ind., i., 322.

Kadamum; Hume! Fleming! Akati; Fleming! Minikoi; Fleming!

A field and road-side weed in tropical Asia, Africa and Anerica.

9. Abutilon indicum G. Don: Mast. in Hook. f., Flor. Brit. Ind., i., 326. 
var. typica. A. indicum G. Don, Gen Syst. i., 504. Sida indica Linn., Sp. Pl. (ed. ii.) 961; Roxb., Flor. Ind., iii., 179. Minikoi ; Fleming!

VAR. populifolia W.\& A., Prodr. i., 56. A. populifolium G. Don, Gen. Syst., i., 503. Sida populifolia Lamk., Encycl. Meth., i., 7; Roxb., Flor. Ind., iii., 179.

Kadamum; Hume! Fleming! Akati; Fleming! Minikoi; Fleming!

Both varieties are widely dispersed in India, the second being the more common in Western India. A weed of cultivation, cosmopolitan in the tropies.

10. Urena sinuata Linn., Sp. Pl. 692; Roxb., Flor. Ind., iii., 182; Hook. f., Flor. Brit. Ind., i., 329.

Kalpéni; Aleocts!

A weed of fields and roadsides, cosmopolitan in the tropics.

11. Hibiscus Solandra L'Herit., Stirp., i., 103, t. 49; Roxb., Flor. Ind., iii., 197; Hook. f., Flor. Brit. Ind., i., 336.

Minikoi ; common, Fleming!

A weed of fields and roadsides, confined to India, Ceylon and tropical East Africa.

12. Hibiscus tiliaceus Linn., Sp. Il.694; Roxb., Flor. Ind., iii., 192; Hook. f., Flor. Brit. Ind., i., 343.

Akati; Fleming! Minikoi ; Fleming!

A littoral species, cosmopolitan on tropical sea-shores.

13. Hibiscus rosa-sinensis Linu., Sp. Pl. 694; Roxb., Flor. Ind., iii., 194; Hook. f., Flor. Brit. Ind. i., 344. The ShoeFlower.

Minikoi ; cultivated, Fleming!

Cultivated in gardens throughout India; native of China.

14. Thespesia populnea Corr., Ann. Mus. Par. ix., 290; Hook. f., Flor. Brit. Ind., i., 345. Hibiscus populneus Linn., Sp. P1. 694 ; Roxb., Flor. Ind., iii., 190. The Portia Tree.

Anderut; planted, Alcocli! Kiltán; indigenous, Fleming! Akati; both indigenous and planted, Fleming! Kadamum; indigenous, Fleming!

A littoral species, common on all tropical sea-shores in the Old World and Polynesia; naturalised in the West Indies. 330 
15. Gossxpium herbaceum Linn., Sp. Pl. 693; Roxb., Fl. Ind., iii., 184; Hook. f., Flor. Brit. Ind., i., 346; Watt, Dict., iv., 26. Indian Cotton.

Anderut; cultivated, Wood. Minikoi; cultivated, F'leming.

Cultivated throughout India, yielding the Indian cottons; native of Old World.

16. Gossypium barbadense Linn., Sp. Pl. 693 ; Roxb., Flur. Ind., iii., 187 ; Hook., f., Flor. Brit. Ind., i., 347; Watt, Dict., iv., 35. Barbadoes Cotton.

Anderut; cultivated, Wrod. Minikoi; occurs pretty frequently and grows well, Fleming!

Cultivated throughout India, yielding the American cottons; native of New World.

Tiliacez.

17. Corchorus acutangulus Lamk., Encycl. Meth., ii., 104; Hook. f., Elor. Brit. Ind., i., 398. C. fuscus, Roxb., F]. Ind., ii., 582. Kadamum ; Fleming! Akati ; Fleming! Minikoi; Flleming!

A weed of cultivation, cosmopolitan in the tropics.

\section{Discifloræ.}

Rutacea.

18. Triphasia trifoliata DC., Prodr., i., 536; Hook. f., Flor. Brit. Ind., i., 507.

Minikoi ; Fleming! Not found in gardens, but perhaps originally introduced.

Common in gardens, and as an escape, in many tropical countries; the native country doubtful. The writer has collected this, with all the appearance of being indigenous, in Car Nicobar. It has not, however, been obtained in any locality where the evidence that it is indigenous is unequivocal.

19. Murraya Koenigil Spreng., Syst. Veg., ii.; 315 ; Hook. f., Flor. Brit. Ind., i., 503; Watt, I)ict., v., 288. Bergera Koenigii Linn., Mantiss., ii., App. 563; Roxb., F゙lor. Ind., ii., 375.

Minikoi ; carefully cultivated, Fleming!

20. Citrus medica Linn.: Brandis, For. Flora, 52.

VAR. acida Brandis: Hook. f., Flor. Brit. Ind., i., 515; Watt, Dict., ii., 355. C. acida, Rozb., Flor. Ind., iii., 390. The Sour Lime of India. 
Améni; cultivated, "trees numerous, quality gocd," Robinson; Hume. Anderut; cultivated, Wood. Kiltán ; cultivated, but does not thrive, Robinson. Minikoj; cultivated pretty frequently, Fleming!

Probably a native of India; generally cultivated in the tropics.

21. Citrus Aurantium Linn., Sp. Pl. 782 ; Roxb., Flor. Ind, iii., 392 ; Hook. f., Flor. Brit. Ind., i., 515 ; Watt, Dict., ii., 335. 'The Sweet Orange.

Anderut; cultivated, Wood.

Probably a native of India; cultivated in tropical and sub-tropical countries.

22. Citrus decumana Linn., Syst. Nat. (ed. xii.), ii., 580; Roxb., Flor. Ind. iii., 393; Hook. f., Flor. Brit. Ind., i., 516; Watt, Dict., ii., 348. The Shaddock or Pomelo.

Minikoi; cultivated, only one tree on the island, Fleming.

Native of Malaya and Polynesia, generally cultivated in S.-E. A sia.

23. Agre Marmelos Corr., Traus. Linn. Soc., v., 222; Roxb., Flor. Ind., ii., 579; Hook. f., Flor. Brit. Ind., i., 516; Watt, Dict., 1., 117. The Bael.

Minikoi ; Fleming!

Cultivated and wild throughout India.

SiMaRube正.

24. Suriana maritima Linn., Sp. Pl. 284; Hook. f., Flor. Brit. Ind., i., 522.

Bitrapar; Hume! Fleming! Bangáro; Hume! Kadamum Fleming! Minikoi; Fleming!

Cosmopolitan on tropical sea-shores.

Celastrine和。

25. Pleurostylia Wightii W.\& A., Prodr. 157; Hook. f., Flor. Brit. Ind., i., 617. Celastrus opposita Wall. in Roxb., Flor. Ind. (ed. Carey), ii., 398.

Kadamum; very common throughout the island, Fleming!

Mascarene Islands; Malabar, Ceylon.

RHAMNE更.

26. Colubrina asiatica Brogn., Ann. Sc. Nat., ser. i., x., 369 ; Hook. f., Flor. Brit. Ind., i., 642. Ceanothus asiaticus Linn., Sp. Pl. 196 ; Roxb., Flor. Ind., i., 615. 
Akati; Fleming! Kiltán; Fleming!

Littoral species common on sea-coasts of S. Africa, the Mascarene Islands; India, Ceylon; the Malay Archipelago and Australia.

\section{Ampelidem.}

27. Vitis quadrangularis Wall., Cat. n. 5992; Hook. f., Flor. Brit. Ind., i., 645. Cissus quadrangularis, Rosb., Flor. Ind., i., 407 .

Kalpéni; Alcock!

East Africa; India, Malaya; common on the sea-shores of the Andaman group, where it is unequivocally indigenous. Lawson (Flor. Brit. Ind. 1. c.) states that the stems are eaten in curries in Ceylon. He does not quote any anthority, the statement is certainly not derived from Thwaites, who says (Emm Pl. Zeylan., 62) that the stems are used medicinally. The species is not cultivated in Kalpéni; it is most probably a bird-introduced species.

28. Vitis carnosa Wall., Cat. n. 6018; Hook.f., Flor. Brit. Ind., i., 654. Cissus carnosa, Roxb., Flor. Ind., i., 409.

Kiltáu; Alcock! Fleming!

India and Malay Peninsula; probably a bird-introduced species. Though both Dr. Alcock and Mr. Fleming found it growing profusely, Mr. Hume did not meet with it ; perhaps, therefore, it is a recent introduction, possibly during the interval between 1875 and 1889.

\section{Sapindacek.}

29. Cardiospermum Halicacabum Linn., Sp. Pl. 366; Roxb., Flor. Ind., ii., 292 ; Hook. f., Flor. Brit. Ind., i., 670.

Améni ; Hume! Kalpéni ; Alcock!

A weed of road-sides and waste places, cosmopolitan in the tropics.

30. Allophylus Cobbe Blume, Rumphia, iii., 131; Hook. f., Flor. Brit. Ind., i., 673. Ornithotrope Cobbe Willd., Sp. Pl., ii., 322 ; Roxb., Fl. Ind. ii., 268. Rhus Cobbe Linn., Sp. Pl. 267.

Minikoi ; Fleming!

A littoral or sub-littoral species distributed throughout S.-E. Asia and N. Australia, but almost certainly a bird-introduced, not a sea-introduced, species. 


\section{AnaCardiacem.}

31. Mangifera indica Linn, Sp. Pl. 200; Roxb., Fl. Ind. i., 64l ; Hook. f., Flor. Brit. Ind. ii., 13; Watt, Dict., v., 146. The Mango.

Minikoi; cultivated, only one tree, Fleming.

Cultivated throughout the tropics; native of S.-E. Asia.

\section{Moringez.}

32. Morivaa pterygozperma Gaertn., Fruct., ii., 314, t. 147, f. 2 ; Hook. f., Flor. Brit. Ind., ii., 4อ̃ Watt, Dict., v., 276. Hyperanthera Moringa VabJ., Symb., i., 30; Roxb., Flor. Ind., ii., 今̈68. Guilandina Moringa Linn., Sp. Pl. 381. The Horse-Radish Tree.

Améni; commonly cultivated: Kiltán; occasionally cultivated, Hume.

Cultivated generally throughout the tropics; native of the lower slopes of the North-Western Himalaya.

\section{Calycifloræ.}

Leguminos死。

33. Crotalaria retusa Linn., Sp. Pl. 715; Roxb., Flor. Ind., iii., 272 ; Hook. f., Flor. Brit. Ind., ii., 75.

Akati ; Fleming!

A common weed or escape from cultivation in the tropics, only doubtfully wild in Africa or America.

34. Crotalaria verrucosa Linn., Sp. Pl. 75; Roxb., Flor. Ind., iii., 273 ; Hook. f., Flor. Brit. Ind., ii., 77.

Améni ; Hume! Kadamum; Fleming!

A cosmopolitan tropical weed.

35. Indigofera cordifolia Heyne in Roth., Nov. Sp., 357; Hook. f., Flor. Brit. Ind. ii., 93.

Kiltán; Fleming! Kadamum ; Fleming!

India, Afghanistan, N.-E. Africa, Malaya, N. Australia. A weed of waste places and fields.

36. Indigofera tinctoria Linn., Sp. Pl. 751; Roxb., Flor. Ind., iii., 379; Hook. f., Flor. Brit. Ind., ii., 99 ; Watt, Dict., iv., 387. The Indigo Plant.

Kadamum; whole fields of this species growing in a wild state, Hume! Fleming! Akati; Fleming! 
Cultivated universally throughout India. Here not cultivated, though perhaps originally intentionally introduced. Native of India, but not known truly wild, except in this and similar localities, where it carnot possibly be "indigenons."

37. Tephrosia tenuis Wall., Cat. n. 5970; Hook. f., Flor. Brit. Ind., ii., 111.

Kadamum; Fleming! Akati; Fleming!

A weed of cultivation hitherto known only from Scinde, Panjab, and Concan.

38. Tephrosia purpurea Pers. : Baker in Hook. f., Flor, Brit. Ind., ii., 113.

var. pumila Baker. T. pumila Pers., Synops., ii., 330. T. diffisa W. \& A., Prodr. 213. Galega diffusa Roxb., Flor. Ind, iii., 387.

Kadamum; Fleming! Kiltán; F'leming!

A cosmopolitan tropical weed; very distinct from typical $T$. purpurea, and never exhibiting any intermediate states; probably quite deserving specific rank.

39. Sesbania aculeata Pers., Synops., ii., 316; Hook. f., Flor. Brit. Ind., ii., 114. Coronilla aculeata Willd., Sp. Pl., iii., 114.7. Asschynomene spinulosa Roxb., Flor. Ind., iii,, 333.

Kalpéni ; Alcock!

A weed of wet places and rice-fields throughout the tropics of the Eastern Hemisphere.

40. Sisbanta grandiflora Pers., Synops., ii., 316 ; Hook. f., Flor. Brit. Ind., ii., 1] ว. Sesban grandiflorus, Poir., Encycl. Meth., vii., 127. Asschynomene grandiflora Linn., Sp. Pl. (ed. ii.), 1050; Roxb., Flor. Ind., iii., 331. Agati grandiflora Desv., Jour. Bot., iii., 120. The Aguti T'ree.

Kiltán; Kadamum; Akati; Minikoi; in all four islands planted as a support for the Pepper-vines which the people cultivato carefully, Fleming.

Mauritius; India and Ceylon; Malaya, N. Australia; generally, if not always, planted in India, and usually (especially in South India) grown for the purpose for which the tree is used in these islands (Roxb., Fl. Ind., iii., 332). Native apparently of Malaya. 
41. Arachis hypogea Linn., Sp. Pl. 741; Roxb., Flor. Ind., iii., 280; Hook. f., Flor. Brit. Ind., ii., 161; Watt, Dict., i., 282. The Ground-Nut.

Minikoi ; cultivated, Fleming!

A native of America, cultivated largely in Sonthern India, more rarely in other parts.

42. Desmodium triflorum DC., Prodr., ii., 334; Hook. f., Flor. Brit. Ind., ii., 173. Hedysarum trifiorum Linu., Sp. Pl. 749 ; Roxb., Flor. Ind., iii., 353.

Akati ; Fleming! Kadamum; Flerring! Kiltáu ; Fleming! Minikoi; Fleming!

A cosmopolitan tropical weed.

43. Clitoria Ternatea Linn., Sp. Pl. 753; Roxb., Flor. In?., iii., 321 ; Hook. f., F'lor. Brit. Ind., ii., 208 ; Watt, Dict., ii., 375.

Améni ; cultivated, Hume.

In gardens, or as an escape, throughout the tropics; not in Australia.

44. Mucuna capitata W. \& A., Prodr., 255; Hook. f., Flor. Brit. Ind., ii., 187. Carpopogon capitatum Roxb., Flor. Ind., iii., 284.

Améni; in gardens, " many plints * * * with bunches of deep blackish purple flowers, looking like Hamburg grapes," Hume!

India and Java; perhaps only a cultivated form of the common Cowhage (Mucuna pruriens DC.)

45. Canavalia turgida Grah. in Wall., Cat. n. 5534 A.; Miq., Flor. Ind. Bat., i., 215. C. ensiformis var. turgida Baker in Hook. f., Flor. Brit. Ind., ii., 196. Dolichos rotundifolius Roxb., Flor. Ind., iii., 302. Rheede, Hort. Malabar., viii,, t. 43. Probably $=$ C. . obtusifolia DC., Prodr., ii., 404.

Minikoi; very common, a climber on the Pandanus sea-fence, Fleming!

Littoral species ; coasts of Bengal, Burma, Andamans and Nicobar's, Malay Peninsula and Java (Miquel). Also Coromandel Coast, "on islands at mouth of Godaveri river" (Roxburgh), and Malabar" Coast, "locis arenosis" Cochin (Rheede).

Roxburgh's and Rheede's plant is, without doubt, from the former writer's account and the latter's figure of the "semielliptic" (Roxburgh), turgid pod, the same as Grabam's Wallichian 336 
plant from Penang, yet $\mathrm{Mr}$. Baker places the Indian plant in C. obtusifolia and ragards the Penang one as a variety of C. ensiformis.

It is therefore better in the meantime to consider $C$. turgida Grah. to be a plant specifically distinct from $C$. virosa (the wild form of $C$. ensiformis), as well as from $C$. oltusifulia.

46. Canavalia obtusifolia DC.: Baker in Hook. f., Flor. Brit. Ind., ii., 196 (syn. Dolichos rotundifolius Roxb. excl.); Clegh., Madr. Journ. (n. s.), i., t. 4. Dolichos obcordatus Roxb., F'lor. Ind., iii., 303. Probably $=$ C. lineata DC., Prodr., ii., 404.

Minikoi; on sandy beach, Fleming!

A littoral species cosmopolitan on tropical shores.

It is interesting to ind on the same island examples of both these sea-coast Canavalias. The specimens of. C. turgida are both in flower and with fruit, those of $C$. obtusifolia are in flower only, but are exactly like the Madras ones (in Herb. Calcutta) of Wallich (Cat. n. 5532), of Wiglit and of Gamble. They are well distinguished, as Mr. Baker iudicates, by the racemes in C. obtusifolia being much the fewer-flowered of the two. But the accuracy of the nomenclature is extremely doubtful, for Canavalia obtusifolia DC. (Prodir, ii., $40 \mathrm{l}$ ) is the exact equivalent of Dolichos oltusifolius Lamk. (Dict., ii, 29.5), which in turn is, according to Lamarck himself, the plant figured by Rheede (Hort. Malabar., viii., t. 4.3). It is moreover the equivalent of Dolichos rotundifolius, Vahl (Symb. ii., 81), of which plant De Candolle himself saw a fruiting specimen. Rosburgh identified the plant described by Vahl with that figured by Rheede. It seems therefore clear that Rheede's Katu-T'sjandi, Lamarck's Dolichos obtusifolins, Vahl's and Roxburgh's Dolichos rotundifolius, De Candolle's Canavalia obtusifolia and Graham's Cunavalia turgida are one and the same sea-coast species, which species is entitled to the name Canavalia obtusifolia. On the other hand, it seems clear from the specimens in Calcutta Herbarium that the plant common on the Madras coast figured by Cleghorn, and the Chinese plant cultivated in the Calcutta Botanic Garden described and figured (Icon. Ined., xx., 136) by Roxburgh as Dolichos obcordatus, are specifically identical; their pods, as figured by Roxburghand Cleghorn, agree well with the pods of Canavalia lineata 
DC. (Dolichos lineatus Thunb.) from the sea-coast of Japan as dsscribed by De Candolle (DO., Prodr., ii., 404) and Thunberg (Flor. Japon., 280) and as figured by Iinuma Yokusai (Sómolo-Dusets, ed. ii., vol. xiii., t. 20); the species might therefore be best known as Canavalia lineata. The name "obtusifolia" is more appropriate to $C$. lineata as here understood than to the true $C$. obtusifotia of Rheede's figure. In this respect, however, both species are variable, for the leaves of the Japanese plant (Doliches lineatus Thbg.) are quite like those of the Penang one (Canavalia turgida Grah.) and of that figured by Rheede, though its pods are quite like those of the emarginate-leaved Chinese plant (Dolichos olcordatus Roxb.) and of the rounded or emarginate-leaved Madras plant (Canavalia obtusifolia Baker, not DC.).

47. Phaseolus calcaratus Roxb., Hort. Beng. 54; Flor. Ind., iii., 289; Hook. f., Flor. Brit. Ind., ii., 203.

Minikoi ; an escape, Fleming!

India and Malaya, wild and commoniy cultivated.

48. Vigna lutea A. Gray in Bot. Wilkes' Exped., i., 452; Hook. f., Flor. Brit. Ind., ii., 205. Dolichos luteus Swartz, Flor. Ind. Occ., iii., 1246.

Minikoi ; very common on the beach ; Fleming ?

A littoral species, cosmopolitan in the tropics; not reported fron: any of the Indian coasts; very abundant in the Andamans.

49. Vigna Catjang Endl. ex. Miq., Flor. Ind. Bat, i., 188 ; Hook. f., Flor. Brit. Ind., ii., 205. Dolichos Catjang Linn., Mantiss. 259 ; Roxb., Flor. Ind., iii., 303. Vernac. "Loba."

Améni ; cultivated, Robinson. Kadamum; cultivated, Robinson.

Generally cultivated throughout the tropies of the old world; a native of India. It is interesting to observe that it is under the Arabic name of loba (lutia, Forsk.), and not under au Iudian name that it is known to the inhabitants.

50. Cæsalpinia Bonducella Flem., Asiat. Res., xi., 159; Roxb., Flor. Ind., ii., 357 ; Hook. f., Flor. Brit. Ind., ii., 254. Guilandina Bonducella Linn., Sp. Pl. (ed. ii.,) 545. G. Bonduc Linn., Sp. Pl. 381 (pro parte).

Bangáro ; forming a dense low jungle, Hume! A kati; only one plant met with, Fleming! Kadamum; only one specimen seen, Fleming!
338 
A littoral species, cosmopolitan in the tropics.

51. Cassia occidentalis Linn., Sp. Pl. 377; Hook. f., Flor. Brit. Ind., ii., 262. Senna occidentalis Roxb., Flor. Ind., ii., 343.

Akati; Fleming!

A cosmopolitan tropical weed.

52. Cassia Tora Linn., Sp. Pl. 376 ; Hook. f., Flor. Brit. Ind., ii., 263. Senna Tora Roxb., Flor. Ind., ii., 340.

Kalpéni ; Alcock! Kadamum; Fleming! Akati; Fleming! Kiltán ; Fleming!

A tropical road-side weed, almost cosmopolitan (absent from Polynesia).

53. Tamarindus indica Linn., Sp. Pl. 34 ; Roxb., Flor. Ind., iii., 215 ; Hook. f., Flor. Brit. Ind., ii., 273. The Tamarind.

Améni; cultivated, Hume. Alzati ; cultivated, Fleming.

Combretace

54. Terminalia Catappa Linn., Mantiss., i., 128; Roxb., Flor. Ind., ii., 430; Hook. f., Flor. Brit. Ind., ii., 444. The Country Almond.

Minikoi; both planted and indigenous; "the island abounds with this tree, its wood being put to various uses," Fleming.

A littoral species, extremely abundant in the Andamans and Nicobars as well as on all Malayan shores. Though now growing wild in Minikoi, this species has probably been originally introduced intentionally. It is not known wild in India.

\section{Myrtacee.}

55. Psidium Guajava Linu., Sp. Pl. 470; Hook. f., Flor. Brit. Ind., ii., 468. Psidium pyriferum Linn., Sp. Pl. (ed. ii.,) 672; Roxb., Flor. Ind., ii., 480. Psidium pomiferum Linn., Sp. Pl. (ed. ii.,) 672 ; Roxb., Flor. Ind., ii., 480. The Grava.

Minikoi; cultivated, Fleming.

Native of Mexico, cultivated and often "wild" and quite naturalized in India and other tropical countries.

56. Eugenia Jambos Linn., Sp. Pl. 470; Roxb., Flor. Ind., ii., 494 ; Hook. f., Flor. Brit. Ind., ii., 474; Watt, Dict., iii., 287. The Rose-Apple.

Minikoi ; cultivated, Fleming! 
Cultivated throughont India, Malaya and North Australia; native of the warmer Eastern Himalaya.

57. Edgenia Jambolana Lamk., Encyc. Meth., iii., 198; Roxb., Flor. Ind., ii., 484; Hook. f., Flor. Brit. Ind., ii., 499; Watt, Dict., iii., 284. The Black Plum.

Minikoi; cultivated, Fleming!

Cultivated or wild throughout India and Malaya.

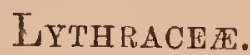

58. Ammania baccifera Linn., Sp. Pl. 120 ; Hook. f., Flor. Brit. Ind., ii., 569. A vesicatoria Roxb, Flor. Ind., i., 426.

Kalpéni ; Alcocts!

A marsh weed, common throughout the tropics of Asia and Australia. The leaves are used as a vesicant in native medicine.

59. Lawsonia alba Lamk., Ill., t., 296, f. 2 ; Hook. f., Flor. Brit. Ind., ii., 573; Watt, Dict., iv., 597. L. inermis Linn., Sp. Pl. 349; Roxb., Flor. Ind., ii., 258. L. spinosa Linn., Sp. Pl. 349. The Mendi or Indian Privet; Henna l'lant.

Minikoi ; Fleming!

A favourite hedge-plant in Indian gardens; wild in Western India, Afghauistan and Persia.

60. Punica Granatum Linn., Sp. Pl. 472; Roxb., Flor. Ind., ii., 409; Hook. f., Flor. Brit. Ind., ii., 581. The Pomegranate.

Améni; cultivated, Hume. Akati; about half a dozen plants bearing good fruit, Fleming. Minikoi; generally cnltivated, Fleming.

Native of Afghanistan, Scinde and Persin; generally cultivated throughout the tropics.

\section{Passiflorem.}

61. Carica Papaya Linn., Sp. Pl. 1036; Roxb., Flor. Ind., iii., 824; Hook. f., Flor. Brit. Ind., ii., 599. The Papaw.

Kiltán; cultivated, Hume; Fleming. Anderut; cultivated, Wood; Alcock. Akati; cultivated, Fleming. Kadamum; cultivated, Fleming. Minikoi; cultivated, Fleming.

Native of America, generally cultivated throughout the tropics; now perfectly naturalised in various parts of India.

Cucorbitace应.

62. Loffa equptiaca Mill. ex Hook. f. in Oliv., Fl. Trop. Afr., ii., 530 ; Hook. f., Flor. Brit. Ind., ii., 614; Watt, Dict., v. 96. L. 340 
pentandra Roxb., Flor. Ind., iii., 712. L. racemosa Roxb., Fl. Ind., iii., 715. L. clavata Roxb., Flor. Ind., iii., 714. Mornordica Luffa Linn،, Sp. Hl. 1009.

Minikoi ; cultivated, Illeming!

Generally cultivated throughout the tropics.

63. Mom^Rdica Charanita Linn., Sp. Pl. 1009; Royb., Flor. Ind., iii., 707 ; Hook. f., Flor. Brit. Ind., ii., 616 ; Watt, Dict., v., 256.

Minikoi ; cultivated, Fleming!

Cultivated in tropical Africa and throughout S. E. Asia.

64. Cecumis Melo Linn., Sp. Pl. 1011 ; Raxb., Flor. Ind., iii, 720; Hook. f., Flor. Brit. Ind., ii., 620; Watt, Dict., ii., 627. C. utilissimus Roxb., Flor. Ind, iii., 721. T'he Sweet Melon.

Kadamum; growing "wild" round the village, Fleming! Kiltán ; cultivated only, Fleming! Akati; cultivated, Fleming! Minikoi, frequent, Fleming!

Cultivated throughout the tropics.

65. Cocumis sativus Linn., Sp. Pl. 1012; Roxb., Flor. Ind., iii., 20 ; Hook. f., Flor. Brit. Ind., ii., 620; Watt, Dict., ii., 632. The Oucumber.

Kiltán; "found growing wild, only one creeper seen," Fleming!

Cultivated throughout India, as it is in all tropical and temperate countries; here palpably an escape from cultivation.

66. Cephalandra indica Naud, in Ann. Sc. Nat., ser. v., v., 16 ; Hook. f., Flor. Brit. Ind., ii., 621. Momordica monadel $\mu$ ha Roxb., Flor. Ind., iii., 708.

Akati ; Fleming!

A rery comınon creeper in hedges throughout Africa, India and Malaya; here most probably a species introduced by birds.

67. Cucurbita maxima Duchesne in Lamk., Encyc. Meth., ii., 151 ; Hook. f., FJor. Brit. Ind., ii., 622; Watt, Dict., ii., 638. The Common Gourd.

Minikoi; cultivated and also growing "wild," Fleming!

Cultivated in all warm countries.

FICOIDEE.

68. Sesuvium Portulacastrum Linn., Sp. Pl. (ed. ii.,) 684 Roxb., Flor. Ind., ii., 509; Hook. f., Flor. Brit. Ind., ii., 659. Portulaca Portulacastrum Linn., Sp. PI. 446. 
Minikoi; Fleming!

A littoral species, cosmopolitan on tropical and sub-tropical shores.

\section{Corollifloræ.}

Rubiacter.

69. Dentella repens Forst., Charact. Gen. 26, t. 13; Roxb., Flor. Ind., i., 532 ; Hook. f., Flor. Brit. Ind., iii., 42. Oldenlandia repens Jinn., Mantiss. 40.

Anderut; Alcocl:!

A weed of moist places throughout tropical Asia, Australia and Polynesia.

70. Oldenlandia corymbosa, Linn. ex Hiern in Oliv., Flor. Trop. Afric., iii., 62; Honk. f., Flor. Brit. Ind., iii., 64. O. biflora Lamk., Encyc. Meth., iv., 553, nec Linn.; Roxb., Flor. Ind., i., 423. O. ramosa Roxb., Flor. Ind., i., 424.

Kalpéni; Alcocle! Kadamum; Fleming! Kiltan ; Fleming!

A weed of waste places aud fields throughout tropical Asia, Africa and America.

71. Oldenlandia diffusa Roxb., Hort. Beng. 11 ; Flor. Ind., i., 423 ; Hook. f , Flor. Brit. Ind., iii., 65.

Anderut; Alcock! Minikoi; Fleming!

A tropical and sub-tropical weed of cultivation in Eastern and South-Eastern Asia.

72. Oldenlandia biflora Linn., Sp. Pl. 119 ; Hook. f., Flor. Brit. Ind., iii., 70.

Kalpéni ; Alcock! Kadamum ; Fleming!

A weed of cultivation confined to Southern India and Ceylon. The Laccadive specimens agree exactly with those of Wight (Herb. Wight n. 1376, Kew Distrib.).

73. Guettarda speciosa Linn., Sp. Pl. 991 ; Roxb., Flor. Ind., i., 686; H.ook. f., Flor. Brit. Ind., iii., 126. Nyctanthes hirsuta Linn., Sp. Pl. 6.

Kadamum ; Hume! Fleming!

A littoral species; found on all tropical shores.

74. Ixora coccinea Linn., Hook. f., Flor. Brit. Ind., iii, 145. VAR. Bandhuca Roxb. (sp.). I: Bandhuca Roxb., Flor. Ind., i., 376. 
Kaiamum ; interspersed with the patches of wild indigo, Hume? Andernt, perhaps cultivated, Alcock. Kalpéni; at edges of patches of cultivation and probably planted, Alcock! Minilzoi; Fleming!

This form of $I$. coccinea is apparently a native of Southern India. It is common in native gardens throughout India and Ceylon: the bark of the root possesses valuable antidysenteric properties.

75. Pavetta indica Linn., Sp. Pl. 110; Hook. f., Flor. Brit. Ind., iii., 150. Irora paniculata Itamk., Eucyc. Meth., iii., 344. Lxora Pavetza Roxb., Flor. Ind., i., 385.

Kadamum; plentiful inshore, Fleming!

South-Eastern Asia; throughout India and Indo-China, and extending from S. China to N. Australia.

76. Morinda citrifolia Linn., Hook. f., Flor. Brit. Ind., iii., 155. vA R. Uracteata Hook. f., Flor. Brit. Ind., iii., 156. M. Uracteata Roxb., Hort. Beng. 15; Flor. Ind., i., 54.4.

Bangáro; Hume! Kalpéni; certainly wild, Alcocli! Kiltán; Fleming! Akati; Fleming! Kadamum; Fleming! Minikoi; extremely plentiful throughout the island, Fleming!

A purely littoral plant, plentiful on all the Indian, Indo-Chinese, Andamans and Nicobars coasts visited by the writer. Here, as elsewhere, in the region where the plant occurs, it is truly wild, and has doubtless been introduced by the sea; it appears to be equally conmon also on the coasts of the Seychelle islands. This form, which it may be perhaps more convenient to consider, with Roxburgh, a species apart from $M$. citrifolia, is never cultivated in India except (e.g., in the Calcutta Botanic Garden) as a curiosity; in Ceylon, according to Thwaites, it is both wild and cultivated, and from Mr. Fleming's note this would seem to be the case in Minikoi. In Bangáro it must of necessity be just as wild as it is in the Andamaus and Nicobars, where, even in uninhabited islands, it is not merely, as Kurz has said, "not infrequent," but is in reality one of tho chief components of the beach-forest nndergrowth behind the sea-fence of Pandanus bushes; sometimes it is common farther inshore.

This variety-or species-is confined to Indin, Indo-China and Malaya, not reaching Polynesia or Australia. 


\section{COMPOSLTE.}

77. Vernonia cinerea Less. in Linnæn, iv., 291, et vi., 673; Hook. f., Flor. Brit. Ind., iii., 233. Serratula cinerea Roxb., Hort. Beng. 60; Flor. Ind., iii., 406. Conyza cinerea Linn., Sp. Pl. 862.

Améni; Irtme! Anderut; Alcock! Kiltán ; Fleming! Kadamun: Fleming! Akati; Fleming! Minikoi; Fleming!

A cosmopolitan weed of waste places and fields.

73. Adenostemma viscosum Forst., Nov. Gen. n. 15.; Clarke, Comp. Ind. 28; Hook f., Flor. Brit. Ind, iii., 242. Ageratum aquaticum Roxb., Hort. Beng. 61; Flor. Ind., iii., 416.

Kalpéni; Alcock! Minikoi; Fleming!

A cosmopolitan tropical weed of fields and waysides which also not infrequently ocenrs on sea-shores growing among the ocean drift at high tide-mark, thus suggesting the possibility of introduction by the sea. The specimens from Kalpéni are probably referable to Clarke's variety reticulata (Adenostemma reticulatum DC. in Wight, Contrib. 8); they have ovate leaves (the largest being 9-11 in. long and $3 \frac{x}{2}-4$ in. across), reticulate; the achenes are elongate and sparsely warted. This variety is characteristic of South India and Ceylon. The Minikoi specimen has no leaves, but the achenes are precisely like those in the Kalpéni specimens.

79. Ageratum conyzoides Linn., Sp. Pl. 839 ; Hook. f., Flor. Brit. [nd., iii., 243. A. cordifolium Roxb., Flor. Ind., iii., 415.

Anéni; Hume! Anderut; Alcocle! Kalpéni; Alcock! Kiltán; Fleming! Minikoi; very plentiful, Fleming!

A reed of cultivation, originally American, but now cosmopolitan in the tropics. Though so common in the Archipelago, it is not recorded from any of the mninhabited islands which would indicate that its wide and rapid dispersal is due altogether to unintentional human action.

80. Blumea laciniata DC., Prodr., v., 436 ; Hook. f., Flor. Brit. Ind., iii., 264. Conyza laciniata Roxb., Flor. Ird., iii., 427.

Kiltán; Fleming! Akati; Fleming!

A weed of waste places distributed throughout S.=E. Asia.

81. Eclipta alba Hassk. in Miq., Flor. Ind. Bat., ii., 65 ; Clarke, Comp. Ind. 134; Hook. f., Flor. Brit. Ind., iii., 3n4. W. prestrata 344 
Minn., Mantiss. 266; Roxb., Flor. Ind., iii., 438. Verbesina Lavenia-alba Linn., Sp. Pl. 902.

Kadaroum; Flleming! Kiltán ; Fleming!

A cosmopolitan tropical weed.

82. Wedelia calendulacea Loss., Syn. 222; Hook. f., Flor. Brit. Ind., iii., 306. Verbesina calendulacea Linn., Sp. PI. 902; Roxb., Flor. Ind., iii., 440.

Anderut: in the excavated cultivation areas, Alcock!

A weed of wet places, widely distributed throughout S.-E. Asia.

83. Wedelia scandens C. B. Clarke, Comp. Ind., 136. W. biflora Hook. f., Flor. Brit. Ind., iii., 306; Prain, Laccadive List, 5. Verbesina scandens Roxb., Flor. Ind., iii., 441. Wollastonia insulari.s DC., Prodr., v., 548. W. Horsfieldiana Miq., Flor. Ind. Bat., ii., 72.

Kadamum; Hume! "the island abounds with this creeper," Fleming! Anderut; Alcoct:! Kiltán; Fleming! Minikoi; very common, Fleming!

A purely littoral species, distributed throughout all the coasts of S.-E. A.sia. For the correction of the error in his former list, the writer is indebted to the kindness of Mr. C. B. Clarke, F.R.s.

84. Bidens pilosa Linn., Hook. f., Flor. Brit. Ind., iii., 309. var. bipinnata Hook. f., Flor. Brit. Ind., iii., 309. $B$. bipinnata Linn., Sp. Pl. 832 ; Roxb., Flor. Ind., iii., 411.

Kadamum; Fleminy!

A cosmopolitan tropical and sub-tropical weed.

85. Crepis acaulis Hook. f., Flor. Brit. Ind., iii., 396. Prenanthes acaulis Roxb., Flor. Ind., iii., 403.

Kiltán; Alcocl.!

A tropical weed, common throughout India and Burma; not reported hitherto from Ceylon.

86. Launea pinnatifida Cass. in Ann. Sc. Nat., xxiii., 85; Hook. f., Flor. Brit. Ind., iii., 416. Prenanthes asplenifolia Roxb., Flor. Ind., iii., 404 in parte, vix Willd.

Bitrapar; Hume! Fleming! Kadamum; Fleming! Minikoi; very plentiful, Fleming!

A littoral species, common on the shores of India, the Mascarene Islands and Fast Africa. 
Goodenovieat.

87. Scaevola Koenigii Vahl, Symb., iii., 36; Hook. f., Flor; Brit. Ind., iii., 421. S. Taccada Roxb., Hort. Beng. 15 ; Flor. Iud., i., 527. Lobelia Taccada Gaertn., Fruct., i., 119, t. 25. Lobelia frutescens Linn., Fl. Zeyl. 148.

Bitrapar; very abundant, Hume! Fleming! Kadamum; abundant on the shore, Fleming! Kiltan; in a dense hedge along the entire lagoon face of the island, Hume, Alcock! Fleming! Akati ; Fleming! Minikoi; Fleming!

A littoral species common on the shores of S.-E. Asia, N. Australia and Polynesia; also in the Mascarene Islands and Africa.

\section{Plumbaginez.}

88. Plumbago zeylanica Linn., Sp. Pl. 151; Roxb., Flor. Ind., i., 462; Hook. f., Flor. Brit. Ind., iii., 480.

Améni ; perhaps an escape from cultivation, Hume!

Cultivated throughout the tropics of the old world, readily escaping and spreading: wild in Southern Asia.

\section{A POCYNEA.}

89. Ochrosia borbonica Gmel., Syst. Veg. 439 ; Hook. f., Flor。 Brit. Ind., iii., 638.

Minikoi ; Fleming!

A littoral species distributed from the Mascarene Islands to Ceylon, the Audamans, Nicobars and Malaya; not reported from Indian coasts.

\section{Asclepiade.}

90. Calotropis gigantea R. Br. in Ait., Hort. Kew. (ed. ii.), ii., 78; Hook. f., Flor. Brit. Ind., iv., 17 ; Watt, Dict., ii., 34. Asclepias gigantea Willd., Sp. Pl., i., 1264 ; Roxb., Flor. Ind., ii., 30. The Mudar.

Kadamum; Hume! very common in the centre of the island near the huts, Fleming!

A weedy shrub of waysides and waste places throughout SouthEastern Asia. It is remarkable that it should be present only in one of the islands, and that it should occur only in the neighbourhood of the people's dwellings; these facts appear to indicate that the introduction of the plant has been here due to human agency, and has, 346 
moreover, been deliberate. 'The milky juice of this plant is employed in native medicine, and it yields a fibre largely used in making fishing-lines.

91. Tylophora asthmatica W. \& A., Contrib. 51 ; Hook. f., Flor. Brit. Ind., iv., 44. Asclepias asthmatica Willd., Sp. Pl., i,, 1270 ; Roxb., Flor. Ind., ii., 33.

Kadamum; Hume! Fleming! Anderut; Alcoclı! Kiltán; plentiful along the shore, Fleming! Akati; Fleming!

A common weed throughout South-Eastern Asia. Its juice, like that of the preceding species, is used in medicine; its presence in so many of the islands, however, as well as its habitat indicate that introduction has not here been deliberate; though found on the shore, it is probably to the wind and not to the sea that its introduction is due.

92. Leptadenia reticulata W. \& A., Contrib. 47 ; Hook. f., Flor. Brit. Ind., iv., 63. Cynanchum reticulatum Willd., Sp. Pl., i., 1258. C. alatum Prain, Laccad. List 5, nec W. \& A. Asclepias suberosa Roxb., Flor. Ind., ii., 38.

Kiltán; Alcocli! Kadamum; Fleming!

A roadside weed and climber in dry jungles throughout India, Barma, Malaya and Ceylon. The Kiltán specimens were erroneously referred to Cynanchun in the former Laccadive List.

Boraginee.

93. Tournefortia argentea Linn. f., Suppl. 133; Roxb., Flor. Ind. (ed. Carey \& Wall.), ii., 4; Hook. f., Flor. Brit. Ind., iv., 145.

Bitrapar; very abundant, Hume! Fleming! Kiltán; Alcock! Akati; only seedlings found germinating on the shore, Fleming! Kadamum; Fleming! Ninikoi; Fleming!

A littoral species extending from Africa and the Mascarene Islands to Ceylon, the Andamans, Malaya and Australia.

Convolvulacea.

94. Ipomœa grandiflora Lamk., Ill., i., t. 467; Hook. f., Flor. Brit. Ind., iv., 198. Convolvulus grandiflorus Linn. f., Suppl. 136. The Coast Moon-flower.

Bitrapar; densely draped over the clumps of Scaevola and Tournefortia, Hume! Fleming! Kadamum; plentiful, Fleming! 
A littoral species extending from Eastern Africa and the Mascarene Islands throughout South-Eastern Asia, and thence to North Australia and Polynesia. This species occurs in America as a cultivated plant only. Ipomcea grandiflora Roxb., Flor. Ind., i., 497, is not this species, but a form of Ipomcea Bona-nox, the true "Moon-flower," originally introduced from America.

95. I Ponea Batatas Lamk., Encyc. Meth., vi., 14; Hook. f., Flor. Brit. Ind., iv., 202 ; Watt, Dict., iv., 478. Convolvulus Batatas Linn., Sp. Pl. 154 ; Roxb., Flor. Ind., i., 483. The Sweet-potato.

Améni; cultivated, Robinson; Hume. Anderut; cultivated, Alcocl:; "of very inferior quality," Wood. Akati; cultivated, "only one small plot," Fleming!

96. Ipomœa denticulata Choisy in D(., Prodr., ix., 379 ; Hook. f., Flor. Brit. Ind., iv., 208.

Minikoi ; Fleming!

A littoral species extending from the Mascarene Islands to Ceylon, the Andamans, Nicobars, Malaya and Burma (extending as far north as Akyab on the coast of Arracan), thence to Nortl Australia and Polynesia, but, like Ochrosia borbonica and Tournefortia argentea, not as yet reported from the coasts of the Indian mainland.

97. Ipomœa biloba Forsk., Flor. Aeg. Arab. 44; Hook. f., Flor. Brit. Ind., iv., 212. I. Pes-Caproe Roth., Nov. Sp. 109. Convolvulus Pes-Caprex Linn., Sp. Pl. 159; Roxb., Flor. Ind., i., 486.

.Bitrapar; plentiful, Hume! Fleming! Kalpéni; Alcocli! Akati; on shore and also solitary plants in interior, Fleming! Kadamum; only on shore and not very common, Fleming! Minikoi; Fleming!

A littoral species, cosmopolitan on tropical sea-shores.

98. Ipomœa sinuata Ortega, Dec. 84; Hook. f., Flor. Brit. Ind., iv., 214. Convolvulus dissectus Iinn., Mantiss. 204.

Minikoi ; Fleming!

Native of America, now widely spread in the Old World: here growing quite wild.

99. Convolvulus parviflorus Vahl, Symb., iii., 29; Roxb., Flor. Ind. (ed. Carey \& Wall.), ii., 51; Hook. f., Flor. Brit. Ind., iv., 220.

Minikoi ; common on the coast, Fleming! 
Tropical Africa; S.-E. Asia; Australia. Here, as on the shores of the Andamans and Nicobars, a purely littoral species; it occurs, however, far inland (as in Assam, \&c.) as well.

100. Evolvulus alsinoides Linn., Sp. Pl. (ed. ii.) 392; Roxb., Flor. Ind., ii., 105 ; Hook. f., Flor. Brit. Ind., iv., 200. E. linifolius Linn., Sp. Pl. (ed. ii.) 392. E. angustifolius Roxb., Flor. Ind. (ed. Carey \& Wall.), ii., 107. Convolvulus alsinoides Linn., Sp. PI. 157.

Kadamum; Flleming!

A weed of dry places in all tropical and sub-tropical countries.

SOLANACE.

101. Solanum torvum Swartz, Prodr. 47; Hook. f., Flor. Brit. Ind., iv., 234. S. stramonifolium Roxb., Flur. Ind., i., 572, nec Jacq.

Minikoi ; Fleming!

A shrubby weed of waste places in South-Eastern Asia and tropical America.

102. Physalis minima Jinn., Sp. Pl. 183 ; Roxb., Flor. Ind., i., 563 ; Hook. f., klor. Brit. Ind., iv., 238.

rar. indica Lamk., Encyc. Meth., ii,, 102; Clarke in Hook. f., Flor. Brit. Ind., iv., 238. Nicandra indica Roem. \& Schult., Syst., iv., 682.

Bangáro; Hume! Anderut; Alcock! Kadamum; Fleming! Kiltan; Fleming! Minikoi; Fleming!

A cosmopolitan weed of raste places and fields; also in Bangáro and Kidamum in this group, as on the Andaman coasts, a distinctly littoral species: the probabilities of introduction by fruit-eating birds or by the sea are almost evenly balanced.

103. Physalis Pereviana Linn., Sp. Pl. (ed. ii.), app. 1670; Roxb., Flor. Ind., i., 562 ; Hook. f., Flor. Brit. Ind., iv., 238. The Winter-cherry or Cape Gooseberry.

Améni ; cultivated, Hume.

Native of America, much cultivated in the Eastern Hemisphere. The specimens from Bangaro attributed to this species in the former list are in reality $P$. minima VAR. indica; Mr. Hume may, however, be right in saying that the Winter-cherry is cultivated in Améni. 
104. Capsicum frutescens Linn., Sp. Pl. 189 ; Roxb., Flor. Ind., i., 574; Hook. f., Flor. Brit. Ind., ir., 239; Watt, Dict., ii., 137. The Chillie.

Minikoi ; cultivated, Fleming.

Cultivated in all warm countries, native place unknown.

105. Capsioum minimum Roxb., Hort. Beng. 17; Flor. Ind., i., 574; Hook. f., Flor: Brit. Ind., iv., 239. The Bird's-eye Ohillie.

\section{Akati ; as a weed, Fleming!}

Cultivated throughout India and Malaya, probably originally Malayan.

This species is extremely apt, in the warmer valleys of the Himalaya and in hot moist localities like the Andamans and Nicobars, to escape and become, as it has become here, a weed of waste places. It is nevertheless doubtless a plant originally intentionally introduced into the Laccadives.

106. Datura fastuosa Linn., Syst. Nat. (ed. x.), ii., 932; Roxb., Flor. Ind., i., 561 ; Hook. f., Flor. Brit. Ind., iv., 242 ; Watt, Dict., iii., 32. The Black Dhatoora.

Améni; frequent, Hume. Anderut; Alcock. Akati; occurs pretty frequently and is not cultivated, Fleming! Kiltan; "only met with one plant about 100 yards from the shore," Fleming! Minikoi; "only one plant seen, grown in a garden," Fleming!

A weed of waste places in tropical Africa and South-East Asia; occurs in Anerica also, but perhaps not there indigenous. The Minikoi specimen, which is from a garden, is the common Black Dhatoora ( $D$. fastuos $a$ ), and though in most of the islands it is clearly only a weed, it is not improbable that it has been originally intentionally introduced. It should not be forgotten that the species may be, and at times is, a bird-introduced one.

\section{Scrophularinex.}

107. Linaria ramosissima $\mathrm{W}$ all., $\mathrm{Pl}$. As. Rar., ii., 43, t. 153 ; Hook. f., Flor. Brit. Ind., iv., 251.

Kiltán; Fleming!

A weed of dry places throughout Afghanistan, India, Burma and Ceylon. 
108. Herpestis Monnieria H. B. \& K., Syn., ii., 125; Hook. f., Flor. Brit. Ind., iv., 272.' Gratiola Monnieria Linn., Sp. Pl. (ed. ii.) 24; Roxb., Flor. Ind., i., 141.

Anderut; Alcock!

A marsh-weed, cosmopolitan in the tropics.

109. Striga lutea Lour., Flor. Cochin. 22 ; Hook. f., Flor. Brit. Ind., iv., 299. Buchnera asiatica Linn., Sp. Pl. 630, in part; Roxb., Flor. Ind., iii., 31.

Akati ; Fleming! Kadamum ; Fleming! Kiltán ; Fleming!

A parasitic weed distributed throughout tropical Africa, the Mascarene Islands, Arabia, India, Indo-China and China. It occurs in the Andamans (as an introduced species); apparently absent from Malaya.

\section{Acanthacee.}

110. Ruellia prostrata Poiret, Encyc. Meth., vi., 349; Hook. f., Flor. Brit. Ind., iv., $411 . \quad R$. ringens Roxb., Flor. Ind., iii., 44.

Minikoi ; very common, Fleming!

Common throughout India and Ceylon and extending to East Africa; absent from Malaya and Indo-China. Roxburgh's description applies to a form with larger leaves and longer internodes than typical $R$. prostrata; in Mr. Fleming's gatherings (five or six in number) both forms occur, as well as intermediate conditions.

111. Bareeria Prionitis Linn., Sp. Pl. 636; Roxb., Flor. Ind., iii., 36; Hook. f., Flor. Brit. Ind., iv., 482; Watt, Dict., i., 400. B. ciliata Hume, Stray Feathers, iv., 446, nec Roxb. B. cristata Prain, Laccad. List 6, nec Linn.

Améni; Hume! Minikoi ; planted as a hedge, Fleming!

Tropical Africa and Asia, perhaps usually only an introduced plant in India.

This is mentioned by $\mathrm{Mr}$. Hume in conjunction with a number of apparently introduced species, and in Minikoi it is also an introduced plant. The specimen on which the presence of $B$. cristata in the group depends, proves on re-examination to be only an example of $B$. prionitis without any trace of spines. Mr. Hume indeed states that, like the spiny Acanthad, the unarmed one is "yellowblossomed" which alone makes its identification with $B$. ciliata (B. cristata) impossible. And Mr. Fleming's Minikoi specimens 
shew the same peculiarity of some being spiny, while others are quite unarmed.

112. Rungia linifolia Nees in Wall., Pl. As. Rar., iii., 110 ; Hook. f., Flor. Brit. Ind., iv., 548.

Kadamum; very common, Fleming! Akati ; common, Fleming!

A weed of dry places confined to Western India.

113. Rungia parviflora Nees: C. B. Clarke in Hook. f., Flor. Brit. Ind., iv., 550.

var. pectinata Clarke: Hook. f., Flor. Brit. Ind., iv., 550. R. pectinata Nees in DC., Prodr., xi., 470. Justicia pectinata Linn., Amoen. Acad., iv., 299 ; Roxb., Flor. Ind., i., 33.

Améni; Hume! Kadamum; Hume! Akati; Fleming!

A universal weed throughout India, Indo-China and Ceylon.

114. Peristrophe bicalyculata Nees in Wall., Pl. As. Rar., iii., 113 ; Hook. f., Flor. Brit. Ind., iv., 554. Justicia bicalyculata Vahl, Symb., ii., 13 ; Roxb., Flor. Ind., i., 126.

Améni ; Hume! Kadamum; Fleming! Kiltán ; Fleming!

Tropical Africa, India and Indo-China; not from Malaya or Ceylon. A common weed in South India, less common elsewhere.

\section{VERBENACEA.}

115. Lippia nodiflora Rich. in Michx, Flor. Bor. Amer., ii., 15; Hook. f., Flor. Brit. Ind., iv., 563. Verbena nodiflora Linn., Sp. Pl. 20 ; Roxb., Hort. Beng. 4.

Akati; Fleming! Minikoi ; Fleming!

A weed of wet places in all tropical and sub-tropical regions, also often met with near tropical sea-shores; not impossibly a birdintroduced species. Though enumerated in Roxburgh's Hortus Bengalensis, this species is not described by him in the Flora Indica.

116. Stachytarpheta indica Vahl, Enum., i., 206 ; Hook. f., Flor. Brit. Ind., iv., 564. Verbena indica Linn., Syst. Veg. (ed. x.), ii., 851; Roxb., Hort. Beng. 4.

Anderut; Alcock !

A common garden-plant, readily escaping and becoming wild, throughout tropical "America where it is indigenous, and tropical Asia where it is probably "naturalized" only. Here it is quite wild; it may have come as a weed, but more probably has been 
intentionally introduced. As with Lippia nodiflora, Roxburgh includes this in the Hortus Bengalensis, but excludes it from the Flora Indica.

117. Premna integrifolia Linn., Mantiss. 252 ; Hook. f., Flor. Brit. Ind., iv., 574. P. serratifolia Linn., Mantiss. 253. P. spinosa Roxb., Flor. Ind., iii., 77.

Kadamum ; "forming thickets," Hume! "very common; a littlo way inshore," Fleming! Kalpéni ; on the shore, Alcock! Minikoi ; coast zone, Fleming!

A littoral and sub-littoral species, very abundant on Indian, IndoChinose, Andamans, Nicobars and Malay coasts.

118. Clerodendron inerme Giertn., Fruct., i., 271, t. 57, f. 1 ; Roxb., Flor. Ind., iii., 58 ; Hook. f., Flor. Brit. Ind., iv., 589.

Kalpéni ; plentiful on the coast, Alcock !

A littoral specios abundant on Indian, Ceylon, Andamans and Indo-Chinoso coasts.

\section{LABIAT 2 .}

119. Ocimum gratissimum Linn., Sp. Pl. 1197 ; Roxb., Flor. Ind., iii., 17 ; Hook. f., Flor. Brit. Ind., iv., 608.

Bitrapar ; growing near the Pir's tomb, Alcock! Kadamum; Fleming! Kalpéni ; Alcock I Minikoi ; Fleming!

One of the Tulsi plants, occasionally cultivated, but generally, occurring as a weed of waste places throughout tropical Africa, the Mascarene Islands, India, Ceylon and Malaya. It also occurs as a weed in America, but there it is probably only an escape from cultivation and not an indigenous plant. Hore, where the people are Mohammedans, the true or sacred Tulsi (Ocimum sanctum) is not found at all, this-the Ram Tulsi-taking its place. In Car Nicobar and in Burma, whore also one Tulsi is as good as another, the people not being Hindus, it is the Gulal Tulsi-the Basil (O. Basilicum)-that is usually found as a weed near native dwellings.

120. Anisomeles ovata R. Br. in Ait., Hort. Kow. (ed. ii.), ii., 364 ; Hook. f., Flor. Brit. Ind., iv., 672. Nepeta indica Linn., Sp. Pl. 571. Ballota disticha Linn., Mantiss. 83. Ajuga distecha Roxb., Flor. Ind., iii., 2.

Kadamum ; Fleming! Akati ; Fleming! Miniloi ; Fleming! 
A weed of roadsides and waste places throughout tropical and subtropical South-Eastern Asia.

121. Leucas aspera Spreng., Syst, ii., 743 ; Hook. f., Flor. Brit. Ind., iv., 690. Phlomis esculenta Roxb., Flor. Ind., iii., 10.

Améni ; Irume! Anderut ; Alcock! Alkati ; Fleming! Kadamum ; Fleming! Kiltán ; Fleming!

A weed of cultivation throughout South-Eastern Asia and in the Mascarene Islands.

\section{Incompletæ.}

NYCTAGINEA.

122. IMirabilis Jalapa Linn., Sp. Pl. 177 ; Roxb., Hort. Beng. 16 ; Watt, Dict., V., 253. The Marvel of Peru.

Akati ; cultivated, Fleming! Minikoi ; cultivated, Fleming!

Native of America, but widely cultivated throughout tropical Asia on account of the supposed purgative properties of its root and as a garden plant.

123. Boerhaavia repens Linn : Hook. f., Flor. Brit. Ind., iv, 709.

VAR. typica. Boerhaavia repens Linn., Sp. PI. 3.

Akati ; Fleming! Améni Hume!

A weed of fields, waysides and wasteplaces, cosmopolitan in tropical and subtropical countries. The more usual form of this species in India (VAR. procumbens Hook.f., Flor. Brit. Ind., iv, 709 ; Boerharvia procumbens, Bunks in Roxb. Flor. Ind., i, 146) does not appear to occur in the Laccadives; the present form is that characteristic of the dricr parts of India, of Beluchistan, Arubia and North-East Africio.

VAR. diffusa Hook. f., Flor. Brit. Ind., i $\nabla, 709$. B. diffusa Linn., Sp. Pl. 3.

Bitrapar ; on the shore, Hume! Anderut ; on the beach, Alcock ! Kadamum ; Fleming! Minikoi ; Fleming!

A littoral plant, cosmopolitan on tropical sea-shores. The sea-shore form differs so markedly in apporance from the usual inland forms and agrees so well with the description of $\nabla A R$. diffusa Hook. f, that it might be convenient to restrict the varietal name " diffusc" to it alone. It does not, however, deserve specific rank, for, as is pointed out in the Flora of British India, it is impossible by their morphological characters to draw a line betwecn the various forms. Even if recognised as a species, it conld not be dealt with as $B$. diffusa Linn. since the probability is that Linnerts based his descriptions, at least in part, on the examination of inland spccimens. 
The "weed" has probably bcen introduced unintentionally by man. The "shore" form very probably owes its introduction to the agency of sea-birds; though it may have been introduced by ocean-currents.

124. Pisonia alba Spanoghe in Linnae, xV, 342 ; Hook. f., Flor. Brit. Ind., iv, 711.

Bitrapar ; Fleming!

A littoral species confined, if Spanoghe's species be really distinct from all the Polynesian and Malayan ones, to the Andamans and Nicobars. The species is rare in the Andamans beach forests (Kure), but it is plentiful on the shores of Narcondam and on those of Batti Malv—one of the Nicobar group. The tree is only known in India and Ceylon as a cultivated species; but as it does not occur on any of the other islands of the group, and as Bitrapar is an uninhabited island, the presence of the species in the sea-coast jungle here must be independent of human interference. Its fruits may have been introduced by birds, since the glutinous lines along their angles admirably adapt them for this mode of dispersal ; but as the majority of the birds that visit Bitra must be sea-fowl, it is much more likely that the species has been introduced by means of ocean-currents. Though not wild, it is frequently cultivated in Ceylon (e.g., at Colombo) near the sea-indeed away from the sea it refuses to grow-and; if the tree cloes not exist in Malaya, Ceylon, cultivated trees may be supposed to have yielded the fruits that have reached the Laccadives. One point, however, against the species being confined, as an indigenous tree, to the Andamans is that the species has been long cultivated in India and Ceylon, and it is therefore extremely unlikely that the plants originally introduced into India came from that group of islands, with which, save for a short period in the end of the last century, there was, till thirty years ago, practically no communication. It appears, indeed, as Sir Joseph Hooker suggests, to be little more than a form of the Polynesian Pisonia inermis Forst.

\section{AMARANTACEZE.}

125. Amarantus viridis Limn., Sp. Pl. (ed. ii), 1405 ; Roxb., Flor. Ind., iii, 605 ; Hook. f., Flor. Brit. Ind., iv, 720.

Minikoi ; Fleming!

A weed of waste places, cosmopolitan in the tropics.

126. स्srua lanata Juss. in Ann. Mus., xi, 121; Hook. f., Flor. Brit. Ind., iv, 728. Achyranthes lanata Linn., Sp. Pl. 204 ; Roxb., Flor. Ind., i, 676.

Bitrapar ; Hume! Kalpéni ; Alcock! Kadamum; very common, Fleming! Akati ; Floming! Miuikoi ; common, Fleming! 
A weed of waste places and also, as here, a common littoral species throughout tropieal and subtropieal Africa, the Mascarene Islands, Arabia and Sonth-Eastern Asia ; here almost without doubt a sea-introduced species.

127. Achyranthes aspera Linn: Hook. f., Flor. Brit. Ind., iv, 730 . VAR. typica. Achyranthes aspera Linn., Sp. Pl. 204 ; Roxb., Flor. Ind., i, 672.

\section{Minikoi ; Fleming!}

A weed of wasto places, cosmopolitian in the tropics.

VAR. porphyristachya Hook. f., Flor. Brit. Ind., iv, 730. Achyranthes porphyristachya, Wall., Cat. 6925.

Bitrapar; Hume! Bangáro ; Hume! Kalpéni; Alcock! Kiltán ; Fleming! Kadamum ; Fleming! Akati ; Fleming! Minikoi ; Fleming!

A wcedy climber common in the littoral zone of the Indian and Malayan coists ; also in the moist valleys of Sikkim, Chittagong, etc.

The common weed is only reported from Minikoi, from which island also (and from most of the others) comes the usual littoral condition whieh in habit simulates $A$. bidentata, $\mathrm{Bl}$., but which has the fimbriate staminodes of $A$. asperc. While $A$. aspera is undoubtedly a plant introdueed unintentionally by man, there is no doubt that here, as often elsewherc, A. porphyristachya is a seaintroduced plant.

\section{POLYGONACEAE.}

128. Tolygonum barbatum Linn., Sp. Pl., 362 ; Hook. f., Flor. Brit. Ind., จ., 37. P. rivulare Koenig in Roxb., Flor. Ind., ii, 290.

Kalpéni ; Alcock !

In wet places throughout tropical Asia and Africa.

\section{PIPERACERE.}

129. Piper Betce Linn., Sp. Pl. 28 ; Roxb., Flor. Ind., i, 158 ; Hook. f., Flor. Brit. Ind., v, 85.

Akati ; Kiltán ; Kadamum; Minikoi ; in all the islands cultivated and, as is the eustom generally in Southern India, trained round the trunks and over the branehes of the Agati (Sersbania grandiflora). "This plant is an objeet of great eare" (Fleming).

Native of Malaya, where, and in the hotter parts of India and Ceylon, it is cultivated.

\section{IAUTINEZE.}

130. Cassytha filiformis Linn., Sp. Pl. 35 ; Roxb., Flor. Ind., ii, 814 ; Hook. f., Flor. Brit. Ind., v, 188. 
Kiltán; on Wedelia scandens in the coast zone, Alcock! Kadamum; on Pleurostylia Wightii, Fleming!

A leafless parasite, common on sei-shores, cosmopolitan in the tropics.

131. Fernandia peltata Meissn. in DC., Prodr., xv., pt. i, 263 ; Hook. f., Flor. Brit. Ind., $\nabla, 188$. Hernandia ovigera Gaertn., Fruet., i., 193, t. 40, f. 3 ; Roxb., Flor. Ind., iii, 577, nec Linn.

Korát ; Hume! Minikoi ; Fleming!

A littoral species extending from the Mascarene Islands and Eastern Africa to Ceylon, the Andamans, Malaya, Australia and Polynesia; like Ochrosia borbonica this does not oeeur on the coast of India, though it is found as far north as Great Coco on the west and as Mergui on the east of the Andaman Ser. Meissner (DC. Prodr., xv, pt. 1, 262-264) omits to quote, and the Flora of British India $(\mathrm{v}, 188)$ does not cite Roxburgh's account of Hernandia ovigera (Flor. Ind., iii, 577-578), which his own diagnosis clcarly shows to be a species different from Hernandia ovigera, Linn. (Amcen. Ac., iv, 125), founded on Rumf's figure (Herb. Amboin., iii, 193, t. 123) of Arbor ovigera. Roxburgh notes the discrepancies, and explains them by depreciating Rumf's drawing. In reality, however, Roxburgh's description is a most vivid and accurate one, made from living specimens of the species named by Meissner (DC. Prodr., xV, pt. i, 263), Hernandia peltata. Roxburgh cites Gaertner's figure (Fruct. i, 193, t. 40, f. 3) as a "very accurate" delineation of the fruit of this tree-an exccedingly just remark, which, however, Meissner has overlooked, for he quotcs Gaertner's description and figure as referring to Linnaeus' species, though they differ very materially from both Rumf's figure and M eissner's own description. of the fruit of Hernandia ovigera.

Hernandia peltata, the species now under review, is a purely old-world plant, which has been treated by Linnaeus and, witl the exceptions of Gacrtner and Roxburgh, by all botanists subsequent to Linnaeus till the appcarance of Mcissner's treatise (1864) as conspecific with the American Hernandia sonora; even now Sir J. D. Hooker (Flor. Brit. Ind., v, 189) suspects that H. peltate is no more than a variety of $H$. sonora. And the basis of the differentiation by both Gaertner and Roxburgh of the present plant from $H$. sonora does not lie in the differences between the two plants that Meissner has pointed out, but in the fact that Linnaeus includcd undcr $H$. sonora not mercly the American tree to which Mcissner would restrict that name, as well as the Ceylon tree, which is undoubtedly $H$. peltata, but also - though doubtfully and with the remark "sed fructus alienus" (Amcen. Ac., iv, 117) - the tree figured by Rumf (Herb. Amboin., ii, 257, t. 85) under the name Arbor regis. Believing, apparently, that Rumf's Arbor regis was, as Linnacus thought, a Hernandia-a bolicf perhaps partly justbut realising that it could seareely be the tree he had boforc him, and sceing that 
it agreed so thoronghly with the figure and deseription of $H$. ovigera given by Gacrtncr, Roxburgh, not having in his possession specimens of the true $H$. ovigera, followed Gaertner in bestowing that namc on this speeics. This eourse was hardly just to Rumf if Gaertner and Roxburgh believed Rumf's figure to be eorrect, hardly just to themselves if they had any grounds for supposing it to be elroneous. It now appears that Rumf's figure is wonderfully reliable, for, besides his figure from a tree in Amboina, therc are before the writer speeimens of undoubtedly this speeies from Java (Zollinger n. 2861, which, however, Zollinger himself has identified with $H$. sonor $a$ ) and specimons reeently colleetcd by the officers of the "Egeria" in Christmas Island, where $B$. ovigera oeeurs (Hemsl., Journ. Linn. Soc., xxv, 357) on the summit, elevation about 1,200 fcct, a rather remarkable faet, since, aeeording to Rumf, it oeeurs, like the other Hernandias, "semper in arenoso solo circa litora."

As has been remarked, the belief of Linnaeus, and of Roxburgh that Rumf's Arbor regis is a Hernandia is probably partly justified, for it is possible, from his aeeount of the habitat of his tree-- "occurrit tam in litore inter leves ac humiles "silvas" (quite the situation affeeted by Hernandia peltata) "quam in montibus "et altioribus silvis" (where to find H. peltata would be somewhat surprising) that Rumf has ineluded two trees in his description. His figure, moreover, bear's out this, for some of the leaves are without, while others exhibit, a pair of glands where the petiole joins the leaf. The figure as a whole, however, suggests at once, as Lamarck (Encyc. Meth., iii, 123) a century ago pointed out, a Euphorbiaceous plant, while Rumf's description of the fruit is altogether suitable to that of a species of this order. The first authors to recognise Rumf's Arbor regis, however, were Teysmann and Binnendyk, who deseribed it as Capellenia moluccana (Nat. Tijds. Ned. Ind., xxix, 239), founding a new genus to accommodate it ; as, however, Capellenia docs not differ generically from Endospermum, the trce has been re-described by Beccari as Endospermum moluccanum (Malesia, ii, 38) in his treatise Piante Ospitatrici, where another species from New Guinea (Endospermum formicarum Beec., Malesia, ii, 44, t. 2) is deseribed, which shares with Rumf's tree the eharacter of sheltering a speeies of ant in its hollowed stems and branches. Tcysmann and Binnendyk described their speeies from trces grown in the Botanic Garden at Buitenzorg; Beceari does not mention the habitat of the New

* Two parallcl instances known to the writer of littoral species ascending to a consiclerable height are met with in Narcondam, where Morinda bracteata ascends to 2,300 fect and in Barren Island, where Terminalia Catappa ascends 1,100 fcet. The explanation of all thrce cases is doubtless the same; these "littoral" species bcing amongst the first to appear on the respective islands were able to spread unchecked from the shore to the summit of their peaks, and the invasion of inland species has not subsequently been sufficicntly great to compel them to retire completely from the unusual localities they had at first invaded.

358 
Guinca specics; in the Caleutta Herbarium there are, howcrer, examples of another closely related species, with the same hollow brenches, collected in. Sumatra by H. O. Forbes, which wcre obtained on the volcano of Kaba at 3,500 fect elevation. This fact, therefore, does not opposc, if it docs not corroborate, the surmise that Rumf under Arbor regis has included trwo trees, one found only on the coast (Hernandia peltata) and one found inland and on the mountains (Endospermum moluccanum).

\section{EUPHORBIACELE.}

132. Ruphorbia Atoto Forst., Prodr, n. 207; Hook. f., Flor. Brit. Ind., $\nabla, 248$.

\section{Améni ; Hume!}

A littoral species ; scashores of India, Malaya, N. Australia and Polynesia.

133. Zuphorbia hypericifolia Linn., Hort. Cliff.198; Hook. f., Flor. Brit. Ind., v, 249. E. parviflora Linn., Syst. Veg. (ed.x), ii, 1047 ; Roxb., Flor. Ind., ii, 472.

Kadamum ; Fleming! Kiltán ; Fleming! Minikoi ; Fleming !

A weed of waste plaees and fields, almost eosmopolitan; not oecurring in Australia or in Polynesia.

134. Euphorbia pilulifera Linn., Amœn. Acad., iii, 114; Hook. f., Flor. Brit. Ind., $\nabla, 250$. E. hirta Linn. Amœn. Acad., iii, 114; Roxb., Flor. Ind., ii. 472.

Anderut; Alcock! Kadamum; Hume! Fleming! Kiltán ; Alcocle! Fleming! Minikoi ; Fleming!

A weed of cultivation, cosmopolitan in tropical and subtropical eountries.

135. Fuphorbia thymifolia Burm., Flor. Ind. 2 ; Roxb., Flor. Ind., ii, 473 ; Hook. f., Flor. Brit. Ind., $\nabla, 252$.

Minikoi ; Fleming!

A wecd almost cosmopolitan in tropical countries, not found in Australia.

136. Phrluanthus Emblica Linn., Sp. Pl. 982 ; Roxb., Flor. Ind., iii, 671 ; Hook. f., Flor. Brit. Ind., v, 289. The Amla.

Améni ; cultivated, Hume.

Distributed, wild or cultivated, throughout Soutl--Eastern Asia; here an intentionally introdueed plant.

137. Phyllanthus maderaspatensis Linn., Sp. Pl. 982 ; Roxb., Ilor. Ind., iii, 654 ; Hook. f., Flor. Brit. Ind., V, 292. P. obcordatus Willd., Enum. Hort. Berol., Suppl, 65 ; Roxb., Flor. Ind., iii, 656.

Améni ; Hume! Anderut ; Alcock! Bitrapar ; Fleming! Kiltán ; Flleming! Kadamum ; Fleming! Minikoi ; Fleming!

A weed of dry plaees and fields throughont tropical Africa, Asia and Australia, probably unintentionally introduced by man even into the island of Bitra, which, though not inhabited, is regrnlarly visited. 
138. Phyllanthus Urinaria Linn., Sp. Pl. 982 ; Roxb., Flor. -Ind., iii, 660 ; Hook. f., Flor. Brit. Ind., $\nabla, 293$.

Kalpéni ; Alcocle! Minikoi ; Fleming!

A cosmopolitan tropical weed.

139. Phyllanthus Niruri Tinn., Sp. Pl. 981 ; Roxb., Flor. Ind., iii, 659 ; Hook. f., Flor. Brit. Ind., v, 298.

Anderut ; Alcock! Akati ; Fleming! Kadamum ; Fleming! Kiltán ; Fleming! Minikoi ; Fleming!

A weed of cultivation almost cosmopolitan in the tropics, not occurring in Australia.

140. Phyllanthus rotundifolius Klein in Willd., Sp. Pl., iv, 584 ; Hook. f., Flor. Brit. Ind., $\nabla, 299$.

Kiltán ; Fleming!

A weed of cultivation distributed throughout tropical Africa, Arabia, Southern India and Ceylon.

141. Phyllanthus distichus Muell.-Arg. in DC., Prodr., xv, pt. ii, 413 ; Hook. f., Flor. Brit. Ind., v, 304. P. longifolius Jacq., Hort. Schoenb., ii, 36, f. 194 ; Roxb., Flor. Ind., iii, 672. Cicca disticha Linn., Mantiss. 124.

Minikoi ; cultivated, Fleming.

In gardens throughout Malaya, India and the Mascarene Islands.

142. Claoxylon IVercurialis Thwaites, Enum. 271; Hook. f., Flor. Brit. Ind., $\nabla, 412$. Tragia Mlercurialis Linn., Sp. Pl. (ed. ii) 1391 (in parte); Roxb., Flor. Ind., iii, 576. Mercuriatis alternifotia Desv. in Lamk, Encyc. Meth., iv, 120. Acalypha Mercurialis A. Juss., Euphorb. Tent. 46. Micrococca Mlercurialis Benth. in Hook., Niger Flora 503. Microstachys mercurialis Dalz. and Gibs., Bomb. Flor. 227.

Akati ; Fleming! Bitrapar ; Fleming! Kadamum; Fleming! Kiltán ; Fleming! Minikoi ; Fleming !

A tropical weed distributed throughout Africa, Arabia and India ; there are also specimens at Calcutta from the Malay Peninsula. Mercurialis alternifolic Desv. is not the same plant as Mercurialis alternifolia Hochst., Un. It., which is an Acalypha (A. Hochstetteri Muell.-Arg.).

143. Acalypha indica Linn., Sp. Pl. 1003 ; Roxb., Flor. Ind., iii, 675 ; Hook. f., Flor. Brit. Ind., $\nabla ., 416$.

Akati ; Fleming! Kadamum ; Fleming! Minikoi ; Fleming!

A weed of cultivation common in tropical Africa and S.-E. Asia.

144. Acalypha fallax Muell.-Arg. in Linnæa, xxxiv, 43 ; Hook. f., Flor. Brit. Ind., $\nabla, 416$. A. indica Prain, Laccad. List. 7, nee Linn.

Andernt ; Alcock! Akati ; Fleming! Minikoi ; Fleming !

$\Lambda$ weed of cultivation confined to South-Eastern Asir. 
145. Ricinus communis Linn., Sp. Pl. 1007 ; Roxb., Flor. Ind., iii, 689 ; Hook. f., Flor. Brit. Ind.,. ., 457. The Castor-oil Plant; vernac. "undel" (Robinson).

Kiltán; cultivated, Hume, Fleming! Anderut; cultivated, Alcock. Kadamum; Fleming! Améni ; cultivated for its oil, Robinson. Bitrapar ; growing near the centre of the island, Fleming! Minikoi ; cultivated and a very common escape, Fleming!

A native of Africa, cultivated generally in the tropics for its oil, but readily cscaping and becoming naturaliscd, its presence in the uninhabited island of Bitra being an excellent instance of the readiness with which it runs wild. It is noteworthy that it was not present in Bitra when Mr. Hume visited that island in 1875.

\section{URTICACFAE:}

146. Ficus Bengalenssis Linn., Hort. Cliff. 471, n. 4 ; King in Hook. f., Flor. Brit. Ind., $\nabla, 499$. F. indica Linn., Amoen. Acad. (ed. iii), i, 27, n. 6; Roxb., Flor. Ind., iii, 539. The Banyan.

Améni; planted, Hume. Kadamum; four trces seen in the neighbourhood. of some deserted luts, from thcir arrangement in a row cvidently planted, Fleming. Minikoi ; planted, Fleming.

Plantcd generally throughout India, wild on the lower slopes of the Himalayas and of the Deccan hills.

147. Ficus retusa Linn., Mantiss. 129 ; King in Hook. f., Flor. Brit. Ind., $\nabla, 511$. F. Benjamina Willd., Sp. Pl., iv, 1143 ; Roxb., Flor. Ind., iii, 550 nec Linn.

VAR. nitida King, Kicus, 50 ; Hook. f., Flor. Brit. Ind., $\nabla, 511$. F. nitida Thunbg, Ficus 14.

\section{Minikoi ; Fleming!}

A large tree common throughout Eastcrn and South-Eastern Asia and extending to New Calcdonia. Mr. Fleming docs not note if the trec be planted in Minikoi. It is possible that it may be, but as its figs are a favourite food with many of the migratory fruit-pigeons, there is no reason why it should not. be a "wild" bird-introduced species.

148. Artocarpus incisa Forst., Pl. Escul. 23 ; Roxb., Flor. Ind., iii, 527 ; Hook. f., Flor. Brit. Ind., $\nabla, 539$; Watt, Dict., i, 330. The BreadFruit Tree.

Kiltán; does not thrive well, Robinson; not much appreciated, Hume; Alcock. Améni ; grows most luxuriantly, Robinson, Hume. Anderut; cultivated largely, Alcock. Akati; only one trec, in a garden, Fleming! Minikoi ; cultivated, Fleming! 
A native of Polynesia and Eastern Malaya, oecasionally cultivated in the hotter parts of India. The Laceadive Archipelago must be near the northern limit of its sueessful cultivation, a fact that is corroborated by the evidenee given above of the want of success, and the small extent of its cultivation in important islands like Kiltán and Akati.

149. Artocarpus integrifolia Linn. f., Suppl. 412; Roxb., Flor. Ind., iii, 522 ; Hook. f., Flor. Brit. Ind., v, 541 ; Watt, Dict., i, 330. The Jack-fruit.

Anderut; a stately-looking tree, with dark green foliage not unlike the broad-leafed elm, Wnod.

Dr. King, to whose attention the passage in Lieut. Wood's paper has been brought, suggests that the notice refers most probably to the Jaek. The tree is gencrally eultivated throughout the hotter parts of India and Indo-China and throughout Malaya ; it is said by Beddome to be truly wild in the Western Ghâts above the Malabar Coast. That its enltivation should not have spread. in the Laceadives is not at all surprising; doubtless the islanders generally view the Jack, as those of Kiltán, aeeording to Mr. Hume (Stray Feathers, iv, 437), regard the Bread-fruit : trees that are all very well in their way, but considering that, instead of fruiting all the year round like the eoco-nut, they all flower and fruit together, and their fruiting season lasts at the outside only two months out of twelve, they are hardly worth the trouble of propagating.

150. Pouzolzia indica Gaud.: Wedd. in DC. Prodr., xvi, pt. i, 220 ; Hook. f., Flor. Brit. Ind., $\nabla, 581$. Urtica suffruticosa Roxb., Flor. Ind., iii, 584.

VAR. typica. P. indica Grad. in Freycinet, Voy., Bot. 503.

Kalpéni ; Alcock! Kiltán ; Fleming! Akati ; Fleming! Kadamum ; Fleming! Minikoi ; Fleming!

A weed of eultivation eommon throughout tropieal and subtropieal Eastern and South-Eastern Asia.

VAR. alienata Wedd. in DC. Prodr., xvi, pt, i, 221. P. alicnata Gaud. in Freycinet, Voy., Bot. 503.

Minikoi ; Fleming!

A common Indian form of the same weed.

\section{Mitonocotyledones.}

ScITAMineze.

151. Musa Sapientum Linn., Syst. Veg. (ed. x), ii, 1303 ; Roxb̆., Flor. Ind., i, 663 ; Watt, Diet. $\nabla, 290$. The Plantain.

Anderut ; cultivated, Wood. Améni; eultivated, Robinson. Kiltán ; eultivated, Hume. Kadamum ; four plants seen near some deserted huts, evidently planted, Fleming. Ninikoi ; cultivated, Fleming. 


\section{AMARYLLIDEAE.}

152. Pancratium zeylanicum Linn., Sp. PI. 290 ; Roxb., Flor. Ind., ii, 124 ; Hook. f., Flor. Brit. Ind., vi, 285.

Minikoi ; Flleming.

India, Ceylon, Malaya.

153. Agave vivipara Linn,, Sp. Pl. 323. A. Centula Roxb., Flol. Ind., ii, 167; Watt, Dict., i, 143. The Bastard American Aloe.

Anderut; cultivated, Alcoek. Kiltàn; introduced from the mainland and grows well, Fleming.

A native of America, cultivated and naturalised in most warm countries.

\section{TACCACE $\mathbb{A}$.}

154. Tacca Plnnatrfida Forst., Plant. Escul. 59 ; Rosb., Flor. Ind, ii, 172. The South-Sea Taro ; vernac. "teerny," Robinson,

Anderut ; cultivated, Wood, Alcock. Chitlac ; cultivated, Robinson. Akati ; cultivated, Fleming! Minikoi ; cultivated, Fleming!

A littoral species common on South-Eastern Asiatic and Polynesian coasts, but also cxtending inland either as a wild or cultivated specice. Though a very common species on the Andaman coasts, the plant is here only found as a cultivated one.

\section{DIOSCOREACE 7 .}

155. Dioscorea bulbifera Linn., Sp. Pl. 1033. Wild I $\mathrm{cm}$. Minikoi ; Fleming!

A common species in a wild state throughout India, Indo-China, and Malaya; possibly conspecific with the next. Mr. Fleming doos not note if it is a cultivated or a wild species. It is sometimes cultivated, and both the root and leaf-tubcrs are eaten. The latter are also in Ceylon used as a fish-bait.

156. Diosconea sativa Linn., Sp. Pl. 1033 ; Watt, Dict., iii, 133. Thc Garden Yam.

Améni ; cultivated, Robinson, Hume. Cultivated generally in the tropics, native country unknown. There are no specimens either in Mr. Hume's or in Dr. Alcock's collection, and it is, therefore, not impossible that it is not $D$. sativa but $D$. bulbifera that is grown in Améni.

\section{LILIACEX.}

157. Gloriosa superba Linn., Sp. Pl. 305 ; Roxb., Flor. Ind,, ii, 143. Anderut ; plentiful, Alcock !

Wild throughout South-Eastern Asia, but also often cultivated as an ornamental plant, and on account of the poisonous properties reputed to reside in its 
roots. It is not cultivated, howercr, in Andernt, and as it is a common littoral species throughout the Andamans and Nicobars, it is here quite possibly a seaintroduced species.

\section{COMMELYNEA.}

158. Aneilema ovalifolium Hook. f., ex C. B. Clarkc in DC. Monogr. Phan., iii, 218.

Minikoi ; Fleming!

$\Lambda$ herbaceous weed of jungles and grassy places confined to Southern India.

159. Cyanotis cristata Roem. \& Schult., Syst., vii, 1150. Commelina cristata Linn., Sp. Pl. 42. I'radescantia imbricata Roxb., Flor. Ind., ii, 120 .

Kadamum ; Fleming! Kiltín ; in grass along with Leucas asperc, Fleming! Minikoi ; on ground and also cpiphytic on Cocos muciferc, Fleming!

A wced of grassy places in the Mascarene Islands, India and Malaya.

\section{Palmedi.}

160. Areca Catechu Linn., Sp. Pl. 1189 ; Roxb., Flor. Ind., iii, 615 ; Watt, Dict., i, 291. The Betel-nut Palm.

Améni ; cultivated, Robinson, Hume. Anderut; cultivated, Wood, Alcock. Kiltán ; does not thrive, Robinson. Minikoi ; cultivated, Fleming.

Cultivated in tropical countries.

161. Cocos nucifera Linn., Sp. Pl. 1188 ; Roxb., Flor. Ind., iii, 614. The Coco-nut Palm.

Améni ; Robinson, Hume. Andernt; Wood, Alcock. Akati ; Fleming. Bangáro ; Hume. Bitrapar ; Robinson, Hume. Chitlac ; of slow growth and not productive, Robinson. Kadamum ; Robinson, Hume, Fleming. Kalpéni, Alcock. Kiltán ; Robinson, Hume, Alcock, Fleming. Koráti ; Hume. Minikoi ; Fleming.

Lient. Wood's list gives the coco-nut as present on all the islands except Kalpéni Féti and Akati Féti, which are montioned as mere sand-banks, but the sand-banks of Pirmalla and Pitti and the coral islets on Cherbaniani and-if, indeed, there are islets there—on Cheriapani reeis are quite devoid of vegetation and if visited at all by the islanders are visited for the purposes of fishing or eggcollecting, not for coco-nuts and coir. Bitra, however, which is uninhabited, has coco-nuts and is visited on account of these by people from the northern islands. The coco-nuts there, from their position as described by Robinson and Hume and from the accounts of the pcople, are evidently only planted. Bangáro and (apparently) Tangáro, two uninhabited islands on the Akati reef, have coco-nuts clearly, from Humc's account of the former, sca-introduced and not planted. Whether: there are coco-nuts on Subeli is not clear'; according to Wood's list, 364 
they occur, but the people misinformed him conccrning so many of the otlicr islands, that till there is direct evidence, the point must remain doubtful.

The question whother the appearance of the coco-nut in this archipelago prcceded that of man, or if the first settlers therc did not rather take the coco-nut with them, is one that it is somewhat difficult to answer. The species is pretty certainly indigenous in the Malay countries and, perhaps, Polyncsia, and seems to have spread thence to India, the Mascarene Islands and Africa. It occurs also in Amcrica, but the question-which has been seriously discussed —as to whether it found its way to the New World from the Old or vice versc, has not jet been satisfactorily answered. The introduction of the coconut into Ceylon at all events has been in all probability a deliberate act, and, as M. de Candolle reminds us (Origin of Cultivated Plants, p. 435), at a period so recent as to be almost historical. That the geographical extension of the tree is largely due to human agency does not admit of question, but that it has been in every place where it occurs intentionally introduced, it is neither possible nor necessary to believe. Its fruits are highly capable of ocean-distribution and form a constant feature of ocean-drifts on tropical shores, and it is one of the earliest species to appear on newly emerged coral or volcanic tropical islands.

As regards the Laccadives, if man did not first settle there on account of coco-nut trees being ahready present, it is difficult to conceive what he went there for"; the surface is not adequate, nor are the conditions favourable for extcnsive cereal or pulse cultivation, and as for a certain period of the ycar the people have to take their boats away from the islands to places of safety on the Malabar Coast, it is clear that fishing could never have been a general or constant industry among them. On the other hand, the coco-nut is in the strictest sensc a cultivated species on all the inhabited islands, and is a planted species even in Bitra, which, on account of its want of a water-supply, is only a visited. island ; and though in. Bangáro it is not cultivated or planted, this island may havc only been stocked by nuts from Akati, the main island on the same atoll subsequently to a dehberate introduction of the species into Akati itself.

Still the state of affairs in Bangaro proves that the tree here can be, at least locally, sca-dispersed ; and taking into account the uninviting appearance that the islands must offer, were they destitute of coco-nuts, one cannot but think it probable that the specics reached the archipelago independently of human agency and prior to human settlement, while the necessity for constant renewal and, as the population increased, for planting to the greatest advantage, has insured that now in all the inhabited islands none but cultivated trees are to be found.

In most of the islands it is deemed necessary to raise the scedling coco-nuts with carc and attention till they are a year old, when they arc transplanted and. 
watered for a few weeks till they become firmly established. After this the young trees are left entirely to themselves, and are neither watered nor manured; they eome into bearing in Kiltân in from 8 to 10 years, and produee fruit so vigorously and plentifully that it is sometimes neessary to support the lixuriant growth of nuts artifieially *; in this island, moreover, the preliminary attention to seedlings is not required.

In some of the other islands, as in Chitlac, where the soil is mueh poorer, the trees do not come into bearing till they are 15 to 20 years old, each tree at best producing only about 50 nuts per annum as against 80 to 85 nuts a year in Kiltán. In Kadamum, too, backward though the cultivation in that island is, the average per annum is about 80 nuts per tree; in Améni, where the cultivation is almost as extensive as in Kiltán, the average is ouly about 60 nuts a year from each tree. These figures are given by Robinson, after careful and prolonged enquiry, as representing the yield in 1844 and 1845; Hume gives the average all over for the four British islands in 1875 at 80 nuts per tree per annum $\uparrow$-doubtless rather a high general estimate, though probably representing the yield of what the people in any of the islands would themselves consider a good tree. Robinson thinks that 60 to 70 nuts would be a pretty fair general average for the whole of these islands, and this is likely to be nearer' the truth than the higher estimate. The islanders try to plant only first class trees, and they ain at obtaining such as will come into full bearing in about 10 years, throwing out every month after that age is reached a fruiting-spike bearing 15 to 20 nuts, and so yielding 180 to 250 nuts a year, and going on bearing at this rate till they are 60 years old. They often do go on bearing, it is said, till they are 70 or 80 years of age, and some are believed by the people to be more than a century old. But a tree that produees a fruiting-spike every month is quite a rarity ; 9 to 10 fruiting branches are all that can be hoped for in twelve months, and from accidents and casualties among the nuts, 8 to 10 a spike is a very high average of nuts. Indeed, it is only trees with an eastern exposure and trees growing in the kat in the centre of the islands that yield so highly; those with a south-westerly exposure or those on the drier parts of the best islands yield as poorly as those of Chitlac, where the conditions, as a whole, are unfavourable.

There is very little exportation of coco-nuts from the islands, much the greater portion of the crop being required for home consumption. As, moreover, the great product of the islands is con, not coco-nuts, an immense proportion of the crop is gathered before the nuts are perfectly ripe and before the kernel is in the best condition for yielding oil. If allowed to remain on the

* Robinson, Madras Joumal, n. s, xiv, 24.

† "Stray Feathers," iv, 410.

366 
tree for twelve or thirteen months, which is the time required for perfect ripening, the husk becomes hard and woody and the coir difficult to separate from the woody particles, requiring longer soaking in its preparation, which darkens its colour and spoils it for the market ; being harder and coarser, too, it becomes, though not wcaker than the best coir ought to be, much more difficult to twist. If, on the other hand, the nuts are gathered too soon, the coir obtained, though excellent in colour and easy to manipulate, is too weak for yarn, though quite good for minor purposes, such as a stuffing material for mattresses.

The proper age of nuts for coir-making is ten months; at the end of the tenth month they are cut and husked, the husks being thrown into soaking-pits, where they are left for a year. These soaking-pits are simply holes in the sand on the lagoon-shore of the various islands, in which the husks are buried and covered over by heaps of coral-blocks to protect them from the ripple of the warcs. After twelve months' soaking the husks are taken from the pits and the coir is separated from the refuse of the husk by beating. If takcn out earlier, it is very difficult to rid the coir of impurities and woody particles; if left longer, the fibre is found to be weakened. In Améni, where, as has been said, the island occupies the whole lagoon-space, and there is, therefore, no protected seashore suitable for coir-soaking, the husks have to be buried in pits dug through the coral-crust within the body of the island. The coir is here, therefore, soaked in fresh, instead of salt water, one result of which is that the Améni coir is weaker than that produced in the other islands; this is, no doubt, the result of the action of some of the products of decomposition in the water of these tanks. A further effect of this method of soaking is a discolouration of the fibre, for the water in the tanks never being changed becomes foul and darkcoloured by the decaying vegetable matter, and imparts this tinge to the coir. The two effects taken together, or perhaps lather the second, used by the buyer as an index of the first, renders Améni coir a less marketable product than the coir of the other islands and reduces it to the level of most of the coir manufactured on the Malabar Coast itself, which is practically all made in this way, protected seashores on which to bury the husks being exceedingly rare cxcept within the lagoons of coral islands.

In separating the coir after the beating by sticks to break up the adhesion and remove impurities, the coir is hand-rubbed, chiefly by the women, to remove the roody tissue betreen the fibres. It is then rolled into loose pads as thick as one's finger by the palms of the hands before being twisted into yarn, of which two strands are made at once.*

* J. Shortt, F.L.S. ; Monograph of the Coco-nut-palm, p. 16, Madras, 1888. 
The yield of fibre is cstimated by Robinson at one pound of coir from each 10 nuts, giving 35 fathoms of yarn. He adds* that " 2 lbs. of such yarn, " measuring from 70 to 75 fathoms, are made up into soodies, of which there are " fourteen to a bundle, averaging about a maund of $28 \mathrm{lbs}$. A Mangalore candy " of $560 \mathrm{lbs}$. will, therefore, be the produce of 5,600 nuts, and should contain "about 20,000 fathoms of yarn."

In contrast with this yield, Robinson mentions that it takes only threc of the large coarse coast nuts to yield a pound of coir, but that this coir will only produce 22 fathoms. A ton of Laccadive coir will thus produce 80,000 fathoms of yam as against 50,000 yielded by a ton of Malabar coir.

By Mr. Robinson's figures, it will take over 20,000 nuts $(22,400)$ to yield a ton of coir, which should produce 784,000 fathoms of yarn. Mr. Hume (Stray Feathers, iv, 440) says it takes about 30,000 nuts to yield a ton of coir.

It is clear from what has been written regarding the Laccadives that they yield by far the best coir produced in India, and it will be equally evident from what has been said here that their superiority lies altogether in the facilities for sca-soaking offered by their lagoons. Yet from all the information that a cousultation of the ordinary trade returins will yield, an enquirer into them might, as Watt remarks, $\dagger$ conclude that the Laccadives export no coir. In trade returns the Laccadive coir from British Islands is given along with that from the Malabar Coast, and in European markets the best Malabar or Indian coir is spoken of as Cochin coir. As a matter of fact, little coir comes from Cochin, and it does not present any features peculiar to itself or superior to those of coir from other parts of Malabar. What the European merchant means by Cochin coir is pretty certainly Laccadive coir. Even when the coir is known to be from the Laccadives,some misunderstanding is produced by its being spoken of as Kiltán coir or Améni coir. As a matter of fact, Kiltán coir has not quite the local reputation of either Chitlac or Kadamum coir, whereas Améni coir is distinctly inferior to that produced in any of the other British islands. The application of the term Améni coir tó the best qualities arises from two circumstances-the fact that the island of Améni is one of the largest and often gives its name Amendivi to the whole group, and that, till quite recently, the lower caste people of Kadamum, where excellent coir is produced, were in some degree subject to their higher caste neighbours of Améni, and were compelled to ship their produce to the mainland in Améni boats.

Besides coir manufacture, a certain amount of coarse sugar (jaggery) manufacture is carried on, not at all extensively, however, in the British islands, since

* Robinson, Madras Journal, n. s., xir, 16.

† Dict. Econom. Products of India, ii, 421 . 
the higher prices given for their coir render its manufacture more profitable to the people. In the Cannanore Islands, where coir is under monopoly and the Cannanore Raj gives much poorer prices for that article than the inhabitants of the British islands obtain, large quantities of jaggery are produced both for home consumption and for cxport to the people on the British islands, the chief islands in which it is manufactured being, according to Robinson, thosc of Anderut and Koráti.

\section{Pandanez.}

162. Pandanus odoratissimus Linn. f., Suppl. 424 ; Roxb., Flor. Ind., iii, 738 ; Balf. f., Jour. Linn. Soc., xvii, 54.

Bangáro ; abundant, Hume. Kadamum ; very abundant, Hume. Améni ; Hume. Kiltan ; only a few plants, Hume. Kalpéni ; Alcock. Minilkoi ; Fleming! a regular sea-fence of this plant surrounds the island, Hamilton.

A littoral species extending from the Indian Coasts to Malaya, Australia and Polynesia.

In the Laccadive Islands proper there is not, in densely peopled and carefully planted islands like Kiltán, more than the merest remnant of a Pandanus sea-fence lcft, though in uninhabited islands like Bangáro and in partially occupied ones like Kadamum, it is well represented. But, curiously enough, it is quite absent from the uninhabited island of Bitra, where also Cocos nucifera does not occur as a littoral and sea-introduced species. In Minikoi, however, where the island is fully occupied and carefully planted, the Pandanus sea-fence has been allowed to rcmain as a belt all round the island. This belt of jungle harbours an immensc number of rats (Mus rattus $\nabla A R$. rufescens)*, which here, as in the other islands, prove vcry destructive to the coco-nut crop. Captain Wentworth Hamilton, Port Officer of Gopalpur, who commanded the S. S. "Martha Heathcote," during a recent official visit to Minikoi, informed the writer in 1889 that the disturbances which led to the visit arose out of a Government order to cut down this jungle and, by removing their shelter, to render possible a systematic attempt to exterminate the rats. The populace objected most strongly to the order, on the ground that this belt of jungle is the abode of cvil spirits that wonld be certain, were their domain invaded, to rctaliate by bringing misfortune on the island. Minikoi, as has been already said, though Laccadive as to political connection, and as much Laccadive as Maldive as to situation, has a Maldive population; there is no evidence of supcrstition so gross among the Mappila population of the other Laccadives; at all events, they do not appear to have any scruples about clearing away the Pandanus belt. 
AROIDEE.

163. Colocasia antiquorum Schott: Engler in DO., Monogr. Phanerog., ii, 491.

VAR. typica. C. antiquorum Schott, Meletem. i, 18. Arum Colocasice Linn., Sp. Pl. 965 ; Roxb., Flor. Ind., iii, 494. The Kachu or Indian Taro.

Améni ; cultivated, Hume. Anderut; cultivated, Alcock. Kalpéni ; both cultivated and wild, Alcock! Kiltán; wild, Fleming. Kadamum; wild, Fleming. Akati ; wild, Fleming. Minikoi ; wild, Fleming.

A native of India, cultivated in nearly all tropical and subtropical countries. There is little doubt that this has been intentionally introduced; it receives, however, slight attention in any of the islands, and in nearly everyone of them it has established itself as a weed.

CyPeracex.

164. Cyperus hyalinus Vahl, Euum., ii, 329 ; Clarke, Ind. Cyperus 46.

Kadamum ; Fleming!

A very rare South Indian weed.

165. Cyperus polystachyus Rottb., Descr. et Ic. 39, t. 11, f. 1 ; Roxb., Flor. Ind., i, 193 ; Olarke, Ind. Cyperus 51.

Minikoi ; Fleming!

A cosmopolitan tropical and subtropical weed, especially in islands and on sea-shores.

166. Cyperus compressus Linn., Sp. Pl. 46 ; Roxb., Flor. Ind., i, 194 ; Clarke, Ind. Cyperus 97.

Kalpéni ; Alcock!

A cosmopolitan tropical weed.

167. Cyperus pachyrrhizus Nees ex Boeck, in Linnæa, XXYV, 545 ; Clarke, Ind. Cyperus 111.

Bitrapar ; Hume! Fleming! Kadamum ; Fleming! Bangáro ; Hume!

A littoral species, confined to the coasts of India. Mr. Clarkc, however, in a letter to the writer, in which he has kindly criticised the former Laccadive List, states that in Dr. Trimen's opinion the purely maritime $C$. pachyrrhizus cannot be specifically distinguished from $C$. conglomeratus (Rottb., Descr. et Ic., 21, t. 15, f. 7 ; Clarke, Ind. Cyperus, 112), a plant occurring in the desert of North-East Africa and South-West Asia (Nubia, Arabia, Syria, Socotrin, Beluchistan).

168. Cyperus pennatus Lami in Poir., Encyc. Meth., vii, 240. Clarke, Ind. Cypertus 194. 
Anderut; Alcock! Kalpéni ; Alcock! Akati ; Fleming! Minikoi ; Fleming! A littoral and estuarine spécies, extending from the Mascarene Islands to India, Malaya and North Australia.

169. Cyperus dubius Rottb., Deser. et Te., 20, t. 4, f. 5 ; Roxb., Ilor. Ind., i, 189 ; Clarke, Ind. Cyperus 197.

Minikoi ; Fleming!

A littoral species, extending from Indo-China and Malaya to India, Ceylon, the Mascarene Islands and the African Coast.

170. Kyllinga brevifolia Rottb., Descr. et Ic., 13, t. 4, f. 3.

Minikoi ; in the sward underneath the coeo-nut trees, Fleming!

Cosmopolitan in the tropies.

171. Fimbristylis diphylla Vahl., Enum., ii, 289. Scirpus sniliacens Roxb., Flor. Ind., i, 227.

Kalpéni ; Alcock!

The solitary specimen is not a good one, and the identifieation is not absolutcly certain. Tho plant is, however, not any of the other Cyperacece enumernted.

Common on seashores and in wet places throughont the tropics.

Granineze.

172. Panicum sanguinale Linn., Sp. Pl., 57.

VAR. ciliare. P. ciliare Retz., Obs., iv, 16 ; Roxb., Flor. Ind., i., 293.

Akati ; dwarfed specimens, Fleming! Minikoi ; very abundant, Fleming!

Cosmopolitan in the tropics; the variety present here scems, hotrever, confincd to the Eastern Hemisphere.

173. Oplismenus Burmanni Beanv., Agrost., 54. Panicum Bumanni Retz., Obs., iii, 10 ; Roxb., Flor. Ind., i, 298.

Akati ; Fleming! Kadamum; Fleming! Kiltán ; Fleming! Minikoi ; Fleming! Everywhere abundant, as is the next species.

Cosmopolitan in tropical and subtropical countries.

174. Oplismenus compositus Roem. \& Schult., Syst., ii, 484. Panicum compositum Linn., Sp. Pl. 57. P. lanceotatum Roxb., Flor. Ind., , 294.

Améni ; Hume! Akati ; Fleming! Minikoi ; Fleming!

Widely distributed throughout the tropies of the old rorld.

175. Setaria verticillata Beauv., Agrost., 51. Panicum verticiatum Linn., Sp. PI. (ed. ii) 82 ; Roxb., Flor. Ind, i, 301.

Améni ; a crop, vernac. "badag," Robinson. Bangáro ; Hume! Kadamum; Fleming! Kiltan ; Fleming! If cultivated at the time of Mr. Robinson's vis ${ }_{\downarrow} i$ (1844), apparently not cultivated when Mr. Hume was at the Laceadives (1875); its presence in the uninhabited island of Bangáro indicates, moreover, that 
here, as elsewhere, the species is one that readily becomes established as a weed.

Cosmopolitan in the tropics.

176. Thuarea sarmentosa Pers., Synops., i, 110.

Bangáro ; Hume! Kadamum ; Fleming! Minikoi ; Fleming!

A littoral species, extending from the shores of Polynesia to Malaya, the Andamans and Nicobars, Oeylon (Thwaites O. P. 2260), the Laccadives, and the Mascarene Islands. As with a number of other littoral species exhibiting the same distribution, this has not yet been collected on the coast of the Indian mainland.

177. Spinifex squarrosus Linn., Mantiss., 300.

Bitrapar ; everywhere in huge patches inside the belt of Ipomca bitoba, Hume! Minikoi ; Fleming!

A littoral species found on the Western Indian Coast from Canara (Thomson) to Malabar (Rheede) and on the east from Puri (Clarke) and Gopalpur (Prain) to Madras (Wight) and Ceylon (Thwaites). Besides extending to the Laccadives, it occurs in Java (Kurz), Siam (Schomburgk), and Ohina (Hance). But in the Oalcutta Herbarium there are no specimens from Burma, the Malay Peninsula, the Andamans or the Nicobars. The headquarters of the genus is Australia, wherc several species occur; and if this species has originally come from the south-cast to India, it has apparently only reached the western, not the eastern, side of the Sea of Bengal, first perhaps reaching Ceylon, whence it has crcpt northward along both the coasts of the Indian Peninsula. Why it should not have become dispersed northward from Java, along the coasts of Sumatra, the Nicobars and Andamans to Burma, it is difficult to conceive.

178. Oryza satrva Linn., Sp. Pl. 333 ; Rosb., Flor. Ind., ii, 200 ; Watt, Dict., v, 498. The Rice crop.

Andernt; a small quantity of rice is grown in the rainy season, not morc than 15 or 20 days' consumption, Wood.

Generally cultivated throughout the tropics; probably originally a native of India, where it often occurs, as Roxburgh says he has himself seen it in the Circars, in a truly wild state, that is, not as an escape from cultivation. It occur's thus, for example, in the Sunderbuns along with another species (Oryzc rocerctata Roxb., Flor. Ind., ii, 206), which is perfectly distinct from 0 . sativa in any of its forms, is never found anywhere else than in the Sunderbuns, and of which no use whatever is made.

The notice by Lieut. Wood is the only intimation of the Laccadive islanders cultivating the rice crop ; but though they do not apparently attempt to grow it now, there is no reason to suppose that Wood was misinformed or mistakcn. For though Robinson does not mention rice as a crop in 1844-45-it will be 
noted that he did not visit Anderut then-he givas a circumstantial account of the cultivation of certain millets and pulses in Améni and Kadamum, but says that in Chitlac field-cultivation was then quite insignificant and that in Kiltan it had given way altogether before the planting of coco-nut trees. Writing thirty years later, Mr. Hume says* that " in former days a certain amount of " millets used to be grown in all the islands; now, even in Améni, littlc or "none appears to be cultivated, and the people are wholly dependent for their "supplies on the mainland, whence they bring, not only rice, but tobacco and "solt, which, curiously enough, nevcr" seems to have been manufactured on the " islands, the people being allowed to get duty-frec salt from Goa."

In Ander'ut, judging from Dr. Alcock's brief notice of the island, there appears to be even to this day more cereal cultivation than in most of the other islinuds; still he does not speak of rice as being grown, and says that the staple crop is ràgi (Eleusine Coracana).

179. Saccharuar officisaruar Linn., Sp. Pl. 54 ; Roxb., Flol. Ind., i, 237.

Minikoi ; cultivated, Fleming.-

Cultivated throughout the tropics.

180. Ischaemum ciliare Retz., Obs., vi, 36. I. tenellum Roxb., Flor. Ind., i, 323.

Kalpéni ; Alcock! Akati ; Fleming! Bitrapar ; Fleming! Kadamum ; Fleming! Kiltán ; Fleming! Everywhere vcry plentiful.

Confined to China, India and Into-China.

181. Ischaemum muticum Linn., Sp. Pl. 1049. I. repens, Rosb., Flor. Ind., i, 323.

Kalpéni ; Alcock ! Minikoi ; Fleming !

Extends from S. E. Asia to Australia and Westcrn Polynesia ; is very common on the coast in the Andamans and Nicobars.

182. Andropogon contortus Linn., Sp. Pl. 1045 ; Roxb., Flor. Ind., i, 253.

Kiltán ; Alcock ! Kadamum ; very plentiful, Fleming !

A common grass of dry places, cosmopolitan in the tropics.

183. ANdropogon muricatus Retz., Obs., iii, 43 ; Roxb., Flor. Ind., i, 265 ; Watt, Dict., i, 245. The Khus-kchus grass.

Kiltán ; a little clump found growing near the mosque, Fleming!

Cosmopolitan in the tropics; herc probably introduced. Hacckel (DC., Monrgr. Phanerog., vi., 542) identifies $A$. muricatus Retz. with $A$. squarrosus Linn. f., but omits to cite Roxburgh's description of the Khus-lkhus grass or to say whether 
in his opinion $A$. squarrosus is, or is not, the Khus-khus. There ean, of contrse, be no possibility of doubt as to the grass intended by Roxburgh, though therts may be some as to the identity of Roxburgh's plant with that of Retzius.

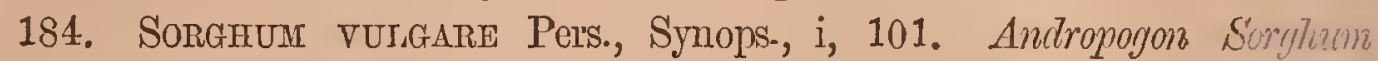
Roxb., Flor. Ind., i, 269. The Sorghum, vernac. "Jowa."

Améni ; eultivated, Robinson. Kadamum ; cultivated, Robinson. Minilioi : grows well, but very little cultivated, Fleming.

Cultivated throughont íarm eountries.

185. Apluda aristata Linn., Amocn. Acad., iv, 303: Rosb., Flor. Ind., i, 324.

Kadamum; filling all the outskirts of the jungle, Hume! Minihoi ; vory abundant, Fleming!

In woods.and hedges throughout South-Eastern Asia.

186. Cynodon Dactylon Per's., Synops., i, 85. Panicum Dactylon Limn., Sp. Pl. 58 ; Roxb., Flor. Ind., i, 289.

Kalpéni ; Alcock !

Cosmopolitan in the tropies. The plant from Bangáro, referred with doubt to this species by Mr. Hume (Stray Feathers, iv, 452), is in reality Thuarece sarmentosa.

187. Ileusine Fgyptiaca Pers., Synops., i, 82 ; Roxb., Flol. Ind., i, 344.

Améni ; Hume! Kadamum ; Fleming!

A cosmopolitan tropieal weed of eultivation.

188. Eleustne Coracana Gaertn., Fruet., i, 8, t. 1, f. 11 ; Roxb., Flor. Ind., i, 343 ; Watt, Diet., iii, 237. The Rugi crop; the Marud Iillet.

Améni ; Robinson. Andertut; Alcock. Kadamum; Robinson. Kalpéni ; Alcock ! Minikoi ; Kleming!

A field erop in India, Egypt and Japan.

189. Fleusine indica Gaertn., Fruet., i, 8 ; Roxb., Flor. Ind., i, 345.

Minikoi ; Fleming!

A cosmopolitan tropieal species, occurring as.a reed in waste places and on waysides.

190. Fragrostis plumosa Steud., Gram., i, 266. E. tenella Trin. var. plumosa Trin., Act. Petrop, vi, i, 398. Poa plumosa Retz, Obs., iv, 20 ; Roxb., Flor. Ind., i, 327. P. tenella Linn. VAR.— Spreng., Syst. Veg., i, 341 .

$\nabla A R_{\text {. }}$ typica.

Kalpéni ; Alcock ! Akati ; Flleming ! Kadamum ; Fleming ! Kiltán ; Flcming! Minikoi ; Flcming!

$\mathrm{V} \Lambda \mathrm{R}$. panicutis fastigiatis. 
Akati ; Fleming! Kadamum ; Fleming! Minikoi ; Fleming!

A common grass in Indian ficlds and waste places.

191. Iepturus repens R. Br., Prodr. Flor. Nov. Holl, i, 207.

Bangáro ; Hume! Bitrapar ; Fleming! Minikoi ; Fleming!

A littoral species, extending from Polynesia and Australia to Ceylon, tho Laccadives and the Mascarene Islands.

\section{CRIPTOGAIMIA.}

LYCOPODIACE

192. Psilotum triquetrum Swart, Syn. Fil., 117 ; Baker, Fem Allies, 30.

Minikoi ; Fleming!

- Cosmopolitan in the tropics.

\section{FILICES.}

193. Nephrodium molle Desv., Mem. Soc. Linn., vi, 258 ; Bedd., Ferns of Brit. Ind., 277. Polypodium parasiticum Linn., Sp. Pl. (ed. ii) 1551. P. proliferum Roxb., Flor. Ind. (ed. Clarke), 752.

Anderut ; Alcock!

Cosmopolitan in the tropies.

194. INephrolepis cordifolia Presl., Tent. Pterid. 79 ; Bedd., Ferns of Brit. Ind., 282. Polypodium cordifolium Linn., Sp. Pl. (ed. ii) 1549.

Anderut ; Alcock !

Cosmopolitan in the tropics.

\section{CHARACE正。}

195. Chara sp., Alcoek, Adm. Rep. Marine Survey, 1891-92, p. 10.

Akati ; in fresh-water tanks, Alcock.

Unfortunately, no specimens were colleeted. It is not at all improbable that Zanichellia palustris (Naiadacece) may be found associated with Chara in this place ; it often is in similar localities.

\section{MUSCI.}

196. Calymperes Dozyanum Mitt. in Journ. Linn. Soc., iii, Suppl. 42. C. mollucense Dozy \& Molk, Bryol. Jav., i, 47, t. 37, nec Sehwaegr.

Minikoi ; Alcock !

Extends from Samoa and the Admiralty Islands to the Philippines, Java, the Andamans (Great Coco Island, where it is very plentiful), Ceylon, India (teste Mitten l.c.) and Minikoi, where it is plentiful. It is the only noss reported 
from the island; Dr. Alcock, writing from the "Investigator," remarks on the presence of so much moss and fungus at Minikoi as compared with the other islinds, where thore are hardly any fungi and there is apparcntly no moss. On this point he adds :- " But the island is ncar the equatorial belt of condensation."

\section{LICHENES.}

\section{(N. O. LICHENACEI.)}

197. Physcia leucomela Michx, Flor. Bor. Am., ii, 356 ; Nyland., Synops. Lich., i, 414.

Minikoi ; on coco-nut trees, Alcock!

Cosmopolitan in tropical and temperate regions on tree trunks.

198. Physcia obscura Fries, Lich. Eur., 84; Nyland., Synops. Lich., i, 427.

Minikoi ; on coco-nut trees, Alcock !

Cosmopolitan on trees and rocks.

\section{FUNGI. \\ (N. O. HYMENOMYCETES.)}

199. Pleurotus cuneatus G. Massée, sp. nov. pilco carnosulo, tcnui, exacte laterali, flabelliformi postice in stipitem brevissimum producto, glabro, albo ; lamellis decurrentibus, divergentibus, subconfcrtis, angustis, albis, siccitate pallide ochraceis ; sporis cllipsoideis.

Minikoi ; on coco-nut trees, Alcock!

Ncarest to Pleurotus scabrellus, Berk.

200. Pleurotus tenuissimus Jungh., Enum. Fung. Jav.

Minikoi ; on dead screw-pines, Alcocte !

Java.

201. Schizophyllum commune Fries, Syst. Mycol., i, 330.

Kiltán ; on rotten branches of Ricinus communis, Fleming!

Cosmopolitan.

202. Polyporus sanguineus Fries, Epicris. 404.

Kadamum; on decayed coco-nut stumps, Fleming! Minikoi ; on dad branches of screw-pine, Alcocti !

Cosmopolitan in tropical and subtropical countries.

203. Polyporus igniarius Fries, Hymon. Eur., 559.

Minikoi ; Alcock!

Cosmopolitan, or nearly so.

204. Trametes IMuelleri Bork., Jour. Linn. Soc, $x, 320$.

Minikoi ; Alcock !

Australia, Brazil. 
205. Firneola polytricha Mont, Syllog. Gen. \& Sp. Pl. Crypt., 181. Minikoi ; "from a wooden house-post," Alcock !

Almost cosmopolitan in tropical and subtropical countries.

ALG正。

206. Nostoc verrucosum Vauch., Conf., 225.

Minikoi ; oovering the ground in damp places, Alcock !

Cosmopolitan.

There are also some Marine Algæ, at least in Minikoi on the reefs of the weather-sidc of the island (Alcock, Adm. Rep., Marine Survey, 1891-92); of these no specimens were collected.

\section{ChaRACTERISTIC FEATURES OF THE FLORA.}

The list given above includes 206 species, representing 156 genera and 61 natural orders; 191 of the species are Phanerogams and only 15 are Cryptegams, giving a proportion of flowering to flowerless plants of about thirtecn to one ; the percentages are :-

Phanerogams, 93. \%;

Cryptogams, $7 \cdot \%$.

Of the Phanerogams 150 are Dicots and 41 are Monocots, the proportion here being nearly four to one ; the percentages are :-

Dicotyledons, $78.5 \%$;

Monocotyledons, $21.5 \%$.

Only three vascular cryptogams have been found in the Archipelago, with only one moss, while at least one species of Chara occurs; two-thirds of the Cryptogams obtained are Fungi or Lichens. It ought not to be concluded, because one of the Frungi enumerated has as yet been reported only from Minikoi that it is truly endemic in that island; in all probability it will yet be found to occur elsewhere. The Marine Algæ mentioned above will in all probability be found when they are at length collected to belong to some of the commoner Indian Ocean forms.

A synoptic view of the Flora is given in the table which follows :- 
78 JOURNAL, BOMBAY NATURAL HIŞTORY SOCIETY, Vol.VIII.

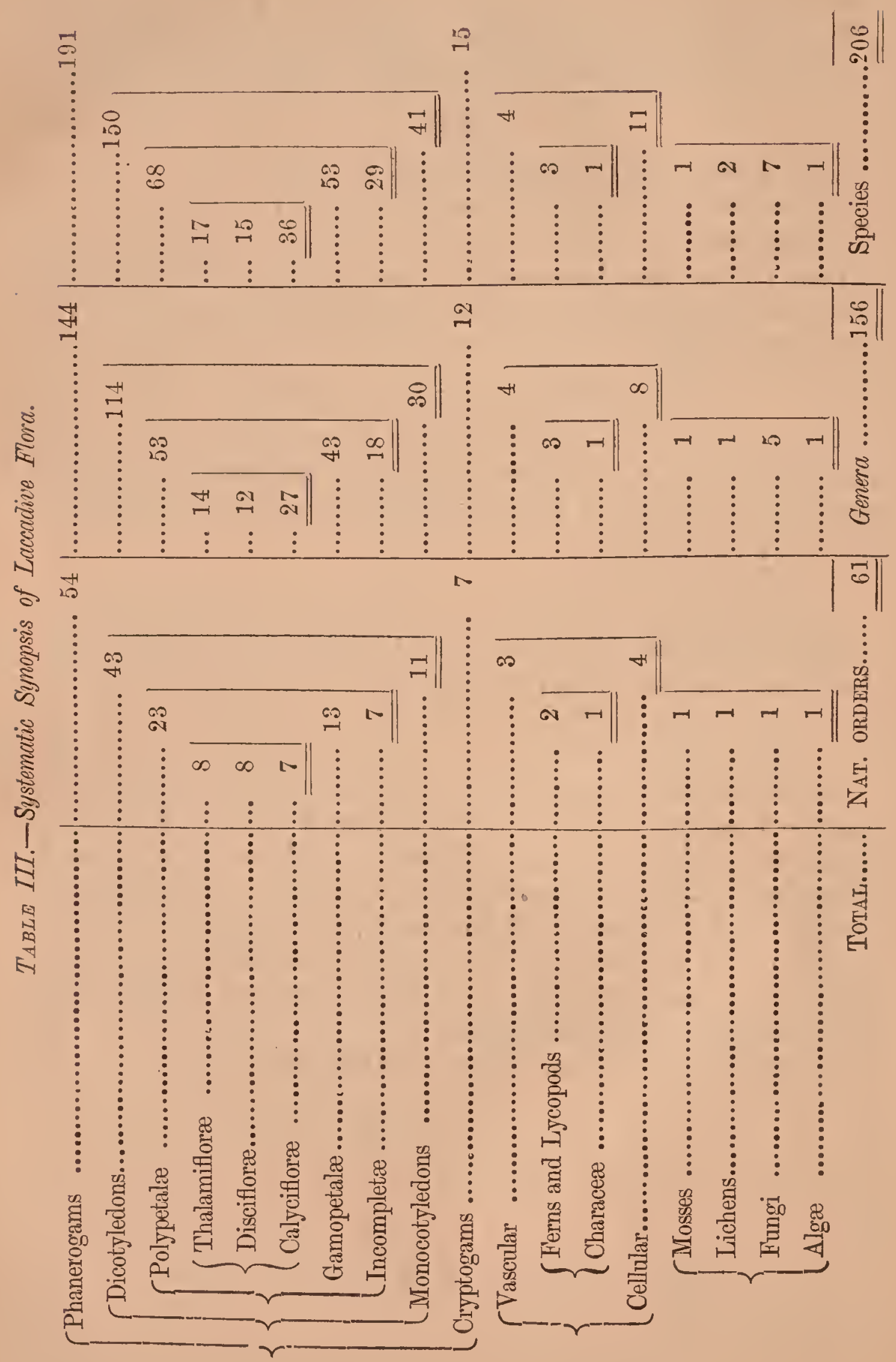


Of the 60 natural orders, 28 are represented by only one species; 10 by two species; 7 by three specics. The most extensively represented natural ordcrs are Leguminosce $(21 \mathrm{sp}$.) and Graminece $(20 \mathrm{sp}$.$) ; followed by Euphorbiacece$ (14 sp.) and Compositce (10 sp.); Malvacece (9 sp.), Rubiacece and Cyperacece (erch $8 \mathrm{sp}$.) ; Convolvutacece and Fumgi (Hymenomycetes) (each $7 \mathrm{sp}$ ); Rutccece, Cucurbitacere and Solanacece (each $6 \mathrm{sp}$.) ; Acanthacees and Urticacece (cach $5 \mathrm{sp}$.$) ; Verbenaceae (4 sp.).$

The land-mark height of the islands of the group is usually about 60 fect; none of them exceed this. Deducting, therefore, the 12 to 15 feet of coral formation that composes the islands, we find that none of the trees in the group are more than 45 to 50 feet high. The tallest trees, and those that in all the inhabited islands, except Kadamum, form at the same time the bulk of the vegetation, are the coco-nuts, which are cultivated; the majority of the remaining arboreal forms are also cultivated species, most of them being fruittrees like Anona muricata, Artocarpus incisa, Mangifera indica, Tamarindus indica, or trees like Moringa pterygosperma, with an immediate, or, like Sesbania grandiflora, with an indirect economic interest. There are only five arboreal species that are at all likely to be truly "indigenous" in the accepted sense of the term; four of these-the Thespesia, the Calophyllum, the Pisonia and Terminalia Catappa-are probably sea-introduced, the fifth (Ficus nitida) is perhaps a bird-introduced species ; four, however, as it happens, are known to be planted by the inhabitants at least in some of the islands, though three of them are undoubtedly " wild" as well as planted.

In the interior of the majority of the islands there is no true jungle, the whole cultivable area being occupied by coco-nut groves with small patches of gardenland $(k a t)$; on this account there is, as might be expected, only a flora of tropical cultivated species, with the usual tropical weeds of cultivation and Indian garden escapes reported from the centre or the islands, and with somc common Indian Ocean littoral species from the sea-fence that lines the shore. In the interior of the smaller uninhabited islands, such as Bitra and Bangáro, a densc jungle does, indeed, exist ; it is, however, composed of littoral species that have spread inward from the beach on both sides of the island till the two sea-fences have met and coalesced in the middle. In these islands the jungle is shrubly, hardly even subarboreal. The only island where there are cousiderable tracts of unoccupied ground, and where a true interior jungle exists, is Kadamum. Hcre also the jungle is of the nature of "scrub," and though there are present in it some quite characteristic inland forms, such as Pavetta, Pleurostylia and Flacourtic, which are not reported from the other islands, these do not exclusively compose the central jungle; characteristically " littoral" species, Premna, Miorinda and the like, cnter largely into its formation. 
Only 47 species are woody, 20 of these being trees, 25 shrubs, and 2 climbers. Of the 20 trees, 15 are cultivated species ; 4 of the remaining 5 are "littoral." Of the 159 herbaceous species, 119 arc herbs proper, 28 are climbers, and 12 are of the class of "tree-herbs" or "shrub-herbs" like MIusa or Carica and Agave or Calotropis.

From the nature of the group we are led to expect that none of the species are really indigenous ; further, that the majority of the species must have been introduced by man, and that next to human agency that of the sea has been most active. Detailed examination confirms these anticipations, for we find that as many as 127 species (three-fifths of the whole flora) are species that have been introduced by man. Of these, 52, or a fourth of the whole flora, are purely cultivated plants ; 7 others that appear mostly in an apparently wild state are likewisc cultivated ; 4 that are cultivated occur occasionally as escapes. These figmres refer to plants grown for economic reasons, but there are 13 other species that are "garden escapes" in the more usual sense, being bright-flowered or sweet-smelling spccies originally grown deliberately. The remaining 64 species are mere wecds.

Of the balance, the larger moiety ( 41 species or one-fifth of the whole flom) consists of "littoral" sca-introduced species; the remainder includes 9 marsh or water specics (a very smal proportion of the flora) and 27 inland specics.

The people of Minikoi cultivate 40 species as against 24 cultivated in Amoni, 18 in Anderut, 13 in Akati, 13 in Kiltán and 11 in Kadamum. The figures for the other islands are not at all complete. Doubtless, for some of thesc they are imperfect, but there is no reason to doubt that the numbers given are approximately true ; they place the islands in a series which accords very well with the general accounts that have been given by those who have visited the islands, of the relative wealth and comfort of the people.

The cultivation of most of the species is the direct result of the intercourse of the people with the Indian mainland, perhaps the chief exccption is their use of the South Sea Islanders' Taro (Tacca pinnatifita). Of the cultivated plants, 10 are originally American, 5 originally African, 2 originally Chimese, the rest either Indian or Indo-Malayan ; the cultivation of nearly all the species is now, however, cosmopolitan in the tropics.

The reeds, like the cultivated plants, are by no means evenly distributed. throughout the Archipelago. Of the whole 64 species, as many as 20 are reported from only onc island; even if we allow for the possibility of a species having been here and there overlooked, the proportion is very high. Without going into too great detail, it may be noted that 8 of these weeds-one-eighth of the reed-list-are reported only from Minikoi ; more remarkable still, 31 speciesvery nearly one-half the list-occur' in one or other of Laccadives proper, but not in Minikoi. The meaning of this is not very clear; it may be partly due to there being no large waste area in Minikoi, as there is for instance in Kadamum; perhaps, too, the people hold less intercourse with India than do those of the other 
islands. That they do hold some may be surmised from the presence in Minikoi of one species, Aneilema ovalifolium, which is found in India only, not appearing even in Ceylon or in any of the other Laccadive Islands. It is, of course, not impossible that this is a bird-introduced species, in which case its peculiarly limited area of distribution is difficult to explain. As regards Kadamum, the same remarks apply to the even more restricted. Cyperus hyalinus; perhaps, however, this species may not be in South India so rare as we at present think.

So far as their general distribution goes, $26(40 \%)$ of the weeds are cosmopolitan in the tropics-a few have not been reported from the Mascarene Islands, though they occur in Africa itself ; other 10 are nearly cosmopolitan, being present in both hemispheres-of these, 4 are absent from Polynesia, 2 from Australia, 3 from Australia and Polynesia, and one, which is confined to South-Eastern Asia and America, from Africa also. Altogether, therefore, 36 of these species, or $56 \%$ of the weeds, occur in the tropics of both hemispheres.

Of the species absent from the new world, there are 2 which extend from the Eastern Hemisphere to Polynesia, and 2 more that extend to Australia without reaching Polynesia. As many as 11 species, or $17 \%$ of the weeds, are com. mon to Africa and South-Eastern Asia ; but 4 of these are African only in the sense that they occur as weeds, no doubt introdnced from India, in Mauritius. Of the whole, 13 species, or $20 \%$ of the weeds, are confined to Asia; all of them occur in India, though it is noteworthy that no fewer than 9 of them appear to be unknown in Ceylon; this being so, we are not surprised to find that 14 of them are unknown in Malay countries.

Considering next the species of the "sylvestrian" class as opposed to those introduced by human agency, we expect that as the islands appeared above sea-level, they must first have afforded a footing for littoral specios. Such plants could scarcely in point of time be preceded even by species of the wind-introduced class, while the conditions on the islands would be much more favourable for sea-introduced than for wind-introduced ones. Introduction by birds could only become active after species of the other classes had been established and had rendered the islands sufficiently attractive and conspicuous for birds to alight on them. We anticipate, therefore, that of the three kinds of species mentioned the littoral sea-introduced class should be comparatively numerous, the other classes relatively scarce. This expectation is fully borne out by the facts.

The const-flora includes 41 unequivocally sea-introduced plants, and forms a fifth, or $20 \%$, of the entire Flora. Of these 41 species, 12 , or $29 \%$ (nearly a third), are cosmopolitan on tropical seashores. Of the remainder, 11 species, or nearly $27 \%$, extend from Polynesia to these islands, no fewer than 9 of them extending further west to Africa, or the Mascarene Islands, or both. There are 3 species that do not extend further east than to Australia and 13 that do not 
extend further than Malaya. On the other hand, 2 species (Launea pinnatifita and Cyperus pachyrhizus) find on the Laccadives and the adjacent Indian Coasts their extreme eastmost extension; the Cyperus is a plant characteristic of the western coasts of India and of Arabia, the Launea occurs on the coasts of Easstern Africa-across the Arabian Sea-as well. With these two exceptions, however, all of the littoral species occur on Malay Coasts, and it is significant of the extent to which the sea-board flora is Malayan rather than Indian. When we observe that though 39, or over $97 \%$, of them are found in Malaya, no fewer than 8 , or $20 \%$, of them are absent from the ncighbouring Indian Coasts. The islands come, therefore, more within the influence of those ocean-currents that sweep up from the south-east from Malayan Seas than does the Indian Coast ; their shorcs, therefore, have some of the species characteristic of nearly every tropical coast from Fiji to the Seychelles that are wanting in India.

Of inland as opposed to littoral species those that are wind-intioduced, as bcing likely to appear earliest, are the first to be considered. These are Phanerogians with seeds or fruits fitted for wind-carriage-of which there are here but two unequivocal examples (Tylophora and Leptadenia)—and small spored Cryptogams, of which there are 14. The two Phanerogams are species confined to SouthEastern Asia ; of the Cryptogams, on the other hand, 10 are cosmopolitan in the tropics ; one (Trametes Muelleri, which occurs likewise in Australia and in South America) is nearly so ; another (Calymperes Dozyanum) occurs throughout SouthEastern Asia and in Polynesia; only two are confined to South-Eastern Asia, and of these one has, so far as is at present known, been found only in Minikoi.

Of the species introduced by birds, whether by being carried in pellets of mud or otherwise attached to their feet or their feathers, or carried as undigested seeds in their crops, the flora affords very few examples.

Of the former subgroup, consisting of marsh weeds with small seeds or fruits, there are but 9 unequivocal examples. They are, as a rule, widely distributed species; here, for example, three occur in both hemispheres-two arc found throughout the tropies of the old world ; one extends from India to Polynesia. Only one is confined to South-Eastcrn Asia, and of one-the Chara, whose specific identity is unknown-

Of the second subgroup, species with soft fruits but resistent seeds, there are only 8 clear examples. Their most notable feature as compared with the last is their confined distribution. None are cosmopolitan, only one extends eastwards as far as Polynesia, and this one (Ficus nitide) does not even in that direction pass beyond New Caledonia; at the same time only one (Datura fastuosa) extends to America, and though its introduction by birds is clearly possible, * it is, no doubt, more usually introduced by man. While three species extend to Austriblia and four to the Mascarene Islands or Africa, it is wortliy of note that none of

* Prain, Proccedings of the Asiatic Society of Bengal (1S91), p. 171. 
them occur both in Africa and in Australia. Indeed, one speoies, Pleurostylia Wightii, exhibits the peculiarity of being restricted to Ceylon, Southern India, the Island of Kadamum and Mauritius ; with this solitary exception, however, all the species of this kind occur in Malaya, as well as in India and Ceylon.

Reviewing in tabular form the facts indicated in the preceding paragraphs, we find the number and proportion of the species that have been certainly, or possibly, or probably influenced by the various distributive agencies to be as follows :-

TABLE IV.-Modes of introduction of Laccadive Plants.

\begin{tabular}{|c|c|c|c|c|c|c|}
\hline \multirow{2}{*}{ INTRODUCED BY } & \multicolumn{2}{|c|}{ Certainly. } & \multicolumn{2}{|c|}{ Possibly. } & \multicolumn{2}{|c|}{ PROBABLY. } \\
\hline & No. of $\mathrm{Sp}$. & Per cent. & No. of Sp. & Per cent. & $\mathrm{No}$, of $\mathrm{Sp}$. & Per cent. \\
\hline 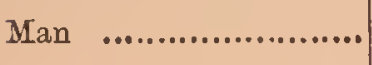 & 115 & $56 \%$ & 139 & $68 \%$ & 129 & $63 \%$ \\
\hline The Sea ...................... & 35 & $12 \%$ & 45 & $22 \%$ & 41 & $20 \%$ \\
\hline Winds $\quad . . . . . . . . . . . . . . . .$. & 16 & $8 \%$ & 18 & $9 \%$ & 17 & $8 \%$ \\
\hline Birds ..................... & 15 & $7 \%$ & 21 & $10 \%$ & 19 & $9 \%$ \\
\hline
\end{tabular}

At the same time, omitting from consideration the cultivated species and garden escapes, the majority of which are exotics, as well as the undetermined Chara, the general distribution of the Laccadive Flora may be tabulated as follows : -

$$
\text { TABLE V.-Synopsis of Distribution of Laccadive Species. }
$$

Cultivated species, garden escapes, undetermíned species

Cosmopolitan in the Tropics.

Almost so : present in both Hemispheres Absent from Polynesia only

Absent from Australia only

Absent from Australia and Polynesia 0100000.0

Absent from Africa, Australia, Polynesia .........

Confined to Old World

$$
\overline{\text { Africa, Australia, Polynesia }}
$$

In Africa, Asia, Australia, Polynesia.................. 13

In Africa, Asia, Australia ...........................

In Africa and Asia

In Asia, Australia, Polynesia

In Asia, Australia.

In Asia, Polynesia

Confined to S. E. Asia
66
51

12

$$
6 \%
$$

$37 \cdot 3 \%$

$251^{\circ}$
$31.6 \%$

$2 \%$
$1 \%$
$2 \%$
$1 \%$

.......... 6.3 2. 2 $9 \cdot 3$

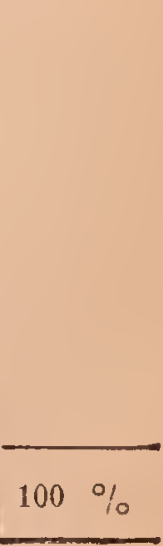

TotaL 
Since this paper was published, the writer has learned that while it is true that in Sir Wm. Robinson's day the Southern Laccadive islands belonged to the Cannanore raj, and though this arrangement was still in force at the time of $\mathrm{Mr}_{\mathrm{r}}$. A. O. Hume's visit in 1875, very shortly after this date they were, owing to revenue arrears, placed directly under British rule.*

The name given in this paper to the excavated areas under cultivation is Wrong. Sir Wm. Robinson gives two names-the tot or kat, and the writer following what has become the more usual custom has unfortunately employed the latter only. But it is the word tot, which is a form of the Malayalam word for garden, that should alone be used; the word kat is a form of a Malayalam word for forest or jungle and is altogether inapplicable. The writer is indebted to Mr. Winterbotham, Collector of Tanjore, for kindly pointing out this error to him.

Mr. Winterbotham informs him also that on Suhelipar reef there is an island, Suheli ; and that it has coco-nut trees. $†$

In addition to the species enumerated in the list of plants should be inserted after n.163, 163b. Alocasia INDICA, Linn, which, as well as Colocasia antiquorum, is cultivated in Kalpéni, and perhaps in some of the other islands.

* It is characteristic of the inexactness of the information contained in the Imperial Gazetteer of India that even its second edition (1886) makes no mention of this not unimportant fact.

What would happen were these arrears to be paid up it is very hard to predict. The inhabitants of the southern islands, after nearly twenty years' experience of settled British administration, declare that they will resist by force any attempt on the part of the Canuanore raj to re-impose on them a native domination.

f It is not unlikely that, as in Bitrapar, these coco-nut trees have been planted. The island has a particularly fine lagoon and is often visited for its nuts and coir; doubtless it would be permanently inhabited were it not that, again exactly as in Bitrapar, when wells are dug only brackish and undrinkable water is obtained. One of the special features of Suheli is the presence of a large Banyan tree, clearly a planted species. 


\section{Index of Species and Synonyas.}

Abutilon indicun $G$. Don populifolium $\mathrm{G}$. Don

Acalypha fallax Muell.-Arg. Hochstetteri Muell.-Arg. indica $L$. indica Prain Mercurialis A. Juss.

Achyranthes aspera $L$. bidentata $\mathrm{Bl}$. lanata I.

porphyristachya Wall. 55 Adenostenima reticulatum DC. viscosum Forst.

Aegle Marmelos Corr.

Aerua lanata Juss.

Aeschynomene grandiflora $\mathrm{L}$.

AgsTI sfinulosa Roxb.

Agati grandiflore Desv.

Agave Cantula Roxb. vivipara $L$.

Ageratum aquaticum Roxb. conyzoides $L$. cordifolium Roxb.

Ajuga disticha Roxb.

Alexandrian LaUReL

Allophylus Cobbe $B l$.

Amarantus viridis $L$.

American Aloe, Bastard

AMLA

Ammania baccifera $L$. vesicatoria $\mathrm{Roxb}$.

Anatto

Andropogon contortus $L$. muricatus Retz Sorghum Roxb. squarrosus L.f.

Aneilema ovalifolium $H$. $f$.

Anisomeles ovata $R . B r$.

Anona muricata $L$.

Apluda aristata $L$.

Arachis hypogaea $L$.

Arbor ouigera Rumph resis Rumph

Areca Catechu $L$.

Artocarpus incisa Forst. integrifolia L.f.

Arum Colocasia I.

Asilepias asthmatica Willd. gigantea Willd.
29 Asclepias suberosa Roxb.

30

60

60

60

60

60

55

$5^{6}$

44

44

32

55

35

35

35

35

63

63

44

$+4$

44

55

29

33

55

63

59

40

40

28

73

73

74

73

64

5.3

28

74

$3^{6}$

57

57

64

$6 \mathrm{I}$

62

70

47

46

BAEL

Ballota disticha L.

BANYAN

Barbadofs Cotton

Barleria ciliata Hume

cristata Prain

Prionitis $L$.

BASIL

Bersera Koenigii Vahl

BETEL-NUT

Biclens bipinnata I. pilosa $L$.

Bird's-eye Chillie

Bixa Orellana $L$.

Black 1) hatoora

Black Plum

Blumea laciniata $D C$.

Boerhaavia diffusa $\mathrm{L}$. repens $L$.

BREAD-FRUIT

Buchnera asiatica L. lineata DC. turgida Grah.

Cape Gooseberry

Carica Papraya $L$.

Cassia nccidentalis $L$.

Tora $L$.

Cassytha filiformis $L$.

Castor-oil

Ceanothus asiaticus L.

Celastrus opposita IVall.

Chara sp.
Bastard Amfrican Aloe procumbens Banks

6 I

63

3 I

64

45

45

$5 \circ$

28

50

40

44

54

54

54

$6 \mathrm{r}$

$5 \mathrm{I}$

Caesalpinia Bonducella Flem. $\quad 38$

Calophyllum inophyllum $L$. $\quad 29$

Calotropis gigantea $R \cdot B r$. $\quad 4^{6}$

Calymperes Dozyanum Mitt. mollucense D. \& M. 75

Canaralin ensiformis DC. obtusifolia $D C$.

Capellenia molucana T. \& B.

Capsicum frutescens $L$.

mininum Roxb.

75

75
36
37

37

37

$3^{6}$

49

58

50

50

Cardinspernum Halicacabum L. 33

Carpoposon capitatum Roxb. $\quad 36$

Cephalandra indica Naud. 
Chillie

Cicca disticha L.

Cissus camosa Roxb. quadrangularis Rosh.

Citrus acida Roxb. Aurantium $L$. decumana $L$. medica $L$.

Claoxylon Mercurialis Thzo.

Cleome viscosa $L$.

Clitoria ternatea $L$.

Const Moon-Flower

Coco-nut

Cocos nucifera $L$.

Colocasia antiquorum Sch.

Colubrins asiatica Brogn.

Commelina cristata $\mathrm{L}$.

Convolvulus alsinoides $L$ Bataías I. dissechus L. grandiflorus I. f. parviflorus Vahl Pes-iaprae L.

Conyza cinerea $\mathrm{L}$. laciniata Roxb.

Corchorus acutangulus Lamk fuscus Roxb.

Coronilla aculeata IVilld.

Cotton

Country Almond

Crepis acaulis H.f.

Crotalaria retusa $L$. verrucosa $L$.

Cucumber

Cucumis Melo $L$. sativus $L$. utilissimus Roxl

Cucurbita maxima Duch.

Cyanotis cristata $R$. $\& S$.

Cynanchum alatum. Prain reticulatum IVilld.

Cynodon Dactylon Pers.

Cyperus compressus $L$. conglomeratus Rotil). dubius Rotth. hyalinus $V a h l$ pachyrrhizus $N$ ees i ennatus Lamk polystachyus Rottb.

j)atura fastuosa $L$.
50 Dentella repens Furst.

60 Desmodium trifloruni $D C$. $\quad 36$

33

I) Hatoora

33

$3 \mathrm{I}$

32

$3^{2}$

3 I

60

28

36

47

64

64

70

32

64

49

48

48

47

48

48

44

44

$3 \mathrm{~T}$

$3 \mathbf{I}$

35

3 I

$3 I$

49

35

34

44

4 I

4 I

4 I

41

64

47

47

74

70

70

7 I

70

70

70

70

50

Dioscorea buibifera $L$. sativa $L$.

Dolichos Catjang L. lineatus Thby Iuteus Siv. obiordatus Roxb. rotundifulius Rusb).

Eclipta alba Hassk. prostrata I.

Elensine acgyptiaca Pers. Curacana Gaertn indica Gaertn.

Endospermum formicarium Becc. $5^{8}$

Eragrostis plumosa Steud. moluccanum Becc. 58 tenella Trin.

Eugenia Jambolana $L$. Jambos $L$.

Euphorbia Atoto First. hirta L. hypericifolia $L$. parviflora I. pilulifera $L$. thymifolia $L$.

Evolvulus alsinoides $L$. angustifolius Roxb. linifolius $\mathrm{L}$.

Ficus bengalensis $L$.

Benjamina IVilld.

indica L.

nitida Thhg.

retusa $L$.

Fimbristylis diphylla $V a h l$

Flacourtia sepiaria Roxb.

Galesa diffusa Roxb.

Gloriosa superba $L$.

Gourd herbaceum $L$.

Gratiola Monnieria L.

GROUND-NUT

Guava

Guetlarda speciosa $I$. 


\section{Gulal Tulsi}

Hedysarun triflorum L.

HENNA

Hernandia ovigera Gaertn. ozigera $\mathrm{L}$. peltata $L$. sonora $\mathrm{L}$.

Herpestis Monnieria H.B.K.

Hibiscus populneus L. rosa-sinensis $L$. Solandra $L^{\prime} H e r$. tiliaceus $L$.

Hirneola polytricha Mont. HoRse-RAdish TREE Hj'peranthera Moringa Vahl

Indian COTTON

Privet

TARO

IN DIGO

Indigofera cordifolia Heyne tinctoria $L$.

Ipomoea Batatas $L$. biloba Forsk.

Bona-nox L.

denticulata Choisy grandiffora Lamk grandiflora Roxb. Pes-caprae Roth sinuata Ortega

Ischaemum ciliare Retz muticum $L$. repens $\mathrm{R} n \mathrm{xb}$. tenellum Roxb.

Ixora Bandhuca Roxb. coccinea $L$. paniculata Lamk Pavtta Roxb.

JACK-FRUIT

Justicia bicalyculata Vahl pectinata $\mathrm{L}$.

$\mathrm{KACHU}$

KhUs Khus Grass

Kyllinga brevifolia Rottb.

Launea pinnatifida Cass.

Lawsonia alba $L$. inermis $\mathrm{L}$.

\section{3}

Lawsonia spinosa $\mathrm{L}$.

40

Leptadenia reticulata $W$. \& $A .47$

Lepturus repens $R . B r$.

LINE

Linaria ramosissima Wall.

Lippia nodiflora Rich.

Lobelia frutescens $\mathrm{L}$.

Taccada Gaertn.

Luffa aegyptiaca Mill. clazata Rnxb. pentandra Roxb. racemosa Roxb.

Mangifera indica $L$.

Mango

Marua millet

Marvel of Peru

MELON

Mendi

Mercurialis alternifolia Desv.

Micrococca Mercurialis Bth. 60

Microstachys Mercurialis Dalz. 60

Mirabilis Jalapa $L$.

Momordica Charantia $L$.

Luffa L.

MOON-FLOWER Inffere $4 \mathrm{I}$

Moringa pterygosperma Gaertu. 34

Mucuna capitata $W$. \&o $A$. $\quad 36$

MUdAR pruviens DC.

Murraya Koenigii Spreng.

Musa sapientum $L$.

Nepetir indica $L$.

Nephrodium molle Desv.

Nephrolepis cordifolia Presl

Nicandra indica R. \& S.

Nostnc verrucosum Vauch.

Nyctanthes hirsuta L.

Ochrosia borbonica Gmel.

Osimum Basilicum L.

Oldenlandia biflora $L$. gratissimum $L$. sanctum $\mathrm{L}$. bifiora Lamk corymbosa $L$. 
Oldenlandia diffusa Roxh. ramosa Roxb. repens $\mathrm{L}$.

42

42

42

Oplismenus Burmanni Beaur. $7 \mathrm{I}$ compositus $R$. \& $S .7 \mathrm{r}$

ORANGE

Omithotrope Cobbe IVilld.

Oryza coarctata Roxb. sativa $L$.

Pancratiun zeylanicum $L$.

Pandanus odoratissimus $L$. $f$.

Panicum Burmanni Retz ciliare Retz

Dactylon L.

lanceolatum $\mathrm{R}$ (ixb.

sanguinale $L$. ierticillatum $\mathrm{L}$.

PAPAW

Peristrophe bicalyculata Nees

Phaseolus calcaratus Roxb.

$\begin{array}{lr}\text { Phlomis esculenta Roxb. } & 54 \\ \text { Phyllanthus distichus Muell. Ars.60 }\end{array}$

Emblica $L$.

longifolizes Jacq.

maderaspatensis $L .59$

Niruri $L$.

obcordatus WVilld. rotundifolius Klein

Urinaria $L$.

Physalis minima $L$. peruviana $L$.

Physcia leucomela Miclix obscura Fries

Piper Betle $L$.

Pisonia alba Span. inermis Forst.

PIANTAIN

Pleurostylia Wightii $I V$. S 4 .

Pleurotus cuneatus Mass. tenuissimus $\int u n g h /$.

Plumbago zeylanica $L$.

Pra plamosa Retz

$$
\text { tenella L. }
$$

Polygala erioptera $D C$.

Vahliana I)C.

Polsgonum batbatum $L$. rioulare Koen.

Polsporus igniarius Fries POMEGRANATE
Ponelo

POON-SPAR

Portia TreE

Portulaca oleracea $L$. Portulacastrum L. tuberosa Rosb.

Pouzolzia alienatu Giud. indica Gaud.

Premna integrifolia $L$ serratifoiia L. spinosa Roxb.

Prenanthes acaulis Roxb. $\quad 45$ asplenifolia Roxb. 45

Psidiun Guajava $L$. pomifermm $\mathrm{I}$. pyrifermm $\mathrm{L}$.

Psilotum triquetrum. Sze. $\quad 75$

Punica Granatum $L$. 40

RA'GI

RAM TUlsI

Rhus Cobbe L. $\quad 33$

RicE

Ricinus communis $L$. 60

Rose-ApPLE

Ruellia prostrata Poir. ringens $\mathrm{Rox} b$.

Rungia linifolia Nees parviflora Nees pectinata Nees

Saccharum officinarum $L . \quad 73$

Scaevola Koenigii $V_{a} h l \quad 46$

Taccada Roxb. $\quad 46$

Schizophytlum commune Fries 76

Scirpus miliacens Roxb. 7 I

Senna occidentalis Roxb. $\quad 39$

Tora Roxb. $\quad 39$

Serratula cinerea Roxb. $\quad 44$

Sesban grandiforus Poir. $\quad 35$

Seshania aculeata Pers. $\quad 35$ grandiflora Pers. $\quad 35$

Sesuvium Portulacastrum $L$. $\quad 4$ I

Setaria verticillata Beauv. 7 I

SHADDOCK 32

SHOE-FLOWER 30

Sida humilis Hilld. $\quad 29$ indica L. 30

populifolia Lamk 30

Solanum stramonifolizm Roxb. 49 torvun Sze. 
SORGHUM

Sorghum vulgare Pers.

SOUR-SOP

South-Sea Taro

Spinifex squarrosus $L$.

Stachytarpheta indica Valul

Striga lutea Lour.

Suriana maritima $L$.

SwEET-POTATO

Tacca pinnatifida Forst.

TAMARIND

Tamarindus indica $L$.

TARO

Tephrosia pumila Pers. purpurea Pers. tenuis Wall.

Terminalia Catappa $L$.

Thespesia populnea Corr.

Thuarea sarmentosa Pers.

Tournefortia argentea $L$. $f$.

Tragia Mercurialis L.

Trametes Muelleri Berk.

Triphasia trifoliata $D C$.

TULSI

Tylophora asthmatica $W$. \& $A .47$

63

72

52

$5 \mathrm{r}$

$3^{2}$

48

63,70

39

72

47

60

76

31
79 Urena sinuata $L$.

74 Urtica suffruticosa Roxb.

30 28 .

Vernonia cinerea Less.

a indica $\mathrm{L}$.

$5^{2}$

nodiftora $\mathrm{L}$.

Verbesina calendulacea L. Lazinia-alba L. scandens Roxb.

$5^{2}$

45

45

45

44

$3^{8}$

Vigna Catjang Endl. lutea $A$. $G r$.

Vitis carnosa Wall.

quadrangularis Wall.

$3^{8}$

33

35 .

35

35

$3 \circ$

YAMI

53
63

Wedelia calendulacea Less. $\quad 45$

Winter-Cherry 49

Woilastonia Horsfieldiana Miq. 45 insularis DC. $\quad 45$

Zanichellia palustris L. 



\section{DIRECTIONS}

FOR

\section{DRYING SPECIMENS OF PLANTS FOR A HERBARIUM.}

REPRINTED FROM THE "ASIAN",

Vol. XXVIII; No. 40I; P. I94:

JUNE IO, 1892. 


\section{DIRECTIONS}

FOR

\section{DRYING SPECIMENS OF PLANTS FOR A HERBARIUM.*}

THE object of all BOTANICAL COLLECTION is to secure such specimens of the various herbs, shrubs and trees to be met with in a particular district as are capable of being studied in a herbarium. To be of use specimens must be dried, and the great object is to dry them thoroughly and to dry them quickly.

For this purpose it is advisable to provide-

First.-A quantity of the thick grey blotting paper made in Indian jails. The sheets of this when folded once measure from is to 22 inches long by I 2 to I6 inches wide. It is very cheap and supplies of it can always be had at the Botanical Garden, Calcutta. This is not only the most efficient drying paper made in India, it is surpassed by no material in the world. But at a pinch other kinds of paper will do, provided the surface be not glazed. Specimens will not, however, dry between the leaves of a note book or in a letter ; it is impossible to absorb moisture sufficiently rapidly if paper with a highly polished surface, like writing paper, be used.

Second.-A few split bamboo or cane wicker-work frames with open meshes. These frames should be of the same size as the drying paper and can be obtained of a basket-maker in any part of India ; a few annas will purchase as many as one requires. In Assam, Burma, or Malaya an obliging villager will put them together for one on the spot. It is not amiss to provide a few pairs of wire frames

* These directions, which are drawn up at the request of Dr. King, C. I. E., F. R. S., Superintendent of the Royal Botanical Garden, Calcutta, are essentially a new edition of the "Directions" issued by that officer in 1875 with added suggestions, the result of exferience, personal and administrative, derived during the past fifteen years from botanical research by Dr. King himself and his officers in the Transgangetic Peninsula and in the Eastern Himalaya, provinces where the difficulties of collection are many times greater than they are in most parts of India or in any part of the North-west Himalaya. They are meant for the assistance of Inclian officers, and in them_reference is made solely to articles that it is easy for a resident in India to obtain. 
of the same size and the same general character as the cane ones. The best kind of wire to use is galvanized wire: for sides of frame No. 7 W.G. $\left(\frac{3}{16}{ }^{\prime \prime}\right)$ is a good size ; for meshes No. I4 W.G. (about $\frac{1}{16}{ }^{\prime \prime}$ ). These have the advantage of standing wear and tear, but possess the disadvantage of being heavier, and it is not advisable, especially if one is moving about a great deal, to lay in a large stock of them. Sheets of book-binders' paste-board are useful when tying up bundles of dried specimens; cane frames do, however, quite as well for this, and paste-board should never be used when drying the plants. If by any chance one comes into possession of the heavy wooden 'dryingframes' and 'pressing-boards' that are sometimes seen in Europe, it is advisable to take an early opportunity of burning them.

Third.-Some thin dry waste paper is needed to put the specimens between when they are dry. Old newspaper is as good as any, and the handiest of the sizes available in India is that of the familiar Pioneer: the ordinary Daily needs folding or cutting; the ordinary Weekly is too small to make bundles with measurements that accord with those of the drying paper and frames. A most fruitful source of trouble in transit and storage and of destruction to specimens is a want of uniformity between the size of the drying and of the storing papers.

Fourth.- Some sheets of tarpaulin, in size 4 fect by $4 \frac{1}{2}$ feet. These are absolutely essential to tie the drying paper and the newspaper up in, and this is the most convenient size* to provide. It is best to have about twice as many sheets as you possess "bundles" of empty drying and storing paper combined. A number of sheets of thin oiled cloth-momjama-the size of the tarpaulin sheets, are also very convenient.

Fifth. - As much stout rope as is necessary to tic up all the tarpaulin-covered bundles one is likely to have and a quantity of fairly stout string.

Sixth - Something to hold specimens when out collecting. It is generally enough to see that one's attendant cooly has the customary wicker basket; make him line it with plantain leaves and put the specimens in it. But, especially in the rains, specimens come home in capital order if laid in a cloth or even if simply done up in a bundle ;

* The size is regulated by that essential factor in all Indian travel-a cooly's load. A comfortable load for an ordinary cooly in the plains is 30 seers (a hill man will carry more, but, all things considered, it is as well not to exceed the plains' figure anywhere), and it is found best to divide this into two bundles, each weighing fifteen seers, measuring as it happens $20 \times 16 \times 9$ inches and containing 150-160 double sheets of drying paper. Bundles a foot in thickness with specimens that are being dried between the sheets weigh eight or nine seers and contain 90 to Ioo sheets of paper. Of these a cooly easily carries three. Newspaper for dry specimens weighs when empty, bulk for bulk, nearly the same as drying paper; when full of specimens one bundle nine inches thick becomes converted into five bundles a foot thick. 
the only thing to be inculcated here is to avoid the use of the tin-box -the orthodox 'vasculum' that the dealer in botanical paraphernalia insists on advertising.

Finally, attach a kukri-frog to the sword-or shikar-belt, and never go into the jungle without putting on that belt and placing the kukri in its frog. This weapon, the well-known curved Gurkha knife, is invaluable to the botanist; it is light and handy, and it is his axe and bill-hook, his spud and pruning-knife all in one.

So much for material, now for method. Gather and dry the whole plant whenever this is possible; when it is impossible to get root, stem and branches together, take portions of the branches 12 to 8 inches long, always selecting those that are slender and in flower or in a more or less advanced state of fruit. Usually such pieces are sufficient, but it is sometimes desirable that more than this should be taken, as for instance when a tree has flowers only on its stem, or when a tree has unarmed branches and yet has spines on its trunk: in such cases a piece of bark and superficial stem (carefully noted as coming from the same tree as that which yields the branch specimens) should be taken to illustrate the fact. Plants or pieces of branches to be of the highest botanical value should show in the same specimen buds, leaves, flower buds, flowers and fruits in all stages up to ripeness. It is, however, often impossible to find all these together in the same branch or even on the same plant. In that case a plant should not be omitted; flowers alone or fruit alone should by all means be taken; another plant or another season often supplies the deficiency, and other collections sometimes contain the missing parts. The only thing to be remembered is that leaf specimens-' samples' of a plant which show neither its flower nor its fruit-are worth nothing, and that their collection is a waste of effort.

The attention of the collector should be principally directed to trees, and after them to small uninteresting-looking plants. Shrubs and showy-flowered species that attract attention by their colours or that can be seen without looking up or looking down may be trusted to take care of themselves. When one entrusts an untrained collector to obtain specimens, care should be taken that he does not confine his attention to the weeds of waste places and of hedgerows around villages; these are usually widely-spread species of little botanical interest.

It has been already said that the specimens have to be dried thoroughly and quickly. If not dried thoroughly, they mould and decay; if not dried quickly, they become unduly discoloured, their leaves drop off and their flowers become disintegrated, making it afterwards always difficult and often unsafe to say that particular leaves and par- 
ticular flowers or fruits belong to the same specimen. When putting out specimens for drying, lay upon one of the bamboo frames or upon a wire frame of the same size four double sheets of drying paper. On the topmost sheet spread as many specimens (which should, however, always be of the same individual gathering) as the sheet will contain in as natural positions as possible, taking care to flatten out the leaves and to prevent the flowers fron curling up. If the specimens be too long for the paper, fold them carefully or cut them in two. But avoid laying one part of a specimen above another; if the leaves or the flowers be too numerous to make this precaution possible, take some of them off, but always leave little bits of stalk to show whence leaves or flowers have been removed. Above this layer of specimens lay four more double sheets of paper; again on the uppermost spread a new layer of specimens, taking care that over the parts where the specimens of the previous layer exert most pressure those of the new layer shall exert little or none at all. Again lay four double sheets of paper and again sprcad a layer of specimens, repeatirig the process till there are six layers of specimens thus accommodated. Above the last place four more sheets of paper, above all a second bamboo or wire frame, and tie up the bundle thus made with string sufficiently tightly to prevent the specimens from slipping about between the sheets of drying paper. In drying thick stems it is often advantageous to split them vertically into two, and where the plant is fleshy the central softer part of the stem may also be taken out and thrown away. Fleshy fruits may be cut into thin transverse and longitudinal slices to facilitate drying. But where this is done, it is worth while also to attempt to dry some specimens of the same fruits uncut. Stone fruits and berries are often very difficult to dry if taken ripe; unripe or already shrivelled ones should therefore be gathered, only the colour of the ripe fruit being noted and ripe seeds collected and preserved. Soft fruits are best of all preserved in spirit. When any very succulent part is to be preserved, it is often a good plan to wrap a sheet of the drying paper round it so as to form an absorbent pad. And always when drying soft structures like succulent stems or gourds or berry and plum-like fruits, also when drying hard fruits that are fragile and when drying fungi, it is advisable to intersperse narrow but thick rolls of paper in such a manner as to obviate all save the very gentlest pressure on them while they are being dried. A little experience will show the colletor that there are many pod and capsule fruits that will, as they dry, break up and shed their contents, no matter what care be bestowed on their drying or what delicacy be exercised in handling them. Many of these, however, will remain intact if judiciously bound with threads while still green and before being 
placed in the drying paper; others can often be kept together if encased in a small net-such the natives of many parts of India will be induced for a small fee to make. When care of the kind is needed and taken, the excellence of the specimen that results amply repays the trouble bestowed, since in all herbaria it is usual to find that fruits of this kind, even when they belong to familiar plants, are but poorly represented. It has been said that all pressing boards should be discarded, this is not because they are cumbersome merely, but because they are positively disadvantageous. The straps that accompany these boards are a constant temptation to pull too tight and so exert a pressure that is always destructive. There should be just enough pressure after leaves and flowers have been flattened out to keep them so ; to effect this the strings with which the bundles are tied should, as has already been said, be drawn tight enough to prevent the specimens from moving between the sheets of drying paper. This is the best gauge of the amount of pressure necessary: it cannot conveniently be less-it never should be greater. Even when used properly, straps are in India a source of vexation; they go so readily out of repair. It is therefore best to begin by parting with them - giving them away gratifies the attendant who receives them and saves his master all further trouble with stitches that come undone and buckles that get broken.

In laying down a rule as to the number of sheets to be placed between different layers of specimens, a number has been chosen that will be found in all ordinary cases sufficient. But a definite figure is mentioned only because a collector just beginning work prefers some precise rule to go by. In reality the amount of paper to be interposed between two layers will depend on the nature of the plant dried and the facilities the collector has for drying it, the second circumstance being as a general rule of infinitely more consequence to him than the first. A very brief experience will show that for many herbaceous plants fewer, and for some thick or even thin-stemmed succulent ones and for certain fruits many more intermediate sheets are necessary. But what one must keep in view, and insist on his native collectors keeping in view, is that whatever number of layers of specimens a bundle may accommodate, it should never consist of more than 30 double sheets of drying, paper or be more than 5 inches thick. Delicate flowers should be carefully put in to paper when gathered: a small portable blotting pad is a very good thing to carry about for this purpose. There they can be kept flat till the close of the day's collection, when the sheets containing them can be laid in the drying paper along with the specimens to which they belong and along with the notes that refer to both. If one does not grudge the trouble and 
if one is collecting in the cold season or in the hot weather, the very best way to dry delicate plants is to take a bundle or two of drying paper to the field and lay the plants between their sheets as gathered.

Some very succulent plants and others with fine but rigid leaves, like pines, require to be plunged for an instant into boiling water ere they are pressed. In this case the superabundant moisture must be absorbed by a cloth or by blotting paper. Orchids should be placed in strong spirit before they are laid in the drying paper : they are best placed in spirit at the close of the day and taken out at the close of the day following when specimens are being changed. But care must be taken, while seeing that the pseudo-bulbs and leaves are covered completely by the spirit, to see also that the flowers protrude above its surface. Ferns, mosses and other cryptogamous plants may be generally dried in the common way; those that grow in tufts should be separated by the hand to form neat specimens. Seaweeds require a slight washing in fresh water, and common blotting paper is the best material for removing the moisture from this tribe of plants. Freshwater plants, besides being preserved by drying in the ordinary way, are often, like soft fruits, best preserved in spirit. Strong spirit should not be used however, as it renders the specimen brittle; the most convenient strength is 50 per cent., i.e., half of pure spirit and half of water. The mixture should be made as required, but time should be given it to cool before immersing the specimen.

Thereare two methods of making notes concerning specimens. One is to note the particulars concerning each on a separate page of a numbered note-book and to attach a slip of paper bearing the number of the note to the specimen. The other is to attach the slip of paper on which the note is written to the specimen to which the note refers. Each method has conveniences of its own, and for collectors who form a private harbarium the first has not a few advantages; on the whole, however, the second method is the one that will in the long run be preferred by most. But both plans to be of any value call for this : any particulars to be noted should be written day by day and placed beside the specimens when they are first laid out in drying paper. If written up and attached afterwards mistakes are certain to occur. The particulars most worth noting are (in order of importance)-date when gathered and locality; height above sea-level of the latter; colour of flower and fruit; habit and, when a plant is cultivated, this fact; also habitat.

The drying paper should be changed after the specimens have lain in it for a day, after that when they have lain in the fresh dry paper for three days, after that once or twice at longer intervals. It will then be found that the specimens are dry. The moist paper removed 
should be thoroughly-dried by the sun or before a fire. As soon as dry it is fit for use again, and, if treated carefully, the same paper may be used over and over again so long as it remains untorn.

Changing the paper between plants is a very simple matter, as the specimens after having been dried a little can be lifted with great ease. In the case of thin-leaved and delicate plants it is sometimes necessary to treat the sheets of paper on which they are laid as part of the specimen, removing these when the papers are changed with the specimens undisturbed upon them to the dry sheets. The uppermost sheets of the bundle where this has been done should be marked, and when next the papers in it are changed, the opposite side should be the one from which the papers are first removed. This ensures a renewal of both papers for every specimen with each alternate change.

This is advice that the collector is urged to begin by following implicitly. Probably he will in a short time ignore it altogether ; to begin with its neglect will only lead to disappointment, and any modification of it must depend entirely on his own appreciation of the atmospheric conditions of his station, and on his facilities for drying his specimens artificially and so of becoming independent of these conditions. In the cold weather in most parts of India the paper does not need to be often changed, while in the hot weather experience will very soon indicate a considerable class of plants that, if placed in thoroughly dry paper and exposed in very thin bundles to the sun, do not require to be looked at or changed at all until placed in the newspaper. At that season of the year a long plank, a flat rock, a sheet of corrugated iron, on which to place the bundles in a single layer in the full sunshine (care being taken to turn the bundles over three or four times a day) afford almost ideal drying facilities. Succulent plants and plants with large or with soft fruits should be in bundles by themselves; these bundles should be seen to every night and dry paper provided for them. Plants of this class, no matter how great one's drying facilities may be, cannot receive fresh paper too often ; mould is certain to attack them; it does so, indeed, more readily when they are being rapidly than when they are being slowly dried, if the paper containing them be not constantly changed. But during the rains, or when the atmosphere is charged with moisture (and this is only too often the case in Burma and Assam), it is a much more difficult matter to dry specimens. Still it can be done. If one is stationed near an ice-machine or a saw-mill or any industry that requires a steam-engine, the drying of specimens is reduced to a matter of diplomacy. Somewhere near the boiler of a river steamer too there is an atmosphere of excellent quality from the botanist's point of view. Still better when one has for a neighbour a 
tea-planter (and he is certain to be the most obliging of men), there is in the dry air of the tea-house an ideal botanical atmosphere. And when none of these are available, there is still a very simple and not at all an expensive plan that can be adopted. This is to convert a mud or brick outhouse into a drying chamber. All openings require to be closed up save a small one (that probably will require to be made) near the floor-level, and another, also small (that probably already exists), about 4 or 5 feet up the wall and on the opposite side of the room from the other. The door must fit fairly tightly. A large chafing dish (such as one's 'khansamah' uses daily in the cook-house, and which is to be obtained in almost any bazar-if not obtainable a subs. titute is easily improvised) placed in the middle of the room with a charcoal fire lit in it completes the equipment. The door being shut, sufficient air passes from opening to opening to keep the fire alive, and yet not enough to prevent this fire from rendering all of air the room contains almost absolutely moistureless. Shelves on which to lay the bundles or rods to which to tie them can be easily fitted up, and with a room such as this at command one is quite independent of the weather. Where an outhouse is not available, it is not a very costly matter to build one of bricks, of mud, or of corrugated iron, where any of these materials are available; where they are not, it is possible with care to dry one's specimens in a similar hut with mudplastered ekra walls and with a thatched roof. Such a house, however may catch fire, and it is advisable to build it at some distance from one's quarters and not to have all one's drying paper in it at a time. The general plan of the drying house, whatever its material, is simplicity itself: ground space 6-10 feet square; walls $6-7$ feet high; doorway the smallest compatible with the possibility of ingress; lower opening 6 inches from the ground in any wall and 4 inches square; upper opening in wall opposite, 18 inches from the eaves and 6 inches square. It is, perhaps, advisable that neither opening be on the side exposed to the quarter whence the prevailing rainy season wind blows.

When moving from place to place in the rainy season collecting is by no means so easy as at other times. One must then follorv implicitly the method of repeated change of papers detailed first, and troublesome as it is to change papers at the close of a long wet day's march, this trouble is really well repaid in the end. There are just a few things that it is well worth remembering. A few specimens well preserved are worth a whole hayrick of half-rotten material. Not that the collector, particularly when beginning work, should venture to decide as to what plants may be left uncollected. The true collector brings everything and leaves it entirely to the botanist who has 
the good fortune to possess or have access to a herbarium to reject or throw away a specimen. Never move on a botanical journey without having each bundle of paper in its own tarpaulin cover. Always see to it oneself at the commencement of the morning march that each tarpaulin thoroughly covers the bundle to which it belongs. Whenever one can make or take an opportunity of getting the bundles near a fire, do so. On returning to head-quarters, do not lose a moment before getting the specimens into fresh paper and bestowing them in the drying chamber.

There is another method of preserving specimens collected during the rains which might be of use where one is taking a very long journey, during the whole extent of which it will be impossible for him to halt for a day or two, so as to take or make an opportunity for redrying a damp paper. This is the method employed by the well-known African traveller Dr. Schweinfurth. The specimens at the end of a day's journey are laid in thick blotting paper, as they are in the ordinary method, only now no more than a single half sheet of paper need be placed between each layer of specimens. When a bundle has been formed, it is held up, so that one corner is higher than the rest. Spirit is poured gently on the paper at this corner, and is continued to be poured until the paper composing the bundle has absorbed so much that it begins to drip from the opposite lowest corner. Then the bundle is laid flat in the bottom of a tin-box of suitable length and breadth. Other similar bundles are formed and placed above the first. When the box is full, the lid is once for all soldered down, and the specimens keep perfectly till the end of the journey. With this as with the ordinary bottling spirit process the chief difficulty is that a spirit sufficiently strong to ensure that the specimens shall keep renders them exceedingly brittle, while a spirit so weak that the flowers are not spoiled by it for future herbarium work does not protect them permanently from decay. Excellent as this system is, it is better, therefore, to use it cautiously and in all cases to consider it but a temporary measure. Use, therefore, a weak spirit, and, when the journey is over, prepare the specimens by drying in the ordinary way.

Specimens that have been sufficiently dried should be laid between single sheets of newspaper. When unusually woody, like pines and oaks, or when there are large fruits attached, the specimens should have rolls of paper interspersed in the manner already described as necessary when drying them, and at the same time care should be used to distribute the specimens pretty equally over the sheets. It is needless to add that all plants when dried ought to be transmitted to the Botanical Garden, Calcutta, with the least possible delay. In the cold and 
hot seasons it is best to transmit them, bundle by bundle, as they get ready, by parcels post. In the rains it is not so advisable to do so if the distance be considerable, and if (as in then frequently the case with frontier districts) there is likely to be a delay in parcel transmission and probably a very inadequate storing accommodation on the part of the post office for the articles delayed. It is of little advantage afterwards to blame the postal authorities : no amount of upbraiding will replace a lost collection. As a matter of fact the post office does its very best everywhere, and knowing this, one should not incur risks where one knows that delays are likely or are even only remotely possible. When sending such bundles, it is well to put several sheets of news-paper out-side the outermost specimen, and besides a cane frame outside all, on both sides, to intersperse cane frames at intervals of about 30 specimens throughout the bundle. The size of bundle will be limited by postal regulations : the thicker it is possible to make it, provided always the specimens are thoroughly dry, the safer its contents will be. Outside the cane frames a covering of the momjama cloth should be sezved; outside this another covering of cloth (ordinary drill or long-cloth is excellent) also served, and it is far better to tie on a stout tag with the address than to write the address on the parcel itself. When it is necessary to keep dry specimens for $a$. few months during the rains until considerable numbers have accumulated, they may be sent in boxes by the easiest available carriage route. If they are to come all the way by cart or rail, it is sufficient to line these boxes with wax-cloth momjama; this ensures the contents remaining dry if the boxes be exposed to passing showers at any time. But if in any part of the journey the boxes are to be exposed to the risks of ferry or river or sea transit, it is best to put them inside a tinlined box (and to have the lining carefully soldered down) before despatching them.

When specimens have to be kept for more than one season, or where the collector retains a set of specimens for his own use, it is necessary to poison them. Unless this is done, they are sure to suffer and ultimately to be quite destroyed by the depredations of insects. Poisoning them, however, is a very simple matter. Some corrosive sublimate should be put in strong spirit ; $\frac{1}{4} t b$ may be dropped into a gallon of methylated spirit, and as the spirit will not dissolve anything like so much, this ensures that it will always have in solution as much corrosive sublimate as it can hold. The mixture should be painted on with a brush. When all the specimens in a bundle have been poisoned on one side, reverse the bundle and paint them on the opposite side; never lift or turn a specimen when poisonining it. It is often supposed 
that the effects of one such dose of so strong a poison must be permanent. No more disastrous fallacy exists. Still no definite rule can be laid down as to when repoisoning should be donc. One is always seeing one's specimens at intervals : when any sign of mischief is apparent at once give another dose.

Calcutta, 1890.

From the Journal, A siatic Society of Bengal, Vol. LXII, Part II, No. 3 , I 893.

153

Note on some methods of preparing Botanical specimens, communicating Memoranda by MessRs. C. MARIES, F.L.S., and R. PANTLING.By D. PRAIN.

[Read June 5th.]

Usually the preparation of botanical specimens is easy; some natural families, however, give a good deal of trouble. Those who have private herbaria are as interested to hear of improved methods of treating such families, as are those who look after public collections. The writer, therefore, would call general attention to modes of dealing with three troublesome families-Magnoliacece, Coniferce and Orchidacea.

I. MagnoliaCE $Æ$. The Champak family is not troublesome to preserve as to the leaves, but theflowers are apt to go to pieces. If, however, pieces of blotting-paper are carefully insinuated between the petals before the specimen is laid in drying-paper, and if the specimen is then rapidly fire-dried, even adult flowers may be preserved entire. Nothing, however, prevents the shrinkage of the large leathery petals. In this order shrinkage is so excessive and so unequal, that in the case of 
herbarium specimens the estimation of the size of the flowers becomes to some extent guess-work.

Those who know Rangoon may recollect the practice of selling bottles of flowers on the stairs of the Shwe-Dagon Pagoda. Unless, however, their stay has been long enough, or their interest sufficiently great, to have led them to notice that the flowers in these bottles are not fresh but preserved, they may have supposed, as the writer did, that the medium in which the flowers are kept is water.

Every one, however, has not been so void of curiosity. When Assistant Surgeon C. L. Bose,* was in Rangoon in I 885, he was struck by the length of time the flowers were kept, and brought some with him to Calcutta for examination. Dr. Warden, then chemical examiner, and Mr. Bose found on examining the fluid that it was a solution of Alum. The solution is of no special strength; the Burman, being a happy-go-lucky individual puts some Alum into the water along with the flowers and is not particular as to the amount.

Mr. Bose brought only Champak petals; some of these are in shape, size, colour and consistence much asthey were when taken from thetree eight years ago. Here then we seem to have the means of overcoming the difficulty, hitherto insoluble, of preserving the natural size in specimens of Magnoliaceous flowers.

Though only Champakwas brought by Mr. Bose, the writer recollects seeing Plumieria and Nymphae flowers as well, and a bottle in which Dr. Warden placed some green leaves with a $1 \%$ Alum solution at the time he examined the Rangoon bottle has its contents very much as they were when he put them in. There is, therefore, no reason why the use of Alum solution should be confined to Magnolia flowers.

It should be understood that the use of Alum solution is only suggested as auxiliary to the usual means of preserving specimens. Wet preparations are to be avoided; they are difficult to handle, difficult to keep, difficult to house, and still more difficult to carry about. But occasions arise when wet specimens are of the greatest moment assupplements todried ones, and the Burmese preservative has the advantages over spirit of not discolouring the specimen or rendering.it brittle. Most important of all, one can carry Alum about as a solid and make a solution when required.

If the bottles are not carefullysealed the specimens do not keep. The flowers immersed in the fluid do not suffer, but as the water evaporates the flowers at the top get exposed to the pair, decay, and fall ina flocculent mass to the bottom. This flocculent matter keeps pushing up others to undergo the same decomposition. But from a well-stoppered bcttle-

* Assistant to the Chemical Examiner to Government, Calcutta. 
a glass stopper with wax is best-the fluid does not evaporate; the flowers, therefore, do not reach the air and seem to keep indefinitely.

II. Coniferæ. The Pine, Fir and Spruce family is usually very troublesome to preserve both in the field and afterwards in the Herbarium, from the readiness with which the cones fall to pieces and the leaves (needles) drop off. In the Calcutta Herbarium there are a number of beautiful specimens of Japanese Conifers presented by Mr. C. Maries, F.L.S., * who collected them. The writer, anxious to learn the secret of the success with which so troublesome a family had been treated, asked Mr. Maries if he would kindly explain his method. Mr. Maries' reply, which he has courteously permitted the writer to communicate to the Society, is as follows:-

"Conifer specimens of the Abies or Piceasection aregenerally rather "difficult to dry. When I was in the island of Yesso, in the North "Pacific, I was very much troubled with them. One night I arrived "very wet at my rooms and stacked my branches of Abies, with the "cones attached, round a big charcoal fire. I fell asleep and woke up "next morning to find my specimens dried beautifully. After this I "always dried them slowly over a charcoal fire, first wiring or wrapping "up the cones. All fir-cones, except Pine, or Spruce, or Cedar, should "be tied up either with cotton or wire immediately they are gathered. "The Spruce section is the most difficult to dry, even roasting is not "always a success."

Mr. Maries goes on to say:- "The way I dry ferns and leaves "of trees for fitting up my bird-cases" (in the Gwalior State Museum) "to preserve their natural shape, is to take some very clean, washed "sand, arrange the leaves in a clean box and fill in with hot sand, and "keep at a temperature of $100^{\circ}$ to $120^{\circ} \mathrm{Fh}$. or even more. They soon "dry (I imagine Spruce would dry like this if very hot) and flowers "dry beautifully in this way, some keeping their natural colours in a "most remarkable manner. When I was young andliving in London, an "old gardener taught me this; he used it for ferns and roses for winter "decorations when fresh ferns and flowers were scarce. All the dried "flowers one sees in florists' shops in London are dried in hot sand. "-C. MARIES."

III. ORCHIDACE E. The Orchid family is perhaps the most troublesome of all natural families to represent in Herbaria. In all the epiphytic kinds the leaves and, in most of them, the flowers also are apt to drop off when the specimens are dried in the ordinary way, while even in ground Orchids the pressure that has to be applied during drying usually so distorts the flower that a true conception of the relative

* Superintendent of the State Gardens and State Museum at Gwalior. 
position of its parts becomes impossible. This is very unfortunate, because there is no natural order where a proper understanding of the position of parts, particularly of the lip and the column, is so recessary. Spirit preparations are most unsatisfactory. If the spirit is sufficiently strong to preserve the flowers the parts become so brittle that when handled they go to pieces; if weak enough to prevent this hardening and consequent friability the spirit does not adequately preserve the specimens. The jars and bottles in which the specimens are placed, moreover, are very apt to get broken, and any one who has tried it will testify to the worry that is caused by the necessity of having to carry about a stock of alcohol. Dr. Schweinfurth when travelling in Africa, made use of a most excellent modification of the method of preservation in spirit. He laid his specimens between sheets of drying paper, laid these in tin-boxesandsoldered them upafter soaking the paperthoroughly with spirit. He was thus able greatly to reduce the initial stock of alcohol and was freed from the subsequent anxiety of possible breakages. But the objections to spirit as a preserving medium for flow ers are not obviated by this mode of applying it, and it remains to be seen whether the Alum solution will answer as a substitute if used in this way.

In the meantime Mr. R. Pantling,* who for many years has made a special study of Orchids, has perfected a method of drying them sofar in advance of anything hitherto accomplished that it is highly desirable, that the details of his process should be made known. At the writer's request Mr. Pantling has supplied these details and like Mr. Maries, has courteously given him permission to communicate the account to the Society. This memorandum is given below ; it will be noticed that it consists of a happy combination, suitably modified, of the ordinary method of fire-drying recommended for all ordinary plants with the hotsand process mentioned by Mr. Maries as that practised by florists in Europe.

"To dry Orchid Specimens. - In order to preserve Orchids so that "the leaves and flowers remain in tact and do not fall away in fragments " as invariably happens to epiphytal species when pressed in the ordi" nary way between drying paper, the procedure to be adopted should "be as follows. Procure a light metal box-I 4 inches, by 12 inches, "by 6 inches deep is a convenient size - and place over the bottom half" an-inch of sand. Arrange a specimen between two sheets of thin " paper inside the box and cover over with a layer of sand taking care, " as far as possible, that the interstices between leaves, etc., are filled "up. Repeat this until the box is full, then place it on a stove or above

" First Assistant, Department of Cinchona Cullivation in Bengal. 
"a fire and dry with a brisk heat. No weights for pressing are neces"sary. As a general rule, the sand at the commencement of drying "should not be allowed to attain a greater heat than can be borne by " the hand, and this should be lessened as drying proceeds or the flowers " may become scorched and rendered useless for purposes of dissection. "Occasionally species (Dendrobium Pierardi Roxb., and Phajus "alba Lindl.) are met with whose perianths will adhere to the paper; " the removal of the perianthcannot then be effected without mutilation. "This may be obviated by using porous drying-paper or blotting-paper " instead of the thin kind recommended above.

"The advantages of drying in hot sand as compared with the " universally aclopted method in paper are:-First, the rapidity in pre"paring specimens; plants belonging to such genera as Saccolabium, "Vanda, Cleisostoma, etc., being ready within a week against a period of " three to four months by the old method. Secondly; when finished the "specimens will be found preserved in their entirety and will not fall "to pieces. The column and lip will be found to have suffered little, "as the pressure of the sand is not sufficient to cause any material dam"age to these organs".-R. PAntLing.

The boxes that Mr. Pantling has found handiest for his purpose are old kerosine tins cut through lengthways; one is placed within the other to give more strength to the tin with a rivet or two hammered through the seams as the solder runs when the boxes are over the fire. The only thing to be guarded against in the process is the adhesion of the flowers of certain species to the paper, and Mr. Pantling shows how this is easily overcome.

The possibilities of this method either as recommended by $\mathrm{Mr}$. Pantling or with slight modifications for the drying of succulent species generally, such as the Cactus family and fleshy members of the Spurge family, as well as for families like Scitaminece-the ginger family-and for water plants, where the flowers are very delicate and therefore very difficult to dry, seem considerable and the plan is well worth trying for them as well as for orchids. 


\section{N D E X.}

[The references are to the numbers at the outer bottom corners of the pages.]

Abor tribes, 3

Abrus precatorius, Linn., 61, 120, 222, 228,284 pulchellus, Wall., 120

Abutilon indicum, G. Don., 329

" populifolium, G. Don., 330

Acacia concinna, DC., 122, 284.

" eburnea, Willd., 87

" Farnesiana, Willd., 29

" pennata, Willd., 122

Acalypha fallax, Muell.-Arg., 360

" Hochstetteri, Muell.-Arg., 360

" indica, Linn., 360

" indica, Prain, 360

" Mercurialis, A. Juss., 360,

Acanthophora Thierii, Lamour., 151

Accretive action of surf, 98

Acheen Head, 94

Achyranthes aspera, Linn., 42, 134, 181, 232,355

$" \quad$ bidentata, Bl., 356
$" \quad$ lanata, Linn., 355
$\quad \quad$ porphyristachya, Wall., 134,
$\mathbf{3 5 6}$

Acrostichum appendiculatum, Willd., 147, 296

" aureum, Linn., 296
$" \quad$ costatum, Wall., 296
scandens, J. Sm., 147, 226,

Actephila excelsa, Muell.-Arg., 289.

Adenanthera pavonina, Benth., 122

Adenostemma reticulatum, DC., 344

$$
\text { ", viscosum, Forst, 4l, 62, }
$$$$
127,179,344
$$

Adiantum lunulatum, Burm., 67, 295

Aecidium esculentum, Barc1, 87

Aegiceras Majus, Gaertn., 128

Aegle Marmelos, Corr., 332

Aerial roots of Avicennia, 54

Aerides multiflorum, Roxb , 138, 225

Aerua lanata, Juss, 42, 232, 355

Aeschynomene grandiflora, Linn., 335 spinulosa, Roxb , 335

Aganosma marginata, G. Don, 287

Agati grandiflora, Desv., 335

Agare Cantula, Roxb., 363

" vivipara, Linn., 35, 363
Ageratum aquaticum, Roxb., 34,4.

" conyzoides, Linn., 38, 62, 344

" cordifolium, Roxb., 344

Aglaia andamanica, Hiern, 116

Agriculture among the Nagas, 14

Ajuga disticha, Roxb., 355

Akati, 309

Alangium sundanum, Miq., 229

Albizzia Lebbek, Benth., 122

" procera, Benth., 61, 122

Alchornea javensis, Muell.-Arg., 233

"r rugosa, Muell.-Arg., 233

Allamanda cathartica, Linn., 30

Allium Cepa, Linn., 33

", sativum, Linn., 33

Allophyllus Cobbe, Bl., 118, 228, 283, 333

Alnus nepalensis, Ham., 14

Alocasia fornicata, Schott., 143

indica, Linn., 384

Alsodeia bengalensis, Wall., 112

Alternanthera sessilis, R. Br., 34

Alyssicarpus vaginalis, DC., 40, 120, 178

Amarantus spinosus, Linn., 39

A méni, 316

," viridis, Linn., 39, 355

"sp., 32

Amherstia nobilis, Wall , 34

Ammannia baccifera, Limn., 41, 340 vesicatoria Roxb., 340

Amoora decandra, Hern., 283

" Rohituka, W. \& A., 116, 283

Amorphophallus bulbifer, Bl., 1+.3, 294

" campanulatus, Bi., 294

" oncophyllus, Prain, 294

" rex, Prain, 293

" tuberculiger, Schott., 143,

294

„ virosus, N. E. Br., 294

"sp., 143

Anamirta Cocculus, W. \& A., 279

Ananas sativa, Adans., 32

Andaman Flora, THE NON-INDIgenous SPECIES OF THE, 25 ; basis of discussion of, 27; cultivated plants among, 28 ; distributional features of, 47 ; interest of, 25 ; intrusion of, $4 \mathrm{k}$; mode of introduction of, 45 ; note by $\mathrm{Kurz}$ on, 26 ; rate of introduction of, 48 ; weeds among, 37 
Andaman Group, history of settlements in, 47 ; non-indigenous species in, 25 ; physiographical relationships of, to Barren Island, 274; - to Coco Group, 93 ;-to Diamond Island, 76;to Narcondam, 274; - to the Nicobars, 272 ; reefs in the, 98 ; thread-bight in the, 150 .

Andaman Sea, 255; bottom contour of the, 272

Anderut, 319

Andropogon contortus, Linn., 40, 146, 373 muricatus, Retz., 373

ar pseudo-ischaemum, Nees, 40

,

Sorghum, Roxb., 374

" squarrrosus, Linn. f., 373

Aneilema ovalifolium, Hook. f., 364 , ovatum, Wall., 140

ANGaMi Nagas, THE, 1 ; agriculture among, 14; appearance of, 4 ; beliefs of, 18; diseases among, 23; domestic economy of, 17 ; dress of, 5 ; dwellings of, 7 ; external polity of, 10,16 ; history of, 4 ; hunting operations of, 12 ; music among, 5; occupations of, 5 ; ornaments worn by, 6 ; social polity of, 21 ; traditions among, 3 ; villages of, 7 ; weapons of, 8

Angelonia salicariæfolia, H. B. K., 38

Anisomales ovata, R. Br., 65, 133, 180, 353 Anodendron paniculatum A. DO., 129, 287 Anona muricata, Linn., 328

"squamosa, Linn., 28

" reticulata, Linn., 34

Anthistivia scandens Raxb., 43

ANthocoma Flavescens, Zoll, on the SYNONYMY OF, 247.

Anthocoma flavescens, Zoll, 249

Antiaris toxicaria, Leschen., 66, 138, 290.

Antitaris calocarpa, Kurz, 111, 279

Apluda aristata, Linn., 374

Apodytes andamanica, Kurz, 283

Aporosa villosula, Kurz, 136

Apostasis in inflorescence of Acacia eburnea, 88

Appearance of Angami Nagas, physical, 5

Aquatic plants in the Coco group, 203

Arachis hypogaea, Linn., 336

Arachnechthra andamanica, Hume, 238

Arbor ovigera, Rumph., 57

, regis, Rumph., 57

Ardeola Grayii, Sykes, 240

Ardisia humilis, Vahl., 128, 224, 230, 286

littoralis, Andr., 224, 230

Areca Catechu, Linn., 33, 233, 364.

Argyreia Hookeri, Clarke, 130

"lanceolata, Choisy, 130

" tiliaefolia, Wight, 130

Arhopala centaurus, Fabr., 243

Aristolochia Tagala, Ch. \& Schlecht., 135, $232,288$.

408
Arracan, 53, 94

Artocarpus Chaplasha, Roxb., 66

" Gomeziana, Wall., 138

" incisa, Forst, 361

" integrifolia, Linn. f., 362

"Lakoocha, Roxb., 290

Arum campanulatum, Roxb., 294

" Colocasia, Linn., 370

Arung Nagas, 3

Asclepias asthmatica, Willd., 347

"gigantea, Willd., 346

", suberosa, Roxb., 347

Asparagus racemosus, Roxb., 140

Asplenium falcatum, Lamk., 296

"Nidus, Linn., 296

Assam, 2

Avicennia officinalis, Linn., 65, 133; aerial roots of, 54

Avifauna of Narcondam and Barren Island, derivation of the, 247

Ballota disticha, Linn., 353

Bambusa Brandisii, Munro, 35

Bangáro, 399

Barclaya longifolia, Wall., 42

Bareil Mts., 2

Barleria ciliata, Hume, 351

" cristata, Prain, 351

" Prionitis, Linn, 351

BARREN ISLAND, ON THE PRESENT CONDITION OF, 81 ; coconut trees in, 270 ; column of steam from crater, 82 ; deposit of sulphur in, 82 ; description of, 264 ; fauna of, 235 ; hot spring in, 82 ; soundings in the vicinity of, 265 .

Barringtonia racemosa, Bl., 124

Basama Fort, 4

speciosa Forst, 124, 223, 229

Bassas de Pedro bank, 319

Bats, frugivorous, in Narcondam and Barren Island, 236.

Batti Malv, description of, 218

Bauhinia acuminata, Linn., 34, 36

" buds used as food, 16

Bay of Bengal, 253

Bays, coral, 97 ; rocky, 100.

Beach-flora of the Coco-group, 102 ; of Diamond Island, 55; of the Laccadives, 381.

Beach-forests in the Cocos, 100.

Belamcanda sinensis, Adans., 32

Beliapani reef, 306

Benincasia cerifera, Savi, 29

Bergera Koenigii, Vahl, 331

Berrya Amonilla, Roxb., 115

Bibliography relating to the Laccadives, 302

Bidens bipinnata, Linn, 345

" pilosa Limn., 245

Bird-introduced species in Barren Island, 300 ; in Coco-group, 201 ; in the Lacca. dires, 382 ; in Narcondam, 300. 
Birds of Narcondam and Barren Island, 237

Bitrapar, 307

Bixa Orellana, Linn., 28, 36, 238

Blachia andamanica, Hook., 6, 136, 289

Blainvillea latifolia, Kurz., 38

Blumea glomerata, DC., 41, 286

" laciniata, DC., 286, 344

", myriocephala, DC., 286

" virens, DC., 127

Boehmeria malabarica, Wedd., 290

Boerhaavia diffusa, Linn., 354 $" \quad$ procumbens, Banks, 354
$\quad \quad$ repens, Linn., 42, 134, 180, 232
$\quad 288,34^{\prime}$

Bombax anceps, Pierre, 280

" cambodiense, Pierre, 281

" insigne, Wall., 113, 279

" malabaricum, DC., 60,280

", pentandrum, Linn., 280

Bonnaya veronicaefolia, Benth., 38

Bor-Abor tribes, 3

Botanical visit to Little Andaman AND THE NICOBARS, ON A, 216

BOTANY OF THE LACCADIVES, 301

Bougainvillea glabra, Choisy, 35

Bovžsta lilacina, Berk., 149

Bragantia tomentosa, Bl., 134

Brahmaputra river, 2

Brassica campestris, Linn., 28

" oleracea, Linn., 28

Breynia oblongifolia, Mull.-Arg., 233 " rhamnoides, Muell-Arg., 289

Bridelia Kurzii, Hook. f., 136 , tomentosa, Bl., 65, 136, 233, 289

Brownea, sp., 34

Bruguiera gymnorhiza, Lamk,, 123, 223

Bryophyllum calycinum, Salisb., 37

Bryum coronatum, Schwaegr., 148, 297

Buchnera asiatica, Linn., 351

Buettneria andamanensis, Kurz., 115

Burra Noon-pong, 79

Butterflies of Narcondam and Barren Island, 242

Byramgore reef, 306

Cachar, Naga raids on, 4

Caesalpinia Bonducella, Flem., 61, 121, $233,228,284,338$.

Bonduc, Kurz., 228

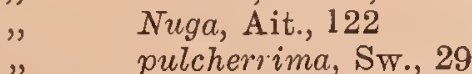

Cajanus indicus, Spr., 29, 36

Calamus andamanicus, Kurz., 142 tigrinus, Kurz., 66, 142

Calanthe veratrifolia, R. Br., 138

Callicarpa arborea, Roxb., 288

longifolia, Lamk, 231

Caloenas nicobarica, Linn., 239

Calophyllum inophyllum, Linn., 112, 221, $2 \div 6,279,329$

Calothrix pulvinata, Ag., 152, 297
Calothrix tasmanica, Kg., 297

Calotropis gigantea, R. Br., 346

Calymperes Dozyanum, Nutt.

" moluccense, Dozy \& Molk, 376,

Camellia theifera, Griff, 34

Canangr odorata H. f. \& T., 28

Canarium euphyllum, Kurz, 116, 282

Canavalia ensiformis, DC., 28, 61, 222, 236

" gladiata, DC., 222

"lineata, DC., 223, 337

" obtusifolia DC., 121, 222, 337

" Stocksii. Dalz., 222

" turgida Grah., 222, 228, 284, 336

" virosa, W. \& A., 222

Canna indica, Linn., 32, 36

Cannabis sativa, Linn., 32

Cansjera Rheedei, Gmel., 116, 283

Cape Negrais, 53, 93

Capellenia moluccana, T. \& B., 358

Capparis ambigua, Kurz, 226

" sepiaria, Linn., 59, 112, 279

" tenera, Dalz., 112, 279

Capricornis bubalina, Linn., 12

Capsicum frutescens, Linn:, 31, 350

" grossum, Linn., 31

" minimum, Roxb., 31, 36, 64 $131,180,350$.

Car Nicobar, reefs of, 98,218

Carapa malaccensis, Lamk, 116, 221, 1283 obovata, Bl., 116, 221

Cardiospermum Halicacabum, Linn., 37, 333

Carica Papaya, Linn., 29, 36, 125, 179, 340

Carrissa Carandas, Linn., 35

Carpophaga aenea, Linn, 239

$"$ bicolor, Scop., 239

Carpopogon capitatum, Roxb., 336

Carum Rosburghianum, Benth., 30

Caryota mitis, Lour., 291

,. sobolifera, Wall., 141

Cassia alata, Linn., 37, 61

"Fistula, Linn., 29

" occidentalis, Linn., 41, 228, 339

" Tora, Linn., 41, 339

Cassytha filiformis, Linn., 135, 350

Castalius, sp., 242

Castarina equisetifolia, Forst. 32, 36, 225; distribution in the Andamans, 218

Catochrysops cnejus, Fabr., 243

Caulerpa clavifera, Ag., 67, 152

" plumaris, Ag., 152

Ceanothus asiaticus, Linn., 332

Celastrus opposita, Wall., 331

Celosia argentea, Linn., 39 cristata, Linn., 32, 134.

Centipeda orticularis, Lour., 38

Cephalandra indica, Naud., 345 
Cephalostachyum pergracile, Munro, 35

Ceratopteris thalictroides, Brogn., 43, 67 147

Cerbera Odollam, Gaertn, 123

Ceriops, sp., 30

Ceriops Candolleana, Arn., 123

,"Roxburghiana, Arn , 123

Chailletia gelonioides, Hook. f., 60

Champereia Griffithiana, Planch., 135

Chara foetida, A. Br, 147

, sp., 379

Cheilanthes tenuifolia, Sw., 43, 296

Chemical character of hot-springs in Barren Island, 84; in Namba Forest, 80

Cherbaniani reef, 306

Cheriapani reef, 306

Chickrassia tabularis, A. Juss., I 16

Chinese Green-Dye, 89 ; preparation of, 92.

Chitlac, 311

Chloris barbata, Sw., 43

Chonemorpha macrophylla, G. Don., 129

Chrysopogon aciculatum, Trin., 40

Cicca disticha, Linn., 360

Cicer Arietinum, Linn., 28

Cinnamomum zeylanicum, Breyn, 35

Cirrepidesmus mongolicus, Pall., 239

Cissus carnosa, Roxb., 333

, quadrangularis, Roxb., 333

Citrullus vulgaris, Schrad., 29

Citrus acida, Roxb., 331

" Aurantium, Linn., 332

" decumana, Linn., 28, 332

" medica, Linn., 28, 60, 331

Civilized species, definition of, 177

Claoxylon longifolium, Muell.-Arg., 133, 233

", Mercurialis, Thw., 360

", molle, Endl., 233

Classes of Andaman cultivated species, 35

Clearings in the Coco group, 104; in Diamond Island, 54

Cleome viscosa, Linn., 37, 328

Clerodendron inerme, Gaertn., 65, 133, $224,231,288,353$

" paniculatum, Linn., 231

Climate of Naga Hills, 2

Clitoria Ternatea, Linn., 28, 36, 336

Cnesmone javanica, Bl., 137

Cnestis ramiflora, Griff., 60

Coast species in the Cocos, 188; in the Laccadives, 381.

COCO GROUP, THE VEGETATION OF THE, 93

Coco-nut trees in Barren Island, 270 ; -

in the Coco group, 183 ;-in Diamond Island, 57 ;-in the Laccadives, 364 ;in Narcondam, 142 ; --in the Nicobars, 186,218

Cocos, the, 93 ; action of surf in, 98 ; 410 beaches and beach vegetation of, 102 bird-introduced species in; 177 ; clearings in, 104; distribution of species noted in, 190; fresh-water lagoons of, 108 ; inland vegetation of, 103,197 ; littoral species in, 189 ; marine plants of, 118 ; nature of flora of, 153; origin of flora of, 175 ; physical features of, 97 ; plants collected in, 111 ; position of, 93; products of, 110; reefs and reef-vegetation of, 97 ; remanent species in, 211; visits paid to, 94; wind-introdnced species in, 197.

Cocos nucifera, Linn., 33, 36, 66, 142, 181, $233,291,364$

Coffea arabica, Linn., 35

Coix Lachryma, Linn., 15, 17, 33, 36

Collema nigrescens, Achar., 148, 297

Collocalia Linchi, Horsf., 237

Colocasia antiquorum, Sch., 35, 36, 370

Colubrina asiatica, Brogn., 60, 116, 283, 332

Commelina cristata, Linn., 364

, obliqua, Hossk., 140

Connarus gitbosus, Wall., 60, 119

, sp., 228

Convolvulus alsinoides, Linn., 349

, Batatas, Linn., 348

", dissectus, Linn., 348

, grandiflorus, Linn., f., 347

" parviflorus, Vahl, 131, 231, 287,348

, pes-caprae, Linn., 348

Conyza cinerea, Linn., $\mathbf{3 4 4}$

" laciniata, Roxb., 314

Cooling of hot spring in Barren Island, 84

Corchorus acutangulus, Lamk., 331

,, fuscus, Roxb., 331

Cordia subcordata, Lamk., 129, 224, 231

Coreopsis, sp., 30

Coriandrum sativum, Linn., 30

Coronilla aculeata, Willd., 335

Corvus Levaillanti, Less., 238

Corypha elata, Roxb., 141

, Gebanga, Kurz., 141

, macropoda, Kurz., 141

Cosmos sulphureus, Cass., 41

Costus speciosus, Linn., 139

Crater of Barren Island, ascent of, 266 ; column of steam from, 82 ; plants growing in, 268.

Creeks in the Coco-group, 103

Crepis acaulis, Hook., 6, 319

' japonica, Benth., 31

Crinum asiaticum, Linn., 139, 225

Crotalaria retusa, Linn., 40, 335

" sericea, Retz., 119, 178

"verrucosa, Linn., 40, 334

Croton sublyratus, Kurz., 136

Crustacea, (Land-) in Barren Island, 24 
Cucumis Melo, Linn., 29, 341

$$
\text { " sutivus, Linn., 26, } 341
$$

"utilissimus, Roxb., 341

Cucurbita maxima, Duch., 30, 341

Cultivated plants in the Andamans, 28 ; the Coco group, 177; the Laccadives, 380 ; the Naga Hills, 15.

Cuminum Cyminum, Linn., 30

Cuncuma leucogaster, Gmel., 237

Cupania Jackiana, Hiern, 227

Cuphea, sp., 29

Curcuma, sp., 32

Cyanotis cristata, R. \& S., 354

Cycas Rumphii, Miq., 138, 225, 233

Cyclea peltata, H. F. \& S., 59, 111, 125

Cyclostemon assamicus, Hook., f., 136, 289

$$
\text { ". macrophyllus, Bl., } 289
$$

Cymaria acuminata, Dene., 248

$$
\text { " elongata, Bth., } 249
$$$$
\text { ", mollis, Miq., } 248
$$

Cymodocea ciliata, Ehrenb., 144, 225, 234

Cynanchun alatum, Prain, 347

$$
\text { " reticulatum, Willd., } 347
$$

Cynodon Dactylon, Pers., 33, 36, 374

Cynometra ramiflora, Linn., 122

Cyperus compressus, Linn., 39, 370

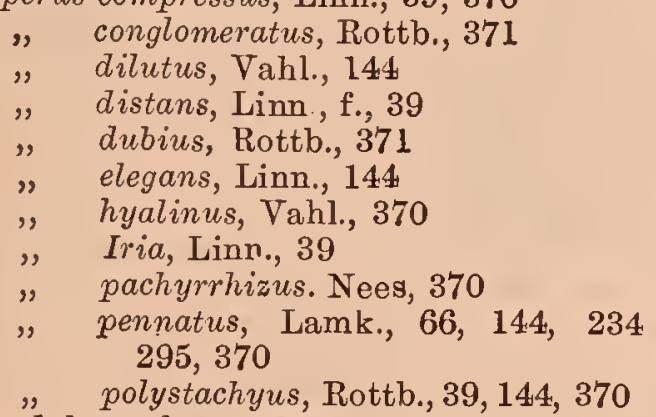

Daedalacanthus malaccensis, T. And., 35

Dalbergia monosperma, Dalz., 284 tamarindifolia, Roxb., 284

Daldinia vernicosa, Cos. \& de Not., 150

Danais, sp., 46, 242

Datura fastuosa, Linn., 31, 36, 291, 350

Daucu.s Carota, Linn., 35

Davallia solida, Sw., 146, 223, 295

$$
\text { " speluncae, Bak., } 295
$$

Dedaelea concentrica, Fr., 149

" flabellum, Berk., 149

" quercina, Fr., 149, 297

" sanguinea, Kl., 149

Deeringia celosioides $\mathrm{R}$. Br., 35, 36

Defences of Naga villages, 7

Dehaasia Kurzii, King, 135

Demiegretta sacra, Gmel , 240

Dendrobium secundum, Wall., 138, 224

$$
\begin{aligned}
& \text { " tenuicaule, Hook., f., } 225 \\
& " \quad \text { terminale, Par. \& Reichb., f., } \\
& 225 \\
& \text { sp., } 290
\end{aligned}
$$

Dendrocalamus strictus, Nees, 35, 146

Dentella repens, Forst., 37, 342
Deposit of sulphur in Barren Island, 82

Derris scandens, Benth., 121, 223, 284

$"$ sinuata, Benth., 121

" uliginosa, Benth., 121, 223

Derivation of Avifauna of Narcondam and Barren Isliınd, 147

Desmodium auricomum, Grah., 41

$$
\begin{array}{ll} 
& \text { laxiflorum, DC., 119 } \\
" & \text { polycarpon, DC., 41, 119, 284 } \\
& \text { triflorum, DC., 37, 41, 120, } \\
& \quad 178,336 \\
& \text { triquetrum, DC., } 119 \\
& \text { umbellatum, DC., } 61,119
\end{array}
$$

Diamond Istand Plants, a list of, 53

Diamond Island, description of, 53 ; distribution of the flora of, 67 ; list of species in, 59 : position of, 53 ; previous notices of, 58 ; sketch of the vegetation of, 54 ; relation of Coco group to, 93

Dictyota dichotoma, Lamour., 151

Dioscorea bulbifera, Linn., 363

$$
\begin{aligned}
& \Rightarrow \quad \text { glabra, Roxb., 66, 139, } 291 \\
& " \quad \text { pentaphylla, Linn., 140 } \\
& " \quad \text { sativa, Linn., 35, 291, } 363
\end{aligned}
$$

Diospyros Kurzii, Hiern., 123, 230, 287

Diplospora singularis, Korth., 126

Diplerocarpus alatus, Roxb., 113

$$
\begin{array}{ll}
" \quad \text { Griffithii, Miq., } 112 \\
\text { pilosus, Roxb., } 113
\end{array}
$$

Directions for DRYing SPECIMENS OF

PLANTS FOR A HERBARICM, 391

Dischidia bengalensis, Kurz, 230

$$
\begin{aligned}
& \quad \text { Griffithii, Hook. f., } 230 \\
& " \quad \text { nummularia, R. Br., 129, } 187 \\
& " \quad \text { Rafflesiana, Wall., 224 }
\end{aligned}
$$

Diseases among the Nagas, 23

Dispersal of 'Tulsi plants, 65, 232, 353

Distinction between indigenous and in. troduced species, difficulty of, 175

Distortion caused by a fungus in Acacia eburnea, 88

Distribution of butterflies and birds in Narcondam and Barren Island, 244 ; of plants in Andamans (non-indigenous', 47; in Diamond Island, 67; in Laccadives, 383

Dodonaea viscosa, Linn., 118, 283

Dolichos Catjang, Linn., 338

$$
\begin{aligned}
& \text { " Lablab, Linn., } 29 \\
& \text { " lineatus, Thunb., 121, 223, } 338 \\
& \text { " luteus, Sw., } 338 \\
& \text { obcordatus, Roxb., } 337 \\
& \text { " rotundifolius, Roxb., } 336
\end{aligned}
$$

Domestic economy of Nagas, 18, 21

Dorites Wightii, Benth., 138

Dracaena angustifolia, Roxb., 140, 225, 291

" spicata, Roxb., 140

Dracontomelum mangiferum, Bl., 118

Dregea volubilis, Benth., 63

Dress of Angani Nagas, 5 
Drying herbarium specimens, 391

Duranta Plumieri, Jacq., 31

Durio Zibethinus, DC., 34

Dyes, Naga, 18

Echinocactus, sp., 30

Eclipta alba, Hassk., 38, 344

prostrata, Linn., 344

Ehretia laevis, Roxb., 63

Elephantopus scuber, Linn., 38

Eleusine aegyptiaca, Pers, 40, 146, 182, 374

" Coracana, Gaertn., 374

" indica, Gaertn., 40, 67, 146, 182, 374

Elikalpéni bank, 318

Ellipanthus sterculiaefolius, Prain, 60

Endospermuun formicarium, Becc., 358

" moluccanum, Becc., 358

Entada scandens, Benth, 61, 122, 284

Epiphyllum, sp., 30

Eragrostis plumosa, Link., 234, 374

" tenella, Trin., 374

" unioloides, Nees, 43

Eranthemum album, Nees, 132

" cinnabarinum, Wall., 132,
231
succifolium, Kurz, 132, 231,
288

Eriochloa annulata, Nees, 40

Eriodendron anfractuosum, DC., 114, 280

Erioglossum edule, Bl., 118, 228, 283

Erosive effects of surf, 99

Erycibe paniculata, Roxb., 64, 130

Erythrina indica, Lamk., 61, 120, 222, 228,284

Eudynamys malayana, Cab., 238

Engenia Jambolana, Linn., 285, 340

" Jambos, Linn., 35, 339

Eulophia decipiens, Kurz, 234

" graminea, Lindl., 234

Euonymus calocarpus, Kurz, 116

Euphorbia antiquorum, Linn., 7, 13, 35

" Atoto, Forst., 136, 232, 359

" hirta, Linn., 359

" hypericifolia, Linn., 359

" parviflora, Linn., 39, 136, 181, 359

" pulcherrima, Willd., 32

" thymifolia, Burm., 39, 65, 355.

Evolvulus alsinoides, Linn., 349

" angustifolius, Roxb , 349

" linifolius, Linn., 849

Extension of Coco Island littoral species, 196

Fauna of NarcondaM aNd Barren Island, Remarks on the, 235

Feasts, Naga, 19

Ficus bengalensis, Linn., 35, 361

" Benjamina, Linn., 137, 290, 361

" brevicuspis, Miq., 137, 290

" callosa, Willd., 137, 290

412
Ficus comosa, Lowe, 137

"Daemonam, Koen., 137, 233, 290

"gibbosa, Bl., 289

glaberrima, Bl., 289

grisea, Wall , 138

hispida, Linn. f., 66, 137, 290

indica, Linn., 361

nervosa, Roth, 290

nitida, Thunb., 137, 361

religiosa, Linn., 35

retusa, Linn , 137, 290, 361

Rumphii, Vahl, 35, 66, 137, 233, 290

variegata, Bl. 290

Fimbristylis diphylla, Vahl, 50, 144, 295, 371

" ferruginea, Vahl, 145, 295

, miliacea, Vahl, 145

" quinqueangularis, Kunth., 145

Flacourtia sepiaria, Roxb., 328

Flagellaria indica, Linn , 140, 225, 234

Flat Rock, soundings in the vicinity of, 271

Flora of Narcondam and Barren IsLAND, ON THE, 253

Flowers used as ornaments by Nagas, 6

Flueggia microcarpa, Bl., 65, 136, 289

Fresh-water lagoons in the Cocos, 108

Fringing reefs in the Cocos, 98

Fruits attached to feathers of birds, 205

Galega diffusa, Roxb., 335

Gallinula phonicrura, Penn., 239

Garcinia cornea, Linn., 60

"Mangostana, Linn., 34

" sp., 112

Garuga pinnata, Roxb., 116, 282

Gelidium corneum, Ag., 152

Gelonium bifarium, Roxb., 289

" sp. 233

"Genna," significance of the Naga term, 19

Geographical position of Barren Island, 264; Coco group, 93 ; Diamond Island, 53 ; Flat Rock, 270; hot springs in Namba Forest, 77 ; Laccadive Archipelago, 301 ; Naga Hills, 2; Narcondam, 256

Geology of Naga Hills, 2

Gilla-Poong, 79

Girardinia heterophylla, Wedd., 7

Glochidion calocarpum, Kurz, 233, 289

Gloriosa superba, Linn., 140, 291, 368 ; distribution of, 195

Glycine hirsuta, Max., 15

Glycosmis pentaphylla, Corr., 115, 227, 282

Glyptopetalum calocarpum, Prain, 116

$$
\text { " zeylanicum, Thw, } 117
$$

Goats in Narcondam and Barren Island, 236 
Gomphostemma dichotomum, A. DC., 249 " dichotomum, Hassk., 249 " flavescens, Miq, 249

Gomphrena globosa, Linn., 32, 36, 134, 181

Gossypium barbadense, Linn., 28, 36, 331

$$
\text { " herbaceum, Linn. } 331
$$

Gouania leptostachya, Brogn., 283

Gracillaria crassa, Harv., 152

Graptophyllum hortense, Nees, 31

Gratiola Monnieria, Linn., 357

Great Coco, 95

Green Dye, Chinese, 89 ; preparation of, 92

Grewia calophylla, Kurz, 115

" laevigata, Vahl, 115, 282

" Microcos, Linn., 115

Guettarda speciosa, Linn., 62, 126, 223, $229,285,342$

Guilandina Bonduc, Linn., 338

$$
\begin{aligned}
& \text { Bonducella, Linn., } 338 \\
& \text { Moringa, Linn., } 334
\end{aligned}
$$

Gynandropsisepentaphylla, DC., 226

Gyrocarpus Jacquinii, Roxb., 124, 228, 285

Habit of Coco Gronp species, 155

Habitat of Coco Group species, 158

Halcyon atricapillus, Gmel., 238

Halimeda discoidea, Dcne, 226

$$
\text { " Opuntia, Lamour., 152, } 226
$$

Halophila ovalis, R. Br., 225

Hebomoia Roepstorfi, Wood-Mason, 243

Hedyotis minima, Burm., 41

Heliotropium indicum, Linn., 38

Hepatica, sp., 148 peruvianum, Linn., 30

Herbarium, Directions For DRYing SPECIMENS OF PLANTS FOR A, 391

Heritiera littoralis, Dryand., 115, 282

Hernandia ovigera, Gaertn., 356

$$
\begin{aligned}
& \text { " ovigera, Limn., } 357 . \\
& \text { " peltata, Meissn., 135, 224, } 232 \text {, }
\end{aligned}
$$

Herpestis Monnieria, H B. K., 351

Heterophragma adenophylla, Seem., 65, 132

Heterotaxy in Acacia eburnea, 89

Hexagonia pergamenea, Berk., 149

" sericeo-hirsuta, Kl., 149

" similis, Berk., 67

" tenuis, Hook., 149

Hibiscus Abelmoschus, Linn., 113, 178

" esculentus, Linn., 34

" populneus, Linn., 330

" rosa-sinensis, Linn., 28, 330

" Sabdariffa, Linn., 34, 113, 178

" Solandra, L'Her., 330

" tiliaceus, Linn., 60, 113, 221, 226, 279,330

Hippeastrum, sp., 32
Hirneola polytricha, Mont., 67, 150, 297, 377

History of Andaman Settlement, 47 ; of Angami Nagas, 4

Hot spring in Barren Island, 82

Hot Springs of the Namba Forest in the Sibsagar District, UPper As. SAM, THe, 77

Houses, Naga, 7

Houttuynia, used as food, 16

Hoya diversifolia, Bl., 129, 287

" parasitica, Wall., 129, 287

Hunting-customs, Naga, 12

Huphina lichinosa, Moore, 244 , nama, Moore, 243

Hydnophytum andamanense, Becc., 223

Hydrocotyle asiatica, Linn., 41

Hydrolea Zeylanica, Vahl, 63

Hydrosaurus salvator, Linn., 312, 240

Hygrophila quadrivalvis, T. And., 42, 132

Hyperanthera Moringa, Vahl, 334

Hypertrophy in Acacia eburnea, 88

Hypolimnas bolina, Linn., 242

Hyptis brevipes, Poit., 42

Ichnocarpus frutescens, R. Br., 63

Illigira Conyzadenia, Meissn., 124

Impatiens Balsamina, Linn., ‘ 8, 36

Imperata cylindrica, Kunth, $\mathbf{4 2}$

Indigenous and introduced species, 175

Indigofera cordifolia, Heyne, 334 tinctoria, Linu., 334

Inland flora of the Cocos, 103 ; of Diamond Island, 67

Introduction of Andamans non-indigenous plants, 45

Laccadive plants, 383

Ipomoea aquatica, Forsk., 41

" Batatas, Linn., 30, 130, 179, 318

" biloba, Forsk, 64, 131, 224, 231, 287,348

Bona-nox, Linn., 30, 348

coccinea, Linn., 35, 36, 130, 179

cymosa, R. \& S., 231

denticulata, Choisy, 64, 130, 224, $231,287,348$

digitata, Linn., 64, 130

grandiflora, Lamk, 64, 130, 287, 347

grandiflora, Roxb., 348

Pes-capr $\mathscr{}$, Roth, 348

Quamoclit, Linn., 30, 36

sinuata, Ortega, 348

Turpethum, R. Br., 131, 287

vitifolia, Sw., 287

Ischæmum ciliare, Retz, 43, 146, 373

" muticum, Linn., 146, 234, 295, 373

repens, Roxb., 373

rugosum, Nees, 43

tenellum, Roxb., 373

Ivias andamana, Moore, 423, 244 
Inora Bandhuca, Roxb., 342

" brunnescens, Kurz, 126, 223, 229, 286 coccinea, Linn., 35,342 cuneifolia, Roxb., 126, 229, $286^{\circ}$ grandifolia, Zoll. \& Mor. 126 paniculata, Lamk, 343

Pavetta, Roxb., 343 rugulosa, Wall., 62

Jania tenella, Kuetz., 151

Japvo mountain, 2

Jasminum, sp., 30

Jatropha multifida, Linn., 32

Jerry Island, 99 purgans, Linn., 32

Jussiaea suffruticosa, Lamk, 4.1

Justicia bicalyculata, Vahl, 352

" Gendarussa, Linn. f., 31

" pectinata, Linn., 352

Kachha Nagas, 3

Kadamum, 313

Kalpéni, 322

Kiltán, 312

Kohima, 3

Konoma, 3

Koradivh bank, 319

Koráti, 319

Kyllinga brevifolia, Rottb , 144, 181, 371 " monocephala, Rottb., 39

Laccadive Archipelago, the 301 ; bibliography of, 302; characters of flora of, 377 ; cultivated species in, 380 ; list of islands in, 325 ; littoral species in, 381 ; names of members of, 326 ; weeds in, 327

Lagenaria vulgaris, Ser., 29

Lagerstroemia calyculata, Kurz, 125

$\begin{array}{ll}" & \text { Flos-Reginae, Retz, } 62 \\ " & \text { hypoleuca, Kurz, 35, } 124 \\ & \text { sp., 125 }\end{array}$

Lagoons in the Cocos, 108

Lampidês elpis, Godart, 243

Landfall Island, 93

Lantana camara, Linn., 31, 36

Launea nudicaulis, Less., 41

" pinnatifida, Cass., 345

Lawsonia alba, Lamk., 29, 340

$$
\text { " } \quad \text { inermis, Linn., } 340
$$

Leea grandifolia, Kurz, 227

", hirta, Roxb., 117

", parallela, Wall., 60

" sambucina, Willd., 117, 227, 283

Lejernea, sp., 148

Lentinus leucochrous, Fr., 148

Lenzites deplanata, Fr., 148 subferruginea, Berk., 148

Lepidopetalum Jackianum, Radlk., 227

Lepraria, sp., 148

Leptadenia reticulata, W. \& A., 347

Leptochloa filiformis, $\mathrm{R} . \mathrm{Br}, 40$
Leptosia xiphia, Fabr., 243, 244

Lepturus repens, $\mathrm{R}$. Br, 475

Lettsomia peguensis, C. B. Clarke, 130

Leucaena glauca, Benth., 29

Leucas aspera, Spr., 354

" linifolia, Spr., 39

Lhota Nagas, 3

Limnanthemum aurantiacum, Dalz., 63

" indicum, Thw., 129

" parvifolium, Griseb., 63

Limnophila conferta, Benth., 64

Linaria ramosissima, Wall., 350

Lippia geminata, H. B. K., 42

" nodiflora, Rich, 39, 133, 352

Lithothamnion polymorphum, Aresch., 151

Little Andamans and the Nicobars, ON A BOTANICAL VISIT TO, 216

Little Coco, 97

Littoral species in the Cocos, 189 ;-Diamond Island, 54 ; - the Laccadives, 381

Livistona Jenkinsiana, Griff., 141

$$
\text { " } \quad \text { speciosa, Kurz, } 14.1
$$

Lizards in Narcondam, 240

Lobelia frutescens, Linn., 346

" Taccada Gaertn., 346

Lo-kao, the Chinese Green-Dye, Note $\mathrm{ON}, 89$

Loranthus longiflorus, Desr., 135

Ludwigia parviflora, Roxb., 37, 41

$$
\text { " prostrata, Roxb., } 37
$$

Luffa aegyptiaca, Mill., 29, 36, 62, 340

" clavata, Roxb., 341

" pentandra, Roxb, 341

" racemosa, Roxb., 341

Lumnitzera racemosa, Willd., 124

Lupinus, sp., 28

Lycopersicum esculentum, Mill., 30

Lycopodium cernuum, Linn., 295

Lygodium flexuosum, Sw., 67, 147

Macaranga Tanarius, Muell-Arg., 66, 137, 289

Mallotus acuminatus, Muell.-Arg., 136

" andamanicus, Hook., f., 136, 289

" Helferianus, Kurz, 136

Mammalia of Narcondam, 235

Mangifera indica, Linn., 28, 334

Mangrove-swamps in the Cocos, 103

Manipur and the Naga tribes, 4

Maries, C., memorandum on plant-drying, by, 403

Marine flora of Coco group, 188; of Diamond Island, 54; of Little Anda. man,

Marsh-plants of the Cocos, 203

Masters, J. W., memorandum on Namba hot-springs by, 71

Mazus rugosus, Lour., 38

Melaleuca Leucadendron, Linn., 35

Melocactus, sp., 30

Melochia corchorifolia, Linn., 40, 60 
Melochia velutina, Bodd, 227

Memecylon odule, Roxb., 124, 299, 285

Mercurialis alternifolia, Desv., 360

Mezoncuron enneaphyllum, W. \& A., 121

Michelia Champaca, Linn., 28

Micrococca Mercurialis, Benth., 360

Microstachys Mercurialis, Dalz., 360

Migrant species, 177

Miliusa, sp., 111

Mimosa pudica, Linn., 37

ITimusops littoralis, Kurz, 128, 224, 230

Minikoi, 322

Mirabilis Jalapa, Linn., 32, 36, 354

Mitreola oldenlandioides, Wall., 287

Modecca cardiophylla, Mast., 125 " cordifolia B1., 125

Momordica Charantia, Linn., 39, 341

$$
\text { " dioica, Roxb., } 39
$$

"Lrffa, Linn., 341

" monadelpha, Roxb., 341

Monochoria vaginalis, Presl., 42

Morinda bracteata, Roxb., 223, 229, 286, 343

" citrifolia, Linn., 126, 223, 229, 343

Moringa pterygosperma, Gaertn., 28, 3f, $60,118,178,33 \pm$

Nozama, 3

Mucuna capitata, W.\& A., 336

" giganter, DC., 120, 223, 281

" monosperma, DC., 61

$"$ pruriens, DC., 120,336

Mukia scabrella, Arn., 37, 229

Murraya Konigii, Spreng., 331

Mus rattus, Linn., 236

Musa sapientum, Linn., 32, 66, 139, 181, 291, 362

Mnsical powers of Nagas, 5

IIussaenda calycina, Wall., 126 " macrophylla, Wall., 126, 229, 285

Myristica glauca, B1 , 65, 135, 288

, Irya, Gaertn., 135

Nacaduba colestis, De Nicév., 242

NaGas, The ANGaMi, 1

Namba Forest, in thle Sibsagar DisTRICT, THE HOT SPRINGS OF THE, 235

Narcondam and Barren Istand, on the FLORA OF， 253 ; -REMARKS ON THE FAUNA OF, 235

Narcondam, coco-nut trees in, 142, 291; description of, 256

Nature of flora of Coco group, 153; of Laccadives, 377 ; of Narcondam and Barren Island, 297

Neckera rugulosa, Mitt, 296

Nelumbium speciosum, Willd., 59

Nepeta, on an uNdescribed Oriental Species or, 85

Nepeta Bellevii, Prain, 85 , indica, Linn., 353
Nephelium Litchi, Camb., 34

Nephrodium molle, Desv., 375

Nephrolepis cordifolia, Presl., 375

Nerium odorum, Sol., 30

Nias Islands, 94

Nicandra indica, R \& S. 349

Nicobars, on a botanical tisit to Little Andaman and the, 216

Nicobar's, reefs in the, 98 ; relationship of Andamans to, 94 ; visits to, 220

Nicotiana Tabacum, Linn., 31

Non-Indigenous species of the AndaMAN FLORA, THE, 25

Nostoc verrucosum, Vauch., 77

Note on Lo-kao, the Chinese GregnDYE, 89

NOTE ON SOME METHODS OF PREPARING BOTANICAL SPECIMENS, 401

Nyctanthes hirsuta, Linn., 342

Nymphaea Lotus, Linn., 59, 111

rubra, Roxb., 111, 177

Occupations of the Angami Nagas, 5

Ochrosia borbonica, Gmel., 128, 224, 230, $3+6$

Ocimum Basilicum, Linn, 65, 232, 353 .

" gratissimum, Linn., 65, 232, 353

"sanctum, Linn., $3 \mathrm{l}, 36,65,232$, 353

Odina Wodier, Roxb., 118, 284

Oldenlandia biflora, Linn., 342

" biflora, Lamk, 342

.. corymbosa, Limn., 38, 229, 285,342

" crystallina, Linn , 41

" diffusa, Roxb., 4.1, 342

" paniculata, Limn., 41

", ramosa, Roxb., 342

, repers, Linn., 342

Onychium auratum, Kaulf., 296

Ophiorthiza Mungow, Limm, 229

Oplismenus Burmanni, Beauv., 295, 71

Opuntia, sp., 30 compositus, R. \& S., 145, $37 \mathrm{i}$

Oriental SPECIES OF NePETA, ON AN UNDESCRIBED, 85

Origin of the Coco group Flora, 175;Narcondam and Barren Island Flora, 300

Ornaments of Angami Nagas, 6

Ormithotrope Cobbe, Willd., 333

Oroxylum indicum, Vent.. 132, 288

Oryza coarctata, Roxb., 372

sativa, Linn., 33, 372

Osbeckin chinensis, Iinn., 61

Otocompsia emeria, Shaw, 238

Oxalis corniculata, Linn., 37

Pachyrhizus angulatus, Rich., 29

Padina pavonia, Gaill., 67, 151, 22i

Padouk, 35

Paederia foetida, Limn., 127, 229, 28 ;

Palaeornis affinis, Tyt1, 238 
Pancratium zeylanicum, Linn., 363

Pandanus odoratissimus, Linn. f., 143, 2ㄴ, 233, 293, 369

Panicum Burmanni, Retz., 371

\begin{tabular}{|c|}
\hline 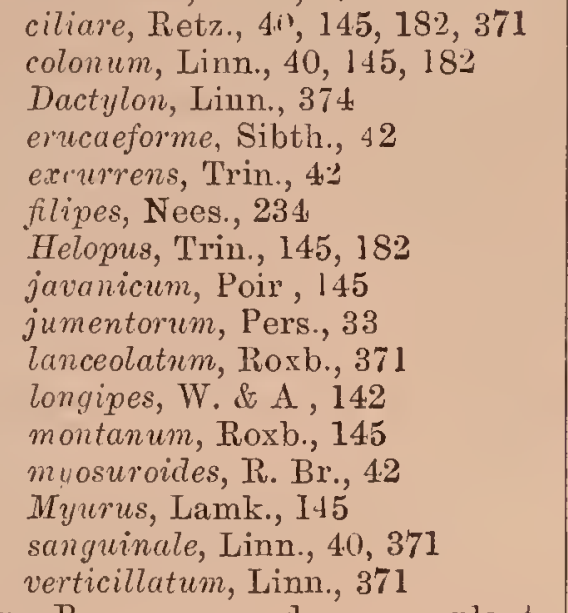 \\
\hline
\end{tabular}

Pantling, R., memorandum on plant drying by, 404

Parishia insignis, Hook. f., 118

Parsonsia spiralis, R. Br., 230

Parthenos gambrisins, Fabr., 243

Paspalum distichum, Linn., 42

" filiculmum, Nees, 40

" pedicellatum, Nees., 42

$"$ scrobiculatum, Nees., 40

Passiflora laurifolia, Linn., 29

Patkoi Mts., 2

Pavetta indica, Linn., 62, 126, 343

Peidicularis, Two Species of, 251

Pedicularis diffusa, Prain, 251

flaccida, Prain, 252

Pemphis acidula, Forst., 124

Peniophora papyrina, Mont., 297

Pentas curnea, Benth., 30

Perilla ocimoides, Limn., 15

Peristrophe acuminata, Nees, 133, 231

$"$ bical!/culata, Nees, 352

Petunia violacea, Linn, 31

Peucedanum graveolens, Benth., 30

Phaseolus adenanthus, C. A. Mey., 284

" culcaratre, Roxb, 338

" lunatus, Linn., 29

" Mungo, Linı., 29

", trilobus, Ait., 34, 36

, sp, 120,178

Phaylopsis parvifiora, Willd., 42

Phlebocalymna Lobbiana, Mast., 116

Phlomis esculentus, Roxb., 354

$$
\text { "sp., } 249
$$

Pholidota imbricata, Lindl , 139, 291

Phyllanthus columnaris, Muell.-Arg., 136

$$
\begin{array}{ll} 
& \text { distichus, Muell.-Arg., } 360 \\
" & \text { Emblica, Linn., 359 } \\
" & \text { longifolius, Jacq., } 360 \\
" & \text { maderaspatensis, Linn., } 359 \\
" & \text { Niruri, Linn., 360 } \\
, & \text { obcordatus, Willd., } 359^{\circ}
\end{array}
$$

Phyllanthus reticulatus, Poir., 289

$$
\text { " rotundifolius, Klein, } 360
$$

" Urinaria, Linn., 42, 359

Phyllochlamys spinosa, Bur., 137

Pliysalis minima, Linn , 41, 131, 288, 319

$$
\text { " Peruviana, Linn., } 349
$$

Physcia lencomela, Michx., 376

$$
\text { "obscura, Fries, 148, } 376
$$$$
\text { ," sp., } 148
$$

Physiography of Barren Isiand, 81, 264, 273; of the Coco-Group, 97; of Narcondam, 256, 273

Physique of Angani Nagas, 5

Piper Betle, Linn., 32, 356

" caninum, B1., 135

Pipturus velutinus, Wedd., 233, 290

Pirmalpar, 808

Pisoniu aculeata, Linn., 134

$$
\begin{aligned}
& " \quad \text { alba, Span., 232, 289, } 355 \\
& " \quad \text { excelsa, B1., 134, 232, } 2 \times 8 \\
& \quad \quad \text { inermis, Forst., 355 }
\end{aligned}
$$

Pisnm sativum, Linn., 28

Pithecolobinm dulce, Benth., 34, 36

Piti Sandbank, 318 Saman, Benth., 34, 36

Plantain in Narcondam, The, 292

Plantago major, Linn, 32

Plants collected in the Cocos, 111; Diamond Island, 59; Laccadives, 328 ; Little Andaman, 221; Narcondam and Barren Island, 279 ; Nicobars, 226

Plecospermum andamanicum, King, 137

Plectocomia assamica, Griff., 7

Pleurostylia Wightii, W. \& A., 332

Pleurotus cuneatus, Mass., 376 , tenuissimus, Jungh., 376

Pluchea indica, Less., 127, 286

Plumbago rosea, Linn., 30

$$
\text { ". zeylanica, Linn., } 346
$$

Plumieria acutifoliu, Poir., 30

Poa plumosa, Retz., 374

" tenella, Linn., 374

Pogonatherum saccharoideum, Beaur., 295

Poinciana regia, Boj., 34

Polity, Naga, 16

Pollia Aclisia, Hassk., 291

", zorzogonensis, Endl., 140

Polygala erioptera, DC., 329

Vahliana, DC, 329

Polygonum used as food, a, 16

Polygonum barbatum, Linn., 39, 134, 356 rivulare, Koen., 356

Polypodium adnascens, Sw., 147, 226, 234, 296

" irioides, Lamk., 147, 296

" phymatodes, Linn., 234

"quercifolium, Linn., 147, 226, 234, 296

Polyporus anstralis, Fr. 149, 297

" grammatocephalus, Berk., 149

"fulvus, Fries, 149 
Polyporus igniarius, Fries, 376

" occidentalis, Berk., 67

$" \quad$ sanguineus, Fries, 149, 376

"xanthopus, Fries, 149, 297

Pometia tomentosa, Kurz, 118

Pongamia glabra, Vent., 61, 121, 223, 284

Popovia parvifolia, Kurz, 226

Portulaca oleracea, Linn., 37, 329

" Portulacastum, Linn., 341

" quudrifida, Linn., 37

" tuberosa, Roxb, $3: 9$

Pothos scandens, Linn, 144, 295

Pouzolzia alienata, Gaud., 362 " indica, Gaud., 362

Premna integrifolia, Linn., 65, 133, 224, 231, 288, 353

obtusifolia, R. Br. 133

" serratifolia, Linn., 353

" spinosa, Roxb., 353

", sp., 133

Prenanthes acaulis, Roxb., 345

Preparis, 93 asplenifolia, Roxb., 345

Products of Coco Islands, 110

Prolification of flower-buds in Acacia eburnea, 89

Psidium Guajava, Linn., 29, 339

" pomiferus, Linn, 339

" pyriferus, Linn., 339

Psilostegixe, 87

Psilotum triquetrum, Sw., 295, 375

Pteris biaurita, Linn., 296

" longifnlia, Linn., 296

Pterocarpus indicus, Willd., 35, 121

Pueraria Candollei, Grah., 121 " phaseoloides, Benth., 61, 121

Punica Granatun, Linn., 29, 340

Pyenmah, Andamanese, 35

Quisqualis indica, Linn., 29

Rain-tree, origin of name, 35 ; rate of growth of, 34

Randia longiflora, Lamk., 126

Raphanus sativus, Linn., 28

Rate of cooling of spring in Barren Island, 84.

Rats in Narcondam and Barren Island, 235

Rauwolfia serpentina Benth., 128

Ravenala madagascariensis, Adans, 35

Reefs, coral, 97 ; sandstone, 100

Regma Nagas, 3

Religion, Naga, 18

Remanent species in the Cocos, 213

REMaRKS ON THE FAUNa OF NARCONDAM AND BARREN IsLAND, 235

Reptiles in Narcondam and Barren Island, 240

Rhamnus catharticus, Linn., 90

" chlorophorus, Dene, 90

" davuricus, Pall., 89

"globosus, Bunge, 90
Rhamnus persicus, Boiss, 90

"utilis, Dene, 89

" virgatus, Roxb., 90

$\therefore$ sp., 90

Rhizophora conjugata, Linn., 123

" mucronata, Lamk., 103

Rhus Cobbe, Linn., 333

Rhyticeros Narcondami, Hume, 238

Rhytisma, sp., 150, 297

Ricinus communis, Linn., 32, 36, 360

Rondeletia speciosa, Lodd., 30

Roots of Avicennia, aorial, 54

Rosu, sp., 29

Rottboellia exaltata, Linn., 42

Rudbeckia, sp., 30

Ruellia prostrata. Poir., 351

, ringens, Roxb., 351

Rungia linifolia, Nees., 352

" parriflora, Nees, 39, 132, 180, 352

" pectinata, Nees, 352

Russellia juncea, Zucc., 31

Rutland Island, 94 ; reefs of, 98

Sacchurnm officinarum, Linn., 33, 373

Salacia prinoides, DC., 117

Sapindus Danura, Voigt, 118

Saponaria Vaccarin, Linn., 37

Saraca indica, Linn., 34

Sarcanthus, sp., 234

Sarcolobus globosus, Wall., 129

Sarcostigma edule, Kurz, 116

$$
\text { " Wallichii, Baill., } 116
$$

Sargassum ilicifolium, Ag., 151, 226, 235

Scierola Koenigii, Vahl, 62, 127, 230, 256,316

Taccrida, Roxb., 346

Schizophyllum commune, Fries, 376

Scindupsus officinalis, Schott., 66, 144

Scirpus articulatus, Linn, 67

" miliaceus, Roxb., 371

" subulatu.s, Vahl., 145

Scoparia dulcis, Linn., 39, 65, 131, 180

Sea of Bengal, 253

Seeds, introduction of, by birds, 202, 206,

211 ; by sea, 189 ; by winds, 197

Seluginella proniflora, Bak., 43

Sema Nagas, 3

Semecarpus heterophylla, Bl., 118, 228, 284

"subpanduræformis, Wall., 118

Senna occidentalis, Roxb., 339

", Tora, Roxb., 339

Serratula cinerea, Roxb., 344,

Sesamum indicum, DC., 41

Sestan grandiforus, Poir., 335

Sesbania aculeata, Pers., 335

", grandiflora, Pers., 28, 335

Sesostris bank, 319

Sesuvium Portulacastrum, Linn., 125, 341

Setaria rerticillata, Beauv., 371

Sida acuta, Burm., 112, 226 
Sida carpinifolia, Linn., 37, 178

"humilis, Willd., 329

" indica, Linn., 330

", populifolia, Lamk., 330

: rhombifolia, Linn., 40

Sideroxylon ferrugineum, H.\& A., 286

Simalu Island, 94

Siphonocladon filiforme, Dc Toni., 152

Siphonodon celastrineus, Griff., 117

Slipper Island, 94

Smilax macrophylla, Roxb., 66, 140

Smithia sensitiva, Linn., 41

Solanum ferox, Linn., 31, 41

" indicum, Linn., 31, 41

" Melongena, Linn., 31, 36, 131, 180,231

$" \quad$ nigrum, Linn., 38, 41

", stramonifolium, Roxb., 349

" torvum, Sw., 31, 38

" xanthocarpum, Sw., 38, 4 I

Solfataras in Barren Island, 12

Sonchus arvensis, Limn., 41

Sophora tomentosa, Linn ., 121, 228

Sorghum vulgare, Per's, 374

Soroo Noon-Poong, 78

Sphenoclea zeylanica, Gaertn., 62

Spilanthes oleracea, Kurz, 38

Spinifex squarrosus, Linn., 372

Spondias mangifera, Will., 118

Sporobolus diander, Trin., 4.0

Stachytarpheta indica, Vahl, 31, 36, 352

Stephegyne diversifolia, H. f., 62, 126

Sterculia alata, Roxb., 115

" campanulata, Roxb., 115

" colorata, Roxb., 115

"paniflora, Roxb., 115

" rubiginosa, Vent, 115, 221, 227, 282

"villosa, lioxb., 114

Stereum cyathiforme, Fries, 67

Sternula melanauchen, Tenim., 240

Striga lutea, Lour, 41, 351

Strobilanthes, used as a dye, a 18

Strobilanthes phyllostachyus, Kurz, 132

Strophanthus Wallichii, A. DC., 129

Strychnos acuminata, Wall., 230, 287

Suhelipar reef, 310,384

Sulphur deposits in Barren Island, 82

Sumatra, 94

Suriana maritima, Linn., 332

Surf, effects of, 98

Swietenia macrophylla, King, 34

$$
\text { " Mahogani, Linn., } 34
$$

Sylvestrian species, 187

Synedrella nodifora, Gaertı., 38

SyNoNym of ANTHocoma FLAVESCENS,

Zoll., THE, 241

Synoptic view of Coco group flora, 215 ; of Laccadive flora, 378

Systematic nature of Coco group flora, 153; of Laccadive flora, 279

418
Tabernxmontana crispa, Roxb., 63, 129

Table Island, 94

Taccea pinnatifida, Forst., 139, 263

Tagetes, sp., 30, 36

Tamarindus indica, Linn, 34, 61, 122, 179,339

Tangáro, 309

Tangkal Nagas, 3

Tectona grandis, Linn. f., 35

Temperature of Spring in Barren Island, 83 ; - of springs in Namba Forest, 78

Tephrosia pumila, Pers., 335

$$
\begin{aligned}
& \text { " } \quad \text { tenurpurea, Pers, }, 336 \\
& \text { " Wall., } 335
\end{aligned}
$$

TERATOLOGICAL EFFECTS PRODUCED ON Acacia EBURnea, Willd., By ACIdium ESCULENTUM, Barcl., 87

Terminalia bialata, Kurz, 124

$$
\begin{aligned}
& \quad \text { Catappa, Lamk , 61, 123, 223, } \\
& 228,284,339 \\
& \text { procern, Roxb., 121. }
\end{aligned}
$$

Thelephora incrustans, Pers., 149, 297

Thespesia populnea, Corr., 60, 113, 221 , 226, 279, 330

Thevetia neriifolia, Juss , 30

Thread-blight in the Andamans, 150

Thuarea sarmentosa, Pers , 146, 372

Thunbergia alata, Boj., 35, 36

$$
\text { " erecta, T. And., } 35
$$

, laurifolia, Lindl., 65, 132

Thysanolmna acarifera, Nees, 295

Topography of Diamond Island, 53

Torenia, sp., 35, 36

Tournefortia argentea, Linn. f., 130, 221, 231,347

T'raditions of the Nagas, 3

Tragia Mercurialis, Linn., 360

Trametes Muelleri, Berk., 376

Trema amboinensis, Bl., 289

Trichomanes pyxidiferum, Linn., 295

Trichosanthes anguina, Linn., 29

,. cucumerina, Linn., 29, 36

, palmata, Roxb., 125, 229 , 285

Tridax procumbens, Linn., 41

Tringoides hypoleucus, Linn., 239

Triphasia trifoliata, DC., 227

Triumfetta Thomboidea, Jacq., 40

'Tulsi plants, dispersal of the, 65, 232, 353

Turbinaria ornata, Ag., 151, 226

Two SPEcies of PeDicularis, 251

Tylophora asthmatica, W. \& A., 347 globifera, Hook. f., 287

Urena lobata, Linn., 60, 113, 178, 226 , simurita, Linn., 330

Urtica suffiruticosa, Roxb., 362

Valonia confervoides, Harv., 152

" fastigiata, Harv., 152 sp., 152

Tandellia crustacea, Benth., 38, 65288 
Vaucheria, sp., 152

Vegetable products of the Cocos, 110

Vegetation of the Coco Group, the, 93

Ventilago calyculata, Tul.117

Verbena Aubletii, Linn., 31

$$
\text { " indica, Linn., } 352
$$

" nodiflora, Linn., 352

Verbesina calendulacea, Linn., 345

" Lavenia-alba, Linn., 345

, scandens, Roxb, 345

Vernonia cinerea, Less , 38, 62, 127, 179. 344

Vigna Catjang, Endl., 29, 338

,I lutea, A. Gr., 121, 223, 284, 338

Villages, Naga, 7

Vinca rosea, Linn., 30, 36

Vitex Negundo, Linn., 65, 133

" pubescens, Vahl, 133

, trifolia, Linn., 31, 36

Wimberleyi, Kurz, 133

Vitis camosa, Wall., 117, 283, 333

"lanceolaria, Roxb., 283

" pedata, Wall., 117, 2:7

" pentagona, Wall, 117
Vitis quadrangularis, Wall., 333

", repens, W. \& A., 283

Vittarict elongata, Sw., 147

War-customs, Naga, 10

Weapons, Angami, 8

Webera Kurzii, Hook. f., 126, 223, 229

Wedelia calendulacea, Less., 41, 345 "scandens. C. B. Clarke, 127, 224, $230,286,346$

Weeds of Andamans, 37 ; of Cocos, 177 ; of Laccadives, 380

Willughbeia edulis, Roxb., 63

Wind-introdaced species of Barren Island, 300; of Cocos, 197 ; of Laccadives, 382 ; of Narcondam, 300

Wollastonia Horsfieldiana, Miq., 345 insularis, DC., 354

Xylaria clavarioides, Mass., 150

Zanichellia palustris, Linn., 144, 375

Zea Mays, Linu., 33

Zephyranthes, sp., 32

Zingiber corollinum, Hance., 139 , sp., 139

Zinnia elegans, Linn., 30, 36

Zizyphus Oenoplia, Mill., 117 
mue

AF'H 3 is 40 





$$
00053288790
$$

